ERDÉLYI TUDOMÁNYOS FÜZETEK

269

KOVÁCS SÁNDOR

\title{
ANGOLSZÁSZ-MAGYAR UNITÁRIUS ÉRINTKEZÉSEK A 19. SZÁZADBAN
}

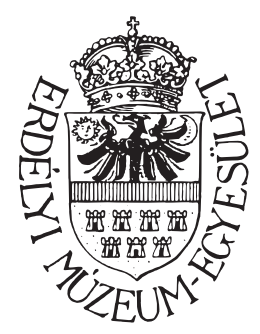

Kolozsvár, 2011 
A kötet megjelenését a Bethlen Gábor Alap

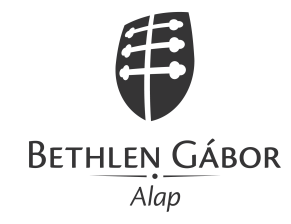

támogatta.

(C) Erdélyi Múzeum-Egyesület, 2011

(C) Kovács Sándor

Felelős kiadó

BIRÓ ANNAMÁRIA

Korrektúra

CZINTOS EMESE

Müszaki szerkesztés, tördelés

BODÓ ZALÁN

Nyomdai munkálatok

GLORIA, Kolozsvár

Felelős vezető

NAGY PÉTER

Descrierea CIP a Bibliotecii Naționale a României

KOVÁCS, SÁNDOR

Angolszász-magyar unitárius érintkezések a 19. században / Kovács Sándor. Cluj-Napoca: Societatea Muzeului Ardelean, 2011

ISBN 978-606-8178-26-4

28 


\section{TARTALOM}

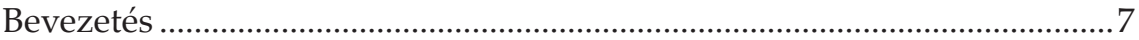

1. A magyar-angol-amerikai unitárius kapcsolatok alakulása

1821-től 1848-ig

1.1. A Brevis Expositio előzményei. Az eddigi kutatási eredmények összegzése

1.2. Az angol levelezési emlékkönyv ....................................................13

1.3. A Brevis Expositio erdélyi fogadtatása és szerkezete ......................18

1.4. Az Angliában élő unitáriusokhoz küldött epistola ...........................22

1.5. Körmöczi és az angol unitarizmus ...................................................... 32

1.6. A Molnos-Bowring-Körmöczi háromszög és az „erdélyi

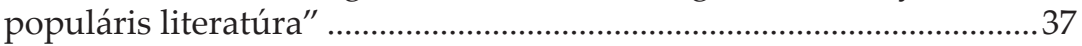

1.7. Bölöni Farkas Sándor napnyugati utazása ........................................42

1.8. Székely Mózes angliai látogatásának következményei ...................49

1.9. Újabb adatok Jakab József angliai útjához..........................................53

2. Angol unitáriusok Erdélyben, magyar unitáriusok Angliában

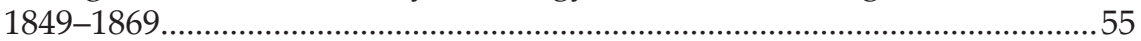

2.1. John Paget János és Erdély ……………………............................55

2.2. Edward Tagart erdélyi látogatása 1858-ban ...................................... 62

2.3. Alfred Steinthal küldetése. Ismeretlen Kossuth-levelek..................65

2.4. Ferencz József és Buzogány Áron 1859. évi londoni látogatása ...71

2.5. A Manchester New College magyar diákjai ......................................74

2.6. Az ösztöndíjalapítástól a szervezett kapcsolatok kiépítéséig ........79

2.7. Az amerikai unitárius kapcsolatok kiépítése a kiegyezés után....93

2.8. J. J. Tayler erdélyi látogatása ...........................................................98

3. Az angol-amerikai-magyar kapcsolatok alakulásának története

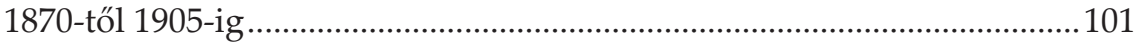

3.1. John Fretwell és Jókai Mór ............................................................101

3.2. Fretwell Magyarországon és Erdélyben ..........................................107

3.3. Kovács János és a kolozsvári English Conversation Club története 
3.4. Kitekintés. Az angol-amerikai-magyar unitárius kapcsolatok teológiai és egyháztársadalmi mérlege ...................................................... 168 Függelék .................................................................................................. 171

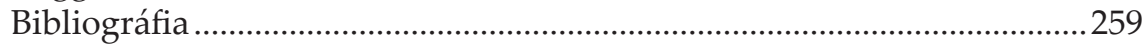

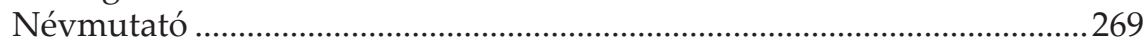

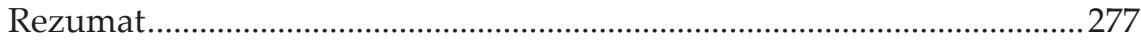

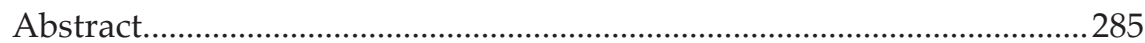




\section{BEVEZETÉS}

Az angol-magyar protestáns kapcsolatok történetének mostohagyermekével, az unitárius egyházzal foglalkozunk dolgozatunkban. Az angolamerikai-magyar érintkezési viszonyok tizenkilencedik századi, az unitárius egyház intézményrendszere köré épülő eseménytörténete úgyszólván ismeretlen a szakma előtt. Ennek több oka is van: a felekezet számaránya és elszigeteltsége, a kolozsvári, oxfordi és manchesteri unitárius könyvtárakban és levéltárakban szétszórt, nehezen hozzáférhető anyag nehezítette a kutatást. A dolgozat módszere, a fentiekben jelzett körülmények következtében is, bátran későpozitivistának is tekinthető. Nem tiltakoznánk ez ellen a megjelölés ellen, hiszen tisztában vagyunk azzal, hogy az irodalmi, politikai, gazdasági, eszmetörténeti kapcsolatok elmélyült elemzése elképzelhetetlen lesz anélkül az intézményes háttér nélkül, amelynek új forrásait szólaltatjuk meg. Ez persze azt is jelenti, hogy az egyes részterületek árnyalt, a felsorolt szakmák módszertani kérdéseit is érintő elemzésére nem vállalkozhattunk. A kronológiai, bibliográfiai, biográfiai, intézmény- és helytörténeti, archontológiai „,anyaghalmozás” reményeink szerint forrásbázisa lehet a későbbi interpretációknak. Éppen ezért értekezésünk irodalomtörténeti vonatkozású fejezeteiben sem vállalkoztunk pl. John Bowring Petőfi-fordításainak elemzésére, vagy az angol és amerikai Jókai-recepció újraértelmezésére, hanem a háttérintézményt és annak vezetőit mutattuk be, azt, ami a felekezet háttérbefolyásolásának érvényesítését szolgálta. Hasonló módon jártunk el az erdélyi unitárius közösség külpolitizálási mechanizmusai bemutatásakor. Bölöni Farkas Sándor „napnyugati” utazásának egyházdiplomáciai jelentőségét, Kossuth Lajos média-politizálásának unitárius vonatkozásait méltattuk. Végső soron mindketten a felekezet erdélyi pozícióit erősítették. A nőnevelést célzó unitárius erőfeszítések kapcsán nem tértünk ki a nőoktatás, illetve a nemek harcának igen-igen terjedelmes irodalmára, megelégedtünk egy rövid felsorolással és annak hangsúlyozásával, hogy az erdélyi nőoktatás sokat köszönhet az angol unitáriusok támogatásának. 
Egy látszólag civil szervezet, a kolozsvári English Conversation Club történetét ismertető fejezetben a magyarországi anglisztika szempontjából is érdekes területet cserkésztünk be. A klub összetett szerepét az unitáriusok társadalmi elhelyezkedésének érzékeltetésével, és az angol nyelv müvelésében és terjesztésében vállalt szerepükkel illusztráltuk. A Budapest English Club története nincs még megírva - szintúgy a pozsonyié sem -, a Függelékben mellékeltük mindkét kör alapszabályát. Könyvünk összeállításában az eseménytörténet többé-kevésbé lineáris követése látszott célravezetőnek. A monográfia és adattár sok esetben nem éppen szerencsés egybeesése helyenként nehézkessé teheti az olvasást, ezért arra törekedtünk, hogy az eseménytörténet gerince lehessen a leírtaknak. A főszövegben igyekeztünk elkerülni a hosszabb idézeteket, az érthetőség azonban megkövetelte, hogy néhány esetben hosszasabban idézzük forrásainkat. A terjedelmesebb idézeteket lábjegyzetben hoztuk, a dolgozat szempontjából fontos szövegeket pedig a függelékben közöltük. Ha az angol szövegrészek saját fordítását adjuk, a szerző iniciáléival [KS] jeleztük. A most megjelenő könyv a Szegedi Tudományegyetemen megvédett doktori dolgozat szerkesztett változata. Köszönetet mondok mindazoknak, akik munkám során tanácsaikkal, szakmai tudásukkal segítettek. Balázs Mihály szakirányítómnak, hogy a készülő dolgozatot többször is elolvasta és tanácsaival segített. Illesse köszönet a kutatásban nyújtott önzetlen segítségéért Sue Killorant, a Harris Manchester College könyvtárosát, Ann Peart-ot, a Manchester College principálisát, Molnár B. Lehelt, az erdélyi unitárius egyház levéltárosát, példás segítőkészségéért és végtelen türelméért. Hasonlóképpen köszönöm Fabiny Tibor professzor és Bíró Gyöngyi tudományos kutató hasznos tanácsait. Külön köszönettel tartozom Hoffmann Gizellának a német nyelvű szövegek fordításáért, türelméért és hasznos tanácsaiért. Köszönöm opponenseimnek, Máthé Tóth Andrásnak és Csorba Lászlónak, az észrevételeket és építő kritikát, hasonlóképpen Szőnyi György Endre támogatását. 


\section{A MAGYAR-ANGOL-AMERIKAI UNITÁRIUS KAPCSOLATOK ALAKULÁSA 1821-TŐL 1848-IG}

\subsection{A Brevis Expositio előzményei. Az eddigi kutatási eredmények összegzése}

A magyar unitarizmus angol és amerikai kapcsolatainak történetét tudományos igénnyel még nem dolgozták fel. A tárgykörben jelentek meg értékes résztanulmányok, elsősorban a Keresztény Magvető című folyóirat különböző évfolyamaiban, ${ }^{1}$ de ifj. Fabiny Tibor 1981-ben készült doktori dolgozatától eltekintve nem készült el az angol-magyar unitárius érintkezések monográfiája. ${ }^{2}$ Ez természetesen nem jelenti azt, hogy a nagyobb

${ }^{1}$ A Keresztény Magvető (a továbbiakban KerMagv) a leghosszabb életü, ma is megjelenő erdélyi magyar nyelvű teológiai és egyháztársadalmi folyóirat. 1861-ben alapították Kriza János (1811-1875) és Nagy Lajos (1828-1910) unitárius kollégiumi tanárok. Hasábjain tanulmányok, fordítások, elmélkedések, életrajzok, oktatási-nevelési kérdések, történelmi adatok, könyvismertetések jelentek meg. 1870-től negyedévenként, 1875 óta havonként jelent meg. 1918-ig 53 kötete látott napvilágot. Két évi kényszerszünet után 1922 elején indult újra, eleinte négy, majd 1928-tól évi hat füzetben. Az 1944 augusztusában megszakadó sorozat 1971-ben a 77. évfolyammal folytatódott. Az angol-amerikai-magyar kapcsolatok alakulásáról részletesen tudósítottak a folyóirat hasábjain.

${ }^{2}$ FABINY Tibor, Fejezetek az erdélyi unitáriusok angol kapcsolatainak történetéból..., Szeged, 1981. (Kézirat, a továbbiakban FABINY). Itt mondok köszönetet a szerzőnek, hogy dolgozatát rendelkezésemre bocsátotta és a további kutatásra ösztönzött. Fabiny Tibor dolgozata és a jelen dolgozat felépítése néhol természetszerüen egybeeséseket mutat. Fabiny dolgozatának felépítése: 1. Az angol és az erdélyi unitarizmus kezdetei - Acontius hatása, 1.1. Acontius a toleranciáról és az angol unitarizmus kezdetei, 1.2. A tolerancia Erdélyben, 1.3. Közvetett és személyes kapcsolatok az erdélyi és az angol unitáriusok között a 16. és 17. században, 2. Szervezett kapcsolatok a 19. században, 2.1. Bevezetés helyett: Kossuth az unitarizmusról, 2.2. A század első fele, 2.2.1. A szakirodalom, 2.2.2. Az előzmények, 2.2.3. Az angol kezdeményezés: Brevis Expositio 1821, 2.2.4. A megkésett válasz: Epistola ad Unitarios in Anglia Missa 1825, 2.2.5. Sir John Bowring levelezése az erdélyi unitáriusokkal 1827, 2.2.6. Bölöni Farkas Sándor és az angliai utazásának a jelentősége 1831, 2.2.7. Jakab József és Anglia -1848, 3. Angol unitáriusok Erdélyben a század második felében (1858-1879), 3.1. John Paget segélykiáltása, 3.2. Eduard Tagart erdélyi látogatása - 1858, 3.3. Alfred Steinthal kettős küldetése - Kossuth ügynökeként Erdélyben - 1859, 3.4. John James Tayler, a kiegyezés utáni Erdély angol tanúja 1868, 3.5. Alexander Gordon és Andrew Chalmers képe a Monarchia Erdélyéről 
összefoglalókban ne hivatkoznának olykor-olykor az unitáriusokra is. Dolgozatunkban részben a Fabiny disszertációja által kijelölt mezsgyén haladtunk, kiegészítve azt a kutatás legújabb eredményeivel.

Gál István volt az első magyar tudós, aki írásaiban az unitáriusok angol kapcsolatainak kivételes fontosságára felhívta a figyelmet, mi több, Magyarország és az angolszász világ. Egy kézikönyv tervezete címủ, 1943-ban írott, a külügyminisztérium kulturális osztályának benyújtott memorandumában meggyőzően érvelt az angol-amerikai-magyar történeti, politikai, gazdasági, vallási, szellemi érintkezések feldolgozásáért és egy kézikönyvben való összegyűjtéséért. ${ }^{3} \mathrm{Az}$ átfogó, minden területet felölelő monográfia Unitárius kapcsolatok fejezetét Szent-Iványi Sándor ${ }^{4}$ (1902-1983) lelkész, politikus lett volna hivatott megírni. Szent-Iványi még kolozsvári évei alatt lefordította és kiegészítette Earl Morse Wilbur (1866-1956) Our Unitarian Heritage címü múvét. ${ }^{5}$ Szent-Iványi kiterjedt angol és amerikai kapcsolatai és kiváló nyelvismerete révén a legalkalmasabb lett volna az Unitárius kapcsolatok megírására. A budapesti unitárius lelkész 1945 után elhagyta Magyarországot, és az Amerikai Egyesült Államokban telepedett le. Életművének értékelésével adós mind az unitárius egyház, mind pedig az Amerikai Magyar Könyvtár és Történelmi Társulat. Gál István memorandumát is elfelejtették, mert 1943 után nem történt kísérlet a monográfia összeállítására.

A román nyelvterületen íródott tanulmányok nagyobbrészt propaganda jellegűek, politikai töltetűek és explicite nem foglalkoznak az unitáriusokkal. Szerencsés kivétel Paul Cernovodeanu, de ő is csak érinti az unitáriusok anglomániáját. ${ }^{6} \mathrm{Az}$ mindenesetre figyelemre méltó, hogy a román tudósok közül Cernovodeanu az, aki a kolozsvári szentháromság-tagadók munkásságára felfigyelt, és a románság és az Újvilág kapcsolatait tárgyaló monográfiájába beépítette a Jacobus Palaeologus Cathechesis Christiana

- 1879, 4. A 19. századi angol-amerikai unitarizmus szabadelvű eszméinek hatása Magyarországon és Erdélyben, 4.1. Erdélyi diákok Angliában, 4.2. A Keresztény Magvető jelentősége: a század eszméinek visszhangja.

${ }^{3}$ Gál István, Magyarország és az angolszász világ, szerk. Frank Tibor, GáL Ágnes és GáL Julianna, Argumentum - OSZK, 2005, 276-277. (A továbbiakban GáL.)

${ }^{4}$ Kovács Sándor, Szent-Iványi Sándorra emlékezünk születésének századik évfordulóján, Unitárius Közlöny (a továbbiakban UK), 2002, január-február 1 sz., 5-6.

${ }^{5}$ Earl Morse Wilbur, Our Unitarian Heritage. An Introduction to the History of the Unitarian Movement, Beacon Press, Boston é. n. című művét az amerikai unitáriusok Vallásoktatási Osztályának (Department of Religious Education) felkérésére írta, első kiadása 1925-ben, ötödik és egyben utolsó kiadása 1956-ban jelent meg. Szent-Iványi Sándor fordítása az általa szerkeszetett Szabadelvü Vallásos Értekezések sorozat tizenegyedik darabjaként jelent meg A mi unitárius örökségünk. A szabadelvü kereszténység összefoglaló története címen az Unitárius Sajtó és Iratterjesztő Bizottság kiadásában 1937-1938-ban.

${ }^{6}$ Paul Cernovodeanu, Contributions to Lord Paget's Journey in Wallachia and Transylvania (1702), Revue des Études Sud-Est Européennes, Tome XI(1973) No. 2, 275-284. 
című művében szereplő kulcsfigurát, Telephust, az indiánt.7 Talán nem lett volna érdektelen párhuzamba állítani Oláh Miklós 1530. október 1-jén Augsburgban V. Károly császárhoz intézett, a konkvisztádát dicsőítő, a vallás és törvény betűjét nem ismerő bennszülötteket lekezelő sorait, Palaeologus merőben eltérő okfejtésével.

Az erdélyi unitáriusok kora újkori angol kapcsolatait vizsgálva elég bő irodalomra támaszkodhatunk mind Johann Sommer Jacobus Aconcius átdolgozását, ${ }^{8}$ mind pedig Palaeologus Erzsébet-apológiáját - Adversus Pii V. proscriptionem Elizabethae Regniae Angliae - és a kolozsvári unitáriusok anglomániáját illetően, azonban az erdélyi fejedelemségben és a szigetországban müködő heretikusok - a könyvek ide-oda áramlásának köszönhető - kapcsolatait semmiképpen sem szabad eltúlozni. Ugyanakkor nem hallgathatjuk el a 16. századi kolozsvári unitárius kollégiumban kibontakozó Erzsébet-kultusz néhány válaszra váró kérdését sem, köztük a De falsa et vera... címü, a lengyel és magyar antitrinitáriusok manifesztumának tekinthető munka feltételezett 1570. évi második, az angliai Erzsébet királynőnek ajánlott kiadását. ${ }^{9} \mathrm{E}$ kérdést legutóbb Balázs Mihály taglalta a De Falsa et Vera Unius Dei Patris Filii, et Spiritus Sancti Cognicione egy példányáról (Adalék az erdélyi antitrinitáriusok angol kapcsolatainak történetéhez) címü tanulmányában. ${ }^{10}$

A magyarországi diákok újkori angliai egyetemjárásáról készült öszszefoglalókban a református diákok mellett az unitáriusok is helyet kaptak. Gömöri György 2005-ben megjelent Magyarországi diákok angol és skót egyetemeken 1526-1789 című kötetében felsorolja azokat az unitáriusokat, akik az oxfordi, cambridge-i vagy londoni kollégiumokban megfordultak. Mindössze hat név: Ádám Rázmán (Erasmus) Péter, ${ }^{11}$ Szentiványi Márkos

\footnotetext{
${ }^{7}$ Paul CernovodeAnu, Ion STANCIU, Imaginea lumii noi în țările române şi primele lor relații cu statele unite ale Americii pînă în 1859, Bucureşti, 1977, 15-19. Vö. Földi és égi hitviták. Válogatás Jacobus Palaeologus munkáiból, ford. NAGYiLlés János, válogatta, az előszót és a jegyzeteket írta BALÁzs Mihály, Budapest-Kolozsvár, 2003, 42-80, 91-116.

${ }^{8}$ Pirnát Antal, Die Ideologie der Siebenbürger Antitrinitarier in den 1570er Jahren, Budapest, 1961, 21-29. Vö. Aart de Groot, Kämpfen für Wahrheit und Einheit in der Kirche: Acontius und Sommer über die "Stratagemata Satanae" $(1565,1570)=$ György Enyedi and Central European

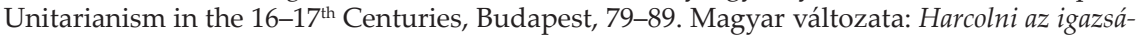
gért és az egyház egységéért. Acontius és Sommer a "Stratagemata Satanaeról" (1565, 1570), ford. Koncz László, KerMag 2004/2, 140-147.

${ }^{9}$ BorbéLy István, A mai unitárius hitelvek kialakulásának története, Kolozsvár, 1925. PÉTER Lajos, A magyar unitáriusok régi angol kapcsolatai, Unitárius Élet (továbbiakban UÉ), 1965(XIX), 2. sz. április-június. Régi Magyarországi Nyomtatványok - Res Litteraria Vetus Operum Impressorum 1473-1635., eds., Gedeon Borsa et alii, Budapest, 1971-2000. 254. Klaniczay Tibor, Jegyzetek Budai Parmenius Istvánról = Hagyományok ébresztése, Bp., 1976, 225-241.

${ }^{10}$ KerMagv 2003, 21-34.

${ }^{11}$ GöмöRI György, Magyarországi diákok angol és skót egytemeken 1526-1789, Budapest, 2005 (Magyarországi diákok egyetemjárása az újkorban 14.), 131.
} 
Dániel, ${ }^{12}$ Régeni Mihály Pál, ${ }^{13}$ Franck Adam, ifj.., ${ }^{14}$ Várfalvi Pálfi Zsigmond, ${ }^{15}$ Kolozsvári Dimjén Pál, ${ }^{16}$ ez pedig kevesebb, mint 2\%-a a vizsgált időszakban Angliában megfordult diákoknak. Ennél is beszédesebb az, hogy az angol heterodoxia neves képviselőivel ápolt 17. század végi személyes kapcsolatok - Henry Hedworth, Newton és Williams Whiston közeli ismerőse volt Várfalvi Pálfi Zsigmondnak - szinte teljességgel eltüntek az erdélyi unitáriusok kollektív emlékezetéből, így a 18. század második harmadában készült és tudós akríbiával megírt Unitario-Ecclesiastica Historiában a felekezet jeleseinek kora újkori angol kapcsolatairól nem találtunk említést. Más kérdés az, hogy a Historia folytatói - a Kozma család - a 18. és 19. századi dokumentumok másolásakor az angoloktól 1821-ben küldött levelet is beiktatták tomusukba. Várfalvi Pálfi Zsigmond 1699. évi peregrinációja után az erdélyi unitáriusok Anglia iránti érdeklődése, a kiéleződő ellenreformációs törekvéseknek is köszönhetően jó néhány évtizedig megszünt, vagy legalábbis látens módon, csak a beavatottak szük körében volt ismert. A németalföldi peregrinusok értesültek a szigetországi történésekről, a fennmaradt levelezésből azonban csak Lázár István esetében tudjuk megállapítani, hogy esetleg egy angliai útról is gondolkodott volna. Lázár 1773-ban tanult Amsterdamban, a londoni unitárius gyülekezet alapítója, Theophilus Lindsey (1723-1808) pedig csak 1774 áprilisában kezdte meg unitárius lelkészi munkáját. Az első angol unitárius gyülekezet temploma, az Essex Hall 1778. március 29-én Londonban nyílott meg, papja Lindsey volt. $^{17}$

Lázár István az angol szociniánusokra vonatkozó információit Johann Joachim Spaldingtól (1714-1804), a neves német lutheránus gondolkodótól kapta. Magdeburgban kereste fel Spaldingot, és püspökéhez intézett beszámolójában a találkozásról egyebek mellett az írta, hogy pártfogója

\footnotetext{
${ }^{12}$ Uo., 165. Szentiványi Márkos Dániel angliai útjáról lásd még: Göмöri György, Angolmagyar unitárius kapcsolatok, UÉ, 1977(XXXI), 4. sz. október-december.; Jankovics József, Szentiványi Markos Dániel nyomában, Megyei Tükör, 1972, 717. sz., augusztus 13. Legújabban: Göмöri György, Kultúránk követei a régi Európában, EditioPrinceps Kiadó, Budapest, 2009, 171-190. Szent-Iványi Sándor, Daniel Szentiványi in England 1665-67, American Hungarian Library and Historical Society, New York 1971. Ez utóbbi tételt nem sikerült megtalálnunk sem az európai, sem az egyesült államokbeli könyvtárakban.

${ }^{13}$ Gömöri, Magyarországi diákok, 291. Lásd még Keserú Bálint, Paulus Michael Rhegenius és a claubergiánus német kartezianizmus = A magyar kartezianizmus 400 éve, Szeged, 1996, 285-296.

${ }^{14}$ Uo., 292. Lásd még B. Kiss Attila, Adam Franck (1639-1717) pályaképe 1-4., KerMagv 2008, 363 kk., 528 kk., 2009, 56 kk., 190 kk.

${ }^{15}$ Uo., 297.

${ }^{16}$ Uo., 48., Lásd még GaAl György, Kolozsvári Dimién Pál (1655-1720), KerMagv 2010, 172 $\mathrm{kk}$.

${ }^{17}$ Twinn, Kenneth, Az első angol unitárius egyházközség megalapitásának 200. évfordulója, KerMagv 1974, 96-100.
} 
nagyon javasolta, hogy Londonba utazzon, az ottani áriánusok meglátogatására. $^{18}$

Lázár valószínű túloz a Johann Salomo Semler (1725-1791) és társai, a poroszországi lutheránus és református lelkészek, illetve tudósok fölfogásának jellemzése során, - unitáriusoknak tartja őket - de semmiképpen nem alaptalan, hogy végső soron valami elvrokonságot tételez föl az iránta tanúsított jó szándékú, befogadó, szolidáris viselkedés mögött. Lázár Spalding tanácsát ugyan nem fogadta meg, és nem került személyes kapcsolatba a szerveződő angol unitárius mozgalom vezetőivel, de Lindsey munkásságát később is érdeklődéssel követte.

\subsection{Az angol levelezési emlékkönyv}

Az EUEGyLt-ból újabban került elő négy kéziratos fólió kötet, Angol levelezési emlékkönyv (a továbbiakban Emlékkönyv) címen. Az Emlékkönyv első részét, az 1825-1867 között folytatott magyar-angol levelezést Buzogány Áron egykori akadémita állította össze azért, hogy az angol-magyar kapcsolatokat dokumentáló anyag lehetőleg egy helyre kerüljön. ${ }^{19} 1868$ ban Buzogány az Emlékkönyvet azzal a meghagyással adta át az Egyházi Képviselő Tanácsnak (a továbbiakban EKT), hogy abba az angol és amerikai korrespondenciát továbbra is bemásolják. Az Emlékkönyvet az EKT határozata értelmében a magyar-angol-amerikai kapcsolatok hivatalos jegyzőkönyvének tekintették és 1911-ig vezették. Az Emlékkönyvet Buzogány Áron kezdte írni a vol. 1., 1-től a 111-ig, majd Benczédi Gergely 1868-tól 1873-ig a vol. 1., 112-től vol. 2., 29-ig folytatta. Benczédi 1873-ban elfoglaltságára hivatkozva lemondott jegyzői tisztségéről. Az EKT Kovács Jánost bízta meg a jegyzőkönyv vezetésével, aki 1873-tól 1894-ig a vol. 2., 30-tól a

18 ,Tiszteletes Spálding urammal is megesmerkedtem, hogy Discursus Gratia más napra mind ebédre, 's mind vacsorára invitáltanak légyen, és ezek, kivált Spálding úr, igen sok jó dolgokat beszéllettek, mind a' berlini, frankfurti etc. tudósokról, 's mind nevezetesen az angliaiakról, és Spálding úr ugyan nagyon jovasolta, hogy Angliában Londonban el-mennék; (utpote ubi certissima plurimos sententiae nostrae de persona J[esu] X[ris]ti, patronos haberem, cum tam ex aliis plurimi, quam etiam Arianorum eruditiores a potiori omnes, sententiam Socini de persona, J[esu] C[hristi] amplexi sunt, referente haec Tiszt. D[omi]no[rum] Spaldingio[rum], qui, uti id abuinde a viris plurimis eruditis audivi, summum cum eruditis Anglicanis habent literarum commercium, et ipse quoque Socinianus, ab orbe e rudito, habetur una cum sociis suis, et primariis viris Beroliensibus etc) ugyan ennek jovaslásából cselekedtem azt is, hogy..." Az Erdélyi Unitárius Egyház Gyüjtőlevéltára (a továbbiakban EUEGyLt) Reg A. Sub. Lit.H. nr. 60. Lázár István - Agh Istvánnak, 1773. október 19. Amsterdam. Nyomtatásban lásd Kovács Sándor, Unitárius egyháztörténet, Kolozsvár, 2009, 175.

${ }^{19} \mathrm{Az}$ angol levelek összegyüjtéséről már 1861-ben döntött az EKT. Jakab Elek, John Paget, Kriza János, Pap Mózsi, Ferencz József és Buzogány Áron tagokat bízták meg az anyag összegyűjtésével. Lásd az Egyházi Képviselő Tanács Jegyzőkönyvét az EUEGyLt-ban (EKT 1861/247.). 
vol. 3., 172-ig folytatta elődei munkáját. Kovács után ismeretlen kéz írt be 82 lapot a vol. 3., 172-től 254-ig, majd 1894-től 1911-ig Boros György végezte a jegyzői teendőket a vol. 3., 254-től a vol. 4., 238-ig). 1911-től Ferencz József vezette a levelezés nyilvántartását, nagyon sok esetben a fogalmazványt ragasztotta be az Emlékkönyvbe, sajnos gondatlansága miatt több lap is megsérült.

A négy fólió, és az ezt kiegészítő autográfok - Angol levelek, Amerikai levelek - Molnár B. Lehel levéltárnok munkájának köszönhetően az utóbbi évtizedben kutatható állapotba kerültek. A kéziratos Emlékkönyv és az Angol és amerikai levelek (autográfok) mellett a kapcsolatok kezdeti korszakának kutatásához felhasználtuk a különféle periodikákban nyomtatásban megjelent anyagokat is.

A magyar unitarizmus angol kapcsolatainak kezdeti történetét elsőként Jakab Elek kísérelte meg összefoglalni 1890-1891-ben megjelent, a Magyar és angol-amerikai unitárius érintkezések e század első felében címü tanulmányában. ${ }^{20}$ Jakab eredményeit is felhasználva Lőrinczy Dénes (1899-1962) akadémita folytatta a kutatást, aki 1923. július 4-én a Unitarian Historical Society felkérésére English Unitarianism and the Hungarian Unitarian Church címen előadást tartott. ${ }^{21} \mathrm{Az}$ angol-magyar kapcsolatok történetét legteljesebben Borbély István irodalomtörténész, teológiai tanár dolgozta fel Simén Domokosról írott szaktanulmányában. ${ }^{22}$ Az 1928 után írott dolgozatok Jakab Elek, Lőrinczy Dénes és Borbély István kutatásaira alapoztak, és lényegében az általuk feltárt eredményeket ismételték meg.

Angol nyelvterületen H. John McLachlan, idehaza ifj. Fabiny Tibor - 1979-ben, Dávid Ferenc halálának 400 évfordulóján a siklósi konferenciára írott - tanulmányát leszámítva, senki nem kutatta érdemben a kezdeti kapcsolatok történetét. ${ }^{23} \mathrm{Az}$ utóbbi években néhány jelentős résztanulmány foglalkozott a kapcsolatok alakulásával, elsősorban a 16. és 17.

\footnotetext{
${ }^{20}$ JАКАв Elek, Magyar és angol-amerikai unitárius érintkezések e század első felében, KerMagv, 1890, 374-389. 1891, 10-42. (A továbbiakban ЈАКАв)

${ }^{21}$ Dionysius LónInCzy, The Hungarian Unitarian Church, Transactions of the Unitarian Historical Society (továbbiakban TUHS) vol. 3., for the years 1923-1926. 20-39, 121-134.

${ }^{22}$ Borbély István, Simén Domokos és kora, KerMagv, 1926, 49-59, 109-131, 210-227. 1927, 49-58, 155-169. 1928, 37-89. (A továbbiakban BorbéLy.) Vö. GÁl Kelemen, A kolozsvári unitárius kollégium története (1568-1900), Kolozsvár, 1935, vol.1, 471-484.

${ }^{23}$ H.J. McLachlan, Links Between Transylvanian and British Unitarians from the $17^{\text {th }}$ Century Onwards, TUHS vol. 17, July, 1980, 73-81. ifj. FABINy Tibor, Accounts and Images of English Unitarians on Transylvania Three Visits: 1859-1879, Acta Litteraria Academiae Scientiarum Hungaricae 21, 1979, 130-143.
} 
századi történésekkel. Balázs Mihály, ${ }^{24}$ Barna József, ${ }^{25} \mathrm{~B}$. Kiss Attila, ${ }^{26}$ és jelen dolgozat szerzőjének ${ }^{27}$ publikációi azonban még alig kerültek be a nemzetközi szakirodalom vérkeringésébe. Az angol-magyar kapcsolatok egyik legkiválóbb ismerőjének, Gömöri Györgynek is csak 2005-ben jelent meg a magyar diákok angol peregrinációját egy kötetben feldolgozó műve, így a korábbi tanulmányok és közlemények nem támaszkodhattak az általa feltárt és összegzett eredményekre. ${ }^{28}$ Részben ennek tudható be, hogy 1979-ben McLachlan a magyar unitárius kapcsolatok 17. századi történetét vázolva, nem lépett túl a már ismert közhelyeken, Várfalvi Pálfi Zsigmond és Adam Franck angliai forgolódását megemlítve le is zárta a korai kapcsolatok történetét, a 19. századi fejlemények ismertetésekor pedig teljes egészében Lőrinczy eredményeire hagyatkozott. David Wykes, a londoni Dr. Williams' Library igazgatója, Pagetről írott tanulmányában az 1850-es évek angol-magyar unitárius kapcsolatairól írt ugyan, de ennek alaposabb elemzésével ő sem foglalkozott. ${ }^{29}$

2005-ben Arthur Long és Alen Ruston vették górcső alá az angol-magyar unitárius kapcsolatok alapdokumentumának számító Unitariorum in Anglia... Brevis Expositio (a továbbiakban Brevis Expositio) címü nyomtatvány genezisét és recepciótörténetét. ${ }^{30}$ A szerzők szerint nem tudni pontosan, hogy a brit unitáriusok mikor és miként értesültek arról, hogy Erdélyben hitrokonaik élnek. Lőrinczy kutatásai alapján a Monthly Repositoryban (a továbbiakban MR) 1811-ben megjelent közleményre, ${ }^{31}$ illetve

\footnotetext{
${ }^{24}$ Mihály BALÁzs, About a copy of «De falsa et vera unius Dei... cognitione» (Additional data to the history of the English connections of the Antitrinitarians of Transylvania), Odredzenie i reformacja w Polsce, Warszawa, 2003(XLVII), 53-64.

${ }^{25}$ József Barna, Máté Dersi's heritage: additions to the reception of Socinianism in Seventeenth century Transylvania $=$ Faustus Socinus and his Heritage, edited by Lech SzczucKI, Kraków, MMV, 443-454.

${ }^{26}$ B. Kiss Attila, i. m.

${ }^{27}$ Sándor Kovács, Contributions to late $17^{\text {th }}$ century relationship of the Transylvanian Unitarians and their co-religionists in England and in the Netherlands = Faustus Socinus... 455-466.

${ }^{28}$ GöмöRI, Magyarországi diákok...

${ }^{29}$ David L. WYKes, John Paget, M.D., of Transylvania (1808-1892), TUHS vol. 17, July, 1980, 54-72. (A továbbiakban WyKes, Paget...)

${ }^{30}$ Arthur Long and Alan Ruston, Unitariorum in Anglia: a Latin Message to Transylvania I-II., TUHS vol. 23, nr. 3, April, 2005, 594-594. nr. 4, April, 2006, 663-670. (A továbbiakban Ruston.)

${ }^{31}$ Unitarians in Transylvania, MR, vol. VI. 1811, 31. A folyóirat 1806-tól 1826-ig Robert Aspland szerkesztésében Monthly Repository of Theology and General Literature címen jelent meg. 1827-től 1831-ig a BFUA megbízásából Thomas Rees (1827 július), majd William J. Fox szerkesztette. A lap címét Monthly Repository and Review of Theology and General Literaturere változtatták. 1831-től 1836. június 18-ig Fox a laptulajdonos és szerkesztő. 1836 júliusától 1837 júniusáig Richard Henry, 1837 júliusától 1838 áprilisáig Leigh Hunt szerkesztette. A lap történetéről lásd: Francis Edward Mineka, The Dissidence of Dissent: The Monthly Repository, 1806-1838 Under the editorship of Robert Aspland, W. J. Fox R. H. Horne and Leigh Hunt. With a
} 
John Kenrick 1820-ban írott, History and Actual Condition of the Unitarians in Transylvania címü cikkére hivatkoznak. ${ }^{32}$ John Kenrick információit Benkő József Transylvania Specialisából, a Siebenbürgische Quartalschriftből, ${ }^{33}$ és egy Göttingenben tanuló erdélyi református diáktól kapta. A református akadémiták közül ifj. Szilágyi Ferenc (1797-1876) volt az egyetlen, aki nem engedelmeskedett az 1819-ben kiadott császári parancsnak, és nem tért haza Erdélybe, hanem beteget jelentett és folytatta tanulmányait. ${ }^{34}$ Minden valószínűség szerint ő lehetett az a „református diák”, akire Kenrick cikkében névtelenül hivatkozott.

Az 1820-as években az angol unitáriusok körében megnőtt az érdeklődés a kontinensen élő hitrokonok iránt. Az 1796-ban alapított Unitarian Fund for the Promotion of Unitarianism by Means of Popular Preaching 1821. június 13-án Londonban, a Parliament Court Chapelben ünnepelte fennállásának tizenötödik évfordulóját. Az ünnepi gyúlésen felvett jegyzőkönyv tanúsága szerint a Unitarian Fund vezető tanácsa a tengeren túl élő hitrokonoknak - itt nemcsak Erdélyre kell gondolnunk, hanem Svájcra, Németországra, Hollandiára, Franciaországra, Indiára és Észak-Amerikára is - kölcsönös ismerkedés reményében megküldte az angol unitáriusok hitelveit, történelmét és szervezetét ismertető Brevis Expositio című latin nyelvü nyomtatványt. ${ }^{35}$

Ruston szerint a Unitarian Fund tagjai nem ismerték a nevükben aláírt levél tartalmát. Arra gondolhatnánk, hogy a Unitarian Fund elnöksége nem sok reményt füzött a nyomtatvány sikeréhez. Hipotézisünket némiképp igazolja, hogy Angliában mindössze egy példánya ${ }^{36}$ maradt fenn a Londonban nyomtatot ${ }^{37}$ Brevis Expositionak, ezzel szemben Erdélyben hat, Berlinben és Párizsban egy-egy példányt sikerült regisztrálnunk. ${ }^{38}$ A szerzőség kérdése is tisztázatlan, Ruston szerint az aláírók, Robert Aspland

chapter on religious periodicals, 1700-1825. (Chapel Hill: University of North Carolina Press), 1944.

${ }^{32}$ Uo., vol. XV., 1820, 193-198.

${ }^{33}$ Andreas THORwäтсHER, Kirchen und Schuletat der Unitarier in Siebenbürgen = Siebenbürgisher Quartalschrift, Fünfter Jahrgang, Hermanstadt, 1797, 1-24. Uö, Von den alten Buchdruckereyen der sozinischen Glaubensverwandten, oder sogenannten Unitarier in Siebenbürgen = Siebenbürgisher Quartalschrift, Fünfter Jahrgang, Hermanstadt, 1794, 264-283.

${ }^{34}$ ZovánYi Jenő, Egyháztörténeti Lexikon, Bp., 1977, 603-604.

${ }^{35}$ Earl Morse Wilbur, A History of Unitarianism in Transylvania, England, and America, Beacon Press Boston, é. n. 149-150. 366. (A továbbiakban Wilbur.); Vö. MR, vol. XVI. 1821, 373.

${ }^{36}$ A londoni Dr. Williams' Library PP 17.2.14 (10) jelzetü kolligátumában.

${ }^{37}$ Alan Ruston tanulmányában azt feltételezi, hogy a nyomtatvány nem Angliában készült. A Brevis 13. oldalán mind a nyomdász, mind pedig a kiadás helye és éve szerepel: Londoni, Prid. Kal. Maj. MDCCCXXI. Typis Ricardi et Arthuri Taylor.

${ }^{38}$ Ruston, i. m., 585. Berlinben a Staatsbibliothekban (Co 6101), Párizsban a Bibliothèque National de France-ban (8-NF-705) maradt fenn egy-egy példány. 
(1782-1845) és William Johnson Fox (1786-1864) aligha tekinthetók a Brevis Expositio szerzőinek.

Robert Aspland ${ }^{39}$ mint lelkész, lapszerkesztő és kiadó számottevő munkásságot fejtett ki az angol unitarizmus történetében. Két jelentős folyóirat alapítása füződik nevéhez. 1805-ben William Vidlertől (1758-1816) átvette a Universal Theological Magazine szerkesztését, és 1806 februárjában Monthly Repository címen adta ki. Aspland szerkesztésében a következő két évtizedben az MR lett a radikális nonkonformizmus és a bibliakritika unitárius szócsöve. A mintegy 1000 előfizetőt maga mögött tudó folyóirat neves szerzők cikkeit közölte, egyebek mellett Thomas Belsham (17501829), John Bowring (1792-1872), Harriet Martineau (1802-1876), Henry Crabb Robinson (1775-1867) írásait. Aspland 1826-ban a szerkesztést átadta az egy évvel korábban alakult British and Foreign Unitarian Association (BFUA) bizottságának, melynek irányítását 1828-ban William Johnson Fox vette át, akinek szerkesztése alatt a MR tulajdonképpen széles olvasótáborra alapozó irodalmi újsággá vált. Az angol unitarizmus eszméit a Christian Reformer, ${ }^{40}$ London (a továbbiakban ChRL) vállalta fel, melyet 1815-től 1845-ig Aspland, 1845-től 1863-ig pedig fia, Robert Brook Aspland, szerkesztett. Aspland szervezői géniusza hívta életre 1805-ben a Unitarian Fundot, 1808-ban a Christian Tract Societyt, 1819-ben pedig az unitáriusok jogait védelmező Association for the Protection of the Civil Rights of Unitarians társaságot. Ő bábáskodott 1825-ben a BFUA születésénél is, és 1841-ig titkára volt a társulatnak.

William Johnson Fox ${ }^{41}$ mint unitárius lelkész és politikus vált ismertté. Az 1825-ben szervezett BFUA külügyi osztálya titkáraként az Egyesült Királyság határain kívül élő unitárius közösségek életét követte figyelemmel. Az erdélyi unitárius kapcsolatoknak nem ő volt a mozgatója, 1821-ben egyike a Brevis Expositio aláíróinak, de egészségi állapota miatt - 1822-ben súlyos idegösszeroppanást kapott - helyét John Bowring vette át. A Brevis Expositiót összeállító vagy megszövegező bizottság tagjairól közelebbit nem tudunk.

\footnotetext{
${ }^{39}$ R.K. Weвв, Aspland, Robert (1782-1845), Oxford Dictionary of National Biography, Oxford University Press, 2004 [http://www.oxforddnb.com/view/article/805]

${ }^{40}$ A lapot 1815-ben The Christian Reformer, or New Evangelical Miscellany címen Robert Aspland alapította. Célja: a reformáció szellemiségének, a sola Scriptura elvének, és az értelem adta szabad vizsgálódásnak hirdetése volt. 1834-től a lap alcíme Unitarian Magazine and Reviewra változott.

${ }^{41}$ R. K. Web, Fox, William Johnson (1786-1864), Oxford Dictionary of National Biography, Oxford University Press, 2004 [http://www.oxforddnb.com/view/article/10047]
} 


\subsection{A Brevis Expositio erdélyi fogadtatása és szerkezete}

Az angol könyvtárakkal ellentétben, Kolozsvárott a Brevis Expositiónak hat nyomtatott és több mint egy tucat kéziratos másolatát tartják számon. 1861-ben Ferencz József Edward Tagartról írt tanulmányában tizenhárom nyomtatott példányt regisztrált. ${ }^{42}$ Az egykori kolozsvári Unitárius Kollégiumi Könyvtár ${ }^{43}$ állományában négy, az Erdélyi Múzeum Egyesület könyvtárában egy, az EUEGyLt-ban pedig egy nyomtatott és egy fénymásolt példányt találtunk meg. ${ }^{44}$ Ez utóbbi az 1990-es években készülhetett, minden valószínűség szerint Erdő János (1913-1996) teológiai tanár, unitárius püspök kérésére. Eredetije valahol lappang. A boríték fénymásolatából, valamint Jakab Elek tanulmányából ${ }^{45}$ megállapítható, hogy ez volt az első példány, amit Aspland és Fox aláírásával 1821. májusában vagy júniusában a kolozsvári szociniánusok teológiát tanító professzorához küldtek. ${ }^{46}$

A Brevis Expositiónak nem nyomtattak sem cím-, sem fedőlapot. Az egy ív terjedelmú nyolcadrét nyomtatvány 1821. április 30-án készült Arthur Taylor londoni nyomdájában. Májusban vagy júniusban postázták, 1821. szeptember 12-én pedig Körmöczi János asztalára került, legalábbis erre következtethetünk a püspöknek a nyomtatvány utolsó, üresen maradt lapjára (15-16 oldal) írt bejegyzéséből: „A[nno] 1821 die 12-a 7-bris acceptae." Jakab Elek szerint a levelet Sylvester György (1786-1829) teológiai tanár kapta, aki az ügy fontosságát felismerve az EKT elé terjesztette, és tulajdonképpen így került Körmöczihez.

1821-et követően a Brevis Expositiónak több példánya is eljutott Kolozsvárra. Kutatásaink során hat nyomtatványt találtunk:

1. Az egykori kollégiumi könyvtár U 57596 jelzetű példánya az 1820as évek végén érkezhetett Kolozsvárra, talán 1827-ben Bowring Molnos Dávidnak vagy Körmöczi János püspöknek küldött levelei valamelyikével. A 13. oldalon Fox neve ki van húzva és helyette a

\footnotetext{
${ }^{42}$ KerMagv, 1861, 187. Buzogány is az Emlékkönyv összeállításakor tizenhárom példányt tartott nyilván.

${ }^{43}$ A Kolozsvári Unitárius Kollégium Könyvtára és Kézirattára az 1948-as államosítás után a Román Akadémia Kolozsvári Könyvtárába került. A kézirattár katalógusát Lakó Elemér munkája alapján 1997-ben adták ki Szegeden. Lásd: The Manuscripts of the Unitarian College of Cluj/Kolozsvár in the Library of the Academy in Cluj-Napoca, Szeged, 1997, vol. I-II.

${ }^{44}$ Az EUEGyLt-ban levő nyomtatvány az Emlékkönyv első kötetében található.

${ }^{45}$ JАКАв Elek, Magyar és angol...

${ }^{46}$ A borítékon a következőket olvashatjuk: „Transilvanie / par Vienne / A. Mons[ieur] le Professeur de Théologie / à l’Université des Sociniens / Autrich a Clausenbourg." Más kézzel a Clausenbourg alatt zárójeleben „(Kolosvar)”. A Transilvanie par Vienne alatt pecsétnyomóval: Payé Paris. Az EUEGyLt-ban levő fénymásolat is az Emlékkönyv első kötetében van.
} 
John Bowringé van beírva: "John Bowring Esq., Unitarian Association Office, 3 Wallrock Buildings, London".

2. Az U 52768 jelzet alatt Bölöni Farkas Sándor 1831-ben Angliában gyüjtött könyvei között is van egy példány a Brevis Expositióból, ennek üresen maradt lapjain Bölöni az angliai és amerikai unitáriusok helyzetére vonatkozó megjegyzéseket tett, ezekre a későbbiekben visszatérünk.

3. Az U 72561 jelzetű füzet Simén Domokos hagyatékában található, nem tudni, hogyan és mikor került Simén tulajdonába.

4. Az U 73056 jelzetü nyomtatvány tulajdonosáról semmi közelebbit nem tudunk.

5. Az EUEGyLt-ban az Emlékkönyvben (vol. I.) levő nyomtatvány lehetséges, hogy a Kriza Jánosé volt, 1822 után küldhették, mert Fox neve itt is ki van húzva és helyette Bowring szerepel.

6. Az Erdélyi Múzeum-Egyesület könyvtárában BCU 91511 jelzetü nyomtatvány possessora Joannis Mayer volt, ezt a példányt is 1822 után küldték Erdélybe.

A nyomtatványok számbavétele után vessünk egy pillantást a kéziratos másolatokra és fordításokra is. A latin másolatok nem bírnak különlegesebb jelentőséggel, ezért csak könyvtári jelzetüket soroljuk fel: MsU 506, 671, 716, 780/D, I, 931/A,C, 1232/B. (Az Erdélyi Múzeum-Egyesület kézirattárában - jelenleg a kolozsvári Egyetemi Könyvtár - Mss 881. jelzet alatt egy latin, az Mss 1264. alatt pedig egy magyar másolat is található.)

A fordításokra több szempontból is érdemes odafigyelni. Kutatásaink során négy fordítást sikerült elkülönítenünk: az id. Kozma Jánosét, a Vargyasi Máté Elekét, a Körmöczi Jánosét és egy ismeretlen fordítóét. A következőkben ezeket ismertetjük.

\subsubsection{A Brevis Expositio és fordítói}

A tizenhat oldalnyi nyolcadrét nyomtatvány nincs szerkezeti egységekre osztva, de öt jól elkülöníthető részből áll. ${ }^{47} \mathrm{Az}$ első rész (1r-3r) rövid dogmatikai összefoglaló az angol unitarizmusról. A szerzők a reformátori örökségre, és „,azon tiszteletre méltó nagy férfiakra” hivatkoztak, akik vallották, hogy a Szentírás a hit és a cselekedetek egyedüli szabályozója, és minden embernek sérthetetlen joga a hit kérdéseiben ítéletet alkotni. Ebből az alapelvből kiindulva tisztították meg a kereszténységet, és állították vissza azt eredeti egyszerüségébe. Ez a reformátorok koráig visszanyúló toposz különösen kedvelt volt az unitáriusok körében is. Eszerint az ős-

\footnotetext{
${ }^{47}$ A teljes magyar fordítást lásd Függelék 1a. sz.
} 
egyház tanainak tisztaságát csak úgy lehet visszaállítani, ha a gyökerekhez nyúlnak, és az egyházat a szentháromság tanától korrumpálatlan, eredeti állapotába állítják vissza. Ezt a munkát az emberben lakozó okosság, a ráció segítségével lehet elvégezni, mi több, Isten igéjének magyarázásában erre kell támaszkodni. ${ }^{48}$ Úgy gondoljuk, nem tévedünk, ha a Brevis okfejtését a közös, Angliában elsősorban John Locke munkásságán átáramló szociniánus örökségben keressük. Az Erdélyben is tanító Joachim Stegmann érvrendszerében találunk a ráció fontosságára utaló hasonló gondolatmenetet, az azonban kizárt, hogy az angolok tőle kölcsönöztek volna. Az erdélyiek nemcsak ismerték, de előszeretettel használták is a stegmanni örökséget továbbgondoló Andrzej Wiszowaty tollán megfogalmazott Religio Rationalist. Meglepő a Brevisben és Religio Rationalisban megfogalmazottak hasonlósága, mégis kevés a valószínüsége, hogy az angolok erdélyi/ lengyel forrásokhoz nyúltak volna, de hogy a szociniánus, John Locke-on is átívelő tradíciót építették tovább, az nyilvánvaló. ${ }^{49}$

Ezután az angol unitárius hitelvek összefoglalása következik: Isten egy, és az Isten szeretet. Néhány közismert lokuszra és a Sömára hivatkozva bizonyították a háromság dogmájának tarthatatlanságát, majd elismételték azt, amit az erdélyiek is az unalomig tudtak: az Atya nagyobb a Fiúnál, a Szentlélek nem önálló személy, hanem Isten hatalmának megnyilatkozása vagy általa adott ajándék. A Názáretbeli Jézus a Krisztus, az élő Isten fia, aki Istentől különbözik, de ugyanakkor egy az Istennel, a kölcsönös akarat egyessége által. Szenvedései, halála „ösztönül szolgálnak a bün eltávoztatására s az igazság tiszteletben tartására", feltámadása záloga a mi feltámadásunknak. Az üdvösség elérése nem a misztériumokban és szimbólumokban, hanem az Isten igéjében és irgalmasságában van. A bün és bűnbocsánat kérdésköre kapcsán kifejtették, hogy mindenkit bűnei arányában ítélnek meg, de miként a törvényhozásban a büntetést nem a boszszú, hanem a megjavulás végett róják ki, úgy Isten is a bűnösök megjavítá-

${ }^{48}$ „(...) Az okosság teendője - írják a Brevis Expositióban -, hogy a kijelentés bizonyítékai felett bírálatot tartson, a Szentírás igaz és kétes igazságú tételeit megkülönböztesse, a valódiak értelméről ítéletet hozzon. Amit az Istentől kijelentettnek ismernek meg, azt a legnagyobb tisztelettel fogadják, s a kegyesség és szeretet kötelességén kívül semmit szentebbnek nem tartanak, mint azt, hogy azon igazságokat, melyeket a szentírásból, annak szorgalmas megvizsgálása után merítettek, nyilván és állhatatosan, de szerényen védelmezzék." JAKAB, i. m. 376-377.

49 "A józan okossággal élő ember, vévén az Isten írott beszédének reguláját (melyen kívül ma egyéb bizonyos beszéde Istennek nálunk nincsen), és azzal helyesen élvén, ...ítéletet tészen, ....amely ítélettel csak az igazságnak hamisságtól való megválasztására való, hogy ki-ki maga hasznára, magának ítéljen. Nem hogy a maga ítéletét hatalommal mások lelkére kösse s regulául tegye: nem lehet senkit annak követésére kénszeríteni..." Keserú Gizella, Andrzej Wiszowaty Religio rationalisa és Erdély = Müvelődési törekvések a korai újkorban. Tanulmányok Keserü Bálint tiszteletére, (Adattár 35.), Szeged 1997, 246. 
sára törekszik: „,hanem hosszan tür érettünk, nem akarván, hogy némelyek elvesszenek, hanem, hogy mindenki megtérésre jusson. (2Pét 3,9b.)"

Az egyetemes üdvözülés már-már univerzalisztikus dimenzióit megnyitva, rövid, de igen fontos leírását találjuk az istentiszteletnek. A diszszenter tradíciónak megfelelően a szertartások különféleségét egyházaikban Pál apostol tanítása szellemében - „A hitben erőtlent fogadjátok be, nem ítélgetvén vélekedéseit (Róm 14,1)" - elnézték, a szeretetet tartván az egyetértés kötelékének.

A Brevis Expositio harmadik része az angol unitáriusok történetét foglalja össze. Az igazság tanúi kezdettől fogva jelen voltak Krisztus egyházában, ezért már a VIII. Henrik „tisztátalan és buja szerelme” következtében a katolicizmustól elszakadt anglikán egyházban is találni proto-unitárius apostolokat. E rész megfogalmazásakor úgy tünik, Lindsey 1783-ban, Londonban kiadott An Historical View... címú munkájára támaszkodtak. ${ }^{50} \mathrm{Az}$ unitarizmus első mártírjai Angliában Joan Bocher (Joan of Kent) (?-1550) és Bartholomew Legate (1572-1612) voltak. Az első vértanúk után a 17. század legnevesebb heterodox gondolkodóit mint az unitarizmus korai bajnokait mutatták be. A türelem és polgári szabadság buzgó védője, John Locke, „,szerencsésen munkálkodott nemcsak az emberi ész természete és művei előadásában, de az okosságnak az Isten igéje magyarázásánál törvényes jogába visszahelyezésében is". Locke és fegyvertársai alkotják azt a láncszemet, mely összeköti a magyar, a lengyel, a németalföldi és az angol heterodoxiát. Locke, Newton, William Whiston, Samuel Clarke nevének felsorolása után a londoni első - nevében is - unitárius gyülekezet alapítója, Theophilus Lindsey bemutatása következett.

A Brevis Expositio negyedik részében az unitáriusokkal rokon felekezeteket, a presbiteriánusokat, independenseket és baptistákat ismertették, illetve azt, hogyan hatott az egyistenhit a disszenter egyházakban és kik voltak első apostolai. Az independensből unitáriussá lett „mind maga századában, mind minden más századokban híres philosophus", Joseph Priestley angol fizikus és vallásreformátor életpályája után az unitárius société alakulásáról szóltak. Először a The Unitarian Society, for Promoting Christian Knowledge and the Practice of Virtue by the Distribution of Books, majd az Unitarian Fund célkitüzéseit ismertették.

A közlemény utolsó, befejező részében az ír misszióról és a teológiai irodalom alakulásáról számoltak be. Az unitarizmus jövőjét, töretlen fejlődését a bibliakritika és a tudományok fellendülésében, illetve ezek hasznosításában látták.

\footnotetext{
${ }^{50}$ Theophilus Lindsey, An Historical View of the State of the Unitarian Doctrine and Worship from the Reformation to Our Own Times. (With some account of the obstructions which it has meet with at different Periods), London, 1783. (A továbbiakban LinDSEY.)
} 
Az erényesség és az emberiség boldogulása, valamint az unitárius kereszténység megismertetése érdekében az Unitarian Fund a világ különböző részein élő hasonló társulatokkal kíván kapcsolatba lépni. A Madrászban és az Amerikai Egyesült Államokban élő unitáriusok megemlítésével véget ér a Brevis Expositio. (Az erdélyiek, noha földrajzilag közelebb voltak Angliához, mint az indiaiak vagy amerikaiak, mégsem kaptak helyet az Unitarian Fund által rajzolt unitárius földabroszon.)

\subsubsection{Az ángliai unitáriusok hitének históriája. Idős Kozma János fordítása}

Az egykori kollégiumi könyvtár MsU 934, 1074 számú kéziratai nemcsak tartalmukban, de kötésükben is egyeznek, egészen biztos, hogy egy „műhelyben” készültek. Az MsU 934-es jelzetü , Az Ángliai Unitáriusok Hitének Históriájának 's jelenlévő vagy mostani állapottyának rövid ki tétele címü kézirat hátsó borítóján 1826. május 29-i dátummal a fordító az énlaki Sala Sámuel ítélőbírónak ajánlotta művét, az: „Angliában, Scotiában, Cambriában, Madrasban, Északi és Napkeleti Amerikában isteni lélek sugárlása által magokat kinyilatkoztatott és mi hozzánk erdélyi unitáriusokhoz megjelentetett unitária szent és nemes eklézsiáknak lelki örömet hozott tudósító újságlevelét". Az első borítóra a címnegyed fölé, ugyanaz a kéz fölírta: "Hatvanötödik példány vagy exemplár." Az MsU 1074-es címlapja hasonló: "Százhuszonnegyedik exemplár vagy példány". Kozma János id. pártfogóinak lelki vigasztalására nemcsak az Az ángliai unitáriusok hitének históriáját másolta vagy másoltatta le százhuszonnégy vagy még annál is több példányban, hanem Sylvester György latin nyelvű válaszlevelének fordítását is. $A z$ angliai unitáriusokhoz küldött levélnek tizennyolcadik darabja maradt fenn Kozma másolatában. Az 1828-ban írott ajánlás Lázár Sámuelnek, a kolozsvári unitárius kollégium felügyelő gondnokának szólt. ${ }^{51}$ A magyar nyelvű kéziratokat vizsgálva megállapíthatjuk, hogy Kozma fordítása örvendett a legnagyobb népszerüségnek. Az MsU 2011. és MsU 859. számú kéziratok is Kozma fordításának másolatai. Az MsU 859 hetedik levelére 1822-ben Kriza János torockói kisdiák, későbbi unitárius püspök ezt jegyezte fel:

„Ezen levél Deák nyelven jött nyomtatásban 1821-ben szeptember 12-én. Az originál nyolc levél nyolcadrétben. Leírta Thoroczkón N[agy] Ajtai Kriza János Etymologista az 1822-dik esztendőben 9-bernek 18-dik napján."

\footnotetext{
${ }^{51} \mathrm{MsU}$ 508. „Nemes Háromszékben Erdővidéki nagyajtai, mostan Kolozsváron rezideáló méltóságos Lázár Sámuel Úrnak Főtisztelendő konzisztóriumunk egyik érdemes konzisztorának és nemes ottani kollégiumunk egyik hív inspektorának lelki vigasztalására. Id. Kozma János mp. Nagy Nyulasi Unitárius administrator és adsessor által 1828-ban 22 Januarii ajánlott."
} 
A tizenegy éves kisdiák alighanem kedvtelésből másolta le a Brevis Expositio fordítását. Talán nem véletlen, hogy negyven évvel később éppen az ő püspöksége alatt kezdődött el az angol kapcsolatok tervszerü és szervezett kiépítése. Kriza 1861. október 5-én keltezett és Simén Domokos angol akadémitának küldött levelében egyebek mellett ezeket írta:

„Én részemről azon fogok működni, hogy viszonyunk minél szorosabbá tétessék (...) valamint, hogy eleitől fogva, már deákságom óta semmit sem óhajtottam inkább, mint ezen, már Istennek hála, folyamatba jött érintkezést." ${ }^{\prime 52}$

Az idézett levélrészlet alapján messzemenő következetést nem vonhatunk le, de néhány további bizonyíték nyomán feltételezhetô, hogy a torockói partikula diákja tanárától, Sebes Páltól (1786-1864) kapott ösztönzést a szigetországban élő unitáriusok históriájának tanulmányozására. A bányaváros unitárius iskolaigazgatója biztosan érdeklődött az angol-magyar viszonyok alakulása iránt, és ezt értelmesebb diákjaival és püspökével is alkalomról-alkalomra megbeszélhette. Feltételezésünk igazolására Körmöczi János püpsök 1824-ben Sebes Pálhoz küldött leveléből idézünk:

„Még egy van, amit megírni jónak látok: mü írtunk az Angliai Atyafiaknak levelet, és abban amit a környül állások megengedtek, de reali existentia nostratum istic in Transylvania vagyon emlékezet, ha ez is in paribus v. copiis meg marad az Ecclesia Ládájában nem lesz superfluum meg valaha egy gondos Atyafi szemei előtt, csakhogy minden változás nélkül maradhasson meg ott." 53

\subsubsection{Vargyasi Máté Elek fordítása}

A második fordítás Vargyasi Máté Elek könyvgyüjtő tudós pap nevéhez füződik. Máté Eleket 1786-ban szentelték pappá. Csokfalván, Abrudbányán és Tordán volt lelkész, de gyenge egészségi állapotára hivatkozva 1805-ben utolsó állomáshelyéről nyugalomba vonult, Kolozsvárra költözött, ahol a régi kéziratok és könyvek között töltötte idejét. Nevéhez füződik az a kéziratban maradt magyar nyelvü Egyházi rendszabások..., mely 1824-ig bezárólag kodifikálta az unitárius joggyakorlatot. ${ }^{54}$ Kiváló egyháztörténeti ismeretei mellett fordítással is foglalkozott, és Owen... János tudós angluj poëta epigrammáinak fordittasa J. Mathe Elek által címen 1823-ban magyarul tolmácsolta az „angol Martialis” epigrammáit (MsU 856), néme-

\footnotetext{
${ }^{52}$ BorbéLy, i. m., 1928, 70.

${ }^{53}$ Körmöczi János Sebes Pálnak 1824. szeptember 14. Kolozsvár, MsU 780/A 43-45.

${ }^{54}$ Vargyasi MáTé Elek, Egyházi rendszabások melyek az erdélyi keresztény unitária eklézsiák, oskolák, és az egyházi itélooszékeken inditandó per folyásának igazgatására, szentírásbeli helyekböl, hazai sarkallatos törvényekböl, császári-királyi függóppecsétes levelekből (diploma), fejedelmi dekrétumokból (rescriptum), guberniumi végzésekböl, tudtára adásokból (intimatum) és fökonzisztóriumi határozásokból egybeszedegettek és IV. darabokban rendbe szerkesztettek, Kolozsváratt, 1824-ben. (Kézirat az Unitárius Püspökség Kolozsvári Könyvtárában.)
} 
lyiket egészen mesteri módon. ${ }^{55}$ A MsU 931/A-B jelzetü kézirat a Brevis Expositio másolata, illetve annak Az ángliai unitáriusok hitének, históriájának, jelenlevő állapottyának rövid kitétele címü fordítása.

\subsubsection{Az Angliában vagy Britániában és Scotiában lévő unitáriusokról}

A harmadik fordítás - MsU 780/J - a Körmöczi Jánosé. Címe: Az angliai unitáriusok hite, s históriája jelen való állapotjának rövid elöterjesztése. A Brevis Expositió nem véletlenül került a püspök és a konzisztórium asztalára. Körmöczi angol szimpátiája régi gyökerü, az egyházfő már akadémita korában jegyzeteket készített a szigetországban élő hitrokonokról. Az MsU 424. számú kézirata valószínűleg Körmöczinek Göttingenben készült feljegyjegyzéseit tartalmazza. Benczédi Gergely adta az autográfnak a Körmöczi János akadémiai jegyzetei címet. Ennek első hosszabb része Európa históriája politikai tekintettel címü, 123 oldalnyi kézirat. Csetri Elek szerint Körmöczi János Georg Christian Gebauernek Johann Georg Meusel által átdolgozott munkája alapján (Anleitung zur Kenntniss der europaeischen Staatenhistorie), állította össze kéziratát. Ebben megemlékezik arról, hogy Európa históriájának első megírója az úttörő Samuel Puffendorf volt, aki 1680-ban kiadott munkájával szerzett magának hírnevet; Gebauer és Meusel csak követték őt. A második rész Az Angliában vagy Britániában és Scotiában lévő unitáriusokról új dátumok (a továbbiakban Új dátumok...) Csetri megállapítása szerint 1787-ben Kolozsvárott íródott. ${ }^{56}$

Szerintünk a kéziraton olvasható 1787-es dátum nem a keltezésre, hanem Gottlieb Jakob Planck Neueste Religions-Geschichtejének kiadására vonatkozik. ${ }^{57} \mathrm{Az}$ Új dátumok... tulajdonképpen Planck müve hetedik fejezetének fordítása. ${ }^{58}$ Planck ismerte és használta August Wendeborn Der Zustand des Staats, der Religion... in Grosbritannienjének az angol unitáriusokra vonatkozó fejezetét. ${ }^{59}$ Mind Wendeborn, mind pedig Planck bőven

\footnotetext{
${ }^{55}$ Owen magyar recepciótörténetével foglalkozott Maczelka Csaba, A két John Owen - $a$ költő és a teológus - hatása magyar értelmiségiekre, emlékkönyveik révén. A MTA ITI Reneszánszbarokk kutatócsoportjának Misszilis és fiktív levelek; naplók, emlékkönyvek, dedikációk és alkalmi feljegyzések a régi magyar irodalomban címü konferenciáján (Körmend, 2010. május 26-29.) elhangzott előadás. Köszönöm a szerzőnek, hogy megjelenés előtt álló dolgozatát rendelkezésemre bocsátotta.

${ }^{56}$ CSETri Elek, Körmöczi János írásai (kézirat), 38. (A szerző kéziratát kiadásra átadta az Erdélyi Unitárius Egyháznak, de erre még nem került sor.)

${ }^{57}$ Gottlieb Jakob Planck, Neueste Religions-Geschichte, Lemgo: Meyer, 1787-1793.

${ }^{58}$ Uo. A hetedik fejezet címe: Nachricht von den Unitariern in Grosbritannien, 445-478.

${ }^{59}$ Lásd August Wendebonn, Der Zustand des Staats, der Religion, der Gelehrsamkeit und der Kunst in Grosbritannien gegen das Ende des achtzehnten Jahrhunderts, Berlin: Spener, 1785-1788 müvének az angol unitáriusokra vonatkozó fejezetét Unitarier, Arianer, Socinianer, Arminianer 271-296. Wendeborn magyar fordítását lásd: Nagy Britanniának egyházi, polgári és tudománybéli állapotja a $a^{\prime}$ XVIII-dik század vége felé. D. Wendeborn Gebhard Friderik Ágoston', londoni predikátor'
} 
merített Lindsey An Historical View... címü, az unitárius eszme fejlődéstörténetét bemutató könyvéből, és így Körmöczi akaratlanul is Lindsey müvének első magyar tolmácsává lépett elő. ${ }^{60} \mathrm{~A}$ felvilágosult püspök számára az angol unitarizmus nem volt terra incognita. Azt nem tudjuk, mennyire ismerhette a kelet-közép-európai heterodoxia korai angol kapcsolatait, de azzal minden bizonnyal tisztában volt, hogy peregrinus elődei már az 1650-es években áthajóztak a csatornán. A holland, majd később a német egyetemeken megforduló diákok nagy része tervezte az angol szociniánusok meglátogatását. Az unitárius peregrinusok ismerhették Krzysztof Crell (Spinovius) kéziratban maradt Epistola de statu Unitariorum in Angliáját, ha mégsem, akkor németalföldi jóakaróik világosították fel őket arról, hogy a szigetországban szociniánusok élnek. (Lásd Samuel Crell, majd fél évszázaddal később Lázár István leveleit). ${ }^{61}$ Lázár Körmöczinek küldött egyik leveléből arra következtethetnénk, hogy a göttingeni peregrinus valamiféle összeköttetésben állt a londoni unitáriusokkal. 1797. július 30-án kelt levelében kérdi Lázár István Körmöczitől:

„A londoni unitárius papnak vette-e a tisztelendő úr levelét? S ha igen, mit írt valami nevezetest? Ezekről jó szívvel venném tudósító levelét." 62

Az, hogy Körmöczi levelezett a londoni unitárius pappal, nem zárható ki teljességgel. Hagyatékában egyelőre nem találtunk Lindseynek küldött vagy tőle kapott levelet. Lindsey kiadott leveleiben nincs utalás Erdélyre és az ott élő unitáriusokra. ${ }^{63} \mathrm{Az}$ egyetlen Erdélyre vonatkozó adat az említett An Historical View... címú múben olvasható. A Dávid Ferenc és Fausto Sozzini közötti krisztológiai vita ismertetésekor egy lábjegyzetben Kolozsvár kapcsán Lindsey megjegyezte, hogy jól megerősített város, és hogy a szociniánusoknak itt - 1755-re utal - jól múködő iskolájuk és nyomdájuk

munkája szerént rövid summába foglalta Zigán János, Pesten, N. Kiss István könyvtárosnál, 1808., 102-104.

${ }^{60}$ Vö. Az Új dátumokat... LindSEY, i. m. következő részeivel: 479-486, 498-515, 529-551.

${ }^{61}$ Kovács, Contributions... 455-466.

${ }^{62}$ Boros György volt az, aki Körmöczi és Lindsey esetleges kapcsolatára felhívta a figyelmet. Az Emlékkönyv első kötete első lapján a következő széljegyzetet tette: „Az angolokkal való érintkezés jóval korábbi nyomára akadtam Lázár István püspöknek Körmöczi János későbbi püspökhez Göttingába írt levelében. Minthogy tudtommal ismeretlen volt az előbbi érintkezés, szó szerint ide iktatom a levélből (...) Ebből tisztán kivehető, hogy Körmöczi levelezésben állott egyik angol unitárius pappal 1797-ben, tehát összeköttetésünk csaknem egybeesik az angol unitárius név használatával s az első gyülekezet megalakulásával. 1912. július 3. Boros György." Nyomtatásban csak 1924-ben közölte észrevételét. Vö. Boros György, Száz esztendő az unitarizmus múltjából, KerMagv, 1924, 219. Angol nyelven Ferencz József írt egy rövid értekezést a kérdésről, lásd Essex Church and Hungarian Unitarianism, The Inquirer, January 26, 1935, 44.

${ }^{63}$ H. McLachlan, Letters of Theophilus Lindsey, Manchester: The University Press, 1920. Uö. More Letters of Theophilus Lindsey, TUHS, 3/4 (1923-1926), 361-377. 
van, és lélekszámuk is számottevő. ${ }^{64}$ Ha Lindsey nem is tudott részleteket a 18. század közepén Kolozsvárott élő unitáriusokról, a Dávid-Sozzini közötti vita leírásával kárpótolta olvasóit a közelmúlt magyar unitárius vonatkozásainak hiányos ismeretéért. Az Essex Street unitárius lelkésze könyvének harmadik részében egy egész fejezetet szentelt a Dávid Ferenc és Fausto Sozzini vitájának. Az On the Controversy Betwixt Francis Davides and Faustus Socinus, Concerning the Worship of Jesus Christ ${ }^{65}$ fejezet megírásakor Lindsey két forrásból is merített - Sozzini ${ }^{66}$ valamint Johann Lorenz von Mosheim ${ }^{67}$ múveiből -, és a gyér adatok alapján tudóshoz méltó akríbiával ismertette a történteket. Sajnálattal állapította meg, hogy minden erőfeszítése ellenére alig talált adatokat Dávid Ferencet illetően. ${ }^{68}$ Ennek ellenére világosan látta, hogy a magyar unitáriusok püspöke munkatársai - Jacobus Palaeologus, Johann Sommer és Matthias Vehe Glirius - nyomán fogalmazta meg nonadorantista doktrínáját. ${ }^{69}$

A Dávid-Sozzini vita ismertetését követően a nonadorantizmus kérdését fejtegette az Of Socinus's Behavior Towards Other Unitarians, Who Refused, and Opposed the Worship of Jesus Christ ${ }^{70}$ címü fejezetben is. Itt a Sozzini-Węgrovszki polémia kapcsán mondatja ki az előbbivel, hogy a nonadorantista tanok megfogalmazója tulajdonképpen Palaeologus volt. ${ }^{71}$ Ha Lindsey Krisztus nem imádása tárgyában végzett kutatásai során írott megállapításait összehasonlítjuk magyar kortársai ugyanabban az időben megfogalmazódó koncepciójával, legjobb esetben is csak mosolyogni tudunk a Kénosi Tőzsér János és Uzoni Fosztó István tollán életre kelő, egyházáért mártíriumot is vállaló magyar püspök naivságán. E beállítás szerint Dávid Ferenc tulajdonképpen galád jezsuita ármánykodás áldozata, aki meggyőződése ellenére hirdette a nonadorantizmus tanát. A szerzők szerint Dávid Jézus istenségének tagadásával éppen azt akarta elérni, hogy "Krisztus tisztelete és dicsősége... még jobban kidomborodjék" ${ }^{72}$

\footnotetext{
${ }^{64}$ LindseY, i. m., 154.

${ }^{65}$ Uo., 154-193.

${ }^{66}$ Fausto SozzinI, De Iesu Christi Invocatione, Krakkó, 1595.

${ }^{67}$ Johann Lorenz von Mosherm, Institutiones historiae christianae, Helmstedt, 1739.

${ }_{68}$ "I have sought much to obtain some information concerning this excellent person, and sufferer for the truth of Christ, Francis Davides: who in that early day bore such a constant and well supported testimony to the one only true God and Father of all, and to the worship of him only; but have been able to glean very little. " LiNDSEY, i. m., 165.

${ }^{69}$ LiNDSEY, i. m., 163.

${ }^{70}$ Uo., 194-211.

${ }^{71}$ Uo., 202.

${ }^{72}$ Kénosi Tőzsér János - Uzoni FoszTó István, Az erdélyi unitárius egyház története I., ford. Мárкоs Albert, a bev. tanulmányt írta, a ford. ... egybevetette BALázs Mihály, sajtó alá rendezte Hoffmann Gizella, Kovács Sándor, Molnár B. Lehel, Kolozsvár, 2005. (Az Erdélyi Unitárius Egyház Gyüjtőlevéltárának és Nagykönyvtárának kiadványai 4/1.), 298.
} 
Térjünk vissza Körmöczihez és a Brevis Expositióhoz. Általánosságban a mindenkori unitárius püspökről elmondható, hogy kezét az európai heterodoxia érverésén tartotta, és figyelemmel követett minden szociniánus/ ariánus megmozdulást. Lázár István halála után Körmöczi János került a püspöki székbe, és elődeihez hasonlóan élénk levelezést folytatott a peregrinusokkal. 1817-ben Derzsi Kanyaró Mihály tanult Göttingenben. Körmöczi arra utasíthatta fiatal papját, hogy látogasson el Angliába. Sajnos a Kanyarónak küldött levél nem maradt fenn, csak a püspöknek írott válasz. ${ }^{73}$ Ebben az angliai zavargásokra, pénzügyi nehézségeire és tetemes kiadásaira hivatkozva az ifjú kibújt az utazás alól. Az igazsághoz az is hozzátartozik, hogy Kanyaró a ráfordított pénzt elherdálta, és egyházának is rossz hírét keltette azzal, hogy Kőrösi Csoma Sándortól is kölcsönkért, mi több, az összeget sem fizette vissza. ${ }^{74}$ Ezek után érthető az az öröm, amit 1821-ben a Brevis Expositio szerzett az unitárius konzisztóriumban. Az elszigeteltségben létéért küzdő felekezet mint mentőövbe kapaszkodott az újra felfedezett angol rokonságba. Körmöczi hiába rajzolt Új dátumaiban árnyalt képet az angol unitarizmusról, a Brevis Expositio valóságos eufóriát gerjesztett. Az angol unitáriusok történelemfilozófiáját az erdélyiek minden fenntartás nélkül átvették, noha Körmöczi püspök Planck múvéből készített fordításában óva intett a túlzásoktól.

\subsection{Az Angliában élő unitáriusokhoz küldött epistola}

Az erdélyi unitáriusok hosszas tanácskozás után Sylvester György neve alatt latin nyelvủ levélben válaszoltak az angoloknak. ${ }^{75}$ Szigetországi hitrokonaikhoz hasonlóan, religiójuk kontinuitásának kimutatására törekedtek. Ezt nemcsak, és nem elsősorban az angol minta inspirálta, hanem a Kénosi Tőzsér János és Uzoni Fosztó István tollán megfogalmazódó, és az 1800-as évekre általánosan elfogadott elv az unitarizmus kárpát-medencei őshonosságáról. Érdemes összehasonlítani az Epistola bevezető részét a Kénosi-Uzoni-féle egyháztörténet második, Az unitárius vallás keletkezése Erdélyben címủ fejezetével. ${ }^{76}$ A szó szerinti szövegátvétel mellett a Historia

\footnotetext{
${ }^{73}$ Kanyaró Mihály Körmöczi Jánosnak, 1817. augusztus 7., Göttingen, Körmöczi hagyaték, EUEGyLt

${ }^{74}$ Vö. Csetri Elek, Körösi Csoma Sándor indulása, Bukarest, 1979, 195-201.

${ }^{75}$ Címe: Epistola ad Unitarios in Anglia missa. Georgius Sylvester, apud Unitarios in Transilvania Claudiopoli S[acro] S[anctae] Theologiae Professor p.o. Unitatis Dei in Anglia Assertoribus. Salutem a Deo Patre et Domino Jesu Christo apprecatur. (A továbbiakban Epistola.) Magyar fordítását lásd Függelék 1b. sz.

${ }^{76}$ „Őseinktől az öregekre, tőlük a ránk szállott hagyomány így szól: 1540-1541 körül Kolozsvár lakosai a katolikus vallásról a lutheránusra tértek. Ez minden kétséget kizárólag igaz. Körülbelül öt évig a lutheránus vallást követték, azután pedig az unitárius vallásra tértek volna át. Ebben nagy munkás volt egynéhány férfi, legmunkásabb pedig Dávid Ferenc. Ő fölállt
} 
szerkezetét is felismerhetni az Epistolában. ${ }^{77}$ Az egyházzá alakulás elnagyolt története után a felekezet jeleseinek portréját festették meg, majd a szertartásrendről, a patrónusokról és az iskolák állapotáról szóltak, a terjedelmi korlátok miatt természetesen nem a Históriához hasonló részletességgel.

A felekezet nagyjai sorában, Dávid Ferencen és Giorgio Biandratán kívül Enyedi György és Szentábrahámi Lombárd Mihály kapott helyet.

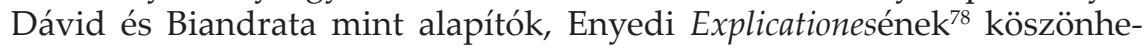
tően, Szentábrahámi pedig főmüve, a Summa Universae Theologiae ${ }^{79} \mathrm{kap}$ csán került be az említésre érdemesek sorába. Ugyanakkor Szentábrahámi müve hídként is szolgált a kelet-közép-európai heterodoxiába való betagolódáshoz. Roppant érdekes, hogy miközben a Summára, mint az erdélyi unitárius teológia sarkcsillagára hivatkoznak, meg sem kísérelik a hitelvek összefoglalását. Míg a Brevis Expositio jól kidolgozott dogmatikai fejtegetéssel kezdődött, az Epistolában nyoma sincs teologizálásnak, egyetlen nagyvonalú utalással Samuel Friedrich Bock porosz szociniánusokról írott múvére ${ }^{80}$, s az abban foglalt dogmatikai princípiumokra hivatkoznak. ${ }^{81}$

egy kerek kőre, mely akkor a Torda utcában, most ugyanannak az utcának a túlsó sarkán áll, onnan beszédet tartott, s hirdette amaz egyedülvaló Istent. Itt az összegyưlt nagyszámú sokaságnak oly nagy hatással prédikált, hogy a hallgatóság, sőt Heltai Gáspár első pap helyeslése közepette a város papjának választották, s a piacon álló, de még egészen be nem fejezett székesegyházba vitték, itt a szószéket neki fölajánlották. Azután az egész várost a maga és az ő hitfelei vallására térítette..." KÉNosı-UzonI, i. m., 149.

${ }^{77} \mathrm{Az}$ Epistola szerint:

„Ezen szájról szájra lett által adás, mely jött eleinkről az öregekre azokról üdővel reánk, tanítja: Kolozsvár (mely anya városa Erdélynek) lakosai 1540-ben és 1541-ben esztendők körül a R. Catholica vallásról által menének a Lutheránára. És mint egy öt esztendeig Lutheránusok lévén azután unitáriusok lettek némely férfiaknak kiváltképpen Dávid Ferencnek munkálkodásából.

Mert ez egy kerek kőről Torda utcában prédikálván midőn egyedül az Atyát állítana amaz egy Istennek; sokak öszvetódulásában oly szerencsésen tanított, hogy az hallgató nép, sőt a plebánus Heltai Gáspár közhelybe hagyásával is a város papjának kikiáltatott, és a piaci nagy templomba vezettetvén katedrát, sőt az egész város az ő vallására állott." MsU 508. Az Angliai Unitáriusokhoz Küldött Levél. Kolozsvár, 1822. A címnegyed fölött id. Kozma Jánosra vallóan: Tizennyolcadik példány vagy Exemplár. A kéziraton nincs ajánlás, fordítója ismeretlen.

${ }^{78}$ EnYEdi György, Explicationes locorum Veteris et Novi Testamenti, ex quibus Trinitatis dogma stabiliri solet, [Claudiopoli 1598, typ. Heltai]. RMNY 836.

${ }^{79}$ Summa universae theologiae Christianae secundum Unitarios, in usum auditorum theologiae concinnata et edita, Claudiopoli, typis Collegii Reformatorum, MDCCLXXXVII.

${ }^{80}$ Samuel Friedrich Воск, Historia Socinianismi prussici, maximam partem ex documentis MSStis. (Königsberg: Hartung, 1754)

81 „Ezen theológia dogmaticum principiumai meg vagynak a számkivettetett lengyelek confessiójában melyet a brandenburgiai electornak ajánlottak volt, 's amely Erdélyben több fejedelmek által megerősíttetett szóról-szóra megtaláltatik Bock Fridrieck Sámuelnek a Burgus Socinianismus históriája 71-ik és következendő lapjain, ki jött Regio Montumban 1754ben." MsU 508. 
Kolozsvárott az Epistolának több szövegváltozata maradt fenn. Körmöczi hagyatékában találtuk meg azt az annotált autográf kéziratot, melyben a püspök éppen a rögzített hitelvek feletti nagyvonalú elsiklást kifogásolta hitfelei részéről. Az Epistolában az erdélyiek azt sugallták, hogy hitük teljesen megegyezik az angol unitáriusokéval. A püspök, az egyház legfőbb őreként, nem tudta elfogadni az efféle általánosításokat, ezért a válaszlevél elküldése előtt jónak látta tisztázni a teológiai kérdéseket. A British Libraryban találtuk meg azt a Confessiót, ${ }^{82}$ melyet Körmöczi 1822. november 29-én válasz gyanánt küldött a Brevis Expositiora. (A Confessiót az unitárius peregrinusok is gyakran osztogatták diáktársaiknak, arra is van példa, hogy kelendősége miatt Amsterdamban újólag kinyomtattatták. $)^{83} \mathrm{~A}$ püspök a Confessiót az angolok figyelmébe ajánlotta, és a nyomtatvány utolsó üresen maradt oldalán rövid levelet is írt hittestvéreihez.$^{84}$ Ebből az derül ki, hogy Sylvester György már elküldte a részletes információkat tartalmazó válaszlevelet, ezért a püspök csak arra szorítkozik, hogy a jövőbeni kapcsolattartás érdekében a levélvívő fiatalembert, Binetz Sándor nyeregkészítőt ajánlja jóindulatú figyelmükbe. ${ }^{85}$

A Sylvester György Epistolájával párhuzamosan Körmöczi János püspök és Nagy Lázár (?-1837) ${ }^{86}$, a kolozsvári kollégium felügyelő gondnokának is levelet küldött Angliába. Bizonyára téved Jakab Elek amikor azt állítja, hogy az EKT által 1822. június 1-jén jóváhagyott Brevis Expositiot a

\footnotetext{
${ }^{82}$ Confessio Fidei Christianae Secundum Unitarios, inter quator in Transylvania Religiones receptas numerata Fundamentalibus Patriae istius Legibus, Diplomatibus, variisque Rescriptis Caesares, verbis Regiis Capitulationibus Principium confirmata, Cibinii die 27. Xbris, Anno 1782. A British Libraryban jelzete: 4224.e.22. (A továbbikban Confessio.)

${ }^{83}$ GÁL Kelemen, Lázár István püspök és külföldi egyetemi tanulmányai, Unitárius Naptár, 1931, 92-102.

${ }^{84}$ „In sequelam epistolarum, Londonii, Prid. Kal. Maji MDCCCXXI., Typis Ricardi et Arthuri Taylor datarum e postulato vestro pro commercio epistolarum habendo pergratum vobis futurum intelleximus, si certiores fecetis in quibusvis orbis terrarum partibus existere Unitarios. Praestitit responsum Rev. Georg Sylvester, Pastor hujus, dum vobis traditae sint necne ignoramus, his lineolis ergo accipite: centum triginta et aliquot esse ecclesias Unitarias in Transylvania, quadraginta quinque milla animarum complectentes quae animo pergarato epistolam vestram acceperunt; hinc factum est ut juvenem bonae indolis Alexandrum Binetz ephippiarium eo inviavimus, ut commercio literis magis frui nobis liceat, quem vobis commendatum de meliori volumus. Claudiopoli, 29, 9br., 1822. Johannes Körmöczi mp., Superintendens Unitariorios in Tranylvania." Confessio, British Library, jelzete: 4224.e.22.

${ }^{85}$ Binetz Sándor valószínủleg a kolozsvári unitárius templom építésében is részt vállaló, naplóíró Binetz Istvánnak lehetett a fia. Életéről egyelőre közelebbi adatunk nincs. Vö. Kolozsvári dolgok a XVIII. század végéról, Ellenzék, 1902. augusztus 26, 193. sz.

${ }^{86}$ Nevéhez fűződik a kolozsvári magyar színház építtetése és történetének megírása. Vö. $A z$ erdélyi magyar színészet hőskora 1792-1821. Nagy Lázár visszaemlékezései (Erdélyi Ritkaságok 1. sz.), Bev. ellátta Dr. JANcsó Elemér, Kolozsvár, 1939.
} 
konzisztórium csak 1825-ben postázta. ${ }^{87}$ A Unitarian Fund 1823. május 21-i gyülésén arról számoltak be, hogy Sylvester György levele megérkezett, és közlését is kilátásba helyezték. Sem Jakab Elek, sem Buzogány Áron nem említi a Nagy Lázár felügyelő gondnok által írt azonnali választ, melyet az angolok a Unitarian Fund évi közgyülésén 1822. május 29-én felolvastak, és amelynek latin eredetijét az MR 1822 júliusában (437-438), angol fordítását pedig a ChRL augusztusban közölte (253-256).

\subsubsection{Mit írt Nagy Lázár az angoloknak?}

A Brevist aláíró R. Aspland és W. J. Fox a kolozsvári szociniánusok teológiát tanító professzorához címezték levelüket. Nagy Lázár első mondatával tisztázta, hogy az erdélyiek nem szociniánusok és nem Miguel Servet (1511-1553) követői, hanem az ország törvényei által bevett unitárius felekezet tagjai. ${ }^{88}$ Mind a Nagy-, mind pedig a Sylvester-féle levélben megfigyelhető a felekezet jogállásának szinte kétségbeesett igazolása. Az évszázados elnyomás után szinte kérkedtek a recepta religio rendszerét körülbástyázó országgyülési végzések felsorolásával. Nagy Lázár levelét abban a meggyőződésben írta, hogy Sylvester, mihelyt a konzisztóriumtól az engedélyt megkapja, részletes tájékoztatást küld az erdélyi unitáriusok helyzetéről. Addig is, ő, mint a 120 egyházközségben élő mintegy 40000 magyar unitárius egyik képviselője, néhány adattal szolgált a múltról és jelen helyzetéről. Beszámolóját azért korlátozta csak Erdélyre, mert, mint írta, a magyar királyságban nem élnek unitáriusok. Nagy Lázár a vallásalapítók sorában meg sem említette Dávid Ferencet, a történések fonalát Miguel Servet halála utánra vezette vissza. Szerinte a genfi máglya ellobbanása után az unitárius vallást 1562 körül Lengyelországból hozta Erdélybe néhány olasz, köztük a legfontosabbak Giorgio Biandrata és Fausto Sozzini. Az unitarizmus gyorsan terjedt a fejedelemségben, olyannyira, hogy a nemesek, tanácsosok, és két fejedelem, János Zsigmond és Székely Mózes is ezt a hitet gyakorolta. A levél a cenzoroknak is szólhatott, hiszen a felekezet közelmúltbeli töretlen fejlődéséről és a keresztény egyházak közöt-

87 „It has occasioned our receiving a Summary Account of Unitarian Affairs in Transylvania, from Sylvester, Unitarian Professor of Theology in the College at Clausenbourg, a translation of which will occupy an early number of the Unitarian Fund Register." The Unitarian Fund Register nr. 3., 20.

88 "Aestimatissimas et gratissimas litteras (...) Professori Socinianorum Claudiopolitano intitulari dignitas, obsigillaté et accuraté allatas, Theologiae Unitariae (quae nominatio Patria legibus stabilita, in Transylvania apud quoslibet religionis asseclas ita in usu est, ut aliter, videlicet Socinianos, Servetianos, etc., compellari nec placeat) Professor in Collegio Unitariorum (...) humillimé et summa cum voluptate accepit et perlegit, aliisque communicavit..." MR, 1822, vol. XVII., 437. 
ti jogegyenlőségről kisebb dicshimnuszt zengett. ${ }^{89} \mathrm{Az}$ unitáriusok jogait, miként a három másik bevett felekezetét is, országos törvények szavatolják - írta -, és ezek betartására a mindenkori osztrák császár esküt tesz. Ezután az Erdélyben megtürt felekezetek, a görögkeleti és a zsidó státusát ismertette, és a mindenható Istennek adott hálát, hogy sem a bevett, sem a megtürt felekezeteket nem üldözik, hanem teljes szabadsággal bírnak, templomot, tornyot építhetnek, iskolát tarthatnak fenn stb., és egymással dicséretes békességben élnek.

Az unitarizmus sarkcsillaga (künoszúra) a közkézen forgó latin confessio, a katekizmus és a Summa Theologiae. ${ }^{90}$ Ezeket - írta - jó lenne valamikor angol nyelvre is lefordítani, és a szigetországban élő unitáriusok tájékoztatására elküldeni.

Ha Nagy Lázár levelét összehasonlítjuk az Epistolával, megállapíthatjuk, hogy mindkettő szerkezetileg a Kénosi Tőzsér-Uzoni Fosztó históriáját követte. A magyar unitárius egyház eredetéről, történetéről, a szertartásokról, az egyházkormányzás formáiról és az oktatási intézményekről tájékoztatták angliai hitrokonaikat. Nagy Lázár visszafogottsága oldódott valamelyest a Sylvester neve alatt elküldött Epistolában, de lehetetlen nem észrevenni azt a kétségbeesett megfelelni akarást, amely egyrészt minden dogmatikai különbség eltussolásával az angolokhoz simul, másrészt az elszenvedett üldözés és igazságtalanság elhallgatásával az aktuálpolitika elvárásaihoz igazodik. Nagy Lázár udvariasan, de határozottan tiltakozott felekezetének szociniánus felcímkézése ellen, Sylvesterék könnyeden nyelvbotlásnak tekinthették az ügyet. A minden teológiai és egyházkormányzati különbséget elfedő, a múltkeresés és felejtés határain mozgó angol-magyar levélváltás hiányosságai ellenére is megtalálta útját a címzettekhez. Az 1821-ben intézményessé vált angol-magyar unitárius diplomácia gyümölcsei a 19. század második felében értek be Kolozsvárott.

${ }^{89}$ Uo. „,...sed neve subsequis temporibus aliquod impedimentum a caeteris tribus Religionibus earumque profitentibus, Romano-Catholica, Reformata Calviniana, et Augustana Lutherana, jam tum in hocce Principatu receptis et difusis, in libero exercitio et Principatus publicis beneficiis, officiis Unitariis inferatur..."

${ }^{90} \mathrm{Az}$ 1782-ben Szebenben kinyomtatott Confessiora történik utalás. 1821-ben a Koncz Boldizsár-féle káté - Katechesis az-az keresztyéni vallásra való tanitás, mely az Erdélyben lévő Unitária Ekklésiák' és oskolák' szükségére mostan újjonnan ki-botsáttatott, Kolo'sváron, a Ref. Koll. Betüivel, 1819 - volt általános használatban, melynek első kiadása 1698-ban jelent meg. A Summa Theologiae pedig az 1787-ben kinyomtatott Szentábrahámi Lombárd Mihály munkájára vonatkozik. 


\subsection{Körmöczi és az angol unitarizmus}

Nagy Lázár 1822-ben küldött levele az angol unitárius közvéleményre a szenzáció erejével hatott. A Sylvester neve alatt 1822-ben vagy 1823-ban küldött levélnek viszont csak fordítása jelent meg a The Unitarian Fund Register és a Unitarian Association for Protecting the Civil Rights of Unitarians címü évkönyvekben.$^{91}$ Nem tudjuk, miért nem közölte az angol unitárius sajtó, hiszen az annalesek csak kevesekhez jutottak el. Azért is érthetetlen ez a hallgatás, mert az amerikaiak által Bostonban kiadott Christian Examiner and Theological Review (a továbbiakban ChExB) teljes terjedelmében átvette a The Unitarian Fund által közölt levelet, ${ }^{92}$ mi több, az American Unitarian Association (a továbbiakban AUA) 1828-ban megjelent évkönyve is újraközölte. ${ }^{93} \mathrm{Az}$ angolok válaszát 1825 . október 19-én néhány nyomtatvány kíséretében gr. Bethlen Domokos hozta Kolozsvárra. William Fox Bethlen Domokossal küldött levelének eredetije nem maradt fenn, de egy angol másolatot megtaláltunk Simén Domokos hagyatékában. ${ }^{94}$ Ennek alapján sikerült azonosítani azt a nyomtatványt, melynek csak magyar címét - Az unitáriusok fundamentális lajstroma - ismertük..$^{95}$ Ehhez a nyomtatványhoz utasította J. W. Fox az angol unitarizmus szervezete és helyzete iránt érdeklődőket, elsősorban Sylvester György kollégáját, akinek a levelet is címezte. A Simén hagyatékában levő kópia alapján megállapítható, hogy Az unitáriusok fundamentális lajstroma tulajdonképpen a The Unitarian Fund Registerre vonatkozik.

Körmöczi kéziratai között megtaláltuk azt a magyar nyelvü autográf szöveget is, amely cím szerint felsorolja és egy-egy rövid „,jegyzésben” ismerteti az 1825-ben Bethlen Domokossal küldött könyvek tartalmát. ${ }^{96}$

\footnotetext{
${ }^{91}$ Translation of a letter from professor Sylvester of Clausenburg, The Unitarian Fund Register no. VI. 51-56.

${ }^{92}$ Account of the Unitarian Churches in Transylvania, ChEx, July/August 1825, 262-269.

A Christian Examiner (1824-1869) tulajdonképpen a The Christian Discipleből (1813-1823) nőtt ki. A Bostonban kiadott havilapot Noah Worcester 1813-tól 1818-ig majd Henry Ware Jr. 1818-tól 1823-ig szerkesztette. John Gorham PaLfrey 1824-től 1826-ig The Christian Examiner and Theological Review címen kéthavonta adta ki a lapot. 1826-tól 1831-ig Francis JenKs, 1831-től 1839-ig James WaLker és Francis W.P. Greenwood, 1839-től 1847-ig Greenwood és William WARE, 1847-től 1851-ig Alvan Lamson és Ezra Stiles GanetT, 1851-től 1857-ig George Putnam és George E. Ellis, 1857-től 1861-ig Frederic Henry Hedge és Edward Everett Hale, 1861-től 1865-ig Thomas B. Fox, William R. Alger és Joseph H. Allen, 1866-tól 1869-ig J.H. Allen és Henry Whitney Bellows szerkesztették. 1870-ben az Examiner beolvadt az Edward Everett HaLE által szerkesztett Old and New-ba (1870-1875).

${ }^{93}$ Third Annual Report of the American Unitarian Association, Presented May 27, 1828, Boston, $58-60$.

${ }^{94} \mathrm{MsU}$ 1019/D.

${ }^{95} \mathrm{JAKAB}, \mathrm{i} . \mathrm{m}$.

${ }^{9} \mathrm{MsU}$ 780/A 62-71. Az Anglus Unitarius Kezeink közt lévő könyvek 7 darabokból állván...
} 
Ezt a jegyzéket Nagyajtai Kovács István is elkészítette 1827 májusában, ${ }^{97}$ és Körmöczihez hasonlóan a címek után rövid eligazítást adott a művek tartalmáról. Nem tudjuk egyértelműen megállapítani, ki fordította ezeket az ismertetőket. Körmöczi kéziratait, és különösen az angol kapcsolatok alakulásáról készített másolatait vizsgálva, egyre erősebb a gyanúnk, hogy a grafomániás püspök olvasott angolul, másként nem tudjuk megmagyarázni azt, hogy miért alakítgatott, javított az angolból készített fordításokon. Bölöni Farkas Sándor szerint Nagyajtai Kovács István az 1830-as évek elején szorgalmasan tanulta az angol nyelvet, őt sem lehet kizárni a fordítók sorából..$^{98}$

A kolozsvári Akadémiai Könyvtár unitárius részlegén (az egykori Unitárius Kollégium könyvtára), bár több tételét megtaláltuk a Fox levelében felsorolt munkáknak, mégis azt gondoljuk, hogy ezek később kerülhettek a könyvtárba, hiszen máig nem vágták fel az íveket, márpedig az ismertetők elkészítésekor csak ki kellett nyitni a könyveket. És most lássuk a magyar unitáriusoknak küldött első angol könyvküldeményt. Az érthetőség érdekében a magyarra fordított címeknek közöljük angol eredetijét is.

1. Az Újtestamentum megjobbíttatott fordításban. Érsek Newcome új fordítása bázisán, korrekt textel kritikai és magyarázó jegyzésekkel, kiadatott a keresztény vallás ismertetését és a virtus gyakorlását a könyvek osztogatása által előmozdítani kívánó Unitária Társaság által.

The New Testament, in an Improved Version, Upon the Basis of Archbishop Newcome's New Translation: with a Corrected Text, and Notes Critical and Explanatory. Published by the Unitarian Society for Promoting Christian Knowledge and the Practice of Virtue, by the Distribution of Books. Forth Edition, with corrections and additions, London, Richard and Arthur Taylor, 1817.

A címhez füzött ,jegyzés” az előszó kivonatos fordítása. Eszerint az 1791-ben Londonban megalakult Unitárius Könyvtársulat (Unitarian Society for Promoting Christian Knowledge and the Practice of Virtue, by the Distribution of Books), céljául tüzte ki az angol Újtestamentum kiadását. A fordítással többeket megbíztak, ${ }^{99}$ végül is William Newcome érseknek a Johann Jakob Griesbach (1745-1812) görög Újszövetsége ${ }^{100}$ alapján készült fordításához írtak bevezető és magyarázó szövegeket. Erdélybe az 1817. évi 4.

\footnotetext{
${ }^{97}$ MsU 1611-2 Az Ánglus Unitárius kezünk közt lévő könyvek...

98 "Of the Unitarians especially, Louis Kelanen (sic!) [Kelemen] and Stephan Kovars (sic!) [Kovács] have given the chief specimens of progress in learning the English language." Translation of Alexander Farkas' Account of the Unitarians of Transylvania, communicated in Latin to the Secretary of the British and Foreign Unitarian Association, MR, 1831, New Series, vol. V., 651.

${ }^{99}$ Vö. Wilbur, i. m., 338-339.

${ }^{100}$ Johann Jakob Griesbach, Novum Testamentum Græce, Textum ad fidem Codicum Versionem et Patrum recensuit et Lectionis Variatatem adjecit D. Jo. Jac. Griesbach. London and Halle, 2 vol., 1796-1806.
} 
kiadást küldték el, az első kiadását 1808-ban Thomas Belsham (1750-1829) rendezte sajtó alá. ${ }^{101}$ (A kritikai fordítás elkészültéről egyébként a Brevis Expositióban már tudósították az erdélyieket. Az 1809-es amerikai kiadás az ortodoxok vehemens tiltakozását vonta maga után. ${ }^{102}$ )

2. Lekturák a genuine keresztény vallás korrupciójával, reviviscenciájával és jövendőbeli befolyásával öszvefüggésben levő tárgyakkal.

W. J. Fox: A Course of Lectures on Subjects Connected with the Corruption, Revival and Future Influence of Genuine Christianity, Third Edition, London, 1822, címü munkájára történik hivatkozás. A jegyzésben egyebek mellett ezeket írták:

„Mi volt a genuina keresztény vallás a maga eredetiségében, úgy amint azt a Jesus és apostolok tanították - mikor, miként, mennyiben korrumpálták annak utána azt, mik azok a korrupciók - mikor érkeztek a legfőbb pontra, mikor kezdettek hanyatlani... a keresztény vallásban - mi által fog a maga régi tisztaságára, eredetiségére jutni a keresztény vallás - mi lesz annak akkor a befolyása a világra s az emberi nemre nézve?"103

Fox hét prédikációból álló sorozata 1818-ban hangzott el, ezek közül „le van fordítva az a Lectura, melynek címe: Az unitarizmus”. A Zak 14,9 alapján írott és Körmöczi másolatában fennmaradt prédikáció fordítását dolgozatunk függelékében közöljük. ${ }^{104}$

3. Az unitárius keresztény vallás lelke. The Spirit of Unitarian Christianity, London 1824. ${ }^{105}$ Ezt a beszédet Fox 1824-ban a Finsbury-templom felszentelésekor mondta. Hozzácsatolták az alapkő letételekor 1823-ban mondott beszédet is. A ,jegyzés” szerint ez a munka „egészen le vagyon már magyar nyelvre fordítva, szükségtelen minden jegyzés reá nézve, az olvasók ítéljék meg." A nyomtatványt nem találtuk meg, de a magyar fordításnak öt kéziratos másolata maradt fenn. Ebből hármat Körmöczi készített, egy Nagyajtai Kovács István kézírása, egyet pedig egyelőre ismeretlen kéz másolt. Körmöczi (MsU 857/A2; B1-2) és az ismeretlen másoló kézirata (MsU 857/A1) között nincs számottevő különbség. Az MsU 857/B/1 Körmöczi készítette másolat hátsó borítóján a következő, a püspöktől származó jegyzet olvasható: „Notam: In Historiam ecclesiasticam inserendam”. A

\footnotetext{
${ }^{101} \mathrm{Az}$ angol Újszövetség fordításokról lásd: John V. MAdison, English Versions of the New Testament: A Bibliographical List, Journal of Biblical Literature, vol 44, no.3/4(1925), 261-288.

${ }^{102} \mathrm{Az}$ „unitárius Biblia” amerikai fogadtatásáról lásd: P. Marion Simms, The Bible in America: Versions That Have Played Their Part in the Making of the Republic, New York, 1936, 255-258.

${ }^{103} \mathrm{MsU} 1611-2$ Az Ánglus Unitárius kezünk közt lévő könyvek...

${ }^{104}$ Lásd Függelék 2. sz.

${ }^{105}$ W.J. Fox, The Spirit of Unitarian Christianity. A sermon delivered at the opening of the Finsbury Unitarian Chapel, on Sunday, February 1st, 1824: to which is prefixed an address delivered on laying the stone of the Chapel on Thursday, May 22nd, 1823, London 1824.
} 
püspök másolatában maradt fordítás magyar címe: Az Unitaria Keresztyén Vallás Lelke egy Predicatio melyet tartott a' Finsburi Unitária Kápolna kinyittatásakor Vasárnap Februárius 1-ső napján 1824-ben melynek elejébe vagyon bocsátva egy beszéd, Melyet tartott a Kápolna első Talp köve le tételekor csötörtökön Május 22-én 1823-ban Fox. W. J. által. Fordittatott Anglus nyelvböl K. István által.

Körmöczi hagyatékának rendezésekor a kéziratokat összezavarták, Fox beszédének fordítását megcsonkították. Az MsU 857/A/1 jelzetű kézirat folytatása a 17. oldallal kezdődően az MsU 898/B jelzethez került. A Nagyajtai másolata az MsU 1265 jelzet alatt megőrizte mind az alapkő letételekor, mind pedig a „Kápolna kinyittatásakor” mondott beszédet. Címlapja csak abban különbözik a Körmöczi-másolatoktól, hogy nem a fordító iniciáléit adja, hanem sejtelmesen csak annyit jegyez meg: „Fordította egy Unitárius." Kelemen Lajos a borító belső oldalára ezt a megjegyzést tette: „NB. A kézírás a Nagyajtai Kovács István kézírására emlékeztet.” Az alapkő letételekor mondott beszéd után (1-23 oldal) a felszentelési beszéd következik (23-90 oldal), textusa Róm 8,9.

4. Csendes vizsgálódás a Szentírásnak a Krisztus személyét illető tanításairól. A mű szerzője Thomas Belsham, angol címe pedig: A Calm Inquiry Into the Scripture Doctrine Concerning the Person of Christ; to Which Are Annexed a Brief Review of the Controversy Between Bishop Horsley and Dr. Priestley, and a Summary of the Various Opinions Entertained by Christians Upon this Subject, második, javított kiadás, London 1817. A könyvtárban levő felvágatlan példány címlapján a következő ajánlás olvasható: „From the Unitarian Assotiation to the Library of Torda Gymnasium." Jegyzés:

„Ezt a munkát a Londoni első unitárius pap - az öreg tiszteletes Belsham úr írta. Ô a Cowardi Calviniana Academiában a Theologia professzora volt hajdan. 1781-ben ezt a munkáját az unitáriusok ellen adta volt ki. Az unitarizmus nagyon kezdett már akkor terjedni - módivá lett volt akkor, azt írja maga Belsham - unitáriussá lenni. Ezen könyvében ő abban az időben azt írta le, mit hisznek a trinitáriusok, mit az ariánusok, mit az unitáriusok - mindenik szektából a legderekabb írók árgumentumait rakta munkájába - s úgy adta tanítványai kezekbe. Az unitarianizmus ellen akarta őket oltalmazni ezzel a könyvivel azt írja, s éppen ezen könyve miatt nagyobb része s a tálentomosabb része mind unitáriussá lett - maga is azután - az akadémiát tehát elhagyta (...) 1805-ben Londonba vitetett papnak az említett munkáját tehát megjobbítva kiadta azután - változtatást nem tett benne, hanem az unitáriusok állításait bővebben adta elé - ezen könyvben tehát minden Angliában lévő szekták tanításai megvagynak - meg az unitáriusoké is. Minden textust felhord a Szentírásból melyből akár directe, akár indirecte azt következtetik hogy az, az unitarizmus ellen vagyon. Megmondja miként magyarázzák azt más felekezetek - $\mathrm{s}$ utoljára mindenkor azt említi miképpen magyarázzák azt az unitáriusok, és hogy ezeké a legjobb, helyesebb magyarázat. Ez a könyv vagy egész bibliothe- 
ka minden Szektából a legtudósabb írók magyarázatjait hozza fel - s meg van benne minden a világon eddig volt Unitárius-Socinianus írók magyarázatja is. NB. ebből is vagyon egy rész fordítva!"

A fordítás az MsU 898/A csomóban van, tulajdonképpen Belsham könyve második része második szakaszával, a The socinian scheme (309-312) címü cikkellyel kezdődően. A második rész első szakaszát - The proper unitarian scheme, or the doctrine of the simple humanity of Jesus Christ (291-308) - teljes egészében lefordították. ${ }^{106}$

5. Az unitarizmus az evangélium tanítása. Lant Carpenter Unitarianism in the Doctrine of Gospel. A View of the Scriptural Grounds of Unitarianism; with an Examination of All the Expression in the New Testament which are Generally Considered as Supporting Opposite Doctrines, London 1811, the 2. ed. Jegyzés:

„Ezen Doctor Carpenter egy a legtudományosabb ánglus unitáriusok közül, csak amint mü láthatjuk is többet írt ez 10-12 unitárius könyveknél. Ebben a könyvében azt mutatja hogy az Unitarianismus az evangyélium és az evangyélium Unitarismus - erre nézve historica introductiot írt - minden evangélista s apostol írására nézve - ezután felhordja az újj testamentumból mind azokat a hellyeket melyek világosan az unitarizmust erősítik - annakutánna említi mind azokat a helyeket a Szentírásból, melyekről mások azt állítják hogy azok az unitarizmus ellen vagynak s megmagyarázza, mindazokat rendről-rendre egytől egyig, hogy azok nincsenek az Unitarizmus ellen s megegyeznek azzal - széles s mély tudománnyal vagyon írva ez és a Belsham Úr fennebb említett könyve tehát úgy nézettethetik, mint amely az egész szentírást úgy magyarázza, ahogy kell azt érteni az Unitáriusoknak."

6. Az unitárius keresztény vallás világos nézetése. A plain view of the Unitarian Christian doctrine: in a series of essays on the one God, the Father, and the mediator between God and men, the man Christ Jesus, 1815.

Richard Wright misszionárius köznépnek írt müve, a jegyzés szerint... „,az angol unitáriusok Summa Universaejét írta meg ad captum populi”.

\section{Az unitárius fundus lajstroma, The Unitarian Fund Register.}

Az MsU 1232 kolligátum Körmöczi több kéziratát is megőrizte, köztük a már ismertetett Brevis Expositio latin másolatát és a későbbiekben ismertetendő Székely Mózes, illetve Bölöni Farkas Sándor levelét. A Brevis ezen másolatát indexszel és tárgymutatóval látta el a püspök, illetve megjegyezte, hogy a konzisztórium szeptember 16-án tartott gyülésében tárgyaltak a kapcsolatfelvétel kérdéseiről. Körmöczi János Unitarii in Transylvania... kezdetü, MsU 2148/H jelzetü befejezetlen levele arról tanúskodik, hogy a

\footnotetext{
${ }^{106}$ Lásd Függelékben 3. sz.
} 
püspök a Brevisre írandó válaszát elküldte - véleményezésre - az egyház világi vezetőinek, Gyergyai László és Koncz János tanácsosoknak is. Gyergyai szerint a Brevisre azonnal válaszolni kell, de nem a Képviselő Tanács, hanem egy privatus, „úgy mint teológiai professzornak neve alatt... azt is megírni, hogy Erdélyországban az Unitáriusoknak hány eklézsiájok vagyon, s mint hány lélek legyen benne." ${ }^{107}$ Koncz véleménye szerint az illetékes államhatóság megkérdezése nélkül nem szabad válaszolni, addig is a fogalmazvány „deákságának csinosítását javasolta, hogy az angliai levél „deákságához hasonlóbbá tétethessék." 108 A Körmöczi kéziratok vizsgálata során meggyőződtünk arról, hogy ő volt a korai angol magyar kapcsolatok mozgatója. A felvilágosult peregrinust, majd teológiai tanárt és püspököt nemcsak saját egyháza, hanem a párizsi, genfi és Amerikai Egyesült Államokbeli közösségek sorsa is élénken foglalkoztatta.

\subsection{A Molnos-Bowring-Körmöczi háromszög és az „erdélyi populáris literatúra”}

Az EKT jegyzőkönyvében az 1821-1826 közötti magyar-angol-amerikai levélváltás egyetlen dokumentumát sem találtuk meg. Az angol unitáriusokkal foglalkozó első EKT-i döntés az 1826. évi jegyzőkönyvben a 43. pont alatt, a W.J. Fox által küldött könyvek átvételére vonatkozik. A levelezés 1825-1827 között valamiért megszakadt, de John Bowringnak a magyar irodalom iránti érdeklődése a kapcsolatok újabb megélénkülését eredményezte. Bowring 1830-ban kiadott Poetry of the Magyars, majd az 1866-ban megjelent Translations from Alexander Petófi, the Magyar Poet keletkezés- és recepciótörténete jól ismert a magyar irodalomtörténetben. ${ }^{109}$ Lakó Elemér 1972-ben tette közé Bowringnak az erdélyi unitáriusokkal folytatott levelezését, ez azonban sajnálatosan nem épült bele a magyar Bowring kutatók összefoglalóiba. ${ }^{110}$ Az kolozsvári Akadémiai Könyvtárban fennmaradt másolatok és fordítások alapján Lakó megállapította, hogy

\footnotetext{
${ }^{107}$ MsU 2148/H. A Körmöczi autográf első lapján ez a figyelmeztetés áll: NB. Ez a küldendő! ${ }^{108} \mathrm{Ua}$.

${ }^{109}$ CZIGÁny Lóránt, Sir John Bowring és a magyar irodalom, Új Látóhatár, 1961/1.; Uő., A magyar irodalom fogadtatása a viktoriánus Angliában, ford. RozsnyaI Bálint, Budapest, 1976. (A továbbiakban CZIGÁNY, A magyar irodalom...); VARANnAI Aurél, John Bowring és a magyar irodalom, Budapest, 1967. (A továbbiakban Varannai.); Sir John Bowring, A magyarok költészete, Poetry of the Magyars, bev. Kiss Dénes, tanulm. Czigány Lóránt, ford. Görgey Etelka, TAKÁcs Zoltán, Allprint, 2006.

${ }^{110}$ LaKó Elemér, Sir John Bowring és az erdélyi „populáris literatura”, Korunk, 1972/8, 1245-1248. Uö., A romániai és az angol unitárius egyház kapcsolatának történetéből, KerMagv, 1972, 204-208. A legújabb magyar Bowring tanulmány szerzője BÁNHEGYI Zsolt, Sir John Bowring, a magyar nyelv és irodalom barátja, Magyar Tudomány, 2004, április 4.sz. 481. [http:// www.matud.iif.hu/04apr/08.html] (A továbbiakban BÁNHEGYI.)
} 
1827-ben Bowring három levelet küldött Molnos Dávidnak, az elsőt április 3-án, a másodikat július 26-án, a harmadikat pedig augusztus 29-én. Az utóbb előkerült Emlékkönyv és az EUEGyLt-ban fellelhető angol autográf alapján bizton állíthatjuk, hogy az augusztus 29-én keltezett levél címzettje nem Molnos Dávid, hanem Körmöczi János püspök volt, és a levél nem franciául, hanem angolul íródott. Bowring áprilisban az MR-ban ismertette az erdélyi unitáriusok állapotát. ${ }^{111}$ A rövid, néhány soros cikk az erdélyi unitáriusok lélekszámát, eklézsiáit és kolozsvári, keresztúri és tordai kollégiumait sorolja fel. Vallomása szerint információit szláv írótársaitól kapta. A másodkézből vett értesülések után kaphatta meg Molnos március 12-én keltezett levelét. Ezzel kezdődött el az unitárius korrespondencia. Mind az áprilisi, mind a júniusi (és nem júliusi!) levél kezdő sorából nyilvánvaló, hogy Molnos márciusban írt az angoloknak. ${ }^{112} \mathrm{Az}$ Emlékkönyvben nem maradt fenn Molnos levelének másolata, de a BFUA nyomtatásban megjelent 1827. évi jelentése rövid angol kivonatát adja. (Innen vette át az AUA végrehajtó bizottsága, és teljes terjedelemben közölte. ${ }^{113}$ ) Molnos levelében megköszönte a Bethlen Domokos révén küldött könyveket, különösképpen a BFUA értékes információkat tartalmazó jelentéseit. Ezeket olvasva megelégedéssel vették tudomásul, hogy az unitarizmus, melyről azt gondolták, hogy kizárólagosan erdélyi produktum, másutt milyen gyorsan és eredményesen terjed. A következő kérdésekre akart választ kapni: Hogyan taníttatják és tartják fenn lelkészeiket? Milyen az angol unitárius disciplina ecclesiastica? Az amerikai unitáriusok az angoloktól kapják-e lelkészeiket? A kérdések feltevése után beszámolt arról, hogy noha az erdélyiek a porosz unitáriusokkal három generáción át húségesen leveleztek, az utóbbi időben a kapcsolat megszakadt. Nagyon örvendenének, ha az egykori porosz unitáriusok jelen helyzetéről valami tájékoztatást adnának. Végül Erdélybe invitálja az angolokat, mert úgy látja, hogy a közeljövőben nem látogat erdélyi unitárius a szigetországba. Azt is megírja, hogy Erdélyben a magyar nyelv a legelterjedtebb, de a tanult férfiakkal latinul és németül, a hölgyek némelyikével pedig franciául is lehet társalogni.

Molnos levelének ismertetése után a BFUA tanácsa abban reménykedett, hogy hamarosan személyes kapcsolatba kerülhetnek a történelem folyamán elfeledett tiszta egyistenhitet újra feltámasztó, és Isten egységének hitét megtartó erdélyi unitáriusokkal. A bizottság nagy örömmel venné, ha

111 Transylvanian Unitarians, MR, April, 1827, 243.

112 „Literis a te datis XII. Kalende Martii, quum antea breviter responderim meo ipsius nomine, nunc denuo iisdem ex eo, quod gero in nostra Unitariorum Congregatione, officio, ad respondendum fusius progredior." Emlékkönyv, vol. I., 11.

${ }^{113}$ Third Annual Report of the American Unitarian Association, 58-60. 
egy arra való diákot Erdélybe küldhetne tanulni, hasonlóképpen örömmel fogadnák yorki kollégiumukba is az Erdélyből érkező diákot. ${ }^{114}$

Bowring 1827. április 3-án, William Foxnak, a BFUA külügyi titkárának megbízásából írt először az erdélyieknek, de Molnos kérdéseire csak részben válaszolt. Ebben a levelében már megpendítette, hogy a „Sclavus nyelvbéli literatúrának némely ágairól" ír valamit. Júniusi levélben már nem magánemberként, hanem mint a BFUA külügyi osztálya titkáraként válaszolt Molnos kérdéseire. ${ }^{115}$ Levelében, a BFUA tanácsi határozatával összhangban, egy ösztöndíj alapításának gondolatát is felvetette. Az augusztus 29-én keltezett levelét már nem latinul, hanem angolul írta, és Körmöczi János püspökhöz címezte. Ebben az erdélyi unitáriusokat jellemző, az őket szomszédaiktól megkülönböztető sajátságokról - szokások, nyelv, zene - szeretett volna információkat kapni. ${ }^{116}$ Az unitárius egyházi énekek fordítását is hálásan vette volna, de Körmöczi válaszlevele nem érkezett meg Angliába, mert Bowring 1828-ban Döbrentei Gábornak azt írta, ${ }^{117}$ hogy az unitáriusoktól semmiféle választ nem kapott. John Bowring ini-

114 The second report of the British and Foreign Unitarian Association with the proceedings of the annual general meeting, held in Finsbury Chapel, London, on the 6th of June, 1827., (a továbbiakban Report of the BFUA) London, 1827, 25-27.

${ }^{115}$ Bowring 1828-tól 1831-ig volt titkára a BFUA külügyi osztályának. 1831-ben lemondását követően Edward Tagartot választották titkárnak, aki haláláig töltötte be ezt a tisztséget. Az 1825-ben alapított BFUA 1882-ig az angol unitarizmus legfőbb vezető testülete volt. 1882-ben megalakult a The National Conference of Unitarian, Liberal Christian, Free Christian, Presbiterian and other Non-Subscribing Congregations szervezet, mely 1929-ig párhuzamosan müködött a BFUA-val. 1929-ben a két testület The General Assembly of Unitarian and Free Christian Churches néven egyesült.

116 „To the John Körmötzi von Nagy-Ajta, Kolozsvár. London 29. August 1827.

Sir, I have had two or three occasions to address our Transylvanian brethren on behalf of the Unitarian Association of this country, who are very desirous of seeing established a frank and frequent communication with your Churches. I hope that time is at hand when this will have effect, and most cordially desire to contribute to it.

But the purpose of this letter is personal. I have published in England several volumes of the popular literature of different countries. I had been very much urged to publish out on that of Hungaria and Transylvania. On your language I know a little, and I have secured through my friend Dr. Kopitar of Vienna a number of magyarian songs etc. furnished him by dr. Rumy. Our Unitarians are very much interested in the popular literature of Transylvania, and I venture to apply to you in the hope that you will be able to give me some information if the Transylvanian Unitarians have any Magyar compositions which are peculiarly their own, this would be exceedingly acceptable to me. I would be pleased if they were accompanied by Latin, German translations to avoid the chance of error. Are any hymns sung in your churches? Could you send me copies or Translation of such? If there be any thing in the habits, manner or language of the Unitarians to distinguish them from their neighbors, that too I would like to know. If you have any music that is characteristic, that would also be welcome. If you will favor me with any communications this Dr. Kopitár Custos Bibliot. Imp. Vienna or my correspondents Miss Reyer Schlik of that peon I will be very much obliged. I am your honorable, John Bowring." EUEGyLt. Angol levelek.

${ }^{117}$ LAKó, i. m, 1245 
ciáléi alatt 1827-ben a MR-ban a lap szerkesztőjének, Asplandnak címzett levél kíséretében két magyar népdal fordítását (Fáj, fáj..., Dirge, Az idő, Time) közölte. ${ }^{118}$ A levelében Bowring megelőlegezte a három évvel később a Poetry of the Magyars címú antológia elöszavában, nyelvünkről megfogalmazott és azóta számtalanszor idézett megállapítását.

„A magyar nyelv egyike a legnevezetesebb európai dialektusoknak, kétségkívül keleti eredetü és alig van valami kapcsolata a környező országok nyelvével, lettlégyen az germán, szláv vagy latin. Régóta müvelték, hiszen már 1539ben Magyar Régiségek és Ritkaságok címen nyelvtana is megjelent."119

„A magyar nyelv magában áll a messzeségben. Más nyelvek tanulmányozása vajmi kevés haszonnal jár, ha ezt a nyelvet próbáljuk igazában megérteni. Lényegében egyedülálló nyelvi öntőformája van, szerkezete és felépítése oly múltba vesző időkre mutat, amikor Európa legtöbb nyelve még nem is létezett, vagy nem volt hatással a magyar vidékre."120

A levél befejező sorai szerint a közzétett két népdalfordítást Bowring az Erdélyből kapott irodalmi 'egyvelegből' (mass of literary communications received from this Terra incognita) válogatta ki. ${ }^{121}$ A népdalok Rumy Károly György (1780-1847) révén Kopitár Bertalan (1780-1844) bécsi könyvtáros közvetítésével kerültek birtokába, és jelentéktelen módosítással megjelentek az 1830-ban kiadott antológiában is. ${ }^{122}$

A Poetry of the Magyars 1830. évi megjelenését kedvezően fogadta mind az angol, mind az amerikai unitárius sajtó. A ChExB-ban a recenzens megállapítja, hogy a kötet ugyan alulmarad a Specimens of the Russian poets csiszolt, civilizált és kevésbé eredeti orosz antológiával szemben, de nemzeti sajátosságai értékessé teszik. Az amerikai kritikusok egyik fő kifogása az volt, hogy a kötetben egyetlen vallásos, az erkölcsöket építő fordítást sem találtak. A szerelem, a harci virtus és a bor dicsérete lehet hasznos, de azokat a recenzens nem tartotta érdemesnek megemlíteni. A magyar költészet

\footnotetext{
${ }^{118}$ John Bowring, Hungarian Literature, MR, August, 1827, 556-557.

${ }^{119}$ Uo. „The former (Hungarian, or as they call it, Magyar) is one of the most remarkable of the European dialects, being undoubtedly of Oriental origin, and having a very slight affinity with any of the idioms of the surrounding country, whether Teutonic, Slavonic, or Romanic. It was cultivated at an early period, and a Grammar entitled Magyar Régiségek és Ritkaságok, was published as early as 1539." Az angol filológus és diplomata összetévesztette Kazinczy Ferenc Magyar Régiségek és Ritkaságok, illetve Sylvester János Grammatica Hungarolatina címü munkáját.

120 ,The Magyar language stands afar off and alone. The study of the other tongues will be found of exceedingly little use toward its right understanding. It is moulded in a form essentially its own, and its construction and composition may be safely referred to an epoch when most of the living tongues of Europe either had no existence, or no influence on the Hungarian region." BÁNHEgYI, i. m. http://www.matud.iif.hu/04apr/08.html

${ }^{121}$ Bowring, i. m., 556-557.

${ }^{122}$ VARANNAI, i. m., 94-98.
} 
- John Bowring megállapítása szerint - még nagyon fiatal és egyszerü. ${ }^{123}$ Az angol unitáriusok véleménye jóval kedvezőbb és elfogultabb is az amerikainál. A MR-ban közzétett könyvismertetőben Bowring bevezető tanulmányából idéztek. ${ }^{124}$

A Molnos-Bowring-Körmöczi levélváltás után 1831-ig valószínűleg szünetelt a korrespondencia. A BFUA 1828-ban egyebek mellett az Erdélybe irányított könyvküldeményről is beszámolt. ${ }^{125}$ A BFUA könyvtársulata a kolozsvári, tordai és székelykeresztúri iskolának szánta a küldeményt, ez azonban csak valamikor az 1840-es években érkezett meg Kolozsvárra. Buzogány Áron az Emlékkönyvben Nagyajtai Kovács István (1799-1872) szóbeli közlése alapján adja elő a történteket. Eszerint az angolok valamikor egy könyvszállítmányt küldtek az erdélyi unitáriusoknak, amit Bécsben lefoglaltak. Az erdélyiek „tudtak valamit ezekről a könyvekről, de vagy nem akadtak nyomába a szállítmánynak, vagy az utánajárásra megbízottak nem fizették ki a kívánt portót érette, s így a könyvek hevertek." ${ }^{126}$ Kovács István Bécsben végére járt a dolgoknak, kifizette a raktározási költséget, így a könyvküldemény Kolozsvárra került. Jegyzék nem készült a könyvekről, és már Buzogány csodálkozott azon, hogy „az a rakás könyv hová lehetett, miután sem a tordai s keresztúri középtanodák könyvtáraiban egy sincs közülök, a főtanoda könyvtárában csak egynéhány, két vagy három példányban pedig egy sem. Sajnálni lehet, hogy a lajstroma sincs sehol az akkor jött könyveknek, hogy bár históriai adatul szolgáljon. Gondos kezelésre semmiképp sem mutat." ${ }^{127}$

Hogy az erdélyiek írtak-e 1828 és 1831 között az angoloknak, nehéz megállapítani. Sem az Emlékkönyv, sem az EUEGyLt-ban található angol levelek nem adnak eligazítást ebben a kérdésben. A BFUA 1830. évi jelentéséből esetleg arra következtethetnénk, hogy folytatódott a levelezés. ${ }^{128} \mathrm{Az}$ Európában élő unitárius egyházak vezetőivel a BFUA egyre jobb kapcsolatot épített ki, és 1830-ban a tanács Bowring három évvel korábban megfo-

${ }^{123}$ Poetry of the Magyars..., ChExB, November, 1830, 193-199.

124 "A brief introduction to our readers is all that we can give to this volume; perhaps all that we need, for Dr. Bowring has anticipated our task, and provided the criticism as well as the poetry." Poetry of the Magyars..., MR, March, 1830, 185-187.

${ }^{125}$ Report of the BFUA, London, 1828, 24-25.

${ }^{126}$ Emlékkönyv, vol. I., 24.

${ }^{127}$ Uo., 25.

${ }^{128}, \ldots$...your Committee have been often led to think it would be a most useful application of a portion of your funds to select occasionally some young men of distinguished talents, and to send them to various stations abroad for the completion of their education. They would be fitted for high stations of usefulness at home in future years, and would in the mean time be the best medium of communication with Unitarians abroad; amongst whom your Committee cannot fail to regard the Transylvanian brethren, whose correspondence and co-operation it appears peculiarly worthy of the British and Foreign Unitarian Association to cultivate with fraternal assiduity and zeal." Report of the BFUA, London, 1830, 22-23. 
galmazott óhajával összhangban ${ }^{129}$ azon elmélkedett, hogy egy jól képzett diákot a kontinensre küld tanulmányok folytatására. Úgy gondolták, hogy az európai peregrináció egyrészt a későbbiek során hasznosítható kiváló képzést biztosítana, másrészt lehetővé tenné a kontinensen, de különösképpen az Erdélyben élő unitáriusokkal való közvetlen eszmecserét. A BFUA külügyi szakosztályának albizottsága hasonló javaslatot terjesztett az 1830. június 2-án Londonban tartott közgyưlés elé. ${ }^{130} \mathrm{~A}$ kontinensen élő unitáriusok helyzetét felmérendő angol unitárius peregrinus finanszírozására nem sikerült anyagi alapot előteremteni, és a BFUA nagy ívű missziós terve csupán ajánlás maradt. Az 1831. esztendőben azonban Bölöni Farkas Sándor jóvoltából akkurátusan pontos információkhoz jutott a társulat.

\subsection{Bölöni Farkas Sándor napnyugati utazása}

Az angol-magyar-amerikai unitárius kapcsolatok szervezésében Bölöni Farkas Sándornak (1795-1842) kiemelkedő szerep jutott. Bölöni személyiségének, valamint a reformkori Erdélyben, illetve Kolozsvárott betöltött szerepének értékelése nem tartozik dolgozatunk tárgyához. Bölönivel mint egyházdiplomatával kívánunk foglalkozni, ezért a Napnyugati utazás és a BFUA jegyzőkönyvei alapján megkíséreljük alátámasztani azt a feltételezésünket, hogy a székely nemes nem pusztán kedvtelésből utazott, hanem egyházának hivatalos megbízottja volt. Az, hogy Angliába érkeztének első pillanatától a vezetô unitárius értelmiség bizalmát élvezte, megerősíti azon hipotézisünket, hogy Bölöni Farkas Sándor az erdélyi unitáriusok akkreditált egyházdiplomatája volt. Az EKT kolozsvári jegyzőkönyvében megbizatására vonatkozó adatot nem találtunk, de útinaplója és az angol,

129 "I earnestly wish to see some zealous labourers in this almost untrodden field. I am sure they would gather a rich and interesting harvest". MR, 1827, 557.

${ }^{130}$ A kérdés fontosságára való tekintettel az Angol Unitárius Társulatnak küldött ajánlást teljes terjedelmében idézzük: „The Association has often had it in view to embrace some plan for drawing more closely its connection with foreign countries and obtaining more accurate and permanent means of information and dissemination of our own views. It has more than once been in contemplation to dispatch a Special Missionary on a journey for the furtherance of these objects. It has occurred to the Sub-Committee, that the object might be well realized by combining it with a plan for occasionally affording the means of improved education to a promising student after concluding his Academical Courses. They beg to suggest the propriety of making an occasional Exhibition (...) for enabling, or at least assisting, a student or young minister, from time to time (...) to pass one or two years in a Foreign University, or in visiting more than one. By these means the circle of his acquirements might be greatly enlarged, and at the same time (as he would remain in connection and correspondence with the Association) its sphere of usefulness and knowledge of what was passing abroad would be greatly increased. The time which would be thus spent in any given spot would also enable the Association to establish more permanent relations abroad, and to obtain much more accurate information than would result from any other means of communication." Uo. 
illetve amerikai források diplomáciai küldetését támasztják alá. Angliai tartózkodását pontosan be tudjuk határolni: 1831. április 19-től július 24-ig volt a szigetországban. Megérkezése után két nappal, április 21-én ezeket írta:

„...21-én Wood úr elvezetett Hunter nevü könyvtároshoz, és ajánlott neki, azután az Unitarian Committee-be vezetett fel, s secretarius úrnak ajánlott, ki több könyveket adott által az angliai unitáriusok históriájára..."131

Vessünk csak egy pillantást Bölöni újdonsült angol ismerőseire. Samuel Wood (1797-1849) unitárius lelkészt, a Christian Tract Society titkárát Balog Pál mutatta be Bölöninek. Wood közvetítésével találkozott a „Unitarian Committee secretariusával", Yates-szel. James Yates (1789-1871) unitárius lelkész, a Royal Society tagja, 1831-től 1841-ig volt a BFUA titkára. Mint klasszika-filológus is ismert Angliában, a William Smith (1813-1893) által kiadott Dictionary of Greek and Roman Antiquities (1842) szócikkeinek egynyolcadát ő írta. Fox a BFUA végrehajtó bizottságának volt a tagja.

És most nézzünk a Napnyugati utazást:

Április 24. „.... South Place-on az unitarian templomba mentem, hol Fox úr prédikállott, a ceremóniák ugyan-azok, mint nálunk, azon különbséggel, hogy a pap eleitől fogva a katedrában ül, alatta egy kisebb katedrában a kántor. A pap előtt egy veres bársony párna van, melyen a Bibliája áll és prédikációja. Midőn bémentem, állottam egy ideig, csakhamar egy angol hozzám jött, s közel a katedrához helyet mutatott nekem, szomszédom pedig énekeskönyvet adott..."132

Április 25. „Wood Sámuel úr az Unitarian Committee gyülésébe vitt, egybegyülvén a tagok, Yates úr propozícióit tett irántam, hogy Erdélyből mint unitarian ideérkezvén, protocollariter gratuláltak nekem, s kijelentették, hogy általam kívánják fenntartani az erdélyi atyafiakkal a közösülést. Rees úr a Racovian Cathechezis fordításával ajándékozott meg..."133

Április 28. „Bowring úrhoz mentem, a híres Poetry of the Magyars kiadójához, ki a legnagyobb szívességgel fogadott. Mutatta sok magyar könyveit, melyek itt kedvesek voltak. 29-én megint Bowring úrnál voltam, s hazánk literatúrájáról hosszas értekezésünk volt." ${ }^{\prime 134}$

Május 5. „...estve a Worship Streetbe a Tract Society esztendős gyülésébe mentem. Wood secretárius eléadta a Committee-nek azon esztendei foglalatosságát, azután új tagok választattak, több propozíciók tétettek, és a végén Aspland praeses úr, hackney-i unitárius pap egy szép beszédet mondott. Vége lévén, Wood úr ajánlott a tagoknak, kik igen szívesen fogadtak, s Aspland úr meg-

\footnotetext{
${ }^{131}$ A dolgozatunkban idézett naplórészleteket a MALLER Sándor szöveggondozásában megjelent Napnyugati utazás; Napló, Helikon, é. n. [1984] kötetből válogattuk. (A továbbiakban MALler.), 197.

132 MALLER, i. m., 198.

133 Uo.

${ }^{134}$ Uo., 200.
} 
hívott Hackneybe. Ezen társaságnak az a célja, hogy a morális és vallásos jó könyveket terjessze."135

Bölöni ismerősei közül külön kell foglalkoznunk John Kenrickkel (1788-1877), ${ }^{136}$ a yorki akadémia tanárával, akinek nevével már találkoztunk, és a későbbiek során is fogunk találkozni. A Napnyugati utazásban, május 25-én a következő bejegyzés áll:

„Professor (Rev) Kenrick urat megtalálván, ez az úr igen nagy szívességgel fogadott. A professzor úr a kontinensen utazván, Göttingában is tanulván, némely ismeretei voltak hazánk iránt... Az institutum stewardjához mentünk, hol az idegenek könyvében nevemet fel kellett írnom, melyet ritkaságáért nagybecsűnek mondott lenni Kenrick úr, hogy erdélyi ember is meglátogatta institutumjokat."137

Kenrick 1810-ben lett a yorki disszenter akadémia klasszika-filológia tanára. Pályája során 1819-ben tett göttingeni, majd berlini tanulmányútja meghatározó volt. Göttingenben Johann Gottfried Eichhorn és Johann Friedrich Blumenbach előadásai voltak rá hatással. Berlinben Schleiermacher filozófiai előadásait hallgatta. A 19. századi német történetkritikai és filológiai iskola rányomta bélyegét későbbi tanári működésére. Kenrick kora legnagyobb unitárius teológusának számított, de nem teológiai, hanem klasszika-filológiai müvei tették elismertté. Bölöni Naplóját szépen kiegészíti a BFUA 1831. május 25-én felvett jegyzőkönyve, mely szerint többen is képviselik a közgyúlésen az erdélyi unitáriusokat, ez pedig a jövőbeni együttmüködés záloga. ${ }^{138}$ A jegyzőkönyvi utalásból arra következtethetünk, hogy legalább három látogató kereste fel a társulatot. Név szerint nem utalnak a magyar urakra, de minden bizonnyal Bölöni és Béldi mellett a BFUA vezetőségét felkereshette a később Amerikát is meglátogató Balog Pál és Wesselényi Farkas, vagy az ekkor Angliában tartózkodó Zeyk József. ${ }^{139}$

Roppant érdekes, hogy Bölöni május 25-röl írott feljegyzései nem egyeznek az ugyanazon a napon, a londoni Finsbury Unitarian Chapelben felvett jegyzőkönyvvel. A BFUA május 25-i jegyzőkönyve szerint a székely

${ }^{135}$ Uo., 203.

${ }^{136}$ David L. Wykes, Kenrick, John (1788-1877), Oxford Dictionary of National Biography, Oxford University Press, 2004 [http://www.oxforddnb.com/view/article/15414]

${ }^{137}$ Maller, i. m., 217.

138 "Several gentlemen are at present in this country who have come accredited to the Association from the Unitarians of Transylvania: they bring satisfactory accounts of the churches there; and the opportunity will of course be improved for the promotion of the intercourse which has already commenced with those ancient and steady professors of the pure Gospel." Report of the BFUA, London, 1831, 15.

${ }^{139}$ A felsoroltak egyike sem unitárius. Balog Pál Bölöni közeli barátja volt, Wesselényi Farkas (1782-1851) Közép-Szolnok vármegye főispánja, Zeyk József (1805-1852) Gyulafehérvár követe volt az erdélyi országgyülésen. Wesselényivel és Baloggal New Yorkban is találkozott Bölöni. 
nemes a BFUA évi közgyülésén vett részt, a Napló szerint pedig Yorkban volt.

A BFUA gyülése több szempontból is jelentős, egyrészt azért, mert Bölöni újból Erdélyre irányította a figyelmet, másrészt mert a külügyi osztály élére Bowring helyébe Edward Tagartot választották, aki a magyar-angol unitárius kapcsolatok további alakításában kulcsszerepet játszott. Bölöni angliai küldetése azért is fontos, mert az 1831. évi közgyúlésen az indiai liberalizmus képviselője, az ún. Brahmo Samaj alapítója, a modern India „atyja” Rajah Ramohun Roy (1780-1833) is jelen volt. Bölöninek köszönhetően a figyelem Erdélyre is kiterjedt, mi több, a frissen választott titkár az erdélyi és amerikai unitarizmus jobb megismerését tűzte zászlajára, és ennek érdekében a közgyúlés elé határozati javaslatot terjesztett elő. ${ }^{140}$

A jegyzőkönyvbe vett határozat rávilágít arra is, hogy Bölöni nem szólalt fel a közgyülésen, és valószínúleg az erdélyi unitarizmusról írott jelentését sem terjesztette elö, hiszen a titkár Székely Mózes göttingeni akadémita közeli látogatását bejelentő levelére utalt. Az Emlékkönyv I. kötetében Buzogány Áron jelentéktelennek ítélte Székely angliai látogatását. ${ }^{141}$ Székely Mózes szeptemberben érkezett Londonba, ekkorra már lefordították Bölöninek az erdélyi unitárius egyházról készített latin jelentését, és közzé is tették az MR szeptemberi számában. ${ }^{142}$ Bölöni nem csak a magyar unitárius egyház kialakulását, kormányzását, az iskolák és oktatás állapotát ecsetelte, hanem az unitáriusoknak a „modern irodalmi” életben betöltött szerepéről is írt. Ez azért is érdekes, mert így az ő szemüvegén keresztül képet alkothatunk arról, hogy ki kicsoda az erdélyi unitárius egyházban.

$140, \ldots$. My motion bears specific reference to the Unitarians of Transylvania and America. To the Unitarians who exist in Transylvania who can be indifferent? (...) I believe that we are honoured on this occasion with the presence of some Transylvanian gentlemen who come accredited to us, and are extremely desirous of further union and co-operation with us. A letter has been received from a gentleman recently elected to fill the Chair of Theological Professor at Clausenburg, and who, in order to qualify himself more completely for it, is at present studying in Germany, stating that there are 110 churches and 50000 souls devoted to the cause of Unitarianism in Transylvania; that Unitarians are elevated to high stations in the civil department of that country; and that he himself is extremely anxious to come here to cultivate a better acquaintance with the Unitarians of this country. (...) I beg leave to move, 'That this Meeting contemplates with satisfaction and delight the manifestation, in various countries, of a spirit of religious inquiry and of Christian zeal; and that our respectful and affectionate greetings are due to our brethren from Transylvania and America, who have shown their sympathy with us by their presence on this occasion." Anniversary of the British and Foreign Unitarian Association, MR, 1831, 420-421. Az MsU 780/ fordításban közli a gyülés lefolyását, Bölöni autográf!

${ }^{141}$ „Azt hiszem, hogy mindjárt Farkas Sándor után Székely Mózes, ki angolul nem is tudott, megjelenése a londoni unitáriusok közt már nem volt esemény. A tapasztalt férfiú után az igénytelen tanuló nem tünt fel." Emlékkönyv, vol. I., 22.

${ }^{142}$ Translation of Alexander Farkas' Account of the Unitarians of Transylvania, Communicated in Latin to the Secretary of the British and Foreign Unitarian Association, MR, 1831, 648-654. 
Bölöni szerint a teológiát Körmöczi János, Füzi János, Molnos Dávid, Szabó Sámuel és Sárdi Sámuel (id.) művelte. A köz- és a büntetőjog legjelesebbjei: Sala Sámuel, Fülöp József, Szolga János, Mezei János, Kovács István, Sikó István, és Gyergyai Ferenc voltak. A történetírókról szólva, egyetlen nevet említ, a Thucydidest fordító Molnos Dávidét. A költészet és zene művelői között említi Aranyosrákosi Székely Sándor, Kelemen Lajos, Gedő József, Gyergyai Ferenc, Szabó Sámuel, Kovács István és Szabó Júliánna nevét. Kifejezetten zenésznek tarja Gyergyai Ferencet és Lászlót és Brassai Sámuelt. ${ }^{143}$

Bölöni angol, majd amerikai megbízatásáról jelentést tett a konzisztóriumnak. Jakab Elek tanulmányában a Kénosi-Uzoni-féle Egyháztörténet folytatóit idézte:

„T. Farkas Sándor úr, kedves hitsorsosunk s vallásunk buzgó védője, Amerikába tett utazása alatt, az unitáriusok ottani állapotáról hiteles följegyzést készített $s$ azt az Erdélyben levő M. és Főtiszt. Consistoriumhoz küldötte, honnan az, az egyház életes tagjaival (seniorok, esperesek) a hívek lelki örömére közöltetett, s általok az eklézsiákban azok buzdítására kihirdettetett." ${ }^{144}$

Bölöni konzisztóriumhoz küldött jelentését nem találtuk meg az EUEGyLt-ban. A kolozsvári unitárius kollégium könyvtárában az U 5276452774 jelzet alatt több nyomtatványt tartalmazó kolligátumot találunk, melynek ötödik darabjára, a Brevis Expositióra már hivatkoztunk. Ezt a példányt látta el jegyzeteivel Bölöni, és ezt vette át szó szerint Aranyosrákosi Székely Sándor az 1839-ben neve alatt megjelent Az Unitária vallás történetei Erdélyben című könyvében. A mü utolsó - Az unitária vallás rövid története több külországokban - fejezete szó szerint követi Bölöni jegyzeteit. Székely Sándor „könnyedséggel” kezeli forrását, egyetlen hivatkozást sem találunk Bölönire. Ez egyébként is jellemző Székely Sándorra, mivel a Nemzeti Társalkodóban neve alatt megjelentetett Zsidó Régiségek Erdélyben is szó szerinti fordítása a Kénosi-Uzoni-féle egyháztörténet prolegomenonjának. ${ }^{145}$

A Jakab Elek közölte jelentéstől csak részben különböző szövegegységet találtunk Körmöczi János előző fejezetben is említett MsU 1232/H jelzetű kéziratában. Úgy gondoljuk, hogy ez Bölöninek a konzisztóriumhoz küldött jelentése. Az 1832. március 28-án kelt jelentés A Farkas Sándor jegyzéseiből címet viseli, de ezzel a megjegyzéssel: Copiae Epistolae, így csak arra gondolhatunk, hogy Körmöczi Bölöninek a konzisztóriumhoz küldött

${ }_{143}$ „In poetry and belles lettres, Alexander Szekely, Luis Kelemen, Josefh Fido (sic!) [Gedő], Francis Gyergyai, Samuel Szabo, Stephan Kovacs, and Julianna Szabo. In music, Francis and Ladislaus Gyergyai, and Samuel Brassai." Uo., 651.

${ }^{144}$ JAKAB, i. m., 25.

${ }^{145}$ Vö. a Prolegomenont a Nemzeti Társalkodó 1838. november 29, II. félév 22. számával, 174. 
levelét/jelentését másolta le. Ugyanakkor ez lehetett az a jelentés, amit a Kénosi-Uzoni-féle história folytatói szerint az „egyház életes tagjai” a hívek lelki örömére az eklézsiákban kihirdettek. ${ }^{146}$

Bölöninek nagy szerepe volt az amerikai unitárius kapcsolatok kiépítésében is. Az Ujjvilágban az első kifejezetten az erdélyi unitarizmussal foglalkozó híradás 1822-ben a Bostonban kiadott Christian Registerben (a továbbiakban ChRB) jelent meg. ${ }^{147}$ A Unitarian Fund 1821-ben készült jegyzőkönyvéből vették át az erdélyi unitáriusok lélekszámára vonatkozó hírt. ${ }^{148}$ 1823-ban a Baltimore-i Book Society évi jelentésében az angoloknak küldött Nagy Lázár-féle levél rövid kivonata olvasható. ${ }^{149}$ Bölöninek köszönhetően az amerikai hitrokonok angol közvetítés nélkül jutottak az erdélyi unitáriusokra vonatkozó értékes adatokhoz. Semmiképpen nem Bölöni hibája, hogy a bostoni unitáriusoktól 1841 után harminchét esztendeig nem érkezett levél Erdélybe. Henry Ware Jr. (1794-1843) az AUA nevében 1831. november 13-án levelet írt Bölöninek, és ehhez mellékelte a társulat jegyzőkönyveit is. Miután ismertette az amerikai unitárius állapotokat, felkérte Bölönit „,a köztünk való levelezésre, mert az egyesületnek különös óhajtása az, hogy a világ minden részeiben az unitárius vallást hívő atyafiakkal egybeköttetést hozzon létre."150 Nem tudjuk, válaszolt-e Bölöni a levélre. December 1-jén Molnos Dávid professzorhoz küldött Ware egy hasonló levelet. ${ }^{151}$ Buzogány az Emlékkönyvben azt írja, hogy tudomása szerint sem Farkas, sem Molnos nem válaszolt a megkeresésre. ${ }^{152}$ Kozma László (1810-1874) ügyvéd az Emlékkönyvben 1868. június 28-án tett széljegyzete szerint Molnos latinul válaszolt a levélre, vele lemásoltatta, és Farkas Sándorhoz küldette „expediálás” véget. Bölöninek az amerikai unitá-

\footnotetext{
${ }^{146}$ MsU 1232/H 110-116. Lásd Függelék 4. sz.

${ }^{147}$ Az AUA által kiadott lap. 1821-től 1957-ig jelent meg, ekkor címét The Unitarian Registerre változtatták. 1961-ben beolvadt a The Universalist Leaderbe majd az UU Worldba. Munkatársai közé a legjelesebb amerikai unitáriusok tartoztak: William Ellery Channing, Henry Ware, Jr., Andrews Norton, George Bancroft, Jared Sparks, Edward Everett Hale, stb.

148 "It has long been anxiously desired, and earnest wishes have been repeatedly expressed at the anniversary meetings of this Society that a correspondence could be opened with the Unitarians of Transylvania, the descendants of that illustrious band which stood so boldly forward in the cause of scriptural truth, at the period of the Reformation, and to the laborious and judicious writings of whose leaders, pure Christianity is so largely indebted. Their numbers have been estimated, by a recent traveler, at upwards of 30,000." ChRB, May 10, 1822, No. 39.

${ }^{149}$ The Unitarian Miscellany and Christian Monitor, Baltimore, 1823, vol. IV., 63.

${ }^{150}$ Emlékkönyv, vol. I., 15-18. Vö. ЈАКАВ, i. m.

${ }^{151}$ Emlékkönyv, vol. I., 18-19.

152 „....talán a közlekedési nyelv bajassága lehetett a főbb nehézség, mely elejtette a további levelezést, pedig nem kétlem, hogy később anyagi hasznunk is lehetett volna a velök való gondosan ápolt s fejlesztett viszonyból, miután az amerikai unitáriusok évenként százezreket gyüjtenek s fordítanak mindenfelé, hol az Unitarizmus érdekei kívánják." Uo.
} 
riusoknál tett látogatásáról az AUA 1832. május 29-én tartott közgyűlésén is megemlékeztek. ${ }^{153}$

Az Emlékkönyvben az amerikai kapcsolatokat illetően - Henry Ware Jr. említett levelein kívül - egyetlen feljegyzést találtunk az 1841. évre vonatkozóan. Az Emlékkönyv és az EKT jegyzőkönyve egybehangzó állítása szerint (EKT 1841/68.) Székely Miklós püspök a Summa Universae Theologiae egy „díszes példányával ajándékozta meg Summer (helyesen Sumner) György unitárius papot". Nagy a valószínűsége annak, hogy Székely Miklós George Sumnerrel, Charles Sumner (1811-1874) jeles amerikai államférfi testvérével találkozott. Feltételezésünket megerősíti a ChRB, mely névtelenül ugyan, de minden bizonnyal George Sumner Szebenből küldött levelét közölte. Az 1841. május 1-jén kelt levélben Sumner felettébb kedvező képet fest az unitárius papokról. Szerinte Erdély legintelligensebb lelkészei, alig van köztük tanulatlan, némelyek franciául is tudnak a német és latin mellett. Találkozott azzal a kálvinista prédikátorral, aki 1818-ban Göttingenben megismerkedett két bostoni unitáriussal. ${ }^{154}$

Henry Ware Jr. 1831-ben írott levele, majd Sumner tíz évvel későbbi látogatása után 1857-ig gyakorlatilag nincs kapcsolat az amerikai és a magyar unitáriusok között. Az Újvilág unitáriusai az Angliából érkező

${ }_{153}$ "We are happy in being able to announce the opening of a correspondence with the Unitarians of Transylvania during the past year. A Transylvanian nobleman, accompanied by a professor of the University, being on a visit to the United States, brought letters to your secretary, - expressed great interest in the religious institutions of the country, - gave and received much information - and promised to maintain a regular interchange of letters after returning to their home. It is particularly gratifying to have thus favorably opened to us a channel of communication with that ancient fraternity, which still flourishes in wealth, learning, distinction and numbers, and constitutes one of the most interesting divisions of the Church." The Reports of the American Unitarian Association Presented at the Seventh Anniversary, May 29, 1832, Boston, July, 1832, 28.

154 "Cibinii (Roman Colony among the Dacians), Hermanstadt, May 1st, 1841.

Among the books I have sent home you will find a work in Latin containing the principles of faith of the Unitarians of Transylvania. This is almost the only place in Europe (except at Geneva and in England,) where Unitarians are to be found; and it was greatly interesting to me to see them all in the cities and villages, fighting up against the opposition of Catholicism and Lutheranism. In Transylvania four different 'religions' were recognized - these three, and Reformers and Calvinists, the latter of whom are most numerous. I saw the preachers in all the little peasant villages through which I passed, and found almost invariably that the Unitarians were the most intelligent, and best educated. Some of them could even speak French, in addition to Latin, (the common language), Magyar and German. In a little village at the foot of the Carpathians, I found a Calvinist preacher, who was at Göttingen in 1818, and there knew two Americans from Boston, who were students, though their names he had forgotten. - Were they not Everett and Lyman? I have a copy of the commission of the Unitarian Bishop, as he is called here, given me by himself; also a MS history in Latin of the Unitarians in Transylvania, besides many statistical facts in regard to their present condition and prospects. These I must reserve for some future occasion." Unitarians in Transylvania, ChRB, September 4, 1841, 142. 
hírek alapján tájékozódhattak valamelyest a kontinensen élő hitrokonaik felöl. A ChRB 1829-ben az unitarizmus történetét ismertető cikksorozatban részletes pontossággal tájékoztatta olvasóit a magyar unitarizmus kezdeti történetéről, de hogy milyen forrás állhatott a szerző rendelkezésére, nem sikerült kiderítenünk. ${ }^{155} 1845$-ben a ChRB néhány statisztikai adatot közölt az unitáriusok lélekszámát illetően, forrásul Robert Wallace ChRL-ban megjelent cikke szolgált.. ${ }^{156}$

\subsection{Székely Mózes angliai látogatásának következményei}

Az angol unitáriusokkal Bölöni Farkas és Székely Mózes látogatása után sem szakadt meg a kapcsolat. A legteljesebb forrásanyagot megőrző Emlékkönyvben ugyan nem maradt fenn levélmásolat, de a BFUA jegyzökönyveinek szükszavú megjegyzéseiből arra következtethetünk, hogy az erdélyi unitáriusokkal évente legalább egy-egy levelet váltottak. Székely látogatásáról a BFUA 1833. évi jegyzőkönyve szűkszavúan számol be. ${ }^{157}$ Nyilvánvaló, hogy a társulat fizette az erdélyi diák utazási költségeit, és hogy a yorki kollégiumot ${ }^{158}$ látogatta meg. A kolozsvári könyvtár számára néhány angol múvet választott $\mathrm{ki}^{159}$, majd hazaindult. Látogatása rövidebbre sikeredett, mint remélték, de úgy váltak el egymástól, hogy Székely lesz az angolok jövőbeni erdélyi tudósítója, és általa füzik szorosabbra a viszonyt a kontinensen élő hittestvérekkel. Látogatásáról fennmaradt Körmöczi János püspökhöz 1832. január 25-én Jénából küldött levelének kivonata. Ebben a párizsi és genfi unitárius közösségek megalakulásáról tudósít, illetve Tagart és Bowring óhajait tolmácsolja. A párizsi és genfi

${ }^{155}$ History of Unitarianism. In Transylvania and Hungary, ChRB, January 24, 1829, no. 4.

${ }^{156}$ Unitarianism in Transylvania, ChRB, October 4, 1845, 1. Vö. Novum et Vetus Calendarium ad Annum Vulgarum 1845, Dierum 365 in Usum Magni Principatus Transylvaniae et Partium Adnexarum. Claudiopoli, tipys Liceii Regii. 285-290. Wallace Nagyajtai Kovács István jóvoltából jutott hozzá a pontos statisztikai adatokhoz. Nagyajtai Angliába küldött hungarikáival a későbbiekben részletesebben foglalkozunk. A könyvküldemény egyik darabja az 1845. évi Calendarium volt. Ebben Kovács piros ceruzával aláhúzta mindazok nevét, akik az Unitárius Egyházban valamilyen tisztséget töltöttek be. ChRL, 1845, 506-507.

${ }^{157}$ Report of the BFUA, London, 1832, 16-17.

${ }^{158}$ A Manchester College yorki korszakáról lásd: Wyкes, David L., 'Dissenting academy or Unitarian seminary? Manchester College at York (1803-1840)’ TUHS 1988, 102-112.

${ }^{159}$ W.J. Fox 1831-ben megjelent Christ and Christianity. Sermones on the Mission, Character, and Doctrine c. kötetben a Székely Mózes possessor-bejegyzését találjuk. M. Székely mp. London 1831. 18. Octobris. 
egyházközségekre vonatkozó adatait a BFUA jelentései, illetve Tagart beszámolói alapján állíthatta össze. ${ }^{160}$

Székely hazatérése után írhatott egy rövid levelet egykori vendéglátóinak, mert a BFUA 1833-ban tartott közgyưlésén arról számoltak be, hogy Kolozsvárott ő lett az unitárius kollégium filozófia professzora, és hogy remélik, nemsokára közvetítésével az egyház helyzetére vonatkozó információkat kapnak. ${ }^{161}$ Székely Mózestől több tudósítás nem érkezett, és az angolok 1834-1835-ben az erdélyi unitáriusoktól sem kaptak egyetlen levelet sem. 1836-ban a társulat arról számolt be, hogy Nagy Lázár biztató híreket küldött Erdélyből. ${ }^{162}$

Ezek szerint Nagy Lázár nemcsak 1821-ben írt az angoloknak, hanem időről-időre tájékoztatta a társulatot az erdélyi dolgok állásáról. 1837-ben bekövetkezett halála után az angol unitárius periodikákban nem találunk Erdélyre vonatkozó utalásokat, kivétel a John Paget Hungary and Transyl-

\footnotetext{
${ }^{160}$ Tekintettel arra, hogy Székely Mózesnek még nem kerültek elő peregrinációja során írott levelei, a Körmöczihez küldött tudósítást teljes terjedelmében közöljük:

„A párizsi és genevai unitáriusok eredetéről és mostani állapotjokról. A párizsi unitáriusoknak eredete az 1828-ik esztendőbe Londonba a keresztény vallás terjesztésére felállíttatott unitárius atyafiakból álló társaság jelentésére esik. Eddig való kiformálódások állapotjáról Edvard Tagart úr ennyit [mondott/írt]: Párizsban egy kápolnájok vagyon egy miniszter felvigyázata alatt, melynek fundamentoma az 1827-ik esztendőbe tétetett volt le. A kápolnák száma még nem igen nevekedett de az hallgatóké napról napra szaporodik nem csak Párizsban hanem a körül levő városocskákba és falukba is.

A genevai unitáriusok históriája hosszabb időre terjed ki mint a párizsiaké. Itt az unitarizmus kedvelőit és oltalmazóit az 1788-ik esztendőre lehet tenni, mely idő tájt néhány oskolákba a reformata confessio helyébe az oskolák tanítói új confessiót akartak substitualni Genevai Catechismus nevezeti alatt. 1805 esztendőben az Bibliának az megjobbíttatott kiadása jelent meg. 1807-ben pedig ehhez járult még a liturgia reformálása is. De mindezen előre tett lépések mellett vallásoknak állandó bázist az 1826-ik esztendeig nem vethettek. (Ámbár, hogy egy Málom [sic!] nevű tudós pap aki hivatalától való felfüggesztése után is tulajdon kertjébe maga költségén építtetett kápolnájába sokaknak hirdette az igaz tudományt, s mindent elkövetett az új vallásnak megalapíthatására). Ekkor az Anglus unitáriusok segedelmezése által építettek a reformátusok engedelméből legelsőbben törvényesen egy kápolnát, ez az egy rövid idő alatt annyit szült, hogy ma a belső városba 4 kápolnájok 8 papjok, a külső városba pedig három szent hajlékok s ugyanannyi lelkipásztor felvigyázása alatt e mai napig igazgatik.

Edward Tagart Londonban egy magyar anglus nyelvre fordított prédikációt kér. Bowring úr egy theológiát kér." MsU 1232/G, 109-110.

${ }^{161}$ Report of the BFUA, London, 1833, 17.

162 "A cheering account was given of the correspondence with France, Geneva, etc. and reference was made to a Latin letter recently come to hand from our Unitarian brother and friendly correspondent Lazarus Nagy, of Clausenburg, in Transylvania: his report of this interesting portion of the Unitarian Church is very encouraging. The Transylvanian Unitarians are increasing in numbers; additions are made to their churches; and their colleges and schools are prospering." Anniversary of Unitarian Association, ChRL, 1836, 497.
} 
vaniája kapcsán közölt, a magyar unitáriusokat érintő rész. ${ }^{163}$ Az 1840-es években Berde Áron (1819-1892) fontolgatta azt, hogy Angliába megy, Iszlai László felügyelő gondnoknak 1842. decemberében egyebek mellett ezeket írta Berlinből:

„Angliába az unitárius atyafiakhoz írtam, mely alkalommal hozzájok menendő szándékomat nyilvánítottam, válaszokról, legyen az elmehetésemre nézve kedvező, vagy nem, tudósítani fogom a méltóságos urat."164

Nem tudjuk, Berde kapott-e egyáltalán választ levelére, tervezett angliai útjára nem került sor.

Nagyajtai Kovács István sem volt szerencsésebb Berdénél, de neki legalább megadatott, hogy 1845-ben néhány hungaricát juttasson el Londonba. Dán Róbert a Manchester College-ban található magyar könyvekről írott tanulmányában viszonylag részletesen tárgyalja a könyvek útját, és nem tartja kizártnak azt sem, hogy Kovács 1845-ben járhatott Angliában. A College-nak adományozott könyvekbe mind a könyvtárnok, mind Kovács bejegyezte a dátumot: „May 1845”. ${ }^{165}$ Dán a donációs jegyzék 8. pontjában Enyedi György Explicationes címü munkáját ismerteti, és közli a becses 1617. századi possessorok nevét is. Feltünő ugyanakkor, hogy ugyanannak a jegyzéknek 7. pontja alatt szereplö Defensio Franciscis Davidis egykori tulajdonosáról nem mond semmit. A címlapon olvasható possessor bejegyzés - Joannes Warffaluinus - az unitáriusok negyedik püspökére, Várfalvi Kósa Jánosra irányítja a figyelmünket. Kovács István az előzéklapon itt is gondosan leírja a könyvvel kapcsolatos legfontosabb tudnivalókat. ${ }^{166}$

Dán cikkében említést tesz az Explicationes egy másik példányáról is, mely 1859-ben került a könyvtárba. Ennek történetét is ismerjük, mi több, azt is tudjuk, hogy nem a könyvtáros látogatott Erdélybe, miként ezt Dán állítja, hanem Alfred Steinthal útján került a kötet a Manchester College birtokába. (Nemcsak a latin, hanem a magyar fordítása is megvan a münek: a D/1620/2 jelzet alatt Toroczkai fordítását őrzik. Possessorai és a könyv angliai útja külön tanulmányt érdemelnének.) Szorosabb tár-

${ }^{163}$ John PAget, Hungary and Transylvania; with Remarks on Their Condition, Social, Political, and Economical, London, 1839, vol. 2. A magyar hitrokonokat érintő részlet lásd vol. 2. 502503. Részleges magyar fordítása: John PAGET, Magyarország és Erdély, Helikon, é. n., válogatta, szerkesztette, a szó- és névmagyarázatot és a tanulmányt írta MALLER Sándor, fordította RAKovszky Zsuzsa.

${ }^{164}$ BiÁs István ifj., Unitárius egyháztörténeti adatok (1619-1896), Marosvásárhely, 1910, 215.

${ }^{165}$ Dán Róbert, Nagyajtai Kovács István könyvajándéka a Manchester (New) College-nak, Magyar Könyvszemle, 1979, 382-384.

166 "Notis que de Libro sub titulo Defensio Francisci Davidis etc. editio in Sandii Bibliotheca Antitrinitariorum p. 59 occurunt hoc solum adjicendum habeo: agitur in eo de rebus respectu Transylvanorum Unitariorum gravissimis; idem tamen ob summam ejus raritatem, apud nos hoc die paucissimis notus. Stephanus Kovacs mp. 1845” Könyvtári jelzete D1582/1. Harris Manchester College, Oxford. 
gyunkhoz visszatérve megállapíthatjuk, hogy Kovács nem járt 1845-ben Angliában, ugyanis éppen májusban ülésezett a BFUA, s ha Kovács István ekkor Londonban tartózkodott volna, nehezen hihetö, hogy ne vett volna részt a közgyűlésen. Könyvei minden valószínüség szerint John Relly Beard (1800-1876), az 1854-ben Manchesterben alapított Unitarian College első principálisa készülő monográfiájához szolgáltattak anyagot. (Angliában két unitárius főiskola müködik, a Manchester New College és a Unitarian College Manchester. Előbbi 1786-tól 1803-ig Manchesterben, 1803-tól 1840-ig Yorkban, 1840-tôl 1853-ig újból Manchesterben - ettől az időtől nevezik Manchester New Collegenak - 1853-tól 1889-ig Londonban, 1889-től napjainkig Oxfordban székel. ${ }^{167}$ Az 1854-ben alapított Unitarian College célja elsősorban nem az akadémiai képzés, hanem a missziós munkára való képzés volt. ${ }^{168}$ ) Beard 1846-ban adta ki az Unitarianism Exhibited in its Actual Condition című művet. Ennek az erdélyi unitáriusok történetét taglaló fejezetét Nagyajtai Kovács István írta. A máig meglévő kéziratos tanulmány címe Az erdélyi unitáriusok rövid históriája hiteles kútfö́k után. Ezt John Paget 1846 márciusában fordította angol nyelvre. ${ }^{169} \mathrm{~A}$ Beard szerkesztésében megjelent kiadványában az erdélyi szerző neve nincs feltüntetve - Kovács István valószínűleg a cenzúrától félt -, de a fordító, J. P. iniciáléja Pagetre utal. A fordítás szöveghű, Paget csak egy-két esetben rövidített a hosszabb körmondatokon. Nagyajtai autográfja az egykori kolozsvári unitárius kollégium kézirattárában az MsU 1179/40-41 jelzet alatt található. Természetesen a fordító kihagyta a saját érdemeit magasztaló részt, így az nem került be a kötetbe. ${ }^{170}$

Kovács István, talán azért, hogy a készülő kötet összeállításában segédkezzen, a legfontosabb unitárius forrásokat John Beardhoz is eljuttatta. Az általa küldött könyvek a College költözésével Londonba, majd Oxfordba kerültek.

\footnotetext{
${ }^{167}$ Valentin David Davis, A History of Manchester College from its Foundation in Manchester to its Establishment in Oxford, London 1932. Lásd még: Simén Domokos, Az angol unitáriusok londoni akadémiájának rövid ismertetése, KerMagv, 1863, 288-297.; ERDő János, A Manchester College története és kapcsolata az erdélyi unitárius egyházzal, KerMagv, 1986, 138-158.

${ }^{168}$ Leonard Sмітн (ed.), Unitarian to the Core: Unitarian College Manchester, 1854-2004, Unitarian College, Manchester, 2004.

${ }^{169}$ Unitarianism in Transylvania = J.R. BEARD, Unitarianism Exhibited in its Actual Condition, London, 1846, 296-315.

170 „Midőn az erdélyi mostani unitáriusokról és ezek kebelébe tartozó írókról emlékezünk, nem lehet említést nem tennünk még egy férfiúról. Paget János angolhon szülöttje is Erdélyben él most mint második honában. Mind személyes tulajdonai, mind a Hungary and Transylvania, London 1839 címú munkája által megnyervén és bírva ott minden rangúak és hitvallásúak köz szeretetét és tiszteletét. Unitárius hitsorsosaira nézve, azok fő jóltevői sorában áll ő, és azok különös örömüknek tartják, hogy őt övéik közé számolhatják." Nagyajtai Kovács István, Az erdélyi unitáriusok rövid históriája hiteles kútfók után, MsU 1179/40, 28.
} 


\section{9. Újabb adatok Jakab József angliai útjához}

1821-től 1848-ig szórványos magyar-angol unitárius kapcsolatokról beszélhetünk. 1848-ban egy fiatal akadémita látogatott Angliába, és ezzel a kapcsolatok is új irányt vettek. Jakab József (1821-1855) életrajzát Várfalvi Nagy János írta meg a Keresztény Magvetőben, ezért dolgozatunkban nem térünk ki részletes ismertetésére; hasonlóképpen eltekintünk skóciai útinaplója elemzésétől is, ennek töredékeit a Berde Áron szerkesztette Ipar és Természetbarát közölte. ${ }^{171}$

Jakab József 1848-ban Aranyosrákosi Székely Sándor püspöktől és a konzisztóriumtól latin nyelvü ajánlólevelet kért, hogy Angliába mehessen. Célja részint továbbtanulás, részint a megszakadt kapcsolatok újrafelvétele volt (EKT 1848/13., 48.). Az EKT az ajánlást megadta, és Jakab feladatai közé sorolta az egyház céljaira szervezendő gyưjtést is. A gyưjtőívet is elkészíttették és Pagetet kérték fel a fordításra. Az angol arisztokrata nem zárkózott el a kérés elől, csupán azt javasolta, hogy a gyüjtőív mellé készítsenek egy kimutatást az egyház szükségleteiről. A Tanács a gyüjtés gondolatát ejtette, de Jakabnak megadta az ajánlólevelet. A göttingeni akadémita 1846-tól szorgalmasan tanulta egyik skót barátjától, William Nisbettől az angol nyelvet, és 1848 márciusában elindult Angliába. Néhány napot a forrongó Párizsban töltött, majd megérkezett Londonba. „Tanulmányairól” nem sokat tudunk, a közintézményeket látogatta meg és néhány előadást hallgatott. 1848. június 14-én Londonban részt vett a BFUA huszonharmadik közgyúlésén, ahol tiszteletére díszes oklevelet állítottak ki, és a jegyzőkönyvben megörökítették nevét. ${ }^{172}$ Hazatérése után, 1848. augusztus 31-én kelt levelében, részletesen tájékoztatta az angolokat a magyarországi és erdélyi forradalmi állapotokról. ${ }^{173}$ Egy másik levelében

\footnotetext{
${ }^{171}$ VÁrfalvi Nagy János, Jakab József életrajza, KerMagv, 1872, 209-236., JAKAB József, Töredékek scotiai uti naplómból, Ipar és Természetbarát, 1848. szeptember, 19-23. sz.;

172 „That this Meeting is happy to welcome as a Visitor at this Anniversary, Mr. Jakab, later a Student at Clausenburg, in Transylvania, and trusts that his visit to this country may be the means of strengthening the bonds of union between the Unitarians of England and the time-honoured Churches of Transylvania." Report of the BFUA, London, 1848, 5. Az oklevél a EUEGyLt-ban Kolozsvárott, Kovács János hagyatéka, 2. doboz, 38. sz.

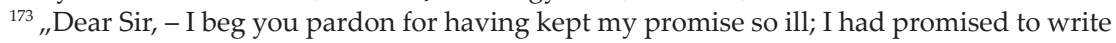
to you in a month, but I have arrived in my native country but three weeks ago. I spent a week with my parents and my kinsmen, two weeks with military exercises, for you must know that no sound person does exist in whole Hungary who is not occupied with weapons; we are all ready to bear us with the greatest legion of the world. Besides, I was occupied with editing a scientific newspaper, whose editor is at present in Budapest, the capital of Hungary, where tomorrow a large meeting of ministers and schoolmen is to be held. As for Hungary, it is not true that inter arma silent Musae. Our right hands hold in the morning the pen, in the night arms. In the left hand of ministers is the Bible, in their right the sword. Our country is surrounded with enemies, but our hearts with courage and more beautiful hopes. My fellow
} 
arra kérte egykori vendéglátóit, hogy maradjanak kapcsolatban, már csak azért is, mert az unitárius vallás a legtökéletesebb a keresztény vallások sorában. A kölcsönös levélváltás mindkét fél vallását jótékonyan segítheti, különösen az erdélyiekben ébresztheti fel a (vallás)szabadság iránti vágyat. Mindent meg kell tenni a szabadság kivívása és az unitarizmus hirdetése érdekében - írta angliai ismerőseinek. ${ }^{174}$ A jövő stratégiáit ekképpen vázoló fiatalembert elsodorta a forradalom. A szabadságharc győzelmét óhajtó angol unitáriusok azon kívánsága sem teljesedhetett be, hogy Magyarországot szabad, felvilágosult kormány vezesse. A világosi fegyverletétel után az angol unitáriusokkal tartott kapcsolat jóformán megszünt és Erdélyből 1857-ig nem érkezett „unitárius” levél Angliába.

religionists have accepted my reports of my reception in England with great satisfaction, and they will feel happy, so soon as a larger Unitarian meeting takes place to write to you, and to send their thanks for your kindness to me, for the Books sent to our Library, and for your wish for greater union to be established between us. I shall begin my working in two weeks as second Minister of the Congregation of Klausenburg, and on the 1st of November as Professor of Logic. I had arrived at Paris just as the revolution broke out. I was confined four days to my lodging, and spent four days in having my passport examined, and having been in Paris for eight days in such a miserable condition, I went to Strasburg and from thence to Germany. I saw only the siege of two barricades - the whole of the outside of the town - mounted to the top of the renowned monument of Napoleon and visited the Botanical and Zoological Gardens. This is my whole experience of Paris. Never mind; I spent three beautiful months in England; I enjoyed your friendship, and this is sufficient for me till I shall have an opportunity to see Paris once more again. Yours etc. J. Jakab." Report of the BFUA, London, 1849, 9.

174 „To go into all our peculiarities I do not find necessary; I conclude my words by calling on you to carry on a regular correspondence with us Transylvanian Missionaries; may we write once or twice in a year to each other. I am convinced that Unitarianism is the more perfect amongst the religions of all Christian sects, but I am not of opinion that Unitarianism has attained its highest point of perfection. By the correspondence proposed we shall exercise a great influence on each other's religious life, and finally on the whole of our religion. We have done much, but we have yet much to do, especially we Transylvanians, who have neglected so much our deemed liberty of conscience. I shall rouse those who are yet sleeping; there are a great many who wake already. We shall do all which there is to do, at first for our liberty, and then for the propagation of Unitarianism. You will support us in our endeavours." Uo., 10. 


\section{ANGOL UNITÁRIUSOK ERDÉLYBEN, MAGYAR UNITÁRIUSOK ANGLIÁBAN 1849-1869}

A forradalom és szabadságharc leverése után az erdélyiek 1857-ig nem adtak életjelt magukról. Ebben az esztendőben Bécs germanizáló, elsősorban az önálló tanintézményeket sújtó politikája miatt kénytelenek voltak a szigetországban és az Amerikai Egyesült Államokban élő testvéreik segítségét kérni. A kapcsolattartó személy 1857-1860 között John Paget volt.

\subsection{John Paget János és Erdély}

John Pagetnek a reformkori Magyarországot és Erdélyt megörökítő múvét Maller Sándor ismertette legalaposabban az 1987-ben szerkesztésében és válogatásában megjelent szövegkiadásban. ${ }^{1} \mathrm{~A}$ dolgozatnak nem célja Paget életmúvét feldolgozni, sem pedig monográfiát írni róla; a különböző angol, magyar és román folyóiratokban megjelent közlemények és újságcikkek foglalkoztak az Erdélybe települt unitárius orvos-gazdálkodó útleírásával és a magyar forradalomban és szabadságharcban betöltött szerepével, ezért csak az unitárius egyházzal kapcsolatos kérdéseket tárgyaljuk. ${ }^{2}$ Mi történt 1857-ben, hogy az unitárius konzisztórium Paget közbenjárását kérte? Bécs abszolutista-germanizáló politikája következté-

\footnotetext{
${ }^{1}$ Maller, i. $\mathrm{m}$.

${ }^{2}$ Wykes, Paget...; Czigány Lóránt, Paget, John (1808-1892), Oxford Dictionary of National Biography, Oxford University Press, 2004 [http://www.oxforddnb.com/view/article/]; Kovács Sándor, Egy angol magyar unitárius életútja. John Paget (1808-1892) = A Szent szabadság oltalmában. Unitáriusok az 1848-49-es szabadságharcban, szerk. GAAL György, Kolozsvár, 2000, 316-334., Uő. Kétszáz éve született John Paget, Erdély magyar honpolgára, KerMagv 2008, 203-218., GÁL, i. m., 211-215. A fontosabb román bibliográfiák közül Pagetre vonatkozóan lásd: NicolaE Iorga, Istoria românilor prin călători, Bucureşti, 1929, vol. IV, 163-165.; Călători străini despre Țările Române în secolul al XIX-lea, Serie nouă vol. III (1831-1840) vol. îngrijit de Paul Cernăvodenu, Georgeta Filitti, Daniela Busă... Bucureşti: Editura Academiei Române, 2006, 836-845.;WEBER Peter, Românii din Transilvania şi Ungaria la mijlocul secolului al XIX-lea în impresiile de călătorie ale lui John Paget = Anuarul Institutului de Istorie G. Bariț din Cluj-Napoca, tom. XLIV. 2005, 51-59. Carmen Andraş, România şi imaginile ei în literatura de călătorie britanică, Dacia, 2003, 126-129, 171-173, 258-260, 326-331.
} 
ben az egyházi oktatási intézményeket osztrák mintára teljesen át kellett alakítani, és a fenntartásukhoz szükséges összeget kimutatni. A kormány az 1849-ben kibocsátott Organisationsentwurf - Az ausztriai gimnáziumok és reáliskolák szervezetére vonatkozó szabályzat értelmében kívánta megreformálni az oktatást. A rendelet szerint a nevelés és oktatás fölött az állam gyakorolja a főfelügyeletet. Ezzel a protestáns egyházak iskolái igen nehéz helyzetbe kerültek. Mindezekkel együtt elmondható, hogy a népoktatásügy jelentős fejlődésen ment keresztül. Az Entwurf rendelkezései többek között a tanárok létszámának és fizetésének emelését - a nyolcosztályos gimnáziumnak 12, a négyosztályosnak 6 rendes tanár alkalmazását -, illetve megfelelő iskolai felszerelést, a laboratóriumok és szertárak fejlesztését írták elő. Az egyház szegénysége miatt ezeknek teljesítése lehetetlennek látszott. $\mathrm{Az}$ iskolák megmentése érdekében az egyház híveitől azt kérte, hogy évenként egy ezüst garassal járuljanak hozzá azok fenntartásához. Az utasításoknak megfelelően az EKT elkészíttette az iskolák fenntartásához szükséges alapok kimutatását, ugyanakkor képviselői, Székely Mózes és Kriza János által felkérték az Aranyosgyéresen megtelepedett és magyar honosítást nyert John Pagetet, hogy angol ismerőseinél járjon közben érdekükben. Paget az egyház anyagi helyzetét kimutató statisztikák áttanulmányozása után 1857. március 4-én segélykérő levelet írt hajdani tanárának, John Kenricknek. Tulajdonképpen tanácsot kért egykori professzorától, Kenrick azonban bölcs belátással a teljes levél szövegét közzététette a ChRL-ban, és ezzel az erdélyi unitárius oktatásügy javára általános akciót indított el. ${ }^{3}$ Kenrick 1857. március 26-án Pagethez írott leveléből tudjuk, ${ }^{4}$ hogy a BFUA tanácsa azonnal 100 font sterling segélyt szavazott meg, és intézkedett a segélykérő levél kinyomtatásáról és köröztetéséről. Kenrick levelével egy időben a társulat titkára, Edward Tagart is írt Pagetnek. ${ }^{5} \mathrm{~A}$ korabeli magyar fordításban fennmaradt levelek fényt derítenek a BFUA kezdeményezte sikeres gyűjtésre. Tagart rendkívül jó szervezőkészségről tett tanúbizonyságot, hiszen nemcsak az angliai, de az amerikai unitáriusokat is bevonta az akcióba. (Ennek részleteit a következő fejezetben ismertetjük.) A gazdasági válság miatt az amerikaiak tevőlegesen nem vehettek részt a gyüjtésben, de rokonszenvükről biztosították erdélyi testvéreiket. Tagart pontosan akart tájékozódni a begyűjtendő segély felhasználásáról, és a BFUA választmánya nevében is a következő kérdéseket intézte Pagethez, illetve a magyar unitáriusokhoz:

\footnotetext{
${ }^{3}$ Letter of John Paget, esq. to the Rev John Kenrick, ChRL, 1857, 301-304.

${ }^{4}$ EUEGyLt Angliai levelezés 1827-1925/1857. Kenrick levele több szempontból is érdekes, ezért teljes terjedelmében közöljük. Lásd Függelék 5. sz. Az Emlékkönyvbe nem másolták be ezt a levelet.

${ }^{5}$ Uo., Tagart Pagetnek, London (Hampstead), 1857. március 25.
} 
„Kívánatos volna tudni: hogy a netalán begyưlendő pénz mi módon fog beruháztatni (invested); kik lesznek azon vagyonnak gondviselői; minő biztosítás van arra nézve, hogy a jövedelem vagy kamat éppen a meghatározott célra fog fordíttatni, ti. a tanári fizetések nevelésére vagy a tanárok számának szaporítására; s vajon fogja-e az biztosítani a végcélt, úgy mint az erdélyi unitáriusok vallási intézeteinek s nevelési alapítványainak a kormány beléavatkozásától való függetlenséget? Nem lehet-e attól tartani, hogy amely mértékben tesznek eleget az Unitáriusok az osztrák követeléseknek, a kormány abban a mértékben fogja a követeléseket változtatni vagy feljebb fokozni oly célból, hogy minden tudományossági s protestánsszerú érdeket elnyomjon vagy absorbáljon?"6

Az 1857. június 3-án tartott közgyưlésén arról számoltak be, hogy a tanács rendkívüli segélyén kívül még 500 fontot gyűjtöttek az erdélyi unitárius oktatásügy megmentése érdekében. ${ }^{7}$

Ifj. Fabiny Tibor az Országos Levéltár Kossuth-gyüjteményében több értékes dokumentumot is talált Paget kérelmének angliai visszhangjáról. A Coventry-i lelkész, Thomas Hunter (1810?-1898) Kossuthnak is megküldte az erdélyi unitáriusok támogatását célzó körlevelet, hogy ő is igazolja Paget helyzetjelentését, s ezzel is nagyobb népszerüséget szerezzen az ügynek gyülekezetében. ${ }^{8}$ Hunter május 3-án írt levelére Kossuth még aznap válaszolt, ezt a Coventry-i lelkész megküldte a londoni The Inquirer szerkesztőségének (minden bizonnyal innen vette át a New York-i Christian Inquirer $){ }^{9}$

${ }^{6}$ Uo.

${ }^{7}$ Report of the BFUA, London, 1857, 8-9.

${ }^{8}$ Fabiny, i. m., 101-102.; T. Hunterről lásd: Kovács János, Hunter T. emlékezete, KerMagv, 1898, 97-98.

${ }^{9}$ Tekintettel arra, hogy a magyar Kossuth-kutatók sem ismerhették a levél tartalmát, teljes terjedelmében közöljük: „Sir - Returning from a lecturing excursion, I find your communication of May 3, which I have the honour of answering herewith.

As to the internal merit of Mr Paget's appeal, 'assistance to the Unitarian schools of Transylvania,' I not only fully sympathize with it, but I should greatly rejoice if my testimony and the expression of my approbation would contribute towards adding to the interest which the cause ought to command.

That an attack has been made on the freedom of Protestant education is true beyond the worst of what men in this country can realize in their mind. Not only has an attack been made on the freedom of education in the Protestant schools, but the self-government of the Protestants (Calvinists, Lutherans, and Unitarians alike), in church and school, founded on solemn treaties and conventions, forming part and parcel of the public law of Europe, guaranteed by several European powers, and some of them especially negotiated under the mediation of England - that freedom and self-government, the precious fruit of five great revolutions and of a struggle of 200 years' duration, is entirely subverted, and the Protestant schools of the country are placed under the arbitrary control of the same Minister of the Austrian Court, whose especial charge it is to give effect to the Concordant which delivered the country bound hand and feet unto the power of priest craft, intolerance, and fanaticism. I can not point out any modern work on Hungary supplying a correct information on the present condition of that country. Speech and the press are gagged, meetings are forbidden, an infernal spy system hushes the complaints, and the Concordat empowers the Roman Catholic 
Kenrick május 17-én a yorki St. Saviourgate Chapelben az erdélyiek érdekében prédikált. Röviden ismertette az európai heterodoxia és a magyar unitárius egyház történetét. Észak-Olaszország és Lengyelország antitrinitárius mozgalmainak bemutatása után az erdélyi unitárius fejleményeket vázolta hallgatóinak. A Szapolyaiakat illetó információi nem éppen helytállóak, de a yorki unitárius gyülekezet nem botránkozott meg azon, hogy Szapolyai János lányát a lengyel király vette feleségül, s hogy Giorgio Biandrata az öreg János király udvari orvosa volt. Az erdélyi unitárius oktatás veszélyeztetett létét Claudius Aelianus Varia Historiajából vett illusztrációval érzékeltette. Eszerint a Mytilene-beliek szövetségeseik lázadását azzal torolták meg, hogy a lázadók nem taníthatták gyermekeiket. Mindennél nagyobb büntetés volt az ostobán viselkedő és a kultúra iránti teljes közömbösséggel viseltető új nemzedéket látni. A klasszikus példa után a keresztények hasonló eljárására emlékeztette hallgatóit, majd az angol felekezeteknek az egységes nemzeti oktatás politikáját meghiúsító szűkkeblü bizalmatlanságáról szólva visszakanyarodott céljához. Ausztria úgy gondolja, hogy az unitárius egyház oktatást szolgáló alapjai elégtelenek, és a színvonal emeléséért aggódó atyai gondoskodásával arra szólította fel a felekezetet, sokszorozza meg a tanárok létszámát és emelje meg fizetésüket. Amennyiben a felekezet erre nem képes, a kormányzat szívesen felvállalja az oktatás terhét, különösképpen, hogy ezzel az iskolák feletti ellenőrzési jogot is megkapják. A hang ugyan Jákobé, de a kéz Ézsaué figyelmeztet Kenrick -, a végső cél a liberális szellemű unitárius oktatás elsorvasztása és annak a képzett, de szubtilis jezsuita irányítás alá helyezése. Ezt megakadályozandó született meg az erdélyiek felhívása, és erre az angol hittestvéreknek cselekvően kell válaszolni. ${ }^{10}$

Bishops to exclude from circulation any book they may dislike. [Here reference is made to accompanying papers, especially to a memorial on the present condition of the Protestants of Hungary, drawn up at Kossuth's request by M. Irányi, a fellow exile, resident in Paris.] I most fervently wish in the interest of religious freedom, morality, and interest that England should awake to a lively sense of Christian duty for the subject. I have no hesitation in confessing my conviction that the cause of Protestantism in Hungary is a hundred thousand times of greater importance to the Christian world than the conversion of some straggling Patagonians, on which treasures are yearly expended by the numerous religious societies of Great Britain. Please to accept, etc. Kossuth. Regents's Park, London, May 3, 1857." The Unitarians of Transylvania, The Inquirer, May 16, 1857, 311.

John Kenrick néhány soros ismertetőben az erdélyi unitáriusok iránt érdeklődő olvasóknak Beard könyvét ajánlja, majd megjegyzi, hogy az erdélyi hitrokonokra már édesapja is felhívta a figyelmet egy 1793-ban mondott prédikációjában:

"I believe that the condition of the Unitarians in Transylvania was first brought to the notice of the English Unitarians, in recent times, by a note to my father's sermon before the Western Unitarian Society, at Tauton, in 1793. The information contained in it was derived from his friend, the late John Foster Barham..."

${ }^{10}$ John KenRICK, Unitarians in Transylvania, ChRL, 1857, 377. 
Ma már lehetetlen nyomára lelni annak, hány angol unitárius közösségben gyüjtöttek az erdélyi hittestvérek javára, a The Inquirer is rapszodikusan számol be az ilyen alkalmakról. Nem tudjuk, hogy Hunternek Kossuth tekintélyére alapozott lobbija mennyire volt sikeres, tény az, hogy Paget segélykiáltása után tekintélyes lelkészek emelték fel szavukat az erdélyi unitáriusok érdekében. James Martineau (1805-1900) a liverpooli Hope-street egyházközségben a Galata 6,10 alapján prédikált. Beszédének kivonatát a Northern Daily Times alapján a The Inquirer közölte. ${ }^{11}$ A prédikáció tekintélyes része vallásbölcselet, az ember-Isten viszony elemzése. Az erdélyi kérdést Kenrickhez hasonlóan a reformáció oldaláról közelítette meg, és a szabadelvü oktatás megtartásáért adakozásra hívta fel hallgatóságát. Liverpoolban, a Renshaw-street Chapelben az Amerikából Angliába költözött William Henry Channing (1810-1884) lelkész is az erdélyiek érdekében prédikált. A fent ismertetett beszédek közül ez volt az egyetlen homília, mely az erdélyi unitáriusok küzdelmes történetét viszonylag pontosan ismertette hallgatóival. ${ }^{12}$

Június 28-áról való az az újabb híradás, mely a gyűjtésre vonatkozik. A Loughborough-i lelkész Charles Clement Coe (1830-1921) prédikációja után 27 fontot gyüjtöttek. A felsorolt „akciókon” kívül meg kell említenünk, hogy a BFUA főtanácsát követő fogadáson John James Tayler (17971869 ) a vallási és polgári szabadságra mondott pohárköszöntőt. (A társulat ülésein máig szokásban van a világ polgári és vallásszabadságára - Civil and Religious Liberty all over the world - mondott pohárköszöntő.)

A reformáció századának felvilágosult szabadgondolkodói - indította beszédét - Olaszországból Svájcba, majd Franciaországba menekültek, vallásos meggyőződésük miatt azonban innen is menekülniük kellett, és Lengyelország adott otthont számukra. Krakkóban telepedtek meg [elírás lehet, biztosan Rakowról van szó] ahol messze földön híres iskolát és nyomdát működtettek. Tudós akríbiával megírt könyveik óriási hatással voltak az európai teológusokra, a politikai helyzet kedvezőtlen alakulása miatt azonban a lengyel szociniánusoknak választani kellett: hazájukat vagy vallásukat hagyják el? Az előbbit választották és sokan Hollandiába, Angliába telepedtek át, de egy kis csapat Erdélyben keresett és talált menedéket. Ez a bátor és értelmes nép, mely az erdélyi hegyek között megőrizte vallása és szokásai tisztaságát, intézményeit, most abba a veszélybe került, hogy elveszíti az ifjúság oktatásának jogát. Óriási erőfeszítéssel 18000 font sterlinget gyüjtöttek össze és még 2000 fontra lenne szükségük, ezért fordultak hozzánk segítségért. Amikor a ma reggeli jelentésben azt hallottam,

\footnotetext{
${ }^{11}$ The Unitarians of Transylvania. Rev. Mr. Martineau's Sermon, The Inquirer, May 23, 1857, 331.

${ }^{12}$ Uo., Rev. Mr. Channing's sermon, 331-332.
} 
hogy mi minden gazdagságunk, intelligenciánk, és a jót munkáló elkötelezettségünk mellett mindössze 500 fontot gyüjtöttünk, nagyon szégyelltem magam. Azt hiszem ezt nem hagyhatjuk ennyiben, különösképpen, hogy az amerikai unitáriusok tudtunkra adták, hogy nem sokat remélhetünk tőlük. Sok van még bennem az ó Ádámból és nem tudnám megmondani, hogy ebben az ügyben azért vagyok érdekelt, mert szeretem a személyesés a vallásszabadságot, vagy pedig azért, mert teljes lényemmel gyưlölöm Ausztriát, zsarnok szellemiségéért, melyet, ha nem akadályozunk meg időben, kioltja a szabadság utolsó lángjait is. Remélem, hogy mindazok, akik még nem tették meg kötelességüket az elnyomottakkal szemben, most az utolsó órában előrelépnek, és belenyúlnak pénztárcájukba, nem csak azért, hogy egy felekezetet megmentsenek a pusztulástól, hanem hogy az igazságot és szabadságot mentsék meg a rá leselkedő veszélytől. [KS $]^{13}$

Tayler beszéde után még 124 font gyưlt az erdélyiek javára. A pohárköszöntőből azt is látni, hogy az angolok nem igazán voltak tisztában az erdélyi unitáriusok történelmével, és neves tanáraiknak is elég homályos ismeretük volt az erdélyi unitarizmus eredetéről, lelkesedésük azonban pótolta hiányosságaikat, és gyüjtésük sikerrel járt. 1858. május 26-án a BFUA tanácsa arról számolt be, hogy 1220 fontot, 10 shillinget és két penynyt gyưjtöttek, és reményeik szerint őszig meglesz a szükséges 2000 font.

A BFUA erdélyi referense Paget volt, vele tartották a kapcsolatot, minden Kolozsvárt érintő ügyben tanácsára hallgattak. A levelezés nem volt zavartalan, valószínűleg az osztrák titkosrendőrség számlájára írandó a kézbesítetlen levelek nagy száma. Paget 1857 után a BFUA-nak küldött leveleit nem kézbesítették, és csak az 1858. március 28-án keltezett levél érkezett meg rendeltetési helyére. Ebben arról tudósít, hogy az erőszakos németesítés első veszélye elmúlt, és az osztrák kormány tudomásul vette az iskolafenntartásra gyűjtött alapot, az egyház pedig kész végrehajtani a kormány által megkövetelt átalakításokat. Az Angliában gyújtött öszszeg elküldésével kapcsolatban Kriza János tanácsát követték, egy londoni bankba Paget nevére 1000 fontot helyeztek letétbe, melyet az angol nemes a kollégium kuratóriumára testált át. Levelében Paget a BFUA elnökségét biztosította a kuratórium szakértelméről és az összeg rendeltetésszerű felhasználásáról. Végül arra a kérdésre, hogy a feltételek teljesítése után az osztrák kormány nem támaszt-e újabb követeléseket, Paget azt válaszolta, hogy az abszolutista kormány sem szegülhet szembe büntetlenül a közvéleménnyel. ${ }^{14}$

\footnotetext{
${ }^{13}$ British and Foreign Unitarian Associatin, ChRL, 1857, 454.

${ }^{14}$ Report of the BFUA, London, 1858, 7-8. A beszédet a The Inquirer, June 6, 1857, 363., a levelet hasonlóképpen az Inquirer, April 17, 1858, 244, közölte. Teljes szövegét lásd a Függelékben 6. sz.
} 


\subsubsection{Az erdélyi segélykérés amerikai visszhangja}

Paget Angliába küldött levelével egyidőben az amerikai hitrokonok is tudomást szereztek az erdélyi unitáriusok iskoláik megmentéséért folytatott küzdelméről. 1857. május 26-án az AUA harminckettedik közgyülésén Ezra Stiles Ganett (1801-1871) az AUA egykori elnökének javaslatára a közgyülés az erdélyiek ügyét magának vallotta és ötszáz dollár gyorssegélyt szavazott meg. ${ }^{15}$

Ugyanakkor az AUA végrehajtó bizottsága körlevélben szólította fel az egyházközségeket az adakozásra, erre tervek szerint 1857 október utolsó vasárnapján került volna sor. Amint már fentebb is említettük, az amerikaiak Edward Tagart közvetítésével értesültek az erdélyi helyzetről. A BFUA titkára mind Paget, mind pedig a konzisztórium levelét továbbította. Paget 1857. július 20-án, Kolozsvárott keltezett levelét Henry Adolphus Mileshez (1809-?), az AUA titkárához intézte. A konzisztórium felkérésére részletes pontossággal ismertette az erdélyi unitárius egyház helyzetét. Bécs germanizáló politikájának az iskolákkal szemben támasztott követelései - a tanárok számának és fizetésének növelése stb. - az egyházat erején felüli áldozatra kényszeríti, írta Paget, majd részletes kimutatást készített a felekezet anyagi helyzetéről, számadatokban mutatva ki, mekkora összegre van szükség az önálló iskolarendszer fenntartásához. A befejezésben

15 "Whereas, it appears from intelligence received by the Executive Committee of this Association, through the British and Foreign Unitarian Association, that the Unitarians of Transylvania are in imminent danger of losing the control of those institutions for education in the support of which they shown such an enlightened and steadfast interest, and on their free enjoyment of which depends not only the continuance of their religious liberties, but even the transmission of their religious faith to future generations, and that this danger can be averted only by their success in raising a sufficient sum for the endowment of these institutions, a sum much beyond their pecuniary ability, therefore, -

Resolved, That we rejoice in the opportunity of expressing our admiration of the faithful attachment of the Unitarians of Transylvania to their Christian belief, through the various fortunes which in past years and centuries have attended the profession of their faith, and under recent circumstances of peculiar trial.

Resolved, That in these distant brethren we recognize fellow-disciples, contending for the principles of truth and freedom which lie at the foundation of this Association.

Resolved, That the attempt to deprive them of the control of their seminaries of education entitles them to our warmest sympathy, and that the appeal which has been made on their behalf deserves a cordial and practical response.

Resolved, That the Executive Committee of this Association be instructed to take such measures as they may think proper for bringing the situation of our Transylvanian brethren before the Unitarian Christians of this country, and for collecting money for their relief; and that they be authorized to appropriate five hundred dollars from the Treasury of this Association for this object." Quarterly Journal of the American Unitarian Association, vol. IV., Boston, $1857,499-500$. 
drámai módon mutatott rá arra, hogy a kelet-közép-európai unitarizmus fennmaradása az angolszász hitrokonok jóakaratától függ. ${ }^{16}$

Paget helyzetjelentésével együtt Tagart továbbította azt a latin nyelvü levelet is, melyet Kriza János és Kovácsi Antal írtak az amerikai unitáriusoknak. Az egyház elöljárói tárgyszerüen ismertették a tanárok és iskolák helyzetét, és azok fenntartásáért tett erőfeszítéseket, majd hitrokonaik segítségét kérték. ${ }^{17} \mathrm{Az}$ Egyesült Államokon végigsöprő gazdasági válság miatt az amerikaiak nem segíthettek, de érdeklődéssel követték az angliai gyưjtés eredményét, és mihelyt lehetőségeik engedték, anyagilag is támogatták erdélyi hittestvéreiket.

\subsection{Edward Tagart erdélyi látogatása 1858-ban}

Edward Tagart (1804-1858) nevét említettük már az előző fejezetekben. William Tagart gyapotkereskedő másodszülött fia Bristolban kezdte el tanulmányait, majd 1820-tól a Manchester College-ban, Yorkban, John Kenrick irányítása alatt folytatta. ${ }^{18}$ Évfolyamtársai közül John Pagettel élete végéig jó kapcsolatban maradt. A yorki évek után a norwich-i Octagon Chapel hívta meg lelkészének, de a Martineau családba való beházasodása miatt rövidesen elhagyta gyülekezetét. A Martineau dinasztia norwich-i eredetü volt. Tagart minden ellenzés dacára a neves lelkész és vallásbölcselő, James Martineau (1805-1900) bátyjának özvegyét vette feleségül. A Martineau családdal egész életében konfliktusban állt, és a James nevével fémjelzett új teológiai iskola vehemens bírálója volt. James Martineau a Biblia tekintélyével szemben az egyén belső vallásosságát helyezte előtérbe, míg Tagart a régi, Priestley és Belsham alapította biblikus unitarizmus eltökélt harcosa maradt. Norwich után a londoni Little Portland Street Chapel hívta meg lelkészének. E gyülekezett tagja volt többek között Charles Dickens is, akit meghitt baráti viszony füzött a Tagart családhoz. ${ }^{19}$ Londonba érkezése után nem sokkal, 1832-ben a BFUA John Bowring helyébe a külügyi osztály titkárává, 1841-ben pedig a társulat főtitkárává választották. A BFUA munkája, de különösképpen az erdélyi unitáriusok sorsa mindennél jobban érdekelte, ezért 1858-ban a társulat kérésére örömmel

\footnotetext{
${ }^{16}$ Quarterly Journal of the American Unitarian Association, vol. V., Boston, 1858, 234-241. Lásd Függelék 7. sz.

${ }^{17}$ Uo. angol fordításban, latin eredetije az EUEGyLt-ban, Kriza levelei között Kriza János és Kovácsi Antal levele az amerikai unitáriusokhoz.

${ }^{18}$ R. K. Weвв, Tagart, Edward (1804-1858), Oxford Dictionary of National Biography, Oxford University Press, 2004 [http://www.oxforddnb.com/view/article/26914]

${ }^{19}$ James MacLuckie Connel, Dickens' Unitarian Minister, Edward Tagart, TUHS vol. 8, 1944, 68-83.
} 
vállalta erdélyi küldetését. ${ }^{20} 1858$. október 12-én Brüsszelben bekövetkezett halála miatt útjáról írt személyes beszámolóját nem tehette már közzé, de jegyzetei és levelei alapján osztálytársa és barátja, John Paget, majd később lánya, Lucy Tagart publikálta az erdélyi út tanulságait. ${ }^{21}$

1858 májusában a BFUA évi közgyülését a Little Portland Street Chapelben tartotta. A Tagart emlékére kinyomtatott füzet őrizte meg a közgyülésen mondott beszéd kivonatát, mely az erdélyi ügy iránti eltökélt szándékának bizonyítéka. ${ }^{22}$

Az angol források mellett bőséges magyar anyaggal is rendelkezünk, hiszen Buzogány az Emlékkönyvben, Ferencz József a Keresztény Magvető első számában, Borbély István pedig a Simén Domokosról írott tanulmányában foglalkozott Tagart látogatásával, akinek legnagyobb érdeme a Manchester New College magyar ösztöndíjának megszervezése volt. ${ }^{23}$ Az erdélyi unitáriusok angliai peregrinációjának ismertetése előtt vessünk egy pillantást Tagart erdélyi útjára. 1858. augusztus 7-én indult el Londonból, és családja kíséretében először Svájcba ment, ahol mintegy három hetet töltöttek. Tagart és kisebbik lánya, Lucy, szeptember 3-án Erdélybe indultak, a család többi tagja hazatért Londonba. A szokásos útvonalat követték: Zürich-Konstanz-Augsburg-Regensburg-Bécs, innen hajóztak le Pestre, majd vonattal utaztak Nagyváradig. A Pest-Nagyvárad útvonal nem sok lelkesedéssel töltötte el, hiszen szeptember 16-án feleségéhez írott levelében az út egyhangúságáról és a vonat lassúságáról panaszkodott. ${ }^{24}$

${ }^{20}$ Tagart életéről lásd: Memoir of the Late Rev. Edward Tagart, F.S.A, ChRL, 1859, 65-85. A Memoir of the Late Edward Tagart, Who Died 12th October, 1858, [h. n. és é. n.] Printed for presentation only.

${ }^{21}$ John PAget, Recollections of Mr. Tagart's Visit to Transylvania, ChRL, 1858, 746-753.; The Late Rev. E. Tagart's Visit to the Unitarian Churches of Transylvania, The Inquirer, December 18, 1858, 815-816.; Lucy TAGarT, The Hungarian and Transylvanian Unitarians. (Some account of their origin, vicissitudes, and present condition, complied from various sources), London, 1903.

${ }^{22}, \ldots$...it was so important that the whole subject of Unitarianism in that country, its churches and institutions, should be well understood, and that any effort towards promulgating our views in the east of Europe should be promoted, that it was desirable some member of the committee should in the course of the autumn, visit Transylvania: and being himself somewhat of an antiquarian and somewhat of a geologist, and strongly attached to Unitarian views, he said he should like to undertake the mission, and visit those churches which had existed for the last 300 years in that distant part of Europe, on the borders of the dominions of the Turks, among the Ural Mountains, the members of which had maintained their university, their schools and chapels, and their ministry, from the time of Socinus to the present hour." A Memoir of the Late Edward Tagart..., 20.

${ }^{23}$ Emlékkönyv, vol. I., 24-29.; BORBÉLY, i. m.

24 „From Pesth to Gross-Wardin is a long, dreary, dusty, unbroken plain, over which the train moved at a rate of perhaps sixteen miles an hour, stopping at every station five or ten, or fifteen or thirty minutes, just as it might be, without the least attention to the value of time..." Memoir of the Late Rev. Edward Tagart, ChRL, 1858, 79-80. 
Nagyváradról Kolozsvárig postakocsin hatodmagával tizennégy órát utazott. Hogy hű képét adja kalandjaiknak, feleségének lerajzolta a kocsit. A fárasztó úton szunyókálás közben hol arról képzelődött, hogy farkasok loholnak nyomukban, hol meg arról, hogy pénzükre vándorcigányok leselkednek. ${ }^{25}$ Kolozsvárott Paget házában szálltak meg, de az idő rövidségére való tekintettel házigazdájuk már másnap bemutatta őket az unitárius elöljáróknak. Meglátogatták a kollégiumot, könyvtárat, megnézték a hálószobákat, mindenről pontosan tájékozódtak. Vasárnap részt vettek az istentiszteleten, majd az ezt követő EKT ülésen, ahol Tagartot tiszteletbeli tanácsossá választották, és átadták az igazoló latin oklevelet. Angolul mondott köszöntő beszédét Paget fordította magyarra. Ezt a korabeli tollvivő is megörökítette, ugyanez a beszéd került Buzogány révén az Emlékkönyvbe is. Tagart megköszönte tanácsossá választását, és az angol unitáriusok üdvözletét tolmácsolta. Csodálattal adóznak - mondta - az erdélyiek áldozatkészségének, éppen ezért Paget segélykiáltása után igyekeztek erejük szerint segíteni, és arra kérte hitrokonait, hogy az anyagi támogatást mint „rokonérzelmeik bizonyítékát” fogadják. (A gyưjtés 1231 fontot eredményezett, melyet a magyar unitáriusok 1859-ben vettek kézhez, és a latin nyelvű köszönőlevelet Steinthallal küldték meg hittestvéreiknek. ${ }^{26}$ Másnap, hétfőn Paget vezetésével Kolozsvár környékét járták be, megnézték a tordai iskolát (tiszteletükre a teljes diákságot kivezényelték), a tordai hasadékot és a marosújvári sóbányát, természetesen Paget aranyosgyéresi kúriáján szálltak meg. Látogatásuk 23-án csütörtökön véget ért, és a szokott útvonalon visszaindultak, azonban Tagart utazása során összeszedett betegsége miatt csak Brüsszelig juthattak el. Állapota itt válságosra fordult, és október 12-én - valószínűleg maláriában - meghalt.

Látogatásának fő célja az volt, hogy a Manchester College-ban magyar unitárius diákok részére ösztöndíjat alapítsanak. Pagettel is ennek lehetöségét elemezték; ennek gondolata foglalkoztatta Drezdában és Pagethez küldött utolsó levelében is. Nem pusztán egy ösztöndíj felajánlásáról volt szó, hanem a Berlinben tanuló diákok tanulmányait kívánta előmozdíttatni. ${ }^{27}$ Kik voltak a „,berlini diákok" és hogyan egyengették Erdélyből angliai útjukat? Tagart Lucynak 1858-ban az Inquirerben megjelent, apja töredékes naplójához füzött magyarázó jegyzeteiből tudjuk, hogy Kolozsvárott már

\footnotetext{
${ }^{25}$ Uo.

${ }^{26}$ Emlékkönyv, vol. I., 25-26.

${ }^{27}$ "I quite agree with you in the opinion that the most efficient and promising way of helping our friends at Klausenburg, and giving an impetus to the cause of the rational Christianity in Hungary, will be that of assisting in the complete education of the students now at Berlin, and of one or two others who may follow them. I shall endeavour to impress this on the minds of some of our influential people in England, and am quite sanguine of success." Recollections...ChRL, 1858, 749.
} 
konkrét nevekben gondolkodtak a Londonba küldendő diákokat illetően. Ferencz József és Marosi Gergely neve jött szóba, mint ígéretes jövendő tanároké. ${ }^{28}$ Edward Tagart októberben bekövetkezett halála a tervet nem hiúsította meg, mert Paget fáradhatatlanul az ösztöndíj megszervezése mellett agitált. 1858. november 7-én Tagart Lucyhoz írott levelében fejtette ki az angol tanulmányút tudományos és erkölcsi hasznát. ${ }^{29}$ Az ösztöndíj megszervezése még két évet váratott magára. Tagart halála után Steinthal Alfred vállalta fel egy újabb erdélyi látogatás fáradalmait. A BFUA első erdélyi küldötte életét áldozta az angol-magyar unitárius kapcsolatok jövőjéért.

\subsection{Alfred Steinthal küldetése. Ismeretlen Kossuth-levelek}

Steinthal erdélyi útjának és Kossuthtól kapott titkos megbízatásának részleteit ifj. Fabiny Tibor derítette fel doktori dolgozatában és az Acta Litteraria Academiae Scientiarum Hungaricaeban közzétett tanulmányában. ${ }^{30}$ Most csupán arra vállalkozunk, hogy az 1848-1849-es forradalom és szabadságharc történetének, valamint a Kossuth-emigrációnak a korabeli angol unitárius sajtóban, elsősorban a The Inquirerben megjelent cikkeire hívjuk fel a figyelmet, illetve Kossuth unitárius kapcsolatait illetően néhány újabban előkerült Kossuth-levél kapcsán kiegészítsük ifj. Fabiny kutatásait. Az előző fejezetben hivatkoztunk Kossuthnak Thomas Hunter unitárius lelkészhez küldött levelére. A következőkben két másik levelet ismertetünk. Az első levél a Western Unitarian Society of England 60. évfordulóján 1851. október 22-én a Gloucesterben tartott gyưlés határozata nyomán született. Az igazság és a vallásszabadság terjesztésében érdekelt unitárius felekezet vezetői rokonszenvük tanúságaként felhívást intéztek Kossuthhoz, melyet George Armstrong (1792-1857) bristoli lelkész november 1-jén olvasott fel az ex-kormányzónak. ${ }^{31}$ Kossuth elöször szóban köszönte meg a magyar

\footnotetext{
${ }^{28}{ }_{\text {}}$ The two whom they propose to send are students who have been spending the last one or two years at the universities of Berlin and Göttingen, both very promising and talented young men. One of them was for some time tutor in Mr. Paget's family. Their names are Gregory Marosy and Joseph Ferencz." The Late Rev. Tagart's visit...The Inquirer, December 18,816 .

${ }^{29}$ "The great question is the possibility of getting some of our students to England. If we could have professors here at the head of the college, who had spent some time in England, I believe, not only that the system of education would be improved but that a change in the whole moral tone and style of the establishment would and must take place. It is very difficult for men who have never seen anything better to feel the defects of what exists." Uo.

${ }^{30}$ Lásd a 22. sz. jegyzetet. FabINY, i. m., 105-118.

$31, \ldots$ As a religious denomination deeply interested in the exercise and extension of the right of free thought concerning the truth and character of the Divine dispensations, we do not assume too much in saying that to us the securities for human liberty are peculiarly dear. And in proportion as this feeling is strong, so must our admiration and reverence be for those
} 
haza és személye iránti rokonszenvet, majd november 7-én levélben is. Ebben ügyes retorikával az általa vezetett kormány vallásügyi határozatára is hivatkozva, újból hitet tett a szólás- és gondolatszabadság mellett. ${ }^{32}$

Kossuth 1856-ban került kapcsolatba Steinthallal, az akkor még Bridgwaterben szolgáló unitárius lelkésszel. Kossuthnak Steinthalhoz intézett egyik leveléből arra következtethetünk, hogy a bridgwateri közösség szervezhetett valamilyen, az ex-kormányzóval és Magyarországgal szimpatizáló megmozdulást, és erre természetesen Kossuthot is meghív-

who are foremost among mankind in maintaining or defending that essential condition to the happiness and progress of the human race. (...) In the fall of the Hungarian cause - the cause of constitutional liberty and order - we behold the peril, if not the fall, of freedom for all the nations as well as your own. A bigoted and haughty Priesthood has every where shown how much it had to gain by your loss! Protestantism has reeled under the blow which has renewed the disasters of the days of Tilly and Wallenstein. Our Unitarian brethren of Transylvania weep over the ruins of the altars which your generous rule would have spared them. And in proportion as we mourn these results, must be our honour for him whose success would have averted them - but for whom it may be reserved by the Providence to repair them in the future; and to perpetuate through coming generation the glory of the name identified with the happiness of Hungary, and the consolidated liberties of surrounding Europe." Kossuth and the Unitarians of the West of England, The Inquirer, November 8, 1851, 716. A londoni cikket szó szerint átvette és közölte a New York-i Christian Inquirer 1851. november 29-i számában.

32 "Gentleman, - I have received with peculiar feelings of gratification the Address signed by you as a Committee of the Western Unitarian Society of England, and adopted by a meeting of that body on the $22^{\text {nd }}$ of October last.

The perusal of that address fills me with varied emotions - emotions of respect, of gratitude, and of abundant hopefulness. You address me in the emphatic character of a "Religious denomination"; and your address abounds, nevertheless, in sentiments of as steady approval of the course which my countrymen and myself have pursued during our late struggles as I have found in any address with which I have yet been honoured in this country. My people are a God-fearing people; they knew that the God of Justice was with them; and it was this that strengthen their hearts and arms under the sore dangers and difficulties with which they had to cope. They believe, and I devoutly feel assured myself, that it is ordained for wise and good purposes that we have been caused to succumb, for a season, to the unheard-of and unrighteous combinations, which, in wresting from us our liberties, have endangered the civil and religious liberties of the whole of Europe. It was the first principle of my Government, that thought and opinion should be free. In Transylvania the Unitarian body had long enjoyed certain rights and protection. In Hungary proper, it had long been the policy of the House of Hapsburgs to seek to crush out that free development of thought and independence of mind - so antagonistic to political subserviency - which forms the cardinal characteristic of true Protestantism. It succeeded in making the laws bear with nomination. One of the first works accomplished by the Government of which I was a member in 1848, was to remove all such unjustifiable and harsh restrictions. It is the enjoyment of religious freedom, and of political liberty, which my countrymen have actually thus had, - and well know how to prize, that makes them look forward, even now, with assured confidence, and me with unflattering hope, to the hour when a gracious Providence shall be pleased to open to us the opportunity of showing to the world again, that we are willing to stake all on the altar of Religious and Civil Liberty. I have the honour to be Gentleman, your obedient Servant, L. Kossuth." Answer of M. Kossuth to the Address from the Membres and Friends of the Western Unitarian Society, The Inquirer, November 15, 1851, 733. 
ták. ${ }^{33} \mathrm{Az}$ erdélyi unitárius egyháztörténetírás különös hangsúlyt fektetett Kossuthnak a felekezet iránt érzett rokonszenve népszerüsítésére, és nem is minden alap nélkül. Kossuth angliai népszerüsége elválaszthatatlan unitárius kapcsolataitól, erre nemcsak Borbély István hívta fel a figyelmet a Simén Domokosról írott tanulmányában, hanem Raymond Holt is. ${ }^{34}$ Ismeretes Kossuth Lajos Kovács János teológiai tanárhoz írott levele, melyben a felekezet reményteljes jövőjét ecseteli. ${ }^{35}$ A következőkben e levél történetét ismertetjük. Bölöni Farkas Sándornak az Egyesült Államokban tett látogatása után ötven évvel az erdélyi unitárius egyház elérkezettnek látta az időt, hogy képviselőt küldjön az amerikai unitáriusok évi (1882) közgyülésére. A választás Kovács Jánosra, a kollégium történelem-angol szakos tanárára esett, aki 1882. augusztus 27-én megkezdte fél évig tartó utazásait. ${ }^{36}$ Kovács 1884-ben Kossuthnak ajándékozott egy, az édesanyját, Weber Karolinát ábrázoló a dagerrotip arcképet, melyet amerikai útja során 1882-ben Medfordban kapott Mary Stearnstól. Kossuth hosszú levélben köszönte meg a kolozsvári unitárius igazgató tanár kedvességét, és ebben fejtette ki véleményét az unitárius vallásról. Az ex-kormányzónak a felekezetről alkotott pozitív véleményét az angol és amerikai unitarizmus ismerete mindenképp befolyásolta, de hatással lehetett rá az is, hogy Jakab Elek 1879. szeptember 19-én elküldte neki Dávid Ferencről írott monográfiáját. A kormányzóhoz címzett levélben egyebek mellett ez áll: „Méltassa

33 „8 South Bank, Regents Park, London May 10th 1856.

Dear Sir

In reply to your favour of May $5^{\text {th }} \mathrm{I}$ beg to state that I have met with so warm a reception in Scotland and here received invitations which even from a material point of view offer such advantages, that under my present circumstances unnecessary to be detailed, I could not but proffer them to the expectations you hold out for a visit to Bridgwater. My engagements will detain me about fo(r) two months and prevent me from accepting your invitation.

I have the honor to be, Dear Sir your obediant servant

Kossuth." Kossuth Steinthal Alfredhez írott levele 1856. Lelőhely: John Ryland University Library, Woodhouse Collection of the Unitarian Colege Collection A 2'

${ }^{34}$ Raymond V. HoLt, The Unitarian Contribution to Social Progress in England, London, 1938, 146, 221.

${ }^{35}$ A levél eredetije Kovács János örökösei meghagyásából a budapesti Unitárius Püspöki Hivatalba került. A kolozsvári tanár halála után fia, Kovács Kálmán őrizte a nagybecsű Kossuth-ereklyét, majd ennek halála után lánya, özv. Haas Tivadarné Kovács Margit örökölte. Ő kérte fel dr. Vernes Lászlót arra, hogy a magyarországi Unitárius Egyháznak adja át a féltve őrzött kincset. Boros Ildikó révén a levelet Vernes László átadta Huszti Jánosnak, és 1987. január 31-én a Püspöki Hivatal irodájában Kriza János arcképe mellé függesztették ki.

${ }^{36}$ Kovács János, Egyek vagyunk a hitben és a szeretetben. Jelentés az 1882. augusztus 27-tól 1883. március 7-ig tartó amerikai útjáról, KerMagv, 1978, 28-40. (A Mikó Imre által közzétett jelentés a cenzúrán csak úgy mehetett át, ha bizonyos részek kimaradtak. A teljes jelentés az Emlékkönyv, vol. II., 135-158. Ennek részleteire a Kovács János munkásságát tárgyaló fejezetben visszatérünk.) 
elolvasásra Kormányzó Úr e könyvet. Sokat talál abban drága figyelmére, tán rokonszenvére is méltót." ${ }^{37}$

Kossuth Kovács Jánosnak küldött levelét az unitáriusok a lehető legszélesebb körben terjesztették. Teljes terjedelemben közölte a Keresztény Magvető (1884-ben), a Történelmi Lapok 1848-49. 1896 szeptemberében, az 1904-ben kiadott Kossuth Lajos iratai X. kötete, és részleteket közölt a sokat idézett levélből az Unitárius Élet is 1987-ben, ${ }^{38}$ de közölte a Kossuth Ferenc által szerkesztett Egyetértés, és ennek nyomán a Londonban élő Bath Gunszt jóvoltából angol nyelvű kivonatát is olvashatjuk a Pall Mall Gazette 1884. május 21-én megjelent számában. Kovács János a történtekről tájékoztatta Mary Stearnst, és Kossuth levelének kivonatát is ismertette. Stearns 1884. április 13-án Magyarország egykori kormányzójának a következő levelet küldte:

„Kossuth Lajos Úr, Magyarország Kormányzója, kedves és tisztelt hősöm s a szabadságharc apostola!

Engedje meg, hogy kifejezzem azt a boldogságot, melyet nekem az az üzenete okozott, melyet a Kovács János tanár úrhoz írt levelében kifejezni méltóztatott. Szent elragadtatással olvastam az ön igéit. Ez igék visszavarázsolják fiatal éveim legszentebb érzelmeit. Ez érzelmek az idővel nemhogy elmosódtak volna, sőt élénkültek, az ön iránt táplált mérhetetlen tiszteletem és határtalan vonzalmam a korral csak még fokozódott.

Ön talán alig fog emlékezni reám, ki férjével Önt 1852-ben New Yorkból való elutazása elött egy este szerény hajlékában felkereste. Én ekkor az indulat árjától át voltam hatva. Könnyeim peregtek, midőn kezemet kezében tartotta. Nemes lelkű férjemtől vette Ön át az adományt szeretett és szerencsétlen ha-

${ }^{37}$ Szabad György, A levéltáros és történetíró Jakab Elek pályaképéhez, Levéltári Közlemények, 44-45. évf., 1973/1-2, 1974/1-2 sz. 549-557.

${ }^{38}$ Kossuth és az unitarizmus,. UÉ, 1987, 2. sz. A cikk ismeretlen szerzője több téves adatot is közölt írásában. A kolozsvári tanár nem 1883-ban Amerikából hazafelé tartva látogatta meg Kossuthot, hanem két évvel korábban, 1881-ben, amikor a Brit és Külföldi Unitárius Társulat londoni konferenciáján vett részt. „Ide jövő utamban meglátogatván Kossuthot, a nagy hazafi és híres szónok így szólt hozzám: «Örvendek kedves barátom, hogy önök összeköttetésben vannak az angol és amerikai unitáriusokkal; mondja meg nekik, hogy Angliát, s különösen Skotiát második hazámnak tekintem; terjesszék elveiket Magyarországon oly széles körben, amennyire csak tehetik; az ők hitök az egyedüli, melynek jövője van; az egyedüli, mely hat az értelemre és érdeklődővé teszi a közönyöst is: szívemből sikert kívánok a budapesti vállalatnak.» Robert Spears, az Angol és Külföldi Unitárius Társulat titkára, nem az évi közgyűlésen mutatta be Kovács Jánost, hanem az egybegyưltek tiszteletére rendezett fogadáson mondott pohárköszöntőjében méltatta hazánkfiát és vele együtt Kossuthot: „Néhány évvel ezelőtt találkoztam Kossuthtal, s midőn a nagy hazafi megtudta, hogy unitárius vagyok, kezet szorított velem, s így szólott: «Hazámban az unitáriusok a legjobb, legnemesebb, legtisztább jellemú és legderekabb emberek közé tartoznak mindazok között, akikkel találkoztam.»" Vö. Hivatalos Jelentése Kovács János igazgató tanárnak, melyet mint a "Brit és Külföldi Unitárius Társulat" az évi közgyúlésre küldött képviselö az unitáriusok E.K. Tanácsához f. évi július 31-én beadott, KerMagv, 1881, 243-257. 
zája számára, hogy ama rég letünt időre egy felvillanó fényt vethessek íme, másolatát küldöm ama levélnek, melyet Ön akkor, hozzánk intézett.

Bocsásson meg, hogy az eredetit nem küldöm. Becses ereklye az. Szent előttem annyira, hogy még Önnek, Kossuth Lajosnak sem adhatom ki kezemből: Eme sorok így szólnak

New-York, június 17. 1852.

Stearns L. György úrnak s nejének, Boston

«Önök ma engem oly tekintélyes anyagi segéllyel tiszteltek meg, szegény, szenvedő hazám részére, s ezt oly szívélyes szeretetre méltó módon tették, hogy kötelességérzetem parancsolja nemcsak a puszta köszönetnek adni kifejezést, de kifejezést adni annak a jól eső érzésnek is, amely gyászba borult szívemre vigaszt nyújtott. Ennek emléke, mint az örömnek egy sugara fog élni szívemben. A mindenható Isten áldja meg Önöket, legalázatosabb szolgája: Kossuth Lajos».

Íme, kedves, nemes mártírom, most már jobban megérti azt is, hogy miért tartottam, őriztem én az Ön édes anyjának az arcképét, s miért indíttattam arra, hogy elküldjem Önnek a Kovács János tanár biztos őrizete alatt.

Más nem őrzi meg. Halhatatlan sóvárgással örökre őszinte híve: Mrs. Mary Stearns." ${ }^{39}$

Kovács János teológiai tanár 1895-ben Kossuth Ferenctől azt a megbízatást kapta, hogy gyüjtse össze az apja Angliában és Amerikában tartott felolvasásai szövegét és 1897 végéig fordítsa le magyar nyelvre. Kovács elvállalta a felkérést, amerikai ismerőseivel is levelezett e tárgyban, de a teljes gyüjtéssel és fordításokkal nem készült el. Munkájának részeredményeit a 1848-49. Történelmi Lapok hasábjain közzétette, de gyanítjuk, hogy gyüjtése ennél sokkal bővebb lehetett. ${ }^{40}$

Kossuth angol és amerikai unitárius támogatóinak névjegyzékét nem célunk összeállítani, csupán a Londonban kiadott The Inquirerben megjelent, Kossuthtal és a magyar forradalommal és szabadságharccal foglalkozó cikkekre hívjuk fel a figyelmet. Az angol felekezeti sajtó történetében az unitáriusok voltak azok, akik a magyarországi eseményeket rokonszenv-

\footnotetext{
${ }^{39}$ 1848-49. Történelmi Lapok. 1896. szeptember 1. 17. sz.

${ }^{40}$ 1895. október 6-án Kossuth Ferenc a következőket írta Kovács Jánosnak:

„Tekintettel azon buzgalomra, melyet Ön úgy Amerikában, mint itthon dicsőült Kossuth Lajos Amerikában tartott beszédei és felolvasásai körül már eddig is kifejtett (...) ezennel felkérjük illetve megbízzuk, hogy az említett beszédeket és felolvasásokat, valamint dicsőült nagy hazánkfia működésére vonatkozó összes adatokat összegyűjtse s magyarra fordítsa akként, hogy azon 1897. végéig teljesen rendelkezésünkre álljanak, hogy a folyamatban levő kötetek sorába iktathassuk. (...)” Kovács János a megbízatást elvállalta: „(...) örömmel jelentem ki, hogy Kossuth Lajos dicsőült hazánkfiának az Eszak-amerikai Egyesült Államokban tartott beszédeit és felolvasásait, valamint ottani működésére vonatkozó összes adatokat, amelyeket én 1882-83-ban amerikai utazásom alatt összegyưjitöttem, s amelyeket az alkalomból ottani ismerőseim által még tetemesen gyarapítani akarok, a jelzett (1897. év végére) időre lefordítani, tisztelt Nagyságotoknak rendelkezésökre bocsátani, s a tiszteletdíj későbbi megállapításába beléegyezni kész vagyok."
} 
vel és figyelemmel követték. Kossuthról és a magyar forradalomról a The Inquirerben a következő cikkek jelentek meg: The war in Hungary, July 21, 1849, 450. English Sympathy with the Hungarians (vezércikk), July 28, 1849. The Hungarian Surrender (vezércikk), August 25, 1849. Russia and Turkey (vezércikk), October 13, 1849, 640-642. M. Kossuth Farewel to Hungary, November 17, 1849, 726-727. The Hungarian Prisoners, January 11, 1851, 34. The Hungarian Struggle. Arrival of refugees, March 8, 154. The Hungarian Refugees, April 19, 251. Kossuth and his Companions in Turkey, May 10, 291. The Hungarian Refugees, July 12, 436. Kossuth, October 11, 639. Sayings and Doings Connected with the Hungarian Patriots, October 18, 665-666. Arrival of M. Kossuth, October 25, 680-681. Kossuth (vezércikk); Kossuth in England, November 1, 695-697.; Kossuth in England; Kossuth and the Unitarians of the West of England, November 8, 710-711, 715-716. Kossuth in England; Answer of M. Kossuth to the Address from the Members and Friends of the Western Unitarian Society; November 15, 728-730, 733. Kossuth in England; Kossuth's Departure from England, November 22, 737-738, 745-747. Kossuth and his Country, November 29, 759-761. The Reception of Kossuth in the United States, December 20, 804-805. Kossuth in the United States, December 27, 820.

Az Inquirer Kossuthról írott cikkei után térjünk vissza Steinthal küldetéséhez. A liverpooli unitárius lelkész elsősorban egyházdiplomata volt, aki azért utazott Erdélybe, hogy az angol unitáriusokat tájékoztassa az erdélyiek sorsáról, és a Tagart halálával megszakadt ösztöndíj-alapítás kérdését újólag felelevenítse. Egyházdiplomáciai küldetéséről részletes beszámolót közölt a ChRL-ban és az Inquirerben. ${ }^{41}$ Steinthal azt az utat járta végig, amit a későbbi angol-amerikai unitárius látogatók is követtek, és elsőként írta le az Aranyos völgyének és Torockó vidékének megragadó szépségét. Tordán megmutatták neki az egykori fejedelmi lakot, és az angol látogató elragadtatással szólt az 1575-ben (sic!) kimondott vallásügyi törvényről. Aranyosgyéresen Paget vendége volt, és elődjéhez, Tagarthoz hasonlóan vendéglátójával az alapítandó angol ösztöndíj kérdéskörét vitatták meg. ${ }^{42}$

${ }^{41}$ Rev. S. A. Steinthal's Account of his Visit to Transylvania, ChRL 1859, 477-489, 530-538.; Rev. S. A. Steinthal's Report of his Mission to Transylvania, The Inquirer, June 25, 1859, 543-544.; Ugyanezt a cikket közölte a New York-i Christian Inquirer, August 13, 1859.

${ }_{42}, \mathrm{Mr}$. Paget is very deeply impressed with the great advantage that would accrue from the education of some of the students in England, as even if they were not immediately to take up the position of professors, their higher attainments and increased culture would greatly add to the influence of the ministry, and raise the Unitarians very much in public estimation. To myself it seems a false system to take young men immediately on leaving college to fill the responsible post of professors. They have not had time to digest and arrange the knowledge they have gained, nor obtained that authority which age and experience alone can give." Uo. 
Jelentésének második részében az 1850-es évek magyar unitárius teológiai gondolkodásáról ad rövid áttekintést, megállapítva, hogy Erdélyben a német teológiai iskola két reprezentánsa, J. S. Semler és Karl Gottlieb Bretschneider (1776-1848) lutheránus teológus örvend különösebb népszerúségnek. Meglátása szerint a Manchester New College-ban alapítandó ösztöndíj azáltal frissítené fel az erdélyi unitárizmus vérkeringését, hogy a Londonban tanuló diákok a rációt hittel ötvöznék, - így ellensúlyozódna a teológiai racionalizmus kritikai szemlélete - és tisztultabb formáját kapnák Isten Krisztuson keresztül adott tanításának. Steinthal nem csak remélte, hogy az erdélyi és angol unitarizmus egymásra találnak, de az 1859-ben tartott BFUA közgyưlésén mindent megtett annak érdekében, hogy a magyar ösztöndíj kérdését megszavaztassa. Ez volt a BFUA első olyan közgyűlése, ahol erdélyi képviselők, Ferencz József és Buzogány Áron is felszólaltak.

\subsection{Ferencz József és Buzogány Áron 1859. évi londoni látogatása}

Az erdélyi peregrinusok John Paget és a konzisztórium ajánlóleveleivel ellátva május 11-én, Párizson keresztül érkeztek a szigetországba, itt 10 napot szándékoztak az angol unitáriusok körében tölteni. Buzogány viszszaemlékezéseiben nem utal arra, hogy Erdélyből sugallták volna az angliai látogatás gondolatát, de a fentiekben láttuk, hogy a szálak Aranyosgyéresre, Pagethez vezettek. A peregrinusok Londonba érkezésük után két nappal felkeresték a BFUA titkárát, Robert Brook Asplandot (1805-1869), aki bemutatta őket néhány angol unitárius családnak. Németül folyhatott a társalgás, mert angolul sem Ferencz, sem Buzogány nem tudott. John James Taylerrel és James Martineauval is ekkor ismerkedtek meg, előbbi 1868-ban Erdélybe látogatott, Martineau pedig az Angliában tanult magyar diákok Nesztóra volt. A magyar vendégeket Thomas Marshall (18251919), az Inquirer szerkesztője házánál szállásolta el, és bemutatta őket a legbefolyásosabb angol unitáriusoknak. A tervezett tíznapos látogatás az angol vendégszeretetnek és a közelgő BFUA közgyülésnek köszönhetően, több mint egy hónapig tartott, így az erdélyi diákoknak bő alkalmuk nyílt az ismerkedésre. Mindenütt a „legszívesebb rokonszenvvel, vendégszeretettel fogadtak - írja Buzogány az Emlékkönyoben. Látszott, hogy nem annyiban személyünket tekintik, hanem bennünk az erdélyi unitáriusok képviselőit." ${ }^{\prime 3} \mathrm{~A}$ társalgás politikai kérdéseket is érintett, és bizony gyak-

${ }^{43}$ Emlékkönyv, vol. I., 32. 
ran vitába is keveredtek vendéglátóikkal. ${ }^{44}$ A politizálás mellett elsősorban az egyházi szervezet és istentiszteleti élet iránt érdeklődtek, s vasárnaponként más-más gyülekezetbe jártak. Buzogányt meglepte a „,szép harmóniás éneklés," s az is, hogy az erdélyi szokással ellentétben a lelkészek felolvassák beszédeiket, melyek olykor „egészen dogmatikus színűek, olykor meg külső társadalmi kérdéseket fejtegetnek." A BFUA június 15-én tartott évi közgyưlésére Londonba érkezett Steinthal is, és a közgyülésen röviden beszámolt erdélyi küldetéséről. Az erdélyi hitrokonok üdvözlő és köszönő iratát átadta Ferencz Józsefnek, így a BFUA elnöksége magyar kézből vehette át azt. Steinthal, valamint Ferencz és Buzogány közgyứlésen mondott beszédét teljes terjedelemben közölte az Inquirer, de pontos magyar fordítása megvan az Emlékkönyvben is. ${ }^{45}$ Steinthal beszédében röviden ismertette az erdélyi unitárius viszonyokat, majd Paget és Tagart tervére utalva, egy angol ösztöndíj alapítását szorgalmazta. ${ }^{46}$ Steinthal felhívása után Ferencz József lépett a szónoki emelvényre. Nem sikerült kideríteni ki fordíthatta beszédeiket angolra, valószínűleg németül vagy latinul írhatták meg, majd angolra fordíttatták és azt olvasták fel. Ferencz József beszédében megkövette hallgatóságát, hogy Shakespeare nyelvét merte botorul ajkára venni, majd elmondta, miért jött Buzogánnyal Németországból Angliába:

„,...látni a földet, mely annyi jeles embernek szülőföldje; látni a földet, melyen képzeletünk a szabadság eszményképét kereste mindig; látni a földet, mely életet adott azon vallásnak, mely az egész kontinensen csak a kis Erdélyben tudott gyökeret verni." ${ }^{\prime 7}$

Megköszönte a magyar unitáriusok iránt megnyilvánuló rokonszenvet, és azt, hogy vállalták az unitárius oktatás fenntartásának anyagi támogatását. Kegyelettel emlékezett Tagart küldetésére, és biztosította az angolokat,

44 „,...ook mindnyájan az akkori osztrák álláspontról nézték a válságos hadjáratot, s neheztelni látszottak, hogy a magyar miért nem lelkesedik az osztrák zászlóért; nem igen értették, hogy mi követelései lehetnek a magyaroknak az osztrák kormánytól; miért makacskodik azzal szemben? Stb. De e részben nem hagytuk magunkat, s örömmel tapasztaltuk, hogy többen bevallották, hogy hazánk jogi álláspontjáról s méltányos követeléseiről más fogalmaik voltak, mielött fejtegetéseinket hallották, s most igazat adnak nekünk. Nők is szerettek erről beszélni, s köztök nagy pártot szereztünk magunknak." Uo.

${ }^{45}$ British and Foreign Unitarian Association, The Inquirer, June 18, 1859, 518-519. Vö. Emlékkönyv, vol. I., 31-44.

${ }^{46}$ „,ti. hogy egy erdélyi unitárius pap vagy tanár jelöltet koronként látnánk el magunk költségin itteni akadémiai szemináriumunkban... Tapasztalatból merített meggyőződésem, hogy ily módon lendületet nyerne az ottani papnevelés ügye, s könnyíttetnék az emelkedettebb gondolkozásmódra jutás papjaik közt.... Uraim, meg vagyok győződve, hogy e Társulat volt titkárának, néhai Tagart tisztelt emlékének örökítésére semmi sem volna méltóbb annál, ha e Társulat az ő neve alatt egy alapítványt tenne a mi Manchester College-ünkben. Emlékoszlopa lenne ez mind előttünk mind erdélyi hitrokonaink előtt azon szolgálatnak, melyeket a néhai a mi közös ügyünkben tett." Uo., 39.

${ }^{47}$ Uo., 40. 
hogy néhai titkáruk emlékét Erdély bércei közt mindaddig ápolni fogják, míg egyetlen unitárius él a hazában. Buzogány is felszólalt a közgyűlésen, beszédében a magyar unitarizmus küzdelmes történetét vázolta. ${ }^{48}$

Az Inquirerben megjelent angol jegyzőkönyv és Buzogány visszaemlékezései között némi ellentmondás fedezhető fel. Az Emlékkönyvben Buzogány azt írta, hogy a tanács elvileg kimondta az ösztöndíj alapítását, a határozati javaslat megfogalmazását egy albizottságra bízta, őket pedig „kéz alatt" megkérdezték, nem akarják-e az ösztöndíjat egy évre igénybe venni? Az EKT hazatérésüket szorgalmazó határozatára hivatkozva az ajánlatot udvariasan visszautasították, és június 21-én hazaindultak. Az említett angol jegyzőkönyv nem tett említést erről az epizódról, és a magyar ösztöndíj kérdése sem szerepelt a határozati javaslatok között.

Ferencz József és Buzogány Áron londoni látogatása több szempontból is eredményes volt. A londoni unitárius értelmiség és a BFUA tanácsa az erdélyi peregrinusoktól, Steinthaltól, de legfőképpen a John Pagettől kapott információk birtokában elviekben egyezségre jutott a magyar ösztöndij (Transylvanian Education Fund) kérdésében, és a BFUA 1860. május 30-án tartott közgyűlésén megszavazták a magyar diákok támogatását. A közgyűlés ugyan egyetértett T. Marshall azon megjegyzésével, hogy az erdélyiek tudományban többet gyarapodhatnak a német egyetemeken mint Angliában, azonban abban is egyetértettek, hogy a német racionalizmust, és a 18. században meghonosodott száraz, spekulatív unitarizmust az angol unitarizmus hivatott ellensúlyozni, másfelől pedig az akadémitákon keresztül szorosabbra füzhető Erdély és Anglia unitáriusai között a viszony. 1860 őszén a londoni Manchester College megnyitotta kapuit az első unitárius akadémita, Simén Domokos előtt.

\footnotetext{
48 „,..Uraim, önök s önök elődei más társadalmi s politikai körülmények közt éltek. Önök más elvek s eszmék közt nevelkedtek fel mint mi; önök s apáik gondolkozásaikban tetteikben nem voltak annyira korlátozva, mint mi s a mi apáink. Önök elődei inkább hagyományozgatták gondolataikat az utódok számára, mint a mi elődeink. S ezekből folyólag az önök vallási irodalma gazdagabb a mieinknél, nem csak mennyiségben, hanem minőségben is; s az önök kollégiumában, azt hisszük, emelkedettebb s szabadabb szellem találtathatik, mint a mieinkben ez idő szerint. Íme uraim, ezt értettem, midőn fennebb azt mondtam, hogy az angol unitárius egyház gazdagabb nem csak anyagiakban, hanem szellemi fejlettségben is idősebb testvérénél, az erdélyi unitárius egyháznál. És most hiszem uraim, hogy megértették, amit kifejezni akartam, s egyet értenek velünk abban, hogy a köztünk jövendőben is fenntartandó szorosabb viszony közös ügyünkre, s nevezetesen önöknek erdélyi hitsorsosaik iránt állandóan meleg rokonszenve s részvéte reánk nézve bizonyosan jó gyümölcsöket fogna teremni." Emlékkönyv, vol. I., 43-44.
} 


\subsection{A Manchester New College magyar diákjai}

Az angol ösztöndíj történetének ismertetése előtt röviden szólnunk kell az unitárius peregrinatio academica történetéről. Az erdélyi unitárius egyház folyamatosan küldte ki tehetséges ifjait a külországi egyetemekre, hogy tudásban, világlátottságban felzárkózhasson a többi protestáns felekezet mellé. Az 1560-as évektől 1848-ig összesen 178 unitárius akadémita bujdosott "felsőbb országba”, a látogatott akadémiák száma pedig 281. ${ }^{49}$ A magyar unitáriusok számára - hazai egyetem és föiskola hiányában -, a magasan képzett értelmiségi szükséglet biztosításának a külhoni peregrináció volt egyetlen, bár felettébb költséges, de járható útja. 1568-1638 között az olaszországi, páduai és bolognai egyetem bizonyult a legnépszerübbnek. 1639-1711 között az odera-frankfurti és leideni akadémia vonzotta az unitárius diákokat, hogy aztán 1712-1848 között a súlypont a bécsi akadémiára tevődjön át. A 18. században a Habsburgok politikai érdekei azt kívánták, hogy a protestánsok Bécsen kívül ne tanulhassanak. Ez részint a felvilágosodás eszméinek korlátozására, részint politikai, gazdasági érdekből történt. Vissza akarták fogni Erdélynek az osztrák érdekekkel ellentétes országokban történő kapcsolatkiépítési próbálkozásait, valamint a peregrinusok általi pénzkivitelt. A Bécsen kívüli tanulást az útlevél megszerzéséhez kötötték, ez pedig jelentősen megnehezítette a továbbtanulást. A bécsi egyetemhez való kötöttség kényszere alól a Manchester New College-ban felajánlott ösztöndíj szabadította föl az unitárius egyházat.

A magyar unitárius akadémiták külhoni peregrinációját 1869-ig nem kötötték pályázathoz, hanem a tanári kar által javasolt lelkészjelöltet vagy jelölteket a Főtanács megerősítette, velük reverzálist íratott, s külföldi tanulmányútjukra áldását adta. 1832-ben a nyárádszentlászlói zsinaton elhatározták, hogy az akadémiára menendő ifjak 1833. január első vasárnapján Kolozsvárott vizsgát kötelesek tenni. A Főgondnok és az Unitárius Kollégium felügyelő gondnoka elnöklete alatt működő vizsgabizottság az eredményt a Főtanács elé terjesztette, és a testület kijelölte a „,külső országi akadémiára” küldendőket. Az 1869 júniusában tartott Főtanácson azt a döntést hozták, hogy a külföldi ösztöndíjakat pályázat útján töltik be. Pályázhattak a kolozsvári lelkészjelöltek, valamint a tordai és székelykeresztúri gimnázium tanítói. Az 1869-ben hozott végzés lényegi változást nem hozott az addig meghonosodott gyakorlatban. A keresztúri és tordai tanárok nem tolongtak az egyetlen Manchester New College-beli ösztöndijért. Maradt hát továbbra is a lelkészjelöltek pályáztatása, melyen csak 1880-ban változtatott a Főtanács.

${ }^{49}$ Szabó Miklós, Az erdélyi unitáriusok külföldi egyetemjárása 1848-ig, KerMagv, 1991, 85-104.; Szabó Miklós, Tonk Sándor, Erdélyiek egyetemjárása a korai újkorban 1521-1700, Szeged, 1992; Szabó Miklós, Szögr László, Erdélyi peregrinusok. Erdélyi diákok európai egyetemeken 1701-1849, Marosvásárhely, 1998.; GöMöRI, i. m. 
Dr. Berde Áron főgondnoknak a tanárválasztást, valamint a londoni Manchester New College-ban való tanulást tárgyaló beadványára az a határozat született (51.§.), hogy a Manchesterbe küldendő ifjak a papnevelde szigorlatot tett végzettjei lehetnek, akiket az EKT egy évvel a tanulmányút megkezdése elött jelöl ki. Az akadémitajelöltek angol, görög és latin nyelvből voltak kötelesek vizsgát tenni a papnevelde tanári kara előtt. A Londonban tanult lelkészjelöltek a határozat értelmében rendes tanárnak voltak alkalmazhatók, sőt a gimnáziumokban a „bölcselmi tanszéken” taníthattak. ${ }^{50}$

Simén Domokossal, ${ }^{51}$ a fiatalon elhunyt teológiai tanárral kezdődött meg az erdélyi unitáriusok Angliában való képzése, és amint fentebb már jeleztük, ez nagyrészt John Paget kapcsolatainak és egyházdiplomáciai tárgyalásainak volt köszönhető. Ố tájékoztatta a BFUA tanácsát a papok, de különösen a tanárok helyzetéről. Terveiben az erdélyi akadémita nemcsak teológiát, de világi tudományokat - geológia, kémia, zoológia, mechanika - is tanult volna:

„Ezt azért ajánlom, mert én jól ismerem az itteni viszonyok alapján, hogy mely tárgyak tanulmányozása volna legkívánatosabb. Erdélyben majdnem teljesen lehetetlen tanulni ezeket a tudományokat, nemcsak azért, mert nincsenek megfelelő tanítók, hanem azért is, mert ezeket csupán könyvekből tudományos felszerelések nélkül tanítani majdnem lehetetlen. Ilyenek pedig ebben az országban nincsenek. .... természettudományok iránti érdeklődés fel fog ébredni, ....az unitáriusság tekintélye emelésére nagy befolyással volna, ha erre alkalmas emberek közülünk kerülnének ki, és hasonlóan jól hatna a közönségre, ha tudományosan felkészült emberek saját intézeteikben végeznék azt a munkát, s innen kiindulva irányítnák a nagyközönséget az új tudományok útjain. ...gazdag könyvtár, jól fölszerelt laboratórium és szertár kellene. Az én szemem előtt tehát az lebeg, hogy teremtsük meg a professzorok egy felsőbbrendű osztályát. ....a tanulók elhelyezkedése... minden egészségügyi törvények legteljesebb kijátszását jelenti, sőt ellenkezik a természetes tisztaság szabályokkal is. ...azok, kik Angliában látják, hogy miképpen lehet javítani a helyzeten és hogyan kell gondoskodni az ifjúságról, módját fogják találni, hogy ott is némi javulás létesülhessen." ${ }^{52}$

${ }^{50}$ Az ösztöndíj szabályzaton csak 1933-ban módosítottak. Az EKT az 1930-as években két angol és két amerikai ösztöndíj „,birtokában” - Pacific Unitarian School (Berkeley), Meadville Theological School (Chicago), Manchester New College (Oxford), Unitarian College (Manchester) - úgy döntött, hogy szabad versenyt hirdet az ösztöndíjakra, „és aki a kívánt vizsgán kiválóbb eredményt mutat fel, az részesül az ösztöndíj kedvezményében". E határozat mellett ismét megújították az 1880. évi főtanácsi határozat azon pontját, mely kimondta, hogy „,a Londonból haza jövő ifjak kötelesek tanulmányaikat feltüntető bizonyítványaikat az EK Tanácshoz bemutatni". A versenyvizsgák során a tanárjelölteket a Manchester New College-ba, a gyakorlati lelkészi pályára készülőket pedig a Manchester College-ba irányították.

${ }^{51}$ BorbÉLY, i. $\mathrm{m}$.

${ }^{52}$ Gál Kelemen, Káli Nagy Elek élet- és jellemrajza, (Az Erdélyi Unitárius Egyház Gyűjtőlevéltárának és Nagykönyvtárának kiadványai 3. Szerk. Kovécs Sándor és MoLNÁR B. Lehel), Kolozsvár, 2003, 114. Gál néhány részletet ragadott ki Paget leveléből, az Emlékkönyv- 
Paget tervével összhangban 1859. augusztus 30-án a Főtanácson elhatározták, hogy a kolozsvári Kollégiumban bevezetik az angol nyelv fakultatív tanítását, mert ez „szükséges kulcsa szent vallásunkat érdeklő némely tekintélyes eszmeforrásoknak," ugyanakkor a BFUA tanácsához egy üdvözlő levelet küldtek..$^{53} \mathrm{Az}$ angol nyelvet fakultatív jelleggel 1861-től Buzogány Áron kezdte tanítani.

A The Inquirer 1860 júniusában, ${ }^{54}$ a ChRL júliusban beszámolt az angol-magyar unitárius kapcsolatok megszilárdítása érdekében a külügyi bizottság készítette ösztöndíj tervezetéről, és Pagetnek ebben a kérdésben adott felvilágosításáról. ${ }^{55} \mathrm{~A}$ magyarrá lett angol nemes éppen az ösztöndíj-alapítás kapcsán került ellentétbe a Főtanáccsal. Paget az erdélyi ifjak angliai taníttatását egészen más szemüvegen át nézte, mint az egyházi vezetők. Terve szerint minden évben egy-egy ifjú - nem szükségképpen pap - vette volna igénybe az 50 font sterling ösztöndíjat úgy, hogy a tanulmányait befejező peregrinus gondjaiba fogadta és bevezette volna újonnan érkező társát nemcsak az egyetemi, hanem a társadalmi életbe is. $\mathrm{E}$ terv szerint az Angliában szerzett tapasztalat az erdélyi, szociális, vallási és gazdasági élet javára kamatozott volna. Paget terveivel összhangban a BFUA vezetősége az ösztöndíj anyagi alapjait összegyüjtendő, a The Inquirerben felhívást tett közzé, amiben körvonalazódott az angol fél vállalása. ${ }^{56}$ A Transylvanian Unitarian Church címen megjelenő cikk szerzője bevezető gondolataiban a világ legősibb unitárius keresztény egyházának egyistenhitét dicsérte, majd a nagy-britanniai és írországi hitrokonoknak a magyar unitárius oktatás és nevelés fennmaradásáért hozott áldozatát ismertette az olvasókkal. A magyar oktatás színvonalának emelését Angliába küldendő ifjaik révén kívánják megvalósítani, akik a teológia és a természettudományok alapos tanulmányozása után hazatérnének és felekezetük hasznára válnának. A taníttatás költségeit az erdélyiek korlátolt anyagi lehetőségeik miatt nem tudják vállalni, de Paget információi szerint, ha a költségek felét előteremtik, a terv megvalósítható. Simén Domokos 1860. évi kiadásait

ben nem maradt fenn másolata/fordítása. A BFUA 1860. évi jegyzőkönyvében találtuk meg és fontosságát tekintve érdemesnek tartjuk teljes terjedelmében közölni. Lásd Függelék 8. sz.

${ }^{53}$ Address from the Unitarians of Transylvania, The Inquirer, February 18, 1860, 139. Vö. Emlékkönyv, vol. I., 49.

${ }^{54}$ "On the strong recomandation of their correspondent, Mr. Paget, and in conformity with the wiews expressed in a letter from the Consistory, the Committee recommended that steps should be taken to rise a Transylvanian Education Fund, for the purpuse of assisting one or more students in regular succession to visit this country, avail themselves of literary, scientific, and theological instruction, and enjoy the opportunity of seeing the practical working of the free institutions of this country." Religious intelligence, The Inquirer, June 2, 1860, 461.

${ }^{55}$ ChRL, 1860, 453.

${ }^{56}$ Religious Intelligence. The Transilvanian Unitarians, The Inquierer, August 18, 1860, $697-$ 698. 
a BFUA pénztárából fedezték, ugyanakkor azt kérték a gyülekezetektől, hogy járuljanak hozzá egy állandó ösztöndíjalap megteremtéséhez. Buzogány veretes fordításában idézzük a következőket:

„Mi megvalljuk, hogy külföldre ható működéseinkben nem tudunk ennél többet ígérő tervet gondolni; olyant, mely az unitárius kereszténység érdekeinek előmozdítására kedvezőbbnek látszanék. Mi nem kételkedünk azon, hogy ugyan ezért felhívásunkat azonnal nemes eredmény ne kövesse... 100 fontra volna szükség évenként, hogy a szóban forgó segélyt két tanulónak megadhassuk... reméljük, hogy egyesek aláírása, s gyülekezeteinkben történendő gyüjtögetés által oly összeget fogunk előállíthatni, mely az erdélyi unitáriusokat viszont felbátorítandja oly intézkedések tételére, melyek nyomán sok éveken keresztül tanuló ifjak legjobbjait, teológiai s tudományos nevelésök végett Angliába, mihozzánk küldhetik. Azon reményt tápláljuk, hogy ilyetén ügynek a vallási és polgári szabadság számos barátai készséggel nyújtandnak segítséget." 57

A jegyzőkönyvekből nem derül ki pontosan, miért zárkóztak el az egyháziak két ifjú taníttatásától. 1861-ben a BFUA titkára Paget közvetítésével felvilágosítást kért a Simén Domokos ösztöndíjának erdélyi résztámogatásával kapcsolatosan. Az EKT 147/1861. szám alatt értesítette Pagetet, hogy az ösztöndíj felajánlásakor nem volt szó semmiféle segélyezésről, Simén nem kért támogatást, és a Képviselő Tanács sem tett erre vonatkozó ígéretet. Buzogány szerint az EKT és Paget közötti nézeteltérés abból adódott, hogy Paget „egyéni nézeteit” - az erdélyi unitáriusok annyival támogatják akadémitáikat, mint az angol fél - az EKT tudta és beleegyezése nélkül közölte Asplanddal, a BFUA titkárával. ${ }^{58}$ Az ügy elvi szinten a zsinat elé került, és Simén Domokos, valamint a mindenkori angol akadémita részére megszavaztak évi 500 forint segélyt, és elhatározták, hogy Simén hazatérte után újabb ifjút küldenek a Manchester College-ba, ezzel azonban az angol akadémiták ügyét még nem sikerült elintézni. 1862-ben a Főtanács újból megtárgyalta az Angliába küldendő ifjak segélyezésének kérdését, és ellentétben az egy évvel korábban hozott határozattal, megállapította, hogy a közpénztár évi 500 forinttal nem tud hozzájárulni az akadémiták költségeihez. A döntésről értesítették a BFUA tanácsát, és sajnálattal közölték,

${ }^{57}$ Emlékkönyv, vol. I., 69-72.

${ }^{58}$ Uo., 53-55. „Paget egyéni nézete ezen tárgyra nézve már korábban az volt, hogy ha egy vagy két ifjúnknak Londonban leendő kiképezetésére az angolok 50 font sterlinget ajánlnak: ugyanannyit az erdélyi unitáriusok is adjanak. Úgy vélekedett, hogy jobb ha két ifjú az angoloktól kap 50-50 fontot évenként, mint hogy egy kapjon 100 fontot; s másfelől nem tette fel, hogy ezen - különben nemes - terve ellen az Egyházi Tanács kifogást tehessen bármi okból. Később nekem is nyilvánította Paget úr ezeket, s azt is, hogy részéről el sem fogadná az 50 fontot sem évenként, ha mi nem vagyunk képesek ahhoz magunk részéröl is még egy annyit adni. Paget úr sokat várt volna attól, ha minden pár év alatt egy két magasabb míveltségú ifjú kerül haza az unitáriusok kebelébe, mint mondá, ha szintén az ilyenek egyszerü gazdai vagy külső hivatali pályára lépnének is, az unitáriusok értelmi súlyát növelnék." 
hogy ",jelen évre" semmi módot nem találtak a Londonban tanulandó ifjú segélyezésére. Mindez, írták, nem „lágymelegség, s az ügynek illőleges fel nem karolása..., hanem tiszta számokra fektetett számítás eredménye." 59 Robert Brook Aspland titkár, 1863. július 13-ról a Kriza püspöknek írott levelében a BFUA nevében az utaztatást leszámítva, vállalta egy diák taníttatásának költségeit, és kérte az egyházfőt, hogy

„küldjön egy tanulót, aki tanulását a mi egyetemünkön bevégezze, és lásson valamit a mi boldog országunk szabad, alkotmányos kormányának munkáiból.".60

A hideg fejjel végzett számítások eredményét s a szegénységet Paget közömbösségnek fogta fel, és az egyházi ügyektől visszahúzódott. Kriza János Siménnek küldött leveleiben szinte könyörög, hogy az angol hitrokonok az erdélyi valóságot és rettenetes szegénységet nehogy a fukarság jeleként értelmezzék.

„Levelem hangulatából is kiérezheti Simén úr, hogy a mi erdélyi állásunk nagyon szegényes, amit Ovidius turpis egestasnak nevez, mi sokkalta alantibb fok a pauperitásnál, mely a rómaiaknál inkább a középszerű sorsot jelenti. Mi erdélyi unitáriusokul ennél alantabb állunk. Azért legyen szíves kedves Simén úr, a mi helyzetünket, amikor szóba jön, az angol atyafiaknál ily szempontból terjessze elö, mert amint Paget úr beszéli, onnan kapott levelek után, ott rólunk szörnyű kedvezőtlen vélemények terjedtek el, mintha mi nem sietnénk nyílt karokkal az angol atyafiak szimpátiájának viszonzására s valamint ön irányában schmutzigul viseltük magunkat - ezek a Paget úr kifejezései -, most is úgy viseljük, nem akarván ön helyébe más ifjút rendelni." ${ }^{61}$

Simén helyzetét az is megnehezítette, hogy 1861-ben a konzisztórium beleegyezése nélkül Raffaj Károly (1835-1894) göttingeni akadémita is ellátogatott Londonba. Kriza János leveléből az derül ki, hogy a fiatalember az angol unitáriusokon élősködött, tőlük pénzt kért, azt állítván, hogy őt az erdélyi unitáriusok küldték Angliába. A kellemetlen helyzetből Simén mentette ki a konzisztóriumot azzal, hogy a BFUA évi közgyűlésén „a sok balítéletet eloszlatta". ${ }^{62}$

A 19. század második felében egyre több unitárius forgatta fejében azt, hogy Angliában tanul, és ehhez elsősorban a püspöktől kértek támogatást. Krizának Siménhez írott leveleiből tudjuk, hogy hasonló terveket fontolgatott az a Sándor Mózes (1839-?) is, akit Simén helyére szerettek volna Londonba küldeni. Nem tudjuk, hogy angliai tanulmányútja csak az anyagiak miatt hiúsult-e meg, vagy más oka is volt. Sándor Mózes, a székelykeresztúri Gimnázium későbbi tanára, 1862 nyarán két hónapot Londonban

\footnotetext{
${ }^{59}$ Uo., 75. Vö. Report of the BFUA, London, 1863, 9-12.

${ }^{60}$ Emlékkönyv, vol. I., 77.

${ }^{61}$ BORBÉLY, i. m., 73.

${ }^{62}$ Uo., 76.
} 
töltött, de sem levelei, sem jelentése nem került elő. A Channing-fordítók sorában találkozunk nevével, ebből gondoljuk, hogy ismerte a nyelvet. ${ }^{63}$ Az Angliában megforduló és nem egyházi támogatással tanuló unitárius akadémizánsok közül ki kell emelnünk a magyar fogászat úttörőjének, Iszlai Józsefnek nevét, aki 1872-1874 között tanult Londonban. Kriza 1861. október 5-én Siménnek ezeket írta az ifjúról:

„Iszlai József nevű ifjú, önnek volt tanulótársa, eltökélve magát állhatatosan arra, hogy Londonba menjen a természeti tudományok hallgatására, pénzzé tette minden rászállott birtokát, valami 3000 pfrtot csinálván ki belőle, s kérve engemet arra, hogy ajánlanám őt Londonba. Én nem láttam más módot, mint önnek ajánlani őt, hogy utasítaná tanulási pályáján. Az ifjú nagytehetségü, habár egy kissé excentrikus." ${ }^{64}$

A világi unitáriusok egyházi alapból történő angliai taníttatását a 19. század hatvanas éveiben nem lehetett megvalósítani, a lelkészek és tanárjelöltek angliai peregrinációja viszont sikertörténetnek bizonyult, és a századvégre az akadémitáknak köszönhetően az erdélyi unitárius egyház mind szervezetében, mind teológiájában megújult.

\subsection{Az ösztöndíjalapítástól a szervezett kapcsolatok kiépítéséig. Az 1860-as évek az angol-magyar unitárius levélváltás tükrében}

A kiegyezést megelőző években a Manchester New College-ban három magyar diák tanult. Simén Domokos 1860-tól 1862-ig, Benczédi Gergely 1864-től 1866-ig, és Uzoni Fosztó Gábor 1866-tól 1868-ig. A felsoroltak közül egyedül Benczédi érte meg a huszadik századot, ő azonban nem befolyásolta döntő módon az unitárius teológiai gondolkodás alakulását, és kolozsvári közélete is szokványosnak tekinthető. Egyháztörténeti munkássága kiemelkedő, de az angol kultúra népszerúsítésében nem tartozott az akadémiták élmezőnyéhez. Simén életrajzát, roppant sokoldalú munkásságát Borbély ismertette idézett tanulmányában, dolgozatunkban nem ismételjük meg megállapításait. Simén volt a 19. század második felének egyetlen olyan unitárius teológusa, aki felkészültségben állta a versenyt a magyar protestáns felekezetekkel. Nyomtatásban megjelent munkái hoszszú időn keresztül az unitárius teológiai oktatás alapmúveinek számítot-

${ }^{63}$ Channing Ellery Vilmos válogatott müvei. Angolból fordítják és kiadják az unitárius tanárok. II. kötet. Vallásos tárgyú beszédek. Kolozsvárt, K. Papp Miklósnál, 1872, 152-187. (Sándor Mózes a 6. és 7. értekezést fordította.)

${ }^{64}$ Uo., 71. 
tak. ${ }^{65}$ Ígéretes karrierjének korán bekövetkezett halála vetett véget. Uzoni Fosztó Gábor káprázatos nyelvérzékével - öt modern nyelvet beszélt és a klasszikus nyelvekben is otthonosan mozgott - és éles felfogóképességével nyerte el az angolok bizalmát, sajnos labilis idegzete idejekorán öngyilkosságba kergette. ${ }^{66}$

A kiegyezés előtti angol-magyar kapcsolatokat az akadémiták többé-kevésbé folyamatos jelenlétükkel, a hivatalos egyházvezetés pedig rendszeres levélváltással biztosította. Az Emlékkönyv, a BFUA tanácsának jegyzőkönyvei, valamint a ChRL hasábjain megjelent levelek, cikkek és tudósítások elég pontos képet adnak a történtekről.

A Főtanács nevében az 1859. augusztus 30-án írott első angol nyelvű levélben újólag megköszönték az iskolák támogatását, valamint Buzogány és Ferencz József szíves fogadtatását. ${ }^{67}$ Válaszlevelükben az angolok arról biztosítják erdélyi rokonaikat, hogy tanintézeteikben szívesen látják a magyar diákokat, hiszen a reformáció korában sok jó szolgálatot tettek. Most elérkezett az idő, hogy

„a derékül megkezdett munkát tovább vihessük, $\mathrm{s}$ a szent tudománynak $\mathrm{s}$ igazságnak ügyét bármely mértékben tovább fejleszthessük: mi óhajtjuk, hogy önök, ama munkásoknak utódai, a mi áldásainkban, amennyire lehet, részesülhessenek." ${ }^{68}$

1860-ból mindössze az említett levél érkezett a szigetországból. Buzogányék látogatása nyomán a BFUA Könyvtársulata 60 unitárius művet küldött a könyvtár részére. Ezt köszönte meg Székely Mózes és Pap Mózes abban a Simén Domokost is ajánló levélben, melynek az Emlékkönyvben ugyan nem maradt fenn másolata, de amely a ChRL hasábjain az első magyar unitárius akadémita megérkeztét hírül adó rövid beszámoló kíséretében megjelent. A szerkesztői üzenetből értesülünk arról, hogy Simén a nyelvet karácsonyig megtanulandó, Thomas Lethbridge Marshallnak, a The Inquirer szerkesztöjének vendége volt (ő látta vendégül Buzogány Áront és Ferencz Józsefet is). ${ }^{69}$ A két Mózes az erdélyi unitáriusokra jel-

\footnotetext{
${ }^{65}$ A legfontosabbak: A szentháromság eredetének és kifejlődésének története, Pest, 1872, Az evangéliumi csodák tekintettel az Ó- és Újtestamentumi összes csodákra, Kolozsvárt, 1875. Tanulmányai, fordításai a KerMagvben jelentek meg.

${ }^{66}$ Uzoni Gábor Benczédi Gergelyhez Londonból küldött leveleit lásd a Függelék 9. sz.

${ }^{67}$ Emlékkönyv, vol. I., 48-49.

${ }^{68}$ Uo., 52.

${ }^{69}$ A The Inquirer az első angol unitárius hetilap, 1842. július 9-én jelent meg azzal a céllal, hogy rendszeresen tájékoztasson a felekezetet érdeklő kérdésekről, de ugyanakkor egy általános újság szerepét is betöltse. T. L. Marshall 1856-tól 1888-ig volt a lap főszerkesztője. Vö. W.G. TARrant, Some Chapters in the Story of "The Inquirer", TUHS vol. IV, 1927-1930. 35-44. Lásd még The Inquirer A History and Other Reflections, é. n., [1992] London; H. McLachlan, The Unitarian Movement in the Religious Life of England, London, 1934, 212-220.
} 
lemző cirkalmas bevezető formula után tért tulajdonképpeni tárgyára, az angolok figyelmébe ajánlották Simént. ${ }^{70}$

1861-ből egyetlen, a tordai püspökválasztó zsinatról a BFUA tanácsának küldött levél maradt fenn az Emlékkönyvben. A zsinaton hozott határozatok egy része az angol-magyar kapcsolatokra, illetve az ösztöndíjra vonatkozott. Simén Domokos második évi támogatására 500 forintot szavaztak meg, és az angol nyelv fakultatív tanításával megbízták Buzogány Áront. Ugyanakkor elhatározták, hogy angol hitrokonaikat értesítik a fontosabb egyházpolitikai eseményekről, s hogy Simén hazatérte után újabb akadémitát küldenek a londoni Manchester New College-ba. Az Emlékkönyv tanúsága szerint az angol kapcsolatokról és az ösztöndíjról készült beszámoló úgy hatott a püspökválasztó zsinatra egybegyưltekre, mint:

„....frissítő harmat az életerős, de a szabad levegőnek elzárása miatt kifejlésében megszorított növényre, vagy mint szelíd napsugár, mely a felettünk levő borús égen is áttörve, szebb napok beköszöntését remélheti. Áldjuk az Egy igaz Istent, ki szent fia, az Úr Jézus Krisztus által igaz ismeretére vezetett, hogy Európa nyugati részén hủ bajnokaira s buzgó apostolaira talált azon vallás, melynek igazságai tiszták, mint a hegyi forrás kristály vize, szentek mint az Istennek minden múvei, boldogítók mint az idvességnek biztos zálogai, $\mathrm{s}$ amelyeket Európa keleti részében, itt Erdélyben, a legnagyobb politikai és vallási rázkódások között is sikerült dicső elődeinknek épségben tartani fenn úgy, hogy mi Isten segedelmével néhány év múlva az Unitaria vallásnak háromszázados ünnepét fogjuk megünnepelhetni!"71

A ChRL hasábjain megjelent fordításban hiába keressük a magyarok patetikus szófordulatait, Paget száraz tárgyilagossággal tényeket közölt az angolokkal, ennek ellenére a kolozsváriak a későbbiekben sem változtattak leveleik retorikáján. ${ }^{72}$ Ugyanebben a lapszámban az Angliában, Skóciában és Írországban élő unitáriusok nevében egy, az erdélyi zsidók hátrányos megkülönböztetését elítélő nyilatkozatot is közöltek. Az angolok a személyi-és vallásszabadság minden embert megillető jogaira hivatkozva felhívták Kriza püspök figyelmét az unitarizmus szellemével ellenkező anomá-

\footnotetext{
${ }^{70}$ "May God grant that he shall spend his time there to his own profit and your satisfaction, and he may return to this country enriched with the knowledge of religious truth, and so be once a worthy labourer in the vineyard of our Master! We believe the best way in which he can express his thanks for your generous sacrifices in his behalf, is by appropriating the English modes of feeling and thinking, and by engrafting them on the native Hungarian character. That he may so be fit to work with zeal and success, and by preaching and promoting the truths of the Unitarian faith may show himself in his works a true servant of the Lord. We recommend him." Transylvanian Church and Students, ChRL 1860, 711-712.

${ }^{71}$ Emlékkönyv, vol. I., 66.

${ }^{72}$ Intercourse between the Unitarians of Transylvania and Great Britain, ChRL 1862, 41-44.
} 
liára. ${ }^{73}$ Nem lenne okunk kételkedni az angol hitrokonok tiszta és nemes, a személyi és vallásszabadság jogát mindennél fontosabbnak tartó szándékában, csakhogy a záró sorok nyílt prozelitizmusra buzdítanak. A 19. századi judaizmus várható változásai, az angolok szerint, az unitáriusokra mutatnak, mint az isteni gondviselés azon eszközeire, akik Izrael fiait az igaz keresztény hitre vezethetik. Nem tudjuk, Kriza válaszolt-e egyáltalán a levélre, Siménnek 1862. áprilisában egyebek mellett ezeket írta:

„A zsidók ügyében hozzám intézett szózatot olvastam. Amit az erdélyi szociális téren tehetünk, megtesszük. A magyar politikai úton teend, mihelyt tennie meg lesz engedve a világszellemtől. De most bizonyos elfásultságba estek a lelkek, - általános a zsibbadás." ${ }^{74}$

Ezek után a zsidó emancipáció kérdése a kiegyezés utánig lekerült a napirendről. Nem tartjuk teljesen kizártnak, hogy a szombatosság kapcsán került terítékre a kérdés, bizonyára a zsidó származású Steinthal közvetítésével.

1861-ből az Emlékkönyv csak a zsinatról szóló tudósítást őrizte meg, de a ChRL júniusi száma további részletekkel szolgált az esztendő magyar-angol korrespondenciájáról. ${ }^{75}$ Elsőként Paget számolt be az osztrák kormánynak a magyarországi protestantizmus autonómiáját sértő intézkedéseiről, és arról az erős és egységes ellenállásról, melyet ez protestáns részről kiváltott. Az erdélyi unitarizmus helyzetéről írva, bizakodva tekintett az eljövendő nemzeti kormányra, és elégedetten nyugtázta, hogy az egyházközségek és iskolák irányítási és felügyeleti joga visszaállíttatott. Nem tudjuk, érkezett-e válasz Paget beszámolójára, az Emlékkönyv csak John James Tayler, a Manchester New College principálisa 1861. április 16-án írott, Székely Mózesnek címzett latin nyelvű levelét örökítette meg. Tayler Simén Domokos filozófiai és teológiai tanulmányairól írt, és megerősítette, hogy a College kész a Siménhez, Buzogányhoz és Ferencz Józsefhez hasonló kiváló fiatalemberek fogadására. A lelkészképzés javát szolgálná - írta -, ha évente legalább egy alkalommal levelet váltanának, ezzel is segítenék és kölcsönösen bátorítanák egymást. A tudós principális a kölcsönösséget abban látta, hogy részükröl elküldenék az újabban megjelent teológiai munkákat, Erdélyből pedig a kolozsvári könyvtárban levő fontosabb nyomtatványok és kéziratok pontos leírását adnák. Az együtt-

\footnotetext{
${ }^{73}$ "We feel assured that you are worthy descendants of those early Transylvanian Unitarians who nearly three centuries ago were careful to assert and defend religious liberty as well as pure Christianity. Should it now be your happy privilege to assist in the extinction of religious antipathy, and in conferring on the Jews of Transylvania the rights now withheld from them, you will give good proof, alike to Christians and Jews, of your undoubting faith in the religion of the Messiah, and of your being animated by the pure and loving spirit of your Great Master, whose help and prayer were equally ready to bless Gentile and Jew." Uo., 45.

${ }^{74}$ BorbéLY, i. M., 77.

${ }^{75}$ British and Foreign Unitarian Association, ChRL, 1861, 373-377.
} 
működés jegyében javasolta, hogy amennyiben Kolozsvárott akadna az unitarizmus történelmét új megvilágításba helyező mủ, azt közös erővel kiadhatnák, de már az is óriási szolgálatot tenne a szakirodalomnak - írta -, ha a kolozsvári kéziratok és nyomtatványok cím- és tartalomjegyzéke kiadásra kerülne. Simén tanulmányai kapcsán fogalmazta meg a Manchester New College magyar diákokkal szembeni elvárásait: alapvető angol nyelvismeret, matematikai ismeretek, latin és görög nyelv és irodalom. Erre az alapra bizton lehet építeni! ${ }^{76} \mathrm{~A}$ befejező sorokban az unitarizmus hivatásáról elmélkedett, majd azt kérte erdélyi kollégájától, hogy a BFUA soron következő májusi üléséig válaszolják meg levelét. ${ }^{77} \mathrm{Az}$ EKT a tanárokat bízta meg a válaszadással, ami időben el is készült, csakhogy Buzogány hiába kért az Emlékkönyv részére egy másolatot Székelytől, soha nem kapta meg. A latin eredeti angol fordítása megjelent a ChRL-ben. ${ }^{78}$ Ebben Székely Mózes a magyar-angol kapcsolatok ötven éves történetét, valamint 1831-ben tett látogatását, Londonban és Yorkban szerzett barátai, John Bowring, W. J. Fox, T. Rees, Edward Tagart emlékét idézte fel, végül a magyar honfivá lett John Pagetnek köszönte meg az angol-magyar kapcsolatokért és az unitarizmus ügyéért vállalt áldozatát. Írt az osztrák elnyomásról, a püspökválasztó zsinat összehívásának megtiltásáról, a diákok múltbeli, hollandiai és németországi peregrinációjáról, majd az angol ösztöndíj kérdésére térve újólag megköszönte a principálisnak Simén tanulmányi költségeinek vállalását.

Tayler az erdélyi nyomtatványok és kéziratok jegyzéke kiadása tárgyában tett javaslatának jelentőségét nem ismerték fel Kolozsvárott. A könyvtárnokot megbízták egy jegyzék elkészítésével, és néhány nyomtatványt postáztak a principálisnak. Ezek között volt: Szentábrahámi Summa Theologiae címú munkája - melyből minden gyülekezet és lelkész számára felajánlottak egy-egy példányt -, a Koncz Boldizsár-féle magyar káté 1857. évi, az énekeskönyv 1837. évi, a Halotti énekeknek 1856. évi kiadása és a Keresztény Magvető első kötete. Az unitarizmus történetét „,új fényben bemutató egyháztörténetet" illetően, Kénosi Tózsér János-Uzoni Fosztó István

\footnotetext{
${ }^{76}$ "For entering advantageously on our course of study, it is above all things desirable that your young men bring with them the following attainments: an accurate acquaintance with the rudiments at least of our tongue, and with elementary mathematics - and, in addition, of the Latin language and literature (which yet flourishes with a certain vigour in your country), as also of the Greek a still more thorough knowledge. On these foundations once duly laid all the higher learning may be safely built up." ChRL, 1861, 374-375.

${ }^{77}$ Emlékkönyv, vol. I., 56-58. Vö. A Letter from Rev. John James Tayler, A.B., Pincipal of Manchester New College, London, to Rev. Moses Székely, Bishop-substitute of the Unitarian Churches in Transylvania, and President of the Holy Consistory, ChRL, 1861, 374-375.

${ }^{78}$ Translation of a Letter from the Rev. Moses Székely, of Aranyos Rákos, Bishop-substitute of the Unitarian Churches in Transylvania, and Ecclesiastical President of the Consistory, to the Rev. John James Tayler, B.A., Principal of Manchester New College, London, ChRL, 1861, 375-377.
} 
klasszikusnak számító kéziratos múvét ajánlották. ${ }^{79} \mathrm{~A}$ levél és a könyvküldemény megérkezett a címzetthez, aki Simén Domokos segítségével lefordította, és a ChRL-ben publikálta az erdélyi könyvek - elsőként Szentábrahámi, majd a káté és az énekeskönyvek - történetét és tartalomjegyzékét. ${ }^{80}$ A Summa Theologiae és az énekeskönyvek alapos szemléje után a kortárs unitárius irodalom szócsövének számító, Kriza János és Nagy Lajos alapította teológiai folyóirat, a Keresztény Magvető első kötetét ismertette Tayler. Természetesen Simén segített a fordításában, azonban a józan kritikai megállapítások a principális tollából származtak, aki szerint a frissen indított szaklap nem lépett túl a liturgia, a gyakorlati teológia és statisztika tárgykörén. A Keresztény Magvetóben vizsgált kérdések egyike sem érintette a kritika-teológia vagy a vallásfilozófia határmezsgyéit, ami az erdélyiek provincializmusára, az üldöztetéstől terhes történelmére vezethető vissza - állapítja meg Tayler -, azonban az egészséges fejlődéshez a tudományos teológia tiszteletteljes, de megalkuvást nem ismerő eszközeit kell használni, és ezt sajátíthatják el az Angliában tanuló diákok, új lendületet adván ezzel a magyar unitárius teológiai gondolkodásnak. A recenzens szerint az erdélyi unitáriusok teológiai felzárkózását Ausztria és Magyarország javuló kapcsolata, és az új püspök, Kriza János megválasztása is segíti. Kriza bemutatása után újból a kapott könyvekről, ennek kapcsán pedig az unitárius nyomda sorsáról, a bibliafordításokról és a magyar nyelvről elmélkedett, és sokadszorra fogalmazta meg a már Bowring által óhajtott gondolatot, miszerint valamelyik angol diák megtanulhatna magyarul. ${ }^{81} \mathrm{~A}$ kis nemzetek nyelvi elszigeteltségén és a jövő lingua franca megteremtésén elmélkedett írása utolsó részében. Megoldásként két járható utat látott: egyik, a nemzeti nyelvek valamelyike, pl. a francia általános elfogadása,

79 „With regard to new materials, illustrative of our ecclesiastical history, I would remark, that Francis (sic!) Foszto Uzoni, formerly pastor of our church in Bágyon, wrote, in two volumes, in a clear and elegant style, in Hungarian and Latin, an account of the origin and subsequent propagation of our religion in former centuries. Of this excellent historical work we possess only a single copy in manuscript. On the credit and authority of the aforesaid excellent historical work, from about the middle of the last century more especially, several smaller works and manuals, still existing in MS., for the use of students, were prepared and put forth by the following distinguished men - Michael Lombard Abrahami, Stephen Agh and Alexander Székely, at different periods bishops of our church. At the present time, one of our countrymen, Stephen Kovacs, a historian well known, and I may add, of high reputation, among all Hungarians, is engaged in writing a history of our religion and commonwealth." Uo., 376.

${ }^{80}$ An Account of Some Books Recently Transmitted from Clausenburg by the Transylvanian Unitarians to the Principal of Manchester New College, London, ChRL, 1861, 493-496, 521-530.

$81, \ldots . . \mathrm{I}$ can not but hope that some one will be found among our young and rising men to take up the study of the Magyar, and make us better acquainted with the early history of a community who were so largely concerned in some of the first impulse of the Reformation." Uo., 527. 
másik, a latin visszavezetése. Ódivatú tudós lévén, az utóbbit támogatta, argumentuma szerint azért, mert ezzel elejét vehetnék az európai nemzetek közötti irigységnek és féltékenységnek, másfelől pedig a latin nyelv pedáns pontossága tökéletesen megfelel a tudományos igényeknek. Tayler hűséges maradt álláspontjához, és az Erdélybe küldött leveleit latinul írta. Buzogány egyetlen Tayler levelet talált meg és másolt be az Emlékkönyobe, azonban biztosan tudjuk, hogy Székelynek is írt, és Kriza püspöknek is, ez utóbbi a Tayler leveleit összesítő kötetben maradt fenn. Ebben újból megismételte a kolozsvári könyvtár régiségeinek katalógusát sürgető kérését. ${ }^{82}$

Az erdélyiek persze most sem küldtek katalógust, de a könyvtárban levő duplumokról jegyzéket készíttettek és azokat felajánlották hitrokonaiknak. Könyvtörténeti szempontból talán nem jelentéktelen számba vennünk, mi is került az 1860-as években a londoni Manchester New College könyvtárába, és mit ajánlottak Erdélyből az 1863. november 22-én keltezett, a BFUA tanácsához küldött levél aláírói, Kriza János és Pap Mózes.

1. [Samuel] ${ }^{83}$ Przypkowski, [Opera (ed. Philippus van Limborch?)] Cogitationes sacrae [ad initium euangelii Matthaei et omnes epistolas apostolicas. Nec non tractatus varii argumenti, praecipue de jure christiani magistratus. Quorum catalogus post praefationem exhibet. Eleutheropoli /i. e. Amsterdam/], 1692.

2. [Johann] Sommer, Refutatio scripti Petri Caroli. Ingolstadti [i. e. Kraków], 1582.

3. [Johannes] Volkelius, De vera religione [libri quinque. Quibus praefixus est Iannis Crelii Franci liber de Deo et eius attributis, et nunc demum adjuncti ejusdem de uno Deo patre libri duo. In quibus multa etiam de filii Dei et spiritus sancti natura differentur ita ut unum cum illis opus constituant.] Racoviae, 1630.

4. [Almási Gergely Mihály], Tractatus aliquot succinti. De generatione Christi De libero Arbitrio.[De Justificatione cum annexis.] Claudiopoli 1702.

5. Stephani Dersii [Dersi Gergely István], Tractatus theologico diacriticus quattour religionum in Transylvania vulgo receptarum praecipuae capita et fundamenta complectens. 1756 (kézirat)

6. In genere contra omnes locos controversas argumentum. (kézirat)

\footnotetext{
82 „Librorum rariorum, vel manuscript. vel. impress. qui, ut audivimus, de antiqua ecclesiae vestrae historia multi adhunc in bibliotheca Claudiopol. latent, si catalogum accurationem describendum nobisque transmittendum statueritis, gratissimum, crede mihi, Unitariis Anglicis feceritis." John T. Hamilton, Letters embracing his life of John James Tayler, B.A., London 1873, vol. 2., 210-211.

${ }^{83} \mathrm{~A}$ felsorolásban a szerző nevét és a pontos címleírást [] egészítettük ki.
} 
A felsorolt hat művet megküldték az angoloknak, a kolozsvári könyvtár duplumainak lajstromát is mellékelték a küldeményhez, azzal a megjegyzéssel, hogy „felszólításukra készséggel fogunk küldeni belőlük önöknek." ${ }^{84}$ A mellékelt könyvjegyzék a következő:

1. Inter Erasmum et Socinum Disputationes de unigeniti Filii Dei existentia. Racoviae, 1626. [De unigeniti filii Dei existentia, inter Erasmum Johannis, et Faustum Socinum senensem disputatio. Irenopoli /i.e. Amsterdam/ 1656. In Faustus Socinus, Opera II. Bibliotheca Fratrum Polonorum vol. 4.]

2. Francisci Davidis, [Defensio Francisci Davidis in] De non invocando Jesu in precibus. [Cracoviae, 1582]

3. [Hieronymus] Moscorovius, Disputationes cum... de statu primi hominis. Racoviae, 1610. [De statu primi hominis ante lapsum disputatio, quam Faustus Socinus Senensis per scripta habuit cum Francisco Puccio Florentino anno 1578, in qua habetur responsio ad defensionem Francisci Puccii suorum argumentorum de immortalitate hominis et omnium rerum ante lapsum], Racoviae 1610.]

4. [Faustus] Socinus, Prelectiones theologiae. Racoviae, 1627.

5. [Faustus] Socinus, [De] Jesu Christo servatore, [Basel], 1594.

6. [Johannes] Crellius - Commentarius in [I.II.III.IV. capp. et partem Vti cap.] evangelii [Matthaei. In Johannes Crellius, Opera I,II (ed. Adam Francus Jr.) Eleuthreopoli / i.e. Amsterdam/, 1656. Bibliotheca Fratrum Polonorum vol. 1.]

7. [Johannes] Crellius, Ethica Christiana, [seu Explicatio virtutum et vitiorum, quorum in sacris literis fit mentio. Praefixa est ejusdem ethica aristotelica, ad sacrarum literarum normam emendata. In Johannes Crellius, Opera IV, Irenopoli /i.e. Amsterdam/, 1656. Bibliotheca Fratrum Polonorum vol. 6.]

8. [Johannes] Crellius, Opera omnia, exeg[etica, didactica et polemica. Magnam partem hactenus inedita. Adjecti sunt indices 1. Locorum S. Scripturae explicatorum. 2. Rerum Memorialium et Phrasium S. Scripturae. In Johannes Crellius, Opera III Eleuthreopoli / i.e. Amsterdam, 1656. Bibliotheca Fratrum Polonorum vol. 5.]

9. [Johannes] Volkelius, Nodi gordii a [Martino] Smiglecio nexi Dissolutio. [Racoviae, 1613.]

10. [Philippus van] Limborch, Theologia christiana [ad praxis pietatis ac promotionem pacis christianae unice directa. Editio tertia, ab autore recognita et aucta.] Amsterdam, 1700.

${ }^{84}$ Emlékkönyv, vol. I., 81. 
11. [Ionas] Schlichtingius - Quaestionum ad regnum Dei, [Rakow, 1625]

12. [Ionas] Schlichtingius - [Jonae Slichtingii de Bukowiec] Commentaria posthuma, [in plerosque Novi Testamenti libros. Bibliotheca Fratrum Polonorum vol. 5., Amsterdam, 1656]

13. [Ionas] Schlichtingius, Commentarius in epistolam ad Habraeos, [In Johannes Crellius, Opera omnia exegetica... Eleutheropoli /i.e. Amsterdam/, 1656. Bibliotheca Fratrum Polonorum vol. 1.]

14. Simon Episcopius, Opera theologica, [Amsterdam, 1650.]

15. Responsio ad Jacob. Paleol. Librum [Ad Jac. Palaeologi librum, cui titulus est defensio verae sententiae de magistratu politico, etc. Pro Racoviensis responsio... In Faustus Socinus, Opera II. Bibliotheca Fratrum Polonorum vol. 4.]

16. [Johannes Ludovicus] Wolzogen, Opera omnia, exeg[etica], didact[ica], et Polem[ica]. Quorum seriem versa pagina exhibet. Cum indicibus necessariis. In Johannes Ludovicus Wolzogen, Opera I, Bibliotheca Fratrum Polonorum vol. 8. Irenopoli /i.e. Amsterdam/, 1656]

17. [Johannes Ludovicus] Wolzogen, Commentari[us] in [partem] euangelii Joannis. [In Johannes Ludovicus Wolzogen, Opera I, Bibliotheca Fratrum Polonorum vol. 8. Irenopoli /i.e. Amsterdam/, 1656]

18. [Johannes Ludovicus] Wolzogen, Commentari[us] in euangelia Matthaei. [In Johannes Ludovicus Wolzogen, Opera I, Bibliotheca Fratrum Polonorum vol. 8. Irenopoli /i.e. Amsterdam/, 1656]

19. De falsa et vera [unius Dei Patris, Filii et Spiritus Sancti cognitione libri duo, Alba Iuliae, 1568.]

Ez utóbbit kihúzták a lajstromból, nem lévén belőle duplum. A jegyzékben felsorolt műveket nem küldték el Londonba, és Tayler is beleunhatott a kolozsvári katalógus várásába, mert többé nem tette szóvá. (1868-as látogatása során személyesen győződött meg arról, hogy értékes könyvekben és kéziratokban bővelkedik ugyan a kolozsvári könyvtár, de szakszerü leírást adó katalógus nem készült az anyagról.) A BFUA 1864. évi jelentésében köszönettel nyugtázta a társulatnak küldött könyveket. ${ }^{85}$ Buzogány szerint Tayler megsértődhetett azért, hogy levelét válaszra sem méltatták, és a könyveket a BFUA tanácsához küldték, holott a Manchester New College a tanácstól független intézmény volt. A csorbát kiköszörülendő, Buzogány egy magánlevélben megkövette a tudóst:

„....írtam egy magánlevelet, melyben előhoztam, hogy a Consistorium, mikor a könyveket elküldte, abban a tudatban volt, hogy az mindegy akár az Assotiationak, akár Taylernek küldi, szoros kapcsolatban gondolván állani a két

\footnotetext{
${ }^{85}$ Report of the BFUA, London $1864,9$.
} 
testületet; s mivel éppen levelet küldött akkor a Consistorium az Assotiatonak, azzal együtt küldte a könyveket is." ${ }^{86}$

A kiegyezésig folytatott levelezés legfontosabb fegyvertényének a Manchester New College-ban alapított ösztöndíj tekinthető. A Főtanács részéről többször is felmerült annak gondolata, hogy az angol hitrokonok nagylelküségét valamilyen módon viszonozni kell. 1861-ben Koronka Antal (1806-1885) esperes azt javasolta, hogy a londoni alapítvány mintájára a kolozsvári főiskola fogadjon egy angol diákot. ${ }^{87}$ Az EKT (217/1861) az indítványt elvetette, részint anyagi megfontolásból, részint azért, mert a főiskola infrastruktúrája és oktatási rendszere messze elmaradt a kontinens német egyetemei mögött. Az angol unitáriusokat nem értesítették Koronka javaslatáról, pedig Tayler igencsak azon volt, hogy diákjai közül valakit a magyar nyelv tanulmányozására állítson.

Az 1860-as években Londonban tanuló erdélyi akadémiták sem érdeklődési körük szerint választották ki a hallgatandó tárgyakat, hanem az éppen szükséges egyházi igények diktálták azt. Így eshetett meg Benczédi Gergellyel, hogy a londoni egyetemen drága pénzért hallgatott természettudományi előadások mellett a Manchester New College teológiai előadásait is föl kellett vennie, noha elmenetele elött kikötötte, hogy semmilyen körülmények között nem vállal papi szolgálatot. Elképzelhetetlen szomorúság ülte meg lelkét, amikor 1866-ban Kriza püspöktől arról értesült, hogy a Fótanács a kolozsvári eklézsia másodpapjává választotta. 1866. augusztus elsején megkeseredetten írta Naplójába:

„Eddig még nem tettem említést egy dologról, ami pedig meglehet reám nézve igen nevezetes s ez az, hogy a július elején tartott főtanácson megválasztottak egyik másod papnak Kolozsvárra. Engem papnak!! Már többször írtam a főtisztelendő püspök úrnak ez ügyben. Tisztán megírtam, hogy én arra soha sem köteleztem magamat, hogy pap legyek, amihez soha kedvem és hajlamom nem volt. Mikor akadémiára megválasztottak, akkor is megmondtam Kriza úrnak, Berde Áron úrnak stb., hogy pap lenni nem akarok s Kriza úr azt mondta, hogy „jaj arról ne is álmodjak, mert azt nem kívánják”, és íme most mégis. Amint látszik a főtisztelendő úr egy levelemet sem terjesztette a konzisztórium elé, aminek okát én gyanítom. Ide is írom, hogy ha valaha engem vádolnak s e sorok valakinek [itt a Naplóból egy lap ki van tépve, valószínúleg Krizát kompromittáló sorok lehettek K.S.] ....alapja nincs. Én készebb lennék meghalni mintsem esőért s beteg emberért könyörögjek - mert ez mind ámító komédia. Tudok pl. esetet hogy egy fiú, Gedő Sándor tanulótársam Szamosfalváról - fogadásból megett egyszerre 4 font disznóhúst s halálos beteg lett - 5 nap múlva megholt. Na már az ilyenért könyörögni istenkáromlás volna - pedig megteszik. Örök törvényei vannak a természetnek, melyek a mi sopánkodá-

\footnotetext{
${ }^{86}$ Emlékkönyv, vol. I., 72.

${ }^{87}$ Uo., 58-59.
} 
sainkra meg nem változnak, hanem nekünk kötelességünk ezen törvényeket kikutatni s magunkat hozzájuk alkalmazni.

Aztán nem sokkal könnyebb-e a papi kötelességeknek is lelkiismeretesebben megfelelni annak aki nyelveket tanít pl. csupa görög vagy latin nyelvet?! Ezeknek semmi dolgok sincs, míg nekem a laboratóriumban s fizikai múzeumban roppant sok a teendőm. Aki a természettudományokkal foglalkozik csak az tudja helyesen megítélni hogy mennyi idejében kerül egy kísérlet végrehajtás, instrumentum felszerelés, számítás stb; mert nekem előre mindent ki kell számítanom, hogy nevetség tárgyává ne legyek. A paposkodás végképpen le is kötne Kolozsvárhoz, szünidő alatt se mehetnék sehová, pedig aki növénytant, ásványtant stb. tanult, annak csak szükséges az országban gyüjteni. Londoni életemet eléggé megkeserítette az a pár tárgy is, amit az egyetemtől egészen külön levő és független unitárius egyetemen kellett kényszerből hallgatnom, mert nem szentelhettem saját szakomra elég időt." ${ }^{88}$

A természettudományok szeretetén növekedett Benczédi nem volt megveszekedett materialista. Az EKT „hírzárlata” miatt az angolok nem tudhatták, hogy Benczédi nem papnak készül, ezért ugyanolyan elbánásban részesült, mint a többi akadémita. A Manchester New College ösztöndíja pedig a teológiai képzést írta elő. Az erdélyi diák súlyos anyagi áldozat mellett, tulajdonképpen teológiai ösztöndíja kárára kísérleti kémiát és fizikát hallgatott az egyetemen, és ezekből a tárgyakból jeles osztályzatot szerzett. Angol barátai a természettudományok eljövendő magyar professzorát látták benne, csakhogy a teológiai stúdiumok és a kolozsvári unitárius kollégium laboratóriumai és szertárai nem sokat segíthettek a szakmai előlépésben. Benczédi véleménye az volt, hogy a természettudományokat a német egyetemeken sokkal olcsóbban lehetett volna hallgatni mint Angliában, és kár az alapvetően teológiai ösztöndíjat elfecsérelni. 1864. augusztus 9-től 1866. október 4-ig volt Angliában, itt vezetett Naplójának csak töredékét ismerjük, (1866. július 23-tól október 4-ig) de ez is elég ahhoz, hogy tanulmányútjáról, ismerőseiről képet alkossunk. A rendkívül borúlátó fiatalember önérzetét sértette, hogy feljebbvalói ígéretük ellenére pappá választatták. Londoni életét eléggé megkeserítette az a pár tárgy, amit az egyetemtől külön levő Unitarian College-ban kellett hallgatnia, mert saját szakterületére nem fordíthatott elég időt.

„Úgy meggyűlöltette csak ez is a teológiát, hogy semmi szín alatt sem tudnám magamat még egyszer rá adni. Másfelől itt 100 font sterlinget kaptam egy évre (1000 forint), amiből 40-50 fontot tandíjakra adtam. Ezért kellő számú könyveket sem szerezhettem, a kísérletekre szükséges instrumenteket meg nem vehettem, több fontos tárgyat nem hallgathattam, a legnyomorultabban éltem, mert soha sem ebédeltem oly értelemben mint az angolok veszik, ruházatom is

\footnotetext{
${ }^{88}$ BenCzÉdi Gergely Napló kézirat az EUEGyLt-ban.
} 
szűkön s kopottan lévén, társaságokba nem igen mehettem és mégsem kértem a státustól pénzt csupa becsületességből." ${ }^{89}$

Peregrinusként néhány, a magyar unitáriusok helyzetét ismertető cikket közölt az Inquirerben, és angolra fordította az 1864-ben megjelent Ferencz József-féle káté 22., 23., 24., 25., 55., 56., 57., 64., 65., 66., 67., 70., 71., 72., 73., 74., 83., 89. számú kérdéseit. ${ }^{90}$ Ugyancsak az ő nevéhez füződik Jakab Elek Szentábrahámiról írott, és a Keresztény Magvető első kötetében megjelent tanulmányának angol fordítása. Ennek kiadását fontolgatta, a BFUA végül nem tudni miért, mégsem vállalta fel. ${ }^{91}$ Angliai forgolódásáról és magyar emigráns ismerőseiről szúkszavúan számolt be naplójában. Talán nem érdektelen a Benczédi rajzolta emigráns portrékra egy pillantást vetnünk. Hazatérése évében, 1866. augusztus 2-án a következőket jegyezte Naplójába:

„Testileg is nagyon beteg vagyok, talán soha többé hazámat meg nem látom, de sokkal terhesebb lelki betegségem. Pénzt tovább nem várok; ma még megjártam a szomszéd Regent's parkot, hol szomorúságomban annyiszor találtam enyhelyet. Az utcán láték egy dölöngésző részeg olaszt, kit a policeman-nek nyakon csíptek és elvittek, nálunk még ordítoznak is még éjszaka is a részegek. Ma írtam levelet Párizsba tanuló Bihari Péternek ${ }^{92}$ is, tudatván vele, hogy e hó 9-é indulok, s szíveskedjék nekem privát szállást szerezni.

Itt megemlítem azokat a magyarokat, akikkel Londonban találkoztam.

Vukovics Sebő, ${ }^{93}$ volt igazságügy-miniszter.

Rónay Jácint, ${ }^{94}$ győri volt tanár, barát, igen nagy tudományú, finom műveltségű s meglepőleg szabadelvű derék ember, ki Angliában is dicsőséget szerzett a magyar névnek. Tanításból tartotta fenn magát, többek közt Southerland hercegnét is Gaye Lalina k. a. t ő tanította meg nyelvünkre. Egy Smith nevü unitárius embernek pedig két leányát latin nyelvre tanította.

Diósy Márton, ${ }^{95}$ most borkereskedő.

Lóránt János, ${ }^{96}$ volt tüzér kapitány a komáromi kapituláció után várúr volt, ki pesti születés, családi neve Leutner, melyet Londonban változtatott meg. A bécsi katonai iskolában nevelkedett. Tanult ember, magán leányneveldében német nyelvet és mathézist tanít. Elméje kissé megháborodott, mert azt hiszi, hogy az osztrák kormány spiclikkel veszi körül, meg akarja mérgezni, ezért egy helyt soha nem eszik kétszer, s még így is papirosba takarva többször hozott hozzám húst megvizsgálás végett, hogy nem mérgezték-e meg, mert a

\footnotetext{
${ }^{89}$ Uo.

${ }^{90}$ G. Benczéd, Hungarian Unitarian Catechism, The Inquirer, March 31, 1866, 197-198.

91 ,Your Committee have received from Transylvania the MS. of an interesting biographical work, illustrating the history of Transylvanian Unitarianism during a part of the last century. The work is composed in English, and may perhaps be considered not unworthy of publication hereafter by the Association." Report of the BFUA, London, 1867, 9.

${ }^{92}$ Bihari Péter (1840-1888) református tanár.

${ }^{93}$ Vukovics Sebő (1811-1872) a reformkori liberális ellenzék tagja, igazságügyminiszter.

${ }^{94}$ Rónay János Jácint (1814-1889) bencés tanár, természettudós, író.

${ }^{95}$ Diósy Márton (1818-1892) Kossth Lajos titkára, hírlapíró, borkereskedő.

${ }^{96}$ Leutner (Lóránt) János, tüzérkapítány, magántanár.
} 
kelner kuvasz szemekkel nézett reá. Egyszer azt mondta, hogy 50000-nél több spicli van Londonban, aki mind reá vigyáz.

Mednyánszky. ${ }^{97}$

Horváth Pál, kolozsvári gyógyszerész, önkéntes száműzetésben, egy bolond idea valósítása végett.

Szeremley, aki a parlament épületét chemiai vegygyel behúzván, gazdag ember lett.98

Oláh... ez egy cigány, ki valamelyik bandával jött ki Magyarországból s itt maradt és dohányboltot nyitott.

Feitinger nevü német Magyarországról, egy nagy csaló.

Mayer, a derék öreg, kiről már szóltam.

Kéhler Rezsőről, a Pinto-Leit \& brother nagy kereskedő ház egyik vezetője.

Lápossy Ferenc, debreceni orvos fia, ki a kereskedelemben magát kimívelni jött ide s az 11. p. említett kereskedő házban jó fizetésben van. Derék fiú.

Kovács, volt ügyvéd s most zöldség áruló szegény ember, menekült.

Pulszky Gábor, Ferenc fia, most végezte a mérnöki kurzust kitűnőleg. Igen jó barátom.

Somogyi, menekült. Most fizetésből tartja fenn magát. Nagy nyomorúságban él. Egykor négylovas hintón járó alispán volt."

Benczédi hazatérte után nem kellett papként elhelyezkedjen, hanem Berde Áron helyére tanárnak választották. Tagja volt az angol levelezést bonyolító bizottságnak, és vezette az Emlékkönyvet is. Helyébe a Főtanács Uzoni Gábort küldte Angliába. Uzoni saját költségén már 1865. októberétől Göttingenben, 1866. áprilisától pedig a jénai egyetemen tanult. 1866. szeptemberében iratkozott be a londoni Manchester New College-ba, és bár lehetősége lett volna három esztendőt itt tölteni, 1868. áprilisában betegsége miatt kénytelen volt tanulmányait megszakítani és hazatérni. Orvosi diagnózis nem áll rendelkezésünkre, de egykori tanára J. J. Tayler egyik John Kenrickhez küldött leveléből és Uzoni későbbi kolozsvári megnyilvánulásaiból depresszióra gyanakodhatunk, végül ez kergette öngyilkosságba is. ${ }^{99}$

\footnotetext{
${ }^{97}$ Mednyánszky Sándor honvédezredesről van szó, aki 1866-ban csatlakozott Klapka seregéhez, addig Londonban élt.

${ }^{98}$ Szeremley Miklós, Liebe mérnökről van szó, az ún. silicat zopissa nevű kőkonzerváló szerére utal Benczédi. A forradalom idején alezredesként szolgált Komáromban, 1850 körül Londonban telepedett le.

${ }^{99}$ "We have had one sad disappointment. I remember you were much pleased at our last examination with the appearance and performances of Uzoni, a student from Transylvania. He was indeed a young man of fine talent and great promise, which we hope may yet bear fruit. But about six weeks ago, he was seized with an extreme mental depression, accompanied by constant sleeplessness, which completely unhinged him and made it necessary for him to give up his studies. It arose, I believe, from bodily causes, and was not occasioned by over-work of the head. We took him twice to see Dr. Jenner, who carefully examined his case, and said he saw no reason to apprehend anything serious; but recommended immediate change of air and scene and a return to his natiéve country." Letters of John James Tayler... vol. II., 293. Az Uzoni öngyilkosságával kapcsolatosan lásd Kolozsvári Közlöny, 1870, 136. sz.; Magyar Polgár, 1870, 137. sz.
} 
1867-ben Angliából újabb 324 darabból álló könyvküldemény érkezett, köztük sok duplum is. Ezek szétosztásáról az EKT intézkedett. Ugyanebben az évben Székelykeresztúrról a kolozsvári Kollégiumba került Simén Domokos, és Buzogánytól átvette az angol nyelv oktatását. A Főtanács 1866ban küldött levelében az egyház fennállásának közelgő, háromszázados évfordulójáról, s az erdélyi unitáriusok helyzetéről adott némi eligazítást. Egyetlen részletét emeljük ki a levélnek, mely az angol unitarizmuson belül egyre élesebbé váló polémiáról tudósít. A régi ún. Priestley-féle biblikus iskola és a Martineau vezette modern, minden „izmuson” felülkerekedő nézet csapott össze, végül a humanista teizmus irányába mutató Martineauféle iskola győzött. A kolozsváriak meglepő nyilatkozatát - a vitatkozás az élet jele ${ }^{100}$ - az angoloknak szánták, a magyar unitárius felekezeten belül az „élet jele” a huszadik század első felében mutatkozott meg, és ezzel Kriza János álma is beteljesedett. A költő püspök Siménnek írt egyik levelében a The Inquirer olvasása adta gyönyörüségről ezt írta:

„,...nem tehetem, hogy ki ne jelentsem, mily magas élvezetet szerez az én lelkemnek ez angol folyóirat olvasása s mennyire óhajtom, hogy évről-évre mentül több olvasói legyenek erdélyi egyházunkban, hogy ezáltal legalább szellemi rapportban lehessünk az angol tudományos teológiával s az ottani vallásos élet hatalmasabb s mélyebbre ható folyamával. Ilyentén villanyos láncolat nélkül maholnap elzsibbadnánk s lassanként a régi századok arcát élettelenül visszaidéző múmiává lenne egyházi egyéniségünk." ${ }^{101}$

Mint láttuk, az 1860-as évek levélváltása az angol-magyar kapcsolat történetében a két egyház kapcsolatrendszerének megszilárdulásához vezetett. A hatvanas évek akadémitái egyházdiplomaták is voltak, nagyrészben rajtuk múlott, hogy az angol fél érdeklődése Erdélyre irányult. Az egyház fennállásának háromszázadik évfordulóját 1868-ban angol képviselet mellett ünnepelhették az unitáriusok. Kriza János püspök álma valóra vált, és a magyar unitárius egyház lassan felengedett zsibbadtságából.

\footnotetext{
100 „Mind az Inquirerből, mind Benczédi Gergely úr nyilatkozataiból értésünkre esett, hogy angolhoni hitrokonaink közt egy kis meghasonlás fejlődött ki, mely az önök Társulatát is közelről érdekli. A szabadsággal együtt jár a pártoskodás, s a vitatkozás az élet jele: mi hisszük, hogy e meghasonulás és vitatkozás veszély nélkül fog lefolyni, sőt az Unitarizmusnak újabb lendületet, elveinknek határozottabb alakot fog adni. Adja Isten, hogy úgy legyen!" Emlékkönyv, vol. I., 100.

${ }^{101}$ BorbéLY, i. m., 68.
} 


\subsection{Az amerikai unitárius kapcsolatok kiépítése a kiegyezés után}

Az Emlékkönyv I. kötetében fennmaradt levelek közül a legbizakodóbb hangvételü közvetlenül a kiegyezés után született, és 1868-ban küldetett el az angol unitáriusoknak. Ennek minden sorából reményteljes jövővárás sugárzik, az unitarizmus kelet-közép-európai misszióját és az egyéni- és vallásszabadság minden nemzetre kiterjedő jótékony hatását illetően. Az 1868. év teljes mértékben feljogosította az erdélyieket az ehhez hasonló remények táplálására. De lássuk előbb az említett, kiegyezés után született levelet.

A politikai változás a felekezet életében is átalakulást hozott, nemcsak azáltal, hogy a későbbiekben, Magyarország felekezeteihez hasonlóan, államsegélyben részesültek, hanem elsősorban abban, hogy az erdélyi kancellária feloszlatása és az unió során az államapparátusba unitárius értelmiségiek kerültek, és Budapest potenciális missziós központtá változott. A fővárosban létesítendő egyházközséget már ebben a levélben az angol unitáriusok figyelmébe ajánlották. Örömmel írták hitrokonaiknak, hogy:

„....mi is a magyar minisztérium alatt állunk, képviselőink Budapesten vannak s a törvényhozásban részt vesznek; a minisztériumhoz erdélyi férfiak, közöttük unitáriusok is vannak beosztva; sőt Selmeczre a bányászati s erdőszeti akadémiához is közelebbről két unitárius ifjú neveztetett ki tanársegédül, ami nyílt elismerése az unitárius vallás jogosultságának, amit már az 1848-ki törvények biztosítottak ugyan, de alkalmazásba még nem vétettek volt, úgy, hogy az unitárius vallás gyakorlata addig tulajdonképpen csak Erdélyre szorítkozott.

És itten nem tehetjük, hogy ki ne fejezzük azon reményünket, mely szerént a dolgok ilyetén állásában talán Budapesten is alakuland egy unitárius gyülekezet; mert a hivataloknak ottani központosítása mind többeket vivén ki innen Pestre azok idővel annyira szaporodhatnak, hogy egy eklézsia alakítása nélkülözhetetlenné válik. Igaz, hogy ezen remény valósulását még csak távol jövőben látjuk; aminek valósulása közelebbről megtörténhetik: az vallásközönségünknek állami segélyben való részesítése." ${ }^{102}$

A kolozsvári egyetem tervezésével, a várost Nagyváraddal összekötő vasútvonallal és a zsidó emancipáció kérdésével folytatódik a levél, majd az egyház fennállásának háromszáz éves évfordulója kapcsán szervezendő ünnepségről értesítik az angolokat, egyben felkérik a társulatot, küldjön képviselőket az augusztusban Tordán tartandó zsinatra. A gazdaságipolitikai élet alakulását a következő megjegyzéssel zárták:

${ }^{102}$ Emlékkönyv, vol. I., 102-104. A szöveghú angol fordítást lásd: Report of the BFUA, London, $1868,41-42$. 
„...azt hisszük, hogy ha még mindig van mit kívánnunk, hogyha sok dolog még mind nem foly is lépes kedvünk szerint, mindazonáltal a jelzett politikai átalakulás elég arra, hogy ezen, mint alapon, nemzeti s ezzel együtt egyházi és vallási életünk tökéletesítését munkáljuk s egy óhajtott jobb jövőnek nézzünk elébe." 103

A veretes „lépes kedvünk szerint” szószerkezet angol fordítása „may not be to our taste" már nem Paget, hanem valamelyik hazatért angol akadémita nevéhez füződik. A „lépes kedv" teljességgel illett az iskolai és egyházi állapotok részletezéséhez, hiszen mind a tordai, mind pedig a keresztúri gimnázium jelentős átépítés, bővítés alatt állt, és a Főtanács azt is fontolgatta, hogy Dicsőszentmártonban is beindít egy újabb gimnáziumot. Utóbbi terve meghiúsult, és bizony a keresztúri iskola bővítése is még jónéhány évig elhúzódott.

A jubileumi zsinat, valamint John James Tayler erdélyi látogatása jelentőségének ismertetése előtt egy másik hasonló fontosságú látogatásról kell szólnunk, nevezetesen Charles Dall (1816-1886) 1868 tavaszán tett kolozsvári és Aranyos menti útjáról. Dall, teljes nevén Charles Henry Appleton, az Amerikai Unitárius Társulat indiai misszionáriusa, bár tagja volt néhány tudományos társaságnak - az American Oriental Societynak és az Asiatic Society of Bengalnak is - az amerikai unitarizmus történetében középszerü egyházi írónak számít. Felesége, Caroline Wells (Healey) Dall (1822-1912), viszont a 19. század kiemelkedő írója, az amerikai feminizmus jeles képviselője volt. ${ }^{104}$ 1844-ben kötött házasságuk nem sikerült, Dall beteges, labilis alkat volt, és lelkészi szolgálatának első évtizedei meghasonlásba torkollottak. Életcélját a calcuttai unitárius misszióban találta meg, ez viszont a feleségétől és családjától való eltávolodását jelentette. 1855-től kezdődően 1886-ban bekövetkezett haláláig tulajdonképpen Indiában élt, és ez alatt az idő alatt mindössze ötször látogatta meg Bostonban élő családját. 1868-ban az Amerikai Egyesült Államokba tartva kereste fel Erdélyt, és lett a magyar unitáriusok amerikai nagykövete. Hazatérte után Charles Lowe-nak (1828-1874), az AUA titkárának biztatására a Monthly Journalban közzétette Kolozsvárott írott naplója néhány részletét. ${ }^{105} \mathrm{~A}$ Boston környéki unitárius lelkészek társulata Dall javaslatára 1868. novemberében az erdélyi hittestvérekkel rokonszenvező határozati javaslatot terjesztetett elő, és kilátásba helyezték egy erdélyi ifjú amerikai taníttatását

\footnotetext{
${ }^{103}$ Uo.

${ }^{104}$ Negyvenöt kötetnyi Naplójából nyújt válogatást Helen R. DeEsE ed., Daughter of Boston. The Extraordinary Diary of a Nineteenth-century Woman, Caroline Healey Dall, Beacon Press, 2005.

${ }^{105}$ Visit of Rev. C.H.A. Dall to the Unitarians of Hungary, Monthly Journal, 1869, vol. X., March, 83-87.
} 
is. ${ }^{106}$ Dall erdélyi látogatása során Benczédi Gergely társaságában bejárta az Aranyos vidékét. Kolozsvárott a vasárnapi istentisztelet után a népes érdeklődő közönségnek a kollégium dísztermében rövid előadást tartott Indiáról és az amerikai unitarizmusról. Az indiai misszionáriust társai azzal igyekeztek lebeszélni erdélyi útjáról, hogy „itt félvadak az emberek" és élete sem lesz biztonságban. Dall saját szemével győződött meg arról, hogy „olyan mívelt közönségünk van, mint akár Bostonnak vagy Londonnak" ${ }^{107}$ A magyar unitáriusok kihasználva a kedvező alkalmat, a Főtanács nevében levelet küldtek amerikai hitsorsosaiknak. Ebben nagyon röviden vázolták egyházi és iskolai állapotukat, megemlítették a közelgő zsinattal kapcsolatos előkészületeket, majd a magyar-amerikai unitárius kapcsolatok múltját elevenítették fel Bölöni 1831. évi észak-amerikai, George Sumnernek pedig 1841. évi erdélyi látogatására utalva. Üdvözölték William Ellery Channing (1780-1842) és Theodore Parker (1810-1860) szellemi örököseit, azért, hogy

„az Unitarizmus szabad szelleme oly hatalmasan nyilatkozott a rabszolgák felszabadítása kérdésében, mely mint egy sötét folt ült Észak-ámérikának szabadságtól derült ábrázatán." ${ }^{108}$

Dall még nem ért vissza Amerikába, mikor az AUA titkára, Charles Lowe 1868. július 4-én egy magyar nyelvü levelet küldött Kolozsvárra, amelyben az egyház fennállásának háromszázadik évfordulóján üdvözölték hitrokonaikat, és elismerésüket fejezték ki a magyar unitáriusok évszázados hithűségéért. Mivel nem tudták, hogy mi úton-módon segíthetnének a magyar unitáriusoknak, a következő ajánlatot tették:

„Úgy tetszik nekünk, hogy hasznos szolgálatot tennénk ha a Dr. Channing és más írók munkáit Európa különböző nyelveire lefordítanók. Ennélfogva tisztelettel kérjük, értesítsenek, hogy vajon egy ily vállalat segítené-e a mi célunkat az önök országában és vajon önök közre adhatnák-e ezen munkákat ha elküldenők. A mi szándékunk az, hogy válogatott értekezéseket bocsássunk ki magyar, német és zsidó nyelven, ingyen való szétosztás végett, meglévén győződve, hogy az ily gondolatkicserélés nem lenne haszon nélkül. Önök természetesen sokkal jobban tudják, mint mi hogy vajon ez segítene-e, és ezért az önök ítéletére bízzuk egy ily vállalat célszerüségének eldöntését.".109

\footnotetext{
${ }^{106}$ "That the Rev. C. H. Dall be authorized by the members of the Boston Association of Ministers, to extend their sympathy to the Unitarians of Transylvania; and assure them of our willingness to assist any young men who may desire to study divinity in our schools" MsU 1619/A2. Charles Dall levele Simén Domokosnak.

${ }^{107}$ Emlékkönyv, vol. I., 104-109. Vö. C.H.A. Dall látogatása, KerMagv, 1868, 258-260.

${ }^{108}$ Emlékkönyv, vol. I., 111.

${ }^{109}$ Uo., vol. I., 127-129.
} 
Kolozsvárott kapva kaptak az alkalmon, annál is inkább, hogy Channingtől már korábban a Keresztény Magvető is közölt fordításokat, ${ }^{110}$ és az amerikai unitárius teológusok közül vitathatatlanul a legnépszerübbnek számított magyarországi protestáns körökben is. A fordítások elkezdése előtt Simén „magánlevélben” tájékoztatta az amerikaiakat arról, hogy a német fordítás nem szolgálná a magyar unitarizmus ügyét, héberre pedig teljesen fölösleges lefordítani, hiszen minden zsidó tud magyarul. Simén és az EKT közös lobbija eredményeként az amerikai fél beleegyezett abba, hogy Kolozsvárott Kriza János, Ferencz József és Simén Domokos irányításával elkezdődjenek a fordítások. A cél megvalósítása érdekében 500 dollárt ajánlottak fel, ${ }^{111} \mathrm{~s}$ az erről szóló utalványt 1870. január 28-án elküldték Kolozsvárra. Itt az EKT elhatározta, hogy Channing műveit 10-12 íves kötetekben ki fogják adni. Az első kötetet ingyen küldik meg a Keresztény Magvető előfizetőinek, a többit pedig a könyvkereskedésre bízzák. A fordítóknak nyomtatott ívenként 12 forintot, a korrektornak pedig 5 forintot fizettek. A kiadást felügyelő bizottság a fordításra szánt első kötetet szétosztotta az angolul tudó kollégiumi tanárok között, és ezzel a munka megkezdődött.

Az első kötet 1870-ben jelent meg Kolozsvárott, előszavát Kriza János püspök írta. ${ }^{112} \mathrm{~A}$ kötetben öt Channing-tanulmányt közöltek az amerikai szerző társadalmi tárgyú dolgozatai közül. A fordítók: Simén Domokos, Ferencz József, Benczédi Gergely, Uzoni Gábor és Kovácsi Antal voltak. 1872-ben jelent meg a második kötet, ${ }^{113}$ mely vallásos tárgyú beszédeket tartalmazott, ezt követte a harmadik élet- és jellemrajzok, ${ }^{114}$ a negyedik vallásos tárgyú dolgozatok, ${ }^{115}$ és végül az ötödik vallásos és társadalmi kérdéseket taglaló kötet. ${ }^{116} \mathrm{Az}$ első kötet említett fordítóihoz csatlakoztak: Sándor Mózes, Marosi Gergely, Kriza János, Kovács János. Az első öt kötet 1870-1874 között jelent meg, tehát még Kriza püspök életében. A fordítások közül Ferencz József és Simén Domokos hét-hét, Kovácsi Antal öt,

\footnotetext{
${ }^{110}$ W.E. Channing, Krisztus iránti szeretet (Love to Christ. A Sermon), ford. Buzogány Áron, KerMagv, 1861, 45-60.

${ }^{111}$ MsU 1019/A2. Az Amerikai Unitárius Társulat titkára, Charles Lowe, 1869. november 26ról Siménnek küldött levelében egyebek mellett ezeket írta: „I have just written to Mr. Kriza that, partly because of your letter, we had unlinquished on purpose of sending you tracts in German and having found it inpracticable to print them satisfactory in the Hungarian language here, we are ready to send to your Consistory $\$ 500$ if they are disposed to supply it to translating and printing selections from our publications."

${ }^{112}$ Channing Ellery Vilmos Válogatott müvei. Angolból fordították és kiadják az unitárius tanárok. I. kötet. Társadalmi tárgyuak. Kolozsvárt a Róm. Kath. Lyc. Nyomdájában, 1870.

${ }^{113}$ Ua. II. kötet. Vallásos tárgyu beszédek. Kolozsvárt, K. Papp Miklósnál, 1872.

${ }^{114}$ Ua. III. kötet. Élet- és jellemrajzok. Kolozsvárt, K. Papp Miklósnál, 1872.

${ }^{115}$ Ua. IV. kötet. Vallásos tárgyuak II. Kolozsvárt, K. Papp Miklósnál, 1873.

${ }^{116}$ Ua. V. kötet. Társadalmi és vallásos tárgyuak, Kolozsvárt, K. Papp Miklósnál, 1874.
} 
Benczédi Gergely három, Sándor Mózes és Marosi Gergely kettő-kettő, Kriza János és Uzoni Gábor egy-egy Channing-írást fordított le.

A magyar unitáriusok nem csak a „tractok” fordításán, hanem az amerikai hitrokonok közvéleményének befolyásolásán is fáradoztak. 1868 novemberében az angol levelező bizottság, melynek tagjait az akadémiták és az egyház csúcsvezetése alkotta, az EKT jóváhagyásával az AUA tanácsának hosszabb levelet küldött, melyben a jövő amerikai-magyar kapcsolatainak fö stratégiai vonala kezdett kirajzolódni, ez pedig Budapestre és az itt építendő unitárius templomra mutatott. A fordításokra adandó segélyt igen hálásan köszönték, de azért nem mulasztották el a nagyobb projekt, a budapesti unitárius templom gondolatának elültetését sem. Hogy erre nézve 1868-ban konkrét terve és elképzelése nem volt az EKT-nak, azt a levélből nem nehéz kikövetkeztetni:

„De midőn e tárgyban javaslatunkat az önök megkeresése folytán - elmondottuk - , nem hallgathatunk el más utat és módot is, amelyen kezet fogva, a tiszta keresztény elveknek nem csak tovább fejlesztésére, hanem a már kifejlesztetteknek állandósítása is eszközölhető volna. Nézetünk szerént e célt leginkább az által lehetne megközelíteni, ha mi legalább Pesten, hazánk fơvárosában, most hirtelen egy unitárius templomot építhetnénk, s ezáltal a központban egy, a vallásos eszméknek irányt adó gyülekezetet alakíthatnánk. Egy ily gyülekezetnek alapja meg is van már, amennyiben ott a minisztériumnál több unitárius atyánkfiai vannak alkalmazva, a képviselő házban több unitárius képviselő van, sőt a kultuszminisztériumnál titkári minőségben egy papi egyénünk is van, aki a papi teendőket szívesen teljesítené. Csak templom hiányzik ahová említett papunk összehívhatná híveit, és ahová mások is elmehessenek megismerni vallásunkat, s levetkőzni az eddig ellene táplált vastag elóítéleteket.

Ha tehát e dologra az önök figyelmét felhívnunk szabad; ha önök ajánlata következtében ez ügyben támogatásukra számíthatunk; mi azt hisszük, hogy a cél valósításával oly gyülekezet alapját vetettük meg, amely helyzeténél fogva a legszebb gyümölcsöket fogja megteremni a szabad kereszténység ügyének." 117

A levelező bizottság javára írandó, hogy kiválóan tálalták a fővárosi unitárius jelenlét előnyeit, ugyanis a templomépítési ambíciók vázolása előtt a bécsi, ún. újkatolikusoktól Kriza János püspökhöz küldött levelet ismertették. Ebben az „unitarizmus” örvendetes terjedéséről és a bécsi szuperintendencia szervezésére tett lépésekről számolt be egy volt jezsuita. A német levél másolatát a BFUA tanácsához is elküldték, és a tanács egyik, az újkatolikus kérdésben járatos tagjától, John Fretwelltől azt a tanácsot kapták, óvakodjanak a bécsiektől; így az erdélyi unitáriusok szerencsésen megúszták a hírnevüket bemocskoló, holmi bécsi szodomitával való társulás ódiumát. A bécsi újkatolikusok vezetője C. A. Forstner, Kriza Jánost

${ }^{117}$ Uo., vol. I., 130-134. A levél angol fordítását teljes terjedelmében közölte a bostoni Monthly Journal, 1869. vol. X., March, 78-83. 
ostromolta hivatalos elismertetésükért. A korabeli pesti sajtó írt is a fejleményekről, az unitarizmus diadalaként harangozták be az eseményeket, szerencsére Kolozsvárról hivatalosan nem vették fel a kapcsolatot a bécsiekkel. Forstnert szodómiáért a hatvanas évek végén, a hetvenes évek elején bezárták, és az ügy ezzel lezárult.

A BFUA-nak küldött levelekben a budapesti templomépítés kérdését jóval óvatosabban közelítették meg, és nyoma sincs az amerikaiakhoz küldött „hirtelenkedéseknek”. A fóvárosban szétszórtan élő unitáriusok gyülekezetté való kovácsolására és pásztorolására fókuszáltak elsősorban, a templomépítéssel pedig csak később hozakodtak elő. Dall 1869-ben Indiába menet újból meglátogatta kolozsvári magyar barátait, néhány napot töltött itt, majd Előpatakra ment, hogy Simén Domokossal találkozzon. Az ő társaságában látogatott el Árkosra, majd Brassón keresztül utazott Calcutta felé.

\subsection{J. J. Tayler erdélyi látogatása}

A Manchester New College principálisa volt tanítványai, Simén Domokos és Benczédi Gergely meghívására 1868-ban vállalkozott a fáradságos európai útra. A BFUA értesülvén Tayler szándékáról, felkérte, legyen a társulat képviselője is a magyar unitárius egyház fennállásának háromszázadik évfordulóját ünneplő zsinaton. A hetvenes éveiben járó profeszszor lánya, Hanna kíséretében 1868. augusztus 26-án érkezett Kolozsvárra. Elődeikhez hasonlóan Váradról postakocsival jöttek Kolozsvárra, hiszen a vasutat még nem építették ki. Innen Aranyosgyéresre mentek, és Paget vendégeiként naponta bekocsiztak Tordára a zsinat munkálataira. A magyar vendégszeretet Paget birtokán az angol szokásrendnek megfelelően alakult, a vendégek azonban Kelemen Benő (1792-1883) meghívására, ennek szucsági birtokán végignézhették azt is, „hogyan mulat a magyar." Wesselényi egykori gazdatisztjének névnapján mintegy hetven vendég vett részt. Az úri muri után az angol vendégeket Simén Domokos és Ürmösi József Budapestig kísérte. Tayler útjáról írt jelentése a Theological Reviewwben és különlenyomatban is megjelent. ${ }^{118}$ Ezt Fabiny részletesen ismertette, és Frank Tibor is számontartotta monográfiájában, ezért nem bocsátkozunk ismétlésekbe. ${ }^{119}$ Érdekes ugyanakkor, hogy a később megjelent román nyelvű összefoglalókban teljességgel mellőzték mind Tayler, mind unitárius társai beszámolóit, egyedül Paget könyvét elemezték az

\footnotetext{
${ }^{118}$ John James TAYLER, Narrative of a Visit to the Unitarian Churches of Transylvania on the Occasion of the Three-Hundredth Anniversary of the First Proclamation of Religious Freedom at Torda in 1568, London 1869. A Theological Reviewben January, 1869, 1-48.

${ }^{119}$ Lásd 22. jegyzetet. Frank Tibor, The British Image of Hungary 1865-1870, Budapest, 1976, $159-160$.
} 
unitárius szerzők közül. ${ }^{120}$ Benczédi Gergely Tayler csinos kis művéről az Emlékkönyoben a következőket írta:

„Aligha csalódom ha azt állítom, hogy a magyar unitáriusokról ily érdekes és terjedelmes értesítést még senki sem közölt. Ügyünknek bizonyosan sokat használ s méltó hogy a derék szerzőről mindig tisztelettel és hálával emlékezzünk meg." ${ }^{\prime 21}$

Tayler tiszteletére 1868 októberében a londoni Hannover-Square Rooms-ban ünnepélyes fogadást rendeztek, mely a korabeli beszámoló szerint a legnagyobb unitárius rendezvények egyike volt. ${ }^{122}$ A látogatás egyik eredményeként, egyébként Taylernek már évekkel korábban megfogalmazott óhajával összhangban, Kolozsvárott elhatározták, hogy a Kénosi-Uzoni-féle egyháztörténet fontosabb részeiről másolatot készítenek, és elküldik hitrokonaiknak. ${ }^{123} \mathrm{Az}$ angliai könyvtárakban nem találtunk egyetlen másolatot sem a Kénosi-Uzoni-féle egyháztörténetből. Valószínúnek tartjuk, hogy Tayler 1869-ben bekövetkezett halálával az unitárius egyháztörténet iránti érdeklődés ellankadt.

${ }^{120}$ Lásd Carmen Andraş, România şi imaginile ei în literatura de călătorie britanică, Dacia, 2003.

${ }^{121}$ Emlékkönyv, vol. I., 122.

${ }^{122}$ Report of the BFUA, London, 1869, 11-12.

${ }^{123}$ "In conclusion, we have the pleasure of informing you that in consequence of the desire expressed by Professor Tayler, we began to copy the more interesting parts of the chronicle of Foszto' Uzoni, which never was published, and in which the history of the Unitarians of this country is recorded. We shall send it to the British and Foreign Unitarian Association when it will be ready. It may be used in writing the history of Unitarianism." Uo., 41. Vö. Emlékkönyv, vol. I., 123-125. 



\section{AZ ANGOL-AMERIKAI-MAGYAR KAPCSOLATOK ALAKULÁSÁNAK TÖRTÉNETE 1870-TŐL 1905-IG}

A kapcsolatok alakulását a 1870-es években jelentős fellendülés jellemezte. Ebben nagy szerepe volt Kovács János angol akadémitának és John Fretwell angol, majd amerikai kereskedelmi ügynöknek. Kovács életrajza, a kolozsvári közéletben betöltött szerepe, valamint amerikai egyházdiplomáciai küldetésének ismertetése részben összefonódott John Fretwellnek a magyar unitarizmusért kifejtett munkásságával, ezért először az angol kereskedőt kell bemutatnunk.

\subsection{John Fretwell és Jókai Mór}

John Fretwell 1837. június 11-én született Leedsben. ${ }^{1}$ Tanulmányairól közelebbit nem tudunk, édesanyja tanította meg írni és olvasni, majd egy "szegény unitárius prédikátor" volt a tanítója. Tizenhárom éves korában a yorki kollégiumba ment, ahol két évet töltött. Apja 15 évesen Londonba vitte, itt kereskedősegéd lett, és többé nem tért vissza a College-ba. Önéletírása szerint:

„„...ettől kezdve önfenntartó voltam, azonban a tudásvágy arra ösztönzött, hogy szabad időmet a tanulásnak szenteljem: régi és modern nyelvek, matematika, természettudományok, és különösen a közgazdaságtan és történelem kitöltötte szabad időmet." ${ }^{2}$

\footnotetext{
${ }^{1}$ Kovács Sándor, Adalék Jókai Egy az Isten címú regényének geneziséhez = Irodalomtörténeti Közlemények, 112(2008), 435-446. Uö., Egy elfelejtett angol unitárius, John Fretwell, és a magyar literatúra = Isten és ember szolgálatában. Erdő János emlékezete (szerk. Szabó Árpád), Kolozsvár, 2007, 231-249.

${ }^{2}$ A német nyelvű kéziratos életrajz Jakab Elek hagyatékával került a keresztúri gimnázium könyvtárába, majd innen a Marosvásárhelyi Teleki Tékába. Könyvtári jelzete: Mss 0563. A fordításért Hoffmann Gizellának mondok köszönetet. Az életrajz alapján készült a Vasárnapi Újság - 1875. július 25., 30. szám, 465 - Fretwellt bemutató írása.
} 
Az ötvenes években a Kossuth-emigráció több tagjával is találkozott, köztük a magyar forradalom iránti rokonszenvéröl ismert William Francis Newman $^{3}$ (1805-1897) klasszika-filológus, erkölcsfilozófussal is, akinek hatására egyre többet foglalkozott a magyarság és az unitarizmus ügyével. Magyarul állítólag egy Lóránt ${ }^{4}$ nevű menekülttől tanult meg annyira, hogy Vörösmartyt, Petőfit, Eötvöst és Jókait olvashatta. Carl Schurz (1829-1906) londoni házában ismerkedett meg jövendőbeli feleségével, Schurz unokahúgával, Bertha Traunnal, akit 1859-ben feleségül vett. Fretwell kapcsolatait és ismeretségi körét részben ennek a házasságnak köszönheti. Feleségének anyja, Bertha Ronge (1818-1863), korának ismert és sokat vitatott személyisége a német iparmágnás, Heinrich Christian Meyer (1797-1848) lánya volt. Apja tanácsára a nála 14 évvel idősebb Christian Justus Friedrich Traun (1804-1881) felesége lett, házasságukból hat gyermek született. Az 1840-es évek közepén Németországban a katolicizmus Johannes Ronge, az új Luther nevéhez kapcsolódó „,botrány” révén kisebb válságon esett át. ${ }^{6}$ Rongét 1844-ben a katolikus egyház kiközösítette a Krisztus-lepel miatt kirobbantott botrányért. A volt pap Hamburgba ment, Heinrich Meyernek lett protezsáltja, itt alapította meg az ún. Német Katolikusok Egyházát, melynek mintegy 50 hívet toborzott Hamburgban, köztük Bertha Traunt is, aki hamarosan kulcsfontosságú szerepet töltött be a mozgalomban. A nők egyenjogúságáért és taníttatásáért, az igaz szerelmen alapuló szabad házastárs-választásért emelték fel hangjukat. Bertha érdeme, hogy sikerült meggyőzni Friedrich Froebelt (1782-1852), az első kisdedóvó alapítóját arról, hogy 1849-1850-ben Hamburgban egy hathónapos tanfolyamot tartson a tárgyról. Bertha elvált férjétől, 1850-ben Johannes Ronge felesége lett. Jövendő férjének radikális politikai nézeteiért el kellett hagyják Németor-

\footnotetext{
${ }^{3}$ John Henry Newman (1801-1890) öccse. John Henry volt az ún. Oxford-mozgalom egyik szellemi atyja.

${ }^{4}$ Lóránt János tüzérkapitányról lehet szó, aki Benczédi Gergelynek is személyes ismerőse volt.

${ }^{5}$ Carl Schurz (1829-1906) hírlapíró, államférfi, németamerikai emigráns. 1848-ban részt vett a német forradalmi megmozdulásokban, ezért emigrálni kényszerült. Londonban telepedett meg, 1852-ben pedig kivándorolt az Amerikai Egyesült Államokba. Meggyőződéses republikánus és abolicionista volt.

${ }^{6}$ Ronge 1844-ben az Arnoldi püspök által Trierben közszemlére állított Krisztus-lepel tisztelete tárgyában röpiratot tett közzé, melyben a katolikus egyházat, papságát és a pápát sértegette. Sikerén felbuzdulva Boroszlóban egyházközséget alapított, és egy új hitvallást szerkesztett. Mozgalma az ún. lipcsei zsinat (1845) után a protestánsok rokonszenvének köszönhetően kiszélesedett. A forradalmi mozgalomban való részvétele miatt emigrált, több évet töltött Budapesten, nevéhez füződik a Froebel-nőegylet alapítása. Életrajzát veje, John Fretwell írta meg: Johannes Ronge and the English Protestants, Unitarian Review, 1888, 19-32. A kérdésről bővebben lásd: Wayne Detzler, Protest and Schism in Nineteenth-Century German Catholicism: The Ronge-Czerski Movement 1844-45 = Schism Heresy and Religious Protest (Studies in Church History vol. 9.) ed. By Derek BAKer, Cambridge University Press, 1972, 341-350.
} 
szágot, és Londonban telepedtek le. Itt az unitárius körökben jól fogadták őket, azonban Berthának válása és új házassága miatt elég sok előítélettel kellett megküzdenie. Hampsteadi otthonukban nyitották meg az első angol kisdedóvót. Bertha a Froebeltől tanult módszert saját anyagával, kifestős könyvekkel stb. egészítette ki. Bertha 1860-ban visszatért Németországba, az óvodát lánya, Bertha Fretwell vezetésére bízta.

John Fretwell 1865-ben Németországból hazatelepedett, és ettól kezdve tevékeny szerepet vállalt az unitárius egyházban. 1868-ban a BFUA tanácsának tagjai közé választották és a külügyi osztály irányításával bízták meg, így került kapcsolatba a magyar unitarizmussal és Jókai Mórral is.

Vizsgáljuk meg először Jókaihoz fűződő kapcsolatát, a kiegyezést követő évtizedek unitárius vezetőivel és Jókaival folytatott levelezése, és az ezzel kapcsolatos újságcikkek alapján.

A Fốvárosi Lapok 1875. november 3-án arról ad hírt, hogy "Jókai Mór, még be sem fejezte $A z$ élet komédiásai című legújabb regényét, s máris egy újat tervez, melyet a jövő évben fog kiadni. Címe lesz: Egy az Isten! ebben az unitáriusok első vallási küzdelmeit fogja festeni". ${ }^{7}$ November 7 -én ${ }^{8}$ a Hon már határozottan leszögezi, hogy a regény a torockói unitáriusokról fog szólni, és „egyszerre fog megjelenni magyar, német, francia, angol, olasz, holland, dán, román és orosz nyelven". A regényt 1876. október 1-jével kezdődően 1877. május 27-ig 121. folytatásban közölte a Hon, és vele párhuzamosan német fordításrészletek is megjelentek egy bécsi lapban. ${ }^{9}$ Az Egy az Isten francia, holland, dán, román és orosz fordítása soha nem készült el ${ }^{10}$ és talán a szerző sem gondolta komolyan, hogy születendő regényét egész Európa olvasni fogja. Ám ha Jókaiban volt is némi józanság unitárius tárgyú regénye kelendőségét illetően, azt hamar szent mámorrá változtatta John Fretwell, az unitárius misszió elkötelezett angol bajnoka.

Fretwellnek mindössze két Jókaihoz intézett levelét ismerjük. Az 1873. december 6-án írt német nyelvű levelében ${ }^{11}$ első magyarországi látogatását idézte fel, majd udvarias bókok után engedélyt kért Jókaitól a Szegény gazdagok fordítására és kiadására. A levél tartalmát Jókai külföldön címen ismertette a Hon:

\footnotetext{
${ }^{7}$ Fốvárosi hírek, 1875, 251. sz., 1119.

${ }^{8}$ Irodalom, 1875, 255. sz., 3.

${ }^{9}$ JóKaI Mór, Egy az Isten (1876-77), szerk. Lengyel Dénes és Nagy Miklós, sajtó alá rendezte Szekeres László, Akadémiai kiadó, Budapest, 1970 (Jókai összes művei, regények 69.), 271-277.

${ }^{10}$ 1878-ban német nyelvre Otto JANKE, 1880-ban lengyelre Josef Kaufmann, 1884-ben csehre, 1888-ban Elisa Pucher olaszra, 1901-ben Percy Favor Bicknell angolra, 1901-ben John FrETwELl angolra, 1909-ben észt nyelvre fordították. Vö. JóKaI Mór, i. m., 277-279.;

${ }^{11}$ Jókai levelezése 1876-1885. Összegyüjtötte és sajtó alá rendezte GYöRfFY Miklós, Akadémiai kiadó, Budapest, 1992, 488., 909-910.
} 
„Fretwell John New Yorkból levelet intézett Jókaihoz, melyben a Szegény gazdagok címü regényének fordíthatási jogát, Jókai arcképét s életrajzát kéri, s egyúttal egy amerikai lapot mellékel, melyben Jókai említett regényét ismerteti." ${ }^{12}$

Ugyanezt ismételte meg a Fövárosi Lapok (1874. január 9.) és a Vasárnapi Újság (1874. január 11. 27 p.) is. A közelebbről meg nem nevezett amerikai lapnak egyelőre nem akadtunk nyomára, és nem sikerült felkutatnunk az 1874-ben New Yorkban megjelent Szegény gazdagok fordítását sem. Kádár Judit Jókai regényei angolul címú tanulmányában ${ }^{13}$ - a korábbi szakirodalommal egybehangzóan ${ }^{14}$ - azt állítja, hogy a Szegény gazdagok 1874-ben megjelent angolul, és megjegyzi, hogy az eredetit pontosan visszaadó fordítás nem aratott sikert. Bár a bibliográfiák Fretwell fordítását számon tartják, sem az OSZK-ban található Jókai-hagyaték, sem az angol és amerikai nemzeti könyvtárak on-line és nyomtatott katalógusaiban nem szerepel a mü, így egyértelmüen nem sikerült kiderítenünk, hogy létezik-e a Fretwell-féle fordítás. Kutatásaink jelen stádiumában valószínünek tartjuk, hogy Fretwell nem készült el a Szegény gazdagok teljes fordításával, s Jókai bibliográfusait a sajtó vezette félre. Átkutattuk a korabeli magyar, angol és amerikai unitárius sajtót, ${ }^{15}$ valamint az EUEGyLt-nak angol és amerikai korrespondenciáját, és az újságcikkek, illetve a levelek fényében nemcsak Jókai angol recepciója, a Szegény gazdagok 1874-es feltételezett kiadása, de az Egy az Isten keletkezéstörténete is új megvilágításba kerül.

1877 áprilisában Ferencz József frissen választott unitárius püspöknek New Yorkból John Fretwell a következő nyomtatott nyolcadrét címlapot küldte: EGY AZ ISTEN; / or, / The People Who Love But Once. / Translated from the Magyar of MAURUS JOKAI / by / JOHN FRETWELL, Jr., and W. N. LOEW. / WITH AN INTRODUCTORY ESSAY BY JOHN FRETWELL, JR., / ON MAURUS JOKAI AND FORTY YEARS OF / HUNGARIAN LITERATURE. / AUTHOR'S EDITION / 1877. Az angol Jókai-recepció történetében a Nincsen ördög mellett ez lenne a második olyan regény, amelyet kiadása évében angolra fordítottak. ${ }^{16}$ A korabeli magyar sajtó

\footnotetext{
${ }^{12} 1874$. január 6. 4. sz.

${ }^{13}$ Irodalomtörténeti közlemények, 1991, 505-542.

${ }^{14}$ Vö. Zoltán Ferenczi, List of the translations of Jókai's works into foreign languages, Bibliofil Könyvtár, 1926., 1. sz., Demeter Tibor, Bibliographia Hungarica, Bp., 1957-58. http://demeter. oszk.hu

${ }^{15}$ A következő periodikákat használtuk: Budapesti Szemle, Egyetértés és Magyar Újság, Egyházi Szemle, Erdélyi Protestáns Közlöny, Erdélyi Gazda, Fövárosi Lapok, Hölgyfutár, Kelet, Keresztény Magvető, Magyar Polgár, Magyar Nemzet, Protestáns Egyházi és Iskolai Lap, A Hon, Vasárnapi Újság, The Inquirer, The Christian Register, The Christian Life, Old and New.

${ }^{16}$ CZIGÁnY, A magyar irodalom...201-272., KÁDÁr, i. m., 505-542; SzILAsI László, A selyemgubó és a "bonczoló kés", Osiris - Pompej, 2000., 213-217 (a továbbiakban SzILAsi), Francis MagYar, Jokai's Reception in England and America, American Slavic and East European Review, Vol. 17, no. 3. (oct., 1958), 332-345.
} 
nagy érdeklődéssel követte Jókai külföldi népszerűségét, és időközönként - nyilvánvalóan unitárius közvetítéssel - szemlézte a New Yorkban és Londonban megjelenő periodikákat. ${ }^{17} 1877$ márciusában a The Christian Life $e^{18}$ hosszabb szemelvényt közölt Jókai Egy az Istenének angol fordításából..$^{19}$ (A regényrészlet eredetileg a The Christian Registerben jelent meg, ${ }^{20}$ a londoniak is innen vették át.) A fordítás alapjául szolgáló részlet a Hon hasábjain volt olvasható - 1876. október 15. -, és az első könyv ötödik fejezetének „De hát hol van az a világrész...” kezdőmondatától a „Hold megvilágította a vidéket..." bekezdésig tart.

Fretwell a püspökhöz küldött címlap verzójára írt levelében Jókai Angliába csábításáról, s az angol és amerikai unitáriusoknak a nagy magyar író tollán megelevenedő regényes életrajzáról ábrándozott. ${ }^{21}$ Mint tudjuk, Jókai egyetlen unitárius tárgyú regényt írt, az Egy az Istent. Az angol és

17 „Jókainak „Egy az Isten” című regényét Amerikában angol nyelvre fordítják Fretwell János és Loew Vilmos, az „Ellenőr” New Yorki levelezője.” Vasárnapi Újság, 1877. március 4. 9. sz. 140.; Magyar Polgár, 1877. március 4. 52. sz. Fretwell valószínúleg a New York-i magyar klubban került kapcsolatba Löw Vilmos (1847-1922) ügyvéddel, müfordítóval. A Kolozsvárt megjelenő Hölgyfutár 1877. február 1-jei számában Magyar népszínmü-elöadás New Yorkban címen rövid beszámolót közölt Abonyi Lajos $A$ betyár kendője tengerentúli bemutatójáról. A Honból átvett tudósításban a többi között azt olvassuk, hogy az előadás után Löw Vilmos köszöntötte a „magyar nemzetet.“ Utána Fretwell „hosszantartó beszédével üdvözölte Jókai Mór koszorús költőnket, s angol nyelven mondott szónoklatát e magyar nyelven mondott szavakkal fejezte be: angol a nyelvem, magyar a szívem. Hogy a tervbe vett közös fordítás miért nem valósulhatott meg, nem tudjuk. Löw Vilmos magyar unitárius vonatkozású írásait alkalomszerüen közölte az amerikai felekezeti sajtó. Vö. John Kriza, the poet of the Magyars and Bishop of the Transylvanian Unitarians, Unitarian Review, 1883, vol. XIX, 165. Müfordításait rendszeresen elemezte a Budapesti Szemle, Vö. Gems from Petöfi and other Hungarian poets (translated) with a memoir of the former and a review of Hungary's political literature, 1882, 30 vol., 478-443.; Magyar Songs. Selections from modern Hungarian poets, 1888, 54 vol., 134-141.

${ }^{18}$ A The Christian Life címú hetilapot Robert Spears lelkész alapította. A konzervatív unitarizmus szócsövének számító lap 1876-tól 1929-ig jelent meg. Spears 1899-ben bekövetkezett halála után Samuel Charlesworth szerkesztette 1910-ig, ezt követően R.W. Kittle majd D. Delta Evans szerkesztette.

19 "A Unitarian Village in Transylvania", The Christian Life, Vol. II., No. 45., London, Saturday, March 24, 1877. 146.

${ }^{20}$ Vö. Magyar Polgár, 1877. március 22. 67. sz. A ChRB néhány száma megvan Kolozsvárt az Akadémiai Könyvtárban, de az 1877-es év felettébb foghíjas, sajnos Oxfordban és Manchesterben is hiányzik az unitárius periodikák közül.

${ }^{21}$ "And above all I wish Jókai Mór could once be persuaded to visit our meetings not of course as a sympathiser of our religious ideas but as a student of our institutions. I should be very glad if after completing "Egy az Isten" he could be persuaded to write a second novel illustrative of Unitarian life in England and America. And I shall be very glad to supply him much of the material. How good it would be if the greatest of your writer would write a novel founded on the lives of our great Unitarian heroes Sir John Bowring, Priestley, Channing, Martineau, Dall, Lindsey, Governor Andrew, W. J. Fox, Miss Nightingale, and their connection with Kossuth and other champions of Hungarian freedom." Fretwell Ferencz Józsefnek, New-York 1877. április 3. A levél az Egy az Isten angol ford. címlapjának hátára íródott. Lelőhely: EUEGYL, Amerikai levelezés 1876-1924. 
amerikai unitáriusok regényes életrajza tollán nem elevenedett meg, s a magyar unitáriusokról írott müve angol fordítására is negyedszázadot kellett még várni. Az 1901-ben közzétett The Christian in Hungarian Romance (a továbbiakban The Christian...) nem fordítás, hanem adaptáció, Fretwell szerény próbálkozása Jókai unitárius tárgyú regényének angol és amerikai ízlés szerint való tálalására. Ez a tanulmány messze elmaradt az 1877-ben készült fordítás-részlet mögött. Az Egy az Isten néhány részletének első angol tolmácsa Fretwell volt ugyan, de a "teljes” fordítás Percy Favor Bicknell nevéhez füződik, aki Fretwell tanulmányával egy időben Mannasseh. A romance of Transylvania címen jelentette meg fordítását. ${ }^{22}$ Ezt előkészítendő, Bicknell az erdélyi unitáriusok életét és irodalmát bemutató kiadványokat kért Ferencz József püspöktől. ${ }^{23} 1901$ áprilisában Fretwell még abban a tudatban adta ki adaptációját/tanulmányát, hogy az Egy az Isten nem jelent meg az Amerikai Egyesült Államokban. A 124 oldalas nyolcadrét tanulmányt természetesen Jókainak ajánlotta. Az előszóban a „magyar románc" négy hercegét, Keményt, Eötvöst, Jósikát és Jókait méltatta. Kemény Zsigmond pesszimisztikus hangulatú regényeiben a kálvinista fejedelem szombatosok elleni gyűlölete elevenedik meg. Jósika Miklós Erdély történetét mutatta be olvasóinak a Báthory- és Rákóczi családok uralkodása alatt. Fretwell szerint Jókai az egyetlen olyan magyar író, aki a Jézus őszinte követését életcéljául választó „,embert” regényhőssé emeli, s mint ilyen, rokon Lynn Linton, Humphrey Ward és Hall Caine hasonló érzésvi-

${ }^{22}$ Percy Favor Bicknell, Mannasseh. A Romance of Transylvania. Retold from the Hungarian..., Boston. L.C. Page \& Company, 1901. Ugyanebben az évben a londoni J. Macqueen is kiadta, utolsó kiadását a londoni Walter Scott Publishing Co.: London \& Felling-on-Tyne eszközölte 1910-ben.

23 ,Tisztelt Uram! Legyen szabad egy kérést intéznem önhöz, mégpedig egy kissé hibás német nyelven, mivel az én magyar nyelvismeretem még csak olvasásra elég.

Hiába igyekeztem magamnak a magyarországi unitárius irodalomról egy kis tájékozást szerezni és tiszteletes Van Ness úr, aki a múlt nyáron Kolozsvárt volt és önt ismeri, azt tanácsolta, hogy Önhöz folyamodjam.

Bátorságot veszek ennélfogva Önt kérni, legyen szíves néhány újonnan megjelent, magyar unitáriusoktól írt könyvnek a címét velem közölni, főleg olyanokat, amelyek az amerikai olvasóközönséget érdekelhetik. Talán egy nyomtatott lajstromot is küldhet. Azt is szeretném tudni, minő unitárius folyóiratok jelennek meg Magyarországon. Célom ezen kérésben kettős: Óhajtom a magyar unitárius irodalmat megismerni egyfelől, másfelől talán egy néhányat angolra lefordítva kiadni.

Nagyon lekötelezve fogom érezni magamat, ha ezen kéréseimben segítségemre lesz. Legyen szíves magyarul válaszolni. A mai postával két lajstromot küldök önnek jobbára az Amerikai Unitárius Társulat által kiadott unitárius könyvekröl. Ezek talán érdekelni fogják Önt. Ha bármiben viszontszolgálatot tehetek, parancsoljon velem. Kiváló tisztelettel, Percy F. Bicknell stb." Bicknell - Ferencz Józsefnek 1900. április 5. Malden, Mass. Emlékkönyv, vol IV., 25-26. Az egyházfö levélben köszönte meg az amerikainak a magyar nyelv iránti érdeklődését, majd udvarias szabadkozások közepette kéziratos jegyzéket küldött az erdélyi unitárius kiadványokról. 
lágú hőseivel. ${ }^{24}$ Ezt követően a magyar és angol unitarizmus történetét és kapcsolatait vázolta. A regény keletkezéstörténetére utalva megismételte a tizenöt évvel korábban mondottakat: ${ }^{25}$ Jókai az ő közvetlen hatására kezdett unitárius regénye megírásához.

\subsection{Fretwell Magyarországon és Erdélyben}

1873 májusában a bécsi világkiállításon ügynökösködő Fretwell levelet írt két régi kolozsvári unitárius ismerősének, Brassai Sámuelnek és Kovács Jánosnak. (Brassaival 1871-ben Londonban a BFUA évi közgyülésén ismerkedett meg, Kovács Jánost londoni akadémitaként ismerte meg. ${ }^{26}$ ) Mivel levelére Brassai nem válaszolt, Kovácsot kérte, közöljék, mikor látogathatna Kolozsvárra. ${ }^{27}$ Kriza János püspök és az EKT megbízásából Kovács János pünkösd ünnepére Kolozsvárra invitálta a jeles angol vendéget, akinek háromnapos látogatásáról beszámolt a korabeli felekezeti és világi sajtó. ${ }^{28} \mathrm{~A}$ minden iránt érdeklődő angol kereskedő meglátogatta a város nevezetességeit: az egyetemet, a múzeumot, a fellegvárat, sétateret, az unitárius templomot, iskolát stb., részt vett a pünkösdi istentiszteleten, majd ezt követően az EKT gyưlésén, ahol tiszteletbeli taggá választatott. A tagságot igazoló latin nyelvű okiratot Kriza János püspök ünnepélyes köszöntő kíséretében adta át „,a szabadság klasszikus hazájából” érkezett vendégnek, akit Winfriedhez, azaz Szent Bonifáchoz hasonlított beszédében, az angol unitáriusokat pedig Bonifaciusoknak nevezte: „Bonifaciusok - jóltevők ránk nézve, azt hálásan érzi vallásközönségünk már csaknem félszázad

${ }^{24}$,Those who have been so fortunate as to read the works of the four great princes in the realm of Hungarian romance, Kemény, Jósika, Eötvös and Jókai, will appreciate the picturesque effect (...) Jókai is the only one who ... has made a man who honestly tries to imitate Jesus the hero of a Hungarian romance, - as Mrs. Lynn Linton, Mrs. Humphrey Ward, Hall Caine, and others have made their characters to do in other countries and under other conditions." The Christian..., 8-9.

${ }^{25}, \ldots$...in 1874(sic!) I was the guest of Maurice Jókai, at his vineyard in Balatonfüred. He was complaining of the want of heroism in our age, and I who had just been preparing a series of lectures on American heroism, drew his attention both to this and the scope which the story of the Unitarian Churches in Transylvania offered for poetic treatment. Soon after this he published his "One is the Lord" in the newspaper of which he was the editor..." John Fretwell, Maurice Jokai, The Inquirer, March 27, 1886. Vö. Fretwell János felolvasása Jókairól, KerMagv, 1886, 53-54.

${ }^{26}$ BrASSAI soha nem készült el londoni küldetésének beszámolójával. Kovács János 1903. március 24-én az Angol társalgó körben Brassai Sámuel 1871. évi angol útja előadásában anekdotaszerű részleteket közöl az „utolsó polihisztor” angliai látogatásáról. (EUEGyLt, Kovács János hagyatéka 1. doboz 5 sz., kézirat.)

${ }^{27}$ Emlékkönyv, vol. II., 31-32.

${ }^{28}$ Ferencz József, Fretwell J. úr látogatása, KerMagv, 1873, 189-197. Lásd még: Ifjabb John Fretwell úr Kolozsvárott, Magyar Polgár, 1873. június 8. 130. sz. 
óta...". Fretwell válaszában röviden ismertette az angol és amerikai unitarizmus történetét és helyzetét, majd megígérte, hogy minden lehetőt megtesz az erdélyi unitárius intézmények érdekében.

„Valamint eddig is szívem vágya volt, úgy ezután is az leend életem feladatává tévén sorsotok enyhítését, közintézeteiteknek tettleges segéllyel való támogatását. Erre nézve angol és amerikai hitsorsosaink buzgó és áldozatos érdekeltségeit éleszteni s felhívni legközelebbi lépéseim tárgya leend." ${ }^{29}$

Az ígéret nem maradt pusztába kiáltott szó, a kolozsvári látogatást júniusban Budapesten amerikai-angol-magyar értekezlet követte. A kezdeményező ezúttal is Fretwell volt, aki a világkiállításon résztvevő amerikai unitáriusokat először a kolozsvári unitáriusok látogatására, ${ }^{30}$ majd az idő szorításának engedelmeskedve a budapesti találkozásra kapacitálta. ${ }^{31} \mathrm{Te}-$ kintettel arra, hogy I. Ferenc József osztrák császár az amerikai pavilont

\footnotetext{
${ }^{29}$ Ferencz, uo.

${ }^{30}$ Fretwell Kovács Jánosnak, 1873. május 8, Bécs, Emlékkönyv, vol. II., 34.

„Kedves Kovács Úr! Tiszt. Hale E. Eduard úr a bostoni unitárius egyház jeles szónoka és az Old and New kiadója, továbbá Kidder unitárius bankár ma ideérkeztek. Én azonnal, igyekeztem őket rábeszélni, hogy látogassák meg Kolozsvárt, de mivel csak 10 napot töltenek itten nem tehetik. Azonban Budapestre örömmel lemennének a jövő vasárnap. Azért szeretném, hogy minél több befolyásos unitárius emberrel találkozzanak, kiktől megtudva a szükségleteiket s óhajtásaikat, majd midőn Amerikába visszatérnek kelthessnek élénk érdekeltséget önök irányába. Mi szombaton reggel fogunk elindulni a gőzössel s estve 7-kor ott leszünk, s így vasárnap egy értekezletet tarthatunk hitrokonainkkal. Azt óhajtanám megtudni s nekik megmondani, hogy mennyi pénz kellene egy Budapesten építendő templomra; továbbá, hogy mi a kolozsvári unitáriusok legfőbb óhajok ügyeik előmozdítására nézve; mennyi kellene új tanári állomások alapítására évenként stb. Egyáltalában a legégetőbb szükségeikről akarunk tudomást szerezni, hogy aztán segíthessünk. Ha nem is vihetnők ki mindazt, mit kívánunk, de Hale úr nagy befolyásánál fogva tehet valamit az önök érdekében. Kérem írja meg Budapestre, hogy minél számosabban gyűljenek össze. Mindenekfelett arról akarom meggyőzni az amerikaiakat, kiknek több pénzük van, mint nekünk Angliában, hogy pénzüket itten üdvös célra adnák. Remélem, hogy önt is látni fogom Budapesten. Előre telegrafirozni fogok önnek s Buzogány úrnak is. Sok köszönet a könyvek küldéséért. Isten áldja meg önt s egyházukat."

${ }^{31}$ Hajós János és Buzogány Áron, Az amerikai, angol és magyar unitáriusok találkozása Budapesten, június 14, 15, 16-án 1873., KerMagv, 1873, 262-280. Lásd még: Unitáriusok gyúlése, Protestáns Egyházi és Iskolai Lap, 1873, 15. évf., 792-793. Különfélék, Erdélyi Protestáns Közlöny. Egyházi és iskolai hetilap, 1873. június 19. 25. sz., 200. Az unitárius gyülésről, Uo., 1873. június 26., 207-208. Unitárius tanácskozás, Kelet, 1873. június 17. kedd, 549. Uo. június 19. csütörtök, 557. Mr. John Fretwell Bp.-re jön tanácskozni, A Hon, 1873. június 15. 135. sz., 587. Az unitárius gyúlés, Fővárosi Lapok, 1873. június 18., 138. sz., 601. The First Unitarian Conference at BudaPesth, The Inquirer July 12, 1873, 454.

Az amerikaiak tudósítója Edward E. HALE volt, az Amerikai Unitárius Társulat elnökéhez R. R. Shippenhez küldött részletes beszámolóját közölte a ChRB, July 12, 1873, (72 vol.) Rev. E. E. Hale in Hungary címen. A post scriptumban a magyarokról alkotott balvélemények eloszlatására egyebek mellett ezeket írja: „Let me beg you to dismiss from your mind any notions, borrowed from picturesque travels, by which you may suppose our Transylvanian friends to be a nation of Sylvans in costume, of shepherds, of hunters, or other frontiersmen simply. The gentleman I have met are as accomplished gentleman as are in the world."
} 
éppen a konferencia napján látogatta meg, az eredetileg 24 tagúra tervezett angol-amerikai delegációból mindössze hárman utaztak Budapestre, Edward Everett Hale, ${ }^{32}$ bostoni lelkész, az Old and New címú lap kiadója, Emma Southwick ${ }^{33}$ írónő és John Fretwell. A találkozón a fóvárosi unitáriusokat elég népes küldöttség, a kolozsváriakat Kovács János és Simén Domokos képviselte. Fretwell akkurátus pontossággal mindent idejében lelevelezett a budapesti unitáriusok vezetôivel, Buzogány Áronnal és Hajós Jánossal, ${ }^{34}$ és a találkozás az általa megírt forgatókönyv szerint zajlott. A vendéglátók meglepetésére és nagy-nagy megelégedésére Fretwell magyarul köszöntötte az egybegyülteket, s az egyházi és világi lapok nem győzték magasztalni „,a londoni előkelő kereskedőt és buzgó egyháztagot, ki tisztán az unitarizmus kedvéért magyarul is megtanult". Az „unitarizmus kedvéért" magyarul is "megtanuló" Fretwell semmit sem bízott a véletlenre, felszólalása angol szövegét két héttel korábban fordításra küldte Kovács Jánosnak.

A budapesti értekezlet után egy évvel Boston egyik templomában (South Congregational Church) Edward Hale elnöklete alatt, az erdélyi unitárius oktatás javára gyülést tartott az Amerikai Unitárius Társulat. ${ }^{35}$ A felszólalók - Fretwell, Edward Hale és Robert S. Morison ${ }^{36}$ - jól kimunkált beszédeikben a magyar unitárius oktatásügy támogatásáért lobbiztak. Az eredményről az utólag tiszteletbeli erdélyi konzisztorrá választott Hale értesítette Kriza János püspököt. ${ }^{37}$ A Kolozsvárott létesítendő két új tanári állás fenntarthatóságának anyagi alapjait pár hónappal később Anna Richmond 5000 dolláros alapítványa koronázta meg. Anna Richmond (1810-

\footnotetext{
${ }^{32}$ Edward Everett HALE (1822-1909) amerikai unitárius lelkész, író. 1846-tól a worcesteri Church of Unity, 1856-tól 1899-ig a bostoni South Congregational Church, 1903-tól haláláig az AEÁ szenátusának lelkésze. 1870-1875 között szerkesztette az Old and New című lapot, a bostoni The Christian Examiner (1824-1869) utódát. Hale 1851-1857 között Frederic Henry Hedge-dzsel együtt szerkesztette az Examinert.

${ }^{33}$ Emma Soutнwick a bostoni Travell and Comercial Bulletin tudósítója volt. 1896-ban másodjára látogatott a magyar fővárosba. Vö. Ellenzék, 1896. július 30.

${ }^{34}$ Hajós János (1819-1899) ügyvéd, országgyülési képviselő, a budapesti unitárius egyházközség alapító tagja és gondnoka.

${ }^{35}$ The Cause in Hungary. Third meeting in aid of the work of the Unitarian Association. Word and Work of the American Unitarian Association, Boston, April, 1874. A beszédek magyar fordítását lásd: Simén Domokos, Az elsó értekezlet ügyünkben Amerikában KerMagv, 1874, 128 149. Lásd még: Vasárnapi Újság, 1874. március 22., 188.; Protestáns Egyházi és Iskolai Lap, 1874, 12. sz. március 22., 375-376.

${ }^{36}$ Morison S. Robert (?-?) amerikai lelkész 1873-ban Kovács János társaságában beutazta Erdélyt, élményeit 1873-ban Two days in Transylvania címen közölte az apja, John H. Morison szerkesztésében megjelenő Unitarian Review and Religious Magazine vol. 2, November, 1874, 357-368. 47.

${ }^{37}$ Edward E. Hale - Kriza Jánosnak 1874. július 10. Rhode Island, Emlékkönyv, vol. II., 45-
} „Kedves Barátom! 
1881) 1875. március 3-án a kolozsvári unitárius főgimnázium javára 5000 dollárt adományozott egy főiskolai tanár fizetésének fedezésére. Gyermekei az alapítványt 1883-ban tízezer dollárra egészítették ki. ${ }^{38}$

Az angolok és amerikaiak 1873. évi fóvárosi látogatása irodalom- és politikatörténeti szempontból sem lebecsülendő. Edward Hale és Fretwell Deák Ferenccel való találkozása különösebb változást nem eredményezett a politikában, ám a Jókaival való találkozás konkrét eredményt hozott. A Hale szerkesztésében Bostonban megjelenő Old and New címü havilap Jókai A mennyei parittyakövek elbeszélését Sling-stones. A Hungarian story címen közölte. ${ }^{39} \mathrm{~A}$ fordító kilétét nem sikerült kiderítenünk, a Jókai-bibliográfiákban az elbeszélés egyáltalán nem szerepel az angolra fordított müvek sorában.

Több egy événél, hogy Pesten unitárius barátaimtól elváltam. Úgy érzem, mintha az az elválás öntől való elválás lett volna, s én minden évi gyűlésen megemlékeztem mindarról, amit ott élveztem és tanultam. Óhajtottam írni Önnek, hogy tisztán elmondjam Önnek, hogy minő alakban segíthetnek a mi egyházaink az önökéin. Van szerencsém megmondani, hogy mi képesek leszünk önöknek, legalább két évre 1000 dollárt küldeni, azzal a kívánsággal, hogy ez Kolozsvárt két tanári állomás felállítására használtassék. Valóban az a reménye és óhajtása az önök itteni atyjafiainak, hogy önök ez idő alatt találni fognak más eszközöket az ottani intézet nagyobbítására, úgy hogy önök még összesen 4 új tanárt állíthatnak bé, amint önök ezt múlt évi levelökben kifejezték. Önök minden esetre számíthatnak nálunk a jelen évre 1000 dollárra, és a jövőre is 1000 dollárra. Felkérem Kidder urat, a National Conferentia pénztárnokát, hogy azonnal küldjön önöknek 500 dollárt és az év végével ő küldeni fog még önöknek ötszázat. Legyen szíves részünkről kifejezni a konzisztóriumnak, s a konzisztórium által az önök egyházainak, hogy az amerikai unitáriusok örömmel elismerik ama szolgálat becsét, amelyet a magyarhoni unitáriusok az igazságnak és az egyháznak hoztak, és a Pesten nyert értesítés után ezt láttuk a legjobb útnak, amelyen önök iránti hálánkat kifejezzük. Elismerjük azt a szolgálatot, amelyet önök egyházai az egyszerű vallás ügyének tettek, akkor, amikor önökön kívül másokat nem ismertek el, hogy amaz ügyért harcoljanak. És mi elismerjük azt a szolgálatot, amelyet Magyarhon Európának a 17. század sötét és válságos idejében hozott. Egyszersmind jelezni kívánjuk amaz újabb győzelmek iránti érdekeltségünket, amelyek Magyarhont ismét független nemzetté tették. Remélem nem hibázom, ha hozzáteszem, hogy mi örvendenénk, ha oly győzelmeket látnánk, amelyek oly eredményben végződnének, hogy a magyarhoni keresztény egyház függetlenné lett minden polgári tekintélytől, uralomtól és beavatkozástól. Engedje Uram, elmondanom önnek személyesen, hogy nagy szerencsémnek tartom öntől levelet kapni, és remélem, hogy bokros levelezései közt néha meg fog emlékezni a konzisztórium legtávolabbi tagjairól. A konzisztorrá lett kinevezést, melyet Ön nekem Morrison úr által elküldeni szíves volt, a legnagyobb érdekeltséggel fogjuk őrizni én és gyermekeim. Én nyári otthonomban, a tenger mellett, Rhode szigetén írom e sorokat. Itt ma abban a szerencsében részesültem, hogy Fretwell és Morison urak meglátogattak. Szükségtelen mondanom, hogy sokat beszélgettünk magyar barátainkról. Önnek híve

Edward E. Hale"

${ }^{38}$ Vö. Boros György, Richmond Anna, KerMagv, 1882, 49-51. Kovács János, Richmond Anna élete és jelleme, KerMagv, 1883, 230-245.

${ }^{39}$ Old and New, 1874. vol. IX., 591-599. 
Fretwell 1875-ben a Richmond alapítvány átadása ügyében, de kereskedelmi célokat is szem előtt tartva, újból meglátogatta hazánkat. ${ }^{40}$ Balatonfüreden ${ }^{41}$ Jókai vendége volt. Elmondása szerint az író arról panaszkodott, hogy a bécsi krach (1837) sivár, hérosztalan kort hozott Magyarországra. Fretwell az amerikai és erdélyi unitárius „hősökre” hívta fel az író figyelmét, ${ }^{42} \mathrm{~s}$ a balatonfüredi beszélgetés és a budapesti ${ }^{43}$ találkozás eredményeként megszületett Jókai unitárius regénye, legalábbis erre következtethetünk Fretwellnek Simén Domokoshoz 1875. november 26-án Yorkshire-ből küldött leveléből. Itt pendíti meg először a készülő regény fordításának gondolatát. ${ }^{44}$ Ez némiképp egybevág Jókai 1876. július 26-án Balatonfüredről Teleki Sándornak írott soraival:

„Ha Isten úgy akarja, az idén csakugyan eljutok Hozzád. Ugyanis augusztus 3-án megyek Kolozsvárra, onnan 8-ikán Torockóra. Az unitárius atyafiakról kell mértéket vennem, mert egy regényt akarok rájuk szabni..." 45

Az Egy az Isten kritikai kiadását sajtó alá rendező Szekeres László szerint a „nagy unitárius ünnepségek" ${ }^{46}$ irányították Jókai figyelmét az erdélyi vallásfelekezetre, csakhogy 1876-ban nem volt jelentős unitárius ünnep Erdélyben, és a Dávid Ferenc halálát kommemoráló jubileumi zsinat előkészületei is alighogy megkezdődtek. Jókainak nem állt szándékában 1879-

${ }^{40}$ Erdélyi és magyarországi élményeit négy részletben közölte az angol unitáriusok lapja, a The Inquirer. Letters on Transylvania and Hungary. I. The Heart of the Szeklerland, The Inquirer, August 7, 516-517.; II. Klausenburg, Uo., 547-549.; III. On the Transylvanian Pactolus, Uo., 563564.; IV. On the Danube, September 4, 580-581.

${ }^{41}$ „In 1875 I was again in Hungary, and, while at Balaton Fuered, I was the guest of Maurus Jokai..." The Christian...20-21.

$42,(\ldots)$ in 1875 [Jókai] saw around him the results of the Vienna financial crisis of 1837, and remarked to me that there are no heroes now-a-days. I ventured to tell him of a few whom I had known in America, and suggested that he might still find heroes in Transylvania. He went there, and soon after, in the Feuilleton of Budapest Journal, there appeared this romance, under the title, „Egy az Isten" („One is the Lord," or "There is a God"). The Christian... $20-21$.

${ }^{43}$ A budapesti józsefvárosi választók ünnepélye, A Hon, 1875. július 23., 166. sz. Fretwell az alkalomhoz illő beszédet mondott, - német nyelven, mert "szívem és szemem magyar, de nem hallásom és nyelvem” -, felszólalását egy általa szerzett német verssel zárta: „Meer über ruft Brittania / Dem Volke Arpads zu: / Wach auf oh meine Schwester / Von deiner langen Ruh'! // Fest, wie Thoroczko's Felsen, / Hielst du an deinem Recht; / Als Oesterreich durch zu Knechten / Selbst ward des Russen Knecht! // Du hast Unrecht gelitten, / Geniess jezt Gottes Huld; / Dein Feind ist nun geschlagen / Durch seine eigene Schuld. // Doch Ungarlandes Erde, / Durch warmt von Sonnenshein, / Giebt Brod dem Sohne Arpads / Und auch den besten Wein. // Verzeiht dem alten Feind' / Hebt hoch den Kopf empor! / Éljen Magyarország / És éljen Jókai Mór!

${ }^{44}$ "(...)I hear that our friend Jókai Mor is writing a new Unitarian Novel - „Egy az Isten” the one God - I wish to have it that I may translate it into English and publish it in the United States for the benefit of your cause." MsU 1019/A2

${ }^{45}$ Mıкó Imre, Egy Jókai-regényhős 1848-ban, = Akik előttem jártak, Bukarest, 1977, 299.

${ }^{46}$ JóKAI, i. m., 292. 
re, Dávid Ferenc mártíriumának háromszázadik évfordulójára regényt írni, s az unitárius tárgyú regénynek a Fớvárosi Lapokban beharangozott „nagykeltü" angol kiadása egyértelmüen Fretwell szerepére utal. ${ }^{47}$ Szekeres azon megállapítása, hogy Jókai Charles Boner Erdélyről írott könyvének $^{48}$ angol és amerikai népszerüségére alapozta az Egy az Isten kelendőségét, nem helytálló. Boner Transylvaniáját ismerte és felhasználta Jókai, de nem erre alapozta eljövendő regényét. Boner művének megjelenése után több angol és amerikai unitárius írt Erdély és Torockó egyedi szépségérőll ${ }^{49}$ ráadásul Fretwell unitárius olvasóit óva intette, hogy cum grano salis kezeljék Boner múvét. ${ }^{50} \mathrm{Az}$ angol kereskedő Erdélyre éhes olvasóinak Jókai német fordítású „elbájoló novelláit”, a Szegény gazdagokat és Erdély aranykorát ajánlotta Boner helyett. Kérdés az, hogy ha Fretwell 1874-ben kiadta a Szegény gazdagok angol fordítását - miként ezt a magyar bibliográfiák feltüntetik -, miért nem azt ajánlotta az angol olvasónak? Bizonyára azért, mert teljes fordítás a regényről nem készült. Jókai ismerhette Fretwellnek a Szegény gazdagokról készült angol részfordításait, de az 1874-ben megjelent teljes angol változatról nem tud. ${ }^{51}$ Fretwell, Jókaival egybehangzóan, több levelében is megemlíti, hogy Erdélyről tartott előadásai során a Szegény gazdagok tájleírásait fotókkal illusztrálja, ezért újabb és újabb fényképeket kér erdélyi barátaitól. Magyarbarát érzelmeinek köszönhető, hogy a fővárosi és a kolozsvári sajtó élénk érdeklődéssel követte minden mozdulatát.

${ }^{47}$ „Az angol kiadásnak nagy kelete várható, főleg Amerikában az unitáriusok közt, mivel e regény az első unitárius küzdelmeket hazánkban fogja festeni." Fővárosi Lapok, 1875. november 7., 255. sz., 1138. Ezt ismétli meg a Vasárnapi Újság is 1875. november 14., 46. sz., 731.

${ }^{48}$ Charles Boner, Transylvania: Its Products and its People, London, 1865.

${ }^{49}$ Vö. John James TAYLER, Narrative of a Visit to the Unitarian Churches of Transylvania on Occasion of the Three-Hundredth Anniversary of the First Proclamation of Religious Freedom at Torda in 1568., London, 1869.; Robert S. Morison, Two days in Transylvania, The Unitarian Review, 1874. vol. II., 357-369. John FreTwell, Three Centuries of Unitarianism in Transylvania and Hungary, New-York, 1876.; Alexander Gordon, Report of an Official Visit to Transylvania on the Occasion of the Trecentennial Commemoration of Francis David, London, 1879.;

${ }_{50}$ "Having often been asked to recommend books on this interesting country, I would remark that Boner's, Transylvania its Products and its People, must be read cum grano salis, Boner being evidently prejudiced against the Magyars by his intercourse with their jealous German neighbours. The German reader I would refer to the charming novels of Moritz Jokai, who has sketched with master hand, in Die armen Reichen and Die Golden Tage Siebenbürgens the old romantic land beyond the Pusztas, and its inhabitants, with all their striking differences of manners, customs, race, religion, and speech". Fretwell John, Account of Some Hungarian Works Presented by the hon. Alexis Jakab, The Inquirer, May 29, 1875, 351-352.

51 ,,Regényeimből kiválasztotta azokat, amik Erdélyre vonatkoznak. Többek között a Szegény gazdagokat. Azon tájakat, ahol a regény egyes részei lefolynak, üveglapokra lefényképeztette. Az amerikai nagy városokban aztán felolvasásokat tartott az angolra fordított részletekből, s a felolvasásokat egy camera obscura közvetítésével a leírt tájak mint ködfátyolképek tüntek fel a hallgatóság elé, átváltoztatva, mikor az elbeszélés színhelye változott." A Hon, 1875. július 14., 158. sz. 
1875-ös második magyarországi útja során Jókai lapjában ${ }^{52}$ mint dúsgazdag üzletembert mutatta be:

„,...olyan üzlete van amely körülfogja az egész földet. Manilában egy pár száz indus gyújti számára a kaucsukot, Singaporeban a rotangot: azokat Mr. Fretwell gyárai New Yorkban a yankeek számára, Hamburgban az indogermán és uraltaji stb. népfajok számára dolgozzák fel. A kaucsukból fésűk készülnek, a rotangból nádszékek és esernyőnyelek". ${ }^{53}$

A meglehetősen hosszú cikket több napilap átvette, így Fretwell a Magyar Polgárból ${ }^{54}$ értesült gyártulajdonossá való előléptetéséről. Azonmód helyesbítést kért ${ }^{55}$ azzal, hogy ő ügynöke és nem tulajdonosa a New York-i és hamburgi gyáraknak. 1875. évi látogatásáról írtak: a Fỗuárosi Lapok, ${ }^{56} \mathrm{a}$ Hon, ${ }^{57}$ az Egyetértés és Magyar Újság, ${ }^{58}$ a Protestáns Egyházi és Iskolai Lap, ${ }^{59}$ a Keresztény Magvető, ${ }^{60}$ a Magyar Polgár, ${ }^{61}$ a Kelet, ${ }^{62}$ a Vasárnapi Újság vezércikkében életrajzát ${ }^{63}$ és portréját is közölte. Fretwell látogatásának emlékét nem csak a korabeli sajtó, hanem a székelykeresztúri Unitárius Gimnázium is őrzi. A derék angol július 16-án Kovács János társaságában felkereste a gimnáziumot, s az épület befejezéséhez szükséges pénzalapot hazatérte után előteremtette. ${ }^{64}$ Hálából az építkezés befejezése után 1877ben, a gimnázium könyvtárhelyiségében kétnyelvű márvány emléktáblát állíttattak. ${ }^{65}$

\footnotetext{
${ }^{52}$ Jókai cikkét Kovács János lefordította és közölte az Inquirerben. Vö. John Kovacs, Hungarian Correspondence, The Inquirer, July 31, 1875, 500.

${ }^{53}$ A Hon, 1875. július 14., 158. sz.

${ }^{54} 1875$. július 16., 160. sz.

${ }^{55}$ Mr. John Fretwellről, Fővárosi Lapok, 1875. július 21., 164. sz., 739. Vö. Vasárnapi Újság, 1875. július 25. 30. sz., 476.

${ }^{56} 1875$. július 15., 159. sz., 717., július 20., 163. sz., 736., július 24. 167., sz., 751., július $26 .$, 168. sz., 756 .

${ }^{57}$ A budapest-józsefoárosi választók ünnepélye, 1875. július 23., 166. sz.

${ }^{58} 1875$. július 16., 89. sz., július 23., 95. sz.

${ }^{59} 1875$. augusztus 1., 31. sz., 1006.

${ }^{60}$ Rafaju Domokos, Levél, Újszékel, július 1875., KerMagv, 1875, 342-344. 407.

${ }^{61}$ Levelezés. Székelykeresztúr, 1875. július 16-án. (Mr. John Fretwell), Magyar Polgár, 1875. július 20., 163. sz., 1875. július 28. 170. sz.

${ }^{62}$ Ifj. Fretwell János úr, Kelet, 1875. július 22., 165. sz., 651.

${ }^{63}$ Fretwell Balaton-Füreden, Vasárnapi Újság, 1875. július 18., 29. sz., 460., július 25., 30. sz., 476.

${ }^{64} \mathrm{~A}$ The Inquirerben négy részben közli erdélyi útjának tapasztalatait, és az első közleményt - Letters on Transylvania and Hungary. The heart of the Szeklerland - a következö felhívással zárta: "Compared with the importance of the work, the sum which I ask our people to give (£250) is ridiculously small; it will complete a building which will serve at once as a monument of our Jubilee, of the good Bishop Kriza, and of our interest in the work of these men, who form the vanguard of Religious Liberty in Eastern Europe." The Inquirer, August 7, 1875, 516.

${ }^{65}$ SÁNDor János, A székelykeresztúri Unitárius Gymnasium történelme, Székelykeresztúr, 1896, 83-87. Vö. GÁL Kelemen, Káli Nagy Elek élet-és jellemrajza, Kolozsvár, 2003, 109-129. (Az Erdélyi Unitárius Egyház Gyưjtőlevéltárának és Nagykönyvtárának kiadványai 3.) Az emléktábla
} 
Második magyarországi látogatása után Fretwell még élénkebb figyelemmel követte az Egy az Isten születését. 1876 júniusában Philadelphiában az erdélyi unitáriusokról tartott előadásában utalt Jókai készülő regényére és ennek várható hatására. ${ }^{66}$

Az alkalom akaratlanul is a bécsi világkiállítást juttatja eszünkbe, hiszen 1876-ban az Egyesült Államok történetében először éppen Philadelphia adott otthont a sokadalomnak. Fretwell június 6-án tartott előadását igen hatásosan azzal indította, hogy három évvel korábban hasonló rendezvényen vett részt, és az ősi Duna-parton strázsáló várak emléke még elevenen él lelkében. A Fairmount Park fensége nem a múltra, hanem a jövőre mutat, ott pedig nemcsak az ipar és technika vívmányainak látott biztos helyet Fretwell, hanem az unitarizmus eszméinek is, ezért hallgatóit az unitárius múltba, Erdélybe vezette. Történelmi bevezetése az egykori Dácia bemutatásával kezdődött. Hallgatósága aligha figyelt fel arra, hogy Potaisa, azaz Torda előadásában Patavisává alakult, és az sem tünhetett fel, hogy Decebál dák királynak a Torda melletti Keresztes-mezőn Traianuszszal vívott csatáját Kolozsvárral hozta kapcsolatba a szerzö, összetévesztvén Potaisa (Torda) városát Clausenburggal (Kolozsvárral). A hun-magyar eredettörténet után a szászok erdélyi betelepülését érzékletesen a Robert Browning által is megverselt hamelni patkányfogó legendájával vezette fel. A sajátságosan fretwelli értelmezés szerint a monda kialakulásához (1284-ben Hamelnben egy patkányirtó bűvös erejü sípjával az összes patkányt a Weser folyóba csalta. Midőn az előzőleg kialkudott bért nem kapta meg, a hamelni gyerekeket sípjával a közeli Kappelbergbe csalogatta. Itt a gyereksereget elnyelte a Kappel-hegy gyomra. Később Erdélybe vitte őket, és ők lettek az erdélyi szászok ősei.) - a torockói német eredetű bányászok munkája és életmódja is közrejátszhatott. Fretwell Erdély és Torockó iránti vonzalmának gyökere ide nyúlik vissza, ezért is érdeklődött olyan behatóan Jókai Torockón játszódó unitárius regényéről.

szövege: „In July 16th 1875 Mr. John Fretwell Jr. of England visited this College and induced his unitarian friends in England to subscribe the sum of $200 \mathrm{ftt}$ for the completion of the buildings as a memorial of their brotherly sympathy with the Unitarians of the Szeklerland and of their reverence for the late Bishop Kriza a noble pupil of this school. Faith is the spring of action. Take away / A nations faith in what it can and ought. / A creaping slow decay / Unnerves its arm freezes its inmost thought. / We are all saved by hope; / Hope teaches man his worth. / Opens new portals, gives him force and scope. / And when it shews new havens creates a glad new earth."

${ }^{66}$ "A Hungarian novelist, Moritz Jokai, who, when his works are translated into English, will be regarded as one of the greatest modern novelists, not only for his artistic power, but also for the direct influence of his writings on the thought and life of his people, gives in his latest novel, "There is a God; or, the People who Love but Once”, a strong testimony to the influence of their simple and earnest faith on the Transylvanian Unitarians of to-day." Fretwell, Three Centuries..., 20. 
1876. karácsony másodnapján Chicagóból Kovács János kolozsvári tanárnak arról számolt be, hogy megkapta Jókai regényét, és fordításával hatalmas szolgálatot tehetne az erdélyi unitáriusoknak. ${ }^{67} 1877$. január 31-én New Yorkból hasonló hangnemben írt Ferencz József püspöknek, először említve meg, hogy az Egy az Isten fordításán dolgozik. ${ }^{68}$ Három hónappal később április 3-án New Yorkból Ferencz József püspöknek és Kovács Jánosnak írja, hogy a Honban gyönyörüséggel követi a regény folyását, és hogy felkérte Jókait az amerikai és angol unitáriusok regényes életrajzának megírására. ${ }^{69}$

1877. szeptemberében Fretwell harmadízben járt Magyarországon és Erdélyben. Ezen az útján kereskedelmi célokat tartott szem előtt és néhány, számára később előnytelennek bizonyuló üzletet kötött az Erdélyi Pince Egylettel. ${ }^{70}$ Üzleti tárgyalásai mellett természetesen unitárius barátaival is találkozott, és mint tiszteletbeli konzisztor részt vett az EKT ülésén, ahol Ferencz József püspök köszöntötte. A Keresztény Magvető hírrovatában csak néhány mondatban utaltak látogatására, a Magyar Polgár viszont az Egyházi Képviselő Tanácson mondott beszédét is közölte. ${ }^{71}$ A tiszteletére

${ }^{67}$ "I get Jokay's new romance. If I could have had this to translate and publish in The Inquirer it would have helped your cause more than anything else that I have done. I wish you had sent it to me at once. I have as you see written to Liptay about it and I hope that either you or he will take care that it is sent to me." Fretwell Kovacs Jánosnak 1876. december 26. Chicago. Lelőhey: EUEGyLt, Amerikai levelezés 1876-1924.

${ }^{68}$ „I I am also translating Egy az Isten into English and hope with Jókay Mór's permission to sell the copyright for such a sum that it will also help your schools." Fretwell Ferencz Józsefnek 1877. január 31. New York. Lelőhey: EUEGyLt, Amerikai levelezés 1876-1924.

${ }^{69}$ "I read the Hon regularly at the Hungarian Club here and I am quite delighted to follow the course of Jókai's novel. It is really splendid and I wrote to him yesterday to suggest that when he has finished it he should write a second novel bringing his heroes to England and America. We have so many heroic men and women among the Unitarians of our both countries. It was the Unitarian Sir John Bowring who in 1830 published the first English work on the poetry of the Magyars, and in later years translated the songs of Petoffi. It was the Unitarian F.W. Newman, whose book on the crimes of the house of Austria against its own liege subjects excited English sympathy for Hungary. The Unitarian Stansfeld was the best friend of Mazzini and Kossuth. The American Unitarian Dr. S.G. Howe fought for Greece in 1831. Dall in Calcutta, Steinthal, Tagart, Tayler, and other visitors to Transylvania have all played a great part. Then the lives of Priestley, Lindsey, Governor Andrew, and the others would give much interesting material for a novel. Your viszont látasig a nyáron. Makes me think that you may perhaps be at the May meetings in London. Is that so perhaps I may be there but this is not quite certain. I wish Jókai could once be there and see our people at their best." Fretwell-Ferencz Józsefnek 1877. április 3. New York. Lelőhey: EUEGyLt, Amerikai levelezés 1876-1924.

${ }^{70}$ Erdélyi boraink a külföldön, Erdélyi Gazda, 1877. október 12., 41. sz., 343. Erdélyi boraink vegyelemzése Angliában, Uo., december 28, 52. sz., 433. (Az összesen 11370 palack és kilenc és fél hektoliter bort megrendelő Fretwell nyakán maradt a szállítmány egy része, barátainak írott leveleiben arról panaszkodott, hogy a Pince Egylet meglehetősen borsos árat számított fel boraiért.)

${ }^{71}$ Magyar Polgár, 1877. október 2., 224. sz.; 
adott vacsorán pohárköszöntők egész sora éltette a magyar-angol-amerikai barátságot. ${ }^{72}$ Hazatérte után a Journal of the Society of Arts-ban cikket írt az erdélyi húsiparról, melyet aztán sorozatban a Magyar Polgár is közölt. ${ }^{73} \mathrm{Az}$ erdélyi húsexport ötletével nemcsak a kolozsvári Kereskedelmi és Iparkamara foglalkozott, hanem a Magyar Kereskedelmi Minisztérium is. Fretwell a kolozsvári iparkamarának a nyers marhahús közvetlen Kolozsvárról Londonba szállítására tett javaslatot. 1878 júliusában a londoni Meat Importation and Storage Company képviselőinek társaságában negyedszer látogatott Magyarországra. ${ }^{74} \mathrm{~A}$ kolozsvári Kereskedelmi és Iparkamara július 12-én tartott értekezletén néhány elvi kérdésben megállapodtak, de az erdélyi viszonyok elmaradottsága (Kolozsvárott csak 1887-ben épült korszerü vágóhíd) elriasztotta az angolokat a komolyabb üzletkötéstől. Fretwell mindenesetre nem mondott le magyar barátairól, testi táplálék helyett szellemit ajánlott. Ennek jegyében a budapesti English Clubban két előadást is tartott, az elsőt október 9-én (Egy yankee felolvasása egy német szövegróll), ${ }^{75}$ a másodikat pedig december 1-jén (Reminiscences of Canadian travel) ${ }^{76}$ Ez utóbbi fellépés alkalmával is a pesti unitáriusok érdekében lobbizott, hiszen Bedő Albert, a budapesti unitárius egyházközség gondnokának nemzetközi elismertségnek örvendő erdészeti szakmunkái jó alkalmat szolgáltattak a felekezet újbóli exponálására.

Ötödik és egyben utolsó magyarországi útjára 1882. decemberében került sor. A pesti unitáriusok mellett találkozott Trefort Ágoston és Kemény Gábor miniszterekkel, de felkereste Jókait is. A Magyar Polgár hasábjain Jakab Elek áradozott „a mi barátunkról” és ugyanő lehetett az is, aki Fretwellnek a budapesti unitárius presbiterek gyưlésén mondott beszédét lejegyezte és közzétette. ${ }^{77} \mathrm{~A}$ látogatásról, és különösen a Jókaival folytatott tárgyalásokról a cikkíró nem adott eligazítást, ezért csak felételezhetjük, hogy az angol nem tett le azon korábbi szándékáról, hogy Jókait unitárius hőseivel Angliába és Amerikába csábítsa.

\footnotetext{
${ }^{72}$ Uo., október 4., 226. sz.

${ }^{73}$ Transylvania as a Source of Meat Supply, Journal of the Society of Arts, December 7, 1877, 43. Vö. Erdély mint a hússzolgáltatási képesség forrása, Magyar Polgár, 1877. december 18., 288 sz.;

${ }^{74}$ Magyar Polgár, 1878. július 2.3., 149-150 sz.

${ }^{75}$ Fővárosi Lapok, 1878. október 9., 232 sz., 1125.

${ }^{76}$ Magyar Polgár, 1878. december 1., 277. sz.

${ }^{77}$ Fretwell János Budapesten, Magyar Polgár, 1882. december 19., 290. sz.
} 


\subsubsection{Akik csak egyszer szeretnek}

Jókai egyetlen unitárius tárgyú regényt írt, így az angol és amerikai unitáriusok "regényes élettörténete” máig ismeretlen a szélesebb magyar olvasóközönség elött. Fretwell 1877-ben a hírek szerint elkészülhetett az Egy az Isten fordításával, ${ }^{78}$ de a címlapot kivéve a mű nem látott nyomdafestéket. 1900. július 14-én Ferencz Józsefhez küldött levelében az öregember bölcs rezignációjával állapítja meg, hogy a húsz esztendővel korábban készült fordítást - amennyiben azt kiadásra szánja - teljes egészében át kell, hogy dolgozza. ${ }^{79} \mathrm{~A}$ fordítás megjelentetését Boros György amerikai látogatása tette újból időszerűvé. Az Egyházi Képviselő Tanácsnak tett jelentésében Boros beszámolt arról, hogy Jókai regényének fordítása és kiadása érdekében eljárt, és hogy „Ellis könyvnyomdász a kiadást biztosította, Fretwell úr a fordítást magára vállalta." ${ }^{80}$ A szó szoros értelmében vett fordítást Fretwell nem jelentette meg, az 1901-ben közzétett tanulmány célját legrészletesebben Ferencz Józsefhez írott levelében (1901. május 30. London) okolja meg, megelőlegezve ezzel az angol Jókai-recepció mára már általánossá vált megállapításait is: ${ }^{81}$

„Én nagyon helytelennek találnám a regénynek egy teljes szó szerinti lefordítását mivel az oly dolgokat is tartalmaz amik az angol szemérmet sértenék; részben terjengős is, össze kellene vonni, de vajon [Jókai] beleegyeznék-e ebbe? Amit írtam, az az én tulajdonom, azt hagytam ki amit lehetett, de a fordítás más dolog, s nem könnyú dolog a szerzővel kiegyezni. Egy magyarázatra is szükség van, mert némely dolog ami a magyar és német olvasó elött könnyen érthető az amerikai előtt idegen ezért az én kis könyvem mint magyarázat bármely fordításhoz szükséges lesz. Nekem mindegy, ha másvalaki lefordítja is a

${ }^{78}$ A Magyar Polgár Hírharang rovatában (1877. október 2., 224. sz.) a következőket olvassuk: „Isten adjon hazánknak sok oly jó barátot, mint Fretwell úr, ki Jókai Egy az Isten címú regényének angolra fordításával irodalmunk terjesztésében is kitünő érdemet szerzett."

79 "There has been some talk of now publishing a translation of Jokai's Egy az Isten I made one many years ago, but there was such a prejudice among the American publisher's against a Unitarian Novel, that no one would undertake the risk of publishing it, and I had not the money to do so on my own account. And as I wrote this translation twenty years ago, I should have to recast it in order to satisfy my judgment on literary form today. Mr. Boros will probably speak to Dr. Jókai about it in passing through Budapest on his way to Kolozsvár." Fretwell Ferencz Józsefnek 1900. július 14. Providence. Lelőhely: EUEGyLt, Amerikai levelezése 1876-1924

${ }^{80}$ Boros György, Az amerikai Unitárius Társulat 75. évi jubileuma Bostonban. Jelentés a magyarországi Unitárius Egyház Képviselő Tanácsához, Kolozsvár, 1900, 21.

${ }^{81}$ "Az angol olvasók elsődleges stratégiája a válogatás, a diszkrimináció. Nyilvánvaló a szándék, hogy nem fordítanak le, nem olvasnak olyan szöveget, amely műfajilag értelemszerűen nem illik bele saját elvárásrendszerükbe. Eleve úgy válogatnak, hogy számukra rokonszenves olvasmányélményekben legyen részük, ha tetszik: tetteiket az öröm elve mozgatja. (...) az angol Jókai rövidebb szövegeket írt, a magyar szövegekhez képest sok esetben egész fejezetek hiányoznak." SzILAsI, i. m., 221-222. 
múvet. Ez mindig veszteséggel jár és szívesebben vesztek valamit egy olyan munkán ami az unitárius ügynek használ, mint amely művön csak a kiadó nyer." 82

A tanulmányt a kiadó, a bostoni James H. West Co. röplapon népszerüsítette, és Hall Caine The Christian ${ }^{83}$ és W. H. Mallock Romance of the Nineteenth Century ${ }^{84}$ címü regényeinek gondolat- és kérdésfelvetésével hasonlította össze. A bevezetőben Fretwell, a tanulmány közzétételét igazolandó, utalt az angol Jókai legnépszerübb regényére, a tizenhárom kiadást megért Nincsen ördög fordítására és fogadtatására. ${ }^{85}$ A kiadó - Cassel - előszava szerint az elbeszélés az amerikai ízlésnek minden korábbi Jókai regénynél jobban megfelel. Nem tudjuk olvasta-e Fretwell a The Critic-ben megjelent recenziót, mindenesetre véleménye megegyezik a recenzensével. ${ }^{86} \mathrm{Az}$ angol unitárius szerint Jókai több mint háromszáz regénye közül a Nincsen ördögöt legjobbnak kikiáltani ugyanannyit jelent, mint azt mondani, hogy az amerikai olvasó ízléséhez Shakespeare minden müve közül a Lucretia meggyalázása illik a legjobban. Tanulmányában Jókai azon mesterművét ismertette meg olvasóival, amelyben nem az ördög tagadása, hanem Isten jelenvalósága a hangsúlyos, ezért is There is a God... a fordítás alcíme. Nem arról van szó tehát, hogy Fretwell helytelenül fordítja az Egy az Isten címét - miként azt a Budapesti Szemle recenzense, Kropf Lajos jeles tudós állítja ${ }^{87}$-, hanem az ördög tagadásának vagyonszerző cinizmusával, az Istenben bízó puritán életet állítja olvasói elé követendő eszményül. Kropf Lajos recenziója a felekezetek közötti pengeváltás unitáriusokra irányzott oldalvágása.

„Torockó volt ugyanis az unitárius Manasseh Adorján születéshelye és az unitárius gazember, Benjamin Vaydor is itt szerepelt. (...) Fretwell még 1873-ban, a világkiállítás alkalmával találkozott Bécsben az utcán egy másik amerikaival, dr. Everett Hale-vel Bostonból s vele, továbbá egy kolozsvári tanárral s több

\footnotetext{
${ }^{82}$ Emlékkönyv, vol. IV., 42-43.

${ }^{83}$ Sir Hall Thomas CAIne (1853-1931) angol dráma- és regényíró, Krisztus trilógiáját magyar nyelvre is lefordították; The Christian, London: Heinemann, 1897.

${ }^{84}$ William Hurrel Mallock (1849-1923) angol író; Romance of the Nineteenth Century, New York: G.P. Putnam's Sons, 1881.

${ }^{85}$ Dr. Dumány's wife; or, "There is no devil," a romance by Maurus Jókai; tr. from the Hungarian by F. Steinitz, New York, Cassel Publishing Co. [1891]

${ }^{86}$,"The old-fashioned novel-reader, who prefers incident and dramatic situation to the psychological studies in vogue to-day, will find 'There is No Devil' a work after his own heart. Indeed, there is something remote and primitive about the artistic atmosphere of the book; ...And in spite of the airs we give ourselves, it cannot be denied that the class of readers to which such a story appeals is a large one, and one which is by no means deficient in culture. And after all, the culture which does not enlarge one's capacity for enjoyment is plainly imperfect." The Critic: a Weekly Review of Literature and the Arts (1886-1898), July 11, 1891, 14-15.

87 „E regény címe Egy az Isten, nem pedig Van Isten, mint azt Fretwell a címlapon lefordítja helytelenül." Lásd Budapesti Szemle, 1902. július, 154-156.
} 
erdélyi állami tisztviselővel lerándoltak Budapestre s itt megtartották az első unitárius isteni tiszteletet... ${ }^{88}$ Van egy rövid bevezetés-féle is... Magasztalja persze Dávid Ferencüket is..." 89

Hogy a recenzens az unitáriusokkal nem rokonszenvezett, az a napnál is világosabb, „az unitárius gazember”, „,a bevezetés-féle” kifejezések, Dávid Ferenc magasztalásának ironikus említése, és az 1873-ban tartott értekezlet eljelentéktelenítése nem az unitáriusok iránti lelkesedéséről árulkodik. Jóval tárgyilagosabb a Magyar Nemzet Tudomány és Irodalom rovatában megjelent ismertető: ${ }^{90}$

„Amerikában The Christian in Hungarian Romance címmel egy amerikai író, John Fretwell (...) több mint tíz ívre terjedő tanulmányt írt koszorús költőnk, Jókai Mór Egy az Isten címü mesteri regényéről. A Bostonban és Londonban megjelent munka bevezetésében Fretwell a regény tárgyával kapcsolatosan érdekes áttekintést ad az unitárius vallásnak magyarországi történetéről és az amerikai unitarizmushoz való viszonyáról. Majd tekintettel arra, hogy az Egy az Isten angolul még nem látott napvilágot a teljes fordítás megjelenéséig tizennégy fejezetben, a legjellemzetesebb részleteket szó szerint idézve, tömör, de mindvégig vonzó kivonatban elmondja a regény tartalmát. (...) Az amerikai olvasó részére a munka végéhez csatolt tanulságos jegyzetek könnyítik meg Jókai mestermúvének élvezését..."

Az erdélyi unitárius lapok agyonhallgatták Fretwell vállalkozását, a Keresztény Magvető és az Unitárius Közlöny szerkesztőségében nem akadt recenzens. Az amerikai periodikák közül a $C h R B$ közölt rövid részletet az előszóból és néhány mondatban ismertette a tanulmányt. ${ }^{91}$

Az 1900-as évekkel kezdődően a világi sajtó is egyre ritkábban adott hírt a magyarok lelkes barátjáról. Utolsó magyarországi és erdélyi útját 1901-re tervezte - üzleti ügyben Egyiptomba indult -, de a kolozsvári Unitárius Kollégium új épületének átadási ünnepségein már nem lehetett jelen, váratlan betegsége Chemnitzben (Németország) tartotta, és csak levélben köszönthette szeretett magyar barátait.

„Nagyon sajnálom, hogy nem vehetek részt angol barátaimmal ama kirándulásban, melynek célja az önök üdvözlése; üdvözlöm önöket e sorok által. Sajnálom, hogy nem tehetem ezt személyesen, de olyan rosszul vagyok, hogy utamat nem folytathatom s kénytelen vagyok itt maradni. Testvérem fog engem képviselni. Őszinte hív barátja, Fretwell János. 1901. szeptember 1. Chemnitz." ${ }^{\prime 92}$

\footnotetext{
${ }^{88}$ Az első nyilvános unitárius istentiszteletet 1869. június 13-án tartotta Budapesten Ferencz József. Lásd: Első nyilvános unitárius istentisztelet Pesten, Pest, 1869.

${ }^{89}$ Budapesti Szemle, 1902. július, 154-156.

${ }^{90}$ Jókai regényei, Magyar Nemzet, 1901. október 4., 249. sz.

${ }^{91}$ A Unitarian Novel, The Christian Register, 1901. majus 9., 519.

92 Újságkivágás Kovács János hagyatékában, egyelőre nem sikerült azonosítanunk.
} 
Ferencz József püspök 1906-ban írt levelében még egyszer, utoljára szól az Egy az Isten fordításának sorsáról, s ajándékként megküldi Bicknell fordítását. Levelében sajnálattal állapította meg, hogy Bicknell a szöveget nagyon meghúzta, és éppen az unitáriusokat illető rész hiányzik. Azon is sajnálkozott, hogy saját fordításának kiadása jótevője, Caroline Richmond halálával végképp meghiúsult. A huszadik század első évtizedében Fretwell neve kikopott a magyarországi és erdélyi folyóiratokból. 1906 után már csak nekrológját közölte a Keresztény Magvetó, a magyar nemzet és az unitárius egyház elfelejtette egykori nagy barátját és támogatóját, pedig a székelykeresztúri unitárius gimnázium kapuja fölött ma is figyelmeztet a kétnyelvű márványtábla: „Hit a tett forrása. ${ }^{93}$ Vedd el / Egy nemzet hitét melyben hathat s hatnia kell / S a lassú enyészet belopódzva / Erőtlenné teszi kezét, hideggé legbensőbb gondolatát. / Mindnyájan a remény által mentetünk meg. / Remény tanítja az embert önbecsére / Tár fel új kapukat ád erőt és czélt / S mutatván új eget teremt egy derült új földet."

\subsection{Kovács János és a kolozsvári English Conversation Club története}

Kovács János ${ }^{94}$ a Székelykeresztúr melletti Fiatfalván született, tanulmányait a keresztúri gimnáziumban, majd Kolozsvárott folytatta, ahol lelkészi oklevelet szerzett. 1870. április 17-tôl szeptember 17-ig a zürichi egyetemen nyelveket és filozófiát hallgatott. Szeptember 18-án Londonba indult, Bázel, Frankfurt, Heidelberg, Wiesbaden, Mainz, Köln, Rotterdam és Harwich érintésével 25-én szerencsésen megérkezett az angol fővárosba. A Manchester New College-ban töltött két esztendő - 1872. július 27-én indult haza - döntő módon meghatározta életét. Hazatérte után egy évvel a Ferenc József Királyi Tudományegyetemen angol nyelvet és irodalmat adott elő, 1876-ban pedig Kolozsvárott megszervezte az Angol Társalgó Kört (English Conversation Club). Ennek történetét nem kutatta sem a magyarországi, sem az erdélyi anglisztika, pedig az angol nyelv népszerüsítésében a Conversation Club és elnöke igen fontos szerepet játszott. A kör jegyzőkönyvei elvesztek, vagy jobbik esetben lappanganak valahol, és csak reménykedhetünk előkerülésükben. Ezek hiányában elsődleges for-

\footnotetext{
${ }^{93}$ A székelykeresztúri Unitárius Gimnázium nemrégiben restaurált zászlaján is Fretwell kedvenc mondása áll: Hit a tett forrása. (Ma már kevesen tudják, honnan került az iskola lobogójára a jelmondat.)

${ }^{94}$ Gác Kelemen, Kovács János (1846-1905). Felolvasta az Országos Középiskolák Tanáregyesületének kolozsvári közgyưlésén 1905. április 1-jén. Nyomtatásban Gámán János kolozsvári nyomdájában jelent meg év nélkül Édesapánk Kovács János emléke címen. Születése századik évfordulóján Benczédi Pál méltatta, lásd Kovács János (1846-1905), UK, 1947, LVII. évf., 1 sz., február 15.
} 
rásokként a korabeli kolozsvári napilapokat, az angol, illetve amerikai unitárius periodikákat és az EUEGyLt-ban levő Kovács János hagyaték levelezésanyagát használtuk. ${ }^{95}$ Forráskutatásról lévén szó, fontosnak tartottuk, hogy a feltárt eredményeket szükség szerint hosszasabban idézzük. ${ }^{96}$

$\mathrm{Az}$ English Conversation Club három évtizedes történetében, és az angol nyelv és irodalom kolozsvári oktatásában az Angliában tanult unitárius pap- és tanárjelöltek játszották a főszerepet. A magyar unitáriusok angliai peregrinációja 1860-tól a második világháborúig töretlen volt. A Manchester New College-ban, 1905-től kezdődően pedig a manchesteri Manchester Home Missionary College-ban ${ }^{97}$ szerzett tapasztalataikat és nyelvismeretüket akadémitáink hazatértük után is a lehetőségekhez mérten igyekeztek hasznosítani.

Az angol nyelv és irodalom erdélyi népszerüsítésének kedvezett az 1872-ben alapított Ferenc József Királyi Tudományegyetem. A kétéves angliai tanulmányútját 1872-ben befejező, s a kolozsvári Unitárius Főgimnáziumban történelmet és angol nyelvet tanító Kovács Jánosnak a kolozsvári tudományegyetem tanácsa 1873. április 27-én Trefort Ágoston (1818-1888) vallás- és közoktatásügyi miniszter 6463/1873. számú rendelete alapján megadta a jogot, hogy az egyetemen az angol nyelvet és irodalmat tanítsa, és az ezzel járó illetményeket igénybe vegye. Kovács János kinevezésével kezdődött a kolozsvári Ferenc József Tudományegyetemen a rendszeres angol nyelvoktatás. Több mint harminc évig, 1873-tól 1905-ben bekövetkezett haláláig Kovács volt az angol nyelv és irodalom lektora. Helyét, ugyancsak lektori minőségben, 1905-től 1919-ig Boros György teológiai tanár, majd unitárius püspök, az English Conversation Club egykori titkára vette át. Boros 1893-tól 1895-ig a kolozsvári Kereskedelmi Akadémián tanított angol

\footnotetext{
${ }^{95}$ A 19. század utolsó negyedében Erdély kulturális fővárosában három számottevő lap jelent meg: a Magyar Polgár (1876-1886. 1897-1904., 1887-1897 között Kolozsvár címen jelent meg), a Kelet (1871-1882) és az Ellenzék (1880-1944), ez utóbbi lévén az egyetlen megszakítás nélkül megjelenő politikai, közgazdasági és társadalmi napilap. Kutatásaink során elsősorban ezekre támaszkodtunk. Az angol unitárius periodikák közül a The Inquirert (1842- ), The Christian Lifeot (1876-1929), az amerikaiak közül pedig a The Christian Registert (1821-1957) használtuk.

EUEGyLt Kovács János hagyatéka 1-2. doboz.

${ }^{96}$ A napilapokra való hivatkozások során az évet, hónapot és lapszámot adtuk meg, oldalszámra csak a számozott újságok esetében tudtunk utalni. A kolozsvári napilapokban az angol klubra vonatkozó adatok legnagyobbrészt a hírrovatban - A Kolozsvári Angol Klub - jelentek meg, vastag kezdősorral szedve, ezért hivatkozáskor nem a címre, hanem az évre és lapszámra utaltunk.

${ }^{97}$ H., McLachlan, Register of students 1854-1829, 64., 66., 73., 75-77., Rezi Elek, Adatok a Manchesteri Unitarian College történetéhez, KerMagv, 1986, 27-32., McLACHLAN H., The Unitarian Home Missionary College, London, 1915., Sándor Kovács, Transylvania and the Unitarian College, Manchester: The Sharpe Hungarian Scholarships = Unitarian to the Core: Unitarian College Manchester, 1854-2004, ed. by Leonard Sмітн, h. n., 2004, 143-160.
} 
nyelvet. Gaal György szerint a kolozsvári tudományegyetemen az unitáriusok az angol nyelvtanári lektorátusban nélkülözhetetlennek bizonyultak. ${ }^{98} \mathrm{Az}$ ",angol nyelv beszélésében és írásában való tökéletesítésére," ${ }^{99}$ 1876. októberében Kovács János a helyi napilapokban az Angol Társalgó Kör alapítására felhívást tett közzé. ${ }^{100}$

Az angol nyelv múvelése Kolozsvárott az 1840-es években kezdődött a John Paget alapította Angol Olvasó Körben. Kovács kezdeményezése részben Paget munkája folytatásának is tekinthető. Az Angol Olvasó- és az Angol Társalgó Kör párhuzamosan müködött 1887-ig, ekkor az Olvasó Kör 2000 kötetes könyvtárát az English Conversation Clubnak adományozta, alapítói pedig a Kovács vezette klubnak lettek örökös tiszteletbeli tagjai. ${ }^{101}$ A kolozsvári English Conversation Club magyarországi viszonylatban is számottevő, hiszen Pozsonyt és Budapestet leszámítva, ahol Liptay Pál, majd Pulszky Ferenc elnök vezetése mellett 1874-től 1890-ig müködött a Budapest English Club, a kolozsvári az egyetlen megszakítás nélkül müködő angol kör. ${ }^{102}$ (A pozsonyi angol körnek csak az alapszabályzatát találtuk meg, müködéséről nincsenek adataink. ${ }^{103}$ ) A pozsonyi és a fővárosi klub történetével nem kívánunk részletesebben foglalkozni, ezért dolgozatunkban megelégszünk néhány részadat közzétételével. A mintegy 80-85 rendes és 23 rendkívüli taggal müködő Budapest English Club ${ }^{104}$ egyetlen nyomtatásban is megjelent titkári jelentését (az 1885-1886. év) találtuk meg. Charles Bächer főtitkár beszámolója szerint hivatali elődei a közgyűlés előtt élőszóban olvasták fel jelentésüket. Ô a szokástól eltérően a Club egyéves tevékenységéről írott/nyomtatott beszámolót készített.

A Kolozsvárott müködő Társalgó Kör elnöki-titkári beszámolói egyelőre nem kerültek elő. Az angol nyelv müvelését felvállaló két klub között nem volt szorosabb kapcsolat, és ez nem csak a tagok vallási hovatartozására vezethető vissza. A Budapest English Club egyetlen unitárius tagja Der-

\footnotetext{
${ }^{98}$ GaAl György, Unitáriusok a kolozsvári egyetemen, KerMagv, 1998, 127-140.

${ }^{99}$ Magyar Polgár, 1877. november 19., 265. sz.

100 „Felhívás egy alakítandó Angol Társalgó Körbe (English Conversation Club) való beállásra. Többek felszólítása következtében angol társalgó kört szándékszom alakítani. Akik tagok akarnak lenni, jelentkezzenek Kovács Jánosnál. Cél: az angol nyelv ápolása. Kolozsvár 1876. október 16. K.J." Ébredés, 1876. október 18., 15. sz.; Kelet 1876. október 19., 239. sz.; Magyar Polgár, 1876. október 18., 239. sz. Gál Kelemen, Kovács János (1846-1905) életrajzában az Angol Kör megalapítását 1876. november 9-re teszi. Egyelőre nem sikerült nyomára akadnunk Gál adatolásának, a kolozsvári sajtó októberben adott hírt az eseményről.

${ }^{101}$ Paget János ajándéka, KerMagv, 1887, 77.

${ }^{102}$ A Budapesti English Club szabályzatát lásd Függelék 10. sz.

${ }^{103}$ Lásd Függelék 11. sz.

${ }^{104}$ A Budapest English Club 1885-1886 évi, tizenegyedik közgyülésére készült titkári beszámoló 84 rendes, 23 rendkívüli és hat tiszteletbeli tagról számol be.
} 
zsi Károly helybéli lelkész volt, míg Kolozsvárott az unitárius értelmiség, ha nem is dominált, de jelentős szereppel bírt a társalgó kör történetében.

A Magyar Királyi Belügyminisztérium jóváhagyási záradékával (1877/2566 sz.) ellátott kétnyelvü, a kolozsvári Stein János nyomdájában készült alapszabályzatot - Rules of the English Conversation Club at Kolozsvár; A kolozsvári Angol Társalgó-Kör alapszabályai - az 1877. február 8-án tartott közgyülés fogadta el. ${ }^{105}$ Autentikus jegyzőkönyv nem áll rendelkezésünkre, ezért a megalakulás körülményeit, valamint a választmány teljes névjegyzékét nem ismerjük. A kolozsvári magyar sajtóban megjelent rövid híranyagból csak azt lehet megállapítani, hogy az angol nyelv müveléséért a kör nyolc taggal megkezdte múködését, s hogy elnökül Kovács Jánost, titkárul Péterfi Dénes ${ }^{106}$ (1851-1925) kolozsvári unitárius lelkészt, pénztárnokul pedig Széky Miklóst (?-1912) választották. Az alapító rendes tagok Péterfi és Széky kivételével, a kolozsvári Ferenc József Királyi Tudományegyetem tanárai voltak: Finály Henrik (1825-1898) nyelvész, történész, Jenei Viktor (1840-1887) jogbölcsész, Concha Győző (1846-1933) politológus, jogász, és Török Aurél (1842-1912) orvos, antropológus. ${ }^{107}$

A kolozsvári English Conversation Club megalapításáról az angol unitárius periodikák közül elsőként a The Christian Life ${ }^{108}$ számolt be. A ChRB 1877 márciusában vagy áprilisában közölte a kör célját és szabályait. Sem az angliai könyvtárakban, sem a kolozsvári Unitárius Kollégium könyv-és folyóirat-gyüjteményében nem találtuk meg a Kovács által a The Christian Registerből kiollózott, datálatlan cikket. ${ }^{109}$ A Londonban szerkesztett The

${ }^{105}$ Magyar Polgár, 1877. február 8., 31. sz.

106 PÉTerfi Dénes (1851-1925) kolozsvári unitárius lelkész, egyházi író. 1873-1875 között volt a londoni Manchester College diákja. Lásd: GÁL Kelemen, Péterfi Dénes (Unitárius Könyvtár 5. sz.), Cluj-Kolozsvár, 1925.

${ }^{107}$ Dolgozatunkban nem vállalkozhattunk arra, hogy megvizsgáljuk, befolyásolta-e az Angol Klub tagjainak tudományos és/vagy politikai világnézetét, úgy gondoljuk, hogy további kutatások adhatnak választ kérdésünkre.

${ }^{108}$ March 24, 1877, 140.

109 „Prof. Kovács has established an English Conversation Club the Rules of which he has kindly sent us. The object of this club is to secure improvement both in speaking and writing English. At weekly meetings the members engage themselves in practicing English according to methods unanimously fixed. English is used exclusively at Club meetings, and in every communication relating to its affairs. The Club intends to establish an English library for the use of its large number of members who are divided in to two classes, ordinary and not ordinary members. Not ordinary members cannot vote or hold office. A member may be excluded if he works on purpose to shorten the society either in property or in reputation. The General Meeting, which consists of all the members, is the legislative body and the highest legal court; it is to be held usually once a year. In case if this English Conversation Club will not keep its operation concerning the purpose and proceeding fixed in the rules; and inasmuch as, through the further continuance of its operation either the State, or the property of its members, would be in danger; so it will without delay be suspended by the Royal Government, and after its suspension according to the result of the ordered regular investigation, it will 
Inquirer 1877. április 7-én közölte Kovácsnak a Conversation Club tárgyában a szerkesztőhöz írott levelét. ${ }^{110} \mathrm{~A}$ kör elsődleges célja eszerint az angol nyelv elsajátítása és múvelése volt. Ennek érdekében a tagok hetente találkoztak, a közösen elfogadott tanrend szerint rendszeres nyelvoktatásban részesültek, angol újságokat olvastak, ${ }^{111}$ előadásokat hallgattak, és kizárólag angolul társalogtak. A kör müködését érintő minden kérdésben, házon kívül is, az angol nyelvet használták. A körnek tagja lehetett minden olyan nagykorú férfi, aki a kör működésében részt kívánt venni, és a választmánynál jelentette szándékát. Titkos szavazással döntöttek felvételéről, és ha felvételt nyert, nevét beírta a kör anyakönyvébe. A kör legfőbb döntéshozó testülete az évente legalább egyszer összehívott közgyưlés volt. A közgyülés által a rendes tagok sorából megválasztott tisztségviselők (elnök, titkár, pénztárnok, választmány) irányították az évközi tevékenységet. A rendkívüli tagok részt vehettek a rendezvényeken, használhatták a könyvtárat, de nem

entirely be dissolved, too, or, perchance, it will be compelled to the strictest observation of the rules under the Condition of its dissolution." Kivágott újságcikk a Kovács János hagyatékban. Lelőhely: EUEGyLt Kovács János hagyatéka.

110 "Sir, - The Hungarian students of Manchester New College carry home with them such a deep impression and kind recollection of England that they always speak with the greatest enthusiasm about the religious and family life, manners and customs, high culture and personal freedom of the English nation. Having such an opinion of the English people, they seize every opportunity of making the manly and expressive English language more widely spread in Hungary. The English language got quite into fashion at Kolozsvár in the course of a couple of years. Professor J. Kovács, who teaches the English language in the University, too, has instructed a great many in English, amongst these even many University professors, and in order to bring them into a closer union, he formed an English Conversation Club on the 15th of October last. In order to show the purpose of the club, I will quote a few lines of the rules, which have been printed on the one side in English, on the other in Hungarian: At Kolozsvár a society has been formed under the title of English Conversation Club, the object of which is to attain improvement both in speaking and writing English. For this end the club holds at least one meeting every week, where the members engage themselves in practising English according to methods unanimously fixed. The members have to use exclusively the English language, not only at the meetings of the club, but also in every communication which concerns the affairs of the club. The club will establish a library containing English books and papers for the use of the members etc. After confirmation of the rules by the Minister of the Interior, a committee was formed. Professor J. Kovács was unanimously elected president, and Mr. Dénes Péterfi as secretary. These gentlemen, on entering on their duty, spoke very appropriately of the English people and their literature, and explained why the Hungarians ought to choose as an example the English nation. This club is getting on admirably well; there are already many members. We have now English papers, and hope to establish a library by-and-by. If any of our English friends will come to Kolozsvár, they will be quite welcome in our club, and will have the opportunity of conversing in their own language." Kovács János levele a The Inquirer szerkesztöjéhez. The Inquirer, 1877. április 7.

${ }^{111}$ Nem tudjuk, hogy a megalakulás időpontjától kezdve milyen angol újságokat járattak. 1890-től a közgyưlésen beszámoltak a megrendelt vagy ajándékba kapott lapokról. A kör a Contemporary- és a Quarterly Reviewra fizetett elö, Paget a Pall Mall Gazettet és az Atheneumot, Brassai pedig a Nineteenth Centuryt rendelte meg a kör javára. 
voltak választók és választhatók. A kör mindaddig fennáll, amíg legalább hét tagja lesz. Feloszlás esetén a fennmaradó vagyon kezeléséről az utolsó közgyülés határoz, azzal a korlátozással, hogy az magáncélra nem fordítható. Ha a feloszlást kimondó közgyűlést nem lehet egybehívni, a vagyon felett Kolozsvár városi tanácsa határoz. Az 1877-ben elfogadott alapszabályzatot csak az alapító elnök halála után módosította a közgyülés. Az új, 1907-ben közzétett statútum elsősorban a tisztségviselők nemi megoszlásában hozott újat. Eszerint női és férfi elnöke van a klubnak, és az alelnökök egyike is kötelezően nő. A húsztagú választmány felét nők alkották. Úgy gondoljuk, hogy a női egyenjogúság jegyében fogant új szabályzat gyökerei a londoni Channing Schoolba nyúlnak vissza. A kolozsvári angol klub történetének ismertetése előtt szólnunk kell a magyar unitárius papleányok londoni taníttatását felvállaló ún. Sharpe alapítványról.

\subsubsection{A Channing House School és a Sharpe alapítvány}

Samuel Sharpe (1799-1881) mint egyiptológus és bibliafordító írta be nevét a tudománytörténetbe, kevesen tudják azonban azt, hogy bankárként is jelentős szerepet töltött be. ${ }^{112}$ Noha anglikán családban született, 1821-ben unitárius hitre tért, és William Johnson Fox finsbury-i gyülekezetét látogatta. Sharpe unokatestvérével, Sarah-val kötött házasságából hat gyermek született, de csak két lány, Emily és Matilda érték meg a felnőttkort. Matilda Sharpe (1830-1916) ${ }^{113}$ nevéhez füződik a londoni ún. Channing School alapítása. Nővére, Emily 1905 októberében 2839 font sterling értékű alapítványt tett az erdélyi unitárius paplányok londoni taníttatására. Az alapítványtevő előtt egy Budapesten vagy Kolozsvárott beindítandó leányiskola célja lebegett. Az unitáriusoknak - noha Kolozsvárott a leányoktatás terén tisztes, a 17. század első évtizedeire visszavezethető múlttal rendelkeztek $^{114}$ - a 19. században nem volt lehetőségük leánygimnázium kiépítésére, úgyhogy lányaik vagy a De Gerandóban, a De Gerandó Antónia által 1880-tól igazgatott Felsóbb Leányiskolában, vagy a katolikus, vagy pedig a református leányiskolában folytatták tanulmányaikat.

A Sharpe nővérek közül Matilda nevét emlegetik a lexikonok. Elsősorban oktatásszervezőként és iskolaigazgatóként tartják számon, de festőnőként is büszkélkedhet néhány jeles alkotással. Portréi közül hármat

\footnotetext{
${ }^{112}$ Vö. Alexander Gondon, Sharpe Samuel (1799-1881), rev. M.L. Bierbrier, Oxford Dictionary of National Biography, Oxford University Press, 2004 [http:www.oxforddnb.com/view/ article/25236]

${ }^{113}$ Ruth WatTs, Sharpe Matilda (1830-1916), Oxford Dictionary of National Biography, Oxford University Press, 2004 [http:www.oxforddnb.com/view/article/47128]

${ }^{114}$ Herepei János, Hozman János diák, a kolozsvári unitárius Leányiskola tanítója, Adattár 3., szerk. KesERứ Bálint, Budapest-Szeged, 1971, 505-507.
} 
(Samuel Davidson NPG1539, Joseph Bonomi NPG1477, Samuel Sharpe NPG1476) a National Portrait Gallery, London őriz. (Talán nem mellékes, hogy Emilyről festett portréja Kolozsvárott a püspöki hivatal falát díszíti.) Samuel Sharpe 1881-ben bekövetkezett halála után Matilda Robert Spears (1825-1899) lelkész segítségével bentlakásos iskolát alapított az unitárius lelkészek lányai számára. Matilda igazgatása alatt a Highgate Hillen 1885 januárjában megnyílt - (azóta is múködik) - a Channing School. ${ }^{115} \mathrm{Az}$ iskola hamarosan túlnőtt a felekezeti kereteken és évente mintegy 60 bentlakó lány oktatását biztosíthatta. 1892-1957 között 29 magyar lány tanult az intézetben. ${ }^{116}$ Az erdélyi oktatás történetében egyedinek számító kezdeményezés leglelkesebb támogatói a Sharpe nővérek voltak. A teljesség igénye nélkül közöljük a Channing Schoolban tanultak névsorát.

1. Buzogány Mariska 1892-1893

2. Fangh Erzsébet 1893-1894

3. Telekes Szilvia 1895-1896

4. Kovács Irén 1897-1898

5. Boér Lenke 1901-1903

6. Killyéni Erzsébet 1903-1904

7. Zsakó Lenke 1904-1905

8. Pákei Márta 1905-1906

9. Pünkösti Márta 1906-1907

10. Boros Irén 1907-1908

11. Morvay Ilona 1908-1910

12. Morvay Margit 1908-1911

13. Yäger Gizella 1910-1912

14. Tompa Mária 1912-1914

15. Boros Rózsika 1913-1914

16. Bácsi Margit 1920(?)-1922

17. Deák Margit 1920-1923

18. Sámi Magda 1920(?)-1922

19. Diószeghy Erzsébet 1925-1927

20. Páli Rózsika 1929-1931

21. Káli Nagy Magda 1935-1937

22. Kiss Viola 1937-1938

\footnotetext{
${ }^{115} \mathrm{Az}$ iskola nemrég ünnepelte fennállása 125. évfordulóját. Ez alkalomra készült a Channing School: a chronicle of 125 years 1885-2010. Channing Association, 2009.

${ }^{116}$ DeÁк Margit, Emlékezés a "Channing House-Schoolra", Unitárius Értesítö, 1924, III. évf., 4. sz., 4-7.; A Channing School magyar növendékei, UÉ, 1985, július-augusztus, 39. évf., 4. sz. Vö. Zsakó Erzsébet, Hinni és tenni. Az unitárius Nőszövetség története, Kolozsvár, 2003, 153-165. Lásd még: Törökné Borbély Lenke, Unitárius leánynevelés a londoni Channing House Schoolban, UK, 1997, július-augusztus, 68. évf., 4 sz.
} 
23. Csiki Klára 1938-1939

24. Koncz Ildikó 1938-1939

25. Harsányi Klára 1938-1939

26. Bikkfalvi Barbara 1945 után

27. Anghy Gyöngyi 1948-1949

28. Anghy Anikó 1951-1952

29. Amanda Davidson

A felsoroltak közül többen aktív szerepet vállaltak az unitárius nőmozgalomban, mások a tanügyben tudták kamatoztatni Londonban szerzett ismereteiket. A kolozsvári angol klubban egyedül Kovács János lánya, Irén vállalt szerepet.

\subsubsection{Angolok és/vagy franciák}

Az angol klub megalapítását illetően Kovács János hagyatékában egy, az angol és francia kultúra erdélyi versengését illusztráló levelet találtunk. A Déváról küldött misszilis szerzője Giles Dietriefstein, akiről csak annyit tudunk, hogy a Magyar Polgárból értesült a kör megszervezéséről, és 1876 késő őszén vagy 1877 kora tavaszán Kovács János elnökhöz írt levelében üdvözölte a felettébb hasznos kezdeményezést, már csak azért is, mert szerinte a francia nyelv és kultúra demoralizáló befolyását a gyönyörü angol nyelv és kultúra ellensúlyozhatja. ${ }^{117}$

A kolozsvári angol kör elnöke és tagsága teljes létszámban részt vett az 1879. február 1-jén alapított Francia Klub (Club Français de Kolozsvár) rendezvényein. ${ }^{118} \mathrm{~A}$ város két nyelvklubja példás békességben élt egymás mellett, nem a rivalizálás, hanem az angol és francia nyelv, illetve szokások ápolása volt a cél. Versengeni azért sem lehetett, mert mindkét klub ugyanabból a miliőből verbuválta tagjait, és horribile dictu az elnökség tag-

\footnotetext{
117 „Dear Sir! I hear from the M[agyar] P[olgár] that you are to form an English Club. I can't but greet this idea as a very good one and as in accordance of the spirit of the age. The superficial French language and its demoralising influence in this country must be dispossessed by the manly and beautiful English language and there are no better means to enact this, than to popularising it by a central Club. But I don't think this enough. There is a great deal of persons speaking and reading English dispersed in the country and to them a club is of no use. This even mentioned persons are obliged to forget their English for they are not able to procure themselves English books, at least not without great sacrifices. Won't you find it good, therefore to direct your attention on erecting of an English library too? And of course the possibility of getting books o'er the country. I am Sir your most obediently Giles Dietriefstein. By the count Horváth-Toldy, Déva Giles Dietriefstein." EUEGyLt Kovács János hagyatéka 2 doboz, 32/D.

${ }^{118}$ Az EUEGyLt-ban, a Kovács hagyatékban 1/26. jelzet alatt találtuk meg a francia klub nyomtatott alapszabályzatát és alakuló gyülésének meghívóját. Szövegét lásd Függelék 12. sz.
} 
jain is megosztoztak. Finály Henrik, a francia klub elnöke egyetlen angol meetingről sem hiányzott, és 1877-től 1898-ban bekövetkezett haláláig tagja volt az English Conversation Club választmányának; Széky Miklós hüséges pénztárnoka volt mind az angol, mind a francia klubnak; Duret József, a kolozsvári egyetem első francia lektora és a francia klub nyelvtanára, 1886tól 1892-ig, haláláig, tagja volt az angol klubnak. Az Angol Társalgó Kör megalakulásának első esztendejében 29 gyülést és 12 felolvasást tartottak.

\subsubsection{Az English Conversation Club első éve}

A társalgó kör első esztendeje igen gazdag volt előadásokban, a heti rendszerességgel megtartott találkozók majdnem mindenikén felolvastak a tagok. Az 1877. évről, a későbbiekhez viszonyítva, meglepően gazdag híranyagot találtunk a kolozsvári és az angol unitárius sajtóban, ezért részletesebben ismertetjük a kör első évének történetét.

A megalakulás és az alapszabályzat februári elfogadása után április 5-én került sor az első előadásra, melyet Kovács János tartott az 1871-ben tett írországi útjáról. ${ }^{119} \mathrm{Az}$ angol klub elnöke 1870-től 1872-ig volt a Manchester College diákja, és előadásában 1871. évi írországi élményeit elevenítette fel. Az alapszabályoknak megfelelően angol felolvasást hallhattak a tagok, de a téma iránti érdeklődésnek köszönhetően magyar nyelvű változata a kolozsvári Hölgyfutárban, a Magyar Polgár heti mellékletében jelent meg. ${ }^{120} \mathrm{~A}$ fényképekkel gazdagon illusztrált felolvasás az egykori diáknak 1871. augusztus 23-án a peeli kikötőben (Isle of Man) való behajózásával kezdődött. A Belfastban partra szállt erdélyi peregrinus a város nevezetességeinek szemrevételezése után Írország egyik igen-igen népszerü látványosságához, a Giant's Causeway-hez kalauzolta hallgatóit. Tudomásunk szerint ez az ír természeti csoda első magyar leírása, ezért idézzük a szerzőt:

„Belfasttól - Portrushig, mely az utolsó vasúti állomás a Giant's Causewayhez, a legérdekesebb látvány a gyönyörü Lough Neagh (neagh-i tó), mely legnagyobb a brit szigeteken s Európában csak a Lagoda, Onega és genfi tavak múlják felül. Festői fekvése s a partjain található különös kövületek és kövek miatt nagyon sokan látogatják ezt a belföldi tengert. Szélein szebbnél szebb rózsák s különös virágok, mik a kertekben is csak gondos ápolás mellett nőnek, a legdúsabban tenyésznek. A nép között az a hagyomány van elterjedve, hogy hullámai egy eltemetett város tornyait fedik. Ezt a hagyományt a hírneves irlandi költő Moore Tamás is megörökítette egyik szép költeményében. Portrush várostól, mely tengeri fürdőhely s merész sziklák alatt fekszik, a tengerpart hosszában Dunluce kastélyig mintegy 27 barlang látható, miket a hullámok

\footnotetext{
${ }^{119}$ Magyar Polgár, 1877. április 10., 81. sz.

${ }^{120}$ Kovács János, Irlandról, Hölgyfutár, 1877. április 12., 114.
} 
szakadatlan mozgása alakított. Dunluce kastély, mely egy szikla párkányán függélyesen áll a hullámok felett, egyike a legnagyszerübb, regényesebb és festőibb kastélyoknak. Innen 2 angol mérföldnyi utazás után eljutottunk kitüzött célunkhoz, a Giant's Causewayhoz. Nagyszerű és fenséges látvány tárul itten a szemlélő elé! Négy angol mérföldnyi területen az örökösen zúgó tenger hullámai felett gyönyörü bazalt oszlopok (mintegy 40000) emelkednek, melyek mind úgy látszanak, mintha ki volnának szépen vágva, simítva, művésziesen alakítva s olyan találóan egymáshoz illesztve, hogy azt képzelnők, miszerint azok a találékony emberi ész remekművei, holott csak a természet változhatatlan törvényének eredménye. A bazalt oszlopok különbféle alakjuk szerint, különböző neveken is fordulnak elő, mint po. Giant's amphitheatre (Óriás színkör), mely bizonyára a legszebb színkör a világon. Az alakja oly tökéletes félkör, amelyet egy művész sem alakíthatott volna jobban azzá. Továbbá: óriások kapuja, orgonája, ágya; kémény teteje, legyező, ikrek stb. nevek jönnek elő. A Giant's Causeway a természetnek oly bámulatos müve, oly nagyszerü látvány, melyet leírni s elbeszélni nem lehet!"121

Az április 5-i előadást követően június 2-ig pontosan nyomon követhető a kör tevékenysége. A következő felolvasások hangzottak el: Péterfi Dénes április 13-án az angol társadalmi, vallási és politikai életről, ${ }^{122}$ Hőgyes Endre (1847-1906), aki 1883-ig volt tagja a klubnak, április 22-én a szellemi munkával foglalkozók betegségeiről, ${ }^{123}$ Felméri Lajos (1840-1894), az Angliát is megjárt egyetemi tanár, május 3-án nevelésünk örökölt bajairól,, ${ }^{124}$ Finály Henrik május 17-én a római pénzrendszer kifejlődéséről, ${ }^{125}$ Török Aurél május 24-én $A$ mi valódi elődünk címmel tartott előadást. ${ }^{126}$ Ez utóbbi felolvasás több szempontból is jelentős volt. Elöször is azért, mert ez volt az első alkalom, hogy az English Conversation Club egy ízig-vérig angol úriembert, George Browingot (?-1877) látta vendégül, másodszor pedig azért, mert a Bristolban élő Mary Carpenter könyvadományával megvetette alapját az eljövendő Angol Könyvtárnak. Mary Carpenter (1807-1877) ${ }^{127}$ nevét a szociálisan hátrányos helyzetü gyermekek intézményes oktatása és nevelése terén kifejtett munkássága tette ismertté Európában és Indiában. Az unitárius hölgy a The Inquirerből ${ }^{128}$ értesült a kolozsvári társalgó

\footnotetext{
${ }^{121}$ Uo.

${ }^{122}$ Magyar Polgár, 1877. április 13., 84. sz.

${ }^{123}$ Uo., április 22., 92. sz.

${ }^{124}$ Uo., május 3., 100. sz.

${ }^{125}$ Uo., május 17., 112. sz.

${ }^{126}$ Uo., május 27., 120. sz.

${ }^{127}$ J. Manton, Mary Carpenter and the Children of the Streets, London: Heinemann, 1976; Joseph Estlin Carpenter, The Life and Work of Mary Carpenter, London, 1879.; Magyarul: Kovács János, Carpenter Mária emlékezete, KerMagv, 1877, 357-364. Carpenter Mária emlékezete, Hölgyfutár, 1877, 4. sz., 31-32, 37-38.

${ }^{128}$ Letter from Hungary, The Inquirer, April 7, 1877, 225. A kiadóhoz küldött levelet Kovács János szignálta.
} 
kör megalakulásáról és könyvtáralapítási szándékáról, és a cél érdekében harminc könyvet ajándékozott. Mary Carpenter meggyőződéssel vallotta, hogy az angol nyelv arra hivatott, hogy a müvelt világ nyelve legyen, és hogy az unitarizmus elvei és gondolatai gyakorlati tettekkel egyesítve fennmaradnak. ${ }^{129}$

A május 24-i előadás második nevezetessége George Browing „fiatal angol tudós és költö" 130 volt, akinek magyarországi és erdélyi útjáról és tragédiába torkolló életéről hosszasan cikkezett a korabeli magyarországi és erdélyi sajtó. ${ }^{131} \mathrm{~A}$ Teleki grófok sáromberki parkjában 1877. július 24én öngyilkossá lett Browing életéről mindmáig nem született monográfia. Ács Tivadar a múlt század negyvenes éveiben írott egyik rövid cikkének zárómondata - „kegyeletteljes és hasznos dolgot müvel az a kutató, aki [Browing kéziratait] közkinccsé teszi" - jámbor óhaj maradt, ${ }^{132} \mathrm{~s}$ a tragikus végü angol fiatalember nyolcfüzetnyi kéziratos naplója, ${ }^{133}$ versfordításai ${ }^{134}$ nem kerültek feldolgozásra, kiadásra. Az Erdélyt keresztül-kasul beutazó Browingnak az Angol Körben június 3-án tartott felolvasását alapos előkészület, már-már reklámízű kampány előzte meg. Június végét John Paget (1808-1892) vendégeként az Aranyos mentén töltötte. Gyéresről járta be a vidék nevezetességeit és vette szemügyre a látnivalókat. A tordai hasadék és a sóbánya meglátogatása, a sósfürdőben való megmártózás legalább annyira fontos volt számára, mint Torda városa értelmiségével találkozni. Útját és Torda környéki forgolódását a város frissen alapított politikai, iro-

\footnotetext{
${ }^{129}$ "I believe with you that, English is destined to be the language of the civilized world, and that our thoughts combined with practical acts will live." Az 1877. július 1-jén Bristolban kelt levél angol eredetijét lásd: EUEGyLt, Kovács János hagyatéka 2. doboz 32/C.

${ }^{130}$ Kelet, 1877. május 27., 119. sz.

${ }^{131}$ Pesti Napló, 1877. január 10., 18., 31.; Fővárosi Lapok, január 11., 18., 23.; Zemplén, január 11.; Budapesti Napilap, január 16., 22., 29., 31.; Ellenőr, január 18.; Pester Lloyd, január 18., 29. április 6.; Ung, január 21.; Vadász és verseny-lap, január 21.; Magyarország és a Nagyvilág, január 28.; A Hon, január 30., 31., április 6.; Nemzeti Hírlap, február 1.; Debreceni Ellenőr, január 18.; Egyetértés, április 10.; Szabolcs megyei Közlöny, április 19.; Békési Lapok, május 6.; Orosháza, május 13., 20.; Alföld, május 13.; Szegedi Híradó, május 29.; Temesvarer Zeitung, május 12.; Magyar Polgár, május 23., 27., 30., június 2., 5.; július 14., 26., 28.; Haladás, június 2., július 28.; Kelet Népe, július 14.; Hölgyfutár, május 10., június 7. stb. stb.

132 Ács Tivadar, Erdély Browningja, Láthatár (kisebbségi kultúrszemle), 1943, 5. sz., 109 110.

${ }^{133} \mathrm{Az}$ Erdélyi Múzeum-Egyesület egykori kézirattárából a Browing anyag a kolozsvári egyetemi könyvtár kézirattárába került. A Napló könyvtári jelzete: Mss 2527. I. My Diary. April. Budapest-Hungary 1877., II. My Hungarian Diary. Travels in Alföld. May 1877., III. My Hungarian Diary. May 16/26. 1877., IV. My Hungarian Diary. May 27 - June 11. 1877., V. My Hungarian Diary. June 1877., VI. My Hungarian Diary. Gold District; Abrudsburg. June 20-26. 1877., VII. My Hungarian Diary. June 26 - July 1877., VIII. My Hungarian Diary. July 1877. A napló negyedik és ötödik füzetében vannak unitárius vonatkozások.

${ }^{134}$ Mss 2531. Out of Hungarian Flower Gardens, 1877. January.
} 
dalmi és müvészeti lapja, a Haladás ${ }^{135}$ közölte. De nem csak a tordai, hanem a kolozsvári újságírók is hosszasan írtak Browingról, idézték hazánkról, városunkról írott sorait, s egyebek mellett Kovács Jánoshoz intézett levelének egy részletét is:

„Miután Európának legtöbb országát beutaztam, biztosan mondhatom, hogy az angol nyelv egy országban sincs annyira elterjedve, mint Magyarországon, és itten egy városban sincs oly jól képviselve, mint Kolozsvárt."136

A szép magyar hon iránt érzett vonzalmát 1877 februárjában gróf Forgách Kálmán nagyszalánci birtokán To Hungaria címen meg is verselte. A Forgách család emlékkönyvébe írott kedves sorokat Browing halála után közölte a kolozsvári sajtó. ${ }^{137}$ A sajtó által költőnek kikiáltott Browingot annak dacára, hogy Petőfi-fordításokkal is kacérkodott, túlzás lenne a múzsák kegyeltjének nevezni. ${ }^{138}$ Fordításait Out of Hungarian Flower gardens címü füzetébe másolgatta be. ${ }^{139}$ Browing az Angol Klubban június 3-án vasárnap tartotta meg előadását. A kolozsváriak az Angol királynőhöz címzett vendéglőben izlandi utazásáról hallottak jól felépített felolvasást. A magát a Royal Society tagjának kiadó utazó lényegében a Budapesten január 31én megtartott felolvasását ismételte meg. A Hon 1877. január 30-án közölte előadása szillabusát: „Bevezető megjegyzések. Izlandi példabeszédek. Megérkezés Izlandba. A gejzírek. A természet szépségei. A nagyszerű napnyugat és északi fény. Izlandi utak. Patakok és hidak. Izlandi lovak. Sport. Stb. Kivándorlás. Izland története. A két Edda. Stb. Amerika felfedezése

${ }^{135}$ Haladás, 1877. június 2., 5. sz. 1. évf.

${ }^{136}$ Magyar Polgár, 1877. június 2. 124. sz.

137 „From a far off friendly shore, / Comes a stranger to thy land, / Brave Hungaria, - and thy sons / The sons of Árpád give their hand / In welcome to the wanderer / From the white cliffs of Albion! / Hail to thee, - holy Magyar soil / Bright with the blessings of the sun! / Land of the grape, - land of the free / Hungaria, a long, long life to thee!" Az angol eredetit Ács Tivadar cikkéből vettük át. A cikkíró a magyar fordítást is közli, de tévesen Hegedús Sándornak tulajdonítja. A Magyar Polgár (1877. június 2.) helyesen Hegedús Istvánt (1848-1925) nevezi meg fordítónak.

138 „Kirkconnel fellépéséig (1927) többen akadtak olyanok, kik a magyar költészet angol nyelven történő megismertetését tüzték ki feladatukul, több-kevesebb sikerrel. Ezek közül meg kell említeni, a már említetteken kívül, Browing György nevét, aki Petőfinek néhány versét fordította le 1877-ben; hogy ezek a fordítások nyomtatásban megjelentek-e, nem tudjuk. A fordító fiatalon, tragikus körülmények között hunyt el Erdélyben s néhány kéziratát a kolozsvári Egyetemi Könyvtár őrzi." SzentKirályi József, Magyar költemények angol fordításban, Bp., 1943, 6.

${ }^{139}$ Ilusztráció gyanánt álljon itt a Jó költőnek tartanak fordítása: „They call me a good poet...

That I may be - I think so too - / But do not thou flatter me / Not thou, my darling. / Before thee I blush / When thou flatters / And why? Compared with thee / I feel my littleness. / In the tiniest thought / That panes thro' thy brain / In the tiniest feelings / That swells thy breast / In one flesh of thine ege / That flies stealthiles towards me / In one lowe of thine. / That strikes swiftly my soul! / In one smile of thine / There is more poesy my darling / Than in all the five hundred and fifty verses / That I have written up till now." 
az izlandiak által a 10. században. Kolumbusz Izlandon." A kolozsvári felolvasás forgatókönyve már Budapesten megíródott, s az utazónak nem maradt más hátra, mint learatni a babérokat. Felolvasása után az egyetem több jeles tanárával találkozott, a magyar irodalomról, illetve Petőfi angol fordításairól írott naplósorai meglepően jó tájékozottságról tanúskodnak. Meltzl Hugóval (1846-1908) - (a jeles filológus Brassaival együtt Összehasonlító irodalomtörténelmi lapok ${ }^{140}$ címen havilapot szerkesztett, Browing meg is említi naplójában) - június 4-én folytatott beszélgetéséről Naplója $I V$. füzetében is megemlékezett. Meltzl Hugó összehasonlította Bowring fordításait E. D. Butler ${ }^{141}$ sokkal sikeresebb fordításaival. ${ }^{142}$ Butler Hungarian Poems and Fabels for English readers (London, 1877) kiadását az erdélyi és az angol unitáriusok is figyelemmel követték - Brassaiék rendszeresen közölték fordításait összehasonlító irodalomtörténeti lapjukban - és Péterfi Dénes, Butler alkalmi magyar nyelvtanára révén, az unitáriusok személyes érdemüknek is tekintették a kötet megjelenését. A Kolozsvárott megjelenő Kelet könyvismertetését ${ }^{143}$ - több mint bizonyos, hogy erdélyi unitárius közvetítéssel - átvette a Londonban megjelenő The Christian Life is. ${ }^{144}$ Kolozsvár vezető értelmiségének szimpátiáját és ajánlásait bírva Browing talán abban a hitben folytatta útját, hogy a kolozsvári Egyetemen az új tanévben angol nyelv és irodalomból habilitál. ${ }^{145}$ Gyulafehérvár felé vette az útját, előbb azonban néhány Aranyos és Torockó menti unitárius intermezzo következett. Torockón az alkalomra írt ünnepi beszéddel köszöntötte a püspöki vizitációra érkező Ferencz Józsefet. Naplójában (V. füzet), június 16.-i dátum alatt részletesen leírta a püspöki vizitáció fogadtatását, sőt a püspökhöz intézett köszöntő szavait is.

A vasárnapot Torockón töltötte, ahol részt vett az istentiszteleten, és az angol és amerikai unitárius látogatókat megszégyenítő részletes leírását adta a helyi népviseletnek (Napló V. füzet, június 17). ${ }^{146}$

\footnotetext{
${ }^{140}$ Lásd Összehasonlító Irodalomtörténeti Lapok, válogatta, sajtó alá rendezte és jegyzetekkel ellátta GAAL György, Kriterion, 1975.

${ }^{141}$ Edward Dundas ButLeR (1842-1919) nyelvész, könyvtárnok, műfordító, a Magyar Tudományos Akadémia és a Kisfaludy-társaság müfordításaiért és a magyar kultúra népszerüsítéséért kültagjának választotta. Vö. CZIGáNY, A magyar irodalom... 185-190.

${ }^{142}$ My Hungarian Diary, May 27 - June 11, 4. füzet. Mss 2527.

${ }^{143}$ Kelet, 1877. november 29.

${ }^{144}$ „,The work lying before us, Hungarian Poems etc., translated by E.D. Butler, of the British Museum, is also in great measure due to the Unitarian Church, in so far as it had an indirect influence in its being brought into existence that is incontestable. Whether we should attribute it to this indirect influence or the translator's own merit we do not know (...)" Hungarian Poems etc., The Christian Life, December 29, 1877, 628.

${ }^{145}$ Magyar Polgár, 1877. július 28., 171. sz.

${ }^{146}$ „,For centuries the people of Toroczkó had been celebrated for their picturesque national dress. Torockó is a Unitarian town - far away from the steam path situated in a beautiful valley where the rocks tower up on the one side towards the sky, jagged and bare - and on
} 
Ezután összehasonlítja a svéd gyülekezeti életet a torockóival. A „fránya" torockóiak nem énekelnek a templomban, s az, hogy oltár sincs, egyáltalán nem növeli az istentisztelet hatását. ${ }^{147}$

A korabeli angol és amerikai unitárius utazóknak a románság iránti előítéletei meglehetősen erősek voltak. Browing az etnográfus szemével nézte Erdély lakóit, s tolla alól a románság munkaerkölcsét bíráló megjegyzések mellett a népviseletet és szokásokat dicsérő őszinte mondatok kerültek ki. ${ }^{148}$

the other high mountains covered with forests and woodlands. The soil is fruitful and the people well to do because they are industrious sober and saving - the last mentioned not being a characteristic in general to be attributed to the Hungarians. The greater number of the 1737 inhabitants are Hungarians; those however not Hungarian are Roumanians - but this is a small proportion - as may be gathered from the fact that the Unitarian Church is the only religious edifice in the town. The Religion of the Roumanian is Greek Catholic - ununited and those who dwell in Torockó have to make a pilgrimage to the neighbouring Roumanian village of Borve [Borév] when they wish to attend divine service.

This morning there were about 500 in the Church - and all in their national dress. The dress of both men and women is peculiar to Torockó and the neighbouring village of Torockószentgyörgy. It is to be found in no other part of Hungary nor indeed of Europe.

The men wear thick flannel pairs of trousers white and tight fitting with a red narrow stripe down the sides and lips Hessian boots with blue silken tinsels in the front. Their shirt is of warm white linen with huge loose sleeves, and over this a waistcoat of wait tanned leather embroidered with yellow and red and braided with a multicoloured braid in different patterns - and the collar to this waistcoat is of fox fur - such a waistcoat costs between 30-40 florins - about three guineas. Over this is worn a thick black woollen cloth mantel also embroidered in red and yellow braid - the lads however being contend with a jacket and tight fitting sleeves of coarse light blue serge - A large round post felt hat crowns the edifice.

With the women - their high festival dress is white - the sleeves and wrists being embroidered in red - over this comes a white red braid and a collar of fox fur like the men - their heads are tightly bound round with a white fine linen handkerchief - and they wear red Hessian boots turning stripes up at the [...]. The marriageable maidens wear as headdress a crown of gold made of papier mâché - tied behind with a red lace - and some twenty or thirty vane coloured bands falling down from the crown behind.

Some of them had green aprons of silk, others of purple and dark blue. Most of the women held in their hand a little nosegay of roses and on entering the church they raised a handkerchief to cover their mouth while they read a little prayer." George Browing Napló V. füzet. (My Hungarian Diary. June 1877. Mss 2527, Erdélyi Múzeum-Egyesület Kézirattára. Ma Kolozsvári Egyetemi Könyvtár különgyưjteménye)

${ }_{147}^{1}$,But the congregation did not appear to have any hymn books - nor did they join in the hymns. In Dalecarlia in Sweden it is so beautiful the church music because the whole congregation lift up their praises to God with one angelic voice. These facts at Torockó and also the absence of an altar has not a good effect." Uo.

148 ,The Wallachians are not a people belonging to the Western civilisation. In their gardens are only weeds and crab apples. They desperately dislike work. The Wallach only grows onions and there he does not even produce from year to year from his own seed - but each year buys fresh seed on the market place of Kolozsvár. But on their fields they plough and sow kukurutz or Turkish corn - török busza - in Transylvania but in Hungary, tengeri, over sea. Kukurutca is a Slav word - but is more used than any other and a term understood in every part of Hungary. (...) The Wallachian costumes are very beautiful, and the type of feature es- 
Június 21-én, vasárnap naplója tanúsága szerint a verespataki román mise után meglátogatta a vidék nevezetességét, a Csetatyet. Ennek leírása után a római aranybányászat technológiájáról, rómaiak és dákok összecsapásairól írt, majd I. Ferenc császárnak Erdélyről írott négysorosa kapcsán jellemzi a vidéket és lakóit. A császár együgyü versikéje a büszke magyar, a lusta román, a részeges német és a szorgalmas szász emlékét örökítette meg. Browing megjegyzi, hogy van ugyan némi igazság abban amit a császár egykor írt, de a románok sorában jól felkészült kiválóságokkal találkozott erdélyi útja során. (Napló, VI. füzet). ${ }^{149}$

A magyar, román és német sajtó ${ }^{150}$ figyelemmel követte Browing Gyulafehérvár és Szeben környéki hosszabb-rövidebb utazásait. Erdély románságáról, bár kezdetben elmarasztaló volt a véleménye, a legnagyobb elismeréssel írt, és józan kritikával mutatott rá a magyar kormány kisebbségpolitikájára, már-már profetikus jóslatokba bocsátkozott a Monarchia

pecially of the men remarkably fine. Their hair falls down in its natural state seldom making the acquaintance of the barber and their deeper tanned skin and dark flashing eyes remind much of the Roman peasant in the Mediterranean." My Hungarian Diary. Gold District; Abrudsburg. June 20-26. 1877. Mss 2527.

149 "A proud Hungarian / A lazy Wallachian / A drunken German / An industrious Saxon and this is to some extent true in the present days - only that Wallachian should not be characterized as lazy. The Wallachians nearly fifty years ago when Emperor Francis gave out his critical opinion were all liegemen or thralls, but since 1848-1849 they made great progress and some of the most intelligent and best informed men it has been my good fortune to meet in Transylvania belong to the Roumanian nationalities - the word Wallach being no longer allowed within their own circles. They complain currently against the oppression of the Hungarian government and apparently with some reason. It is their most sincere wish to found schools for the education of the Roumanian youth but monies collected in Roumania for the reestablishment of a gymnasium or higher school in Brassó (Kronstadt) were not allowed to come into the country. This happened during the present year but the Hungarian government will not be able to hold this nation back - because its desire for having an education is sincere and they are remarkably capable of instruction when once they put their energies into play as is in fact when Roumanians and Hungarians find themselves together in the school. The Roumanians are generally the first and the last in the mixed nationality classes in Hermanstadt, and as a nation are moderate in their political desires as in their daily wants. They can live on extremely little and were the political constellation otherwise would be the most intelligent in the Monarchy. Up to the present however they are looked upon by the Hungarians about the same light that the British have hitherto been in the habit of regarding the people of India ..." Uo.

${ }^{150}$ Telegrafulu Romanu nr. 51. Anul XXV. Sibiiu 30 iuniu, 1877. 205.

„Hosszabb időt töltött Gyulafehérvárott, innen az abrudi hegyen keresztül átrándult Bucsonyba és Topánfalvára. Meglátogatta a templomokat és a falusi iskolákat, és érdeklődött a román nép életviszonyai felől, álmélkodott a hely szépségén, a vendégszereteten $\mathrm{s}$ a románság tiszta háztáján, szorgalmán. Néhány napja Szebenben van, ahonnan gyalog járja be Nagydisznód, Cód, Bojca, Procsesd, Resinari és Seliscea községeit. Megcsodálta a háziipart, s dicsérte vendéglátóit, a román falusi pópákat és jegyzőket." [Fordítás K.S.] Hermanstadter Beitung vereinigt mit dem Siebenbürger Boten 1877, Juli 10. Hermanstadt Dienstag. Nr. 91., 651.

Tageblatt 1877, Juli 10. nro.1076. 635. 
sorsát illetően. Július 3-án Teutsch püspökkel folytatott beszélgetéséről számolt be naplójában (Napló, VII. füzet). ${ }^{151}$

Browing júliusban elkövetett végzetes tette után még néhány napig foglalkoztak öngyilkossága okainak elemzésével, aztán alakja feledésbe merült. Az Összehasonlító irodalomtörténeti lapok 1877. szeptember 15-i számában rövid német nyelvű nekrológot közölt az elhunyt etnográfusról. Valószínűleg Meltzl lehetett a szerző, a szenzációhajhász bulvársajtótól eltérően tárgyilagosan próbált közelíteni a tragikus esethez. Megállapítása szerint a fiatal etnográfust a tífusz félelemkeltő jelei kergették öngyilkosságba. Browingnak köszönhető az irodalomtörténeti lapok címének angol fordítása, 1877. júniusától a nyakatekert A Bi-weekly Paper for the Comparison of History of Literatures helyett, a szabatos A Fortnightly Periodical for Comparative Literature címen jelent meg.

Az angol kör tagjai legközelebb november 17-én az Európa szállodába gyültek össze, hogy megünnepeljék a fennállás első évfordulóját. ${ }^{152}$ Kovács János elnöki beszámolójában elmondta, hogy a nyolc alapító taggal indult kör egy év leforgása alatt tizenkét új taggal gyarapodott, létszáma húszra emelkedett. A június 15-én elhunyt Mary Carpenter emlékét és adományát

\footnotetext{
${ }^{151}$ "Spent an hour with Dr. Teutsch the Bishop or superintendent of Transylvania for the Lutheran Confession - a thorough going literary man - well posted in all data concerning the Saxons as indeed might be expected his book entitled Die Geschichte des Siebenbürgern Sachen für das Säshseschen Volk being at present the standard authority. The Hungarians perhaps would not say so but then the Hungarians and the Saxons are not the best friends in the world. The former have now the reins of government in their hands how long they will be able to hold on is a question especially should the Hungarian government not hit upon some more happy mode of administering justice with common sense. When the Saxons wished to pay their officials a proper salary the government stepped in and interfered because they were afraid they would have to do the same instead of continuing the old system of underpaying the officials and shutting the eyes to bribery and corruption. It would be less expensive in the long run were the Hungarian Government to see with clearer eyes than apparently at present their powers the undermining influence on the whole fabric of the state that the present system of winking at wickedness must sooner or later entail. Although' the Hungarians are extremely hospitable to strangers and even to their own countryman yet they have grave faults - are far too materialistic - each plays for his own good at the palpable expense of the fatherland and this in a country where the patriotism should be real and not feigned - not a string of loose words that make a great deal of noise - a great deal of clatter - but the nation should hold itself together for all emergencies for there is no denying the fact that the position of Hungary with the present European questions on the tapis is not an enviable one nor one that can be maintained in status quo in the event of an European war.

In the afternoon I paid a visit to the Roumanian Archbishop or Metropolite of Transylvania, who appeared an extremely intelligent man. We conversed in German. He received me most kindly and on my expressing a wish to become more closely acquainted with Wallachian or rather Roumanian affairs his excellency rang the bell and ordered the servant to conduct me to his private secretary who had received instructions to show me every possible attention and to give every facility for the carrying out of my wishes." My Hungarian Diary. June 26 July 1877. Mss 2527.

${ }^{152}$ Magyar Polgár, 1877. november 17., 265. sz.
} 
a kör jegyzőkönyvében is megörökítették. Az angol jótevő életrajzát Kovács közölte a Hölgyfutárban és a Keresztény Magvetóben. A Conversation Club egyéves fennállását ünneplő társaság, Szász Róbertet és Szombathelyi Gusztávot leszámítva, a kolozsvári tudományegyetemen tanított. Finály Henrik, Jenei Viktor, Török Aurél, Concha Győző, Hőgyes Endre, Gyergyai Árpád, Szász Béla (1840-1898) költő, műfordító, egyetemi tanár, Koch Antal (1843-1927) 1895-ig volt a kolozsvári egyetem tanára, geológus, és Szabó Károly (1824-1890) történész vettek részt az ünnepségen. Az éves működés mérlegét egy levél kíséretében az angol unitárius lapszerkesztőknek is megküldték. Kovács János elnök megelégedéssel nyugtázta, hogy a kolozsvári napilapok pozitívan értékelték a klub tevékenységét, és azt remélték, hogy nemcsak az angol nyelv, de az angol szokások is meghonosodnak Erdélyben.

Az 1878. év jóval szegényebb volt eseményekben az előzőnél; a körnek nem volt egyetlen angol látogatója sem, és az esztendő során mindössze két híradás foglalkozott tevékenységével. Januárban megtartották az évi rendes közgyúlést, ${ }^{153}$ megválasztották a régi-új tisztikart, a nyári szünet után pedig október 17-re az elnök gyűlésbe hívta a tagokat. ${ }^{154}$

\subsubsection{Alexander Gordon és Andrew Chalmers Magyarországon és Erdélyben}

1879-ben a Magyar Unitárius Egyház alapítója, Dávid Ferenc halálának háromszázadik évfordulóját készült méltóképpen megünnepelni, és a jeles eseményre mind az angol, mind az amerikai Unitárius Társulat képviselőit meghívták. Talán a tervbe vett egyházi ünnepségekre való tekintettel az elnök már január 9-én megbeszélésre hívta a tagokat. ${ }^{155} \mathrm{~A}$ közgyưlést végülis március 6-án tartották meg, megejtve a szokott választásokat. A tisztikar soraiban nem történt változás, a választmány tagjai kivétel nélkül egyetemi tanárok lettek: Felméri Lajos, Finály Henrik, Concha Győző és Koch Antal. A kör nemcsak az angol nyelv múvelését, de az angol szokások, a „munkakedv és előrehaladás" erdélyi meghonosítását tűzte ki célul. ${ }^{156} \mathrm{~A}$ tavaszi klubélet valószínűleg a normális kerékvágásban haladt, a tagok hetente találkoztak, társalogtak. A kolozsvári sajtóban július 9-én jelent meg az első, a klubot is érdeklő, de elsősorban az unitáriusok készülő ünnepségére utaló híradás. ${ }^{157} \mathrm{~A}$ londoni tudósító szerint az BFUA-t az

\footnotetext{
${ }^{153}$ Magyar Polgár, 1878. január 27., 23. sz.

${ }^{154}$ Uo., 1878. október 17., 239. sz.

${ }^{155}$ Uo., 1879. január 9., 6. sz.

${ }^{156}$ Uo., 1879. március 8., 56. sz.

${ }^{157}$ Angolok az erdélyi részekben, Magyar Polgár, 1879. július 9., 155. sz.
} 
erdélyiek zsinatán Alexander Gordon ${ }^{158}$ (1841-1931) belfasti lelkész fogja képviselni. A jól értesült londoni újságíró szerint Gordon ívenként kapja John Fretwelltől Jakab Elek Dávid Ferenc emléke címü - az emlékzsinaton bemutatandó - monográfiáját, és annak angol fordításán dolgozik. Jakab Elek monográfiája angolul nem jelent meg, bár kiadását többször is tervbe vették. ${ }^{159}$ Gordon behatóan tanulmányozta a magyar unitáriusok történetét, és a jelek szerint valamennyire magyarul is megtanult. 1879-ben, Ferencz József püspöknek a következő magyar nyelvű levelet küldte:

„Tisztelendő Uram! Engedje meg Ön, hogy szíves hálámat adjak önnek a barátságos leveljéért. Szándékom van ha Isten úgy akarja Kolozsvárott megérkezni nyolcadhó tizenegyedik vagy tizenötödik napjakor. Én ismét önnek Pestről jelentkezni fogok. Bocsásson meg, hogy úgy rosszul a magyarságot írjam. Szeretnék egy hosszabb levelet írni, de nem tehetek róla: hanem remélem, hogy hozzátok megyek, és szemtől szembe szólok, hogy a mi örömünk teljes legyen. ${ }^{160}$ Legalázatosabb szolgája, Gordon Sándor."161

A belfasti ír unitárius lelkész magyar nyelvismerete mellett egy másik adat is tanúskodik. Az ünnepi zsinatról írt beszámolójában ${ }^{162}$ Torockó kapcsán, Jókai Egy az Isten címü regényére hivatkozva, elmondta, hogy hosszú utazása során a regény kedves bája feledtette fáradalmait. ${ }^{163} \mathrm{Ha}$ Fretwell csakugyan elkészült a regény fordításával, akkor ezt olvashatta Gordon Erdélybe vezető útján, elképzelhető azonban az is, hogy magyarul olvasta Jókait. Hogy magyarul legalább olvasni megtanult, tanúsítja az is, hogy az Inquirerben és a Christian Lifeban rendszeresen szemlézte a Keresztény Magvetót. Az emlékzsinatról a The Christian Life szerkesztőjéhez

${ }^{158}$ Alexander GoRdon (1841-1931) unitárius lelkész, történész és bibliográfus, 1889-től 1911-ig volt a manchesteri Unitarian Home Missionary College principálisa. Lásd: Herbert McLachlan, Alexander Gordon (9 June 1841 - 21 February 1931) a Biography with a Bibliography, Manchester University Press, 1932.

${ }^{159}$ A fordítás gondolatát még a századfordulón is latolgatták az erdélyi unitáriusok. Boros György az Amerikai Unitárius Társulat 75. évfordulóján tett amerikai látogatása során mindent megpróbált, hogy „,e nagy teológus és hatalmas reformátor élete és múködése ismertté tétessék a külföld előtt is", de Jakab müvének angol fordítására nem került sor. Vö. Boros György, Az ámérikai Unitárius Társulat 75. évi jubileuma, Kolozsvár, 1900. 4.

${ }^{160}$ A 2 Jn 1,12 parafrázisa. „Sok írnivalóm van számotokra, de nem akartam papíron és tintával írni; remélem azonban, hogy eljutok hozzátok, és személyesen beszélhetünk, hogy örömünk teljes legyen."

${ }^{161}$ Emlékkönyv, vol. II., 86.

${ }^{162}$ Alexander Gordon, Report of an Official Visit to Transylvania, London, 1879. A 42. lapra terjedő nyolcadrét füzet tartalmát ismertette a KerMagv, 1880., 68-70. Lásd még: FABINY Tibor, Accounts and Images..., 138-142.

163 „,... I knew it from the powerful romance of Maurice Jókai, Egy az Isten (God is One), the reading of which had beguiled the long houres of my railway and steam-boat travel... This is the church whose bell, according to Jókai, has no Calvinism, about it, but rings out ever, with brave single strokes, the Unitarian creed, „,One! One! One! One!” Report of an Official Visit to Transylvania, 14. 
küldött levelei alapján készült el a későbbi, ${ }^{164}$ 1879-ben nyolcadrét formában nyomtatásban is megjelent, a BFUA tanácsának benyújtott hivatalos jelentése. Gordon 1879-es kelet-közép-európai útja után is ápolta kapcsolatait magyar barátaival. ${ }^{165} 1929$ decemberében az erdélyi unitáriusok Dávid Ferenc halálának 350. évfordulójára emlékeztek, és Boros György püspök az ünnepségekre meghívta az agg professzort is. Gordon, előrehaladott korára hivatkozva, udvariasan visszautasította a meghívást. A gondviselés kísértése lenne - írta - nyolcvannyolc évesen, télvíz idején a kontinensen utazni. ${ }^{166}$ Dávid Ferenc iránti háláját az emlékzsinaton felolvasott levelével rótta le. ${ }^{167}$

Az unitáriusok 1879. évi zsinatára egy másik angol vendég is érkezett, Andrew Chalmers (1840-1912) személyében. ${ }^{168}$ Az angol látogatók mellett az amerikai John Healy Heywood (1818-1902) louisvillei lelkész látogatására is számítottak, ő azonban nem tudott részt venni az ünnepségeken. Chalmers 1879. szeptember 6-án előadást tartott a társalgó körben Beaconsfield és Gladstone politikájáról és a „keleti kérdéshez” való viszonyukról. ${ }^{169}$ Mint meggyőződéses Gladstone-párti, Disraeli kormányát (1874-1880) bírálta, és előrevetítette Gladstone liberális pártjának

164 The Hungarian Celebration, September 6, 1879, 431-432. The Celebrations in Hungary September 13, 1879, 444. Hungary, September 20, 1879, 456. A Journey's end, October 4, 1879, 479-480. A The Christian Lifeban közzétett beszámolóiból The Transylvanin Trecentenary címen közölt részeletet a bostoni The Unitarian Review and Religious Magazine, October 1879, 427-431.

${ }^{165}$ A The Christian Lifeban többször cikkezet erdélyi unitárius témakörben. Fontosabbak: Bishop George Enyedi, 1881, 33., Hungarian Unitarian Church, 1880, 213-214., Transylvania, 1884, 466., Déva, 1887, 574., A Glance Back, March 12, 1921, 84. A Transylvanian Captive, 1924, 252-253.

${ }^{166}$ H. McLachlan, Alexander Gordon..., 122.

${ }^{167}$ A Magyar Unitárius Egyház Fötanácsának a Dávid Ferenc halála 350-ik évfordulója emlékünnepélyével kapcsolatosan Kolozsvárt, 1929. november 10., 11. és 12. napjain tartott évi rendes üléseiről szerkesztett Jegyzókönyv, szerk. Varga Béla, Kolozsvár, 1930, 14-15.

${ }^{168}$ Andrew Chalmers (1840-1912) Cambridge-i majd Wakefield-i lelkész. Magyarországi és erdélyi élményeit megírta, és kiadta Transylvanian Recollections: Sketches of Hungarian Travel and History címmel. Magyar ismertetőt közölt róla Kovács János, Chalmers Erdélyról, KerMagv 1881, 41-46. A keresztúri zsinatról írott beszámolóját a Manchesterben kiadott The Unitarian Herald (továbbiakban Herald...) folytatásokban közölte. A The Unitarian Herald hetilapot 1861ben Manchesterben alapították John Relly Beard, William Gaskell, Brooke Herford és John Wright lelkészek. A lap 1889-ben beolvadt a Christian Lifeba. Lásd: Hungary: The Francis David Trecentenary, Herald... September 12, 1879, 293. Transylvanian Recollections, Herald, October 8, 317. October 10, 326. October 17, 333. October 31, 348-349. November 14, 365. November 21, 373. November 28, 380-381. December 5, 389-390. December 19, 405-406. Januray 2, 1880, 5. January 9, 13. January 16, 21-22. February 6, 44-45. February 20, 62. March 5, 77-78. March 19, 91. April 16, 122-123p. May 14, 159-160. June 18, 198-199.

${ }^{169}$ The Policy of Gladstone and Beaconsfield in Reference to the Eastern Question, Transylvanian Recollections, 83-96. Az Angol Körben tartott előadásról terjedelmes beszámolót közölt a Kelet, 1879. szeptember 10., 206. sz. 
győzelmét (1880-1885). A kormányváltás rendszerint külpolitikai irányváltással is jár(t), s Gladstone-éknak a bulgáriai atrocitások széles sajtónyilvánosságával sikerült az angol közvéleményt a törökök ellen hangolni. Az English Conversation Club tagjai természetesen törökbarát álláspontot képviseltek, és Chalmers előadása élénk vitát keltett. Magyarországon és Erdélyben nagyon erős volt a török szimpátia (parlamenti felszólalások, diáktüntetések stb.), a Liptay Pál vezette budapesti English Clubban már 1877. október 20-án, a Vámbéry Ármin tartotta felolvasáson - The civilizing efforts of the Turks - a török sebesültek javára gyüjtöttek. ${ }^{170}$ A nézetkülönbségek ellenére a kolozsvári előadás is jól sikerült, és „Chalmers általános éljenzésben (cheers) részesült”. Az előadót Kovács János javaslatára a klub tiszteletbeli tagjává választották, és azt kívánták, hogy „győzzön Gladstone, mint szabadelvü, csak a mi keleti kalkulusainkat ne zavarja." ${ }^{171}$ Gladstone győzelme alaposan összezavarta a Monarchia „keleti kalkulusait”, de igazolta Chalmers politikai tisztánlátását. Chalmerst és Gordont hazatérésükkor, 1879. október 22-én, ünnepélyesen fogadta a BFUA tanácsa. Boros György a Manchester College egyik tanárának, Kovács János a Christian Life szerkesztőjének küldött leveleikben beszámoltak a zsinatról és megköszönték a kiváló képviseletet. ${ }^{172} \mathrm{Az}$ angol egyházdiplomaták tiszteletére a londoni Cannon Street Hotelben rendeztek nagyszabású fogadást, melyen nemcsak unitáriusok, de a Kossuth-emigráció két tagja is részt vett. ${ }^{173} \mathrm{~A}$ BFUA elnöke, David Martineau, üdvözölte az egybegyưlteket, majd felkérte a társulat titkárát, Henry Iersont (1819-1892), olvassa fel a kolozsvári konzisztórium üdvözlő iratát. Ezt követően az elnök rövid felvezetőt tartott a magyar unitarizmus történetéről, majd a képviselők kaptak szót. Chalmers a magyar unitáriusok szabadságszeretetét és hithüségét emelte ki beszédében, és azt, hogy a kelet-európai hitrokonaik iránti szimpátia Isten akaratával egyező magvetés, mely előbb-utóbb termést hoz. Gordon az erdélyiek angol-rajongásáról, és arról a vallásos toleranciáról beszélt, melyet a keresztény testvérfelekezetek részéről utazása során megtapasztalt. ${ }^{174} \mathrm{Az}$ unitáriusok szegények - mondta -, de lélekben és erkölcsben gazdagok, sokkal többet törődnek a neveléssel és oktatással, mint a föld túrásával. Kiváló falusi iskolákat tartanak fenn, annak ellenére, hogy mezőgazdasági eszközeik nagyon kezdetlegesek. Gazdagságuk az elmékben gondosan elültetett tanokban áll, és magyarországi hitrokonaik nem egy „izmusnak”, hanem egy Egyháznak a tagjai. Ezt követően Gordon az egy-

\footnotetext{
${ }^{170}$ A Hon, 1877. szeptember 28., 253. sz.

${ }^{171}$ Kelet, 1879. szeptember 10., 206. sz.

${ }^{172}$ Boros György, The Hungarian Tercentenary, The Christian Life, October 4, 1879, 475. Kovács János, Hungarian Correspondence, Uo. October 18, 503.

${ }^{173}$ Welcome Meeting in London, The Christian Life, October 25, 1879, 510-511.

${ }^{174}$ Uo.
} 
ház felépítését és az iskolák állapotát ismertette, majd a budapesti misszió fontosságára hívta fel a figyelmet. A BFUA tanácsa határozati javaslatban köszönte meg küldöttei munkáját, és vállalta továbbra is a kelet-európai hitrokonokkal a kapcsolatok ápolását. A fogadáson Steinthal is felszólalt, felidézvén 1859. évi erdélyi élményeit. Gordon beszámolóját már 1879-ben kiadta, Chalmers folytatásban megjelent ismertetőjét csak 1880-ban tudta kinyomtattatni. Útirajzaik nem sokban különböztek az elődeik - Tagart, Steinthal, Tayler - által írt hasonló beszámolóktól. Chalmers kis könyvének megjelenése után négy cikkből álló sorozatban, A Unitarian Church for Budapest címen, továbbgondolta élményeit és a magyar nemzet történetéről adott áttekintőt. A címből ítélve az olvasó arra gondolhatott, hogy a fővárosi templomépítés érdekében agitált a szerző. Ez meg is történt ugyan a befejező közleményben, de megelőzőleg hosszasan írt a magyarok eredetéről, Pannóniába jöveteléről, a hun-székely eredetről és az unitarizmus kialakulásáról. ${ }^{175}$ Utolsó közleményében tért rá a budapesti templomépítés fontosságára. A cél, írta, nem pusztán egy épület felhúzása, ahol alkalomszerü istentiszteletet tartanak, hanem az unitárius misszió központjának megteremtése. E központ köré csoportosulhatnak mindazok, akik a modern szellem képviselői, és akik hitüket az evangélium egyszerűségében keresik. A fővárosi központ kiépítése Chalmers szerint lassan oda fog vezetni, hogy Kolozsvár unitárius intézményei is Pestre költöznek. Kolozsvár túl kicsi ahhoz, hogy befolyásolni tudná a közvéleményt és a nemzetet, Budapest azonban bír ezen előnyökkel. ${ }^{176}$ Chalmersnak a fővárosi unitárius templom anyagi támogatását sürgető kampánya annak a Kolozsvárról és Budapestről irányított lobbinak volt szerves része, mely Nagy-Britannia és Írország unitáriusainak összefogásával kívánta a pesti papságot fenntartani és a templomot felépíteni. A budapesti unitáriusok 1880. január 8-i keltezéssel céljuk megvalósítása érdekében egy Kovács János szerkesztette angol nyomtatványt terjesztettek. Ebben utaltak az angol látogatók beszámolóira, az unitarizmus erdélyi történelmi gyökereire, valamint a 16. századi Duna-Tisza közi unitárius misszióra, Egri Lukács, Karádi Pál, Vá-

\footnotetext{
${ }^{175}$ Herald, August 1880, 255., 263., 277.
}

176 „Pesth (...) has the strong current of a fresh and vigorous life flowing through its spacious streets and squares. With its 330000 inhabitants, its vast educational and literary institutions, its increasing commerce, its splendid public buildings and hotels, and its magnificent position on both banks of the Danube, it is rapidly becoming what Venice and Vienna formerly were, the meeting place between East and West, between Oriental and European civilization. Like Edinburgh, it affords a remarkable contrast of venerable antiquity and mediaeval picturesqueness on the one hand with modern elegance and energetic enterprise on the other. Few can enjoy the unsurpassed prospect from the citadel of Buda, with the Danube like a broad band of silver dividing the fortress-palace and quaint streets of the ancient capital from the stately terraces and broad esplanades of Pesth, without inwardly indulging in the prophesy that here one of the great cities of the future has been founded." Uo., 287. 
laszúti György szerepére. Az unitarizmus Királyhágón-túli kontinuitása az ellenreformáció mesterkedései miatt elakadt, az 1848. évi országgyűlési végzés és a kiegyezés utáni erdélyi unitárius migráció azonban lehetővé tette a fővárosban is egy magyar unitárius egyházközség megszervezését. A fővárosi jelenlét előnyeinek felsorolása után az állandó papság fenntartása és a templomépítés érdekében anyagi segítséget kértek hittestvéreiktől. Chalmers cikksorozata lényegében ehhez az akcióhoz kapcsolódott, nem is egészen eredménytelenül, hiszen 1881-1890 között az angol és amerikai unitáriusok 100-100 font sterlinggel járultak hozzá a fővárosi állandó lelkészi állás fenntartásához. ${ }^{177}$ Chalmers 1880 után is élénk kapcsolatot ápolt erdélyi barátaival. Kovács Jánoshoz küldött levelei mellett a Magyar Polgárban közölt írásai is bizonyítják a magyar unitáriusok és a nemzet iránti rokonszenvét. ${ }^{178}$

${ }^{177}$ Szaniszló József, A budapesti unitárius egyházközség története a jegyzőkönyvek tükrében, Budapesti Unitárius Egyházközség, 2010, 44.

${ }^{178}$ "Nagy szükség van arra, hogy jelenleg Anglia és Magyarország jobban megértsék egymást. Mivel a két nemzet nagy tévedésben van a keleti kérdést vagyis inkább az arra vonatkozó nézeteket illetőleg. Mi angol szabadelvűek nem szeretjük Oroszországot és elhatározott szándékunk oda hatni, hogy a Dunától északra maradjon és a Prut folyótól eltávolíttassék. De mi úgy véljük másfelől, hogy eljött már az idő, hogy a Duna-melléki nemzetek is a civilizáció útjára lépjenek és azt óhajtjuk, hogy Magyarország is nagylelkűséget és szívességet mutasson irántuk. És ez lesz a legjobb mód a muszka befolyás és terjeszkedés meggátlására. De ha önök féltékenyek (irigylik) az ők szabadságukra: akkor arra kényszerítik őket, hogy az északi despotizmushoz folyamodjanak védelemért. (But if you grudge them their freedom you will compel them to turn to the despotism of the north for protection.) Nagyon el lévén jelenleg foglalva, nem írhatok e tárgyról bővebben. De legyen meggyőződve, hogy Magyarország nagyon kedves nekem s ha körülményeim engednék, szeretnék egy pár évet Budapesten tölteni s írni mind az angol és a magyar lapok számára, hogy ezáltal sok téves nézetet eloszlassak és barátságosabb érzelmet hozzak létre a két nemzet között. De itten is ügyüket szolgálni fogom, s ama tapasztalatokat s tanulmányokat, melyeket a múlt évben szerencsés valék önöknél szerezni: az önök előnyére a legjobb szándékkal érvényesíteni fogom." Magyar Polgár, 1880. április 20., 91. sz. 


\subsubsection{Angolok és amerikai látogatók a kolozsvári English Conversation Clubban}

\subsubsection{Joseph Henry Allen és a legősibb unitárius közösség}

Az English Conversation Club 1880. január 15-én tartotta évi első közgyülését; Kovács az elnöki megnyitóban az angol nyelv müvelésének sokoldalú előnyeiről értekezett. ${ }^{179}$ A körnek huszonhat tagja volt, a tagsági díjat 1880-ra a rendes tagok részére három forintban állapították meg. A Budapestre távozott Koch Antal helyére választmányi tagnak Brassai Sámuelt választották meg. Angol látogatója 1880-ban nem volt a körnek, és legközelebb szeptember 30-ra hívta gyưlésbe a tagokat az elnök. ${ }^{180}$ A klub fennállásának első éveihez viszonyítva nagyon megcsappant a felolvasások száma. Ezt pótolta némiképp az Angliában tanuló unitárius papjelölt, Varga Dénes (1851-1938), a Magyar Polgárban rendszeresen közölt Londoni leveleivel. ${ }^{181}$ Varga a nyári szünidőben tett utazásait és élményeit ismertette a kolozsvári olvasókkal. A fontosabb angol fürdőhelyeket és az itt látott fürdőzési szokásokat írta le. Wakefieldi látogatása során, Oliver Goldsmith The vikar of Wakefieldjére utalva, a kolozsváriak által ismert unitárius pap, Andrew Chalmers wakefildi müködését és magyar ügybuzgóságát ismertette. A Fortnightly Review 1880. áprilisi számában John Arthur Evans Az ausztriai ellenforradalom a Balkánon (The Austrian Counter Revolution in the Balkans) címen hosszabb cikket írt, és a Monarchia felbomlását jósolta. Chalmers és Varga igencsak kifogásolta a szerzőnek a magyar nemzetről írott jellemzését. Hogy jellemezi a nemzetet anélkül - kérdi cikkében Varga -, hogy annak nyelvéből valamit értene, annak szellemét fel tudná fogni, és anélkül, hogy tán valaha országunkban is járt volna? Chalmers erdélyi beszámolója utolsó közleményében reagált Evans cikkre. Ebben amellett érvelt, hogy:

„,a magyar nemzet nem ellensége a szláv népek szabadságának, mint azt némelyek el akarják hitetni. A magyar állam hosszú tapasztalatokon okulva választja meg politikai álláspontját; önfenntartáshoz való erejének és képességének elég látható jelét adja. Országgyưlése 986 év előtt gyűlt össze, és így egyike a legrégibb törvényhozó testületnek Európában." 182

\footnotetext{
${ }^{179}$ Uo., 1880. január 17., 13. sz.

${ }^{180}$ Uo., 1880. szeptember 30., 226. sz.

${ }^{181}$ VARga Dénes, Londoni levél, 1880. szeptember, Magyar Polgár, 1880. szeptember 22-25., 219-222. sz. Vö. Andrew Chalmers, Transylvanian Recollections. Hungarian Patriotism XVIII., Herald, May 14, 1880, 159-160.

${ }^{182}$ Magyar Polgár, 1880. szeptember 23., 220. sz.
} 
Nagyon szép nyilatkozat ez Chalmerstől - írta Varga -, különösen, ha tekintetbe vesszük, hogy ő meggyőződéses liberális-párti, Gladstoneékkal pedig a magyar nemzet nem tud egyetérteni. A nyári szabadságát mulató unitárius diák olvasóit Wakefieldből Yorkba, majd New Castle-be kalauzolta. Ezután Edinburgh, Glasgow, Liverpool, és Birmingham bemutatása következett. Az angol ipari központok után Standfordba, a múzsák helyére, majd Oxfordba, és végül Windsorba látogatott.

1881-ben nem történt rendkívüli esemény a társalgó körben. Az elnök fontos egyházdiplomáciai küldetésben a Magyar Unitárius Egyházat képviselte a BFUA évi közgyülésén. 183 Útja egyházpolitikai szempontból roppant fontos és sikeres volt, nemcsak azért, mert a francia és olasz szabadelvű protestánsok vezetőivel, Athanase Coquerel (1820-1875) ${ }^{184}$ és Ferdinando Bracciforti ${ }^{185}$ milánói tanárral találkozott, hanem azért is, mert Kossuth Lajost is meglátogatta torinói otthonában. Kossuth 1884-ben levelet írt Kovács Jánosnak, és ebben az unitarizmusról is részletesen kifejtette véleményét. A magyar unitáriusok a felekezet hírnevének öregbítésére a levelet a legszélesebb körben népszerüsítették, és ezzel is erősítették magyarországi pozíciójukat. Kovács János 1881. évi egyházdiplomáciai útja során Londonban találkozott Joseph Henry Allennel (1820-1898), a Harvard Divinity School egyháztörténészével. Kovács meghívására Allen Magyarországra és Erdélybe követte újdonsült barátját, és útjáról a Christian Register és a The Unitarian Review hasábjain számolt be. Tárgyilagos, meleghangú beszámolója 1881 késő őszén különlenyomatban is megjelent, magyar kivonatát közölte Kovács János a Keresztény Magvetóben. ${ }^{186}$ Allen kolozsvári jelenléte új színt és életet vitt a magyar-amerikai kapcsolatokba. Ismeretes, hogy az 1870-es években az amerikai-magyar unitárius kapcsolatok egyik legelkötelezettebb támogatója az angolból amerikaivá lett John Fretwell volt. Ô azonban a magyar gazdaság felemelését célzó sorozatos

${ }^{183}$ Hivatalos Jelentése Kovács János igazgató tanárnak, melyet mint a „Brit és Külföldi Unitárius Társulat" ez évi közgyülésére küldött képviselő az unitáriusok E. K. Tanácsához folyó évi július 31-én beadott, KerMagv, 1881, 243-247.

${ }^{184}$ Athanase-Josué Coquerel (1820-1875) Laurent Charles fia, francia protestáns teológus, a vallásszabadság és liberalizmus elkötelezett híve. Nevéhez füződik az első francia nyelvü teológiai folyóirat - Nouvelle Revue de Theologie - megalapítása. A francia Protestáns Történelmi Társaság is neki köszönhette létét. Liberális nézeteiért és Rénan Jézus életéről 1864-ben írott cikkéért a protestáns ortodoxia kiközösítette. 1873-ban a bécsi kiállításról Kolozsvárra is eljött, Kriza Jánossal is találkozott. A KerMagv unitárius érzelmeiért és liberális beállítottságáért rendszeresen tudósított az angol és amerikai unitáriusokkal fenntartott kapcsolatáról. Vö. KerMagv, 1861, 237.; 1867, 280.; 1871, 234.; 1872, 77.; 1873, 201.;

${ }^{185}$ Ferdinando BRACCIFORTI (?) szótárszerkesztő, liberális gondolkodó, a milánói unitárius csoport vezetöje.

${ }^{186}$ Rev. Joseph Henry Allen, A Visit to Transylvania and the Consistory at Kolozsvár, Boston: George H. Ellis, Franklin street 1881. Allen Henrik tanár látogatása Erdélyben, KerMagv, 1882, $42-48$. 
üzleti kudarcai (borexport, húsfeldolgozás) után visszalépett a tevőleges támogatástól, helyét Allen vette át. A magyar unitáriusok már egy évtizeddel korábban fontolgatták egy missziós csoport Észak-Amerikába küldését, de a terv különféle okok miatt meghiúsult. ${ }^{187}$ 1881-ben az Amerikai Unitárius Társulat meghívására, de Joseph Allen biztatására és tanácsára is hallgatva ${ }^{188}$ az egyház Kovács János amerikai egyházdiplomáciai küldetését határozta el. Allen hazatérése után több nyilvános gyülésen is méltatta a magyar unitárius egyház kelet-közép-európai jelentőségét. 1881. október 5-én Princetonban, a Ministers' Institute-ban hosszú felolvasást tartott a legősibb unitárius közösségről. ${ }^{189}$ Hallgatóságával ismertette a magyarok történelmét, beszélt a székelyek hun eredetéről, a szabadságharcban tanúsított rettenthetetlen bátorságukról, majd az unitarizmus kialakulását vázolta a kezdetektől 1881-ig.

\footnotetext{
${ }^{187}$ 1868-ban Charles Dall kalkuttai misszionárius Kolozsvárra látogatott, s a magyaramerikai kapcsolatok Bölöni Farkas Sándor által lángra lobbantott, de rövidesen kialudt tüzét újból felszította. Dallnak Kovács Jánossal folytatott levelezéséből az derül ki, hogy az erdélyi unitáriusok komolyan fontolgatták az amerikai pénzgyűjtő körút megszervezését, s tengerentúli testvéreiktől komoly anyagi segítséget reméltek. Az 1873-ra tervezett körút végül is tűzvész áldozata lett, 1872. novemberében ugyanis óriási tűzvész pusztított Bostonban s az amerikai unitáriusok anyagi erejüket elsősorban a tűzkár enyhítésére kellett fordítsák. Vö. Dall levelét Kovács Jánosnak 1873. március 26. Calcutta. Kovács hagyaték 2 doboz 32/D.

${ }^{188}$ Emlékkönyv, vol. II., 132-133. Joseph Allen Kovács Jánosnak, 1882. május 28. Cambridge.

„Nagy örömmel értesültem a napokban az Amerikai Unitárius Társulat titkárától, hogy az Önök konzisztóriumát föl fogja hívni, hogy a folyó évi szeptember hóban Saratogában tartandó nemzeti konferenciára képviselőt küldjön. És minthogy önök gyakori érintkezésben vannak az angol unitárius hit rokonokkal, én bízom, hogy a képviseltetés nem lesz lehetetlen s kivihetetlen; 30-40 font sterlingre menne a szorosan vett költség, melyet az Angliába küldött követnek útiköltségeihez pótolni kellene. A még felmerülendő felesleges kiadásokat azok az eklézsiák, melyekben az illető küldött prédikálna, örömest fedeznék. Tegyük fel, hogy az útiköltség Angliába s vissza 50 font sterling; onnan Amerikába 40-50 font sterling: összesen 100 font sterling. De nekem úgy tetszik, hogy az összeg általában véve kevés amaz egyetemes előnyhez képest, mely abból származnék; mert kétségkívül egy küldött személyes megjelenésével sikerre emelhetné az én eddigi törekvéseimet; ti. személyesen s élő szóval hozni s állítani a mi népünk élénk képzeletébe az önök helyzetét, működését s az önök azon igényeit, melyek által rokonszenvünkre számíthatnak. Én a többek között igyekeztem felmutatni politikai helyzetüket, s érdekeltséget kelteni az iránt, hogy Európa délkeleti részén minő fontos missziót teljesítenek a nevelés terén $\mathrm{s}$ a szabadelvü vallásos nézetek terjesztésében, s hogy milyen szép jövő áll önök előtt. Az ilyesmik, s különösen vallásos működéseik s mozgalmaik nagyon érdekelnék a mi népünket. Minden információ, melyet (például: Ön) adhatna, s azok a kérdések, amelyekre felhívnák, hogy megfeleljen, olyanok lennének amiket én a legnagyobb fontosságúnak tekintek. (...)

Öszinte híve, Joseph Allen."

189 The Oldest Unitarian Community, The Unitarian Review, January 17, 1882, 38-52.
} 


\subsubsection{Charles Brace Erdélyben, Kovács János Amerikában}

Az amerikai tanár felolvasásával egy időben Kolozsvárott is élet költözött az Angol Társalgó Körbe, és féléves szünet után 1881 őszén elkezdődtek a felolvasások. A sort ezúttal is az elnök nyitotta meg, 1881. december 1-jén A Lecture on London and the Customs of London people ${ }^{190}$ címü felolvasásával. ${ }^{191}$ Az előadó elsősorban okítani és szórakoztatni akarta hallgatóit, ezért dióhéjban ismertette a főváros fejlődéstörténtét, néhány friss statisztikai adattal pedig annak dinamikus fejlődését illusztrálta. Előadásának csupán vázlata maradt fenn, így a címszavakból következtethetünk annak tartalmára: Rikkancsok, A vasárnap Londonban, Utcai prédikátorok, Színház, Vendégfogadók, Családi élet, Angol kényelem.

Az új 1882. esztendő első közgyülését január 19-én tartották. ${ }^{192}$ A klub tavaszi és kora nyári tevékenységéről nincs adatunk. Kovács János elnök éppen észak-amerikai útjára készült - 1882. augusztus 27-től 1883. március 7-ig -, amikor augusztus 12-én a magyarok régi, kedves ismerőse, Charles Loring Brace (1826-1890), az amerikai Gyermeksegélyző Társaság (Children's Aid Society) alapítója és titkára érkezett a városba. ${ }^{193} \mathrm{Az}$ angol klub tagjai az Újvilág nevű vendéglőben találkoztak az immár harmadjára Magyarországra látogató Brace Charlesszal. Brace-t első, 1851-ben tett magyarországi útja során Váradon kémkedés vádjával letartóztatta az osztrák rendőrség, két hónapig börtönben ült. Élményeit Hungary in 1851; with an Experience of the Austrian Police címen New Yorkban adta ki 1852-ben. ${ }^{194}$ 1872 nyarán másodszor látogatott Magyarországra, útja során unitáriusokkal is találkozott. Nyárádmenti unitárius tapasztalatairól, Farkas György szengericei esperessel folytatott beszélgetéséről, az erdélyi felekezetek békés együttéléséről elmélkedve az erdélyi unitarizmus Nyugat-Európát is megelőző, a vallásos toleranciát törvénybe iktató szerepét méltatta. ${ }^{195}$

\footnotetext{
${ }^{190}$ Kovács János hagyatéka 1 doboz 5. sz.

${ }^{191}$ Ellenzék, 1881. december 2., 276. sz.

${ }^{192}$ Ellenzék, 1882. január 17., 13. sz.

${ }^{193}$ Brace 1853-ban alapította a Gyermeksegélyző Társaságot. A szervezet célja az volt, hogy az amerikai metropolisokban hányódó gyermekeket kijuttassa a városból, ahelyett, hogy intézetbe helyezné el őket. Eleinte kisebb, majd nagyobb csoportokat küldtek nyugat felé, és ott farmercsaládok gondjaira bízták őket. Az 1929-ig tartó program során az „árva szerelvények” mintegy 100 ezer gyermeket szállítottak nyugatra. Vö. Stephen O'ConNor, Orphan Trains: The Story of Charles Loring Brace and the Children He Saved and Failed, University Press of Chicago, 2004.

${ }^{194}$ Magyarul lásd: Charles Loring BRACE, Magyarország 1851-ben: személyes beszámolóval az osztrák rendőrségröl, ford. és az utószót írták LÉvaI Csaba és VIDA István Kornél, Attraktor, 2005.

195 "At an age, when Philip Second was burning Protestant heretics, and Elizabeth tormenting Catholics, and the Jews were driven from city to city, and the idea of religious liberty was unknown in the civilized world, the little Kingdom of the Seven Burgs under Unitarian influ-
} 
Az unitáriusokról általában azt állapította meg, hogy magas erkölcsi érzékkel bírnak, és hogy tagjaik a legértelmesebbek az Erdélyben élő felekezetek között. ${ }^{196}$ Utazásai során írott leveleit sorozatban közölte a New Yorkban kiadott Christian Union címú hetilap. ${ }^{197}$ A magyar sajtó Brace portréjának és életrajzának közlésével rótta le háláját. ${ }^{198}$ Brace utolsó magyarországi és erdélyi látogatására 1882-ben került sor. Ekkor kereste fel Kolozsvárott Szabó Károlyt, Finály Henriket, Ferencz Józsefet és Felméri Lajost, ekkor beszélt az angol klubban is. A kolozsváriak vendégszeretete után a Kemény család meghívására Marosvécsre utazott, innen pedig Tusnádra, ahol Teleki Domokosnével találkozott. ${ }^{199}$ A sajtóban megjelent közlemények szerint a „magyar nemzet lelkes barátja” a nők jogairól írandó könyvéhez gyüjtött anyagot. Müve 1882-ben jelent meg Londonban, de a magyar hölgyek jogait csak az Appendixben tárgyalja a Corpus Juris Hungariae alapján. ${ }^{200}$

Brace magyarországi látogatása egybeesett Kovács János amerikai küldetésével. Kovács 1882-ben az AUA meghívására a magyar unitáriusok küldötteként vett rész a saratogai konferencián. Észak-amerikai útjáról írott jelentését az Emlékkönyv második kötetébe is bemásolta, így pontosan tudjuk követni az eseményeket. (A fôvárosi és kolozsvári sajtó több-kevesebb rendszerességgel közölte útjáról küldött beszámolóit.) A kéziratban maradt jelentést Mikó Imre publikálta a Keresztény Magvetóben, de a cenzor néhány a kor ideológiájával ellenkező részt kihúzott. ${ }^{201}$

Bölöni Farkas Sándor után Kovács volt az unitárius egyház második amerikai diplomatája, ezért részletesebben foglalkozunk küldetésével. Az AUA főtitkára, Henry A. Thayer a társulat nevében levelet írt Ferencz József püspöknek, és felkérte az egyházvezetőt, küldjön képviselőt a Sa-

ence, preached through its Parliament (at Mediasch), and acted out in its civil life, the doctrine of universal tolerance; and to that doctrine, have its people been faithful ever since." $A$ drive, Christian Union, November 13, 1882, 404.

196 "The unitarians are the most intelligent of all the sects or churches." The Religious Character of the Hungarians, Christian Union, November 27, 1882, 444.

${ }^{197}$ Hungary Re-visited After Twenty-one Years. Vienna, September 25, 1872, 265. Scenes in Hungary. Incidentes and Talks, October 2, 284. Scenes in Hungary, October 9, 304. The Great Hungarian Puszta, October 16, 326. Debreczin, October 23, 346. An old Siebenbürger Baron, November 6, 383. A drive, November 13, 404. The Religious Character of the Hungarians, November 27, 444. A Transylvanian Conservative, December 4, 464. The Hungarian Social Life, December 11, 483. An Oriental Race on European Soil, January 29, 1873, 82-83.

${ }^{198}$ Egy amerikai polgár Magyarországon, Vasárnapi Újság, 1873. május 25., 126-139.

${ }^{199}$ Magyar Polgár, 1882. augusztus 14.; Ellenzék, 1882. augusztus 14.

${ }^{200}$ Gesta Christi: or a History of Humane Progress Under Christianity, London: Hodder and Stoughton, $1882,477-478$.

${ }^{201}$ Mıкó Imre, Kovács János amerikai utazása, KerMagv 1978, 26-28.; Kovács János, Egyek vagyunk a hitben és a szeretetben. Jelentés az 1882. augusztus 27-tól 1883. március 7-ig tartó amerikai utamról. KerMagv 1978, 28-41. 
ratogában szeptember 18-22 között tartandó közgyülésre. Kovács János Joseph Allentől már előzőleg értesült a meghívásról, és barátja biztatására, de a konzisztórium jóváhagyásával indult amerikai útjára. Küldetését Budapesten kezdte, itt Trefort Ágoston fogadta, aki nemcsak az egyetemi szabadságot adta meg, hanem ajánlólevelet állíttatott ki számára, és felkérte, hogy útja során tanulmányozza az amerikai tanintézeteket, hazatérte után pedig készítsen jelentést tapasztalatairól. Az egyházi és nemzeti érdekeket egyaránt képviselő diplomata augusztus 29-én Brace kíséretében Bécsből indult útjára, de amerikai ismerőse csak Nürnbergig kísérte, Kovács azonban megállás nélkül folytatta útját, és 42 órai utazás után szeptember 1-jén megérkezett Londonba. Hajójegyet váltott, s szeptember 6-ig, elutazásáig, régi barátja, Chalmers wakefieldi lelkész vendége volt. Liverpoolban a Cunard Line társaság Allepo nevü hajójára szállt és 12 és fél napi utazás után megérkezett Bostonba. Beszámolója szerint folyton viharban voltak, tíz napig annyit szenvedett, hogy „egy egész életre elég lenne. Az idő alatt sem írni, sem olvasni nem tudtam." Egynapos késéssel szeptember 19-én megérkezett Saratogába, és 20-án mintegy 2500-3000 unitáriushoz szólt. Az egynapos késést ügyes tréfával ütötte el:

„Gyakran mondtam az angol hajóskapitánynak: Uram! Az önök nemzeti himnusza így hangzik: Rule Britannia, Britannia rules the waves! No, kedves Uram! Most mutassa meg, hogy Britannia csakugyan tud uralkodni a habokon s elvihet-e engem Bostonba vasárnapra? Megpróbálom - felelé a nyájas kapitány - hanem keddre oda viszem. S amint kedden reggel a kikötőben tőle elbúcsúztam, így szólott hozzám mosolyogva. Látja Uram, hogy Britannia mégis uralkodik a habokon." 202

Beszédét kiváló retorikával építette fel, Új-Anglia és Erdély ugyanazon szélességi fok alatt fekszik és a két ország unitáriusai a „széles” szabadelvüségben hasonlítanak egymásra. A történelmi múlt összekapcsolása is jól sikerült.

„A magyar unitárius egyház - mondta - már akkor élvezte aranykorát, amikor azokat a fákat, melyekből a »May flower « épült, a favágó fejszéje még le sem ejtette volt. (...) Azóta az unitarizmus csillaga, valamint a hatalomé nyugat felé vette útját. S nyugat mostan a lelkesedés és eszmék gazdag kincseit küldi vissza, hogy a régi országokat új életre serkentse."203

Ha a keletről nyugat egére vándorolt csillag nem is szúrt szemet a cenzornak, az amerikai demokrácia dicsőítése nem kerülhette ki piros ceruzáját, ezért Kovács beszédének alább közlendő része 1978-ban nem láthatott nyomdafestéket.

\footnotetext{
${ }^{202}$ Emlékkönyv, vol. II., 138.

${ }^{203}$ Uo.
} 
„Megvallom, nagyon megilletődve érzem magam, midőn látom, hogy mily nagy és hatalmas nemzet az, melynek országában vagyok, s mily mívelt és válogatott az a közönség, mely előtt állok. Igen! Az Egyesült Államok egy új világ, s népe a földgömb első nemzete, a szabadságot és haladást illetőleg. És én, mint az önök vendége, s mint magyar, örvendek nagy előmenetelük s fényes jövőjük felett.

Ezután megemlítettem Bölöni Farkas Sándor utazását, s Amerikáról írt könyvének hatását; meg Kossuth, s számüzött társainak szívélyes fogadtatását; hogy ez élénken él minden igaz magyar szívében, s ama vendégszeretetért a magyar nemzet örökre hálás lesz. (...) Én egy szabad nemzet fia vagyok, mely nyolc évszázadon keresztül ugyanazon polgári szabadságnak volt őre Európa keleti részében, melyet önök a földteke nyugati oldalán fenntartanak, s mintegy bámulatos példával állanak a vén Európa, s a világ előtt. Az én nemzetem köszönti az önök fiait, kik hatalmasok a tudományban, gazdagok a kereskedelemben, kitünők az iparban; kik, mint az ős rómaiak arra vannak hivatva, hogy a világ művelődésében vezérszerepet vegyenek. (...) Én biztosítom önöket, hogy mi is, mint önök, a szabadságot jobban szeretjük az országnál, jobban barátainknál, sőt jobban életünknél. Kossuth azt mondá mikor új Angliában volt: Legyetek hatalmasság a földön. Én is ugyan azt mondom. Hadd legyenek önök a tengerek urai, a világ mívelői, s az emberiség dicsősége."204

A beszéden annyira felbuzdultak az amerikaiak - írta Kovács -, hogy könnyen lehetett volna legalább 2500 dollárt gyưjteni az iskola javára. Kolozsvárott azonban azt az utasítást kapta, hogy semmiféle egyéni akciót ne kezdeményezzen, és a gyüjtést is csak az amerikaiak felhívására kezdje el, így a kedvező alkalom kihasználatlan maradt. A saratogai konferencia után kezdődött el az erdélyi iskolaigazgató körútja. Szeptember 23-án régi ismerőséhez és barátjához, az 1873-ban Erdélyt is meglátogató Robert Morisonhoz ment Peterboroba, ahol vasárnap prédikált. A helyi újság szeptember 28-i számában röviden írtak a magyarországi tanár látogatásáról. Peterboro után Cambridge-be utazott, ahol ugyancsak egy Erdélyt megjárt tanár, Henry Allen vendége volt. Itt is részt vett az istentiszteleten, és a kolozsvári Channing tanári szék részére megkezdte a gyüjtést. ${ }^{205}$ Boston környékén a legkülönfélébb egyházi és világi rendezvényeken vett részt, beszédeiben Magyarország alkotmányát és természetesen az unitárius egyház történetét, felépítését és oktatási intézményeit ismertette. North-

${ }^{204}$ Uo.

${ }^{205}$ A Channing tanári széket tulajdonképpen 1874-ben alapították. A budapesti konferencia után Edward E. Hale értesítette Kriza püspököt, hogy két évre biztosítják két tanár fizetését, így született a Channing-Priestley alap. 1883-ra az alap teljesen kimerült és Kovács János feladatává tették a gyüjtést. Kovács meglátogatta a nagyobb gyülekezeteket, előadásokat tartott és tekintélyes összeget gyüjtött. (Priestley neve fokozatosan lemaradt a Channing neve mellől, az amerikai gyüjtés eredményeként egy tanár fizetését sikerült az alapból fedezni, ezért természetszerúleg Channing alapként emlegették.) Az alap 1915-ben még negyvenháromezer koronával rendelkezett. A hadikötvényekbe fektetett összeg a világháborúval együtt elveszett. 
Eastonban a politikus és iparmágnás Ames családdal került kapcsolatba, azonban a családról, illetve az amerikai szellemről írott mondatai szintén a cenzúra áldozataivá lettek.

„North-Easton az emberbaráti szeretetnek egy kiváló helye, s mégpedig Ames család által lett azzá. Az unitárius eklézsia számára építetett egy gyönyörü templomot s paplakot 190 ezer dollárral. (Az egyetlen hely, hol Amerikában az eklézsiának rendes paplakja van.) Építtetett egy középiskolát, nyilvános könyvtárat, felszerelve könyvekkel is, s tanácsházat a község számára. Íme az amerikai szellem. Ott, aki meggazdagodik erkölcsi kötelességének tartja jótékony célokra áldozni. S a közmívelődés előmozdítása iránti érdeklődés az amerikai unitáriusoknak fő jellemvonása, amiről minden városban s községben személyesen győződhettem meg."

A vasárnapi prédikáció után az Ames családtól 1000 dollár gyűlt a Channing tanszékre, sőt ígéretet kapott egy, a család neve alatt létesítendő tanszék támogatására. Kovács barátai tanácsára nemcsak a Channing, hanem a Richmond alapot is megcélozta, és felkereste a kolozsvári unitárius gimnázium javára 5000 dollárt adományozó Anna Richmond Providence-ben élő gyermekeit. A legidősebb fiú, Walter Richmond, további 5000 dollárt adott az édesanyja nevét viselő kolozsvári tanszék fenntartására. ${ }^{206}$ Providence után Newportba, Channing szülővárosába látogatott, majd visszatért Cambridge-be, november 3-án pedig elindult Kanadába. Montreal, Toronto, Buffalo, Detroit, Ann Arbor meglátogatása után Chicagóba érkezett. Rövid madisoni látogatás után november 25-én St. Luisba indult, innen Cincinnatibe, majd Clevelandbe ment. Útját a meadville-i unitárius papnevelő intézet meglátogatásával folytatta. Az itt tartott előadás után Washingtonba ment, ahol az elnökkel és a kultuszminiszterrel is találkozott. Baltimore, Philadelphia és New York voltak következő állomásai. Január 1-jén érkezett vissza Cambridge-be, ahonnan aztán átment Bostonba, és a környékbeli egyházközségekben prédikált. Útja során 28 templomban prédikált és nagyon sok összejövetelen tartott hosszabb-rövidebb, Magyarországot és az unitarizmust ismertető beszédet. Grindall Reynolds, az AUA titkára, 1883. február 7-én a konzisztóriumnak küldött levelében megköszönte Kovács kiváló munkáját. ${ }^{207}$

\footnotetext{
206 "Az egyetlen teljes teológiai tanár fizetését 1883-tól jórészt a Richmond Anna tanszékalapítvány kamataiból fedezték. Ezt 1875-ben létesítette az amerikai hölgy egy hittan tanári szék fenntartására, s családja 1883-ban Kovács János igazgató-tanár amerikai látogatása alkalmával kiegészítette: alaptőkéje tízezer dollárt tett ki." Gál Kelemen - Benczédi Gergely - GaAl György, Fejezetek a Kolozsvári Unitárius Kollégium történetéből, Kiadja az Erdélyi Unitárius Egyház a kollégium alapításának 450. évfordulójára, Kolozsvár, 2007, 180.

${ }^{207}$ Grindall Reynolds, Az Amerikai Unitárius Társulat titkárának levele az Egyházi Képviselő Tanácshoz, KerMagv 1883, 137-138. Ugyanitt az EKT nevében írt válaszlevél is olvasható.
} 
Kovács János 1883 márciusában tért haza féléves észak-amerikai útjáról, itthon igazi hősnek kijáró ünnepléssel fogadták, nemcsak a fővárosban, de Kolozsvárott is. ${ }^{208}$ Március 8-án este érkezett haza, a kolozsvári indóháznál családja, barátai és tisztelői ünnepélyesen fogadták. Március 9-én az unitárius kollégium ifjúsága fáklyás menettel tisztelgett világlátott tanára előtt. Kolozsvár értelmisége a Stadler-kertben rendezett társas vacsorát tiszteletére. ${ }^{209}$ A nagyszabású bankettet gróf Eszterházy Kálmán főispán pohárköszöntője nyitotta meg. A főispáni köszöntőre Kovács János válaszolt, és a mintegy háromnegyed óráig tartó beszédben összefoglalta utazása történetét. A vacsorán jelen volt Kolozsvár értelmisége. Életes Károly plébános, Groisz Gusztáv jogász, Grefstein lutheránus lelkész, Szász Béla és Hegedűs István egyetemi tanárok, Weisz József ügyvéd nevét sorolták fel a hírlapírók. Kovács János hazatérése után az angol kör ősszel megkezdte előadásait, majd az újévben, január 25-én megtartották a közgyülést. Az elnök beszámolóját követően tisztújítás következett, de tekintettel arra, hogy Péterfi Dénes titkári tisztségéről való lemondását a választmány nem fogadta el, a tisztikarban nem történt változás. 1884-ben az English Conversation Clubnak 25 rendes tagja volt, két angol folyóiratot járattak, a Contemporary Reviewt és a Nineteenth Centuryt. ${ }^{210}$

\subsubsection{James Thompson Bixby erdélyi körútja}

James Thompson Bixby (1843-1921) orientalista, a Meadville teológiai intézet tanára, 1882 őszén Chicagóban találkozott Kovács Jánossal, és megígérte, hogyha Európába látogat, felkeresi a magyarországi és erdélyi unitáriusokat. ${ }^{211}$ Európai utazásai során 1884-ben látogatta meg hittestvéreit, és szeptember 25-én Kolozsvárott, az English Conversation Clubban tartott előadása általános tetszést aratott. ${ }^{212}$ Erdélyi és magyarországi élményeit 52 oldalra terjedő cikksorozatban tette közzé a The Unitarian Reviewban. ${ }^{213}$ Az English Conversation Club megalakulásáról, szerepéről írva elismeréssel szólt tagjai nyelvismeretéről, a klasszikus és modern angol irodalom-

\footnotetext{
${ }^{208}$ Egy hazánkfia amerikai útja. (Kovács tanár fogadtatása Trefort miniszter által), Pesti Hírlap, 1883. március 4., 63 sz.; Egy nagy utazás eredményei. (Kovács tanár jelentése), Pesti Hírlap, 1883. március 6., 64 sz.; Kovács János távozása Budapestről, Magyar Polgár, 1883. március 8., 55. sz.

${ }^{209}$ Társas vacsora, Magyar Polgár, 1883. március 10., 57. sz.

${ }^{210}$ Magyar Polgár, 1884. január 28., 22. sz.

${ }^{211}$ Bixby T. Jakab amerikai tanár látogatása, KerMagv, 1884, 322-326.

${ }^{212}$ Bixby T. Jakab az angol körben, Magyar Polgár, 1884. szeptember 27., 223. sz.

${ }^{213}$ A Visit to our Hungarian Brethren, February 1885, 134-155, July 38-55, August 117-131. Magyar ismertetőt közölt róla: Kovács János Bixby Jakab amerikai tanár hazánkról, KerMagv, 1885, 47-50, 234-241.
} 
ban való jártasságukról. ${ }^{214}$ A különböző felekezetekhez tartozó mintegy negyven tag többé-kevésbé olvas és beszél angolul - írja - és otthonosan tájékozódik az angol irodalomban. Az angol klubban tartott előadását a kolozsvári napilapokban megjelent tudósítások és élménybeszámolója alapján rekonstruáltuk. ${ }^{215}$ Előadását Európa egyik legszebb és legérdekesebb fővárosa, Budapest magasztalásával kezdte. Az angol-amerikai látogatók sorában, Browingot leszámítva, Bixby volt az egyetlen, aki a magyar müvészet, különösképpen a képzőmüvészet iránt behatóan érdeklődött. A bécsi képtárak szemrevételezése után a Magyar Nemzeti Múzeumot kereste fel, és csodálattal szólt a magyar festészetről. Munkácsy Krisztus trilógiája volt rá a legnagyobb hatással. ${ }^{216}$ Munkácsyn kívül alkotásaik alapján világhírü festőművésznek tartotta Benczúr Gyulát, Madarász Gyulát, Székely Bertalant, Than Mórt, Wagner Sándort, Ligeti Antalt, Spányi Bélát és Markó Károlyt. A festők mellett elismeréssel szólt a magyar zenéről és Liszt Ferencről. Felejthetetlen élmény volt számára - írta -, hogy Jénában részt vehetett Liszt Krisztus oratóriuma előadásán. Bixby szerint Kolozsvár tanintézményeinek köszönhetően, méltán érdemesül az erdélyi Athén nevezetre. Magyarországi és európai tapasztalatai meggyőzték arról, hogy a magyarok Egyesült Államok iránti rokonszenve egyedülálló Európában. Bölöni Farkas Sándor óta a magyarok úgy tekintettek Amerikára - mondta -, mint a szabadság kiváltságos Isten által kiválasztott helyére. Széchenyi angol rokonszenve, Kossuth Lajos angol és amerikai népszerüsége minden magyarban elkötelezettséget ébreszt az Egyesült Államok, és a Magyarországra látogató amerikaiak iránt.

Az előadás után „egymást érték” a pohárköszöntők. Kovács János az angol nyelv müvelésének előnyeiről s az angol kör eredményes tevékenységéről szólt, kiemelve, hogy:

„a csak nem régen többször itten volt Brace amerikai tanár által Amerika legnagyobb hírlapjában hazánkról közreadott előnyös ismertetések keletkezése szintén az angol társalgó körnek tulajdonítható," 217

ezért poharát a kör gyarapodására és további fennállására ürítette. Concha Győző Kossuthra, az emigránsokra és Amerikára, mint a nyugati civilizáció vezetőjére köszöntötte poharát. Boros György a kolozsvári tudomány-

214 ,I found them well posted in English literature, not only that of the past centuries, but the prominent works in science, politics, and belles-lettres of the present day, and able to converse with intelligence and fluency about them." A Visit...II., Unitarian Review, July 1885, 53.

${ }^{215}$ Egy angol estély, Ellenzék, 1884. szeptember 26.

216 ,There is hardly a great European gallery, that has not a representation of the same scene from some artist renown, but I have never seen any that was more impressive. The powerful conception of the various groups and their graphic delineation made them seem to stand in living action before the eye." A Visit...I., Unitarian Review, February 1885, 137.

${ }^{217}$ Ellenzék, 1884. szeptember 26. 
egyetem tanári karára, az angol kör törzsgárdájára, Finály Henrik Bixbynek a magyarokról alkotott jó véleményének megmaradására ürítette poharát. A jókívánságokkal elhalmozott vendég szeptember 28-án Budapestre utazott, ahol nemcsak az unitáriusok őszi hálaadási istentiszteletén és úrvacsoráján vett részt, hanem az éppen kezdődő országgyưlésen is. ${ }^{218}$

Bixby 1884. évi látogatása után kiadott élménybeszámolója az amerikaiak figyelmét a háromszáz éves múltat maguk mögött tudó magyar unitáriusokra irányította. Új-Anglia fiatal unitárius közösségei számára az erdélyi múlt ismerete - Bixby szerint - olyan, a történelmi múltban gyökerező biztonságérzetet adhat, mellyel könnyen visszaverni a metodisták, baptisták, presbiteriánusok azon vádját, hogy eredetüket csak Priestley-ig és Channingig vezethetik vissza. ${ }^{219} \mathrm{~A}$ fájdalmas nemzeti tragédiák és vallásos üldözés közepette a magyar unitáriusok tántoríthatatlan hithüségről tettek bizonyságot. Múltuk és népük bensőségesebb ismerete - írja Bixby még jobban elmélyíthetné az amerikai-magyar kapcsolatokat. ${ }^{220} \mathrm{Az}$ amerikai tanár hazatértekor ajándékba kapta Enyedi latin Explicationesének egy példányát, mely jelenleg a chicagói egyetem könyvtárában van.

\subsubsection{Az angol klub története a millenniumig}

1885. január 15-én az English Conversation Club a Hungáriában tartotta meg az évnyitó és tisztújító első közgyülést. ${ }^{221}$ Péterfi Dénes lemondott tisztségéről, ezért Boros György személyében új titkárt választottak. A választmány tagjai sorában nem történt változás. A választások és az elnöki beszámoló után Kovács János Edgar Allan Poe-nak a The Raven címü versét mondta el. A körnek az év során több jeles vendége volt. A sajtó csak a londoni születésü, de Sydneyben élő F. W. Elliotnak az angol klubban tartott előadásáról számolt be. ${ }^{222} \mathrm{Az}$ ausztráliai utazó európai körútja során látogatott el Kolozsvárra. Jövendőbeli veje, Roggendorf Arnold honvédfőhadnagy Budapesten vezette oltárhoz ausztrál aráját. Konstantinápolyból Budapestre a legrövidebb út Bukaresten, Brassón és Kolozsváron át vezetett.

\footnotetext{
${ }^{218}$ A Visit..., Unitarian Review, August 1885, 117-131.

219 ,Whenever a Unitarian meets with such open criticism or with unspoken prejudice or prepossession resting tacitly upon such grounds, then he will turn, if he is wise, to the record of Unitarianism in that land where it had its historic beginning; and he will be able to exhibit the worship of the One only God as a strong and legally recognized worship, not merely one or two hundred years ago, but three hundred. He will be able to trace back Unitarianism as a specific and organized religion, not only to days before Wesley organized his little band of fellow-workers at Oxford, but to a date anterior to that when Roger Williams first preached or the Westminster Catechism was yet formulated." Uo., 130-131.

${ }^{220}$ KerMagv 1885, 238.

${ }^{221}$ Magyar Polgár, 1885. január 17., 13. sz.

${ }^{222}$ Kovács János, Ausztráliai utazó Kolozsvártt, Magyar Polgár, 1885. november 15.
} 
Az 58 esztendős örömapa születendő magyar unokái kedvéért magyarul is elkezdett tanulni. A kolozsvári angol körben, miután anyanyelvén köszöntötte az egybegyűlteket, az ausztrál viszonyokat ismertette. Kovács János az ausztrál utazóról írott kolozsvári tárcájában az erdélyi románságról is írt. Elliot a Bukarest-Brassó vasútvonalon megismerkedett egy román bojárral - természetesen franciául folyt a társalgás -, aki beszélgetés közben megemlítette, hogy a gazdag és szép Erdélyt többségben románok lakják, és csak idő kérdése, hogy Romániához is csatolják. 1885-ben Kovács is úgy gondolta, hogy Erdély hovatartozásának kérdése örökre „nemzeti aspiráció" marad,

„mert az a nép, melyet [Elliot] átutaztában itt-ott, s a mai hetivásáron is látott, aligha érvényesíteni bírja e nemzeti aspirációt." 223

Alig egy héttel Elliot látogatása előtt az unitárius egyháznak amerikai vendégei voltak. Az alapítványtevő Richmond család tagjai: Knight Richmond, Caroline Richmond, az alapítványtevő Anna Richmond lánya és Ednah Bowen érkeztek a budapesti kiállításra, és innen látogattak el Kolozsvárra. Útjukat részletesen ismertette a világi és a felekezeti sajtó is. ${ }^{224}$

1886. február 12-én a Hungária szálló különtermében tartotta az angol kör tizedik rendes közgyülését. ${ }^{225} \mathrm{~A}$ tagok sorában új nevekkel találkozunk: dr. Nagy Ferenc (1852-1928) jogász, politikus, egyetemi tanár, 1881-től 1890-ig a kolozsvári egyetem tanára, Sigmond Ákos, Stein Gábor, Deáky Albert, a kolozsvári Unió Szabadkőmúves Páholy alapító nagymestere, Duret József (?-1892) az egyetemen a francia nyelv és irodalom lektora, Szathmáry Elek [az Ellenzékben György] és Petrán József az új tagok. A közgyưlés a szokásos napirend szerint zajlott: elnöki beszámoló, választások. Az elnök beszámolója szerint 1885-ben az Angol Klub vendége volt: Sgn. Angelo Gubernatis (1840-1908) olasz orientalista, filozófus, író, Mr. Samuelson liverpooli ügyvéd, ${ }^{226} \mathrm{Mr}$. Duncan ugyancsak liverpooli törvénybíró, Mr. Thomson, a Morning Post főmunkatársa, Londonból és Mr. Elliot Sydneyből.

\footnotetext{
${ }^{223}$ Uo.

${ }^{224}$ Richmond Anna utódai Kolozsvárt, KerMagv 1885, 322-324. Amerikai vendégeink s újabb adományaik, Uo., 389. Amerikaiak Hódmezővásárhelyen, Vásárhelyi Közlöny, 1885. november 1. Amerikai vendégek Aradon, Arad és vidéke, 1885. október 30. Amerikaiak Szegeden, Szegedi Híradó, 1885. november 1. JАКАВ Elek, Észak-amerikai vendégek a magyar fövárosban, Egyetértés, 1885. november 7. Amerikaiak Kolozsvárt, Ellenzék, 1885. október 27., 975.

${ }^{225}$ Ellenzék, 1886. február 12. 33. sz., 131.

${ }^{226}$ Letters from Transylvania I-II. címen két, James Samuelson tollából származó újságcikket találtunk a Kovács hagyatékban. Az első tudósítás 1885. június 25-i, kolozsvári, a második június 20-i segesvári keltezéssel, Samuelson aláírásával jelent meg valamelyik angol napilapban.
} 
Évközben több angol is megfordult a városban anélkül azonban, hogy az angol klubba bevezették volna őket. Augusztusban Finály és Kovács János vendégszeretetét élvezte John Evans, a neves angol numizmatikus, régész és geológus, az angol numizmatikai társaság megalapítója, aki lányával érkezett Kolozsvárra. ${ }^{227}$ Érdekes, hogy sem Kovácsot, sem Finályt nem zavarta Evans politikai felfogása, az 1880-ban a Balkán-félsziget és a Monarchia sorsát feszegető cikke (The Austrian Counter Revolution in the Balkans) öt évvel később feledésbe merült. Augusztus végén az angol unitárius Lawrence család tagjai voltak Kolozsvárott, ${ }^{228}$ James Clark Lawrence egykori (1868) londoni lordmajor vezetésével. A négytagú küldöttség (James Clark, Williams, Jane és Henry Alfred) 28-án érkezett Budapestre, 29én pedig részt vett a kolozsváriak istentiszteletén, majd a főtanácsi ülésen. A vendéget Ferencz József püspök köszöntötte és mutatta be a főtanácson. Köszöntő szavaira James Clark Lawrence „,emelkedett szellemü beszéddel felelt.” Az egynapos látogatás során a Lawrence család képviselői Kovács János kalauzolása mellett ismerkedtek a várossal, találkoztak Pagettel, 30án pedig Budapestre utaztak. A volt lordmajor augusztus 31-én a fóvárosból egy levél kíséretében 62 forintot küldött Ferencz Józsefnek, az eklézsia céljaira fordítandó, ugyanakkor a magyar unitáriusok 1848 elötti, 1869-es és 1885-ös statisztikáját kérte a püspöktől. ${ }^{229}$ A főpásztor szeptemberben részletes levélben számolt be egyháza múltjáról, és a lélekszám alakulásáról. ${ }^{230} \mathrm{~A}$ Lawrencek jóindulatát nem sikerült a magyar ügynek megnyerni, és a dúsgazdag angol családdal tartott hivatalos egyházi kapcsolat 1886ban megszűnt.

Szeptember 18-án újabb londoni vendége volt Kolozsvárnak, ezúttal egy anglikán lelkész, akit a napilapok Lambert Book néven mutattak be a nagyérdemű olvasónak. A tévesen írt név mögött a jeles szociális reformer, Lambert Brooke (1834-1901) rejtőzött. Valószínű, hogy az angol klubban is megfordult, a város tanintézményeit kivétel nélkül végigjárta, és a színház is kellemesen lepte meg. Rövid látogatása során Felméri és Kovács társaságában ismerkedett a kincses Kolozsvárral. ${ }^{231}$

Az English Conversation Club október 28-án ünnepelte fennállásának 10. évfordulóját. A Hungária szállodában szervezett ünnepségen jelen volt: Brassai Sámuel, Finály Henrik, Concha Győző, Fabinyi Rudolf (1848-1920)

\footnotetext{
227 Angol régész Magyarországon, Magyar Polgár, 1886. augusztus 2. 174. sz.

${ }^{228}$ Magyar Polgár, 1886. augusztus 26., 194. sz. Az Unitárius egyház évi rendes közgyủlése, Ellenzék, 1886. szeptember 11., 820-821. Vö. Angol vendégeink, KerMagv, 1886, 246. Boros György, Hungarian Crespondence, The Inquirer, September 15, 1886, 623-624.

${ }^{229}$ Emlékkönyv, vol. III., 38.

${ }^{230}$ Uo., 39-41.

${ }^{231}$ Magyar Polgár, 1886. szeptember 18., 214. sz.
} 
vegyészprofesszor, Nagy Ferenc, Mr. Mackenzie, ${ }^{232}$ Mr. Hart, Szász Béla, Jenei Viktor, Széky Miklós, Mózes András (1837-1888) kolozsvári unitárius lelkész-tanár, Péterfi Dénes, Boros György, Papp Samu, Duret József, Alder Lipót, Veisz Mór, Kauffmann Samu fömérnök, az izraelita hitközség ellenőre.

A kolozsvári English Conversation Club elnöke 1886. december 10-én a budapesti angol körben tartott elöadást Social Life of the Americans címen. ${ }^{233}$ A fővárosiak 1885 novemberében tizenegyedik közgyúlésükkor elkészítették a felolvasások sorrendjét. Elképzelésük az volt, hogy november 25-én Pulszky Ferenc The First Hungarian Emigrants in America címen tart felolvasást, december 9-én Kovács János tart előadást, hogy aztán 1886-ban Szabó József Down Amongst the Mormons és Vámbéry Ármin My Lecturing Tour in England című előadása következzen. A jelek szerint a Budapest English Clubban az év végén és az újév elején pezsdült meg az élet. 1887. január 20-án Pulszky Ágoston országgyülési képviselö, Az angol iskolai élet címen tartott előadást. Az Angliában tanult előadó ismertette az oktatási rendszert, kiemelve, hogy:

„míg nálunk a szülők szükséges tanuló-helynek tekintik az iskolát, addig Angliában nevelési hely az, hol az ifjak sporttal s más mulatságokkal is foglalkoznak... Az ilyen nevelésmód képezi az angol gentlemant." 234

Kolozsvárott az 1887. év első közgyülését február 25-én tartották a Hungária szálloda különtermében. ${ }^{235} \mathrm{~A}$ kör újabb tagokkal gyarapodott: Dr. Rózsahegyi Aladár (1855-1896) orvos, 1883-tól a kolozsvári egyetem nyilvános rendes tanára, dr. Lánczy Gyula (1850-1911) történész, egyetemi tanár 1886-tól 1891-ig tanított Kolozsvárott, dr. Széchy Károly (1848-1906) irodalomtörténész, egyetemi tanár 1890-től tanított Kolozsváron, Kozma Ferenc (1844-1920) pedagógus, tanfelügyelö, és Perczel Mór nyert felvételt a tagok sorába. Az összejövetel legjelentősebb eseménye a John Paget, gróf Bethlen Dániel és báró Wesselényi Józefa Szacsvay Sándorné alapította Angol Olvasó Kör könyvtárának átvétele volt. Az 1840-es években alapított olvasókör még életben levő tagjai könyvtárukat az English Conversation Clubnak ajándékozták. A közgyülés az adományozókat örökös tiszteletbeli tagokká választotta. A mintegy 2000 kötetet számláló könyvtár szakszerü működtetésére a választmány dr. Lehmann Róbert (1837-?) jogászt, a kolozsvári Kereskedelmi Akadémia tanárát kérte fel.

\footnotetext{
${ }^{232}$ Claud Mackenzie Aranyosgyéresen telepedett meg és Paget Olivérnek és Ellennek Ilona nevü lányát, John Paget unokáját vette feleségül. Házasságukból egy gyermek született. Ilona második férje gróf Teleki László volt. Ebből a házasságból két gyermek született.

${ }^{233}$ Budapesti Hírlap, 1886. december 10.

${ }^{234}$ Ellenzék, 1887. január 22., 67.

${ }^{235}$ Uo., 1887. február 25., 179.
} 
Az 1887. esztendő különösen nehéz megpróbáltatások elé állította Kovács Jánost, a kör elnökét. Tavasszal az édesanyját, augusztusban pedig hétéves, Árpád nevü kisfiát veszítette el. A sajtó egyetlen összejövetelről ad hírt, 1887. október 6-án az elnök gyưlésbe hívta a tagságot. ${ }^{236}$

A tizenegyedik közgyưlését 1888. február 16-án, a Hungária különtermében tartották. ${ }^{237}$ Kovács János elnöki beszámolója után Boros György titkár örvendetes híreket közölt. Brassai Sámuel saját költségén a kör részére megrendelte a Ninteenth Centuryt, Ajtai K. Albert pedig a könyvtár katalógusának kinyomtatását ígérte meg, mely márciusban el is készült..238 Claud Mackenzie aranyosgyéresi földbirtokos 50 forintos adományával gyarapította a kör vagyonát. A tisztikarban és a választmányban nem történt változás, a könyvtárnoki teendőket továbbra is Lehmann Róbert látta el. A könyvtárat a külső tagok évi 3 forint tagdíj kifizetése mellett használhatták. A nyári szünidő utáni első rendes összejövetelt október 11-én tartották. ${ }^{239}$

1889-ben a közgyűlés április 10-én volt. A tagok jegyzőkönyvileg mondtak köszönetet Ajtai K. Albertnek a könyvtárlajstrom kinyomtatásáért, Pagetnek az Atheneum, Brassainak pedig a Nineteenth Century járatásáért. 1889-ben a körnek 26 rendes, 4 tiszteletbeli és 9 olvasó tagja volt. ${ }^{240}$

Az 1890. február 6-án tartott közgyülésen jelen voltak: Brassai Sámuel, Finály Henrik, Ajtai K. Albert, Sigmond Ákos, Rózsahegyi Aladár, Péterfi Dénes, Szathmáry Elek, dr. Concha Győző, Kauffmann Sámuel, Maetz Frigyes. Az elnök a megnyitó beszédében özv. Vas Miklósnéra, a kör egyik legszorgalmasabb olvasójára emlékezett. A közgyűlés újraválasztotta a tisztikart. 1890-ben a klubnak 24 rendes, 4 tiszteletbeli és 10 olvasó tagja volt. A könyvtárat az óvárban, a Mátyás király utca 1. szám alatt a régi távirda helyiségében helyezték el, a könyvtárosi teendőket Széky Miklós végezte. 1890-ben ez volt az országban müködő egyetlen angol társalgó kör. A budapesti kör a kellő érdeklődés hiányában feloszlott. ${ }^{241}$ 1890-ben Kovács Jánost újabb tragédia érte, július 25-én meghalt felesége, Kriza Lenka.

Az English Conversation Club 1890 késő őszén Henry Iersont fogadta. 1890-re elkészült a budapesti unitárius templom, az átadási ünnepségekre a BFUA tanácsa Henry Ierson titkárt delegálta Magyarországra. A templomszentelésen a titkár mellett jelen volt Miss Lucy Tagart és Miss Florence Hill is. Miss Tagart a Christian Life szerkesztőjének küldött leveleiben szá-

\footnotetext{
${ }^{236}$ Uo., 1887. október 7., 897.

${ }^{237}$ Uo., 1888. február 17., 157.

${ }^{238}$ A könyvjegyzéket lásd: Catalogue of the Kolozsvár English Conversation and Reading Club's Library, Kolozsvár, Ajtai K. Albert nyomdája, 1889.

${ }^{239}$ Ellenzék, 1888. október 10., 941.

${ }^{240}$ Uo., 1889. április 11., 347.

${ }^{241}$ Fő̃árosi Lapok, 1890, 39. sz.
} 
molt be az eseményekről. ${ }^{242}$ Ierson erdélyi barátai megívására Kolozsvárra is ellátogatott. Küldetéséről a BFUA tanácsának Report of a Visit to Hungary címen számolt be. Kolozsvárott, a Hungária külön termében vacsorát adott tiszteletére az angol klub. Az elnök köszöntő szavai után Ierson az angol nyelv tanulásának és tanításának müvészetéről tartott rövid előadást. ${ }^{243}$ Nem sokkal magyarországi kirándulása után 1892-ben meghalt.

1891-ben a februári közgyúlés után ${ }^{244}$ a Conversation Club nem adott életjelt, pedig az év során több angol és amerikai vendége is volt a városnak. Augusztusban az oxfordi püspök lánya, Miss Margaret Fletcher és barátnője, Rose de la Quense látogatásáról írtak a lapok. A festőmüvészként bemutatott hölgyek Szádeczky Gyula kíséretében Kalotaszegről érkeztek. Kolozsvárott Finály Henrik vendégei voltak. Erdélyt alaposan becserkészték, voltak Szamosújváron, Besztercén, Marosvásárhelyt, Vízaknán, Tordán, Brassóban, Előpatakon, Szebenben, Déván és Vajdahunyadon. ${ }^{245}$ Útjukról kis képes beszámolót tettek közzé Sketches of Life and Character in Hungary (London és New York, 1892.) címen, melyet magyarul Kropf Lajos ismertetett. ${ }^{246}$

Szeptemberben a New York-i Illustrated News munkatársa, John Pennel és neje vendégeskedett Kolozsvárott. Az atlétikai klub adott vacsorát tiszteletükre, a klub alapító elnöke, Felméri Lajos egyetemi tanár tagja volt az angol társalgó körnek is.

1891-ben a bostoni The Unitarian Review közölte Kovács Jánosnak, The Spread of the English Language as a Means of International Intercourse and Culture címü előadását. ${ }^{247}$ A szerző Az angol nyelv a nemzetközi érintkezésekben címen csak 1901-ben jelentette meg magyarul írását. ${ }^{248}$ Ebben az angol nyelv elterjedéséről értekezve megállapítja, hogy az Amerikai Egyesült Államok hatalmas kiterjedése, az angol gyarmatok, valamint a nyelv struktúrájának köszönhető, hogy az angol nyelv lekörözi német és francia vetélytársait, és a jövő század uralkodó (világ)nyelvévé válik.

„Ha a francia nyelv még ezután is folytonosan a diplomácia nyelve marad, úgy bizonnyal az angol lesz az egyetemes tudósítás, vagyis nemzetközi közlekedés nyelve és ez annak állandó nagy hatalmat kell, hogy biztosítson." ${ }^{249}$

\footnotetext{
${ }^{242}$ Five Days in Buda-Pest, The Christian Life, December 13, 1890, 598., December 20, 610., January 10, 1891, 22. A The Christian Life, November 22, 1890, 558., közölte a budapesti unitárius templom fényképét.

${ }^{243}$ Henry Ierson, Report of a Visit to Hungary, London 1891, 23-24. Vö. UK, 1890, 191-193, 204-205. Jerson Henrik az angol körben, Kolozsvár, 1890. november 3., 251 sz.

${ }^{244}$ Kolozsvár, 1891. február 27., 47 sz.

${ }^{245}$ Angol müvészek Kolozsvárt, Kolozsvár, 1891. augusztus 1., 173 sz.

${ }^{246}$ Élet-és jellemrajzok Magyarországról, Erdélyi Múzeum 13. kötet, 1896, 275-277.

${ }^{247}$ Unitarian Review, October, 1891, 300-308.

${ }^{248}$ Erdélyi Múzeum, 1901. XVIII. 6. füzet, 309-318.

${ }^{249}$ Uo., 315.
} 
A Monarchia geopolitikai helyzetét tekintve elismerte a német nyelv fontosságát, de minden gyakorlati szempontot figyelembe véve, az angol nyelv tanítása mellett kardoskodott. Az angol nyelv ismerete nemcsak a nagyvilágban való utazást könnyíti meg, de gazdag irodalma kárpótolja azokat, akiknek az utazás nem adatik meg. Az angol irodalom nagyobb szellemi élvezetet nyújt, , mint a francia irodalom frivol novellái és felületes közleményei, melyek a jelenlegi francia irodalom halmazát képezik." 250

Szilárd meggyőződéssel vallotta, hogy az angol nyelv gyakorolja a legjobb hatást az ifjú nemzedékre, ezért arra kell törekedni, hogy taníttatása az elméleti és kereskedelmi iskolákba mihamarabb bevezettessék. A legkellemesebb munka - írta - segíteni az angol nyelv elsajátítására vállalkozóknak, megosztani velük azt az örömet és gyönyörűséget, melyet az nyújt, hogy ez a világnyelv és gazdag irodalma egybeszövődik személyes életünkkel és gondolatainkkal.

Az English Conversation Club 15. rendes közgyülését 1892. március 12-én a Hungáriában tartotta. ${ }^{251} \mathrm{~A}$ körnek 26 rendes, 10 olvasó és 3 tiszteletbeli tagja volt, új tagként pedig dr. Ákontz Károly és Gyalui Farkas (1866-1952) egyetemi tanárt, valamint Hindy Árpád (1843-1898) hírlapírót vették fel. A könyvtár állománya is jelentősen gyarapodott, ezért egy új könyvszekrény vásárlását határozták el. A kör teljes vagyonértékét 1892ben 1600-1800 forintra becsülték. Az angol folyóiratok közül saját pénztárból a Contemporary- és a Quarterly Reviewt járatták, Brassai a Nineteenth Centuryra, Paget pedig az Atheneumra és a Pall Mall Gazettere fizetett elö. A 15. közgyülést záró vacsorán kedélyes pohárköszöntők sora éltette Brassait és Kovács Jánost, a klub elnökét. A kör estélyeit minden csütörtökön 7 órától 10 óráig tartotta a Hungária különtermében.

1892. április 11-én meghalt John Paget, a Conversation Club örökös tiszteletbeli tagja és nagylelkű mecénása. A házsongárdi kriptán lefelé fordították a család címerét, hiszen egyenes ágú leszármazottja nem maradt a családnak. A Pagetek azonban, Edmond Arthur, John Paget testvére ágán Erdélyben is tovább éltek. Arthur fia, Olivér 1877-ben Aranyosgyéresre költözött, 1881-1883 között a kolozsvári Unitárius Gimnáziumban folytatta tanulmányait. Kalandos, regénybe illő életpálya után, 1927-ben halt meg Marosugrán..$^{252}$

\footnotetext{
${ }^{250}$ Uo., 317.

${ }^{251}$ Kolozsvár, 1892. március 12., 46. sz.

${ }^{252}$ Arthur Paget életútját Ruffy Péter mutatta be az erdélyi Pagetekről írott négyrészes riportsorozatában. Lásd: Ruffy Péter, Paget Claudenál, III. Eduard király erdélyi leszármazottjánál, Brassói Lapok, 1939, XLV., 256., 257., 259., 260. szám, november 5., 6., 9.
} 
1892 őszén a Club könyvtárát költöztették a Mátyás király utcából a Bel-Király utca 6. szám alá. ${ }^{253}$ Karácsony havában került sor az év utolsó felolvasására, Kovács János Chicagóról tartott fényképekkel illusztrált elöadást. Az Amerikai Egyesült Államok bámulatosan fejlődő városát mutatta be az előadó. A kolozsváriak joggal ámuldozhattak a világ legnagyobb vágóhídjának leírásán, hiszen a Szamos menti város vágóhídja is ebben az időben, 1887-ben épült fel Pákei Lajos tervei szerint. A Union Stock Yardon levő amerikai létesítmény 345 hold területen feküdt, és elég tágas volt ahhoz, hogy egyszerre 25000 ökör, 100000 sertés, 22000 juh és 2000 ló feldolgozását tegye lehetővé. Az utca előtt leölik a disznót, s a vágóhíd másik oldalán már sonka, kolbász jön ki - mondta Kovács előadásában.

Az 1893. évi első közgyűlést február 23-án tartották, és John Paget emlékének szentelték. ${ }^{254} \mathrm{Az}$ elnök előadásában az angol orvosból magyarrá lett földbirtokos életpályáját ismertette. Az alkalomhoz illően a kör tagjai mellett ott látjuk az erdélyi arisztokrácia képviselőit: özv. br. Bánffy Jánosné, br. Kemény Kálmánné, özv. gr. Bethlen Sándorné, özv. br. Wesselényi Istvánné, Szacsvai Sándorné sz. báró Wesselényi Józefa, gr. Bethlen Gergelyné lányaival, gr. Bethlen Balázs személyében. Ajtai K. János felajánlotta, hogy az elnök emlékbeszédét angol nyelven 200 példányban kinyomtatja. Paget első életrajza Kovács János tollából Kolozsvárott jelent meg 1893-ban. ${ }^{255}$

Június 17-én Samuel June Barrows (1845-1909) amerikai unitárius lelkész, a Christian Register főszerkesztője érkezett Kolozsvárra. ${ }^{256}$ Barrows egy évet töltött Európában, beutazta Angliát, Skóciát, Hollandiát, Németországot, hat hónapot töltött Athénban, majd a Balkánon keresztül utazva jutott el Kolozsvárra. Felesége és későbbi életrajzírója, Isabel C. Barrows ${ }^{257}$ Kovács Jánost, a család régi ismerősét levélben kérte, legyen férje segítségére kolozsvári útja megszervezésében. Barrows június 17-től 23-ig volt Kovács János és az unitárius egyház vendége, elődeihez hasonlóan őt is tiszteletbeli tanácsossá választották. A város nevezetességeinek megtekintése után Boros György kíséretében Tordára ment, ahol Brassai Sámuellel találkozott. A vallásszabadság szülőhelyén, a tordai fejedelmi ház emlékkönyvébe ezeket írta:

\footnotetext{
${ }^{253}$ Kolozsvár, 1892. szeptember 26., 219. sz.

${ }^{254}$ Uo., 1893. február 24., 45. sz.

${ }^{255}$ In Memoriam John Paget Esq., Kolozsvár, 1893. (An Oration in Memory of the Late John Paget Esq. Honorary Member of the „Kolozsvár English Conversation Club”, delivered by prof. John Kovács, president, at the Anniversary Held on the 23-d of February 1893 in Kolozsvár)

${ }^{256}$ Amerikai vendég Kolozsvárott, Kolozsvár, 1893. június 19. 137 sz.; Barrows J. Sámuel látogatása Kolozsvárt, UK, 1893, 121-123. Hungarian Correspondence, The Inquirer, July 29, 1893, $478-479$.

${ }^{257}$ Isabel C. BARrows, A Sunny Life, 1913.
} 
„El vagyok ragadtatva, hogy itt lehetek e teremben, hol a lelkiismeret szabadságát, jogát tisztelték és még inkább el vagyok ragadtatva annak meggondolásán, hogy ez a szent örökség, mely elveszett volt, életre kelt és tisztelik. Megismeritek az igazságot, és az igazság szabadokká tesz titeket." 258

Barrowst 1896-ban az Amerikai Egyesült Államok kongresszusa tagjává választotta, az amerikai börtönreform-bizottság tagjaként dolgozott. Jesus as a Penologist című dolgozatát Kovács János lefordította és a Keresztény Magvetóben megjelentette. ${ }^{259}$

1894. március 8-án az English Club 18. közgyülését tartotta. Az elnök az előző évi látogatókról emlékezett meg, köztük Buckle tábornok és Fitz Gerald, a Daily News levelezőjének neve is elhangzott. A választmány új tagokkal bővült: dr. Mezei Sándorral, dr. Hantz Mihállyal és dr. Pap Sándorral.

1895-ben a közgyưlést az Angol Királynő szállodában tartották február 24-én. ${ }^{260}$ A jelenlevők sorában újabb neveket találunk: Ferencz József püspök és Gálfi Lőrinc unitárius teológiai tanárét, valamint Walton Edéét. Boros titkár lemondott tisztségéről és helyébe Gálfi Lőrincet választották. A kör rendes tagjai sorába Ferencz József püspök és Walton Ede nyert felvételt. Az elnök beszámolójában a nemrég elhunyt Felméri Lajosra, az English Conversation Club alapító tagjára emlékezett. A közgyülést követő vacsorán a tagok W. F. Annesley Londonból küldött plumpudingját is megkóstolták. Péterfi pohárköszöntőjében Hindy Árpádnét éltette, aki Ázsiában született, gyermekkorát Amerikában töltötte, Franciaországban és Angliában nevelkedett és Londonban ment férjhez. ${ }^{261}$

Augusztus 24-én amerikai vendéget fogadtak a kolozsvári unitáriusok. A BFUA és az AUA küldötte, William Henry Lyon, bostoni lelkész érkezett Kolozsvárra. Kovács János kíséretében Bölönbe utazott, részt vett a zsinaton, majd a brassói unitáriusokkal a Cenk alatti városba ment, hogy „megismerje a magyar állam oláh elemeinek aspirációit." ${ }^{262}$ Az egyik brassói tanárral a nemzetiségek jogairól folytatott beszélgetése során a Monarchia nemzetiségi politikáját az Egyesült Államokéval hasonlította össze, és megállapította, hogy noha Amerika nem olyan par excellence nemzeti állam, mint Magyarország, mégis mindenkitől megköveteli az angol nyelv ismeretét. A tengerentúli vendég tiszteletére a brassói unitáriusok búcsúvacsorát szerveztek és meghívták a helybéli románság képviselőit is. Lyon

${ }^{258}$ Ellenzék, 1896. augusztus 4.

${ }^{259}$ Jézus mint büntetóbíró, KerMagv, 1902, 181-193.

${ }^{260}$ Kolozsvár, 1895. február 15., 38. sz.

${ }^{261}$ Hindy Árpádné Gyurmán Etelka, Gyurmán Adolf (1813-1869) újságíró lánya. Etelka Törökországban, Kütahiában született, 1851-től New Yorkban, 1854-től Londonban élt. Anyja második férje az ugyancsak emigráns Grisza Ágost volt (1818-1884). Etelka 1867-ben Londonban ment férjhez Hindy Árpád (1843-1898) hírlapíróhoz.

${ }^{262}$ Amerikai lecke az oláhoknak, Kolozsvár, 1895. augusztus 30., 197. sz. 
a nemzetiségi kérdést amerikai eleganciával intézte el, és a vacsorán megjelent

„oláhoknak hatalmas beszédben ajánlotta, hogy legyenek jó magyar állampolgárok, tiszteljék és tanulják a nyelvét a magyar fajnak, amely ezt a szép hazát megszerezte, szolgálják híven hazánkat, amely őket befogadta s legyenek büszkék arra, hogy olyan államnak polgári, amilyen a magyar állam."263

A bostoni lelkész a The Christian Registerben közzétett beszámolóját egyelöre nem tudtuk megtalálni, valószínüleg ugyanazt publikálta a The Inquirerben is. Részletesen elbeszélte útját, Ferencz József püspökkel való találkozását, a fogadtatását Apácán és a zsinat székhelyén, Bölönben. Az erdővidéki székely településről készült leírása a tizenkilencedik századvég paraszti életének hü képét adja. ${ }^{264} \mathrm{~A}$ zsinat megnyitó ülése, Ferencz József püspök lelkészi szolgálatának 40. jubileuma, és a lelkészszentelés az egzotikum varázsával hatott az Egyesült Államokból érkezett látogatóra. Az angol-magyar unitárius kapcsolatok eredményeinek számbavétele során megállapította, hogy az Angliában tanult ifjú lelkészek szerepe az angol szellemiség és erkölcs magyarországi meghonosításában a lehető legszélesebb körre terjed. Zárómondatában a magyar unitárius misszió támogatására buzdított. ${ }^{265}$

\footnotetext{
${ }^{263}$ Uo.

264 "The village of Bölön seems to be made up almost entirely of small farmers, many very poor, none more than comfortable. Their houses are all of one story, of stone or brick covered with plaster, the roofs sometimes thatched, but usually tiled. The barns are all thatched, and with their very high, steep roofs, and the rails which are laid across their ridge poles to keep the straw down, are the most picturesque buildings to be found in Europe, albeit a little barbaric in appearance. The peasants are all of rather low stature, muscularly strikingly so; the women looking careworn and almost sad with constant overwork. Their manners are simple, gentle, warm-hearted, and nothing seems so improbable at first sight as that they should be the descendants of the fierce Huns whom Gibbon so graphically describes." William H. Lyon, The Unitarian Synod in Hungary, The Inquirer, September 28, 1895, 615.

265 "It is missionary work which our Hungarian brethren are doing, therefore, with their churches and universities, contending with a religious condition in their land which has passed away almost wholly from England or America, and if we care to do any work outside our own countries, there is no better ground for it than the land where Ferencz and Kovács and Boros and their brethren are fighting so well." Uo., 617.
} 


\subsubsection{Az English Conversation Club 20. születésnapja. Angolok és amerikaiak Kolozsvárott a millennium évében}

1896-ban, a millennium esztendejében ünnepelte a Conversation Club 20. születésnapját. Az elnök a március 12-én tartott közgyűlési beszédében ügyes retorikával kapcsolta egybe Magyarország 1000. és az English Conversation Club fennállásának 20. évfordulóját. A nevezetes 1896. évben a klubnak 23 rendes és 17 olvasó tagja volt, könyvtára pedig 2400 kötetet számlált. A Bel-Király utcába költöztetett Bibliotheca újból helyet változtatott, és a könyvtárnok, Széky Miklós házában talált végleges otthonra. Az elnökség soraiban az előző évhez viszonyítva nem történt változás, a választmány Concha budapesti meghívása és Felméri halála következtében megújult. A kör alapító tagjai közül egyedül Péterfi Dénes került a vezető testületbe. Az új választmány tagjai: Brassai Sámuel, Hindy Árpád, Péterfi Dénes és Szathmáry Elek voltak. Új tagként felvételt nyert Kacsóh Pongrác (1873-1923) zeneszerző, zenepedagógus, tanár. A közgyűlésen az elnök a himnuszt szavalta el, természetesen angolul, Gálfi Lőrinc titkár pedig Oliver Goldsmithtől olvasott fel, hogy mit, arról nem írtak a lapok. ${ }^{266}$

1896. július 31-én George Bruce Halsted (1853-1922), az austini (Texas) egyetem matematikusa érkezett Kolozsvárra. ${ }^{267} \mathrm{~A}$ nem euklideszi geometria amerikai szakértője több tanulmányában is foglalkozott a jeles matematikusok - Bolyai János, Nicolaj Ivanovics Lobacsevszkij (1792-1856), Giovanni Saccheri (1667-1733) és Henri Poincaré (1854-1912) - munkásságával. Lobacsevszkijnek 1896-ban Oroszországban szobrot állítottak, ennek leleplezésére Halstedet is meghívták, így ejtette útba Erdélyt. Természetesen Marosvásárhelyre is elzarándokolt, onnan pedig Bedőházi János tanár társaságában Kolozsvárra jött Farkas Gyulát és a kolozsvári tudományegyetemet meglátogatni.

Július 22-én egy másik amerikai, Dyer Frank Chester (1869-?) érkezéséről írtak a lapok. Chester bostoni unitárius, Szíriában töltött egy esztendőt a sémi nyelvek tanulmányozásával. ${ }^{268} \mathrm{~A}$ budapesti egyetemen kívánta folytatni tanulmányait, Goldziher Ignácnál arab nyelvet és irodalmat akart hallgatni. Kolozsvárra azért jött, hogy magyarul megtanuljon. Chestert 1897-ben az Amerikai Egyesült Államok budapesti konzuljává, 1904-től pedig főkonzullá nevezték ki. Kovács Jánosnak haláláig meghitt barátja volt. Július 23-án mindkét amerikait bevezették az angol klubba. Kovács

\footnotetext{
${ }^{266}$ Kolozsvár, 1896. március 13., 61. sz., Ellenzék, 1896. március 13., 61. sz.

${ }^{267}$ Amerikai látogató, Kolozsvár, július 21., 164 sz.; Amerikai tanár Bolyairól, Ellenzék, 1896. július 23., 166 sz. Lásd még: Kelemen Lajos, Bolyai János Üdvtanáról = Múvelődéstörténeti tanulmányok, szerk. SAs Péter, Kriterion, 2006, 235-236.

${ }^{268}$ Boros György, Hungarian Correspondence, The Inquirer, August 15, 1896, 529. Amerikai vendég Kolozsvárott, Kolozsvár, 1896. július 22., 165. sz.
} 
a „szabadság hazájának kiváló tanférfiait” szeretettel köszöntötte azért is, mert „Amerika a magyarok iránti rokonszenvét, vendégszeretetét fényesen bebizonyította és éreztette Kossuth Lajossal s emigránsainkkal." ${ }^{269}$ Halsted az elnökhöz és a kör tagjaihoz intézett pohárköszöntőjében a Bolyaiak világhírnevét és Magyarország szépségét éltette. ${ }^{270}$ Hazatérte után Texasban After a Thousand Year in Hungary címen tartott felolvasást. ${ }^{271}$

Chester beszédének eredetije nem maradt fenn, a Kolozsvár tudósítója szerint azért jött Magyarországra, hogy a nyelvet tanulmányozza. Kolozsvárra az angol kör s a testvéri viszony vonzotta. Barátaitól azt kérte, segítsenek a nyelvtanulás nehézségei legyőzésében. Örvend annak, hogy Jókait, Aranyt, Petőfit hazájukban eredetiben fogja olvasni. Chester szeptember elején ment Budapestre, addig többnyire Kovács János társaságában ismerkedett a nyelv rejtelmeivel és Erdély szépségeivel.

\footnotetext{
${ }^{269}$ Amerikai tudósok ünneplése Kolozsvárt, Kolozsvár, 1896. július 24., 167. sz.

270 "Mr. President and Gentlemen of the English Conversation Club:
}

I welcome with great pleasure this opportunity of expressing my gratitude for the cordial hospitality with which I have been received in Hungary. I knew that the Hungarians were renowned for hospitality, but the reality has exceeded the picture. I came from a far distant part of America to visit in Hungary the birthplace of a scientific idea so profound that though published at Maros-Vásárhely more than half a century ago it is only now that the world is beginning to appreciate and assimilate it. The Hungarians Bolyai Farkas and Bolyai János are today renowned in the most distant west in Texas and in the most distant east in Japan; and are studied in the Universities of both these countries. I come here in homage to Hungarian genius, and I find a land brilliantly picturesque, a capital, Budapest, wonderful for the charm of its situation, rich in achievement and in promise, its attractions heightened by the grand millennial exposition. Here in Kolozsvár I find a veritable new Athens, a capital in the realm of mind, a community which may be justly proud of its exceptional educational advantages and intellectual life. But wherever I go in this lovely land, so worthily to have inspired the splendid patriotism of 1848 , I am dazzled by the striking beauty of the Hungarian ladies. Of my own country it is difficult to speak to you because of the extreme diversity of its different parts. We have with us tonight in Mr. Chester a representative of Boston, of our North and East. Boston is a city of Unitarians, where life is strict, were all the people are white and good, but where I fear that the delicious Hungarian wines are not duly appreciated. I myself am here from an utterly different region, from Texas, in our South and West, where races of four distinct colours are intertwined in the struggle for existence. There besides the dominant whites are the cruel red Indians, the treacherous yellow Mexicans, and the superstitious black Negroes. No Unitarians are there, and human life is not held sacred. In Texas to steal a horse is worse than to murder a man. So you see how difficult is to judge America. But when we have endured not nearly a hundred but a thousand years and celebrate our millennium we may be as homogeneous as your own happy land.

I propose a toast to the English Conversation Club, and to Hungary." Kovács János hagyatéka, 2. doboz. 38. sz.

Halsted, George felolvasása a Kolozsvári Angol Klubban 1896. július 23.

${ }^{271}$ Bolyai emlékezete Amerikában, Ellenzék, 1897. január 12., 8. sz. 
A budapesti millenniumi rendezvények során a nemzetközi sajtókongresszus néhány résztvevője június 18-19-én Kolozsvárt is megfordult. Miss F. C. Armstrongnak a Journalistban megjelent írását Hindy Arpádné lefordította, és a férje lapjában, a Kolozsvárban megjelentette.

„Kolozsvárt a polgármester, hírlapírók és a Kárpát-egylet fogadtak bennünket, de milyen fogadtatás volt az! Amelyet soha többé nem reménylünk, csak ha az édes Kolozsvárra mehetnénk még egyszer vissza. Anyanyelvünkön fogadtak és jól beszélik, úgy, hogy nehéz elhinni, hogy Európának a keleti részén vagyunk; kocsik vártak reánk és elvittek a New York szállodába, mely fényre és kényelemre egyforma a londoni Metropole-szállodával..."272

A klub vendégül látta azt a három fiatalembert is, akik kerékpáron szándékoztak beutazni a világot, és akik augusztus 23-án értek Kolozsvárra. John Foster Fraser, Frank H. Lowe és Samuel Edward a Daily News munkatársaiként mutatkoztak be, és Kovács és az angol klub több tagjának társaságában közös vacsorán éltették az angol-magyar barátságot. ${ }^{273}$

A magyar unitárius egyház a millennium évében szeptember 6-7-én Budapesten nemzetközi konferenciát szervezett, melyre angol hittestvéreiket is meghívták. A konferencia programját William Copeland Bowie (1855-1936), a BFUA nemrégiben (1892) választott titkára június 20-án az Inquirerben közzétette. ${ }^{274} \mathrm{~A}$ fővárosi sajtó ismertette a kongresszus lefolyását, legrészletesebben az Egyetértés elemezte az eseményeket. A nemzetközi unitárius találkozóra érkezett, tekintélyes angol és amerikai delegáció néhány tagja - John Briggs Lloyd (1836-1897) liverpooli, Theodore William Chickering (1855-1915) New York-i lelkész - Erdélybe és Kolozsvárra is ellátogatott, de az angol körben csak az utóbbit mutatták be. ${ }^{275} \mathrm{Az}$ English Conversation Club tagjai mégsem panaszkodhattak arra, hogy társaságukat elkerülnék az amerikai és angol látogatók. 1896-ban Halsted és Chester után még négy amerikai vendége volt a körnek. Szeptember 14-én Emma Southwick érkezett Kolozsvárra, Kovács János 1882-ben Philadelphiában tett látogatását viszonzandó. ${ }^{276}$ Southwick hetedszerre látogatott az öreg kontinensre, és másodjára kereste fel Magyarországot. 1873. évi útján az első angol-amerikai-magyar unitárius találkozón Fretwellék társaságában járt Budapesten. 1896-ban a washingtoni békedelegáció tagjaként látogatta meg a fővárost, majd Kovács meghívására Kolozsvárt. Az English Con-

\footnotetext{
${ }^{272}$ Miss F.C. Armstrong, Kirándulás Erdélybe, Kolozsvár, 1896. augusztus 21. 189 sz.

${ }^{273}$ Világot bejáró angolok, Ellenzék, 1896. augusztus 25., 193. sz.

${ }^{274}$ Hungarian Unitarian Conference, The Inquirer, June 20, 1896, 395.

${ }^{275}$ A budapesti konferenciáról lásd: H. Enfield Dowson, Unitarians at Buda-Pest, The Inquirer, October 24, 1896, 679-681. Gálfi Lőrinc, Nemzetközi unitárius konferenia Budapesten, KerMagv, 1896, 263-266. Legrészletesebben Értesitó a nemzetközi unitárius konferenciáról. Tartatott az ezredévi kiállitás alkalmából Budapesten 1896. szeptember 6. és 7. napján. (szerk. Boros György), Kolozsvárt, 1897.

276 Angol írónő Kolozsvárt, Kolozsvár, 1896. szeptember 14., 208. sz.
} 
versation Clubban hazája fővárosáról, Washingtonról tartott előadást. ${ }^{277}$ Az elnök Emma asszony előadása után Theodore William Chickering (1855-1915) New York-i unitárius lelkészt és nejét köszöntötte. ${ }^{278}$ Chickering dr. Jankovich Pál, a Dávid Ferenc Egylet székelykeresztúri körének elnöke, és Német István unitárius lelkész társaságában Székelykeresztúrra, majd a Nyikó vidékére látogatott.

Az English Club utolsó amerikai vendége 1896-ban James Samuel Capper (1840-1904) kvéker volt. Capper a budapesti békekongresszuson ismerkedett meg Kovács Jánossal, és minden bizonnyal az ő meghívására jött Kolozsvárra. ${ }^{279}$ Október 22-én a New York szálloda különtermében Shakespeare-ről tartott előadást, elmondta a Hamlet-monológot, majd John Greenleaf Whittiernek Channinghez írott költeményét szavalta el a népes közönségnek. ${ }^{280}$ Capper részt vett az unitáriusok október 25-én tartott Főtanácsi gyưlésén. Ferencz József püspök magyar köszöntését angolul viszonozta, kiválóan megszerkesztett beszédében a bostoni kvékerek és az erdélyi unitáriusok közös gyökereire irányította hallgatói figyelmét. Erdély ellenállhatatlan vonzerőt gyakorolt rám - mondta - mindenekfölött azért, mert itt van a vallásszabadság bölcsője. A reformátorok és a zarándok atyák vallási türelmetlenségét koruk elvakultsága miatt nem kárhoztathatjuk, annál inkább magasztalandó Dávid Ferenc és János Zsigmond, a vallásszabadság törvényének becikkelyezéséért - írta. ${ }^{281}$

\subsubsection{Az ezredfordulótól az alapító elnök haláláig}

A millenniumi ünnepségek után az angol klub jó ideig csendben folytatta megszokott tevékenységét. A felolvasásokról, látogatókról az ezredfordulóig alig-alig ír valamit a helybéli sajtó. Az Ellenzék 1897-ben Deyer Frank Chester amerikai konzullá való kinevezését közölte olvasóival, és azt, hogy a főváros első amerikai konzulja januárban egy hetet töltött Kovács János barátja otthonában. Chester minden évben megismétlődő látogatásait leszámítva úgy tünik, hogy vagy az angol klub szenderült „Csip-

\footnotetext{
${ }^{277}$ Ellenzék, 1896. szeptember 16., 210. sz.

${ }^{278}$ Amerikaiak Székelyföldön, Ellenzék, 1896. szeptember 18., 212. sz.

${ }^{279}$ Angol író Kolozsvárott, Kolozsvár, 1896. október 17., 237. sz.

${ }^{280}$ Ellenzék, 1896. október 23., 241. sz.

${ }^{281}{ }^{\prime \prime}(\ldots)$ we prize and honour the Catholic and Christian wisdom of Bishop Francis Dávid, who when the whole State in the middle of the sixteenth century became Unitarian, proclaimed absolute toleration to all other confessions, and the enlightened John Sigismund, who made this absolute toleration the law of the land in 1557 at Torda. In this respect George Fox was the spiritual descendant of Francis David; and William Penn, in granting absolute freedom of conscience in the constitution of Pennsylvania, was the worthy successor of John Sigismund." Mr. S. J. Capper and the Hungarian Unitarians, The Inquirer, November 7, 1896,
} 717. 
kerózsika-álomba", vagy pedig a napilapok tettek hallgatási fogadalmat, mert 1897-ben és 1898-ban csak a francia társalgó kör évi közgyüléséről adtak hírt. Ha az angol klubban elcsendesült is az élet, az egyházdiplomácia hibátlanul múködött, és koronként vendégek is érkeztek. 1899. júliusában Thomas Van Ness, a bostoni Second Church lelkésze érkezett Magyarországra. Budapestről Chester konzul kísérte Kolozsvárra. A Keresztény Magvető beszámolója szerint Van Ness „inspirációt nyerni, és inspirációt adni" jött, tulajdonképpeni úti célja az 1900-ban Bostonban szervezett Nemzetközi Kongresszus előkészítése volt. ${ }^{282}$ A magyarországi unitáriusokat 1900-ban Boros György képviselte a jeles eseményen.

1900 októberében Walter Crane (1845-1915) festő, könyvillusztrátor budapesti tárlata után Kolozsvárt is meglátogatta, ahol képei egy részét az Iparmúvészeti Múzeumban állították ki. ${ }^{283}$ Tiszteletére bankettet rendeztek, ${ }^{284}$ Múvészet és szocializmus címü írását közölték a Magyar Polgár tárcájában. ${ }^{285} \mathrm{Az}$ angol képzőművész családja és Rozsnyay Kálmán festőmúvész kíséretében október 29-én érkezett Kolozsvárra, ahonnan Bánffyhunyadra, majd Budapestre utazott. ${ }^{286}$ A sajtó nem említette, hogy bemutatták volna az angol klubban, a tiszteletére rendezett banketten azonban a Conversation Club több tagja is jelen volt, így ha közvetve is, de találkozott Kolozsvár angolbarát képviselőivel. Elutazása után, november 5-én Kovács Jánoshoz levelet írt és barátjának emlékképpen egy rajzot küldött. ${ }^{287}$ Ezen Kovács János és egy leány torockói népviseletben fogadják az ideutazó angol látogatót. A háttérben Kolozsvár jelképe és egy lombos fa, rajta szalag Éljen Kolozsvár felirattal. Az angol feje fölött darvak (crane = daru), Kovács feje fölött sas, Erdély jelképe. A kép alján a következő sorok: „To Professor

\footnotetext{
${ }^{282}$ KerMagv, 1899, 238.

${ }^{283}$ GÁL, i. m., 533-540., Kolozsvárott kiállított képei: Az igazság (akvarell, karton), Szénakaszálás Utópiában (akvarell 720 K.), A salisbury-i templom tornya (akvarell 432 K.), Páva és fügefa című papírkárpitját az Országos Iparművészeti Múzeum vásárolta meg. Május ébredése, ónrajz. Longfellow: The skeleton in Armour címü verséhez készült illusztrációk, A munka diadala 4800 K. A világ meghóditása c. olajfestményét a berlini tárlat után először állították ki hazánkban. Lásd Magyar Polgár, 1900. október 27., 247. sz. Ehhez a festményéhez egy verset is írt, címe: The world's conquerors. (lásd: Magyar Polgár, Walter Crane, mint költő, október 29., 248 sz.)

${ }^{284}$ Bankett Walter Crane tiszteletére, Magyar Polgár, 1900. október 25., 245 sz.; Walter Crane a szinházban, Uo.;

285 1900. október 29., 248. sz.

${ }^{286}$ Walter Crane Kolozsvárott, Magyar Polgár, 1900, október 30., 249. sz.; Ugyanazon a címen október 31-én a bankett lefolyását, és azt ismertették, hol járt a művész. Walter Crane, Magyar Polgár, 1900. november 2., 251. sz.; Kovács Jánosnak levélben köszönte meg szívességét: Walter Crane levele, Magyar Polgár, 1900. november 8., 256 sz.

${ }^{287}$ Lásd: Kós Károly, Walter Crane, Pásztortűz, 1924, X. évf., 10. sz., 52-54. Crane erdélyi útjáról legújabban lásd: Murádin Jenő, Walter Crane a száz év elötti Kolozsváron és Kalotaszegen = Ars Hungarica, 2008, 36. évfolyam 1-2. szám, 229-244.
} 
Kovács, with kindest regards, as a little souvenir of our most pleasant visit to Kolosvár. Budapest. Nov: 4, 1900. Walter Crane."

1901 nyarán a Pákei Lajos tervei alapján készült Unitárius Gimnázium új épülete ünnepélyes átadására Lucy Tagart vezetésével 31 tagú delegáció érkezett Kolozsvárra. Fogadtatásukról részben az unitárius egyház, részben az Erdélyi Kárpát Egyesület gondoskodott. A többségében unitárius urak és hölgyek vezetője az a Lucy Tagart volt, aki negyvennégy évvel korábban apja, Edward Tagart társaságában utazott először Magyarországra. Augusztus 29-én érkeztek Budapestre, ahonnan szeptember 2-án folytatták útjukat Arad, Déva, Vajdahunyad, Torda, Torockó és Kolozsvár felé. Rövid ittlétük alatt megnézték az új kollégiumi épületet, majd az unitarizmus történetében először a kolozsvári templomban angol nyelvü istentiszteletet tartottak. ${ }^{288} \mathrm{Az}$ angol klubbal való kapcsolatuk minden valószínüség szerint a felekezet határain belül maradt, és csak az Angliában tanult akadémitákkal találkoztak.

Az angol klub 1902. évi müködéséről sem tudunk sokkal többet mondani. Csak gyanítjuk, hogy megtartották közgyülésüket és normális kerékvágásban zajlott a kör élete. Az utolsó datálható előadást 1903. március 24-én Kovács János elnök tartotta Brassai Sámuel 1871. évi londoni látogatásáról. Az előadó húsz esztendő távlatából tekintett vissza az utolsó erdélyi polihisztor londoni látogatására. Brassai Bélteky János társaságában utazott, majd résztvett a BFUA évi közgyülésén. A közgyülést követő banketten nagy feltünést keltett zöldes színü frakkjával és az érthetetlenség határát súroló németes kiejtésével. Így esett meg - mondta Kovács -, hogy az egyébként angolul olvasó és író Brassai kiejtése miatt az ő tolmácsolására szorult. A kolozsvári angol társalgó kör alapító elnökének ez volt az utolsó előadása. 1905. január 27-én meghalt. Lázár Ernő hírlapíró, egykori tanítványa az Ellenzékben, január 30-án Mister is dead címü cikkében siratta el: Meghalt Mister, a világ legszeretetreméltóbb, legbecsületesebb embereinek egyike. Az elnök halála után az angol társalgó kör nem oszlott fel, 1907-ben újólag kinyomtatták alapszabályzatukat, és alkalomszerüen találkozgattak is az első világháború kitöréséig. A háború után az impériumváltás nem az angol-, hanem a franciabarát politikának kedvezett, így az 1876-ban alapított Conversation Club is, sok-sok egylet-társához hasonlóan, feloszlott. Talán egyszer jegyzőkönyvei is előkerülnek, újabb adalékot szolgáltatva az angol nyelv- és kultúra erdélyi múveléséhez.

A fővárostól távol, a nem egészen húszezer lakosú Kolozsvárott szervezett English Conversation Club a 19. század utolsó harmadában müködő egyik legdinamikusabb egylet volt. A Kovács János és a Ferenc József Tudományegyetem tanárai köré szerveződő mozgalom ügyesen fogta vi-

${ }^{288}$ Angol istentisztelet a kolozsvári unitárius templomban, KerMagv, 1901, 315-317. 
torlájába a kiegyezést követő liberális szellemet, nem utolsósorban az angol és az amerikai unitarizmus felekezeteken túlmutató, a polgári fejlődést és az egyén személyes szabadságát hirdető ideológiáját/teológiáját.

Erdély szellemi fővárosának hírnevét öregbítették azok az angol és amerikai látogatók, akik a városban és az angol klubban megfordultak. Szerencsés egybeesés, hogy az unitáriusok testvérfelekezeti kapcsolatai során 1860-tól megnyílt az angliai továbbtanulás lehetősége, így a legtehetségesebb fiatal papok Londonban, illetve Oxfordban ismerkedhettek nemcsak az angol teológiai irodalommal, hanem a hétköznapokkal is. Az English Conversation Club alapítása, ha részben is, az angol nyelv és az angol morál erdélyi meghonosodását szolgálta. A mindenkori londoni, majd oxfordi akadémiták feladatuknak tekintették - egyházi teendőik mellett - a klub életébe is tevőlegesen bekapcsolódni. A Conversation Club érdeme, hogy az angol nyelv müvelését Kolozsvárott a polgári értelmiség feladatává tette, az erdélyi unitáriusok angol kapcsolatainak felhasználása a szerencsés egybeesésen túl a felekezet nyitottságát igazolja. Így tehát a magyar-angol kapcsolatok történetében helye van a kolozsvári English Conversation Clubnak is.

\subsection{Kitekintés. Az angol-amerikai-magyar unitárius kapcsolatok teológiai és egyháztársadalmi mérlege}

Nem könnyű megválaszolni azt a kérdést, mivel járult hozzá az angolszász unitárius teológia a magyar teológiai irodalom fejlődéséhez. Talán nem járnánk el helyesen, ha az angolul beszélő hitrokonok teológiai rendszerében keresnénk magyar megfeleléseket, inkább arra kell figyelnünk, milyen változások következtek be a magyar unitarizmus történetében a 19. század második felében, és hogy ezek elindítóit kereshetjük-e Angliában vagy az Egyesült Államokban.

Akik csak egy kicsit is jártasak az unitárius teológiában, azok ismerik Szentábrahámi Lombárd Mihály Summa Universae Theologiae címü munkájának korszakmeghatározó jelentőségét. ${ }^{289}$ Az erudítus püspök arra vállalkozott, hogy a magyar unitáriusok hitelveit úgy rendszerezze, hogy azok elfogadásra találjanak az Erdélyben élő protestánsok körében is. Ez a kizárólag remonstráns és szociniánus örökségből merítő dogmatika teljesen hátat fordított a 16. században megfogalmazott nagy ívứ nonadorantiz-

${ }^{289}$ Summa Universae Theologiae Christianae Secundum Unitarios, Claudiopoli 1887. Magyarul: A keresztény hittudomány összege az unitáriusok szerint, ford. Derzsi Károly, Kolozsvár 1899. 
musnak. ${ }^{290}$ A Summa jelentőségéről azért kell szólnunk, mert a 19. századi erdélyi unitarizmusnak - az angol kapcsolatoknak köszönhetően - sikerült kimozdulnia a Szentábrahámi-féle dogmatikai merevségből. Tisztában vagyunk azzal, hogy Szentábrahámi rendszerének alapjait már Körmöcziék óvatosan elkezdték bontogatni, azonban a kiművelt teológus fők kivételével ez nem ért el a papságig és az erdélyi unitárius közösségekig. A kiegyezést megelőzó évtizedekben az erdélyi unitárius teológiában lassan helyet kaptak az angol és amerikai teológusok müvei. Kriza János munkásságának egyik első terméke volt a hét kiadást megért ún. Channing-féle káté. Ebben Kriza névtelenül ugyan, de a lehető legszélesebb körben propagálta William Ellery Channing amerikai unitárius vallásbölcselőnek irénikus szellemben írott nézeteit. ${ }^{291}$ Krizát egyházában leggyakrabban azzal vádolták, hogy az angol-amerikai barátságért elárulta a magyar unitarizmus ügyét. Nem véletlen egybeesés az, hogy a Channing-fordítások fénykora Kriza püspökségére esik, ${ }^{292}$ miként az sem, hogy a korszak legjelentősebb irodalmi vállalkozásának, az angol és amerikai teológiai irodalomnak hasábjain helyet adó folyóiratnak, a Keresztény Magvetônek elindításában és szerkesztésében a költő püspök főszerepet játszott.

Az angol hitrokonság másik jelentős eredménye az angol és erdélyi felekezeti történetírás felpezsdülése volt. Nem sokkal az erdélyi hittestvérek felfedezése után Angliában elég hosszú vita kezdődött arról, mennyiben tekinthető az angol unitarizmus autochton produktumnak? Gaston BonetMaury francia egyháztörténész meggyőzően érvelt a londoni Strangers' Church és a kontinensről átszivárgó szociniánus müvek katalizátor volta mellett, ${ }^{293}$ míg angol ellenfelei - Alexander Gordon és J. J. Tayler - a mozgalmat teljességgel a dissenter tradícióba ágyazottan, minden szociniánus hatástól mentesen látták. Dolgozatunk szempontjából egyáltalán nem mellékes, hogy mind Gordon, mind pedig Tayler ellátogatott Erdélybe. A gyökerek keresése természetszerüleg nem lehetett mentes bizonyos érzelmi kötődéstől, ez azonban Kolozsvárott bocsánatos bünnek számított, és ez a fajta önkeresés adott lendületet az erdélyi unitárius történetírásnak. Nevezhetjük ezt pozitívnak, hagiografikus elemektől terheltnek, provinciálisnak, de nem mehetünk el szó nélkül Jakab Elek, Kanyaró Ferenc, Bor-

${ }^{290}$ Dolgozatunkban nem célunk Szentábrahámi teológiáját elemezni, ezt megtették előttünk mások. Lásd: VÁri Albert, Szentábrahámi theológiája, KerMagv, 1900, 145-154, 257-267, 307-319; 1901, 65-77, 188-200, 302-314; Vö. MasznYık Endre, Szent-Ábrahámi Mihály, mint dogmatikus, Theológiai Szaklap, 1903 július - 1904 szeptember (1-5 sz.), 199-211, 267-280, 337-348.

${ }^{291}$ A kérdésről lásd: Endő János, Egy névtelen káté 1845-ból. Channing, E.W. kátéja, Kriza János átdolgozásában = Teológiai Tanulmányok, Kolozsvár 1996, 107-141.

${ }^{292}$ Uo., Channing magyar nyelven, 142-167.

${ }^{293}$ Gaston Bonet-Maury, Early Sources of English Unitarian Christianity, London, 1884, 115135. 
bély István nem mindennapi teljesítménye mellett. Jakab Dávid Ferencéletrajza indította el a felekezetet önmaga megtalálásának útján. A múlt hőseinek, elsősorban Dávid Ferenc alakjának újraértelmezési folyamatát akaratlanul is az angol hitrokonok kezdeményezték. A Tayler által szorgalmazott közös egyháztörténet kiadása meghiúsult ugyan, de ennek nem teológiai, hanem kulturális okai voltak. A három évszázados elnyomásból lassan ébredő magyar unitáriusok prioritása a provincializmusból való kitörés volt, és ezt nem a közös egyháztörténet kiadásával, hanem a budapesti templom felépítésével, a fővárosi bázis kiépítésével kívánták elérni. A templomépítés és a magyarországi misszió hihetetlen erőket mozgatott meg Angliában és az Egyesült Államokban. Csak példának okáért említjük, hogy a budapesti lelkész javadalmazását évtizedeken keresztül az angol és amerikai unitáriusok finanszírozták!

A kiegyezést követő egyháztársadalmi megújulásnak újból csak angol gyökereit találjuk. A Boros György által 1884-ben alapított Dávid Ferenc Egylet csíráját Angliában kell keresnünk, a frissen hazatért akadémita az angol vallásos élet mintájára szervezte meg az unitarizmust, de a közmüvelődést is szolgáló nagy múltú egyletet is, ${ }^{294}$ melynek folyóiratában, az Unitárius Közlönyben rendszeresen beszámoltak a külföldi unitárius megmozdulásokról. Az Egylet kolozsvári és vidéki felolvasó ülésein a legkiválóbb katolikus, református, zsidó tudósok olvastak fel. Az 1870-1880ban alakult vallásos egyletek közül az unitárius Dávid Ferenc Egylet volt az egyetlen, mely kapuit szélesre tárta, és nemcsak keresztény, de zsidó előadókat is szívesen látott a felolvasó pulpitusnál. Mind a Dávid Ferenc Egyletben, mind a Keresztény Magvetóben rendszeresen felolvastak/írtak az angol és amerikai egyházi életről. Ha megvizsgáljuk a Magvetőt, azt fogjuk látni, hogy nem volt egyetlen olyan füzet sem, amelyben ne tudósítottak volna a tengerentúli hitrokonokról, vagy ne fordítottak volna valamelyik klasszikusnak számító angol vagy amerikai unitárius szerzőtől.

A budapesti lelkész, Derzsi Károly alapította Unitárius Kiskönyvtár több mint ötven füzetre rúgó sorozata zömében angol unitárius traktátusok fordítása. Azt megállapítani, hogy ezeknek a magyar misszióban mekkora szerepük lehetett, ma alighanem lehetetlen.

A tizenkilencedik századi angol-amerikai-magyar unitárius kapcsolatok döntő módon járultak hozzá a magyar viszonylatban - számarányát tekintve - kis közösségnek számító unitárius felekezet öntudatának megerősítéséhez. Talán nem lenne érdektelen a magyar-angol unitárius kapcsolatok poszt-viktoriánus történetét és az első világháborút követő eseményeket elemezni.

\footnotetext{
${ }^{294}$ A Dávid Ferenc Egyletröl lásd a legutóbbi tanulmányt: GAAL György, A Dávid Ferenc Egylet és kiadványai = Múzsák és erények jegyében, Kolozsvár, 2001, 137-173.
} 


\section{FÜGGELÉK}

A Függelékben közölt szövegrészeket a mai helyesírás szabályait követve átírtuk, a központozást értelemszerúen módosítottuk. A 19. században készült fordítások stílusán nem javítottunk, hanem a problémásnak látszó szövegrészek mellett, szögletes zárójelben közöltük az eredeti szövegváltozatot is. Az elírásokat, téves dátumokat [sic!] jelöltük.

\section{1a. Brevis Expositio, KerMagv 1890, 376-389.}

a) Az angol unitáriusok hitvallása

Azon tiszteletreméltó nagy férfiak, akik a reformáció fáklyáját elöl vitték, kivált e két elvet igyekeztek mindenek felett világosan megmagyarázni és megszilárdítni: hogy a szentírás egyedüli szabályozója a hitnek és cselekedeteknek, és hogy minden embernek legszentebb és meg nem változtatható joga, hogy ezek felől maga alkosson magának Ítéletet. E két elvből indulva ki, sok romlottságot és tévedést téptek ki gyökerestôl, melyekkel a kereszténység egyszerúsége és szépsége már rég elformátlaníttatott volt. E férfiakat vévén maga elé példányképül, s nyomaikon járni igyekezve, de nem úgy, hogy nekik maguknak is tovább menni szabad ne legyen, azon társulat, melyről itt szó van, maga alkotta meg a maga hitét és istentiszteletét.

Az okosság törvényszerű jogát az Isten igéje magyarázásában az unitáriusok különösen követelik, de ezt nem teszik elébe a kijelentésnek, ami pedig gyakran szemökre vettetett; mert mindkettő Istentől eredvén, valódi ellentét közöttük nem támadhat, bárha az nem érti meg mindig, a mit ez tanít. Az okosság teendője, hogy a kijelentés bizonyítékai felett bírálatot tartson, a szentírás igaz és kétes igazságú tételeit megkülönböztesse, s a valódiak értelméről ítéletet hozzon. A mit az Istentől kijelentettnek ismernek meg, azt a legnagyobb tisztelettel fogadják, s a kegyesség és szeretet kötelességén kívül semmit szentebbnek nem tartnak, mint azt, hogy azon igazságokat, melyeket a Szentírásból, annak szorgalmas megvizsgálása 
után merítettek, nyilván és állhatatosan, de szerényen védelmezzék. Az unitáriusok Isten felőli hitének összessége ez: „Egy az Isten, és az Isten Szeretet." Amint nevök is mondja, az igaz, egész és tulajdon értelemben vett egységet állítják: itéletök felőle az, hogy lénye, személye és állata (Substantia) egy. A természet részeinek egymásközti egyezése, a mindenség szerzőjét tanácsára nézve nagynak, munkáiban soknak mutatja. Ez értelmet nemcsak a zsidó és keresztény szentírások nyilván megerősítik, de azt, mint a tiszta vallás forrását és eredetét és legfontosabbat, az embereknek szívökre kötik. Mózes és Krisztus egy értelemben mondják minden parancsolatok közt elsőnek ezt: „Halljad Izrael! a mi Urunk, Istenünk egy úr", és „Szeressed a te uradat, Istenedet teljes szívedből, teljes lelkedből, teljes elmédből és teljes erődből." Ez az első parancsolat. Ez értelemhez híven, az unitáriusok az Istennek többségéről való minden ismeretet, mint az Isten igéjével ellenkezőt, helytelennek tartnak. A szent iratokban sem a Háromság szót, sem e dogmának semmi kifejezését nem találják. Ellenkezőleg: azokból azt veszik ki, hogy: „az Atya nagyobb a fiúnál”, s a Szent Lélek nem önálló személy, de Istennek hatalmi nyilatkozása vagy általa adott ajándék. Minden tökélyt Istennek tulajdonítván, mint minden felség és jóakarat tulajdonosát, őt társ nélkül imádják; s bár igaz, hogy a szent írók, a gonosz okáról, mint valami gonosz szellemről vagyis az ördögről olykor szóltak; de azt nem akarják hinni, hogy a gonosz szellem a hatalomért és uralkodásért Istennel vetélkedjék, annak végzését megváltoztassa $\mathrm{s}$ a világ bármely részét hatalma alá keríthesse. Ezek felett áll az a mondás: „hogy az Isten irgalma minden más munkái felett van”, és ez egészen ellenkezik azok értelmével, akik azt hiszik, hogy Isten az emberi nem nagy részét gonoszságra és örök nyomorra rendelte el az ő visszavonhatatlan végzésével. Minthogy „a bün gonoszság, az igazság egyenesség” ; minthogy jogi parancs az, hogy minden igazságot gyakorló embernek igaznak kell lenni, a léleknek, mely vétkezik, meg kell halni, s minthogy mindenki köteles a maga terhét elhordozni: ezért az unitáriusok nem hiszik, hogy a bűn az igazaknak, az igazság a bünösöknek számíttassék be ami sem a természet törvényével, sem a polgári törvényekkel, sem a szent írásokkal meg nem egyeztethető. Ők azt hiszik, hogy az Atya nevet nem úgy kell venni, mint metaphysikai megkülönböztetést, és közötte s más személyek között való megosztozást, de más nemesebb értelemben, t. i. hogy az a közte és fia, az ő keze míve közt levő viszonyt s emberiség iránti jóakaratát világosan mutassa, s csak az egyetlen Istent jelölje meg, mint az emberek imádására egyedül méltót. Krisztus, a mi urunk pedig Istennek e nevezetet tulajdonítja az isteni természet méltóságosabbá tétele és az ő tanítványainak az ő hirtelen eltávozása miatti vigasztalása végett. Hogy Ô és tanítványai Istennek fiai, szavai bizonyítják. 
Az unitáriusok e felett hiszik: „,hogy a Názáretbeli Jézus, Krisztus”, „,az élő Istennek fia”, s „hogy Ô az emberi nemből származó atyjafiaihoz mindenben hasonlóvá tétetett"; de minden mocsoktól tiszta élete, ritka jótéteménye, teljesített tiszteinek fontossága, kiállott szenvedéseinek keserves volta, végre azon fényes név tekintetéért, a mit Isten neki adott, a legfőbb tiszteletre és becsülésre méltó.

Az unitáriusok hite szerint a szentírásokban a Krisztus az igaz Istentől nyilván megkülönböztetik; mert az Isten az Atya, aki küld, ad, fölken, megszentel, megjutalmaz; a Krisztus pedig, aki küldetik, aki vesz, fölkenetik, megszenteltetik, megjutalmaztatik; mégis úgy ítélik, hogy ez egy az Istennel a kölcsönös akarat és tanács egyessége által, szintúgy, mint nekünk is illik egynek lennünk vele és Istennel. Amint a világ gonoszsága oka volt a Megtartó üldöztetésének és halálának: úgy szenvedései - melyek az általa tanított igazságokat megerősítették, példáját tökéletessé tették, az evangéliumnak az egész világon elterjedését eszközölték, s halottaiból föltámadása a mi feltámadásunknak is zálogává lett - nagy ösztönül szolgálnak a bün eltávoztatására s az igazság tiszteletben tartására. Az unitáriusok ez értelemben vélik veendőnek a szentírás eme szavait: „Meghalt a mi bűneinkért”, és „Az ő vére megtisztít minden büntől”. Az unitáriusok meg vannak arról teljesen győződve, hogy az üdvösségre nem szükségesek homályos és titokszerű (mystikus) hitformák (Symbolum). Pál így szól: „Ha száddal vallást teszel az Úr Jézusról, és hiszed szívedben, hogy Isten őt a halálból feltámasztotta, üdvezülsz." Az Isten igéje által megmutatott szerény, de állandó reményök is van az iránt, hogy irgalmasságánál fogva, őszinte engedelmességöket elfogadja, s az igaz megbánóknak minden fogyatkozását megbocsátja. Ezenkívül az unitáriusok úgy vélekednek, hogy a gonoszoknak büneikhez mért büntetése meglesz: „,akinek sok adatott, attól sok kívántatik", a bűn mértéke szerint kisebb-nagyobb büntetését mindenki elveszi. Minthogy a bölcs törvényhozó is a büntetést nem annyira a megbosszulásért, mint a megjavulás végett szabja, s nemcsak a köztársaság javára, de a bűnösök megjavítására is törekszik: az unitáriusok is többnyire meg vannak arról győződve, hogy Isten uralkodása is olyan, hogy nem akarja: „hogy senki elvesszen, de hogy mindeneket bűnbocsátó kegyelmébe fogadjon".

b) Az angol unitáriusok istentisztelete.

Az unitáriusok isteni tiszteletét főleg egyszerúsége ajánlja: a szertartások különbözését egyházaikban szívesen elnézik; kivívott szabadságukat mindenkivel megosztják, megemlékezvén ama parancsra: „,a hitben gyöngék ügyét fölvegyétek, s gondolataitokat ne fordítsátok mások ítélgetésére és vetélkedésre”; kell: „hogy mindenki a maga értelmében bizonyos le- 
gyen". Ezért inkább a szeretetet tartják egyetértésük kötelékének, mint a hitet, szerencséseknek érzik magukat, s atyjokfiaként fogadnak minden jó embert, aki velök egy hitet akar vallani: „Nekünk egy Istenünk van, az Atya, akitől mindenek, s mi ő benne, és egy Úr Jézus Krisztusunk, aki által mindenek és mi is általa."

c) Az angol unitáriusok története.

Az angol unitáriusok történetét nem könnyü kezdetétől fogva kinyomozni. Mégis bizonyos, hogy az emberi értelem az álomból, melybe anynyi századok sötétsége által elvolt temetve, hirtelen fölébredve, az igazság nyomozására hamar gondot kezdett fordítni. A XV. század közepén Reginald Pecock, asaph-i és cieester-i püspök, aki az erkölcsök és hit reformálásának sürgetője volt, látszik, hogy számbavette azon érveket, a miket a későbbi századok kritikusai, nem csak a Krisztus Istensége ellen, de az ő születésének ama csodás előadása ellen is felhoztak, ami Máté evangéliuma első fejezetében foglaltatik. Püspöki állásáról elűzetett, s amint a hír mondja, állhatatossága nem mentette meg őt, hogy azon rosszak által el ne borítassék, a melyeknek becsületességeért áldozatává lett.

VIII. Henrik király tisztátlan és tilos bujaszerelme a XVI-ik század kezdetén az anglikán egyházat elszakította Rómától. Ez elszakítás, mint amely nem annyiban az igazság keresése által, mint inkább erőhatalommal vitetett végbe, Angliában sokkal kevesebbé tökéletes és bevégzett, mint a reformált hitet valló más országokban. Az egyház fejévé a király lett, új hitformák szabattak meg; de nem kevesen voltak, akiknek mind lelkök állhatatosabb volt, hogy sem véleményeiket a zsarnok intésére most fölvegyék, majd letegyék, mind a szent írásokban és egyházi történetekben való jártasságuk mélyebb, minthogy önkényű tetszését elfogadják. Midőn a hierarchia VIII. Henrik, VI. Edward és Erzsébet királyné uralkodása alatt erejét megszilárdította, a Háromság hittanától idegenkedők sokan föláldoztattak; évkönyvünkben sokak neve jő elé, akik csak az Atya Istent akarván imádni, végső büntetésöket lángok között vették el. Nevezetes a Bocher Joanna esete, akinek kivégeztetése elrendelését Cranmer érsek aki Mária királyné korában, a reformáció iránt vonzalmat tanúsított $\mathrm{s}$ azért a pápisták kegyetlenségét tapasztalta is - a szeretetreméltó VI. Edwárd ifjú királytól csikarta ki, s az szemei könyezése közt mondotta az érseknek: „E dologban egészen a te ítéletedhez alkalmazkodom, neked kell e tettért Isten előtt számolnod." E jeles hölgy az egyszerủ Istenegység hittanát fogadta el, az akkor nem régen angolul kiadott szent írásokat olvasva. Ez új tudomány oly hirtelen terjedt el, hogy elnyomására sok és hosszas üldözés kezdődött. Legate Bertalannak, aki I. Jakab idejében (1611) hiteért megöletett, engesztelhetetlen ellenfelétől bizonyítvány maradt fenn élete és er- 
kölcsei feddhetetlenségéről. Ennek és mások kegyessége és végnapjaikban hősi bátorsága, a nézők lelkét úgy meghatották, hogy később eszélyesebbnek látszott az Isten egységének állítói ellen másképen kegyetlenkedni, hogy ti. börtönükbe bezárva, titokban vesz-szenek el. S bár ezek erényeiről és bántálmaztatásaikról emberi följegyzés nem szól, Isten ujja emléköket halhatatlan betükkel tette megszenteltté, s neveiket az élet könyvébe a legfényesebben fölrajzolta. Az anglikán egyháztól különbözőleg gondolkodók (Dissentientes) rövid diadala I. Károly halála után többnyire a vallásszabadság javára volt, de az unitáriusoknak azzal élni nem engedtetett meg. Biddle János, az erényeiért követésre méltó férfi, aki egy kis unitárius gyülekezetet a maga házában gyüjtött össze, a presbyteri hitvallású theologusok gyülölsége miatt nagy életveszélybe jutott, s miután II. Károly ősei királyi székét visszanyerte, a börtönben halt el. Azon nevezetes fordulata a közdolgoknak (Revolutio) mely III. Vilmost a királyi méltóságra emelte, a protestáns vallás alapjait megszilárdította, a szenátus türelmi engedélyét, mely azon időben szabadelvúnek tartatott, minden különbözőleg gondolkozókra kiterjesztette, de az unitáriusok névszerint kizárattak belőle, sőt kevés idő múlva mostohábban is bántak velök, mert a törvény, mely aztán, 1813. végre eltöröltetett, büntetést, fogságot és számkivetést szabott mindazokra, akik a Háromság bármelyik személye Istenségét tagadták. A XVII. század vége felé az Atya Isten egy Istenségét állítók között különösen két név tündökölt: Locke Jánosé, a türelem és polgári szabadság buzgó védőjéé, aki szerencsésen munkálkodott nemcsak az emberi ész természete és múvei előadásában, de az okosságnak az Isten igéje magyarázásánál törvényes jogába visszahelyezésében is. A szent írások helyesebb előadására nagy befolyással voltak ezen könyvei: A kereszténység észszerüsége („The Reasonableness of Christianity”) és Jegyzések Szent Pál leveleire („Notes on St. Paul's Epistles.”) A másik név Firmin Tamás londoni gazdag polgáré, a szegények bőkezű felsegitőjéé, amint ezt az ő pártfogása által nagymérvben gyarapított több virágzó intézmény tanúsítja. Az Isten egységéről azon időben is kemény vita folyt, s a jeles férfi segítséggel volt sok oly tudós előadás és védelem kinyomatására és kiosztására, melyek az unitárius értekezések gyüjteményeiben ma is - annyi újabb megjelent művek után - megérdemlett becsületben tartva, olvastatnak. Firmin Tamás és amaz időbeli unitáriusok közül legtöbben az anglikán egyház kötelékében maradtak, s ámbár nem a mi feladatunk a különben legjobb férfiakat megítélni, mégis igen sajnáljuk, hogy ez által az ő Istenegység felőli bizonyságtételük súlyából sokat vesztett.

Kezdettől fogva a XVIII. század végéig az anglikán egyházban nagy számú oly theologus volt, akik remélték, hogy a nyilvános hit formáiban (Symbolum) való újítás (Reformáció) nem nehezen végre lesz hajtható; 
s bárha az egyházból nem léptek ki, de mivel azon hitformákat, melyeket közhivatalok elnyerhetése végett alá kellett írni, ismételt aláírásukkal megerősíteni nem akarták, magasb tisztességre juthatásra maguk előtt az utat elzárták. S ezek a maguk tetszése szerint minden alkalmatlanság nélkül éltek. 1710-ben azonban Whiston Vilmos, aki nagy tudományáról, kegyességéről és egyenességéről volt híres férfi, az Istenegység tanának védelmezéseért a cambridge-i egyetemen bírt matematikai tanári tisztétől megfosztatott s a kollegiumból kiűzetett. Clarke Sámuel Háromságról írt tudós könyve sokak szemét és elméjét magára vonta, és az anglikán egyház számos követőinek elméjét az ő hitformáinak megbírálására indította. Ô az isteni tiszteletet vizsgálat alá vette s az Atyán kívül bárkit illethető minden imádást visszautasított. Ez idő óta némely unitárius társaságok mind Angliában, mind Észak-Amerikában, az ő általa megigazított liturgiával éltek, benne néhány kisebb módosítást téve. Ez időben virágzott unitáriusok közül sehogy sem hagyandó ki Newton Izsák, a híres philosophus, aki őszinte és alázatos keresztény volt, a Szentírásnak szorgalmas olvasója; ő az Isten egységét állhatatosan vallotta és a János I. levele (I. r.) 4. versében foglalt fattyú záradékkal szemben, hasznos értekezésében védelmezte. 1771. nagyobbára az anglikán papság közül társaság alakult, mely a szenátushoz többször járult azon könyörgéssel, hogy az egyházi symbolicus könyvek aláírása eltörlésével, legyen nekik szabad másokat felvenni helyettök, a mivel semmi mást nem kivánnak bebizonyitni, mint azt, hogy ők a szent írásokban hisznek. E reménytől elejtetvén, azon idő óta az anglikán egyházból és egyetemekről sok unitárius eltávozott. Ezek közt nevöket a többiek felett emlékezetessé tették Wakefield, Jebb, Evanson és Disney, kik közül az első tudománya és elméje ajándékai által egész Európában ismeretes.

Különösen magára vonta az emberek elméjét Lindsey Theophil eltávozása, aki az igazság iránti szeretetétől indíttatva, a legmagasb tisztességet, amire reménye volt, megvetve, szűkölködésnek tette ki magát, s ha a körülmények úgy kívánták volna, még nagyobbat kiállani is kész volt. Kevéssel azután, hogy egyházi hivataláról lemondott, az Isten tiszteletére London Essex Street nevü utcájában kápolna építtetett, s abban Lindsey a Clarke által megjobbított isteni tiszteleti rendtartást megkezdette. Ez volt az első templom (amint hiszik), mely Angliában határozottan és már eredetekor az egyedül való Atya Isten imádására rendeltetett. Nagy vagyonú, hivataluknál, helyzetüknél, a szenátusban vagy törvényhozásban ékesen szólásukról híres férfiak e templomba jártak eleitől fogva és járnak ma is. Mostani lelkész ott igen tisztelendő Belsham Tamás, előbb a Kálvint követő Dissidensek akadémiájában hittanár, akit írásai - melyekkel vagy a keresztény vallás igazságát és az unitáriusok hitét oltalmazta, vagy az aty- 
jokfiait vak erőszakkal szidalmazó dölyföt rendreutasította, vagy azoknak, akik a halottaktól az őket megillető dicséretet elvonni kívánták, igyekezetét visszatartóztatta - tudósnak, világosnak és nyájasnak bizonyitnak, életének tisztasága, erkölcseinek szelídsége, s szívének jóakarata pedig minden jóknak ajánlják.

\section{d) Az unitáriusokkal rokon felekezetek.}

Eddig az unitárius hitnek az anglikán egyházban való előmeneteléről volt szó. Ez egyháztól, különböző hitfelfogásúak között pedig, a melyek három felekezetre vannak oszolva, s Presbyteri, Independens és Baptista nevet viselnek, hogy a XVIII. század elején az unitárius vallás nagyobb előhaladást nem tett, azon vakmerőség okozta, mellyel a maga véleményét mindenik felekezet védi, amiket, nem mintha öröklés jogán, de munka és igyekezet után bírnának, fóleg ha azért magukat politikai hivatalokból kizártaknak tapasztalják. Akik az anglikán egyháztól legelsőbben kezdettek külön hitnézeteket vallani (Dissentientes), csaknem mind trinitáriusok voltak: sőt azon kétezer pap közül, akik II. Károly uralkodása alatt a hit egyformaságáról hozott törvény által (The Act of Uniformity) javadalmaikból kivettettek, csak Manning Vilmosról bizonyos, hogy ő a Háromság tanától idegenkedett. Azon üldözés, a mit barátja, Emlyn Tamás, dublini pap e hittan felőli különböző eretnek véleménye miatt tiszttársaitól szenvedett, s azon könyvek, melyekkel ügyét védte, sokak elméjét az egy igaz Istenről való tudományra vezették.

Az igazság keresésének szabadsága, az egyháztól különböző hitnézetüek közt, a Presbyterianusoktól indult ki; akiknek mind theologusaik sokkal tudósabbak voltak, mind egyházi kormányzatuk szabadabb, mint az Independenseké és Baptistáké. Az egyházi zsinatok ugyan az angol Presbyterianusok között soha sem használtak igen sokat, és már rég kimentek szokásból. Ez új tudományt közöttük terjeszteni 1718-ig nem volt gyanús, a mikor igen tisztelendő Peirce Jakab, exeteri pap (aki Pál apostol leveleinek Locke által elkezdett magyarázatát tudományosan nevelte) némely a nyugati presbyteriumbeli társainak türelmetlensége által kényszeríttetett, a nyilván bevett háromsági hittan felőli különböző értelmét kijelenteni. Példáját sokan követték, s az egyenetlenség eltávoztatása végett a londoni dissentiens papok vallásos gyülekezetet (Concilium) tartottak, a hol száznál többen voltak jelen; abban azon törekvés, hogy a Háromság tana aláírással tartozó kötelességül kimondassék, (a mit az anglikán egyház hitcikkeinek első és második fejezete rendel), a többség által visszautasíttatott. Ez ellenkezéssel a Peirce véleményei - aki az Arianusok felé hajlott - nem hogy eltöröltettek volna, sőt még sokkal inkább terjedtek, s amint lenni szokott, hogy egyik nézet a másik által nagyobb világosságra jö, a Presby- 
terianusok sokkal nagyobb része Anglia nyugati grófságaiban, nem hogy az Arianismusra fektette volna hitének épületét, de sőt az unitáriusokhoz ment át. E tudománynak a Presbyterianusok között való általános elterjedését nagy mértékben segítették elé igen tisztelendő Lardner Nathaniel írásai, aki az evangéliumi történetek hitelességéről írt könyvében („Credibility of the Gospel History”) tudományának, szorgalmának és lelkülete egyenességének örök emlékét hagyta hátra; a Logos-ról írt leveleiben és a Philippibeliekhez írott levél 2. fejezete 6. verséről írt leveleiben, a Szentírást meghamisítók és a kereszténység ostromlói ellen magát oly erősnek bizonyította be. Most az anglikán egyháztól különböző értelmű majdnem összes Presbyterianusok az unitáriusok hitét vallják, ha a szavakat azon értelemben vesszük, hogy azok mindazokat magukba foglalják, akik csak az Atya Istenségét vallják.

$\mathrm{Az}$ angol Baptisták csaknem kezdettől fogva részben (Particulares), vagy általánosan (Generales) úgynevezettekre oszoltak, amazok Kálvin, ezek Arminius tanait követték. Az elsők a Háromság tanát, az egyedüli igazhitüség (Orthodoxia) közös ismertető jelét visszautasítván, súlyos nézetkülönbségek támadtak közöttük, a miből új kiválás eredett. Nagyobb részök most unitárius hitet vall. Olyak is támadtak a particularisták között nem rég, akik magukat Unionistáknak nevezik, s ezek Sabellius értelmében való unitáriusok. Robinson Róbert, a Baptisták legnagyobb dísze, aki élete végén unitáriussá lett, elébb Krisztus Istensége védelmezését írta meg, mely még ma is ama tan legerősebb védiratai közé tartozik. E férfiban valami sajátságos ékesen szólási hatalom volt, nem az a kimüvelt szónoklat, mely a hallgatók fülét csiklandoztassa, de a mely jeles mondatokkal és érzéssel volt tele, s szóval, arckifejezéssel és kézmozdulatokkal füszerezve, mely a legalkalmasabb volt arra, hogy a hallgatók szívét föllelkesítse azon szabadság szeretetére, melyért az övé lángolt.

Az Independensek a vallástudományban való előmenetel megakadályozására sokkal okosabb tanácsokat követtek. Társulataikat és szószékeiket az eretnekség minden neme ellen hitformák (Symbolum) felállításával és cenzúra menydörgéseivel előrelátólag megszilárdították, a Háromság titkaiba a csecsemőket is beavatták. Községök tehát mindig ugyanazon állapotban maradt meg, de folytonos nézetkülönbségekkel és megtanult szólásformákkal, akik a Szentírás szavaival nyilván soha nem harcolnak. Utóbb ezek papjai és tudósabb községtagjai is nyilvános hitöket az unitáriussal cserélték fel. Ily módon Watts Izsák jeles költő és theologus, akinek énekeit az Independensek és sok más keresztény gyülekezetek használják, agg korában elébbi hitnézeteitől sokban eltért. 
Ezek között született s a papi szent hivatalra oktattatott a mind maga századában, mind minden más századokban híres philosophus, a nagy dicséretre méltó (LL. D.) Priestley József, aki megismerve azon vélemények téves voltát, a melyeket neki tanítottak, az unitáriusokhoz tért át, s minden erejét arra fordította, hogy ama tévelygésekben levőket helyesebb nézetekre bírja. Senkinek inkább nem köszönhető, mint neki, hogy az egy Istenről való tudomány új fény kiárasztása által a mi időnkben napról napra inkább terjed. Mert Priestleyben sok olyan tulajdon volt, ami őt a reformátori küldetésnek fényesen betöltésére képessé tette, s a mivel ő valóban ékeskedett: gyors felfogású elme, ami mindenre alkalmasnak látszott, fáradhatatlan munkásság, veszélytől meg nem rettenő szív, az igazság keresésének égő vágya, s annak, a mit az ész megtalált, előadására bámulatos ügyessége. Ellenei is megvallották, hogy ő nagy ember; akik megismerték lelke egyenességét s jóakaratúságát, s ami benne fő volt, ama kegyességét, mely szerint mindenét Istentől adottnak vallotta, s gondviselését nemcsak dolgainak szerencsés folyásában, de azokban is elismerte, a mik másképpen történtek. Egyébiránt bárha a physika és philosophia müvelésében annyi sikerrel munkálkodott, a mennyivel a hozzá hasonlók közül senki sem, de ama csekély dicsőség által magát az ősöktől elvonatni nem engedte; mert legkedvesebb tisztének azt tartotta, hogy védelmezze a keresztény vallás igazságát, melyet e század kétségbe von azon tévedésnél fogva, hogy minden régit hamisnak tart, és hogy azt jobban megvédelmezhesse, igyekezett azt a szent írások és keresztény régiség felőli tudományával, mellyel a legnagyobb mértékben bírt, régi épségébe visszaállítani. Fájlalnunk kell, hogy ily jeles férfinak, aki hazáját elméje és tudománya hírével ékesítette, azt hálátlannak kellett tapasztalnia. Megváltozván Franciaországban a dolgok állapota, Priestley méltatlanul azon bünnel vádoltatott, hogy Angliában új dolgokat forral, mely hír titkon elterjesztetvén, a nép dühe ellene felköltetett, a tanácsnak - melynek tiszte lett volna azt féken tartani, vagy elnézésével vagy tán épen pártolásával házát megrohanta, ajtóit feltörte, könyvtára, philosophiai eszközei, bibliai magyarázatai tűz martalékává lettek, s maga is alig tudott bántatlanul menekülni. Megértvén, hogy hijában hivatkozik a törvényekre, melyekben amúgy sincs oltalom, elhatározta, hogy önkéntes számüzetésbe Amerikába megy. Ez 1794-ben volt, a hol néhány év múlva meghalt, ama reménnyel, a mellyel kereszténynek meghalni illik, hazájának megbocsátva. Azt hisszük, kevesen vannak az angolok közül, akiknek arcát azon rövid tartamú őrültség most szégyenpirral nem önti el. Az unokák közül bizonyára senki sincs, aki e dolgot hallva, szemlesütve ne mondja méltatlan tettnek. 
Számkivetésbe menése előtt kevéssel Priestley társulatot alakított Londonban ily név alatt: „Unitárius társulat a keresztény ismeretek terjesztésére és az erény gyakorlatára könyvek kiosztása által." (The Unitarian Society, for Promoting Christian Knowledge and the Practice of Virtue by the Distribution of Books.) E társulatnak kettős célja volt. Egyik, hogy egybekötő kapcsa legyen az egyetértésnek s erejüknek egyesítésére hívja meg mindazokat, akik hiszik: „hogy egy az Isten, egy a közbenjáró Isten és emberek között, a Jézus Krisztus". Másik, hogy a keresztény tudományról helyes tanokat tartalmazó s az erények ápolására alkalmas könyveket nyomasson és olcsó áron terjessze. E társulat más jótéteményei közt megemlítendö, hogy gondviselése alatt lett közzétéve az Újszövetségnek Griesbach javítása szerinti fordítása (1808.), melyhez sok tudománnyal írt jegyzetek járultak, előre bocsáttatott a bibliai kritika egy átnézete, a mennyiben az az Újszövetséget illeti. A társulat gondnoka most igen tiszteletreméltó Rees Tamás úr, aki nem rég fordította angolra a rakowi katekézist és jegyzetekkel világosította meg. Azóta több ily társulat keletkezett az országban, elannyira, hogy azok valamelyikében minden unitárius egyház benne van. Ezekkel nem ritkán egybeköttetésbe jőnek az úgynevezett keresztény értekezések társulatai (Christian Tract Societies), melyeknek célja az, hogy inkább az erények ápolására, mintsem hittani viták támasztására irányuló könyveket terjesszenek a tudatlanok között.

Ennek következménye, hogy a Háromság feletti vita már nem forog csak a tudósok közt, de kiterjedett a tudatlanokra is; amiből hamar kitünt, hogy a szószéket nem kevesebbé szükség használni, mint a sajtót, s valamiképp módot kell találni rá, miképpen lehessen elejét venni azon roszszaknak, melyeknek úgy a magán emberek, mint a társulatok ki vannak téve a régi hittani elvek elhagyása miatt. Alakult tehát 1806. egy társulat, melynek neve: Unitárius alap az unitárizmus előmozdítására népszerü predikációk segélyével. (The Unitarian Fund, for the Promotion of Unitarianism by Means of Popular Preaching.) E társulat célja: először a szegénységgel küzdő unitárius társulatokat isteni tiszteletök folytathatásában segítni; másodszor azon prédikátorokat, akik az evangéliumot az unitárius hittanok értelmében a népnek hirdetik fenntartani; harmadszor segélyt adni azon papoknak, akik az unitárius hitet nyilvánosan vallva, magukat önként szegénységnek vetik alá. Ez inkább egybefűzte és megerősítette az angol unitáriusok buzgalmát, mint minden más intézmény. Ennek segélyével az evangéliumi valódi igazság - amint az unitáriusok vélik mindenütt hirdettetni kezdett, hív és alkalmas Missionariusok járták be Angliát és Cambridget, Scotiát is ismét és ismét fölkeresték, a hol már most több unitárius társulat van, s az igazság terjedése nagy lendületet kapott. E társulat határozatai és iratai kezdettől fogva a közelebbi időig nagy tiszte- 
letü Aspland Róbert úrra bízattak, aki azon eklezsiának fényes nevü elnöke, melyben hajdan a nagy tiszt. Peirce és Priestley papok voltak. Helyére következett most tiszt. Fox J. Vilmos úr, az unitárius társulat papja, mely isteni tiszteletét Londonban, a tüzértelep utcai (Artillery Lane) Parliament udvarban (Parliament Court) tartja.

Hyberniát az unitárius Missionariusok még eddig nem látogatták meg. Ott sokan vannak Presbyterianusok és ariánusi hypothesist vallók. De nem hallottuk, hogy lennének olyan nyilvános gyülekezetek, melyek oly értelemben való unitáriusok, amint fennebb ki volt fejtve. Hybernia mind északi, mind nyugati részében kétségkívül szintúgy mint Angliában sokan vannak, akik bár egyénileg az unitárius hitelvek iránt rokonszenvvel viseltetnek, mégis az ottani eklézsiákhoz csatlakoznak.

Polgári ügyekben csaknem az az unitáriusok helyzete, ami a Dissentereké: isteni tiszteletet tartaniok szabad, a közhivatalokból egyformán ki vannak zárva, kivéve, akik az anglikán egyházhoz csatlakoztak; szenátori tisztet mindazáltal viselhetnek, s az a törvény, mely az unitáriusokra a legsúlyosabb büntetést szabta, 1813-ban eltöröltetett, Smith Vilmosnak, az érdemes unitárius férfiúnak javaslatára, akinek neve külföldön is nagy tiszteletben van azon munkásságért mellyel a szabadság ügyét harminc éven át védte. De meg kell vallani, hogy azon törvény már rég elavult, $\mathrm{s}$ nem alkalmaztatott. Minthogy az unitárius tanuló ifjúság a hazai egyetemekre menéstől el volt zárva az által, hogy a tanulóknak kötelességévé tétetett, hogy az anglikán egyház symbolikus könyveit aláírják, az unitáriusok kényszerítve voltak maguknak önköltségükön Akadémiákat állítani. A mostaninak, ami Yorkban van, igazgatója igen tisztelendő Wellbeloved Károly, aki a theologiának is tanára, de a tudományt nem úgy adják elé, mint bizonyos és minden kételyen felül álló véleményeket, hanem felhozva mindazt, ami a Szentírás értelme megvilágosítására szükséges s egybehasonlítván mindezt, amit mindenik felekezet legtudósabb férfiai a tárgyról írtak, az egész dologról az ítélet alkotást a nemes ífjúságra bízzák. Az igazgató társai közül Turner Vilmos (A. M.-tudományok mestere) a görög és latin nyelvet s az ó- és új történelmet. Kenrick János (A. M.) a mathematikai tudományokat és philosophiát adja elő. Vannak az unitárius ifjak között olyak, akik a skót akadémiákat keresik fel, vannak nem kevesen prédikátorok is, akik a Dissentiensek közt elvégezvén az akadémiai tanfolyamot, véleményeiket megváltoztatva az unitáriusokhoz mentek át. Minden hónapban füzetes könyvecskék jelennek meg e címek alatt: Theologiai és egyetemes irodalmi havi Tár (,The Monthly Repository of Theology and General Literature”) és Keresztény Reformátor („The Christian Reformer") miket az unitáriusok azon célból adnak ki, hogy hitöket a támadók ellen védjék, a theologiai tudást mozdítsák elé, s mindent, akár hazai, akár kül- 
földi legyen, ami a vallásra tartozik, az olvasókkal közöljenek. Az utóbbi csekélységbe kerül s különösen a szegényebbek javára alapíttatott.

Angliában, Skóciában és Cambridgeben több van kétszáz unitárius egyháznál. Száz év előtt egy sem volt, ötven évvel azután is kevés, ami e nevet elfogadni kívánta. Még is abból, hogy az unitáriusok száma oly sok nehézség között is ennyire nevekedett, nekik azon reményök támad, hogy közeledik a nap: „a mikor az Úr egy lesz, s az ő neve egyedül fog állani az egész földön." De egyéb bizonysága is van az unitáriusoknak, mi ezen reményüket megerősíti. Azon tudós férfiak munkássága által, akik vagy a szent könyvek különböző kódexeit egybegyűjtötték, vagy az azokban levő érveket kritikai vizsgálat alá vették, a dolog oda jutott, hogy az Újszövetség szövege iránt, igazságérző és tudós férfiak között már szinte semmi nézetkülönbség sincs. Az igazság lassan és szelíden az emberek szívéhez jutván, a hamis vélemények napról-napra azoknál is inkább feledésbe mennek, akik tévedésüket nyilván nem akarják megvallani. Végre, ami legfontosabb, úgy látszik, hogy az emberi ész a mi időnkben saját erejét ki akarja fejteni, maga előtt új és szebb pályát készít s felséges rendeltetését betölteni el van határozva.

A fennemlített unitárius társulat (The Unitarian Fund) azon célból, hogy munkái és határozatai nyilvánosakká legyenek, e rövid Előterjesztést kiadta, s azt mindazoknak ajánlja, akik előmozdítni törekednek azon elvek terjedését, amelyek az ő ítélete szerint a kereszténységnek s az emberek erényességének és boldogságának javára vannak és róla gondoskodnak. Nagy örömmel vette a társulat a hírt, hogy hasonló unitárius társulat Madrasban is alakult, s hogy az némelyeket az indusok közül is a bálványimádásról az egy igaz Isten tiszteletére vitt át. Nem csak ezekkel, de az észak-amerikai unitáriusokkal is levelezést folytat, kiknek száma igen nagy. Rendkívül kedvesen fogja venni, ha értesül arról, hogy így érző egyesek vagy társulatok a világ minden más részeiben is vannak, és örömmel vesz minden tudósítást, melyben számára bővebb alkalom nyílik e szellem elterjedését elősegítni. Ily irányú tudósításoknak e címet kérjük adatni: Rev. W. J. Fox, Dalston, near London. veL: Rev. R. Aspland, Hackney, near London.

Londini, Pridie Kal. Maj. MDCCCXXI. Typis Ricardiet Arthur Taylor. 
1b. Az angliai unitáriusokhoz küldött levél. Kolozsvár, 1822. Sylvester György Erdélyben Kolosvárt az Unitáriusoknál a Szent Theológia rendszerénti professora Angliában az isten egységét állítóknak az Atya Istentől az Úr Jézus Krisztus által minden jókat kíván. [A cím fölött: Tizen Nyolcadik példány v. Exemplár] Ms.U. 508.

Örvendező szívvel vettük az angliai unitáriusok hitek historiájok és jelen való állapottyok rövid rajzolattyát, melyből értettük az igaz tudománynak hirdetésére oly igen megkivántató buzgóságot a vallásban.

Ugyanis azon unitáriusok, kiknek barátságokkal és bizodalmokkal buzgó eleink Lengyel és Burgus országban úgy a Belgáknál is dicsekedtenek; valamely fátum által, vagy elnyomattak, vagy megnémultak s midőn a tudósok munkálkodása által annyira ment a dolog már, hogy nem csak az újabb üdők Atheneuma Németország, hanem egész Európának igazságos bírái az unitáriusoknak meg-hódolt kezeket nyújtottanak.

Úgy véltük, hogy ezen nevezet csak Erdélyben bír polgári jussal. Nem tagadjuk meg hát az Isten kegyelméből nyert alkalmasságot a véletek levelezésre, sőt nagy örömmel a ti rajzolatotok mellé tesszük az erdélyi unitáriusok dolgainak summázatát.

Az mennyei gondviselés Erdélyt különböző népek menedékhelyévé rendelte; itt a választott fejedelmek alatt különböző vallásokra is utat nyitottak; de mivel az erdélyi írók kevés és hiányos volta miatt nagyon homályosok a vallás reformátiójában az Unitária vallás eredetét szájról-szájra lett által adásából kell le hozni.

Ezen szájról szájra lett által adás, mely jött eleinkről az öregekre azokról üdővel reánk, tanítja, [hogy] Kolozsvár (mely anyavárosa Erdélynek) lakossai 1540-ben és 1541-ben esztendők körül a R. Catholica vallásról általmenének a Lutheránára. És mintegy öt esztendeig Lutheránusok lévén azután unitáriusok lettek némely férfiaknak kiváltképpen Dávid Ferencnek munkálkodásából. Mert ez egy kerek kőről Thorda utcában prédikálván midőn egyedül az Atyát állítana amaz egy Istennek; sokak öszvetódulásában oly szerencsésen tanított, hogy az hallgató nép, sőt a plebánus Heltai Gáspár közhelybe hagyásával is a város papjának kikiáltatott, és a piaci nagy templomba vezettetvén katedrát [kapott], sőt az egész város az ő vallására állott.

Nem akarják ezt megengedni mások: a mieink így írnak 1546-ban már a fejedelem és Kolozsvár városa az unitária valláson voltak. Annyi bizonyos, hogy az unitária vallásnak Erdélyben első hirdetője Dávid Ferenc; a Luther és Melanchthon írásait olvasván elsőben a szász eklézsiákkal tartott azután a helvétákot követte s végre unitárius lett. 
De 1564-ig amik történtek nincsenek tisztán. Ezen esztendőben pedig Dávid Ferenc az erdélyi 's úgy magyarországi fejedelem II. János parancsolatjára a magyarok szuperintendensévé választatván az unitáriusok első szuperintendensévé lett.

Hogy kinek-kinek ami övé meg-adjuk: említeni kell itt Blandrata Györgyöt. Nemzetére nézve olaszt Salutis városából aki külömb-külömbféle fátumai után végre mint orvos a Sigmond János fejedelem udvarában jövén 1563-ban Dávid Ferencnek az igaz tudomány hirdetésében segéd kezet nyújtott s az erdélyi unitáriusok 2-dik tanítójának neveztetik.

Ezen két férfiak az egyik a test a másik a lélek doktora másokot is magok mellé vévén azt mívelték, hogy az Unitária vallás az ország gyưlésében Marosvásárhelyt 1568-ban [sic!] törvényesen megerősíttetett.

Ezen esztendőben megújíttatott a státusok és rendek azon határozása is, mely elsőbben 1557-ben az ország gyưlésében Tordán hozatott volt, s azután a vallás ügyében a rendek által 1563-ban megerősíttetett.

Hogy ti. ki-ki amelyik vallást tetszik kövesse minden kényszeríttetés nélkül, a papok tartásában és a sakramentumokkal élésben szabad legyen; és egy fél is a másikot bosszúsággal és erőszakkal ne illesse; sőt az emberiség ki míveltetésének az anyaszentegyházra és a polgári társaságra nézve amaz egyaránt hasznos eszköze.

Erdélyben bé vétetett négy religiók: az r. catholica, evangelico reformata, lutheriana vagy augustana és unitárius religiok uniója minden polgároktól le téjendő hüttel megerősíttetett oly köteleztetés mellett, hogy ti. minden hazafi a négy bevett religiókat egész erejéből megtartani ügyekezni fog. A más vallás elnyomására célzó dolgokban magát sem titkon sem nyilvánosan nem elegyíti, senki személye iránt vallásáért gyưlőlséget és haragot nem tart. A magáétól különböző vallás ellen senkivel nem szövetkezik s elnyomására sem taníttással, sem fegyverrel, sem más úton módon, sem maga, sem más által nem ügyekszik, hanemha így cselekvőket venne észre az ország rendjei előtt fel fedezi.

Ezen fundamentumok meg vettetvén: a négy bevett valláson lévők semmitől nem félhettek akármely vallású lenne a fejedelem.

Mindazonáltal II. János 1571. március 14-kén meg halálozván az utána következett fejedelmek alatt az unitária vallás nagy változást szenvedett; nem a fejedelmek hibájából, hanem az unitáriusoknak egyenetlenségekből. Ugyanis Dávid Ferenc 1578-ban azt mondván egy prédikációjában, hogy a Krisztus mivel természet szerint nem Isten nem lehet hiba nélkül imádni. Ezen állításnak ellene szegezte magát Blandrata György győzedelmeskedett a szuperintendens mint innovátor megítéltetett $\mathrm{s}$ Dévára tömlöcbe küldetvén ott 1579-ben 15-ik novembris életét elvégezte. 
A pásztor a nyáj mellől elragadtatván, hogy a juhok el ne oszlaltassanak a mennyei gondviselés 1579-ben július 1-ső napján az unitáriusok zsinatján rendelt más szuperintendenst, Hunyadi Demetert. A ministerek megegyezvén az Krisztus istenségében, imádásában és országlásában a szabadságuknak vége lett. De az ellenkezők nem szűntek meg ezen üdőtől fogva az Unitáriusokot judaizmussal vádolni egészen 1608-ig [sic!]. Ekkor a Dési Complanatio fejedelem üdősb Rákóczi György előtt a méltatlan vádoltatásnak véget vetett.

Az emberi erőtlenség ezután is próbálgatta több ízben most egyik majd másik bé vett vallást sértegetni.

De az haza törzsökös törvényei melyek az Approbata és Compillata Constitutiokban megirattak $\mathrm{s}$ minden fejedelmek által megerősíttetvén örökös törvényekké lettek, az híveket a vallás szabad gyakorlásában s adatott jussaikban szentül védelmezték. Hogy ezen törvények a választott fejedelmek által ne változtatnának a választott Fejedelem köteleztetésében mindenkor benne volt; hogy ezen törvények megtartására hittel köteleztetnék.

Továbbra midőn Erdély az választott fejedelme után az felséges Ausztriai Ház kegyes védelme alá adta magát a tranzakcióban az ausztriai felséges ház és az erdélyi követek közt 1686-ban június 28-kán, az említett vallások szabadságáról gondoskodtak az hatodik articulusban ilyen szókkal:

A négy bé vett vallásokat Erdélyben és Magyarországnak Erdélyhez köttetett részeiben semmi módon, üdőben és szín alatt meg nem háborítja a templomok, oskolák, papi telkek, jövedelmek és vagyonok elfoglalásában nem mesterkedik az Approbata Törvények szerént.

Nem különben gondoskodott a lotharingiai nagy herceggel tartott tractatus is 1687-ben október 27-én a 2-ik részben 3-ik paragrafusban melyek Leopold császár szent diplomájában 1691-ben megerősíttettek, és minden császárok kapitulatiójában, kiknek az erdélyi nagy fejedelemségben hatalom engedtetett meg-találtatnak.

Ezek ellent nem állván a közelebbről elmúlt század szomorú volt az erdélyi unitáriusokra nézve. Mert a kakkadozó nép [permonus fere populares] látta az hazai vallásbeli villongások gyülölközések által templomaikot, oskoláikot papi telkeiket, s a tudományoknak és vallásnak egyéb eszközeit elragadoztatni, lassanként a közhivatalokból kirekedtek, s csaknem végső ínségre jutottak vala.

De nem volt sokáig tartó ezen szerencsétlenség elő állította Isten a becses emlékezetű római császárt és erdélyi fejedelmet II. Józsefet, hogy az elnyomattatott ügyen segítene, aki igen hamar meghalálozván, az általa megtöretett úton mentenek II. Leopold. És a mostani dicsőségesen uralkodó I. Ferenc császár, a mi kegyelmes fejedelmünk kinek szép tetteit mind 
az anyaszentegyházban mind a polgári társaságban ki ki tudja, és így az 1791-ben tartatott ország gyülése a további elnyomattatásnak ellent állott. Az Erdélyben bé vett négy vallások szabad gyakorlását az jussok és szabadság egyenlőségét megerősítette. Lásd az 1791-béli diéta 53-dik, 55-dik és 56-dik artikulusait.

A fejedelmeket státusokot és rendeket egyaránt dicsérő ezen artikulusok következéséül út nyittatott az unitáriusoknak minden hivatalokra a dicasteriumok mellett, a kerületekben, városokban és mezővárosokban, hogy a több bé vett vallások polgárjaival egyenlőleg a fejedelemnek és hazának szolgálhassanak.

Említeni kellene már kik érdemesítették magokat az unitáriusok közül vagy jóltevőségek által, vagy írásaik által, de nem engedi a levél, hogy hosszas legyek. Nem említem azért Isabella királynét és fiát Sigmond Jánost valamint sok mágnásokat kiknek pártfogások alatt hajdan dolgaink virágzásban voltak.

Nem is tagadhani, hogy a múlt század kezdetén a mostoha üdő a királyi fundationktól, Typográfiánktól több templomainktól fosztott meg, s ami kevéssel bírunk a testiekben, az újabb jóltevők kegyességéből vagyon.

Elhallgatom a régibb írókat is, kik közül Dávid Ferencet és Blandrata Györgyöt az unitáriusok első tanítóit, a szentírásbéli helyeknek (melyekből a szentháromság megállíttatni szokott) magyarázatjáról híres szuperintendenst Enyedi Györgyöt 1592-ben - 1597-ben és másokat Sandius Kristóf és Bock Friedric Sámuel említenek.

Említem csak Szentábrahámi Lombárd Mihályt az Unitaria vallásunknak az habok közül egyik kiragadóját 1737-től fogva 1758-ig híres püspököt ki 1720-tól fogva 1737-ig a kolozsvári oskola dolgait egyedül vitte. Ekkor a professzorság mellett felvállalván a papságot és szuperintedenciát; megérdemlette a késő maradéknál örök emlékezetben hagyatni. Ez a nagy férfiú theológiánkot systhemába szedte, ezen titulus alatt Summa Universae Theologiae Christianae Secundum Unitarios azaz a theológiának az unitáriusok értelme szerént summája. Mely 1787-ben a reformátusok kollégiuma typussával kinyomtattatván ma is a theológiai leckékben kézi könyv.

Ezen theológia dogmaticum principiumai meg vagynak a számkivettetett lengyelek confessiójában melyet a brandenburgiai electornak ajánlottak volt, 's amely Erdélyben több fejedelmek által megerősíttetett szóról-szóra megtaláltatik Bock Fridrieck Sámuelnek a Burgus Socinianismus históriája 71-ik és következendő lapjain, ki jött Regio Montumban 1745-ben. Említeni kell itt a boldog emlékezetü életében szép ajándékokkal gazdag főtisztelendő Lázár Istvánt. 1788-tól [sic!] fogva 1811-ig Erdélyben az unitáriusok szuperintendensét, ki több nagyoknak pártfogását s barát- 
ságát megnyervén legtöbbet tett arra, hogy az mostan bíródó jókot visszanyernők, s itt Kolozsvárt az ő felvigyázása alatt 1792-től fogva 1797-ig [sic!] építtetett templomban s szépen kiszélesített oskolában örökös emlékezetét hadta.

Kevés és cifraság nélkül való az unitáriusok vallásos ceremóniájok Erdélyben. A csecsemők megöntetvén a Krisztus parancsa szerént Mt 28,19 Atyának, Fiúnak és Szentléleknek nevében, az anyaszentegyházba béavattatnak (iktatódnak).

Az hívek naponként kétszer templomba mennek ott dicséreteket és zsoltárokat énekelvén előre, a pap után imádkoznak, vasárnaponként kétszer prédikációt hallgatnak.

Karácsonyban, húsvétban, pünköstben az innep első napján és Szent Mihály napkor kenyeret és bort vévén megbizonyítják keresztényi hitben való állásokot.

Az eklézsiai igazgatás így mégyen. Vagyon 123 eklézsia mely nyolc kerületre osztatott ugyanannyi esperesek alatt. Ezek a szent zsinat és a szuperintendens elölülése (aki a papok közül zsinaton választatódván hivatalában az uralkodó fejedelemtől megerősíttetik), és a külső rendből két fő kurátorok alatt a konzisztórium által, mely áll az eklézsiai és külső rend nevezetesebb személyeiből, igazgatja.

A konzisztóriumban megforduló tárgyakról protokollum vivődik. Ez az erdélyi királyi gubernium által a felséges udvarhoz fel szokott küldetni Bécsbe megvizsgáltatás és tudás végett.

A szuperintendensi hivatalt viszi 1811-től főtisztenlendő szuperintendens Körmöczi János. Az eklézsiák papjai a kolozsvári kollégiumban theológiát és filozófiát végzett ifjakból rendeltetnek, kik közül némelyek minek utána itteni oskolánkban végezettek a bécsi Academialit meglátogatják.

A kolozsvári eklézsiában most pap tiszteletes Szász Mózes.

Ami a tudományok állapotát illeti: A már említett zavaros környülállásokban megfosztatván a fundációktól, melyeket eleink nyertek volt és a tudományok egyéb eszközeitől midőn szinte veszedelmeznének a tudományok a dolgok megváltozásakor.

Második József császár és követői alatt élt Nemes Suki László familiájának egyetlen egy reménysége, az unitáriusoknak az újabb időben legnagyobb segillője; aki oskoláinkot minden szerzeményeiben örökösévé fogadván a szegénységben nyögő múzsáknak tehetsége szerint segítséggel lett. Ennek segedelmével alkalmasint felsegíttetett kolozsvári kollégiumunk melyben az ifjúság nagy haszonnal taníttatik. Itt a theológia zsidó és görög nyelv elementumainak tanittása a második papsággal együtt reám bizatott. 
A filozófiát és literatúrát tiszteletes Fűzi János tanítja. Históriát, geográfiát, kronológiát a német nyelvet tanítt tiszteletes Rector Professor Molnos Dávid. Mathésist és fisikát T. Székely Miklós.

A tudományok elementomait, s valami az alsóbb osztályokra tartozik a gyermekeinknek tanítják hat deákok.

A filozófia végzése után, akik törvényt akarnak hallgatni szabad bémenetelek vagyon R. Catholica fundáción Királyi Lyceumban.

Vagyon az unitáriusoknak még az erdélyi nagy fejedelemségben két gimnáziumok, egyik Keresztúrott, a más Tordán, mindenikben csak az alsóbb leckék taníttatnak, minden oskoláinknak felvigyázója a szuperintendens.

A professzorok tétele módja régibb időktől fogva e volt. A jó reménységgel biztató ifjak minekutánna kollégiumunkban végzettek professzoraiktól a főkonzisztóriumnak ajánlatván további tanulás végett külföldi akadémiára küldetnek.

Hollandia volt doktorainknak első tanítója, az után Németország a jénai és göttingai univerzitásokban. Minekutánna pedig az újabb üdőkben tetszett dicsően uralkodó császár és kegyelmes fejedelmünknek az ausztriai birodalmon kívül lévő univerzitásokra menetelt határok közé szorítani, s a protestánsok számára Bécsben Ausztriában különös univerzitást állítani fel, a mieink is minden közfundáció nélkül tulajdon költségeken jóltevőik által segíttetve ott tanolnak.

Írtuk Kolozsvárt, június 1-ső napján 1822-ben.

Mely: Nemes Háromszékben erdővidéki nagyajtai mostan Kolozsváron resideáló méltóságos Lázár Sámuel Urnak F.T. konzisztóriumunknak egyik érdemes konzisztorának és Nemes ottani kollégiumunk egyik hív inspektorának lelki vigasztalására. Üd. Kozma János mp. Nagy Nyulasi unitárius adminisztrátor és adszesszor által 1828-ban 22-ik January ajánlott. 


\section{Az unitarizmusról. Williams Johnson Fox beszédének fordítása, Körmöczi kézirat. MsU. 898/A. Eredetije: A course of lectures on subjects connected with the corruption, revival and future influence on genuine Christianity, Third edition, London, 1822.}

\section{Az unitarizmusról}

Textus: Zak 14,9

A napon egy Úr lészen, és az ő neve is egy lészen

Az isteni egységről való tudomány megmérhetetlen fontosságú. Az a lelke a judaizmusnak, fundamentuma a keresztény vallásnak; legnemesebb felfedezése az okosságnak; dicsősége a revelációnak; centruma a vallásbéli igazságnak; antidótuma az hitetlenségnek; halálos csapása a bálványimádásnak; eredése a reformációnak vezércsillaga a szabad vizsgálódásnak, útitársa a szabadságnak; szülőanyja a kegyességnek; forrása a világosságnak a lélekben és jóságosságnak a szívben; örököse a hit letett legfőbb uradalmának, amire vagyon intézve a prófécia, és vezéreltetni fog a gondviselés által minden nemzetek között.

Csak egy Isten lehet. Az istenség tulajdonságaival korrekt megfogást lehetetlen összeegyeztetni a birtokosok többségével. A határtalan monarchának nem lehetnek koadjutorai. A mindenhatóság, véghetetlenség és örökkévalóság nem lehet sem megosztott rész, sem közörökség. Egy mindenható léte megengedése kizárja a második mindenhatóét. Egy véghetetlené, a második véghetetlenét; egy örökkévalóé és oszthatatlan valóságé egy más örökkévaló és oszthatatlan valóságét, minden adiciója vagy multiplikációja az isteni személyeknek ki vagyon rekesztve az Istenről helyes idea által, néki egyedül kell a határtalan tökéletesség birtokosának lenni.

Az Isten egysége nem kopár spekuláció, vagyis magános igazság. Ez a propozíció egyedül, mely mintegy képviselője az ő rokon igazságainak, s igaz következéseinek. Szubsztanciája a keresztény vallásnak. Az a Nap a vallásbéli ismeret egén, az alsóbbrendű tudományok ahhoz vannak köttetve a természetnek mint valami vonszó erejénél fogva, s a körül forognak harmóniában, nem lenne bajos helyes okoskodás által tovább nyomozni ezen hasonlatosságot, de anélkül, hogy egy oly tágas mezőbe ereszkedjünk, azt akartuk megjegyezni, hogy a Szentírás összeelegyítette az isteni egységet mindazzal, amit úgy fejezett $\mathrm{ki}$, mint legfontosabbat a hitben vagy cselekedetekben az Isten atyai karakterével. Nekünk egy Istenünk vagyon amaz Atya. Egy az Isten ki mindeneknek Atyja, ki mindenek felett vagyon, és mindenek általa, és tibennetek mindenitekben, az ő vetélkedés nélkült levő jóságával 1Kor 8,6, Ef 4,6. Miért mondasz engem jónak? Nincsen senki több jó az egy Istennél Mt 19,17. 
A judaizmus határok közé szorított és ideig való diszpenzációjával: Halljad Izrael a mi urunk Istenünk egy Isten 5Móz 6,4. A keresztény vallásnak az egész világra kiterjesztendőségével: Az Úr lészen királya az egész földnek - a napon egy Úr lészen, és neve is egy lészen Zak 14,9.

A próféciának kétségbehozhatatlanságával: Én vagyok a te Istened, nincs több Isten én nálamnál és nincsen senki énhozzám hasonlatos; Ézs 46,9-10 ki eleitől fogva megmondom mindennek végét, és eleitől fogva azokat melyek megemlittetnek; ki valamit megmondok az én tanácsom megáll és minden én akaratomat véghez viszem az isteni tisztelettel - a te Uradat Istenedet imádjad, és csak őtet szolgáld Mt 4,50. A Krisztus küldettetésével, és az örök élettel. E pedig az örök élet, hogy tégedet ismerjenek egyedül lenni igaz Istennek, és akit elbocsátottál a Jézus Krisztust Jn 18,3. Az Isten munkálkodásainak részre nem hajlóságával. Avagy az Isten csak a zsidóké? Róm 3,29 Avagy nem Istene-e a pogányoknak is? Bizony a pogányoknak is Istenek. Az ember Krisztus közbenjáróságával, és az idvességnek mindenekre kiterjedésével. Egy az Isten, egy a közbenjáró is Isten között és emberek között, az ember Krisztus Jézus 1Tim2,4-5. Ki adta önön magát váltságul minden emberekért; A mi kötölésségünk summájával: Egy az Isten és nincsen más ő kívüle, és szeretni őtet teljes szívből, teljes elméből, és teljes lélekből és teljes erőből, és szeretni embernek felebarátját mint magát, sokkal nagyobb minden áldozatnál Mk 11,32-33. Az elnyomástól, igazságtalanságtól és embertelenségtől iszonyodással. Vajon nem mindnyájunknak egy Atyánk vagyon-e? Mt 11,10 Avagy nem azon egy Isten teremtetté minket? Az ájtatosságnak név kifejezéseivel: Az örökkévaló királynak pedig a halhatatlan, láthatatlan egy Istennek tisztesség légyen és dicsőség mindörökké 1Tim 1,17. (NB ha ezt a szócskát bölcs Griesbach kihagyattatva találta, vagy az ő fordításában nem találtatik). Ne engedjetek helyet a gyanúnak, vagy ne hozzatok vádat fel, hogy felettébre magasztaljuk ezen tételt, mert csak a Szentírás vezérlését követjük, midőn azt a legfelsőbb magosságra emeljük.

Az unitarizmus vizsgálása nagyon zavarba hozatott, s ügye sértődéssel illettetett azáltal, hogy összeelegyíttetett barátai privát véleményeivel.

Otromba félreértés vagy makacs igazságtalanság, akármit állítottak bizonyos unitáriusok, azt magának az unitarianizmusnak esszenciáléi közé számlálni!

A Krisztus humanitása nem esszencialéja az unitarianizmusnak. Noha különbözöm a legnagyobb tiszteletet érdemlő autoritástól, nem kételkedem mindazonáltal a leghelytelenebbnek ítélni az olyan megszorítást, a nem állhat meg a kifejezés etimológiájával s értelmével, s az ő históriai úzusával. Dr. Price éppen úgy unitárius volt mint Dr. Priestley: így a minden ki csak az Atyát tiszteli, akár azt higgye, hogy a Krisztus teremtett volt 
minden világ előtt, akár azt, hogy csak azólta egzisztált miólta Máriától született.

A philosophica necessitas nem része az unitarianizmusnak. Némely unitáriusok úgy látják, hogy a nyilvános parancsolatja az okosságnak és Szentírásnak, felvilágosítója az Isten karakterének és a gondviselés plánumainak, egy fényes kör a hit keresztje körül és egy kősziklája a remény vasmacskának. De mások megegyeztethetetlennek gondolják azt az Isten fenyegetődségei s ígéreteivel, s az embernek reszponzibilitásával; hasonló különbözés vagyon a másféle nevezetűek spekulatívusszaik között.

A materializmus nem része az unitarianizmusnak. Némelyek közülünk azt hiszik, hogy az ember egy szubsztanciából vagyon formálva, mások, hogy kettőből, némelyek, hogy az ember semmit sem fog tudni magáról az haláltól kezdve a feltámadásig; mások, hogy a boldogságra és dicsőségre általmenetele a léleknek immediate következik a testtől elválása után.

Az angyalok vagy ördögök tagadása nem része az unitarianizmusnak. Némelyek hiszik az egyiket, mások a másikot, vagy mind a kettőt; vagynak bizonyos tanítások melyeknek erősítésében megegyeznek s állíttatnak közönségesen, mások melyeket mű tagadunk. Azonban az ilyen helyek valamint a következés is megmaradnak, melyek közül mindenikhez számos hasonló kifejezéseket lehetne még adni. Helyben nem hagyhatjuk a trinitásról, a Krisztusnak az Atyával egyenlőségéről, az imputált bűn, vagy igazságról és a bosszúálló, vagy örök büntetésről való tanításokat. Nincsen más Isten hanem csak egy 1 Kor 8,4. Ne légyen tenéked énelőttem idegen más Istened 2Móz 10,3. Az Atya nagyobb énnálamnál Jn 14,28. A Krisztusnak feje az Isten. 1Kor 11,3. Amely lélek vétkezik annak kell meghalni Ez 18,20. A fiú nem viseli az Atyának álnokságát, sem az Atya nem viseli a fiúnak álnokságát. Nem minden aki azt mondja nékem Uram, Uram, mégyen bé a mennyországba, hanem aki az én Atyámnak akaratját cselekeszi Mt 8,21.

Másfelől a keresztény vallásról való gondolatok melyek uralkodnak közöttünk az Atya Istennek valóságos egységéről, jól tevő karakteréről, az imádásra egyedül való jussáról, a Krisztusnak a világ üdvezítése véget küldöttetéséről, az isteni kegyelemnek megnyerésére egyedül a szent élet szükségességéről, a részrehajlás nélkült való léendő ítéletre feltámadásról, s mindeneknek végrestaurációjokról; nemcsak, hogy mindnyájan külön vétetve szentírásbeliek, hanem éppen azok tészik összefoglalva az Újtestamentum tanításának felséges rajzolatját.

Én vagyok az első és az utolsó, és én nálomnál több Isten nincsen Ézs 44,6. Az Isten szeretet Jn 4,8. Eljő az óra, és az mostan vagyon, mikor igaz imádók imádják az Atyát Jn 4,23. Ő kente meg a názáretbéli Jézust Szentlélekkel és hatalommal ApCsel 10,38. Az Atya bocsájtotta el az ő fiát a vi- 
lágnak megtartóját Jn 4,14. Megjelent az istennek amaz idvezítő kegyelme minden embereknek Jer 11,11-12. Mely minket tanít, hogy megtagadván a hitetlenséget és a világi kívánságokat, mértékletesen, igazán és szentül éljünk e jelenvaló világban. Azért fáradunk is, és szidalmakkal illettetünk, mivel, hogy bízunk az élő Istenben, ki minden embereknek megtartójak. 1Tim 4,10. Mivelhogy ember által vagyon az halál, a halottak feltámadása is ember által vagyon 1Kor 15,21-22. Mert amiképpen Ádámban mindnyájan meghalnak, azonképpen Krisztusban mindnyájan megeleveníttetnek. Mindnyájon nékünk meg kell jelennünk a Krisztus ítélő széke előtt, hogy kiki elvégye jutalmát annak, amit életben cselekedett ahhoz képest vagy jót, vagy gonoszt 2 Kor 5,10. A teremtett állatok is megszabadulnak a rothadandóságnak rabságából az Isten fiának dicsőséges szabadulásának napján Róm 8,21, ApCsel 3,23. Az Ábrahám magvában áldattnak meg e földnek cselédi ApCsel 3,25.

Ez az unitarianizmus lehetséges-e, hogy a ne légyen igaz? Mi lesz akkor a Szentírásból, mert ennek igaz kifejezéseivel vannak kitéve elcsavarás nélkül az unitarianizmus minden tanításai és tagadva azok, melyeknek azok ellenekbe vannak tétetve!

Ahol az az eset azok előtt kik megismerik az Újtestamentum autoritását a versengésnek vége vagyon; az előadás bizonyítás; a magyarázás megmutatás, ez az unitarianizmus identic lesz a keresztény vallással. Annak cáfolása a Szentírás, és okosság cáfolása. Az a prófétáknak és Apostoloknak fundamentomokra építtetett fel, melynek belső szegelet köve a Jézus Krisztus Ef 11,20. Mi rontana le egy ilyen alkotmányt? Lefúja-e azt az emberi lehelet? Lerontják-e ezt az exkommunikáció dörgései? Elég-e az a vizsgálódás azon lángjaitól melyek közé feldúlódnak az emberi találmány magyarázatja és tartozásai? El fog-e dőlni a zivatarban, vagy morzsálódni az idővel? Nem; változhatatlan igazság az Isten építménye, örökkévaló, mint az egek, mind ezek truccolnak az emberi ellenségeskedéssel, mind ezek jóltevő befolyással vannak a hasztalanul megtámadottra.

Ez a Szentírásbéli bizonyítás különbféle tekintetek által erősíttethetik meg melyek mindazonáltal csak rövideden említtethetnek.

A judaizmus unitarizmus volt, az azért állíttatott fel, s tartatott fenn isteni intézet és agentiánál fogva, hogy megtartassék az egy Isten esmérete a világba. Ez a cél tisztán látszik annak a különös szisztémának eredetében institúcióiban, adminisztrációjában és rezultátumaiban.

A zsidó szisztémát úgy lehet nézni, mint amely az Ábrahám hivattatásával kezdődett. A bálványimádás sebesen kezdődett univerzálissá lenni abban az időben. A hívők Atyja állhatatosan megmarada az egyetlen egy Isten imádása mellett: ezért vala ő megkülönböztetve, ezért elválasztva, ezért megjutalmaztatott maradékaiban, ezért ígérteték, hogy az ő magja 
fogja örökségül venni a földet, és tőle fog származni egy, kiben minden nemzetek meg fognak áldatni. Az Ábrahám könyörgései, s az Istenségnek véle volt kommunikációi környülállásoson elé vagynak adva sok helyeken. Azok a könyörgések egy személyhez voltak intéztetve, azok a revelációk egy személy által, vagy egynek nevében tétettek. Neki semmi trinitás nem reveláltatott, ő semmi trinitást nem imádott. Az Ábrahám szólásformája ez: Uram Isten mit adnál te énnekem? Vajha Ismael élne te előtted, s az Istensége ez: Én vagyok az úr ki tégedet kihoztalak Kaldeának Úr városából 1Móz 15,2; 17,18; 15,7.

A judaizmus azért eredetében unitarianizmus, az Ábrahámnak azért lett elválasztásával s jutalmazásával kezdődik, hogy ő az egy istent imádta a politeizmus generális aposztáziája között.

A judaizmus unitarianizmus volt institúcióban. Semmi reveláció nem tétetett a trinitásról azon pátriárkáknak kik Ábrahám után következtek, az isteni tisztelet éppen azon individuális Jehovának nyújtatott az ígéretek az által tétettek egyik a másik után, azért lett nevezetes mivel az ő nyomdokiban járt. Az ő maradékai rabságba estek Egyiptomba: elérkezék az ők megszabadulásoknak ideje, Mózes küldetik annak végben vitelire. Így szólj az Izrael fiainak: A ti Atyátoknak ura, Istene, az Ábrahámnak Istene, Jézusnak Istene, Jákobnak Istene küldött engemet 2Móz 3,15 tihozzátok. Ez az én nevem mindörökké, ez az én nevem, melynek általa az emberek megemlékeznek rólam minden nemzetségről nemzetégre. Nem következtetjük azért mivel nincs említve, hogy a közbejött időkben semmi reveláció nem tétetődett valamely más személyről az Istenségben: itt a tagadás direkte nem csak a múltra, hanem a jövendőre nézve van; az azután adatott törvények olyanok amilyeneket ettől várhattunk. Amennyiben azok az isteni tiszteletet tárgyazzák, felséges példájok azokat a lélekbe nyomni, hogy csak egy személy a melyet ez illet, én vagyok a te Urad Istened ki kihoztalak tégedet az Egyiptomnak földéből, nem illik hozzád, hogy idegen Istenek előtt meghajolj 5Móz 5,6; 2Móz 39,14, mivel az Úrnak neve bosszúálló erős Isten Ő. Halljad Izrael a mi Urunk istenünk egy Úr. A Sion hegyén elrendelt isteni tisztelet mint a pátriárkáké az egy Isten imádása volt, a nincs intézve a trinitáshoz, nem foglalja magában a trinitásnak semmi esméretét, hanem efektíve és abszolúte kizárja azt magából, s minden más notiót az isteni többségről.

A judaizmus unitarianizmus volt adminisztrációjában. A Mózes törvényei nem oly célból adottattak, mint a keresztény vallás, hogy utat törjenek maguknak más nemzetek között s univerzálissokká legyenek, azoknak céljok a volt, a vallásbéli esmeretnek bizonyos grádusa megtartassék Júdeában míg a Messiás megjelenik. Ezen okból a törvények lelkesített férfiak által gyámolíttattak, kik azért állottak elő időről időre, hogy helyre állítsák 
és megtartsák azoknak tisztaságokat. Három vagy talán kevesebb századokig a Krisztus előtt egymásután következtek a Próféták. Az ezen férfiak által a lélekbe nyomni kívántatások nem fontosság nélkül valók a jelenlevő kontroverziában; azok voltak a Mózes törvényei őrei és magyarázói. Ha az a törvény hibásan adatott volna úgy ki, hogy tanítása az Istennek valóságos egységét ők ki tették volna a hibát. Ha a trinitás homályoson taníttatott, vagy elmellőztetett volna abban, ők világosságra hozták volna azt. Ha a zsidók a Mózes idejében nem lettek volna alkalmatosak azon misztériumnak bevételére, és lassanként kellett volna nékiek elkészíttetniek, ők megtették volna a revelációt; tettek-e ki ők vagy egy hibát? Offeráltak-e vagy egy oly magyarázatot? Adtak-e vagy egy olyan felfedezést? Semmit sem affélét. Illyés egy csudatétel által megszabadítja népét a Baál tiszteletétől, s azok így kiáltanak fel: Az Úr az igaz Isten 1Kir 18,39. Azért vitettetett végbe ezen csudatétel, hogy azok a bálványimádásból egyik fatális tévelygésből az unitarianizmusra, egy más fatális tévelygésre téríttessenek? Gyönyörködött-e úgy próféta az olyan triumfusba? A pszalmista gondoskodó büntetéseket ajánlgat azon célnak elérése végett Zsolt 83,19. Hogy tudják meg, hogy te kinek neved Jehova csak egyedül vagy felséges Isten mind az egész földön. Ézsaiás ezt erősítve említi az istenséget: Én vagyok az Úr, ez az én nevem és az én dicsőségemet másnak nem adom Ézs 42,8. Zakariás e textusban ezen tanításnak univerzális praevalentiáját jövendöli Zak 14,9, s azt jelenti, hogy az az Úr kinek neve egy lészen királya az egész földnek.

Vegyétek a judaizmust az ő eredetében, textusában vagy magyarázatában, a pátriárkák kivel a kezdődett; a könyvet melybe összegyưjtetett; a prófétákat kik által adminisztráltatott, s tiszta lesz, hogy az isteni személyek többségéről való tudomány teljességgel nem volt része annak, ki volt rekesztve abból, megállhatatlan volt azzal, s csak romladékain állíttathatott volna fel annak.

A rezultátumai ezen szisztémának megtetszenek a zsidókban kik úgy gondolkodtak, hogy a trinitásról való tudományt bévenni annyi mint a Mózesét tagadni. Megjegyzendő, hogy a többi maradékai is Ábrahámnak Izmaelről, követői voltak ezen igazságnak.

Hiába disputálják, hogy az egységgel a volt célozva, csak természetében vagy állatjában egy s nem személyében, hogy az a bálványozó politeizmusban volt elénkbe tétetve. A zsidók nem voltak metafizikusok, egy ily szubtilis disztinkciót ők se ki nem gondoltak, se meg nem foghattak volna, se bé nem vették annak terminusait. Aztán az ők egy tévelygésnek ellenébe tétettessék, nem tészi őket kevésbé decisivekké valamely más tévelygés ellen. Az ilyen hathatós erősítések a valóságos egységről a pronomeneknek singularisban tétettetésekkel, az Isten nevében tett nyilatkoztatásokban, s a hozzá 
intézett imádásokban efektive unitárius névvel stempeleztenek meg akár más könyvel a Biblián kívül magoknak ellenvetőiknek ítéleteknél fogva.

Akármi legyen is a keresztény vallás tanítása, az Isten valóságos egysége esszenciáléja a judaizmusnak. A belé van fonva azon csudálatos alkalvány különböző részeibe, az az igaz élete és lelke annak a testnek. Ez elég a kérdés eldöntésére. Annak ami egyszer igaz az Istenről önmagában, mindenkor igaznak kell lennie, elváltozhatatlan. Neki öröktől fogva az ő supponált trónusából coequalis osztozó társaival vagy nélkül kellett lennie. E nem olyan tárgy melynek védelmére nevekedő információt lehetne eléhordogatni. Mü láthatnánk p. o. csak egy Napot, noha három volna, lehetnének három ember személyek, kik közül elsőben csak egy tétetett ismeretessé előttünk s a más kettő annak utána. Ezek nem parallel esetek, nem helyben hagyható az a feltétel, hogy Istennek unitása volt elsőbben revelálva, s trinitása annak utána, mert a revelációja annak az unitásnak exclusiva. Nem az volt kijelentve, hogy van egy isteni valóság, hanem az volt kijelentve, hogy az isteni valóság csak egy. Az Atya istenségének revelációja gondoltathatnék talán úgy, hogy a nem excludálja a fiú és a szentlélek istenségét, de a volt reverálva, hogy az Atya az Isten egyedül, az egyetlen egy és exkluzív Isten. Ezen okból az ilyen bővebb kommunikáció nem addíció, hanem kontradikció lett volna, ami elébb megesmértetett az az esmértetés nem nevekedett, hanem meghamisíttatott volna. Itt tehát nyugodni hagyhatnánk a mi hitünket, de még nem egész az evidencia. A keresztény vallás éppen olyan hathatósan erősíti azt, mint a judaizmus, és mi elmondhatjuk ezen igazságról azt, amit a zsidókhoz író az Isten ígéreteiről és esküvéseiről Zsid 6,18. Hogy a két változhatatlan dolgok által, melyekben lehetetlen dolog, hogy az Isten hazudjon, erős vigasztalásunk lehet nékünk.

A keresztény vallás adoptálja ezen dogmát a judaizmustól.

1. Következőleg a Krisztus az apostolok vagy az elsőbb keresztények és zsidók között az imádás tárgya felett semmi kontroverziának nem lételinél fogva. Ilyen kontroverziának elkerülhetetlenül támadnia kelletett volna, ha ők a trinitás tudományát tanították volna, de semmi nyoma sincs annak s ez a hallgatás ekképpen szóló nyelvvel hathatósan, s ellene állhatatlanul tanítja, vitatja, hogy ők közönségesen mind hitték az Isten egységét.

2. Az imádás tárgya ugyanazonsságának erősítéseinél fogva: nem csak együtt volt imádkozásokban, amit ellenvetőink igen jól érzették s ami nem történt volna ha az egyik trinitárius a másik unitárius volt volna, hanem világos magyarázatban is. Az apostolok imádságai az Ábrahámnak és Jákobnak Istenéhez voltak intézve. Pál megengedte a különbözést az imádás módjában, de nem annak tárgyában. Én azon út szerint melyet szerzettnek mondanak szolgálok az én Atyáimnak Isteneknek ApCsel 24,14. A Jézus 
maga tanúbizonyságul állítja elő magát a zsidóknak hibátlanságokról ezen pontban a szamariai asszonnyal való beszélgetésében. Ti azt imádjátok, akit nem tudtok, mi azt imádjuk akit tudunk, mert az idvesség a zsidók közül támadott Jn 4,22.

3. Az Isten egységének hasonló erősítéseinél fogva: Te hiszed, hogy az Isten egy, jól cselekeszed Jak 2,19. Az Isten egy Gal 3,20.

4. Az imádkozás hasonló kifejezéseinél fogva. Mikor imádkoztok ezt mondjátok: Mi Atyánk Lk 11,2. Hálákot adok Istennek a mi Urunk Jézus Krisztus által Róm 7,25. Meghajtom térdeimet a mi Urunk Jézus Krisztusnak Atyja előtt Ef 3,14. Ama boldog és egyedül hatalmas királyoknak királya és uraknak ura, kinek tisztesség legyen és egy örökkévaló hatalom 1 Tim 6,15-16.

5. Az apostoloknak hallgatások a zsidókhoz beszéléseikben azt mutatja, hogy ők és hallgatóik megegyeztek abban ami az imádás tárgyát illeti, s csak abban különböztek, vajon az egy Isten, kit egyenlőképpen megismertek annak lenni, küldötte-e el a názáretbeli Jézust, hogy szabadítója légyen az embereknek? Hasonlóképpen midőn a pogányokhoz beszélettek, nem látjuk, nem találjuk, hogy trinitást és megtestesült Istent erősítenének, ami kedvesebb lett volna a politeisták előtt, mint a zsidó tudomány, hanem a próféták szokását követték, midőn az aposztata Izraelitákat térítgették, s a bálványok hiábavalóságát mutogatták, és az egy felséges teremtőnek létele $\mathrm{s}$ tulajdonságai természetéből vett próbákot. Kitetsző példánk vagyon erről Pálnak az Athénbeliekhez intézett beszédében.

A keresztény vallás a judaizmusból veszi nem csak az igazságát ezen tudománynak, hanem annak fontosságát is, amint már láttuk összekapcsolja azt mindazzal ami leginteressantabb a religióba vagy az erkölcsiségbe. A Krisztusnál valamint Mózesnél az az első minden parancsolatok között, a Krisztusnál valamint Mózesnél az a fundamentuma az Istenhez való áhítatosságnak, és az emberekhez való jól tevőségnek 5Móz 6,4; Mk 12,29 . Halljad Izrael a mi Urunk egy Úr. Az isteni kinyilatkoztatások szélesebbre terjedésével se szállott alább annak rangja. Egy csillogóbb vagy nemesebb igazság sem tünt fel, hogy homályba hozza annak fényét. Egyenlőleg proeminensnek látjuk azt a keresztény vallás teljes kifejlődésében $\mathrm{s}$ a judaizmus parciális revelációiba, az egyikben a Nap, mely uralkodik a nappalon, a másikban a Hold, mely uralkodik az éjszakán.

Erős argumentum vagyon véve a trinitarizmus ellen abból ami az apostolok prédikálásaikból fennmaradt. De egész kiterjedéssel előadni és mutatni, azt megkívánná minden az apostolok cselekedeteiben emlékezetben hagyott beszédek felidézéseit. Mindegyikre alkalmaztathatók Dr. Toulminnak a Péter első beszédére tett felséges megjegyzéseiket semmi sincs egyéb, hanem a tiszta unitáriusi tudomány. Még egy szó sem esett ki a Pé- 
ter ajakán, ami az emberi természet romlottságát, a Krisztus istenségét és elégtételét, s az ő fedhetetlensége imputációja által eszközlött megigazulást tárgyazná. Egy szó se hasonló ama Moráviánusokéhoz, kik azt hirdették a Grönlandiaknak a teremtőről, hogy az emberi természetet vett magára, s megholt a mi bűneinkért. Péter nem ilyen módon prédikálotta a Krisztust, s mégis foganatos volt az ő prédikálása sokaknak megtérítésére. Ő csak kevés, világos az Atya Isten egységét s felsőségét, a názáretbeli Jézus humanizmusát, s isteni küldöttetését világosító faktumokra támaszkodik, oly faktumokra, melyek tészik az unitáriusok vallástételit. Ezen beszéd fő vonásai alapcikkelyei az unitáriusok credójának.

Bizonyos közönséges karakterisztikái vagynak kitéve a keresztény vallásnak a Szentírásba, melyekre mint próbakövekre úgy lehet tenni az unitarianizmust és trinitarianizmust.

1. Az mint szisztémája a kegyelemnek és irgalmasságnak fennebb való volt a judaizmusnál: A törvény Mózes által adatott, de a kegyelem és valóság (igazság) a Jézus Krisztus által lett Jn 1,17. Ezzel az unitarianizmus tisztán egyez, mely egyiket a másik tökéletesedésének tartja. Hogyha a trinitarianizmus az evangélium, úgy ez alábbvaló volt a judaizmusnál, mert a trinitarianizmus azt tanítja, hogy az Isten részrehajló; a judaizmus azt, hogy: Jó az Úr mindeneknek, és az ő irgalmassága minden ő teremtett állatin Zsolt 145,9.

A trinitarianizmus, hogy a vétek imputálva vagyon az Ádám maradékának, valamint, hogy az alája is vagyon vettettetve igazságosan a kárhozatnak a tízezredik generációig az ő büne miatt. A judaizmus, hogy: A fiú nem viseli az Atyjának álnokságát Ez 18,20. A trinitarianizmus, hogy minden bűnért teljes elégtételnek kell tétettetni az isteni igazságnak. A judaizmus, hogy: Miképpen könyörül az Atya az ő fiain, azonképpen könyörül az Úr az őket félőken, mert tudja, hogy romlandó edények vagyunk, megemlékezik róla, hogy porból valók vagyunk Zsolt 103,13-14. A trinitarianizmus, hogy az ő bosszúállása örökkévaló - a judaizmus, hogy örökké megmarad az ő kegyelmessége 2Krón 7,3. Mondhatjuk-e mindezen religiók közül az egyikről a másikra mégyünk által, nem vettétek a szolgálatnak lelkét ismét a félelemre, hanem a fiúságnak lelkét vettétek, ki által kiáltjuk Abba azaz szerelmes Atyám Róm 8,15.

2. A keresztény vallás mindenek felett egyszerü, érthető, s az ítélő tehetséghez alkalmaztatott volt. Akinek füle vagyon a hallásra hallja - mi dolog, hogy ti magatok is meg nem ítélitek azt, ami igaz? Lk 12,57 és 1Kor 10,15. Úgy szólok, mint tudósoknak, ítéljétek meg ti, amit mondok. Itt engedjétek hadd tégyenek ellenvetőink decisiót. Meg tették ők azt. Nem azzal vádolnak-e szüntelen minket, hogy mindent a magunk értelmünkhez szabunk, kivetköztetjük a keresztény vallást az ő misztériumaiból; nem nyomjuk 
el az értelmet, magyarázatot kívánunk ott, ahol nem lehet adni, s csupa racionális hívők vagyunk? Citáltathattak volna-e olyan bizonyítások, mint a fennebbiek, tétethettek volna-e azok valaha a Krisztus és Apostolok által, ha ők tanították volna a mái ortodoxia paradoxumait?

3. A keresztény vallás evangélium volt, azaz örvendetes tudósítás. E leírás volt, míg tulajdon nevet kapott. Engedelmeskedik-e a trinitárius vagy kálviniánus prédikátor Krisztus ama parancsolatjának: Prédikáljátok az evangéliumot minden teremtett állatnak Mk 16,15. Örvendezteti-e az embereket azt mondani nékiek, hogy ők bünben születtek, valamint az, hogy ők egészen megromlottak, átok alá vagynak esve az Ádám bűne miatt, elkárhozva megbánás nélkül, azonban nem képesek a megbánásra szupernaturális közbejövetel nélkül. Sokan, ha nem a legtöbbek közüllek megorvosolhatás nélkül végetlen nyomorúságra hagyatva? Az idvezítő nem volt képes ezen barbár és gúnyolódó iróniára. Oly lehetetlen az, hogy ilyen szisztéma legyen az evangélium, amilyen lehetetlen az, hogy ő csúfot űzött volna az emberek kínjaiból.

Nem csak karakterizálva van az evangélium, hanem az ő szélesen kiterjedő korrupciója vezér vonásai is ki vagynak jelölve. Megmutatták mely szorosan egyeznek azok a mái ortodoxiával. Misztérium, szövetkezés a statussal, spirituális uralkodás, az imádás tárgyainak sokasítása mind oly terminusok melyeket egy unitárius elmondhatna ama szisztémáról, ortodoxiáról de trinitárius előtt az unitarianizmus a legnagyobb elszakadás az evangéliumtól azok közt amelyek valaha voltak. Az ő lelkét inkább elrémíti az, mint maga a pápizmus, s ő egy pontban ellenkező leírást tenne az evangéliumról. Az ami karakterizálja az evangéliumot, annak korrupciójává tétetne általa s a korrupció prófétai festése lenne az igazság korrekt kópiája.

Ha az olyan bizonyítások milyenek ezek nem elegedendők, ha az autoritás ezen fontosságának $s$ az evidencia különb különbféleségének balanszíroztatnia kelletik kevés és figuráció helyen, vagy éppen kevés bajos magyarázata textusok által, hol találunk meggyőződést? Vagy hol az a tudomány melyről meg lehessen mutatni, hogy az szentírásbéli? Micsoda módját lehet használni a bizonyításnak amely nem támogatja az unitarianizmust? Ennek vagyon legitima inferenciája, direkta implikációja, pozitíva asszerciója. Micsoda kútfejét lehet megnyitni az evidenciának, melyből az bőven nem segíttetik? Rajzolva vagyon az a természetben, keresztül ömlend az Ótestamentumon, tovább terjed az Újban, meg van erősítve a keresztény eklézsia elsőbb históriája által. Melyik az az autoritás, melynek az híjával van? Azt hitte Ábrahám, megfundálta Mózes, megerősítették a próféták, adoptálta a Krisztus, prédikállották az apostolok, szankcionáltatott több ízben magának az Istennek szava által. Egyez az evangélium 
eredeti leírásával, megegyeztethetetlen annak korrupciójának prófétai rajzolatjával. Ha ez nem parancsol hitet, nem mondom, annak hinnének, ha valaki a halottak közül feltámasztatnék is Lk 16,31, mert ennél hatalmasabb csudatételek vitettek végbe annak bizonyítására, s tiszteletére méltóbb szózat által hirdettetett az, nem egy viszont meglelkesült pornak, hanem a mennyei örökkévaló Istennek szózatja által.

Hogy ez a nagy igazság elcsavartatott, s meghomályosíttatott, az, ha megfontolunk minden környülállásokat, új erôsségeket nyújt annak az eredeti keresztény vallások identitásáról. A Pál jövendölése szerint, a bűnös ember kijelentésének, az antikrisztiána aposztázia teljes kifejlődésének s megért korának a római birodalomban esendő némü-nemü változtatással konnexióban kellett megtörténni. E volt legalább a hajdankor közönséges szava által tetetett magyarázat, a mostaniak közül sem adott senki, mely megegyezőbb volna ezen kifejezésekkel: aki most annak ellene áll, mindaddig ellene áll, míglen az eltöröltetik 2Thessz 2,7. Konstantinos alatt, ki a nominális keresztény vallást bévevé, $\mathrm{s}$ az igazgatás székét Keletre tevé által, jutott el az ortodoxia az ő rosszát jövendölő nagyságára. Hanem ha e vala bételjesedése a próféciának, különben soha se teljesedett be, s nem is teljesedhetik.

Bizonyos jelei a veszedelmeztetésnek és aposztáziának meg voltak jegyezve az apostolok által még a legelső eklézsiában. Azok olyanok voltak, melyek az unitarianizmusból trinitarianizmus felé vezérelhetnek, de nem-e lehetséges, hogy ellenkező direkcióba vihessenek. Azok voltak egyáltalában az okok, melyeknek rezultátumit látjuk az ekleziasztika históriában. A többek ezek közül említést érdemelnek.

1. Azon mitológiához ragaszkodás, melynek hívésében a pogány konvertiták fel voltak nevelve. Bálványimádók ne légyetek. A hálaadásnak pohara melyet megszentelünk, avagy nem Krisztus vérével való közösülésünk-e? A kenyér, amelyet megszegünk avagy nem a Krisztus testével való közösülésünk-e? Nem ihatjátok az Úr poharát és az ördögöknek 1Kor 10,7.16.21. Az etnicizmus istenségeinek poharakot: nem lehettek az úr asztalának, és az ördögök asztalának részesei. Részt venni a populáris Istenek áldozó innepjeikben, összekapcsolni ezen innepekkel a Jézus Krisztus eucharisztiai emlékinnepét, általváltoztatni az ő vacsoráját sacrifitiummá, $\mathrm{s}$ őtet Istenné, pogány értelemben vett Istenből keresztény értelemben vett Istenné emelni fel őtet. Ezek oly gradációi a tévelygésben előhaladásnak melyek könnyen megfoghatók, és hihetőkön nőtt magokban. S kombinálván a Szentírást a históriával meglehetős nyilvánossággal jelöltethetnék ki. A pogányok bajosan tisztíthatták volna ki magokat a szubordinált istenségek notióiból - különböző hatalmú és provinciájú istenekhez voltak szokva, kiknek testek s emberi formájok volt, kiket innepek által tiszteltek, 
állatokat áldoztak nékiek az ő templomjakban. Mi természetes vala identifikálni ily ceremóniákkal az úri vacsorát, s egy oly rangra emelni új vallások fundálóját! Annak, aki meggyógyítja a sántát és vakot, megzabolázza a szeleket és habokat, feltámasztja a halottat, s maga felméne a mennybe, az ő anyai nyelvek frazeológiájában természet szerént Istennek kellett lenni. Midőn Pál és Barnabás egy csudát cselekedének Lisztrában, a nép így kiálta fel: Az Istenek jöttek mihozzánk emberi ábrázatban ApCsel 14,11. Hasonló vélekedést formáltak volna ezek a Jézusról, ha látták vagy hallották volna őtet, s ők hova az apostolok autoritása nem hata el, vagy a hívők első generációja nemsokára kihala bajos lett volna ellenkező gondolkozást támasztani. Ezen tendenciának munkálkodni kellett a pogány konvertiták egész korpuszán keresztül, s a Krisztus Istenségében való hívés egy darab ideig tulajdonok vala nekiek.

2. Fundamentum nélküli szégyellés egy oly tanító követőjének lenni, ki alacsony környülállások közt élt és rabok s gonosztevők között halálával hala meg, megvetés és undorodás érzései voltak összekapcsolva a kereszttel, s termékeny tárgya vala az a gúnyolódásnak s kinevetésnek.

Pál felibe emelkedett ezen gúnynak $\mathrm{s}$ elhatározá magában semmi egyebet nem tudni, hanem a Jézus Krisztust, azt pedig ki megfeszíttetett 1Kor 2,2 és nem egyébben dicsekedni, hanem csak a mi Urunk Jézus Krisztusnak keresztjében Gal 6,14. Mindazonáltal az az energia és gyakoriság, mellyel ezen érzések kinyilatkoztattak bizonyítja azt, hogy ő előre el látta veszedelmét az aposztáziának, a hitben vagy cselekvésben sokaknak helytelen szégyenéből, s ehhez képest a Krisztus istenítése egyik első haszna a vala, hogy t. i. kiragadtassék ő szenvedéseinek alacsonyító környülállásai közül, megbizonyíttassék, hogy ő nem holt meg valósággal, hanem fantom feszíttetett meg helyette, s így misztikus leplet vonni a keresztény vallás obnaxius részére.

3. A misztérium és tetsző nagyság szeretete.

Az evangélium egyszerű szépsége nem volt elég kedves bájolni sem a filozófusokat, sem a köznépet. Az egyik fél valami intrikáltabbat kívánt volna, a másik valami bámíttóbbat. A zsidók jelet kévánnak, a görögök pedig bölcsességet keresnek 1Kor 1,22. A trinitásról inkarnációról való tanítások oly sok intrikáltat és bámítottat foglalnak magokban, hogy első s még nem tökéletes formájokban is mindjárt elég hathatósan ajánlották azoknak, kiknek appetitussak éh volt az ilyen eledelre. Azok igen jól el vannak találva, hogy megelégedésekre szolgáljanak mindazoknak, kik homályos spekulációra adták magokat, mindazoknak nem az elsőbbeket felruházzák ezer meg ezer metafizikai kérdésekkel, hogy gyakorolják a szőrszálhasogató elmésségeket. Az utolsóbbaknak fassióikra appellálások által, amire 
materialékot hordnak elé, táplálják az enthusiasmust, mely így gyakran szubsztituálva vagyon a tiszta és meg nem hamisíttatott religió helyett.

4. A korcs filozófia: Meglássátok, hogy valaki ne légyen oly, aki bennetek zsákmányul vessen az emberi bölcsességnek és csalárdságra rendeltetett hiábavaló tudománynak általa, mely emberi rendelés szerént e világnak betüi szerént és nem a Krisztus szerént vagyon Kol 2,8. A gnosztikusok spekulációi nemsokára összeelegyítették az isteni igazsággal. A következő időszakaszokban a trinitárius vélemények sebes előhaladása igen sokat köszönhetett a platonikus filozófusok accessziójának, kik némü-nemü homályos álmodozásokkal voltak eltelve az istenség természete felől, melyekkel valami megegyezőt gondoltak fellelni a keresztény vallásban, vagy melyeket fel is találtak annak védelmezői, hogy amazokat magok részére vonhassák.

Akárminemü, a mai ortodoxiához hasonló vélemények találtassanak annak okáért az ekléziasztika história elsőbb periódusaiban, meg tudjuk fejteni azokat, azon okok munkálódásaiból, melyeknek lételek nem következtetésen, vagy konjunktúrán, hanem az apostolok tanúbizonyság tételein nyugszik. A Szentírás bizonyosokká lészen azoknak valóságokról s kárhoztatja azokat. Azok az okok nyújtják kezünkbe az egyetlen egy vezérfonalat az eklézsiának az első három században volt állapotjához, s amelyeket egy trinitárius teljességgel meg nem magyarázhat. Egyeznek azok a faktumokkal, felvilágosítsák ezeket, melyek viszontagolva igazolják a szent írók gyanításaikat, a rendkívül helytelenül tett gyanításokat, ha az unitarianizmus vala korrupció és herézis.

Helyben van hagyva Mosheim, s más hasonló írók által, hogy voltak az első században olyanok, kik tagadták a Krisztus csudálatos születését, s azt tartották, hogy megkeresztelkedésekor lett felsőbb más embereknél, mikor a küldöttetése céljára szükséges tehetségek adattak meg őnékie, hogy azok nem formáltak különböző korpuszt a második századig. Ezen faktum nagy következésű, ha különböző testet nem formáltak a többi keresztényektőll nagyrészét kellett nekiek a keresztényeknek. Mert ha a Krisztus Istensége volt az originális tanítás, s a Krisztus imádása az originális praxis, azok kik tagadták az egyiket, s megtagadták a másikot, meg nem maradhattak volna a többiekkel egy gyülekezetben. Nékik azonnal ki kelletett volna onnan zárattatniak, amint változhatatlanul kirekesztettek, miólta a trinitarianizmus nyere nagyobb hatalmat. Hogy ők oly sokáig maradtak meg az eklézsiában az egyedül elég bizonysága az ők számos többségének, hitek régiségének, s azon állítások újságának, melyeknek az ellenekbe volt téve. Justinus Martyr a második században, mint egy újító tónusával és módjával említi az ő gondolatját a Krisztus szuperhumanitásáról. Tertullianus, úgy írják a hívők nagyobb részit a maga idejében, mint 
akik borzadtak a trinitásról való tudománytól, és szorosan ragaszkodtak az Isten egyedülvaló monarchiájához.

Órigenész sok olyan keresztényekről beszél, akik nem esmérik a Logoszról lévő misztériumot. Priestley azt jegyzi meg: oly populáris vala az unitarianizmus ezen időkorban (harmadik században), hogy Epiphanes szerint, mikor az unitáriusok valamely együgyű keresztényekkel találkozának, ezt mondának. Nohát barátom, melyik tanítás mellett tartunk, egy vagy három Istent ismerünk meg? A negyedik század dühös disputái, midőn Athanasziosz és Áriosz két részekre szakaszták a keresztény világot nem az arianizmusnak, mint újításnak behozatala által okoztattak, hanem a trinitárius vélemények szoros és kemény s publik kifejezései által, melyek még akkor nem értek vala fel csakugyan szisztematika perfekcióra, amelyre végre jutottak. Lehet-e annak okáért kétség kik voltak az újítók? Vagy melyik az út melyen a folyam ment? Minden oly progresszióra mutat, honnan a kiindulópont csupa unitarianizmus volt, a vég elért pont az vallástételnek Athanasziosz trinitarianizmusa. Midőn a história lapjára mégyünk felfelé szukcesszíve le kell raknunk a különböző időkorokkal azoknak találmányaikot, míg a trinitárium szisztéma egészen oda lesz. Nem találhatjuk fel egészbe azt a szisztémát mindjárt az Athanasziosz írásaiban sem a Tertuliánuszéban és Órigenészében sem a Justinus Martyréiban, a tévelygés úgy vonul vissza, amint haladott elé. Ha nem vagyunk is úgy körülöntve a nap fényétől, mindazonátal a sötétség oszlik, az ég árnyékai tűnőfélben vagynak, a horizont kezd pirulni. Látjuk a múltban a homályos szürkületet, mely megelőzte volt a tudatlanság, új tévelygés hosszú éjszakáját, midôn az igazság s egyszerüség szép formái el voltak veszve, $\mathrm{s}$ minden sötétes bizonytalanság vagy formátlan rémítés vala, $\mathrm{s}$ ha időnkben a vallásbéli isméret állapotja esmét hasonlít a szürkülethez, örülünk, hogy az éjszaka elmúlt, és a nem a sötétség feketeségeinek előposztja most, hanem a nappal virradásának, a napkeltének, mindenfelé szomorító köd oszlásának, a lelkesült természet öröménekének, a föld újuló szépségének, s a tiszta és felséges ég lepletlen fénysugarainak.

Közönségesen úgy beszélünk az unitarianizmusról, mint a keresztény vallás egyik szubdiviziójáról, s nevezzük magunkat unitárius keresztényeknek. De szólhatunk a keresztény vallásról is, úgy, mint az unitarianizmus egyik speciesséről, s mondhatjuk magunkat keresztény unitáriusoknak. A vitatás el van próbálva, más princípiumoknál fogva, mint az evangéliuméi; s nem lesz talán éppen itt, helyen kívül megemlíteni az unitáriusok öt különböző klasszisait kik kívül vagynak a keresztény vallás körén.

1. Görögországnak s Rómának legbölcsebb s legjobb filozófusai felülemelkedtek korok s honjuk babonáin, s felséges ideákkal voltak tele az istenségről, ezek szerint az Isten úgy definiáltatott, mint élő, örökkévaló, 
legjobb valóság. Úgy adatott elő, mint isteneknek és embereknek királya, legfőbb, legnagyobb, legfelségesebb. A nép között sok istenek vannak, azt mondja Antiszthenész, de a természetben csak egy. Mások azt erősítik, hogy az Istennek a realiter egy valóságnak sok nevei vagynak a különböző indulatokhoz képest, melyeket láttatott, és munkálódásokhoz képest gyakorol. Szókratész tanítása e vala: Az Isten univerzális intellektus. Az Isten egy, tökéletes önön magában, ő adja a lételt, és a jól lételt minden teremtményeknek. Ezen férfiak világló fények voltak a sötét helyeken. A bigotteria néha-néha elsietett s gúnyolódó cenzúrával nyargalt ugyan keresztül rajtuk, mindazonáltal a felebaráti szeretetnek, mondjuk inkább az igazságnak tisztelettel kelletik őket velünk neveztetni. S ama liberális és derék férfiúnak Penn Wilhelmnek (kiről több mint egy alkalmatosságom volt jelenteni bámulásomat), az ő egy atya szeretetének gyümölcseiben lévő érzeményeit irántok adoptáltatni.

Az az áldott princípium, az az örökös szózat, melyről kezdettem szólani ti hozzátok, és amely az a világosság, lélek, kegyelem és igazság, melyre figyelmeztetlek titeket minden ő szent jelenéseiben és mutatkozásaiban tibennetek, mely által teremtettek mind a dolgok, megvilágosíttattak az emberek az idvezítésre, nem egyéb, hanem a Pitagorasz nagy világossága, sava az időknek; az Anaxagorasz isteni lelke; a Szókratész jó géniusza; a Timaeus kezdet nélküli princípiuma, s minden világosság szerzője; a Hieron Istene az emberben; a Platón örökkévaló, kimagyarázhatatlan, tökéletes igazság sorprincípiuma; a Zénón mindeneknek teremtője és atyja és a Plótinosz lélek gyökere. Ezek voltak néhányok ezen virtusos pogányok közül, kik úgy ajánltatnak az apostolok által, hogy noha nékiek nem adattak törvények, mint a zsidóknak, mindazonáltal természet szerint a törvényhez illendő cselekedeteket cselekedvén, önön magoknak törvények Róm 2,13-14.

2. A zsidók állandóul unitáriusok voltak viszontagságaikban, számosan lettek közülük keresztények, minekelőtte a trinitásról való tudományt fel nem gondolták, de azólta a megtérésnek vége szakadt. Míg ez a sorompó le nem rontatik, s a keresztény vallás meg nem tisztíttatik, ők tanúbizonyságok lésznek, hogy annak állított védői, valóságos corruptorai.

3. A Mohamed tanítványai. Noha az ő praetentioi az inspirációhoz, az ő fegyvert használása a térítésre, $\mathrm{s}$ földi természete az ő paradicsomának megvetést érdemlenek, mindazonáltal ha elgondoljuk a vastag babona állapotját, melybe kelet keresztényei süllyedtek vala, s az arabusok honnyi bálványozását [native idolatry of the Arabians), meg kell engednünk, hogy ő egy nagy reformációt vitt véghez. Ô ahhoz képest tisztaságot vitt bé a hitbe s isteni tiszteletbe. Bizonyoson, ha megértjük az ő karakterét, mely enthusiasmus és imposturából volt összealkotva több volt az elsőből, mint 
amennyit közönségesen állítottak. Az ő tanítása tulajdon szavával ez: Az Isten egy Isten az örökkévaló Isten; e nem szült, nem is született, s nincsen egy is több, hozzá hasonló. Gibbon azt jegyzi meg: a Korán egy dicsőséges tanúbizonysága az Isten egységének. A mekkai próféta megvetette a bálványok és emberek, a csillagok és plánéták imádását azon rationale principiumból, hogy mindennek, ami származott el kell enyészni, s mindennek, ami született meg kell halni, mindennek, ami romlandó el kell romolni és pusztulni. A mindenség teremtőjében az ő racionális enthusiasmusa, egy vég nélkült és örökkévaló valóságot vallott és imádott, mely forma vagy hely nélkült, kifolyás, vagy hasonlatosság nélkült áll legtisztább gondolataink elébe, önnön természete szükségességénél fogva egzisztál s magába elvesz minden erkölcsi és értelembéli tökéletességet.

Ilyen megfogásoknak az Istenről akárminemű kútfőből meríttettek is azok, áldással kelletett lenni azoknak, kik azokat a bálványimádás, képtelenség, elkorcsosodás cseréjében kapták.

4. Azalatt míg a mái idők sok hitetlenségei meggyőzettetének okoskodások módjának legképtelenebb hamis voltáról, s karaktereknek nagyon elfajulásától, találtattak mások, kik úgy látszik becsületes, noha megtévedett vizsgálódók voltak, kik egybe vetették a keresztény vallást annak abúzusaival, amin egy katolikum országban nem lehet csudálkozni, s mind a kettőt előterjesztették, midőn azokat egyik a másikától meg kellett volna különböztetniek. Sokak ezek közül igen nagy hasznot tettek, midőn a keresztényeket a tisztább hitre, s elébbi esméret jutásnak helyesebb megfogásaira vezérelgették vissza, mindazonáltal nem lehet eltitkolni, s nem is kell azt a meggyőződést, hogy némely keresztényeknek neveztetett vallástételek nem hasonlíttathatnak össze a naturális religióval, úgy amint azt Lord Herbert állítá ezen öt cikkelyekbe:

a. Hogy egy a legfőbb Isten, az Isteneknek istene, vagy minden dolgoknak Istene és Atyja.

b. Hogy minden isteni tiszteletnek és imádásnak ezen egy Istenben kell terminálódni.

c. Hogy az igazságnak és virtusnak szeretete és gyakorlása a fö, s egyetlen egy esszenciális része ezen az egy igaz Isten előtt kedves s általa megjutalmaztatandó tiszteletnek.

d. Hogy a búneink, s az igazságtól és virtustól félretántorodásaink miatt érzett mély bánat, az olyan elkövetett bűnök után következett szívbéli igaz megbánással s jobbulással együtt, a valóságos engesztelés a bűnös, vagy a bünösökért Istennel megbékéltető eszközök.

e. Hogy az Isten, mint bölcs és igazságos ítélő bírája s igazgatója a világnak, bizonyosan megjutalmazza a virtust, s bünteti a vétket mind itt, mind amott. 
5. Bizonyos, hogy sok kínai és indiai filozófusok tanították a tiszta deizmust, kik helyet érdemelnek a bálványozás és vétek tiszteletre méltó ellenzői között. Tudjuk, hogy a jelen való pillanatban egy igen megvilágosodott, s nevekedő szekta áll fenn nem keresztény unitáriusokból Bengálban, kiknek fejek Ramohun Roy, egy méltóságos karakterű s nagy hírü-nevü brahmin. Sokan olvasták közületek, hihetőleg amaz interressans tudósítást az ő tanításáról Belsham úrnak Madrászban, a született indus unitáriusokból álló eklézsia tárgyában Roberts-hez intézett levele praefátiójában. Belsham a londoni unitárius pap, Roberts a madrászi indusok unitárius papja[hoz]. Ố így erősíti a legfőbb valóság egységét:

Az Isten valójában egy, s nincs egy második is. Csak a legfőbb valóság birtokosa a mindenekre kiterjedő ismeretnek. Az Isten egyedül tárgya az isteni tiszteletnek. Imádj egy Istent. Ismerj egy Istent. Az Istenhez kell közelíttetnünk, róla kell hallanunk, róla kell gondolkoznunk, s hozzá hasonlókká lenni kell törekednünk.

Ki nem fogja közülünk azt mondani az érdeklett levél kiadójával ezen rendkívül való férfiúról, hogy ő nem messze vagyon az Isten országától Mt 12,34. Ki ne örvendene az ő tiszta hitének hazafiai tévelygésein győzedelmeskedését?

Nem bizonyítják-e eléggé ezen faktumok, hogy az Isten valóságos egysége, vagy a józan okosság mindenütt világos parancsolatja, mely hirdettetett az egek s a föld által ahol kívánták ezeknek szavakot hallani, vagy valamely originális revelációnak a fragmentuma, mely alászállott a tradíciónál fogva minden időkre, s elhatott minden tartományokra. Kiszedetett a bölcsek és jók által a véle együtt járó képtelenségek másaiból?

Mindenik feltétel magában foglalja annak igazságát és fontosságát. Öröm azt mindenütt felsőbb világosodással s virtussal levő konexióban látni, hogy az vagy menedék volt a közönséges tudatlanságban s elfajultságban, vagy eszköz az emberi nemzet állapotjának megjobbítására, hogy vagy úgy ragaszkodtak hozza az igazság és szabadság hajótöréseiben mint legutolsó deszkához, vagy úgy emelték fel, mint a megújuló jóság zászlaját, s a reformáció szignumát.

Valami antikvitást és univerzalitást tulajdonítanak magoknak a trinitáriusok amidőn alkalmatosság adódván úgy affektálnak beszélleni az unitarianizmusról, mint egy néhány mai üdőbeliek ábrándozásairól. Midőn a keresztény vallás históriájára függesztettük vala vizsgálódásainkat elegendlőleg megmutattuk a csalárdságát ezen előadásnak, mely csupán annak komparatíve később újra feléledésén fundálódik. Az unitarianizmus csak úgy tetszik mái időbélinek, ha az a spirituális domináció és perszekúció korára vitetik. A katolikusok a protestantizmusnak VIII. Henrik országlása idejében kévánnak egy igen új s tisztátalan eredetet adni. A trinitá- 
riusok az unitarianizmust a barbarizmus és szupersztíció amaz özönétől fogva nézik csak mely egészen elborította az erkölcsi világot. A Római Birodalom elromlásakor kiterjede a reformáció érájáig és amelyből némely szekták hamarább támadának, mint mások. A darabos kősziklák és kopasz hegyek csúcsai tetszének ki elsőben, az ember lakhelyéül rendeltetett teres síkságok s termékeny völgyek utoljára tűnének szem eleibe. A sötétes holló hagyá el elsőbben a bárkát, s hamar is lele nyugvóhelyet; de a szelíd galamb sokáig repdese a dúlás szcénája felett, $\mathrm{s}$ visszatére és várakozék, míg egyszer elhozá az olajfa levelet, hogy azt az emberi nemzet bátorsága bizonyító jegyéül adja; maga a nap sem vala képes egyelöre áthatni köd lepte atmoszférát, s megtisztítani a levegőt s visszaállítani az egek derült képét (Perry levele Kinghornhoz) [Perry's lettres to Kinghorn.]

A viszont feléledett unitarianizmus fő szcénája a reformáció ideje táján Lengyelországban volt. Egy csillagkör álla fenn nevezetes karakterekből ott, mely körös-körül hintezé a vallásbéli világosság tüzelgéseit. Azoknak írásaik máig is gazdag tára annak, ami legbecsesebb a bibliai esméretben és kritikában. A legkitetszőbb ezek közt Socinus vala. Fájlaljuk azt az inkonzisztenciát mely néhány lépéseket tétete véle az üldözés útjában, de kénteleníttetünk igazságosaknak lenni az ő nagy érdeme aránt. Tökéletes csendben hala ő meg, azt mondja Robinson, gyönyörködve elmélkedvén szenvedéseiről, jelengetve azon reményeit, hogy fáradozásai meg fognak jutalmaztatni az igazságos ítéló bíró által az utolsó napon. Az ő sírja feliben írt epitáfium mutatja micsoda gondolattal voltak barátai az ő tudománya felől, az a pápizmusra céloz egy márványnak hasonlatosságában: „Luther levoná Babilon fedelét, Kálvin lerontá annak falait de Socinus ásá fel fundamentumit."

Dühös üldözés rohana annak utána az unitáriusok ekléziáira Lengyelországban, de igen számos gyülekezetek maradtak fenn mindeme mái napig Erdélyben. Valósággal egyelőre halálra vadászták őket mind a katolikusok, mind a protestánsok. Példa a Servetus barbarus megöletése a Kálvin ingerléséből. Hasonló szcénáknak voltak helyei ezen országban. Ama szeretetre méltó ifjú fejedelmet VI. Edwardot nagy nehezen tudta reá venni Cranmer, hogy a Bocher Joanna egy kegyes, megvilágosodott és megkülönböztetett asszonyszemély halálos szentenciájának nevét alája írja, azért, hogy tagadta a trinitást. Könnyező szemekkel cselekedte meg azt, és ezen nevezetes megszólítással: „Érsek Úr! Mivel ezen esetben egészen az Úr ítéletére bízom magamot, az Úrnak kelletik erről számot adni, az Istennek."

Az unitárius mártírok históriája intereszáns tárgy lenne. Sokan szenvedtek ezen országban azon törvények alatt, melyek nincsenek fenn többé, de amelyek közül némelyek csak nemrégiben töröltettek ki a Parlament 
aktái könyvéből. Terhesen nyomta az üldözés járma eleink nyakokat, s annak terhe a földig nyomta őket. Lehullottak annak elbírhatatlan súlya alatt, s egyedül a tette az ő monumentumokat. Nem is vették el még a posthuma dicséretnek amaz igen megérdemlett adóját (melyből részesednek oly sokan mások) kiknek neveket egy háládatos ujj letörölhetetlen betúkkel felmetszette a halhatatlanság oszlopára. Elmúltak ők hírnév nélkül, mert ellenkezőink számlálták elő történeteket, s bálványozó keresztényeknek írták meg a keresztény vallás históriáját, de az ő nevek és érdemek fenntartatnak amaz elveszhetetlen oklevelekben, melyek a mindentudó keze által írattak s a menny udvarába gyüjtettek be, melyek ki fognak egykor teríttetni egy bámulandó világ eleibe, hogy ragyogjanak mint a csillagok örökön örökké.

Az unitarianizmus újra feléledett előmenetele hasonlatosságot tulajdoníttatott magának az evangélium eredeti terjedéséhez, mivel az is, mint ez ellenkezve a hatalommal, truccolva az üldözéssel haladott elébb, elébb, s kevés esztendőktől fogva miólta nyilván és világosan prédikáltatott nagy sebességgel terjedett a nép között.

Annyiban amennyiben annak jelen való állapota és jövendőre való kinézései ezen lektúrák folyamatjának közönséges célját tárgyazzák, azok a legközelebbi lektúrában fognak vizsgálat alá vétettetni. A textusa annak az ő finális és univerzális prevalenciájának előre megjövendölése, aminek realizálódni kell. Annak terjedésének célja az, hogy elsőben eloszlassa a tévelygést, megakadályoztassa az egyenetlenséget az eklézsiában, azután, hogy körös-körül járja a föld golyóbisát elvivén minden tartományban az Istennek egységét és szeretetét, az emberek univerzális atyafiságát, akkor osztán az Ư lészen királya az egész földnek, azon napon egy úr lészen, és neve is egy lészen és minden szózat amaz éneket fogja elhozni, míg egyik partról a másikra hangzik vissza: dicsőség a magasságos mennyekben Istennek, és e földön békesség és jó akarat az emberekhez Lk 2,14.

De közöttünk és ama boldog időszakasz között még egy igen hosszú s izzasztó viaskodással teljes intervallum vagyon. Erős állhatatossággal verni vissza a rágalmazás nyilait, szelíd jóltevőséggel megnyerni a sziveltetést azon fegyhetetlenségtől eltántorodás nélkült, mely kárhoztatja az igazságnak legkevesebb részbéli feloldozását is. Változhatatlan türelemmel szállani szembe az ellenkezéssel, tudatlansággal és előítélettel, s állhatatos, egyesült s buzgó törekedéssel állítani vissza a keresztény vallás igazságainak tiszta voltát, az antikrisztiánus tévelygés töredékjein. Ezek felséges kötelességei az ő védelmezőinek, ezek azon fáradságos, de tiszteletre méltó foglalatosságok, melyekre ők hivattattak az Isten és gondviselés által. Midőn tü ezen nemes munkálkodásba egyesültek segéd társai lésztek a föld azon derékjeinek, kik valamely időkorban közbe vetették magokat 
tulajdon veszedelmekkel, hogy akadályozzák az emberek nyomorúságait, vagy sokasítsák azoknak áldásait, kik mint Áron a holt és az élő közibe állanak, hogy elfordítsák a csapást, kik mint Ábrahám mindenekről lemondottak az Istenért. Tü tészitek a reformátoroknak a minden éghajlat alatt és generációkban egymással rokon lelkeknek nevezetes láncát, ama legjobb és legnagyobbtól fogva, - az ő előtte való öröm helyébe szenvedett keresztet, a gyalázatot megutálván Zsid 12,2. - le a tü tulajdon Priestley és Lindsey-etekig, kik hallák az ő lelkesítő szavait: Légy hív mindhalálig és neked adom az életnek koronáját Jel 2,10. És aki hív tüktöket is vélek együtt a szent viadal azon csatamezejére, hogy védelmezzétek az igazság, fegyhetetlenség és jóltevőség ügyét, s arassátok a mennyi dicsőség hervadhatatlan borostyánjait.

\section{Az unitáriusoknak a Jézus Krisztus valóságos emberi létéről való} tanítások. Ezen szakasz fordíttatott a Belsham Tamás munkájából. MsU. 898/A. Eredetije: A summary view of the various opinions which have been entertained concerning the person of Christ, and of the arguments for and objections against each címü második rész első szakaszának The proper unitarian scheme, or the doctrine of the simple humanity of Jesus Christ. Belsham, A Calm Inquiery... London, 1817, 291-308.

Az unitáriusoknak a Jézus Krisztus valóságos emberi létéről való tanittások.

Az unitáriusok tanítása ez, hogy a názáretbeli Jézus minden tekintetben hasonló volt más emberekhez, ugyanazon gyengeségeknek, ugyanazon tudatlanságnak, előítéleteknek, és gyarlóságoknak alájok vettettetve. A Dávid famíliájából származott, Józsefnek és Máriának fia, noha némelyek máig is az ő csudálatos fogantatásáról levő közvélekedéshez ragaszkodnak, hogy ő csekély környüllálások között született, semmi neveltetést és tudományosságbeli különös szerencsét nem nyert, hanem például szolgáló karakterü férfiú volt, és, hogy a régi próféták jövendőléseik szerént Istentől arra választatott és rendeltetett volt, hogy egy új erkölcsi diszpenzációt hozzon be a világba, melynek célja a volt, hogy a zsidó oeconomia eltöröltessék, s a hívő pogányok egyenlő privilégiumu, és kedvességü karba helyeztessenek az Ábrahám maradékával. Más szókkal, arra volt meghatalmazva, hogy kijelentse az egész emberi nemnek, minden megkülönböztetés nélkül felséges tudományát a jövendö életnek, melyben az emberek cselekedeteikhez képest fognak megjutalmaztatni. 
Úgy látszik, hogy Jézus nem volt egészen bizonyos azon tisztelet és méltóság felől, melyre el volt rendelve megkeresztelése utánig, amidőn elküldeték hozzája a Szentlélek látható példázatban (symbol) és amidőn csudálatosképpen úgy hirdetteték ki, mint Istennek szerelmes fia, azaz, mint nagy próféta, vagy Messiás, kit a zsidók vártak, amely eset után közönséges hivatala folyásában a környüllállások szerént, úgy beszél magáról, mint embernek fia, és mint Istennek fia.

A keresztelése után, egyátaljában hiszik az Unitáriusok, hogy egy ideig a pusztában mulatott, hol tökéletesen bétaníttatott küldetésének természetébe, és felruháztatott szabad, csudát tevő hatalommal, melyet megkísértése ábrándozós jelenésétől [visionary scene of his temptation] fogva vett utasítása szerént, nem valamely személyes haszon, hanem csupán küldetése célja előmozdítására gyakorolhatott. Sokan mindazonáltal úgy gondolkodnak, hogy a Jézus egy csudát se cselekedett soha, hanem ha isteni ingerlésből ösztönöztetett arra. Némely tudományos férfiak azt állították, hogy a Jézus a pusztában tartózkodásinak időszakasza alatt isteni látásokkal (visions) szerencséltetett, melyekben Pál apostolként 2Kor 12 [like the apostle Paul] tapasztalta magát az égbe vitetni, és hogy azon szólást, mellyel ő az égből jövetelét célozva el, ezen hypothesisből kell megmagyarázni. De az unitáriusok nagyobb része ezen kifejezésekből csak az ő isteni küldöttetését, azon isméretet, mellyel minden más próféták felett szerencséltetett, Istennek az emberek erkölcsi állapotját tárgyazó akaratyát, és annak új dispensátióit melynek béhozására ő rendeltetett, magyarázzák.

Az unitáriusok hiszik közönségesen, hogy a Jézus, egy esztendeig, és talán kevéssel tovább folytatván közönséges hivatalát, halált szenvedett mindeneknek szemek láttára a keresztfán. Nem azért, hogy lecsendesítse az Isten gerjedező haragját, nem mint egy elégtételt az isteni igazságnak, nem azért, hogy szemeink eleibe terjessze a bünnek rossz voltát, sem nem valami afféle értelemben, hogy a bünért megengeszteltessék az Isten, mert ezen tudományt akármely értelemben, s akármely magyarázattal megvetik ők, mint amely ellenkezik az okossággal, nincs a Szentírásra építve és küssebbitésekre vagyon az isteni tökéletességeknek, hanem úgy, mint egy mártírja az igazságnak, és mint egy szükséges bévezetés az ő feltámadására. Es úgy látják, igen bölcsen volt rendelve a szőrszálhasogatásoknak eltávoztatására az, hogy az ő halála mindeneknek tudtokra történjék, és az ő ellenségeitől okoztassék. [...that his death should be an event of great public notoriety, and inflicted by his enemies.]

Az unitáriusok hiszik továbbá, hogy Jézus harmad napon feltámadott az életre tulajdon jövendőlése szerint, az Istennek hatalma által, és hogy ezen történetnél fogva, nemcsak küldettetése igazságát és isteni voltát bizonyította meg, hanem a halhatatlan életre feltámadásnak egy példáját és 
zálogát terjesztette előnkben tulajdon személyében. Mely okból az egész Újtestamentum elsőszülöttjének és a holtak közül első feltámadottnak nevezik.

Az unitáriusok továbbá hiszik, hogy minekutánna feltámadása igazságát elegendőleg bebizonyította tanítványainak negyven napok alatt, csudálatosképpen eltávozott azoknak társaságából, mely környülállás úgy iratik le, mint az ő mennybemenetele; és hogy kevés napokkal ezen történet után, a Szentlélek közöltetett apostolaival látható példázatban (symbol), jelben pünkösd napján; melytől felruháztattak különb-különbféle nyelvek beszélésének tehetségével, amelyeket soha nem tanultak, és megajándékoztattak sok más tehetségekkel és hatalmakkal, melyek által alkalmatossá tétettek az evangéliumnak a világon terjesztésére s Mesterek halottaiból feltámadása közönséges, és mindeneknek leginkább eleget tevő megbizonyításának előadására.

Az unitáriusok azt állítják, hogy a Jézus és az ő apostolai természetfeletti módon (supernaturally) voltak taníttatva, amennyiben szükséges volt az küldöttetések véghez vitelére azaz, az örökéletről való tudomány kijelentésére, és megbizonyítására, és hogy az Istennek kegyelme egyenlőleg vagyon kiterjedve a pogányokra és a zsidókra, s hogy Jézus, s az ő apostolai, és más első keresztény hívek alkalmatosság szerént lelkesíttettek a jövendő történetek megjövendőlésekre. De azt hiszik, hogy ezen természetfeletti lelkesítés (supernatural inspiration) egyedül csak ezen esetekre volt szorítva; és hogy midőn Jézus, vagy az ő apostolai küldöttségek tárgyával összeköttetésben nem lévő dolgokról terjesztenek előnkbe vélekedéseket, az ilyen vélekedéseket, s az ők ezekről való okoskodásaikat éppen azon figyelemmel és vigyázással kell fogadnunk, milyennel más hasonló környülállások között volt, hasonló neveltetésü, és hasonló gondolkodás módú személyeit.

Az unitáriusok helybenhagyják, hogy az Ó- és Újtestamentum, s kiváltképpen ezen utolsóbb írásai hiteles tanúbizonyságokat foglalnak magukban a történtekről és isteni közbenjövetelekről (divine interpositions); de egészen tagadják ezen munkák íróinak mindenre kiterjedő lelkesíttetéseket (universal inspiration), mint oly tulajdonságot, melyet azok bizonyoson magoknak nem tulajdonítottak, és amelynek állíttása, csak az isteni kijelentés nyilvánosságának zavarba hozására, annak ellenségeinek elésegélésére céloz. Ezen írások igaz eredetiségekről, azoknak értelmeikről és hitelességekről pontban azon úton tészen megítéléseket, melyen más régi írásokéiról.

Sok unitáriusok hiszik, hogy a Jézus az eklézsiával valamely személyes és tapasztalható egybenköttetést folytatott, legalább a környülállásokhoz képest, az apostolok időkora alatt, amint ő világoson megígérte 
volt nékiek Mt 28,20; s ezen úton adják okát azon csudatevő tehetségek, s hatalmok fen léteknek, melyek az ő nevében gyakoroltattak, míg éltek az apostolok, s azon alkalmatosság szerént előforduló személyes megjelenéseknek és közbenjöveteleknek, melyek azólta soha elé nem fordultak. De hiszik, hogy most megvonta minden mind e világgal tapasztalhatólag egybenköttetését, noha némelyek gyanítgatták, hogy máig is jelen van abban s figyelmez annak ügyére.

Az unitáriusok hiszik, hogy a Krisztus vagyon elrendelve a holtak feltámasztásokra, és a világ megítélésére; az első tekintetben azt hiszik, hogy eszköze fog lenni az Atya hatalmának. Az utolsó tekintetben, akár literális, akár figuraciós értelembe vétessenek az arra célozó kifejezések, akár valamely nagy hivatalbéli karakterrel ruháztassék fel személyesen a Jézus, akár semmi ne légyen célul véve azokkal, több annál, hogy az emberek végső állapotjoknak az evangélium kifejezéseivel megegyezőleg kelletik megítéltetniek, úgy gondolkoznak, hogy most nem lehet bizonyost tudni. Hihetőképpen, amint szokott lenni a jövendőlő szólásformákkal, azon történet sokat fog különbözni attól, amit azon szóval literális értelme hágy minekünk várnunk. Hanem akármi légyen azon kifejezések értelme, bizodalommal vagyunk (confident) az aránt, hogy azon rész, melyet a Jézus abba fog vinni nem lesz több annál, mint amennyi tulajdonképpen adattathatik egy emberi valóságnak Jn 5,27, és melynek véghez vitelében az ő apostolai és tanítványai társai fognak nekie lenni, amint megmondottatott Mt 19,28; 1Kor 6,2-3.

Az unitáriusok azonban, hogy meghajolnak a Jézus, mint a legfelsőbb valóság nagy prófétája méltósága előtt, alázatossággal fogadják mindazt, amin az isteni tanúbizonyság jegye rajta láttatik lenni; azonban, hogy úgy tekintik a Krisztus karakterit, mint legtökéletesebbet, s leginteressantabbat, mely láttatott valaha a világgal; azonban, hogy azon feloldhatatlan közösség alatt érzik magokat lenni, hogy engedelmeskedjenek az evangélium parancsolatjainak, és példaadása szerint, valamint kitelhetik tőlök terjesszék az igazságnak esméretét és virtusnak gyakorlását; helyben nem hagyok mindazon személyesen a Jézusnak tett tiszteleteket, és hozzá intézett, akár néki esedezés, akár őtet dicsőittetésbeli beszédeket, melyek tulajdonképpen a vallásos isteni tisztelet definíciója alá jönnek, mint amelyeknek okát nem látja által az okosság, melyeket nem hagy helybe a Szentírás és amelyek küssebbségére vagynak a legfőbb valóság vallásbéli tisztelet ezen egyetlen egy tárgyának tiszteletének, s amelyek szorosson tulajdon értelemben politeisztikumok és bálványozások. Ezen esetben az unitáriusok távol lévén attól, hogy tudva és megátalkodva küssebbitsék a Jézust illető tiszteletet, mint akit úgy ismernek és úgy tisztelnek, mint Urakat és Mestereket, egészen elhitették magokkal, hogy ők az ő méltósága és pél- 
daadásával tökéletesen megegyezőleg cselekszenek, és oly módra, melyről legnagyobb megelégedését önön maga bizonyítaná meg, ha személyesen megjelennék a földön.

Azok akik hiszik a Jézus Krisztus valóságos emberi voltát (humanity) magoknak tulajdonítják az unitárius címet (nevet), nemcsak azért, mivel a szokás, a nyelv közbírája a reformációtól fogva mindeddig ezen nevezetet, s nem sok idők ólta reájok szorította az ilyen keresztényekre, hanem inkább azért, mivel ők azt állítják, hogy szinte csak ők a keresztények közül, kik cselekedeteikkel is megerősítik az isteni egység nagykövetkezésü tudományát, az ő teljes és igaz kiterjedésében, és akik minden teremtményt kirekesztenek minden kivétel nélkül mindenemű részesülésből azon atributumoknak, cselekedeteknek és tiszteleteknek, melyeket az okosság és isteni kijelentés csak az egyetlen egy Istennek tulajdonítanak.

$\mathrm{Az}$ unitáriusok szükségtelennek gondolják valamely bizonyításokat hordani elé annak megmutatására, hogy az a személy, mely gyakorízben mondattatott embernek, mely mindég emberi valóságnak láttatott lenni, amely született, mely élt, amely nevekedett, amely másokkal társalkodott, amely érzett, amely cselekedeteket vitt véghez, amely szenvedett és amely úgy holt meg, mint más emberek, kit közönségesen embernek lenni hittek mindazok, kik őtet látták, és vele társalkodtak, és akik úgy szólítottak, s akivel úgy beszéllettek mint emberi valósággal, s minden vele egy időkorban élők, akár barátjai, akár ellenségei lettenek légyen is azok, - valósággal a volt, aminek maga is állította magát lenni, igazán és valósággal ember és semmi nem több, mint ember. Ez oly factum, melyet minden vonogatás nélkül el kell fogadni, hanemha a legvilágosabb, és meghatározottabb nyilvánosságból az ellenkező következhetik; s úgy gondolkoznak, hogy egy oly bámító, a tapasztalással és analógiával annyira ellenkező faktum, mint egy felsőbb lélek megtestesülése (incarnation) félszeg szócélzások, vagy homályos figuráció és kétséges értelmű frazeológiának tekintetéből nem elhihetô, sőt az okosságnál fogva inkább várhatni, hogy egy ilyen faktum nyilvánossága azon méretékbe legyen tiszta, és elhatározó, melyben az apriori meg nem bizonyítható.

S minekutánna szorgalmatosan vizsgálat alá vették a Szentírást, azt vallják az unitáriusok, hogy egy arra célzó [megtestesülésre] tiszta és kielégítő világosságra se találhattak. Ők azt veszik észre, hogy a Jézus Krisztus vélt praexistens állapotjáról, az ő felségesebb természetéről egy szóval célozás sincs az evangélisták közül háromnál, sem az apostolok tanításait és az apostolok cselekedeteit magában foglaló evangélium első plántálása históriájában; s hogy János igen misztikus író, teli vagyon figar metafórákkal, szimboliális frazeológiával, melyek igen különböznek a több evangélistákot karakterizáló egyszerüségtől. Azon meglepettetésnek s elbámu- 
lásnak sem akadhatnak valamely nyomaira a Jézus tanítványai és követői lelkeket foglalni, amidőn legelsőbben kijelentetett volna nékiek az, hogy az a Mester, kivel ők oly gyakran s oly barátságosan társalkodtak, az ők teremtő Urak volt, vagy legalább egy felséges mennyei lélek emberi formában.

Az unitáriusok továbbá azt állítják, hogy a szentírásbeli nyelv szorgalmatos vizsgálásánál a külön-külön eléforduló phrasesek egymással öszszeköttetésben lételeknek fontolgatásának, az egymással ellenkező helyek gondos összehasonlítgatásánál, és annál fogva, ha a Szentírás önön maga tétetik magának magyarázójává - nem bajos megmutatni, hogy azon kevés phraseseket, melyek a Szentírás egész folyamával ellenkeznek, s amelyekről az a vélemény, hogy azokban a Krisztus felségesebb természete és praexistens állapotja taníttatik, ha az ilyen textusok igaz eredetiséggel bírnak magyaráztassanak azok igazságoson; s a tiszta és szabad kritika megállíttatott zsinórmértéke szerint, az ő valóságos emberi létét helybenhagyó értelemben kelletik magyarázni.

Különösen erősítik annak megmutatását, hogy azon helyek melyekben a Jézus úgy terjeszti magát előnkbe, mint aki mennyből szállott le, semmi többet nem jelentenek az ő tudománya mennyei eredeténél; hogy ahol úgy adatik elé, mint mindeneknek teremtője, csak az újjáteremtés értettetik ott, azaz a dolgoknak azon új állapota, melynek az erkölcsi világban léendő béhozatalára volt rendelve; és hogy a természeti dolgoknak teremtések soholt sem tulajdoníttatott a Krisztusnak, továbbá, hogyha az isteni cím tulajdoníttatott valaha a Krisztusnak az Újtestamentumba (melyet némelyek tagadnak), a csak olyan értelemben esett, milyenben Mózes is mondatott Istennek fáraónál, azaz, mint isteni biztossággal, s annak megbizonyítására csudákot tehető hatalommal felruháztatott valóság. Azt az észrevételt is teszik, hogy ugyanazok, sőt még hathatósabb kifejezések tulajdoníttatnak a keresztényeknek közönségesen, mint amelyekből a Krisztus istenségét szokták következtetni. Ők azt erősítik, hogy a természeti világnak, s annak lakosainak teremtetések és fenntartások egyező értelemmel az Istennek tulajdoníttatott, s semmiképpen nem lehet világosan megmutatni azt, hogy Istennek az emberi nemmel akár a pátriárkákkal, akár a zsidókkal esett valamelyik elsőbb diszpenzációiban személyesen a Krisztusra lett volna célozás, hanem, hogy az ellenkező erősittetik nyilvánságosan és több ízben a Szentírásokban.

Az unitáriusok azt állítják, hogy azon egyes kifejezésekről melyekből a fiú örök életéről való tudomány kövekeztetik, tisztán meg lehet mutatni, hogy azok semmivel többet nem jelentenek, hanem az ő prófétai karakterének, mint megígért Messiásnak, és az Isten prófétái legeltetőjének felsőbb méltóságát. 
Azt jegyzik még továbbá, hogy midőn az apostolok Krisztusról az ő feltámadása s mennybemenetele után beszéllenek, a Krisztus személyére célozva, oly unqualifikált kifejezésekkel élnek, melyeket egy ariánus vagy trinitárius sem tenne magáévá ma szélesen kiterjedő magyarázás és vigyázás nélkül; olyanok azok, melyekkel kétségkívül magok az apostolok nem éltek, ha a Krisztus praexistenciáját, vagy Istenségét hitték volna.

Végre ellene állhatatlan világossággal megmutatta Dr. Priestley azt, hogy a két első századokban a zsidó keresztények csaknem mindnyájan, s a pogány keresztényeknek nagyobb része hitték a Jézus Krisztus valóságos emberi lételét, némelyek elfogadván, mások megvetvén az ő csudálatos fogantatása környülállását. És ezen első keresztény híveknek, mivel ők a keresztény tudományt az apostoloktól, s azoknak immediatus successoraitól tanulták, legjobb értelmeknek kelletett lenni azon homályos frazeológiák magyarázatjában, melyek a későbbi időkben ama Szentíráson nem épült vélemények támogatására alkalmaztattak, melyeket a pogány filozófia hiábavalósága meghamisította, és megalacsonyította a keresztény hit tisztaságát és egyszerüségét. [Itt egy lábjegyzet következik, ami a fordításból kimaradt. See, upon this subject, Haynes of the Attributes of God. Lardner on the Logos. Cardale's True Doctrine concerning Christ. Lindsey's Apology and Sequel. Conversations on Christian Idolatry. Dr. Priestley's History of Corruptions of Christianity, History of Early Opinions, and Defences of Unitarianism. Cappe's Critical Remarks on Scripture, 2 vols. Simpson's Essays on the Language of Scripture. Belsham's Reply to Wilberforce, and Letters on Arianism. Dr. Carpenter's Unitarianism the Doctrine of the Gospel. The Notes to the Improved Version of the New Testament are intended chiefly to exhibit the most approved interpretations of the Unitarian expositors.]

Az unitáriusok tudománya ellen, ezen ellenvetések tétetnek: hogy nekünk a mi vizsgálódásainkat nem az első keresztények vélekedéseikre kell intéznünk akár a judaizmus, akár az ethnicismusból tértek legyenek azok [converts from judaism or heathenism], mert azok csalatkozható, és elöítélettel teljes emberek voltak, mint mü, hanem a Szentírás természetes és világos értelmét; hogy a Szentírások egészen tudatlan emberek számokra irattak, s annak okáért azokat az ők legnyilvánságosabb s populárisabb értelemben kell vennünk; hogy noha a Szent írók közül egyiknek céljával sem ütközött egyben a Jézus Krisztus praexistentiájáról, vagy istenségéről beszédet tartani, mindazonáltal ezen tudomány az Újtestamentum különbféle helyeiben a legtisztább s legkevésbé kétséges kifejezésekkel taníttatik, melyeket lehetetlen másféle értelemre csavarni, hanemha a magyarázásnak csak azon módjánál fogva, mely minden dolgot bizonytalanná, és minden szólásformát haszonvehetetlenné akar tenni; hogy ezen 
felséges tudomány nemcsak egy vagy két helyeken taníttatik, vagy imitt amott eléforduló kétséges értelmú kifejezésekből következtethetik, hanem az Újtestamentumnak igen számos textusaiban, sok különböző frazeológiában erőssíttetik, és hogy gyakran tétettek célzások arra, s okoskodások a felett, mint kétségbe hozhatatlan faktum felett, hogy a Jézusnak, vagy az ö lelkesített, vagy több utasítást vett apostolainak egy pozíció erősítések elegedendő megsemmisíteni minden ellenvetést mely ezen faktumnak apriori meg nem bizonyíthatása, a történetek fólyamival s a természet közönséges analógiájával ellenkezése tekintetéből támadhat, minden más csudákra is hasonlólag alkalmaztatható lévén ezen ellenvetés; hogy csak önkényünk szerént előbbrevaló feltétel azt erősíteni, hogy Krisztus küldettetésének egyetlen egy tárgya a jövendő életről való tudomány tanítása volt, oly tudománynak, mely közönségesen annyira meg volt esmérve, s oly könnyen megmutatható az okosság következtetéseinél fogva, hogy csak ezen célból szintén nem volt szükség az isteni kijelentésre; hogy az értelem elrémül azon ideán, hogy egy emberi teremtett valóság légyen elrendelve a holtak feltámadásának és a világ megítélésének nagyméltóságú hivatalára; azonban hogy azon érthető jelenés ha a világ megváltásának és megítéléseknek hivatala annak tulajdoníttatik, ki teremtője volt a világnak, ki fenntartja és igazgatja azt, ki Istennek minden az emberi nemmel közlött erkölcsi dispensatioban eszköze volt - a Jézus Krisztus praexistens állapotját, méltóságát és felségesebb természetét igen hathatósan gyanította indító ok- és végezetre; hogy ezen tudomány oly világoson kijelentetett a Szentírásban, hogy ámbár kevés speculativus és interresatus emberek által az elsőbb századok olta különböző időszakaszokban kétség alá hozatott, mindazonáltal a keresztények nagy részének vallástételében fő volt az, a keresztény vallás első hirdetésétől fogva a mai napig.

Továbbá, az az ellenvetés tétetik, hogy igen önkény szerént való, és védelmezhetetlen cselekedet az unitáriusokban az, hogy ők kitörlik a Szentírásból mindazt, ami tulajdon princípiumaikkal és hipotézisekkel meg nem állhatónak találnak, s amiket ők meg nem magyarázhatnak kiváltképpen a csudálatos fogantatásról való históriát Máté és Lukácsban; hogy nagyon küssebbítetik az a tekintet és tisztelet, mellyel a Krisztusnak tartoznak midőn úgy adatik elő az ő karaktere, hogy az alája volt légyen vettetve a gyarlóságnak és gyengeségnek, midőn határok közé szoríttatott az ő lelkesítése (inspiration), s midőn ő előítélettel és tévelygéssel terheltetik; hogy tagadni az apostoloknak és az Újtestamentum más íróinak mindenre kiterjedő lelkesíttetéseket, annyi, mint haszonvehetetlenné tenni az Isteni kijelentést, s kétséges értelmúségbe s bizonytalanságba bonyolíttani azt; és hogy ami illeti Krisztusnak a világ, mind emberek, mind angyalok megítélése nagyméltóságú hivatalát az ama szent assessoroknak véle 
együtt létele környülállását, igen világos azon vékonyon, s csak történetesen eléforduló módból, melyben egyik ezen esetek közül említve van, s azon nagy pompából, s gyakor esmétlésből, mellyel a másik ki vagyon hirdetve, hogy azokat különböző értelembe kell venni; és hogy egyik esetben a kifejezéseket literális, a másban figuratív értelemben kell érteni.

Nagy gőgnek festetett a Jézus Krisztus valóságos emberlétét védelmezőkben az is, hogy ők csak magokénak tulajdonítják az unitárius címet, azt a tiszteletes nevezetet, melyhez minden keresztények jussukot fenntartják. A trinitáriusok azért, hogy az állatjában való egységet erősítik a személyek háromságában; a legfelsőbb rendű ariánusok azért, hogy ők, az egy Isten lételét védelmezik, kitől a Logosz, aki teremtette és fenntartja a mindenséget veszi minden tulajdonságait, és hatalmát; az alsórendű ariánusok azért tartnak just az unitárius címhez mert noha ők helyben hagyák, hogy e világot a Krisztus teremtette, és ő igazgatja, ki ezen célra hatalommal és méltósággal ruháztatott fel az Atyától, mindazáltal úgy nézik az Atyát, mint a vallásbéli tisztelet és hódolás egyedül való tárgyát.

Az unitáriusok ezekre azt felelik, hogy ámbár nem vitatják az első keresztények állhatatlanságokat, mindazonáltal úgy gondolkoznak, hogy amidőn meg van mutatva az, hogy a tanulatlan keresztények nagyobb része a két elsőbb századokban hitte a Jézus Krisztus valóságos emberi létit, ez a faktum igen hathatósan gyaníttatja velünk, hogy így taníttatott ezen tudomány az apostoloktól. A keresztény vallás hívői semmi kísértetbe nem jöhettek az aránt, hogy küssebítsék Mesterek tiszteletét, ellenben tudjuk, hogy igen nagy indító okaik voltak nékiek hogy nagyobbítsák az ő rangját és méltóságát az igazság határán túl is, eleitől fogva azon gúnynak és nevetségnek lévén kitéttetve a Krisztus tanítványai, hogy egy keresztre feszíttetett nazarénusnak a követői. Sokkal hihetőbb tehát, hogy a tudományos, és filozófáló keresztények hozták bé a Krisztus személyét tárgyazó új és mesterkélt gondolatokat, mint a tanulatlan, csekély környüllálások között élő emberek, kik közönségesen megelégednek magok a világos faktumokkal, s megátalkodva ragaszkodnak a régi véleményhez.

Hogy nehezteléssel vetik meg amaz oly gyakran s oly igazságtalanul szemekre hányt vádot, hogy ők megcsonkítják s meghamisítják a szent textusokat, hogy alkalmatosakká tegyék azokat feltételeik és princípiumaikra nézve. Ők azt megerősítik, hogy az ők egyetlen egy céljok az igaz eredeti textusoknak az apokrifális interpolatioktól megkülönböztetések, és akárhol észreveszik, hogy valamely hely nem igaz eredetü, vagy kétséges értelmü, ellenvetések okait tisztán megteszik az ellen, s határozások erősségit a megmutatott világosságon készek építeni. 
Hogy ők megesmérik, hogy a Szentírás valamit ír, a tanult úgy a tudatlanok oktatásokra vagyon írva, s hiszik, hogy ami esszenciále abban, akár megtanulásra, akár megcselekedésre elegendendőnek megértheti abból a leggyengébb lelki tehetségü is.

Hogy mindazonáltal, a régi írásokkal bizonyos mértékben szükségképpen össze van foglalva s homályosság, és a frazeológia, mely közönséges és tökéletesen érthető egy időkorban és tartományban, felette kétséges értelmü, s személyes lehet, egy másban, melyben a gondolkodás képességei, és a gondolatok kifejezésének módjai, igen különbözők lehetnek.

Hogy sokak azon helyek közül, melyeken a Krisztus praexistentiájáról, az ő felségesebb természetéről, s amint nevezik, önkéntleg megtestesüléséről való tudomány vagyon építve, nem azon vélekedéssel tétettek, hogy azonnal megértsék éppen azon személyek, melyekhez azok immediate voltak intézve. Maga, Urunk, közönségesen tartott beszélgetéseinek különböző környüllálásaiban misztikus szólásmódokat adoptált, hogy elrejtse igaz vélekedését a zsidóktól, kik világi, és hozzá méltatlan indító okból követték őtet, hogy megelégedetlenekké tegye őket a maga tudományával s eltávoztassa magától őket, s nagyon hihető, hogy a Jézus szólásformáit ezen környülállásokban az ő tanítványai az ő valóságos emberlétét tökéletesen megegyező értelemben értették. Pál apostol hasonlólag leveleiben igen gyakran él figuratív frazeológiákkal, hogy rejtve tartson egy tudományt, ti. a zsidók megvettetését és a pogányok hivattatását, melyet nem mindenkor tartott okosságnak egyenes, és világos terminusokkal említtetni, nehogy, minden ok nélkült megbántást okozzon. Ezen megjegyzés igazságát igen jól tudják mindazok, akik jártasok ezen apostol írásaiban.

Hogy azt tenni ellenvetésül, hogy valamely magyarázás nem természetes, és igen messzünnent ki keresett, csak annyi, mint más szókkal azt mondani, hogy az ellenvető előtt azon magyarázás szokatlan; mert a szólásformákról való vélekedés tökéletesen önkény szerént való lévén, az az értelem mely egynek közönségesnek, s tökéletesen természetesnek láttatik, lehet, hogy másnak fanyar és erőltetett.

Hogy az unitáriusok tagadják, hogy igazságosan vádoltatnának a Szentírás értelmének tekerése, s csavarása törekedésével, azon célból, hogy azokat ön szisztemájokra alkalmaztathassák. Sőt ellenben azt állítják, s világosan megmutatják, hogy a tiszta és szabad kritika réguláihoz szabván magokat, a Szentíróknak éppen az az értelmek, mely értelmet ők kimagyaráznak a homályos és disputált textusokból, és noha könnyen megengedik, hogy akár a Krisztus, akár az ő meghatalmazott, vagy általa utasíttatott apostolainak egy pozitív s világos kifejezések elégséges félrehárintásokra mindazon gyaníttásoknak, melyek ama faktumnak apriori meg nem bizonyíthatása miatt támadnak, hogy mindazonáltal ezen meg 
nem bizonyíthatás éppen az indító ok arra, hogy miért oly késedelmezők ők annak nyilvánossága megesmerésében amire a legvilágosabb és kétség alá hozhatatlan bizonyságok nem találtatnak, és miért vagynak annyira elszánva a legnagyobb kérlelhetetlenséggel vizsgálni meg mindazt, ami egy minden analógiával oly meg nem férhető, oly szokatlan, oly ellenkező, és becsére nézve oly kevés hasznú faktumnak megbizonyítására előhozatik; és szolemniter azt vallják, hogy a legszorgalmatosabb, és részrehajlás nélküli vizsgálódás után sem találhatnak egyetlen egy világos és tiszta kifejezést is, a Krisztus praexistentiájáról, és Istenségéről, sem valamely nyilvánosságot ezen különös tanításokról.

Hogy mindamellett is, amit a régi és mostani írók előhordottak ezen nehézség eloszlatására, még mindig megfoghatatlannak látszik az unitáriusok előtt az, hogy Máté, Márk és Lukács, kiknek céljok volt leírni mindazt, ami tárgyozza a Jézus históriáját és tudományát, melyre az ő tanítványai szükségképpen meg voltak tanítva, és akik közül az utolsó egy tudósítást írt az apostolok küldöttetések és tudományokról, minekutánna Mesterek mennybe ment, és a Szentlélek ajándéka elküldetett, mely által tökéletesen bétaníttattak küldöttetések tárgyaiba, elhagytak volna írásaikból oly materiak, és mestereknek oly nagy tiszteletére szolgáló faktumok, milyen az ő felségesebb természetek, és praexistens állapotja, ha arról valamit tudtak volna, azt sem lehet feltenni, hogy titokban akarták volna hagyni azon faktumot, amaz illetlen félénkségből és gyáva elővigyázatosságból, melyet az első ekleziasztikus írók tulajdonítanak nekiek.

Hogy a Jézus Krisztus Istensége, vagy praexistenciája uralkodó tudomány lett volna a keresztények nagyobb részénél az első és második századokban, azt az unitáriusok nem hagyják helybe; világosan meg van mutatva az ellenkező eset, mely még nem semmisítetett meg, s meg sem semisittethetik. Hanem, megengedik azt, hogy ezen tudományokat a keresztény vallás más több meghamisításaival együtt az első filozófus keresztények tanították, kik szégyenlették a csak keresztre feszíttetett vezért, $\mathrm{s}$ a kereszténység egyszerü tudományát, s hogy azok lassanként hozattak bé szokásba, s oly sokáig uralkodtak az eklézsiába, és hogy a keresztényeknek igen nagy része vallja azokat ma is. Ezen faktum mindazonáltal legkevesebbel sem erősebb bizonyítás ezen tanítások igazságának megmutatására, mint azon igazság megmutatására, hogy a Krisztus valósággal jelen van sákramentumokban, ami ma a keresztények nagy részének vallástétele; s azt remélik, hogy valamiképpen a keresztény vallás az igazság munkálódó erejénél fogva megtisztította volt önön magát a vastag pápális szupersztícióból, akként fogja kitisztíttani magát a még fennlévő hibákból, míg lassanként visszatér azon tisztaságra és egyszerüségre, mellyel legelsőbben megjelent a világon; s azt tartják, hogy a keresztény igazság, 
és emberi boldogság minden barátjainak múlhatatlan kötelessége erejéhez képest, s minden, az okossággal helyben hagyható, igazságos és tisztességes eszközök által segédkezeket nyújtani azon omladékok elhárintgatására, melyek oly sokáig akadályoztatták az evangélium terjedését.

Az unitáriusok nem mondják átalkodva, hogy az Isten nem jelenthetett volna, ha nekie úgy tetszedjék, más tudományokat az emberi nemzetnek ki a Jézus Krisztus által, az egy jövendő életről való legfontosabb következésű tudományon kívül; hanem azt vallják, hogy minekutánna a legnagyobb figyelemmel olvasták az Újtestamentumot, úgy látszik, hogy ezen tudomány egyik nagy tárgya a keresztény revelációnak, mely ezen tekintetben a legillendőbb az Istenhez, és legnagyobb jóltevőségű az emberekre nézve.

Mert akármely könnyelmüleg tekintsék is némelyek ezen tudomány kijelentésit, s akármely tisztán következtethetőnek képzeljék is azt a természet jelenéseiből, tudjuk jól, hogy a Jézus Krisztus megjelenése előtt a pogány világ filozófiája egészen megvetette azt; hogy azon kevesek, kik a jövő élet várását tanították, a legkevésbé kielégítő nyilvánsággal védelmezték vélekedéseiket; hogy a köznép, a leggorombább és képtelenebb esméretekkel bírt arra nézve; hogy az a tudomány ritkán, vagy soha se alkalmaztatott valamely méltó erkölcsös célra; s hogy éppen magok a zsidók, igen zavart, és keskeny határok közé szorított vélekedéseket képviseltek volt ki a jövendő élet jutalmaztatásairól és büntetéseiről. Nem is lehetett ezen vélekedés jobb állapotban, meggondolván, hogy az embernek jövendő létele az ő halálból feltámadásától függ, és következésképpen akárminémű bizonyító okokat sugallottak volna (ezen tudomány megmutatására) az erkölcsi világ fenoménjei; akármiképpen támaszkodtak volna a pogány filozófusok azokra, nagymértékben akadályoztattak volna annak megmutatásában, egy a tapasztalással és analógiával annyira ellenkező faktummal, milyen a sírból való feltámadás - apriori meg nem bizonyíthatósága miatt. Ezen ellenvetés az, melynek elhárintására a keresztény vallás volt kinézve, és amelynek ez egyáltaljában oly tökéletesen eleibe került, hogy akárminémű kétségek és egyenetlenségek forgottak is fenn a keresztények között a hit más cikkelyeire nézve, a jövendő életről való tudomány soha nem hozatott kétség alá.

Az unitáriusok, kik úgy nézik a Jézus Krisztust, mint Józsefnek és Máriának fiát, nem gondolkodnak úgy ezen környülállásokról, hogy - legkisebb mértékben is kisebbítené az az ő prófétai karaktereket, valamint nem kisebbíti a Mózes, Illyés vagy Ézsaiás karakterét és küldetését, hogy ezen próféták a természet útján születtek. Nincs is a Krisztus valóságos emberlétéről levő tudomány egészen béfoglalva az ő csudálatos fogantatásáról fennforgó kérdésbe. 
Ők azt állítják, hogy valamint a Mózesét, úgy a Krisztus méltóságát sem kisebbíti az is, midőn mondatik vala, hogy az ő lelkesíttetése (inspiration) nem terjedt tulajdon tárgyainál tovább - és, hogy más esetekben ugyan azon vélekedésekkel kellett nekie bírni, ugyan azon tévelygéseknek alája vettettettve lenni, melyeknek az ő hazafiai, és azok kik között neveltetett. Továbbá, hogy a Jézus karakterének lassanként kelletett kimívelődni a méltóság és nagyság ezen magos lépcsőjére, mely elő van adva az ő históriájában, a virtusnak gyakorlása, munkálkodásainak erkölcsisége által, az sokkal hihetőbb önön magában, s megegyezőbb a Szentírás kifejezéseivel, nagyobb tiszteletére szolgál a Krisztusnak, s nagyobb hasznokra követőinek a példaadásban, mint az, ha ő természet szerént és szükségesképpen tökéletes, és vétkezhetetlen valóság lett volna, kire semminemú kísértetnek béfolyása nem lehetett volna, s következésképpen semmi tekintetben nem lévén hasonló követőihez, arra se lett volna képes, hogy például szolgáljon nekiek a virtusban.

$\mathrm{Az}$ apostolok és az Ó- és Újtestamentum íróinak mindenre kiterjedő lelkesíttetésekre nézve, az unitáriusok azt állítják, hogy az egy olyan privilegion, melyet azok magok soha magoknak nem tulajdonítottak; egy oly faktum, mely soha meg nem bizonyíttathatik, hogy ezen pontot erösíteni, annyi, mint kisebbíteni a szent könyvek hitelességét, s kigázolhatatlan nehézségekbe [inextricable difficulties], s kézzel fogható képtelenségekbe bonyolítani azoknak védelmezőit. Ami illeti azon megavult [trite], és semmi ellenvetést - hogyha nincs minden lelkesíttésből írva, lehetetlen lesz megkülönböztetni mi vagyon isteni, s mi csupa emberi hatalomnál fogva - elég arra azt felelni, hogy ezen nehézség nem nagyobb, mint azon számos könyvek közül, melyekről egyenlőleg az állíttatik, hogy azok isteni hatalomból írattak, megkülönböztetni, melyek irattak lelkesittéssnél fogva, melyek nem; amit mindazonáltal megcselekedni, a mindenre kiterjedő lelkesítés védelmezői magokat képeseknek vallják.

Továbbá azt állítani, hogy a világ megítélése hivatalát literális értelemben kell venni, mikor az, a Krisztusnak tulajdonittatik, és figuratív értelemben, mikor az apostolainak és tanítványainak, csupa önkény szerént különböztetés melyet nem oltalmazhatni okokkal, és mely azért tétetett, minden autoritás nélkült, hogy egy nehézségtől megmenekedjenek annak tévői.

Feleletül azon kiábálásra, mely néhány esztendők ólta a Jézus Krisztus valóságos emberi vóltát védelmezők ellen támadott, azon okból, hogy magukévá tették az unitárius tiszteletre méltó címet, nem csak a trinitáriusok, hanem az ariánusok nagy részének kirekesztésivel - legyen megjegyezve: hogy itt az egyenetlenség csak a nevezetről forog fenn, annakokáért nem méltó azon indulatoskodásra, mellyel néhány esztendők ólta folytattatott. 
Hogy ezen cím elsőbben a szociniánusoknak adatott, amikor még nem nézetett oly tiszteletre méltó fényben, mint ma, és hogy a szokás azt csaknem egészen azokra szorította, kik hiszik a Krisztus valóságos emberi lételit. Hogy meghatározták a mostani unitáriusok, hogy csak az olyan keresztényeket jegyezzék azzal, kik nem tulajdonítják teremtett valóságnak azon attributumokat, cselekedeteket, és isteni tiszteletet, melyet az okosság és reveláció egyedül az Istennek tulajdoníttanak. Az unitáriusok úgy nézik a teremtést és gondviselést, mint Isten munkáit, mely immediata az ő cselekedete által vitetet végben valamely módon, vagy eszköz gyanánt szolgáló oknak közbenjövetele nélkült: ezt tanítja mind az okosság, mind az isteni kijelentés, azt hiszik ők.

Annak okáért, ezen principiumokkal megegyezőleg ők nem alkalmaztathatják az unitárius címet azon keresztényekre kik a Jézus Krisztusnak tulajdonítják ezen munkákot.

$\mathrm{Az}$ ők ariánus atyafiainak nem kell megütközni az unitárius cím ezen megszorításán, mert éppen ehhez hasonló okból tagadják meg azt a középrendủ ariánusok a felsőbbrendű ariánusoktól, kik isteni tisztelettel tisztelik a Krisztust, kik mindazonáltal erősítik az Isten valóságos egységét: s a felsőrendű Ariánusok viszont megtagadják azt a trinitáriusoktól, kik buzgón védelmezik az Istenség egységét, noha három személyekre különböztetve. [Lábjegyzetben: That Arians were not always so ambitious of passing muster with the Unitarians as they seem to be at present, will appear from the following extract of a letter, now in my possession, from a learned Arian, William Whiston, to another learned Arian, James Peirce, dated Cambridge, July 16, 1708: "Your letter a little suprised me, to find myself suposed to be a Socinian or Unitarian. I never was, nor am now, under the least temptation of such doctrines. I hope you will do me the favour to be one of the examiners of my papers. Till which time you will do kindly to stop so false a report."]

\section{A Socinianum Schema. The Socinian Scheme, Belsham 309-312.}

A szociniánusok azt állították, hogy a Jézus emberi valóság volt, legalább nem volt létele csudálatos fogantatása előtt, de úgy látszik hitték azt, hogy az ő teste más emberekénél felségesebb szubsztanciából volt teremtve, hogy képes lenne azon dicsőséges állapot fenntartására, melyre feltámadása után emeltetett.

Azt állították, hogy minekutána megkereszteltetésekor Messiásnak jelentetett ki, visszavonta magát a pusztába, néhány különös egybenjövetelre bocsáttatott a legfőbb valósággal ott, s alkalmatosság adódván mennybe vitetett fel, hogy bétaníttassék küldettetésének természetébe és céljába, és 
mindazokba, melyeket néki cselekedni és szenvednie kelletett hivatalának véghez vitelében. És ezen hipotézisből magyarázzák mindazon textusokat, melyekben emlékezet tétetett az ő mennybemeneteléről, és onnan jöveteléről.

Minekutánna végben vitte hivatalát, mindeneknek szemek láttokra keresztre feszíttetett. A szociniánusok tagadják, hogy a Krisztus halála valamely mértékben elégtétel lett volna a bünért, de helyben hagyák ha a mondatik róla, hogy ő engesztelés volt a bünért, annyiban amennyiben halálával mindenekre kiterjedő hatalmat nyert, mely meghatalmazta és alkalmassá tette őtet osztán arra, hogy benne hívő tanítványait megmentse a bünnek büntetésétől. Az isteni igazságnak elégtétettetéséről való minden ideát [every idea of compensation to divine justice they reject] megvetnek, mint amely meg nem fér az Isten tökéletességével s ellenkezik a Szentírás legtisztább kifejezéseivel.

A szociniánusok hitték, hogy a Jézus Krisztus feltámadása s mennybemenetele után mindenekre kiterjedő s határtalan hatalommal ruháztatott fel, hogy az egész emberi nem, az igazak és a gonoszok, az élők és a holtak igazgatása alá legyen vettetve, és hogy ő minden rendű és rangú angyalok felett való uralkodásra, akár jók, akár gonoszok légyenek azok, magasztaltatott, sőt az egész teremtett mindenség felett való uralkodásra.

Ezen felmagasztaltatása következésében, és az Atya rendeléséből ő a vallásos tisztelet és imádás tulajdon tárgyává lett, éppen olyan nemü tiszteletnek, milyen magához az Istenhez intéztetik, s ezen okból, s azon méltóság és hatalom tekintetéből melyre ő magasztaltatott mondatott Istennek a szentíróktól.

Ezen nevezetü keresztények Lengyelországban virágzottak a tizenhatodik században. Nevezeteket vették Laelius Socinustól egy olaszországi siennai nemestôl, s ennek unokaöccsétől Faustus Socinusztól, kik ügyes s buzgó pártfogói voltak a Socinian tudománynak, s akik más hasonló buzgó s megvilágosodott értelműekkel együtt szerencsés kimenetellel terjesztették ezen tudományt Lengyel és Erdélyországban.

Nagy vélekedésbéli egyenetlenség volt a Sociniánusok között a Krisztus imádására nézve. Faustus Socinus nagy szorgalmatossággal védelmezte azt, s senkit nem tartott kereszténynek ki megtagadta a Krisztustól az isteni tiszteletet, akármicsoda vallástételt tett légyen is a benne való hitról. Dávid Ferenc, egy igen nevezetes erdélyi prédikátor azt tanította, hogy a Jézus az isteni valóság célja ellen - ki azt akarta, hogy az, az ő királyok légyen -, adatott halálra a zsidóktól; és hogy feltámadása s mennybemenetele után egy oly állapotba helyeztetett, ahol teljességgel semmit sem tud mindazon dolgokról melyek történnek a világban, s következésképpen ő nem lehet a vallásbéli tisztelet valóságos tárgya. Socinus elküldetett, hogy 
meggyőzze Dávid Ferencet az ő tévelygéséről; de nem lévén képes feltétele teljesítésére, s Dávid Ferenc tovább is megmaradván azon tanításában mind publice mind privatim, hogy a Jézus Krisztust imádni pontban annyit tész, mint Szűz Máriát és más szenteket imádni - ezen tiszteletre méltó férfiú tömlöcbe vettetett az erdélyi fejedelem rendeléséből, hol azután nemsokára megholt. Egy szomorú tanúbizonysága annak, hogy az üldözés nincs valamely felekezetre szorítva. Maga Socinus noha nagy és jószívű férfiú volt, mégsem egészen tiszta a Dávid Ferenc szenvedtetésében részesülés gyanújától.

Mind megegyeztek a socinianusok azon vélekedésben, hogy a Szentlélek Istennek a csudatevő tehetségekben és hatalmában kimutatkozott ereje volt, mely közöltetett az apostolokkal és első keresztény hívekkel, s nem egy vagy teremtett, vagy isteni magalételéről meggyőződött értelmes valóság. [It was the uniform opinion of the Socinians, that the Holy Spirit was the energy of God exerted in the miraculous gifts and powers communicated to the apostles and primitive believers, and not a conscious intelligent agent, either created or divine.]

Ezen tudomány ellen, mely különösön a szociniánusoké a következő ellenvetések vagynak: hogy a Jézus személyes mennybemenetele önön magában lehetetlen, és az egészen azon gyermeki feltételen vagyon építve, hogy az ég a mindenségnek egy különös disztriktusa (vidéke), hol az Isten resideál és teszi nyilvánvalóvá különös és tapasztalhatóképpen az ő dicsőségét. Hogyha ezen lokális mennybemenetel és onnan lejövetel literale faktum, semmi kétség nem lehet az aránt, hogy Jánoson kívül más evangélisták is megemlítették volna azt, valamiképpen elébeszéllették az ő megkísírtését (temptation) és megdicsőittetését (transfiguration). Hogy egy ilyen lokalis mennybemenetelnek semmi haszna nem lehetett amidőn az isteni valóság éppen olyan könnyen és tisztán közölhette volna az ő akarattya ismeretét Jézussal, mindamellett is, hogy ez a földön volt, mintha éppen a mindenség legtávolabbi regióiba vitettetett volna ő avégre, hogy a Jézusra alkalmaztatott ezen frázisok „ffelment, leszállott az égből” a Szent János különös kitételei, s minden nagy nehézség nélkül meg lehet azokat magyarázni misztikus és figurációs értelmeket véve, valamint azon más merész és metaforika kitételeket is, melyek oly gyakorta fordulnak elé az evangélista írásaiban.

Továbbá, hogy egy emberi valóságnak az egész teremtett mindenség igazgatására emeltetése a mennyei hierarchia minden képzelt rendjei felibe tett magasztaltatása, és a vallásos isteni tisztelet valóságos tárgyává tétettetése, azért, hogy sem mivel nem cselekedett többet, mint amennyit egy más emberi valóság is hasonló hatalommal felruháztatva képes lett volna megcselekedni, egy olyan eset, mely önön természetében csupa le- 
hetetlen, környülállásaiban a legfelsőbb grádusba hihetetlen, minden tapasztalással, analógiával ellenkezik, és noha nem foglal magában oly nagy ellenkezést mint az Athanasius tanítása, mindazonáltal csaknem annyira hihetetlen. Ezen ellenvetések oly szembetűnők és fontosok, hogy a szociniánusok tanítását mindenek megvetik, legalább ezen országban.

\section{Farkas Sándor úr 1832-i évi jegyzéseiből kivonatok. Bölöni Farkas Sándor levele az unitárius konzisztóriumhoz. MsU 1232/H}

Epistolis ex Anglia nobis haec ad nexta erant:

1831 már 217 eklézsiájok volt az unitáriusoknak csupán Angliában mint egy 52000 hallgatókkal. Skóciában ez előtt 15 esztendőkkel formálódott az első unitária eklézsia Glasgowban, azóta az ország több részeiben is terjedést nyertek. Edinburgban is mintegy 150 hallgatókkal eklézsia formálódott. Irlandiában már régebben is némely helyeken gyülekezetek voltak az 1829. és 1830. esztendőkben pedig az oda való presbiteriánusok közt folyt vallásbéli vitatások következéséül a presbiteriánusokból egyszerre 40 unitária eklézsia formálódott, főbb gyűléseiket Dublinban és Belfastban tartják. Londonban most a következendő unitárium templomok vagynak.

1. York Street St James pap azon templomban Tagart úr. 2. Essex Street Strand papja Magde úr. 3. Carter Lane papja Porter úr. 4. Wood Street a papjára nem emlékezem. 5. Worship Street papja Marden úr, ez a templom közös a baptistákkal. 6. A Jewen Street papja Davidson úr. 7. Artillery lane. 8. South Place. Finsbury Arens, papja Fox úr. 9. Stamford Street Blackfriars papja Rees úr. 10. St Thomas Street Southwark. 11. Hackney papja Aspland úr.

Genevában a reformátusok közt folyt szinte oly vallásbéli vetélkedések miatt mint az irlandiai három esztendő óta nevezetes terjedést nyert az unitária vallás. 1831 július 6-án egy új unitárius periodikus írás is indult meg Genevában franciául.

Gibraltárból 1830-ban azon kedvező tudósítást vette a londoni Assotiatio, hogy az oda való anglusok és számkivetett spanyolokból az unitária vallásnak egy egyesülete formálódott.

Párizsban 1831. július 12-én az ott mulató anglus és amerikai unitáriusok Choiseul utcában (Rue Choiseul nro. 12.) unitárius istentiszteletet kezdettek folytatni.

Kelet-Indiában 1831-ben már két unitária eklézsia volt, mindeniknek indus papja és oskolája. Az egyik eklézsia Madrasba Purservankumban van Papja Roberts William nevü tudós indus ki tamil nyelven már több írásokat adott ki az unitária vallás terjesztésére. A más unitária eklézsia Secunderabadban van, papja Chiniah Abraham, ki templomot és oskolát a 
maga költségén épített. Calcuttában a londoni Associatio most ügyekezik templomot építtetni.

Az amerikai szabad státusokban az unitária vallást legelőször 1794ben anglus tudós Priestley esmértette meg s azolta nevezetesen az északi státusokban bámulásra méltó terjedést nyert. Bostonban mely város tudós férfiai s eszmebéli míveltségre nézve szuperioritással bír a több amerikai városok felett, most (1831 szeptember) már 12 igen szép és népes unitárium templom van. A bostoni gyülés az 1831-ki protokolluma szerént a szabad státusokban e szerént vagynak az unitária eklézsiák:

Massachusettsi Statusban 141 eklézsia 118 pap; Maini Statusban 12 eklézsia 8 pap; New-Hampshire 11 eklézsia 10 pap; Vermont 3 eklézsia 1 pap; Rhode Island 2 eklézsia 2 pap; Connecticut 2 eklézsia 2 pap; New York 5 eklézsia 3 pap; Pensylvania 5 eklézsia 2 pap; Washington 1 eklézsia 1 pap. Maryland 1 eklézsia 1 pap; Déli Carolina 1 eklézsia 1 pap; Georgia 1 eklézsia 1 pap; Kentucky 1 eklézsia 1 pap; Ohio 1 eklézsia 1 pap. Mindösze az Egyesült Státusokban 193 unitária eklézsia. Újak formálódtak közelebbről: Cincinati, Louisville, Missouri és Missisippiben a hallgatók számát most 96000 teszik. Az anglus birtokokban Kanadában közelebbről néhány eklézsia formálódott. A bostoni Társaság minden státusokban misszionáriusokat bocsát, különösen az indusok közé. A bostoni templomba indus és new-yorkiban szerecsen unitárius atyafiakat is láttam megjelenni. Az amerikai unitária theológiai oskola Cambridgeban vagyon közel Bostonhoz, most 47 theológus ifjakat találtam benne. Bostonban öt periodikus írás jelenik meg az unitária vallás terjesztésére, Angliában hasonlatosan öt, és Genovaban egy. Azonkívül több társaságok vagynak a jobb vallásos és erkölcsi könyvek ingyen terjesztésére a szegények közt. A kongresszusban a két legnevezetesebb orátór Ewerette és Webster urak mindketten unitárius atyafiak, nagyon óhajtanák ha az erdélyiek esztendőnként tartani szokott gyűléseik protokollumok bár nevezetesebb részét közlenék.

\section{John Kenrick John Pagetnak, York, 1857. március 26. Lelőhely: EUEGyLt Angliai levelezés 1827-1925/1857.}

Édes Sir!

Én az Ön nagyon fontos és érdekes közleményét, azonnal, hogy kezemhez vevém, elküldém tisztelendő Tagart Edwardhoz, az Unitaria Assotiatio külügyi titoknához, Hampsteadba, Londonban; s éppen ma reggel vevék tőle értesítést a tegnap tartott választmányi gyưlés eredményéről. Elhatározták, hogy gyorsan és erélyesen szükség ez ügyben munkálkodniok. Megszavaztak 100 font sterlinget saját beruházott fundusokból az erdélyi unitáriusok segélyezésére, s azt is meghatározták, hogy az Ön le- 
velének másolatai küldetnének el az Associatio minden lelkészeihez és vidéki pénztárnokaihoz, egy körlevél mellett, mely felhívja ez ügyben nézve a közfigyelmet $s$ eszközölne kongregacionális vagy egyéb gyüjtéseket annak érdekében. Tagart úr írni fog Önnek és körülményesebben értesíteni a szükségekre nézve; de én egyetlen egy napot sem hagyék elmúlni, mihelyest értesülhettem az Assotiatio választmányában történt határozatok felől. Bizton hiszem, hogy a választmány felhívása szíves visszhangra fog találni. Mi unitáriusok jelenleg jóformán meg vagyunk oszolva véleményinkre nézve, némelyek a német hittani új iskola felé hajlanak; mások meg a Priestley iskolájához ragaszkodnak; de úgy hiszem, hogy az erdélyiek iránti rokonszenvre nézve összhangzás leend az régi és új iskolában egyaránt. Különböző vélemények lehetnek köztünk politikai tekintetben is a Magyarország és Austria közti viszonyokat illetőleg; azonban azt mindnyájan érezzük, hogy a nevelési ügyet érdeklő erőszakos rendszabályok kisérletének erélyesen ellenállhatni oly eszközök által, mint az ön levelében kijelöltek. S szerencsére ezen eszközök $\mathrm{s}$ módok a jelen esetben lényegileg békés természetűek. Tagart úr írni fog Önnek bizonyos kezelési kérdések iránt, például a bégyülendő pénzalap miképp leendő kezelését stb. illetőleg, amiket Ön kétségkívül kielégítőleg meg fog fejthetni. Az általa föltett egyik kérdésre nem épen lehet oly határozott feleletet adni, arra tudniillik, hogy minő biztosítás (security) van arra nézve, hogy az ausztriai kormány nem fogja önkényúleg változtatni s nevelni a maga kívánatait ahhoz képest amint azokat kielégítik. Ha Ön e pontot illetőleg képes lesz némi megnyugvást nyújtani nékünk, örömmel vesszük; de én részemről nem tartanám azt elegendő oknak a segély megvonására a jelen esetben, hogy nem lehetünk egészen bizonyosak a felől, mit fog tenni az ausztriai kormány. Tudjuk, hogy mi lesz a következése a segély megvonásának, és az elégséges okul szolgál nekünk annak megadására. Én részemről, bízom a kormányban egy ilyentén ügyben. Önök csakugyan legkevésbé se hagyjanak fel a magok kebelében buzgó működésökkel a netán Angliából s Amerikából várható segély tekintetéből. Mi azon hittel s meggyőződéssel kívánunk tenni, hogy azon összeget miről Ön levelében írt nekünk, erdélyi hitrokonaink össze fogják gyüjteni, - s nagyon valószínűleg azon összegek összegyűjtése szolgálnak föltétlenül a mi adakozásunknak (contribution). Az Association hihetőleg a maga felszólításához fogja csatolni az erdélyi unitáriusok historiájának és jelen állásának egy kis vázlatát, s evégre a Beard tudor munkáját fogja használni.

Meglepve hallám a napokban a Brit Múzeum tagja Sir Madden azon állítását, hogy ama táblák, melyek hír szerint egy magyarországi aranybányában találtattak s Massmanntól egy tudományos magyarázattal ellátva kiadattak, hamisak volnának úgy emlékszem, Öntől hallottam miszerint 
azon táblák egykor az Unitáriusok Kollégiumának könyvtárában léteztek volna, de elsikasztattak onnan. Vagyok önnek leghívebbje, John Kenrick.

Gondolataim közelebbről az Ön adoptált honára szállottak bizonyos emlékkő fölfedezése következtében, mely a Traianus uralkodási korából való, s 20 lábnyi mélyen feküdt a mostani York bensejében, éppen ahol a római Eburacum kapusikátora állott. Wellbeloved úr és én mindketten papírra tevők rajzát az emlékkőnek, a Yorkshirei Philosophiai Társulat számára. Eszembe ötlék a Traján csatamezői Daciában. A kérdéses emlék csakugyan a Decebalus fölötti diadal utáni korból való stb.

\section{John Paget levele a BFUA elnökségének. 1858. március 28. Inquirer, April 17, 1858, 244}

My Dear Sir, - I got your letter a few days ago and I can assure you I was not less suprised than you that you not had received my letter for which I, too, had long been expecting an answer.

I wrote you then, as far as I can recollect, a full account of our present position, then more hopeful than at present. The Government had then appeared satisfied that so much money had been collected for the support of the schools, and the threat of enforcing the German language had apparently died away. It has been now again revived, and one Protestant College in Hungary has been reduced rather than submit. Should the threat be put in execution here, the same results will follow. This has come upon everybody by suprise, as the Emperor, in his last year's visit to Hungary, was understood to promise the contrary. In every other respect, the Unitarians are ready to adopt all the reforms the Government wishes, and the required number of professors has been already appointed, albeit the salaries are still wanting, or, at least, are only nominally what they ought to be. It is true, they escape some of the restrictions imposed on them by Government, as the prohibition to teach Hungarian history exact as an unimportant part of the Austrian history, but in such a way as to avoid scandal or offence. Further they can not, and will not go; and I am convinced that in the end passive opposition will force the Government to yield.

No time has been positively fixed for the deposition of the capital required for the salaries, and it would seem that extraordinary efforts made have rather astonished the Government, and I suspect made them regret having raised a spirit which it will cost some trouble to lay. On this point they are at present silent, but they may recur to it as they have to the German language, and insist on its fulfilment at any moment. The Calvinists are now making collections in the same way and with the same object, although their schools are much better endowed than ours. With respect 
to the transmission of the money, I spoke to Mr. Kriza, and he thought it would be better to make it payable in London to me, when I would draw for it in favour of the trustees of the College. Their money is managed by trustees, with a secretary, etc., who serve gratis, and it is generally lent on mortgage on property within a short distance of Klausenburg, if not within the town, that the security may be the more easily and generally known. At present it can only bring in 5 per cent., although all old mortgages are at 6 . As far as I can make out, the administration of the affairs of the College is not only blameless, but very active and good. As a security, they are obliged to submit their accounts, if I mistake not, to Government auditors every year.

I think I have now answered all your inquires, except as to what security we have that on compliance with these demands no others will be made. I can only say no one seems to fear it; in fact, these have been merely in pursuance of a system of placing all schools on the same footing, no matter how different the circumstances may be, under which they exist. And, besides, even under absolute government, public opinion is not without its influence, nor can it be braved with impunity.

I am very glad to hear that our American brethren will not leave us in the lurch. Their sympathy, thus expressed, dobles the value of their money.

Yours very truly, John Paget, Klausenburg, March 28, 1858.

\section{John Paget Milesnek az AUA titkárának, 1857. július 20. Quarterly Journal of the American Unitarian Association, vol. V., Boston, 1858, 234-241.}

Klausenburg, July 20, 1857.

To Rev. Dr. Miles, Secretary of the American Unitarian Association

My Dear Sir: - I have been requested by the consistory of the Unitarian Church in Transylvania to forward to you the enclosed letter, and at the same time to address you myself in furtherance of the request which that letter contains. It is perhaps necessary, before proceeding further, to say that, although born and bred an Englishman, I have been for the last twenty year married and settled in Transylvania, and am therefore necessarily well acquainted with the affairs of the Transylvanian Unitarians. It is in consequence of these circumstances that I have been chosen as the medium of communication between them and their brethren in England and America. They are at the present moment passing through a crisis of greatest importance, and one in which your assistance may aid in protecting their independence and securing their future prosperity. 
Since the revolution of 1848, the Austrian government, in pursuance of a system of centralization now first introduced into Hungary and Transylvania, has taken the superintendence of all schools and colleges into its own hands. As the Protestants of all creeds have hitherto supported their schools entirely from their own resources, derived either from foundations or voluntary contributions, they have insisted on their right to retain the disposition of those funds, and consequently the nomination of the Professors who are paid from them. The government has recognized this right, but still insists on the adoption in all these schools of the Austrian system of education, and on the support of an equal number of Professors, and on an equal scale of payment, with the schools in Austria.

This change calls both for a great increase in the numbers of teachers, and a considerable augmentation of their salary. Should not the necessary amount of revenue be assured, either on capital or other good security, either some of the schools must be given up that one may remain, or they must be reduced to the rank of private schools, and thus lose the right of granting degrees or certificates essential to the practice of the learned professions, as well as the attainment of civil office.

The Unitarian schools at present existing in Transylvania are the College or Upper Gymnasium in Klausenburg, and two preparatory schools or Under Gymnasia in Thorda and Keresztúr. It is in the highest degree desirable that all these should be maintained, - the College in Klausenburg as the theological seminary and a place of education for those destined for the professions, etc., and the schools of Thorda and Keresztúr because chiefly frequented by the Szeklers, whom the Catholic bishop is unceasing in his endeavours to win over to the Catholic Church. It is among the Szeklers that Unitarianism has its firmest strong-holds. These hardy and simple mountaineers, throughout all the persecutions to which they have been exposed, have maintained their faith with a constancy worthy not only of admiration, but of sympathy and support. Nowhere has the vast importance of the present crisis been more thoroughly felt among the Szeklers; and to those who know the poverty of the country, the result of their efforts to meet it will appear almost incredible. A short statement of the former state of the finances of the Unitarian schools as they were before the present changes, will best enable you to judge of the true state of the case. This statement, I may remark, is reduced from a more detailed one furnished me by direction of the Consistory.

The funded property of the Transylvanian Unitarians has hitherto amounted to 54,988 F.C.M., - (The florin in Conventions Münze amounts, as near as possible, to half a dollar.) - which, at six per cent (the legal inter- 
est up to 1850, and still so for mortgages contracted before that period), amounts to 3,299 F.C.M.

From this sum the following payments had to be made: [itt a kiadások részletes kimutatása következik, a fényképről a számadatok lemaradtak. A hiányzó szavakat [] pótoltuk. Tekintettel arra, hogy sem az oxfordi, sem a manchesteri könyvtár nincs birtokában a teljes folyóirat gyüjteménynek, az amerikai unitárius periodikákat csak elektronikus formában tanulmányozhattuk. További, az Egyesült Államokban végzendő kutatások újabb eredményeket hozhatnak.]

The Bishop's salary

One Professor in Klausenburg, without of lodging,

Four Professors at 300 f. each, with lodging,

The two Rectors of Thorda and Keresztúr, at 250 f., each, with lodging,

Twenty masters, mostly upper students or theological candidates, waiting for Churches, at 40 F.C.M. each,

Cashier,

Exacter, Secretaries, etc.,

Expenses of Consistory,

The expenses of repairs in the College, as well as of apparatus, fuel, etc. are not included, because they were provided from a small tax paid by the students for their College rooms. There was thus every year a deficit of 1,500 F.C.M. which was provided for by annual collections; but these formed a very uncertain and variable resource, and not such as would be accepted by the Austrian government as good security. Even therefore with the [...] mer number of Professors and their meagre salaries, some subscription would have been necessary, although nothing required foreign assistance. But according to the present system the annual expense will amount to 13,400 , or nearly three times which formerly was. The Upper Gymnasium requires twelve Professors and the Under six each, - the salary of Director being 800 F.C.M. and that of Ordinary Professor 600 F.C.M.

To meet this exigency, the Upper Consistory, at a meeting at Klausenburg, in August, 1856, determined to make an earnest [plea] on the Unitarians throughout every part of the country to subscribe liberally for the support of their schools. The invitation was [met] with zeal and alacrity which nothing but a stern conviction [of] impending danger could have produced. From individuals a [sum] of 54,000 F.C.M. has already been collected; and from the cl[ergy] and parishes bonds for the yearly payment of 3,900 F.C.M., w[hich] is equal to a capital of 78,000 F.C.M. To this may be a[dded] 10,000 F.C.M., which will be paid this year, from the Augustinovics fund, so that the whole account will stand thus: 
From old fund at six per cent,

From 10,000 Augustinovics, five per cent

From 54,000 at five per cent, new capital

From parishes and clergy

10,399

From this may be deducted 1,399 for the loss of one per cent on the old fund, as the mortgages are paid, and for some losses on the payment of the parish subscriptions, so that the available sum may be stated as a clear revenue of 9,000 F.C.M., leaving a deficit of 4,400 F.C.M. yearly.

It is to aid them in supplying this deficit that they now call on their brethren of England and America for assistance. They do not come to you because unwilling to put their own shoulders to the wheel, or they would find no advocate in me. They have exerted themselves nobly, but the country, always poor, has not yet recovered from the devastation of the Revolution, and it suffers under the Austrian government for an amount of taxation greater than that of any country in Europe, in proportion to its resources.

On the very verge of European civilization, almost of Christianity itself, alone on the continent of Europe in the profession of the simple and pure doctrines of Unitarianism, they have none to look to for sympathy and support, save their co-religionists of the Anglo-Saxon race in England and America. The emergency is great, their means to meet it are exhausted, their plea for aid is well founded, and I feel sure it will meet with a worthy response from those to whom they always fondly look as friends and brethren.

Believe me, my dear Sir, yours very truly, John Paget.

\section{John Paget levele a BFUA tanácsához, 1859. BFUA - 35th Annual Report, May 30, 1860, 17-18.}

Immediately on my return I laid the matter before the Consistory, who appointed a Comission, consisting of Messrs. Kriza, Buzogány and Ferencz, to inquire into the possibility of carrying out our plan for maintaining one or two Transylvanian Unitarian students in England. These gentlemen called on me an hour or two after the receipt of your letter with the following communication.

The Consistory has determined to send this year one student to London, if they can hope to recieve about $50 £$ in aid of his support for each of the two years they wish him to stay. They can insure him from here, partly from his own resources and partly from a small fund at the disposal of the Consistory, $500 \mathrm{fl}$. ö. w. per annum for this period. The Consistory is not 
able to do more without the consent of the Upper Consistory, as its means are very limited, and under present circumstances it is scarcely probable that the Upper Consistory will meet till winter. The Committee hope, however, either through the aid of this body or by means of private subscriptions, that they will be able before another year to provide a similar sum of $500 \mathrm{fl}$. ö. w. for a second student. Should the Unitarians in England be able to provide a sum to the same amount - that is, $50 £$ per annum for each student - think the plan can be carried out with success.

With respect to the expenses of the journey I believe it can be accomplished, if performed in the quickest and cheapest way, and without seeing anything on the road, for $£ 10$; but it can hardly be expected or even desired that a young man should pass through or near the greatest capitals, the greatest storehouses of knowledge, in Europe, without at least spending a few days in each, and therefore I think if we reckon the journey at $£ 15$ it will be bearer the real cost. The remaining $£ 85$ would, I think - but of that you can judge better than I - suffice to maintain him for the year in London. The student who proposes to come in September next is working hard at English, and another in hopes of the second nomination has already begun. I should very much wish that two students could be mantained at the same time, so that one new should arrive every year and take the place of the one who had finished his studies and was returning home. In this manner the new comer would find one of his own countrymen ready to receive him, who would be able to inform him of the nature of the studies to be pursued as well as of the ways of the country, and who would thus be a great assistance as well as comfort to one who would be otherwise a perfect stranger.

With respect to the nature of the studies these young men should pursue, it is of course understood that theology should form its chief object. But besides this, I have proposed to Mr. Kriza and the Committee, and they highly approve of the plan, that each student should be recommended to choose some one branch of science - geology, chemistry, zoology, mechanics, or whatever else his taste may dictate - to which he should also devote his attention, in addition to the usual divinity course. I shall tell you best what are the chief educational wants, in answer to your question on that matter, by stating why I especially recommend this science as the most desirable object of study. In Transylvania it is almost impossible as yet to follow any of these branches of science with success, not only from the want of adequate teachers, but because they cannot be taught or acquired from books alone, without the aid of collections of specimens or expensive apparatus, and these are not be found in the country. It would be only wasting your time to enlarge on the utility of such studies in general; but I 
may say that they are more particularly needed here because we have no one capable of teaching them, and there will soon be a great demand for that kind of knowledge. A Museum has just been established and richly endowed by the spontaneous offerings of all classes of the people; and, in conjunction with it, a Philosophical Society, of which one of the leading objects is the delivery of popular courses of lectures. A taste for natural science will thus be created, and a demand for men capable of teaching it. I think it would be highly creditable to the Unitarian body to be able to supply this demand from its own ranks; and nothing would tend to raise it more in public estimation than the possession of a set of young men fitted not only for teaching in their own Colleges, but of guiding also the general public in its quest after new paths of knowledge.

Other educational wants of Transylvania I do not insist on - as a good library, a well-supplied laboratory and apparatus-room; for at present I am afraid a great outlay on such matters would scarcely repay itself in usefulness. The want must be strongly felt before its fulfilment can be really efficient. I look to the creation of a superior class of Professors, should our plan be carried out, to make these wants felt, and thus eventually to lead to their fulfilment.

Nor do I allude, among other educational wants, to the very imperfect accomodation afforded to the students in the college buildings, which so much struck both Mr. Tagart and Mr. Steinthal on visiting the Colleges of Klausenburg and Thorda.

It is no doubt a flagrant breach of every sanatory law, and is irreconcilable with proper cleanliness and almost decency; yet the poverty of the greater part of the students is such, and the difficulty of providing fitting accomodation so great in a country where it is impossible to sleep in a room unheated, that at least in the present state of society I am afraid it is irremediable. Again I can only say, those who see and learn better things in England will, I hope, introduce improvements in such matters also. You see I am inclined, at least for the present, to concentrate all our efforts in carrying out this one great object, the education of a succession of young men in England as the means of forming a higher grade of Professors, and thus raising the whole intellectual and moral tone of the Unitarian body. I think it is better not to scatter our forces, but to unite all our efforts to carry this strong point, and then the great battle for further progress may be fought any great danger of defeat.

With best hopes for our success, and many thanks for your kind interest in our wants, believe me, yours truly,

John Paget. 


\section{Uzoni Fosztó Gábor Benczédi Gergelyhez küldött levelei. London. Lelőhely: EUEGyLt, Benczédi Gergely, Az unitárius kollégium története, kézirat 708.}

\section{London, október 16. 1866}

Kedves Barátom!

Nagyon megkéstem ugyan levelemmel, de amint tudhatod, igazán rajtam kívül eső okok miatt; három hétig napjára 7-8 penceből éltem; a budget ily frugalis állapotában nem csoda tehát, ha a külügyekre gondolni sem mertem, a belügyeket is alig s alig óvhatám meg álluk felkopásától. A Nóé galambja tegnapelőtt jött meg, s a magával hozott 10 fontban száraz helyre mutatott, hová a minden oldalról csapongó billek és görbe nézések elnyeléssel fenyegetö özönéből azonnal ki is menekültem s kissé rendbeszedtem magamat.

Örömmel olvastam a püspök úr közelebbi leveléből, hogy egészségben hazaérkezve állomásodat elfoglaltad. Nem kísértem meg szerencsekívánataimat e papírra bízni; bennsők azok és szívből jövők, s nem csak e levél keletének pillanatai adtak lételt nekik, hiú áldozatképpen a formaságok oltárára, melyen az egész világ áldoz. Jókívánságaim irányodban olyan régiek mint ismeretségünk. Kedv, erő és egészség, legyen az ces triplex melleden - s a kezdet nehézségeit könnyüszerrel legyőzöd, ha már végképp le nem győzted még.

Az én kezdetem méltó nyitánya volt a leendő kalamitásoknak. Egyetlen shillinggel maradtam cabmanom kifizetése után, s ha a Lápossy szívessége ki nem húz a sárból bizony csúfot fogtam volna. Nem képzeled mekkora hátrányom volt pénztelenségemben a 37 alatt; sehová sem mehettem el ahol 1-2 shillingbe kerültek volna a megnézendők. A szünidő lefolyt s most kezdődik a haddelhadd.

Hunter urat s Aspland urat mindjárt az első napokban felkeresém, mondhatom nem várt szívességgel és jóindulattal fogadtak. Mindkettőnél voltam ebéden s elláttak olvasmánnyal - ami nem kis vigasza volt szobámba töltött napjaimnak, mert egy átkozott német csizma az első napok alatt úgy tönkre tevé lábamat, hogy teljes egy hétig nem mozdulhattam sehová. Ebédre el el bicegtem a legközelebbi dining room-ba ahol szem nem látta s fül nem hallotta husokon éltem - dog's meat - by turns cat's meat.

A Manchester New College megnyitása tegnap délután volt. Marshall úrral mentem fel s végighallgattam Tayler úr beszédét, melyből édes keveset értettem. Martineau úrnak is ott mutattak be. Látogatást még nem tettem náluk, mert csak pár nappal ezelőtt érkezett meg Tayler úrral egyetemben a sea-side-ról. 
Ma voltam először előadáson. Tayler úr nagyon szíves derék ember, $\mathrm{s}$ a német teológiával nagyon ismeretes lévén sok mindenről beszélgettünk e tárgyban. Tanácsára e félév alatt kevés órát hallgatok; két tárgyat tőle, $\mathrm{s}$ egyet Martineau úrtól, kinek előadása nagyon megijesztett a tegnapelőtt a templomban - mintha csak szanszkrit nyelven beszélt volna.

A Manchester New College nagyon leverő benyomást tett reám, mert félek tőle, hogy az angol teológia a német mellett nagyon hátraállónak mutatja magát. Milyen különbség! Göttingába meg Jénában 20-30 teológiai tanár tantárgyait tetszésed szerint választhatod - $\mathrm{s}$ mármost itt négy tanár keze alá esni s hallgatni egy kis zsidó archeológiát s bevezetést Máté evangéliumába - amit már kétszer olvastam az eredetibe. A filozófiai megkülönböztetéseket pláné nem értem. Mental philosophy meg intellectual philosophy stb. itt külön tárgyak - mert, hogy ez mi lehet, azt nem érthetem. Valóban hidd el, úgy érzem magam mint akit a töltött káposzta és a tokaji bor mellől spenóthoz meg fehér serhez ültetnek. Ma délután egészen nekikeseredtem, ha elgondoltam, mily szépen megértém a német tanárokat - mily hatalmas füzeteket írtam elóadásaikból, mennyire tüzültem és lelkesültem sokszor egy Fisher Kuno s Ritter mély tudománya, szabad észjárása, s gyönyörü nyelvezete mellett, s most itt kínlódjam érdektelen tárgyak mellett, s azokat is félig értve. Baj! Nagy baj ez rám nézve! Majd csak széjjelnézek valami hasznos foglalatosság után.

A nyelvet rontom, ahogy lehet, vajudom s kínlódom amíg sokszor a legegyszerúbb gondolatnak is kifejezést adhatok - s Isten tudja akkor is milyen hibákkal! A kifejezések utáni kapkodásom már sokszor lenevettem titokban magamat. Vasvillával kell egy-egy szót az emlékezet sútja mellől előrántani, s ami a legszebb, gondolatomat sohasem tudom úgy kifejezni, mint ahogy akartam; oly különös szócserék s modifikációk állnak be a szóhajhászás procesusa a [...] a mondatba néha, hogy a tiszta, befejezett kör gyanánt elménkből kiugráló gondolat csúnya szabálytalan több[...]gé válik, mely lépten nyomon bukdácsol legördülésében.

Aztán a stílusbeli nehézkesség ami az utóbbi pár sorban hyppopotámusi ügyetlenséggel [...]nik ki, nem különben a nyelvrontás ferde szülöttje. Vérévé válik az embernek a vontatott, szakadozott, csak úgy találomra odahányt beszéd, amit napestig gyakorol s [...]sába is átmegyen.

A tanárok igen sokat kérdezősködnek utánad, s örömmel hallják, hogy állomásodat elfoglaltad. Tayler úr különös vágyát fejezte ki rólad minél előbb részletes tudósítást nyerni.

Lápossy honfitársunk minden jót kíván s a kovákat ereklyeképpen őrzi a chimney-piecen.

Isten áldjon.

Őszinte barátod, Uzoni Gábor 
London, november 7. 1866.

Kedves Barátom!

Mély keserüséggel hallám a Lápossyhoz küldött levélből, hogy szenvedsz - mégpedig testileg s lelkileg; egyik rosszabb a másiknál s mindkettőnek a légváltoztatás az oka; tudom, hogy ama bizonyos levegő melyben jelenleg vagy s mely vidor kedélyhangulatodat oly hirtelen elsetétíté reám is ugyan azt a hatást teendi... keserú méreg a viszontlátás örömpoharában.

Erős lelkedre bízom ügyed javulását. Lassanként belejövünk a kerékvágásba - habár eleinte az összetörés veszedelmének vannak is kitéve nyikorgó kerékküllőink. „Life is a jest!” Én nagyon hajlandó vagyok a könnyelmüség páncélába burkolózni s kinevetem a bajt ahelyett, hogy búslakodjam rajta. De minthogy tudom hannumanni gyógymódom, mely egy parányi adag félválról vevés porral, vagy fölsemvevés pilulával akar nagy bajokat gyógyítani, nevetségesnek tünhetik fel előtted, egyébre térek.

Az University Calendart a napokban postára tettem, kaptad-e? Egy ennél sokkal fontosabb kérdést kell, hogy tegyek könyveidet illetőleg. Azt írod Lápossynak, hogy küldjem könyveidet, de én nem tudom kedves barátom kinél hagytad, Lápossy sem tudja, amint mondja, s így okvetlen töled kell felvilágosítást kérnünk; mert azt csak te tudhatod, hol hagytad. A szótár nálam van s többi könyveiddel együtt útnak indítom.

Nekem annyi a dolgom, hogy azt sem tudom mihez fogjak. Zsidó, görög, latin, biblia s angol philosophia között hánykodik árva lelkem, mint a mennyből kitaszított Lucifer a végtelen káosz zúgó s harcoló elemei között. Ha látnád mint verejtékezem a Martineau etikáján azonnal imádságra fakadnál elkárhozott lelkem kínjainak rövidítéséért. Shakesperae s Milton bizonyosan megfordul sírjába, ha hallja mint kínozom zengzetes nyelvöket a zsoltárokat meg Lucretius fordításában. Tayler úrnál két tantárgyat hallgatok s ezen kívül az Újtestamentum fordítására van egy órám vele. Minden tantárgyat a senior-classal járok, csak éppen a görögből vagyok degradálva saját kívánságomra - Xenophónt fordítom Arisztotelész helyett, egyfelől azért, mert az utóbbinak elvont okoskodásait képtelen volnék kellő ánglussággal kikínozni - másfelől meg azért, mivel a boldog emlékezetü érettségi vizsgálat óta semminemű görög klasszikussal nem volt bajom s most éppen a grammatika gyökér revíziójának vége felé járván reconvalescens görögségem első lépéséül Xenophónt a legcélszerübbnek találám.

Egyébképpen kezdek beleszokni új életembe. A Romano vivito more - elvénél fogva minden nap buzgón térdelgetek a college-ba s iparkodom minél szentebb kaptára húzni hébe-hóba nevetésre stimolt arcizmaimat. 
Jövő héten könyörögnöm is kell - ám lássák! Ha istentelen angol kiejtésemmel profanálni akarják az imádság szentségét ők hordozzák bűnét, nem én.

Az este Martineau-nál valék estélyen. Sokat kérdezősködtek utánad az angyal házi missek s én feleltem, ahogy lehetett. Különben szörnyü furcsa valaminek találám az egész partyt. Azok a frakkok meg fehér nyakravalók meg a jelenlevők nagyobb részének állára erőltetett konversaciója..., mintha csak valami hajdu állana ott emelt mogyorófa jószággal s félelmes szemjártatással nógatva mindenkit a beszéd robotjára. Különben nem mondom, hogy nem csak nekem tellett mindez így - a vaknak minden fekete, $\mathrm{s}$ a feszes embernek minden feszes, márpedig of course, hogy jómagam meglehetős feszesen találtam magamat a méhkasba, habár nagy lelki vigaszomra szolgál jövőre nézve, hogy mégis jobban találtam magamat, mint hogy egyelőre reméllettem.

Ama bizonyos újságba közlött levél haraggal és bosszúsággal töltött el. Azóta hallgatok is úgy, mint a süket etcéterer. Hogy is ne mérgelődnék az ember! Egy hirtelenségbe odavetett alak és tartalom nélküli irkafirkát mir nix dir nix közzétenni.

Egy dologra kérlek. Nem tudom professori sarui (praedecessorum more) érintik-e most a kollégium egyes lakószobáinak piszok nem lelte küszöbét - de hiszem, hogy in some way or another, találkozol egyszersmásszor régibb ismerôseiddel az oskolából! Ugyan kérlek mond meg Sándor Gergelynek, Kádár Lázárnak (ha ugyan még nem vitték ki árkosi papnak), Török Áronnak, Gálfalvi Sámuelnek s egyéb jó embereimnek, hogy a legszivélyesebben tisztelem őket, s egy percig sem feledkeztem meg rólok, habár levelezés nem folyt közöttünk, aminek részint én, részint ők az okai, mert egy még Göttingából írott levelem válaszolatlanul maradván, azt következtetém belőle, hogy [kegy]vesztetté lettem.

Nem különben szeget vert a fejembe saját hallgatásod is, s már-már rettegés kezde eltölteni, hogy valamivel, habár öntudatlan is megbántottalak, vagy otthon hallottál felőlem valami rettenetes dolgot. Csak előbb közöld velem is hadd állok eleibe. De tréfán kívül szeretném saját leveledből olvasni, miféle auspiciumok alatt kezdéd meg működésedet.

Isten megáldjon s őrizze meg egészségedet!

Öszinte barátod,

Uzoni Gábor

Váradival, ha találkozol néha, közöld baráti üdvözletemet.

Párizsból címzett levelemet kaptad-e? 
London 1 day of July 1867.

11 Harrington Street H. Road

My gentle friend, it is a lovely night

The stars are sparkling from the azure hight,

And beautifully smiles the silver moon,

Whilst I prepare my lyre for some tune.

Alas! My lyre! Poor forgotten thing;

With two years dust is covered every string.

It was to me a useless instrument,

Since all my thoughts towards holy things I bent.

But now, somehow, I'm labouring in vain.

My black-eyed Muse gives me a gentle glow,

And there, you see, the halting numbers flow.

My honest friend, I see you shake your head,

Most gravely asking: ",is the fellow mad?"

Does he not know the value of his time,

To tell his nonsense there in wretched rhyme?

Perchance he did take too much of that ale

Whose melancholy epithet is "pale"?

Bless me! Poor lad! He surely must be crazy,

Or else, by jove, from too much drinking hazy!

First, let me tell you, friend, that you are wrong,

For all my senses are yet sound and strong.

My mind is cloudless as the summer sky;

No fumes of ale are pressing on mine eye!

This is the thing, you know, I have full leisure

To frame my words in some poetic measure.

My last examen I had yesterday,

And time must now my own command obey.

But, by the by, I'll take a new cigar,

And then, I'll ask you, good Sir, how you are?

I hope you got rid of your learned toil,

Of teaching, fretting and that damned turmoil,

Wich haunts the stairs of your gloomy Hall,

From moon's first ray, till nights black shades do fall?

I hope, you don't despise our sparkling wine

Nor shun fair Aphrodite's holy shrine?

A silly question, - mearly serve to waste

My paper - for I knowe, you have some taste;

You know, what is good, and what is beautiful, 
And to be sure, you take from both your pull.

'Tis sweet to revel, once a week, or so...

For, dulce est desipere in loco!

As for myself, thank God, I'm pretty well,

Since all my burden from my shoulder fell.

I mean that beastly thing - examination;

Purgatory of our young generation.

Laugh, my good friend! Our famous college rung

The other days, with accents of my tongue;

I made an English sermon, and proclaimed

To English ears things solemn, height and saint!

And, I should think, they pleased the English ear;

For I was interrupted by ",hear, hear!"

Sir Francis Lápossy honoured friend

(Whom Mercury, the merchant's God defend)

Is very busy and enjoys good health,

Growing in wisdom, knowledge and in wealth.

I tell you friend! The time is near at hand,

Peabody junior he'll be to this land.

And now, dear Gregory, I must curb the speed

Of my own fancy's wild Pegasian steed.

I pray the gods, that each swift, gliding hour

Should bring thee some sweet, fragrant heavenly flower.

Joy and contentment be thy guides through life

May Venus bless thee with a handsome wife!

Remember me to all my college friends,

Who never condescend to trouble their hands

In writing me some pleasant, jolly news

From that long-left, but loved place of my youth!

To Mr. Gibbon, too, remember me

Whose useful theaching I, once, shared with thee.

Tell him, that England still commands the waves;

Britons still feed on oysters and on crabs.

And all things go on smoothly, as of yore

When he did leave the blessed English shore.

Good night, my friend - 'T is half past one, I see 


\section{A Budapesti Angol Társalgó Kör alapszabályai. Lelőhely: MOL törzsszám K 150, év 1882. Kútfő III. tétel 4 szám 7323, csomó 975.}

\section{a. Az Angol Társalgó Kör Alapszabályai, 1876. január 8.}

\section{A kör célja}

§. 1. A kör célja tagjainak tökéletesedése az angol nyelvben, felolvasások, vitatkozások és társalgási eszmecsere útján

II. A kör müködése

§. 2. Ezen cél elérésére, a kör a kijelölendő nap este saját gyülekező helyiségében összejövetelt tart.

$\S$. 3. Minden felolvasás vagy értekezés nyolc nappal előbb jelentendő be az elnökségnél. Mind a felolvasások, mind pedig a vitatkozások és a társalgás kizárólag angol nyelven történik.

§. 4. A kör évenként évfordulóját megüli.

§. 5. A kör választmánya gondoskodik a kör számára megrendelendő hírlapokról, folyóiratokról és angol müvekről.

III. A kör tagjai; ezek fölvétele, jogai, kötelességei és kilépése

§. 6. A kör áll

a. rendes

b. tiszteletbeli tagokból

§. 7. Aki az angol nyelvet bírja és a rendes tagok közé akar felvétetni, köteles magát előbb az elnökségnél két rendes tag által bemutattatni. Neve a kör helyiségében a tagok tudomására három héten át kifüggesztetvén ezen idő elteltével megválasztása fölött a bizottmány szavazata dönt. Ez idő alatt a felveendő a kör helyiségeit mint vendég látogathatja.

§. 8. Minden újonnan belépő tag felvétele jegyének átvétele alkalmával egy forint belépti díjat fizet.

§. 9. Minden rendes tag szavazójeggyel bír és részt vehet a gyüléseken előforduló vitákban és ott nézeteit magyarázhatja; továbbá az egyleti ünnepélyekre vendégeket meghívhat.

§. 10. A rendes tagok 6 forint évenként, azaz 50 krajcár hónaponként, tagdíjat fizetnek, mely összeg a hó első felében fizetendő.

§. 11. A fizetés kötelességét elmulasztókat a pénztárnok meginti, ha ezen intés háromszor sikertelenül történik, az illető tag a körből kizáratik.

§. 12. A körből való önkéntes kilépés azonban nem menti fel az illető tagot a hátrálékos fizetésének kötelessége alól.

§. 13. Egy tag kizárását csupán a választmány eszközölheti, mégpedig általános szótöbbséggel. Ha e tekintetben egyetértés nem jön létre a vitás ügy a közgyülés elé terjesztendő. 
§. 14. Egy már a körből kizárt tag újra befogadása a választmány határozatától függ.

IV. A kör ügyeinek vezetése

§. 15. A kör ügyeit a választmány vezeti, melynek tagjai:

1. az elnök

2. az alelnök

3. a titkár

4. a pénztárnok

5. a könyvtárnok

6. hat választmányi tag és három póttag

$\S$. 16. A választmány minden év november hó első napjaiban választatik, mégpedig a rendes tagok által.

$\S$. 17. Az elnök vezeti a kör belső ügyeit, és azt kifelé képviseli. Elnököl a választmányi és közgyüléseken. Az általa a rend fenntartása végett kiadott rendeletek minden tag részéről szigorúan megtartandók.

$\S$. 18. Az alelnök osztozik az elnökkel az elnöki teendőkben, és ennek akadályoztatása esetére azt helyettesíti.

§. 19. A titkár viszi a kör hivatalos levelezését, szerkeszti a választmányi valamint a közgyülések jegyzőkönyvét, a tagok neveiről jegyzéket készít, és a választmány újraválasztása előtt, köteles évi jelentést tenni a kör állapotáról és működéséről.

§. 20. A pénztárnok gondoskodik a tagsági és felvételi díjak beszerzéséről, és köteles jelentést készíteni a kör vagyoni állapotáról.

§. 21. A könyvtárnok gondoskodik a hírlapokról, folyóiratokról és müvekről, és ezekről jegyzéket vinni köteles.

$\S$. 22. A választmány az egyleti ünnepélyek műsorozatát rendezi és a körülményekhez képest, határoz a tagok kizárása vagy felvétele iránt, összehívja a közgyűlést, az egyleti ünnepélyekre meghívandó vendégek száma felett határoz és szavaz az újonnan belépők felett.

V. A közgyülés

§. 23. Az összes egyleti ügyekben a fő fórum a közgyülés. Ez dönt minden elébe terjesztett kérdés felett, és meghatározza a rendkívüli ünnepélyek megtartását.

§. 24. A közgyưlést a választmány hívja össze. Minden közgyưlés nyolc nappal előbb a napilapokban kihirdetendő.

$\S$. 25. A közgyưlés határozatképes, ha a rendes tagoknak több mint fele van jelen. Szavazásnál csak az abszolút szótöbbség dönt.

§. 26. Bármily a közgyűlés által hozott és az egylet célján belül fekvő intézkedésre vonatkozó határozat minden tagra nézve kötelező erővel bír. 20 rendes tag kívánatára közgyưlés hívandó egybe az elnök által. 
VI. Az alapszabályok változtatása

§. 27. Az alapszabályok változtatására legalább 3/4-nyi szótöbbség szükséges a közgyülésen.

VII. A kör fölosztása

§. 28. A kör feloszlik, ha rendes tagjainak száma nem több mint hat. A netalán maradt tiszta egyleti vagyonfölösleg a londoni és New-yorki magyar egyletek javára használandó.

Liptay Pál ideiglenes elnök

Ransbourgh Sigmond ideiglenes alelnök

\section{aa. Status of the English Conversation Club in Budapest}

Statutes of the "English Club" in Budapest

I. Object of the Club

$\S$. 1. The object of the Club is to attain improvement in speaking the English language by aid of lectures, debates and mutual conversation

II. Operations of the Club

$\S .2$. For this object a meeting will be held in the club-room of the members, one evening a week, hereafter to be fitted.

$\S$. 3. Notices of the lectures and debates must be given to the Presidency a week previously. The lectures debates and conversation to be entirely in the English language.

§. 4. The Club arranges yearly an anniversary of its foundation.

§. 5. The Committee has also to provide the Club with English newspapers and works of English literature.

III. Members of the Club; their admission, Privileges, Duties and Withdrawal

§. 6. The club will consist of:

a. ordinary and

b. Honorary members.

$\S$. 7. Whoever wishes to be received as ordinary member of the Club, must be introduced to the Presidency by two members and know the English language, his name will then be placed 3 weeks long on a list in the Clubs' room for the approval of ordinary members during which time the candidate has the right to visit the club room and than the committee will proceed to ballot.

$\S$. 8. Every new member on receiving his card of membership has to pay the sum of fl. 1 . as entry fee. 
§. 9. Every ordinary member of the club has the right to vote, advice, debate or explain his views upon any topic under discussion during a general meeting; members have the right to invite friends to the festivals of the Club.

$\S .10$. The ordinary members have to pay yearly the sum of 6 . $\mathrm{fl}$ or 50 $c($ ?) monthly which sum must be delivered within the first half of each month.

$\S .11$. Members who neglect to pay will receive a notice from the Cashier which if three times disregarded will entail his exclusion from the society.

§. 12. Any member who wishes to withdraw himself from the Club must give notice of his withdrawal to the Committee, which however does not absolve him from the arrear payments due to the Club.

$\S$. 13. The exclusion of a member depends upon the vote of the Committee, should they not agree the case must be brought before the general meeting.

$\S$. 14. The readmission of an excluded member depends upon the decision of the Committee.

IV. About the Conduct of the Club's affairs

$\S .15$. The affairs of the Club are conducted by the Committee consisting of:

1. President

2. Vice President

3. Secretary

4. Cashier

5. Librarian

6. Six ordinary member and three substitutes

$\S$. 16. The members of the Committee will be elected on the first days of November, and will be chosen out of the ordinary members.

$\S .17$. The President has to conduct the special affairs of the Society; represents it in public; guides the meeting of the committee and presides the meetings of the club. The measures which he has for the maintenance of order must be obeyed by every member.

$\S$. 18. The vice-President shares the duties with the President and represents him during his absence.

$\S .19$. The Secretary conducts the whole of the Club correspondence, and is registrar during meetings of the committee or general meetings; keeps a list of the members and has to give an annual report of the position and efficiency of the Club.

$\S$. 20. The Cashier has to attend to the accounts of the Club's funds of which he is to give a monthly report to the Committee. 
$\S .21$. The Librarian has charge of the books, magazines and papers, and is to keep a list of them.

$\S .22$. The Committee has to arrange the program of any Festivity that may take place, decides, according to circumstances in anything that may concern the exclusion or reception of members, call's together the general meeting, decides upon the number of guests to be invited to any festivity, and ballots for the admission of new members.

V. Of the General meetings

$\S .23$. The general meeting has the chief voice which is decisive in all the affairs of the Club, settles all matters in reference to festivities.

$\S$. 24. The general meeting is called together by the committee; all such meetings must be advertised a week previously in daily papers.

$\S .25$. The general meeting can come to any decision when more than the half of the members are present; no resolution can be accepted without the majority of votes.

$\S$. 26. Any decision of the general meeting which comes within the design of the society is binding upon every member. Twenty ordinary members are able to call together an extraordinary general meeting.

VI. Change of the rules

$\S$. 27. For change of rules, there must be a majority of at least $3 / 4$ of the members present at the meeting

VII. Breaking up the Society

$\S$. 28. The society ceases to exist if the number of ordinary members does not amount to more than $6 ; \ldots$. There be a surplus of the Club's funds this surplus is to be sent and used to the benefit of the Hungarian societies of London and New-York

Liptay Pál ideiglenes elnök

Ransbourgh Sigismund ideiglenes alelnök 


\section{b. Az Angol Társalgó Kör Alapszabályai Budapesten ${ }^{1}$}

I.§. A kör neve és célja

A kör neve: „Angol társalgó kör”. Székhelye: Budapest. A kör célja az angol nyelvnek múvelése, társalgás, vitatkozás, felolvasások, szónoklatok tartása és társadalmi érintkezés által, mely célból a kör hetenként egyszer gyülésezik

II.§. Tagok

$\mathrm{Ki}$ az angol nyelvet elegendően bírja, a körnek rendes tagja lehet.

A felveendő tagot két rendes tagnak kell előzőleg egy meetingen bemutatni, amelyen az mint vendég részt vehet. A tag felvétele iránt a választmány határoz.

Tagsági jegyének kiszolgáltatásakor minden új tag két forint felvételi díjat fizet. A tagsági dij évenként 10 forint, mely 2 forint 50 krajcáros részletekben negyedévenként fizetendő.

Kitűnő társadalmi állású, vagy tudós férfiak, úgy azok, kik a kör érdekeit különösen előmozdítják, tiszteletbeli tagokul választhatók.

Tiszteletbeli tagok három rendes tagnak 14 nappal előbb tett ajánlatára választatnak, kiknek száma a rendes tagok számának egy harmadát meg nem haladhatja.

III.§. A tagok jogai és kötelességei

A rendes tagok jogai:

a. Szavazati jog az egyletet érdeklő minden ügyekben. A szavazást ki-ki csak személyesen gyakorolhatja.

b. Vendégek és tagok bemutatásának, vagy rendes és tiszteletbeli tagok ajánlatbahozatalának joga

c. Bármikor indítványt tenni és aziránt szavazást kérni, ha indítványa még három tag által pártoltatik.

d. A kör könyvtárát használhatni.

e. A választmányra vonatkozó cselekvő és szenvedő választási jog.

f. A jog, a kör bármely meetingjén, kirándulásán stb. részt venni

${ }^{1}$ Az 1876. október 25-én keltezett alapszabályzatot 1877-ben Liptay Pál elnök aláíásával terjesztették fel az illetékeseknek. Érdemi változtatás csak a XI. §. kapcsolatosan történt, itt a belügyminisztérium vonatkozó határozatára hivatkozva a következőket írták: „,Az 1875. évi május hó 2-án 1508 száma alatt kelt belügyminiszteri rendelet IX. pontja: Minden egyleti alapszabályba felveendő, hogy az esetben, ha az alapszabályokban meghatározott célt és eljárást, illetőleg hatáskörét, meg nem tartja, a királyi kormány által; amennyiben további működésének folytatása az állam vagy az egyleti tagok vagyoni érdeke veszélyeztetnék haladéktalanul felfüggesztés után elrendelendő szabályos vizsgálat eredményéhez képest végleg feloszlattatik, vagy esetleg az alapszabály legpontosabb megtartására különbeni feloszlatás terhe alatt köteleztetik." A körpecséten, felül: English Conversation, középen Club, alatta Budapest. Alsó körirat: Angol Társalgó Kör. 
Minden tag köteles:

a. A kör érdekeit előmozdítani.

b. A fölvéti díjat és rendes járulékokat kellő időben lefizetni.

Tiszteletbeli tagok minden fizetmény alul felmentvék.

IV.§. A választmány

A választmány áll egy elnök, alelnök, titkár, pénztárnok és könyvtárnok, hat rendes és három póttagból.

A választmány az évi rendes közgyülésen választatik a rendes tagok sorából egy évre, mely idő után újraválasztható.

A választmány vezeti az egylet ügyeit köteles minden hónapban legalább egyszer ülést tartani.

Az elnök

A kör minden gyưléseiben ő elnököl. Képviseli az egyletet kifelé és minden ügyeiben, és felügyel a kör ügyeinek szabályszerü menetére. Szavazategyenlőség esetén, akár közgyưlésben, akár a rendes meetingekben vagy választmányi ülésekben döntő szavazattal bír.

Az alelnök

Az alelnök helyettesíti akadályoztatás esetén az elnököt, ki ismét szükség esetén egy választmányi tag által helyettesíthető.

A titkár

A titkár vezeti a jegyzőkönyveket, szerkeszti a leveleket, okiratokat, tudósításokat, s egyéb okmányokat, valamint közvetíti a körnek kifelé való összeköttetéseit.

A pénztárnok

szedi a fölvéti és tagsági díjakat, valamint felveszi és kezeli az egylet tőkéit. Köteles a választmány elé havonként pénztári kimutatást és az évi rendes közgyülés elé zárszámadást beterjeszteni. Az elnök írásbeli utalványozása nélkül öt forintot meghaladó kiadásokat tennie nem szabad.

A könyvtárnok

gondoskodik a könyvtárnak rendben tartásáról. Az újon megszerzett könyvekről pontos jegyzéket vinni köteles. A könyveket a tagoknak ő kölcsönzi ki.

A választmányi tagok

kötelesek a kör ügyeinek helyes vezetésében müködni.

V.§. A közgyülés

A rendes közgyülés minden év május havában tartatik meg.

Az elnök rendkívüli közgyülést hív össze, ha azt legalább húsz tag, vagy a választmány kívánja. 
Közgyülés egybehívása tudósítványok által legalább is tizennégy nappal előbb minden tagnak hírül adandó, ha a közgyűlés nem határozatképes, az újból hívandó egybe, mely tekintet nélkül a megjelent tagok számára mindenesetre határozatképes, és határozatai minden tagra kötelezők.

A közgyưlés a következő ügyekben határoz:

a. A mérleg és zárszámadás, úgy a könyvtári leltár megvizsgálásában három közfelkiáltással választott számvizsgáló illetőleg kiküldött tag által.

b. a fölvételi és rendes évi díj meghatározása iránt.

c. a választmánynak megválasztása.

d. az alapszabályok módosítása.

e. a kör feloszlása iránt.

Ki mint tag a közgyűlés napirendjére nem tüzött valamely tárgyat kíván tárgyalni, tartozik ez iránti indítványát legalább 8 nappal a közgyülés előtt az elnöknél vagy titkárnál írásban benyújtani.

VI.§. Határozatképesség és a szavazatokról

A gyưlések határozatképességére illetőleg érvényes határozathozatalra megkívántató szavazatok mennyiségére vonatkozólag:

a. A közgyülés valamennyi tárgyaira nézve, kivéve a d. és e. alattiakat, melyek iránt a szavazatok $2 / 3$ szükséges, határozathozatalra az összes tagok felének jelenléte szükséges, és a szavazatok általános többsége dönt.

b. tiszteletbeli tagok megválasztására az összes tagok felének jelenléte és a szavazatok kétharmada szükséges.

c. minden más ügy feletti határozat tekintetében az összes tagok egy harmadának jelenléte, s a szavazatok általános többsége szükséges.

A szavazás vagy felállás (kézfelemelés) vagy szavazati jegyek által történik.

A kört kötelező minden okirat vagy irománynak az elnök, pénztárnok és titkár által aláírva kell kiállítva lenni, miután az előbb választmányi határozattal jóváhagyatott.

VII.§. Vendégek

Vendégeket minden tag mutathat be kik azonban csak kétszer jelenhetnek meg, ha a választmány által különösen meg nem hívatnak.

VIII.§. Választott bíróság

Bármely a kör tagjai közt felmerült viszálykodások, választott bíróság által intézendők el. Mindegyik fél választ egy bírót, kik ismét egy harmadikat választanak maguknak elnökül, és ha ez elnök választásában megegyezni nem tudnak, sorshúzás fog dönteni. Ha az egyik fél egy hét lefolyása alatt nem választja meg bíráját, a másik fél választja meg mind 
a kettőt. A választott bíróság határozata végleges, fellebbezés vagy más jogorvoslatnak kizárásával.

IX.§. Tagok kizárása

Tagok, kik a pénztárnok kétszeri felszólítására sem fizetik le hátrálékos díjaikat, minden jogok és igényekről lemondottaknak tekintessenek.

Tagok, kik magaviseletük által a körben botrányt okoznak, vagy akik a kör tekintélyét, annak érdekeit és céljait becstelen cselekedetek és magaviselet által sértik, a választmány által kizárandók, mely ezen kizárás iránt legalább 2/3 szótöbbséggel határoz; a kizárt tagnak jogában áll ez ellen a legközelebbi közgyúléshez fellebbezni.

Választmányi tagnak kizárása csakis az összes rendes tagok két harmada szótöbbségének határozata által mondható ki.

X.§.

A választmány a közgyülésnek felelős minden cselekedetért, amelytől felmentését is veszi.

XI.§. A kör feloszlása

Az egylet feloszlik, ha a rendes tagok száma tíznél kevesebb. Feloszlás esetében az egylet vagyona a budapesti szegényalap javára fordítandó.

William Wellin secretary

Dr. Fülöp Károly alelnök

\section{c. A „Budapesti Angol Kör”. A körnek 1880. december 16-án tartott rendes közgyưlésén közlött és az e célból 1881. december 7-re egybehívott rendkívüli közgyưlés által tudomásul vett - új alapszabályai. ${ }^{2}$}

I. szakasz. A kör címe és székhelye dapest

§. 1. A kör címe ezentúl legyen „Budapesti Angol Kör”; székhelye Bu-

§. 2. A kör célja

a. Az angol nyelv és irodalom müvelése, társalgás valamint társadalmi, kereskedelmi, ipar, pénzügyi és nemzetgazdasági kérdések megvitatása útján, tekintettel az esetleges gyakorlati alkalmazásra, továbbá felolvasások és színielőadások útján, belépti díjjal vagy anélkül. E célra a körnek saját állandó helyisége és olvasó szobája legyen, ellátva előkelőbb angol és amerikai lapokkal és könyvtárral.

${ }^{2}$ „16244 szám. Látta a magyar királyi belügyminiszter oly megjegyzéssel, hogy külföldi egyének csakis a királyi belügyminisztérium előleges jóváhagyása mellett választhatók az egylet tiszteletbeli tagjaivá. Budapesten 1882. év március hó 22-én a miniszter helyett [olvashatatlan aláírás] államtitkár." 
b. Angliában és Amerikában a kereskedelem és ipar terén behozott és nálunk is alkalmasnak látszó újítások megismertetése és hazánkba való átültetése az angol és amerikai magyar körökkeli érintkezés útján.

c. Hazai pénzügyi, ipar és kereskedelmi hű tudósítások közlése az angol és amerikai néppel, valamint hason természetü angol és amerikai értesítések terjesztése angol és amerikai lapok vagy a kör által kiadandó angol vagy angol-magyar lap útján.

II. szakasz. Tagok, azok jogai és kötelezettségei

§. 3. A tagok:

a. rendesek

b. alapítók

c. pártolók és

d. tiszteletbeli tagok lehetnek

§. 4. Rendes tagok. Ki az angol nyelvet bírja, 18 éves korát elérte és kinek jelleme kifogás alá nem eshet, a körnek rendes tagja lehet. A felveendő rendes tag, kinek eleve legalább kétszer vendégként kell megjelennie a körben, két rendes tag által ajánlva, a főtitkárnak jelenti be belépési szándékát, kinek előterjesztésére a választmány első ülésében szótöbbséggel határoz a felvétel iránt. Visszautasító határozatát a választmány nem tartozik indokolni, azonban a visszautasított egyén 6 hó lefolyása után ismét folyamodhat felvétel iránt.

§. 5. Az így megválasztott egyén akkor lép a rendes tag jogaiba, ha a megválasztásáról szóló levelet a kör főtitkárától vette, 2 forint beíratási és 3 ft. első negyedévi díj(a)t a pénztárnoknak lefizetett és a kör alapszabályait vagy azok kivonatát saját kezüleg aláírta.

§. 6. Minden rendes tag tartozik fizetni: $2 \mathrm{ft}$. beíratási díj(a)t egyszer $\mathrm{s}$ mindenkorra és $12 \mathrm{ft}$. évi díj(a)t, 1/4 évi 3 forintos előleges részletekben. Bármily hónapban történt a tagság iránti folyamodás, a díj a teljes naptári évnegyed után fizetendő.

§. 7. Ha a tagsági díjak meghatározott időben nem fizettetnek, a budapesti belvárosi járásbíróság útján behajthatók. Ha a hátrálék több egy 6 havinál a tag jogai a befizetésig a választmány által 2/3 szótöbbséggel felfüggeszthetók addig míg a díjait lefizette.

§. 8. Tagok, kik a rendes közgyúlés napjáig díjaikat teljesen le nem fizették, sem cselekvő, sem szenvedő választási joggal azon közgyűlésen nem bírnak.

§. 9. Csak oly tagok választathatnak a kör tisztviselőivé vagy a bizottságokba, kik legalább 6 havon át tagjai a körnek. 
§. 10. Alapító tagok azok, kik legalább 50 forinttal egyszerre járulnak a kör tőkéjének gyarapításához. E tagok a rendes tagok jogait élvezik, kivévén a cselekvő és szenvedő választási jogot.

§. 11. Pártoló tagok azok, kik a kör érdekeit támogatandók 6 forint évi díjjal, mely egyszerre és előre fizetendő, támogatják a kört; jogaik azonosak az alapító tagokéval.

§. 12. Kitűnő állású egyének, tudósok vagy művészek, akik a kör érdekeit különösen előmozdították vagy előmozdíthatják, tiszteletbeli tagokul választhatók meg. Ily indítvány két tag által legalább két héttel a közgyűlés előtt nyújtandó be a választmányhoz, vagy az egyéniségek maga a választmány által jelölendők ki. Ha ezen egyéniségek a közgyưlés által egyhangúlag megválasztatnak, a kör tiszteletbeli tagjává váltak, és a rendes tagok minden jogait élvezhetik, de minden fizetmény alól felmentvék.

§. 13. A francia körreli kölcsönös megegyezés folytán, mely a két kör érdekeinek azonosságán nyugszik, a francia kör tagjai ezen kör tagjaivá felvétetnek a rendes díjak felének vagyis évi 6 forintnak alapszabály szerinti lefizetése mellett a beíratási díj mellózetével, addig míg ezen kör tagjai a francia kör részéről ugyanezen kiváltságos jogokban részesülnek.

§. 14. A tagság megszűnik:

a. Lemondás folytán; ha az illető tag az ebbéli értesítését írásban a naptári év utolsó évnegyedének megkezdése előtt a főtitkárhoz eljuttatta. Ezen esetben a tagság a reá következő első napján megszűnik; addig míg ily lemondás be nem adatott a tagság és az ebből folyó jogok és kötelezettségek épségben maradnak.

b. Kizárás folytán; a kizárást a választmány csak $2 / 3$ szótöbbséggel határozhatja el, hasonlóképpen az időleges felfüggesztést, mely azonban egy hónál tovább a felfüggesztés jellegét nem viselheti. A kizárt tagnak fellebbezési joga van a közgyüléshez.

$\S$ §. 15. A rendes tagok jogai és kötelezettségei:

a. A szavazati jog a kört érdeklő minden ügyekben, ezen jogot azonban ki-ki csak saját személyében gyakorolhatja.

b. Bármikor indítványt tenni és aziránt szavazást kérni, ha az indítvány még legalább 3 tag által pártoltatik.

c. A kör helyiségeit, újságait és könyvtárát használni.

d. A tisztviselőkre és a választmányra vonatkozó cselekvő és szenvedő jog.

e. A kör bármely gyűlésén, felolvasásában, kirándulásán és mulatságaiban részt venni.

Minden tag köteles:

a. A kör érdekeit előmozdítani 
b. A szabályszerinti díjakat pontosan fizetni és általában magát az alapszabályoknak alávetni, melyek nem ismerésével senki nem mentegetheti magát.

§. 16. A tagok jogában áll a kör helyiségeibe vendégeket bemutatni, magán gyưlésekben vagy a kör házi estélyeiben azonban vendégek részt nem vehetnek, hacsak külön a választmány által meg nem hívattak.

III. szakasz. A Kör szervezéséről

§. 17. A kör élén áll 1 elnök, 1 első és 1 második alelnök ki egyszersmind körnagy, 1 főtitkár, 1 altitkár, 1 pénztárnok, 1 könyvtárnok, 1 jogtanácsos és egy 14 tagú választmány éspedig 10 rendes és 4 póttaggal. E tisztviselők az évi rendes közgyưlésen a rendes tagok sorából választatnak meg 1 évre, de újra megválaszthatók.

§. 18. A választmány határozatképes ha beleértve a tisztviselőket (Elnök, első és másod alelnök, főtitkár és altitkár, pénztárnok, könyvtárnok és jogtanácsos) legalább 9 tagja van jelen. A szavazat többsége dönt. A választmányi gyưlés jegyzőkönyve az elnök és főtitkár által hitelesíttetik. A választmány rendesen legalább egyszer havonként gyülekezzék.

§. 19. Az elnök a kör minden gyülésein és minden nyilvános alkalommal elnököl, ő a kör védje, képviseli a kört kifelé és a hatóságok előtt és a kör minden ügyeinek szabályszerű menetére felügyel; szavazategyenlőség esetében döntő szavazattal bír.

§. 20. Az alelnökök az elnököt akadályoztatás esetén helyettesítik, az első és második alelnöki rangsorozás fenntartása mellett. A második alelnök körnagy is lévén, őrködik a házrend fölött, a kör helységeinek, bútorainak és egyéb ingó(sága)inak rendben tartására ügyel és időről időre saját szakmájába vágó javaslatait a választmány elé terjeszti.

§. 21. A főtitkár vezeti a jegyzőkönyveket, szerkeszti a tudósításokat és nyomtatványokat és követi a körnek kifelé való összeköttetéseit. nak.

§. 22. Az altitkár kisegítője és szükség esetén helyettesítője a főtitkár-

§. 23. A pénztárnok beszedi a körnek bármilyen forrásból fizetendő pénzeit és teljesíti a kiadásokat. A bevett pénzek általa biztos helyen tartandók, nagyobb összegek pedig a választmány által kijelölendő fővárosi takarékpénztárba helyezendők el. A pénztárnok köteles a választmány elé negyedévenként pénztári kimutatást és az évi rendes közgyűlés elé zárszámadást terjeszteni. Az elnök vagy az alelnökök egyikének írásbeli utalványozása nélkül öt forintot meghaladó kiadásokat tennie nem szabad.

§. 24. A könyvtárnok gondoskodik a könyvtár és a hírlapok rendben tartásáról. A kör tulajdonát képező könyvekről lajstromot vezet. A könyveket a tagoknak díjmentesen kikölcsönzi. 
§. 25. A kör minden jogügyeiben a jogtanácsos meghallgatandó, kinek tisztségéhez tartozik megvédeni és pártfogásába venni a kör jogait a hatóságok előtt, tiszteletdíj nélkül; azonban minden kiadásait és tényleges költségeit, melyek eljárásában a kör érdekében és a választmány megbízásából végzett ügyekben felmerültek - a kör megtéríti.

§. 26. A választmányi tagok a kör minden ügyeinek vezetésében közremüködnek. A kör tisztviselői hivatalból tagjai a választmánynak.

§. 27. A tisztviselők és választmányi tagok pontosan és lelkiismeretesen fogják a közbizalom folytán reájuk ruházott teendőket végezni. Azon tisztviselők vagy választmányi tagok - az elnök egyedüli kivételével - kik háromszor egymás után a választmányi ülésben meg nem jelentek és meg nem jelenésükről a főtitkárt előre írásbelileg nem értesítették, a választmány által titkos szavazás útján $2 / 3$ szótöbbséggel tisztségüktől megfoszthatók.

§. 28. A kör alapszabálybeli működésének kifejtésére 4 kilences szakbizottságot választ kebeléből, úgy mint:

a. egy irodalmi szakbizottságot

b. egy nemzetgazdasági szakbizottságot

c. egy nemzetközi szakbizottságot

d. egy hírlapi szakbizottságot

Minden bizottság megválasztja az elnökét és előadóját és a hozzá utasított szakkérdésekkel behatóan foglalkozván, előadója által a gyűlésnek beterjeszti jelentését.

§. 29. A rendes közgyưlés minden év első negyedében tartatik meg. Az elnök rendkívüli közgyülést hív össze ha azt legalább 20 tag, vagy ha az összes tagok száma nem haladja meg a húszat, ha tíz tag, vagy végre ha a választmány ezt kívánja. A közgyưlésre minden egyes tag, annak megtartása előtt legalább 14 nappal, külön értesítés által, a napirend közlése mellett meghívandó. Ha a közgyưlés nem határozatképes, egy hónapon belül új közgyűlés hívandó egybe, mely, tekintet nélkül a megjelent tagok számára, minden esetre határozatképes, azonban csak az első közgyưlés napirendjére kitűzve volt tárgyakra nézve.

§. 30. A közgyűlés a következő ügyekkel foglalkozik:

a. A zárszámadást, úgy a könyvtári és berendezési leltárt megvizsgálja három közfelkiáltással választott számvizsgáló által.

b. Megadja a felmentvényt úgy a tisztviselőknek, mint a választmánynak.

c. A felvételi és tagsági díjakat meghatározza.

d. Megválasztja a tisztviselőket a választmány és a tiszteletbeli tagokat és közfelkiáltással kiküld egy háromtagú szavazatszedő bizottságot. 
e. A választmány által kizárt tagok fellebbezését végleg eldönti.

f. A tagok rendes időben tett indítványait tárgyalja.

g. Az alapszabályok módosításával foglalkozik és végzi.

h. A kör feloszlása iránt határoz.

§. 31. Ha valamely tag a közgyülés napirendére nem tüzött tárgyat kíván tárgyaltatni, tartozik ez iránti indítványát legalább 8 nappal a közgyülés megtartása előtt a fötitkárnak írásban benyújtani. A közgyülés jegyzőkönyve a gyưlés elején közfelkiáltással választandó 3 tagú hitelesítő bizottság aláírása által hitelesítendő.

§. 32. A közgyülésnek az alapszabályok megváltoztatására, a kör feloszlására, és ez utóbbi esetben a kör vagyonának hová fordítására vonatkozó határozata foganatosítása előtt a magyar királyi belügyminiszter elé terjesztendő.

§. 33. A közgyưlés határozat képességéhez a szavazati joggal bíró tagok felének jelenléte szükséges. A határozatok egyszerű szótöbbséggel hozatnak, kivévén a 30. §. g. és h. alatti tárgyait, melyek eldöntésére 2/3 szótöbbség kívántatik meg.

IV. szakasz. Általánosak

$\S$. 34. A kör se szóval se írásban nem kötelezhető előleges választmányi határozat nélkül, mely esetben is a jogérvényes okmányok az elnök vagy - rang szerint - egy alelnök, a pénztárnok és egy választmányi tag által írandók alá.

§. 35. A kör tagjai közt felmerülő viszályok választott bíróság által intézendők el. Ily esetben a választott bíróság az 1868. 54. törvénycikk 9. címének 3. fejezete szerint alakítandó meg.

§. 36. Tagok, kik magaviseletük által a körben botrányt okoznak, vagy akik a körnek tekintélyét, annak érdekeit és céljait becstelen cselekvések vagy magaviseletük által sértik, a választmány által - titkos szavazás útján - 2/3 szótöbbséggel kizárandók.

§. 37. A választmány és tisztviselők egyedül a közgyülésnek felelősek, melyhez a felmentvényért fordulniok kell.

$\S$. 38. A kör feloszlik, ha a rendes tagok száma 10-nél kevesebbre apad. Feloszlás esetén az egylet vagyona a „Budapesti kereskedelmi betegápoló egylet" javára fordítandó.

§. 39. Az 1875. év május hó 2-án 1506 sz. alatt kelt belügyminiszteri rendelet IX. pontja szerint minden egyleti alapszabályba felveendő, hogy az esetben, ha az alapszabályokban meghatározott célt és eljárást, illetve hatáskörét meg nem tartja, a királyi kormány által, amennyiben további müködésének folytatása által az állam, vagy az egyleti tagok vagyoni érdeke veszélyeztetnék haladéktalanul felfüggesztetik és a felfüggesztés után elrendelendő szabályos vizsgálat eredményéhez képest végleg feloszlatta- 
tik, vagy esetleg az alapszabályok legpontosabb megtartására, különben feloszlás terhe alatt, köteleztetik.

Pulszky Ferenc, elnök

\section{A pozsonyi angol kör alapszabályai. [Fölterjesztették 1877. január 31-én.] Lelőhely: MOL uo.}

1.§. Az angol kör célja: az angol nyelv és irodalomban való művelődés; e célból a társalgás angol nyelven folyik, angol értekezések, szavalások és felolvasások tartatnak. Vallási, politikai és nemzetiségi tárgyak kizárvák.

2. §. A kör tagjai minden héten egyszer összejönnek és ily alkalommal a jövő összejövetel alkalmaival tartandó értekezések, szavalások és felolvasások tárgyát meghatározzák. Ha a kör anyagi eszközei engedik, az összejövetelek gyakrabban is történhetnek.

3. §. A kör tagjainak száma korlátlan. Tagja minden jó hírü s az angol nyelvben meglehetôs jártassággal bíró férfiú lehet.

4. §. A taggá fölvétel valamely tag ajánlatára és felelőssége mellett történhetik, kinek már ennél fogva is az ajánlottat személyesen ismernie kell. A fölvétel iránt a bizottmány határoz. Az elutasítás indoklása nem követelhető, de választott bírósághoz föllebbezhető.

5. §. Hölgyek a kör tiszteletbeli tagjai lehetnek, ha valamely rendes tag által bevezettetnek. A tiszteletbeli tagok minden járulék fizetésétől mentesek; a 4. §. határozmánya azonban itt is alkalmazandó.

6. §. A kör egyes tagjai havonta egy forintot fizetnek előre a kör pénztárnokának kezébe; amely tag havi járulékának lefizetését két hónapon át elmulasztja, kilépettnek tekintetik.

7. §. A kör igazgatását egy elnök, két alelnök, két titkár, egy pénztárnok és öt bizottmányi tag eszközli. A titkárok egyike a jegyzői és levéltárnoki, másika pedig a háznagyi és könyvtárnoki tisztet is viseli. A bizottmány őrködik a pénztárnoki és háznagyi teendők teljesítése fölött. Pénzbeli kötelezettségek jogerejüségéhez az elnök, pénztárnok és egy bizottmányi tag aláírása szükséges.

8. §. A tiszti kar és a bizottmány havonta kétszer gyül össze; határozathozatalra az elnökkel együtt öt tag jelenléte szükséges. Ily rendes bizottmányi gyưlések tárgyai: a kör jövedelmének hova fordítása, a pénztárnok számadásainak megvizsgálása, a háznagy jelentékenyebb teendői iránt való határozás.

9. §. A tiszti kar és bizottmány minden körév első havában tartandó közgyűlésen választatik s működéséért az egész körnek felelős. 
10. §. A tiszti kar és bizottmány szabja meg a belső ügykezelési szabályokat és az összejövetelek rendjét; a szabályok megtartása fölött az elnök, kit akadályoztatása esetén a jelenlevő alelnökök egyike helyettesít, őrködik; e célból a szabályok ellen cselekvő vagy beszélő tagot rendre utasíthatja, tőle a szót megvonhatja s netaláni engedetlenség, avagy a szabályok gyakori megsértése esetén az illető tagot a körből ki is zárhatja.

11. §. A kört érdeklő ügyekben a tagok közt fölmerülhető vitákat a tiszti kar és bizottság intézi el; a határozatában meg nem nyugvó félnek valamint a taggá fölvétel megtagadása esetén az elutasítottnak joga van egy választott bírósághoz föllebbezni; e bírósághoz a tisztikar és bizottság saját kebeléből három tagot küld ki, kikhez a föllebbező szintén három tagot választ; a hat választott bíró szótöbbséggel elnököt választván, ítélni fog a föllebbezett ügyben. Határozathozatalra elnök és két-két választott bírónak jelenléte szükséges. A határozat indoklásának valamint további föllebbezésnek nincs helye.

12. §. A kör-év szeptember 1-én veszi kezdetét és a következő év május havának 1-én végződik.

13. §. Szeptember és április havában rendes közgyülés tartatik. A szeptemberi közgyúlés tárgyai: 1. a megelőző év pénztári maradványának könyv- és irattárának átvétele, s a kör szünidői képviseletének jelentése; 2. a tiszti kar és bizottmány megválasztása; 3. az alapszabályok netalán szükségessé vált módosítása; 4 . a kört érdeklő jelentékenyebb indítványok tárgyalása.

Az áprilisi közgyülés: a. megvizsgálja a tiszti kar és bizottmány jelentését és megadja az illető fölmentvényeket; b. a körnek a szünidő alatti képviseletéről és c. a pénztár, könyv és irattár feletti gondviselés iránt intézkedik.

Ezen két rendes közgyülés helye, ideje és tárgya 14 nappal a közgyülés előtt a kör helyiségében való kifüggesztés, valamint a helybeli magyar és német lapokban való közlés által kihirdetendő.

14. §. Rendkívüli közgyưlés a tiszti kar és bizottság óhajtására, avagy legalább tíz rendes tag írásbeli kívánságára az elnök által összehívandó. A közhírré tételre nézve a megelőző §. irányadó.

15. §. Közgyúlésen a határozathozatalra a rendes tagok egy harmadának jelenléte szükséges. Ha e szám nem volna együtt 14-ed napra újabb közgyưlés hívandó egybe, ama kijelentéssel, hogy ez alkalommal a jelenlevő tagok, számukra való tekintet nélkül, minden esetre, határozni fognak.

16. §. Úgy a közgyülés, mint a választmány, nem különben a választott bíróság általános szótöbbséggel hozza határozatát; szavazategyenlőség esetén az elnök szava dönt; szavazatok elágazása esetén viszonylagos többséget nyert ajánlat lesz új szavazás tárgya. 
17. §. Ha valamely tag megbélyegző magaviseletet tanúsít, vagy aljas indokból eredő bűntényben marasztaltatik el, a bizottmány által a körből kizárandó lesz. A tiszti kar és bizottmány egyik föladatát képezvén a kör jó hírneve feletti őrködés, úgy saját tapasztalata, mint valamely rendes tagnak figyelmeztetése folytán, köteles az illető tag ellen a kizárási lépéseket megtenni, határozatát azonban csak az érdekelt tag maghallgatása után mondhatja ki. Indoklás és föllebbezés iránt a 11. §. szolgál szabályul.

18. §. A kör feloszlása kényszerüségből vagy a kör tagjainak határozata folytán történhetik. Kényszerüségből feloszlik a kör, ha tagjainak száma annyira megfogyatkozik, hogy a létezők az anyagi fenntartás eszközeit nem nyújthatják, és ekkor két tag írásbeli kérelmére, különben tíz tagnak hasonló alakú indítványára e célból összehívandó közgyűlés, melyen a rendes tagok két harmadának jelen kell lenni, fog a felosztás iránt határozni. Ha a közgyưlés határozatképes nem volna 8-ad napra új közgyülés hívandó össze, $\mathrm{s}$ az ezen megjelenők végérvényesen fognak a feloszlás iránt határozni.

19. §. A kör összes vagyona feloszlás esetén pénzzé teendő, a pozsonyi takarékpénztárba a „Pozsonyi Angol Kör" névre elhelyezendő, s a könyvecske a pozsonyi polgármesternek adandó, ki ezt 3 éven át megőrizteti. Ha a határidőn belül Pozsonyban angol kör alakul, kormánymegerősíttetése esetén a könyv annak tulajdonába bocsátandó; ellenkező esetben a takarékpénztári összeg a polgármester által két egyenlő részre osztva: felében a pozsonyi szegény-alap, más fele részében a pozsonyi „Müvészek és nyelvtanítók" egyletének tulajdonába bocsátandó.

20. §. Az angol kör inkább a bizalmas társalgás és kedélyes együttlét útján kívánván haladni, úgy összejövetelei mint gyűlései és tanácskozmányai valamint ügykezelése körében mellőzni kívánja a szigorú bureaukratizmust és rideg formalitásokat, és megszabandó ügyrendje és házi szabályaiban is ezen irányelvet fogja szem előtt tartani.

21. §. Azon esetben ha a kör a kitüzött cél és eljárás tekintetében hatáskörét túllépi, amennyiben további fennállása és működése által az állam, vagy az egylet tagjainak érdekeit veszélyeztetné, a királyi kormány által haladéktalanul felfüggesztetik $\mathrm{s}$ a megtartandó törvényszerü vizsgálat eredményéhez képest vagy feloszlattatik, avagy az alapszabályok szigorú megtartása különbeni feloszlatás terhe alatt köteleztetik.

Samarjay Mihály

mint elnök

Dr. Révfy László

ideiglenes titkár, mint jegyző 


\section{A kolozsvári francia klub alapszabályai 1879. Lelőhely: EUEGyLt, Kovács János hagyatéka 1/26.}

Monsieur,

Nous avons l'honneur de vous faire part qu 'il s'est formé sous le titre Club francais de Kolozsvár une Société dont le but exclusif est la culture de la language française.

Le Club tient ses Réunions tous les Mardis à partir de 7 heures du soir au Kis Komló (Kismesterutcza.)

En vous priant de prendre connaissance des status çi-joints, notre Club sera bien heureux de pouvoir vous compter parmi ses membres.

Kolozsvár le 1-er Février 1879.

Le Comité: H. Finály président, D. Szász viceprésident, G. Gamauf secrétaire, N. Széky trésorier, J. Duret professour de langues.

Pour tous les renseignements s'adresser à un des membres du Comité.

Club français de Kolozsvár

Sous ce titre s'est formée une Société, dont le but exclusif est la culture de la langue française.

Il y aura une Réunion hebdomadaire: une soirée tous les Mardis comprenant: exercice de conversation, lecture, discours, contes etc.

Le Club est représenté par un Comité permanent de cinq membres, élus en Réunion plenière au scrutin secret. Ce Comité comprend un Président, un Viceprésident, un Secrétaire, un Trésorier et le Professeur de langues.

L'admission au Club a lieu par scrutin secret entre au moins sept membres présents par majorité absolute. La non-admission ne sera pas motivée.

Chaque membre admis s'oblige à payer la somme annuelle de quatre florins, versée chez le Trésorier par moité le 1-er janiver et le 1-er juillet.

Le Président est chargé de veiller aux soins de chaque Réunion et de fixer, assisté du Secrétaire, l'ordre du jour. Il a charge et responabilité dans la répartition des frais ou dépenses nécessaires. Il a le droit au besoin en l'absence du Viceprésident de se faire represénter par un membre du Comité à son choix.

Le Viceprésident représente le Président absent, ses fonctions et ses droits sont identiquement les mêmes. (Voir §. VI.)

Le Secrétaire dresse selon le besoin procés-verbal de chanque Réunion ou séance du Comité. Il assiste le Président dans la fixation de l'ordre du jour.

Le Trésorier à la charge des recettes et dépenses, il est soumis au controle du Comité. 
Le Professeur de langues assiste à chaque Réunion. Sa charge est de veiller à ce que chaque membre puisse se perfectionner dans la langue française. Il est choisi par le Comité, qui le reconnaitra compétent en tout ce qui regarde sa tâche à remplir. Le Professeur aura droit à une remunération annuelle, dont le chiffre sera fixée par la Réunion plenière et payé ultérieurement.

Le Club se reconstitue tous les ans vers la fin du mois de décembre.

Le Club est disoud, si le nombre de ses membres n'atteint pas le chiffre dix. Il peut se dissoudre de lui-même par vote à la majorité de trois quarts de tous ses membres. 


\section{BIBLIOGRÁFIA}

\section{Források}

\section{Kéziratok}

Az Erdélyi Unitárius Egyház Gyüjtőlevéltárában (EUEGyLt)

- Kovács János hagyatéka

- Angliai levelezés (1827-1925)

- Amerikai levelezés (1876-1924)

- Emlék-könyv az erdélyi s angol Unitáriusok közt 1825 óta folyt levelezésekról s egyéb érintkezési viszonyokról, Az EKT számára összeszedte Buzogány Áron, Kolozsvártt, 1867.

- Emlék könyv a magyar, ángol és ámerikai Unitáriusok közt az 1870ik év óta folyt levelezésekröl s egyéb érintkezési viszonyokról, $2^{i k}$ kötet, Egybeszedte Benczédi Gergely tanár, a 29-ik laptól folytatta Kovács János tanár.

- Emlék-könyv a magyar, angol és amerikai Unitáriusok között az 1882-ik év óta folyt levelezések s egyéb érintkezési viszonyokról, III-ik kötet, Egybeszedte, Kovács János ig. tanár.

- Emlék-könyv a magyar, angol és amerikai Unitáriusok között az 1899-ik év óta folyt levelezések s egyéb érintkezési viszonyokról, IV-ik kötet.

- Benczédi Gergely naplója

Az Unitárius Kollégium Kézirattárában (Akadémiai Könyvtár). The Manuscripts of the Unitarian College of Cluj/Kolozsvar in the Library of the Academy in Cluj-Napoca, Compiled by Elemér LAKó, Szeged, 1997.

MsU 424, 506, 508, 671, 716, 766, 780/A-J, 788, 856, 857/A-B, 859, 929/A-B, 930/A-B, 931/A-C, 934, 1019/D, 1074, 1179/40-41, 1232/F, 1265, 1611-2, 2011, 2148/H. 
Az Erdélyi Múzeum Egyesület kézirattárában (Biblioteca Centrală Universitară, Cluj): Mss 881, 1264, 2527, 2531.

Magyar Országos Levéltárban (MOL) K 150, év 1882. Kútfő III. tétel 4 szám 7323, csomó 975.

\section{Nyomtatott források}

\section{Könyvek}

Bıás István ifj., Unitárius egyháztörténeti adatok (1619-1896), Marosvásárhely, 1910.

BölöNi Farkas Sándor, Napnyugati utazás; Napló, válogatta, a tanulmányt írta Maller Sándor, Helikon, é. n. [1984]

Boner, Charles, Transylvania: Its Products and its People, London, 1865.

Confessio Fidei Christianae Secundum Unitarios, inter quator in Transylvania Religiones receptas numerata Fundamentalibus Patriae istius Legibus, Diplomatibus, variisque Rescriptis Caesares, verbis Regiis Capitulationibus Principium confirmata, Cibinii die 27. Xbris, Anno 1782.

Demeter Tibor, Bibliographia Hungarica, Bp., 1957-58. [http://demeter.oszk. $\mathrm{hu}]$

Földi és égi hitviták. Válogatás Jacobus Palaeologus munkáiból, ford. NAGyillés János, válogatta, az előszót és a jegyzeteket írta BALÁzs Mihály, Budapest-Kolozsvár, 2003.

Jókai levelezése 1876-1885. Összegyüjtötte és sajtó alá rendezte GrörfFY Miklós, Akadémiai kiadó, Budapest, 1992.

JókAI Mór, Egy az Isten (1876-77), Akadémiai kiadó, Budapest, 1970 (Jókai összes müvei, regények 69.), szerk. Lengyel Dénes és NAGy Miklós, sajtó alá rendezte SzeKeres László.

Kénosi Tózsér János - Uzoni FoszTó István, Az erdélyi unitárius egyház története I., ford. Márkos Albert, a bev. tanulmányt írta, a ford. ... egybevetette Balázs Mihály, sajtó alá rendezte Hoffmann Gizella, Kovács Sándor, Molnár B. Lehel, Kolozsvár, 2005. (Az Erdélyi Unitárius Egyház Gyüjtőlevéltárának és Nagykönyvtárának kiadványai 4/1.)

Lindsey, Theophilus, An Historical View of the State of the Unitarian Doctrine and Worship from the Reformation to our Own times. With some Account of the Obstructions which it Has Meet with at Different Periods, London, 1783.

McLachlan, H., Register of Students 1854-1829.

Mclachlan, H., The Unitarian Home Missionary College, London, 1915. 
PAgET, John, Hungary and Transylvania; with Remarks on Their Condition, Social, Political, and Economical, London, 1839.

Planck, Gottlieb Jakob, Neueste Religions-Geschichte, Lemgo: Meyer, 17871793.

SÁNDor János, A székelykeresztúri Unitárius Gymnasium történelme, Székelykeresztúr, 1896.

Szentábrahámi Lombard Mihály, Summa universae theologiae Christianae secundum Unitarios, in usum auditorum theologiae concinnata et edita, Claudiopoli, typis Collegii Reformatorum, MDCCLXXXVII.

Wendeborn, August, Der Zustand des Staats, der Religion, der Gelehrsamkeit und der Kunst in Grosbritannien gegen das Ende des achtzehnten Jahrhunderts, Berlin: Spener 1785-1788.

Zigán János, ford., Nagy Britanniának egyházi, polgári és tudománybéli állapotja a' XVIII-dik század vége felé. D. Wendeborn Gebhard Friderik Ágoston', londoni predikátor' munkája szerént rövid summába foglalta Zigán János, Pesten, N. Kiss István könyvtárosnál, 1808., 102-104.

\section{Napilapok, folyóiratok ${ }^{1}$}

Kolozsvári napilapok

- Ébredés (1876-1877)

- Magyar Polgár (1876-1886. 1897-1904)

- Kolozsvár (1887-1897)

- Kelet (1871-1882)

- Ellenzék (1880-1905)

- Unitárius Közlöny (1888-1905)

- Erdélyi Gazda (1873-1880)

- Hölgyfutár. Szépirodalmi hetilap (1876-1878)

Budapesti napi- és hetilapok

- A Hon (1873-1877)

- Fövárosi Lapok (1873-1877)

- Vasárnapi Újság (1873-1877)

- Pesti Hírlap (1883)

- Budapesti Szemle (1860-1880)

Angol unitárius folyóiratok

- $\quad$ The Monthly Repository (1806-1838)

- $\quad$ The Christian Reformer (1815-1863)

- $\quad$ The Inquirer (1842-1921)

${ }^{1}$ Zárójelben a tanulmányozott évek 
- The Christian Life (1876-1905)

- The Unitarian Herald (1861-1889)

- Report of the BFUA (1825-1882)

Amerikai unitárius folyóiratok

- The Christian Register (1821-1905)

- The Christian Examiner and Theological Review 1824-1869)

- The Monthly Religious Magazine (1844-1874)

- The Unitarian Review (1874-1891)

- The Christian Inquirer (1846-1866)

- $\quad$ Old and New (1870-1875)

- Monthly Journal (1869)

\section{Szakirodalom}

Ács Tivadar, Erdély Browningja, Láthatár (kisebbségi kultúrszemle) 1943. 5. sz. 109-110.

Allen, Joseph Henry Rev., A Visit to Transylvania and the Consistory at Kolozsvár, Boston: George H. Ellis, Franklin street, 1881.

Angol istentisztelet a kolozsvári unitárius templomban, KerMagv, 1901, 315317.

Az erdélyi magyar szinészet höskora 1792-1821. Nagy Lázár visszaemlékezései (Erdélyi Ritkaságok 1. sz.), Bev. ellátta Dr. Jancsó Elemér, Kolozsvár, 1939.

Balézs Mihály, About a Copy of «De falsa et vera unius Dei... cognitione» (Additional data to the history of the English connections of the Anitrinitarians of Transylvania), Odredzenie i reformacja w Polsce, Warszawa, 2003(XLVII), 53-64.

BÁNHEGY Zsolt, Sir John Bowring, a magyar nyelv és irodalom barátja, Magyar Tudomány 2004, április 4.sz. 481. [http://www.matud.iif.hu/04apr/08. html]

Barna József, Máté Dersi's Heritage: Additions to the Reception of Socinianism in Seventeeh Century Transylvania = Faustus Socinus and his Heritage, edited by Lech Szczucki, Kraków, MMV, 443-454.

Barrows, Samuel, Jézus mint büntetóbiró, KerMagv, 1902, 181-193.

Beard, J.R., Unitarianism Exhibited in its Actual Condition, London, 1846.

BickNeLl, Percy Favor, Manasseeh. A Romance of Transylvania. Retold from the Hungarian..., Boston. L.C. Page \& Company, 1901.

BІхву T. Jakab amerikai tanár látogatása, KerMagv, 1884, 322-326. 
Bonet-Maury, Gaston, Early Sources of English Unitarian Christianity, London, 1884.

BorbéLy István, A mai unitárius hitelvek kialakulásának története, Kolozsvár, 1925.

BorbéLy István, Simén Domokos és kora, KerMagv, 1926, 49-59, 109-131, 210 227. 1927, 49-58, 155-169. 1928, 37-89.

Boros György, Az amerikai Unitárius Társulat 75. évi jubileuma Bostonban. Jelentés a magyarországi Unitárius Egyház Képviselő Tanácsához, Kolozsvár 1900.

Boros György, Richmond Anna, KerMagv, 1882, 49-51.

Bowring, John, Sir, A magyarok költészete, Poetry of the Magyars, bev. Kiss Dénes, tanulm. Czigány Lóránt, ford. Görgey Etelka, TAKÁcs Zoltán, Allprint, 2006.

BRACE, Charles Loring, Gesta Christi: or a History of Humane Progress Under Christianity, London: Hodder and Stoughton, 1882.

BraCe, Charles Loring, Magyarország 1851-ben: személyes beszámolóval az osztrák rendörségröl, ford. és az utószót írták LÉvAI Csaba és VIDA István Kornél, Attraktor, 2005.

Carpenter, Joseph Estlin, The Life and Work of Mary Carpenter, London, 1879.

Cernovodeanu, Paul, Contributions to Lord Paget's Journey in Wallachia and Transylvania (1702), Revue des Études Sud-Est Européennes, Tome XI(1973) No. 2, 275-284.

Cernovodeanu, Paul; Stanciu, Ion, Imaginea lumii noi în țările române şi primele lor relații cu statele unite ale Americii pînă în 1859, Bucureşti, 1977.

Chalmers, Andrew, Transylvanian Recollections: Sketches of Hungarian Travel and History, London, 1879.

Connel, James MacLuckie, Dickens' Unitarian Minister, Edward Tagart, TUHS vol. 8, 1944, 68-83.

Csetri Elek, Kőrösi Csoma Sándor indulása, Bukarest, 1979.

Czigány Lóránt, A magyar irodalom fogadtatása a viktoriánus Angliában, ford. Rozsnyai Bálint, Budapest, 1976.

CzIGÁNy Lóránt, Sir John Bowring és a magyar irodalom, Új Látóhatár, $1961 / 1$.

DALL C.H.A. látogatása, KerMagv, 1868, 258-260.

DáN Róbert, Nagyajtai Kovács István könyvajándéka a Manchester (New) College-nak, Magyar Könyvszemle, 1979, 382-384. 
DeEse, Helen R. ed., Daughter of Boston. The Extraordinary Diary of a Nineteenth-century Woman, Caroline Healey Dall, Beacon Press, 2005.

Élet- és jellemrajzok Magyarországról, Erdélyi Múzeum 13. kötet, 1896, 275277.

Erdő János, A Manchester College története és kapcsolata az erdélyi unitárius egyházzal, KerMagv, 1986, 138-158.

ERDő János, Channing magyar nyelven = Teológiai Tanulmányok, Kolozsvár, 1996.

Erdő János, Egy névtelen káté 1845-ből. Channing, E.W. kátéja, Kriza János átdolgozásában = Teológiai Tanulmányok, Kolozsvár, 1996.

FAbINy Tibor, Accounts and Images of English Unitarians on Transylvania Three Visits: 1859-1879, Acta Litteraria Academiae Scientiarum Hungaricae 21, 1979, 130-143.

FABINY Tibor, Fejezetek az erdélyi unitáriusok angol kapcsolatainak történetéból..., Szeged, 1981. (Doktori dolgozat, kézirat)

Ferencz József, Fretwell J. úr látogatása, KerMagv, 1873, 189-197.

Ferenczi Zoltán, List of the Translations of Jókai's Works into Foreign Languages, Bibliofil Könyvtár, 1926., 1. sz.

Frank Tibor, The British Image of Hungary 1865-1870, Budapest 1976.

Fretwell János felolvasása Jókairól, KerMagv, 1886, 53-54.

Fretwell, John, Three Centuries of Unitarianism in Transylvania and Hungary, New York, 1876.

GaAl György, Múzsák és erények jegyében, Kolozsvár, 2001.

GAAL György, Unitáriusok a kolozsvári egyetemen, KerMagv, 1998, 127-140.

GaAl György, Kolozsvári Dimién Pál (1655-1720),KerMagv, 2010, 172 kk.

GÁL István, Magyarország és az angolszász világ, Argumentum, 2005.

GÁL Kelemen, A kolozsvári unitárius kollégium története (1568-1900), Kolozsvár 1935.

GÁL Kelemen, Káli Nagy Elek élet-és jellemrajza, (Az Erdélyi Unitárius Egyház Gyüjtőlevéltárának és Nagykönyvtárának kiadványai 3. Szerk. Kovács Sándor és Molnár B. Lehel), Kolozsvár, 2003.

Gál Kelemen, Kovács János (1846-1905). [é. n.]

GáL Kelemen, Lázár István püspök és külföldi egyetemi tanulmányai, Unitárius Naptár 1931, 92-102.

GÁl Kelemen, Péterfi Dénes, (Unitárius Könyvtár 5. sz.) 
GÁLfi Lőrincz, Nemzetközi unitárius konferencia Budapesten, KerMagv, 1896, 263-266.

Gordon, Alexander, Report of an Official Visit to Transylvania on the Occasion of the Trecentennial Commemoration of Francis David, London, 1879.

Göмöri György, Magyarországi diákok angol és skót egytemeken 1526-1789, Budapest, 2005. (Magyarországi diákok egyetemjárása az újkorban 14.)

GöмöRI György, Kultúránk követei a régi Európában, EditioPrinceps Kiadó, Budapest, 2009, 171-190.

Groot, Aart de, Kämpfen für Wahrheit und Einheit in der Kirche: Acontius und Sommer über die "Stratagemata Satanae" $(1565,1570)=$ György Enyedi and

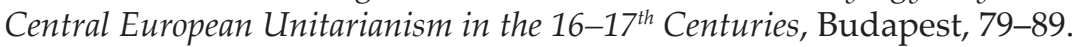

Hajós János és Buzogány Áron, Az amerikai, angol és magyar unitáriusok találkozása Budapesten, június 14, 15, 16-án 1873., KerMagv, 1873, 262-280.

Hamilton, John T., Letters embracing his life of John James Tayler, B.A., London 1873, vol. 2., 210-211.

Herepei János, Hozman János diák, a kolozsvári unitárius Leányiskola tanítója, Adattár 3., szerk. Keserú Bálint, Budapest-Szeged, 1971.

Holt, V. Raymond, The Unitarian Contribution to Social Progress in England, London, 1938.

IERson, Henry, Report of a Visit to Hungary, London 1891.

ЈакАв Elek, Magyar és angol-amerikai unitárius érintkezések e század első felében, KerMagv, 1890, 374-389. 1891, 10-42.

KÁDÁr Judit, Jókai regényei angolul, Irodalomtörténeti Közlemények, 1991, 505-542.

Kelemen Lajos, Bolyai János Üdvtanáról = Müvelődéstörténeti tanulmányok, szerk. SAs Péter, Kriterion, 2006, 235-236.

Keserú Bálint, Paulus Michael Rhegenius és a claubergiánus német kartezianizmus = A magyar kartezianizmus 400 éve, Szeged, 1996, 285-296.

B. Kiss Attila, Adam Franck (1639-1717) pályaképe 1-4., KerMagv 2008, 363 kk., 528 kk., 2009, 56 kk., 190 kk.

Keserú Gizella, Andrzej Wiszowaty Religio rationalisa és Erdély = Müvelődési törekvések a korai újkorban. Tanulmányok Keserü Bálint tiszteletére, (Adattár 35.), Szeged, 1997.

Klaniczay Tibor, Jegyzetek Budai Parmenius Istvánról = Hagyományok ébresztése, Bp., 1976.

Kovács János, Az angol nyelv a nemzetközi érintkezésekben, Erdélyi Múzeum, 1901. XVIII. 6. füzet, 309-318. 
Kovács János, Carpenter Mária emlékezete, KerMagv, 1877, 357-364.

Kovács János, Egyek vagyunk a hitben és a szeretetben. Jelentés az 1882. augusztus 27-tól 1883. március 7-ig tartó amerikai útjáról, KerMagv, 1978, 28-40.

Kovács János, Hivatalos Jelentése Kovács János igazgató tanárnak, melyet mint $a$ "Brit és Külföldi Unitárius Társulat" az évi közgyülésre küldött képviseló az unitáriusok E.K. Tanácsához f. évi július 31-én beadott, KerMagv, 1881, 243-257.

Kovács János, Hunter T. emlékezete, KerMagv, 1898, 97-98.

Kovács János, In Memoriam John Paget Esq., Kolozsvár, 1893. (An Oration in Memory of the Late John Paget Esq. Honorary Member of the "Kolozsvár English Conversation Club", delivered by prof. John Kovács, president, at the Anniversary Held on the 23-d of February 1893 in Kolozsvár.).

Kovács János, Richmond Anna élete és jelleme, KerMagv, 1883, 230-245.

Kovács Sándor, Contributions to Late $17^{\text {th }}$ Century Relationship of the Transylvanian Unitarians and their co-religionists in England and in the Netherlands = Faustus Socinus and his Heritage, edited by Lech Szczucki, Kraków, MMV, 455-466.

Kovács Sándor, Transylvania and the Unitarian College, Manchester: The Sharpe Hungarian Scholarships = Unitarian to the Core: Unitarian College Manchester, 1854-2004, ed. by Leonard SмIтH, 143-160.

Kovács Sándor, Unitárius egyháztörténet, Kolozsvár, 2009

Kovács Sándor, Adalék Jókai Egy az Isten címü regényének geneziséhez = Irodalomtörténeti Közlemények, 112 (2008), 435-446.

Kovács Sándor, Egy elfelejtett angol unitárius, John Fretwell, és a magyar literatúra = Isten és ember szolgálatában. Erdő János emlékezete (szerk. Szabó Árpád), Kolozsvár, 2007, 231-249.

LAKó Elemér, Sir John Bowring és az erdélyi „populáris literatura”, Korunk, 1972/8, 1245-1248.

Long, Arthur and Ruston, Alan, Unitariorum in Anglia: a Latin Message to Transylvania I-II., TUHS vol. 23, nr. 3, April, 2005, 594-594. nr. 4, April 2006, 663-670.

LóRInczy, Dionysius, The Hungarian Unitarian Church, TUHS vol. 3., for the years 1923-1926. 20-39, 121-134.

Madison, V. John, English Versions of the New Testament: A Bibliographical List, Journal of Biblical Literature, vol 44, no.3/4(1925), 261-288.

Magyar Francis, Jokai's Reception in England and America, American Slavic and East European Review, Vol. 17, no. 3. (oct., 1958), 332-345. 
Manton J., Mary Carpenter and the Children of the Streets, London: Heinemann, 1976.

McLachlan, H., Alexander Gordon (9 June 1841 - 21 February 1931) a Biography with a Bibliography, Manchester University Press, 1932.

McLachlan, H., Letters of Theophilus Lindsey, Manchester: The University Press, 1920.

McLachlan, H., Links Between Transylvanian and British Unitarians from the $17^{\text {th }}$ Century Onwards, TUHS vol. 17, July, 1980, 73-81

McLachlan, H., More Letters of Theophilus Lindsey, TUHS, 3/4 (1923-1926), 361-377.

Mclachlan, H., The Unitarian Movement in the Religious Life of England, London, 1934.

Мıкó Imre, Egy Jókai-regényhős 1848-ban = Akik előttem jártak, Bukarest, 1977.

Murádin Jenő, Walter Crane a száz év előtti Kolozsváron és Kalotaszegen = Ars Hungarica, 2008, 36. évfolyam 1-2. szám, 229-244.

O'Connor, Stephen, Orphan Trains: The Story of Charles Loring Brace and the Children He Saved and Failed, University Press of Chicago, 2004.

Összehasonlitó Irodalomtörténeti Lapok, válogatta, sajtó alá rendezte és jegyzetekkel ellátta GaAL György, Kriterion, 1975.

Paget János ajándéka, KerMagv, 1887, 77.

PAGET John, Magyarország és Erdély, Helikon, é. n., válogatta, szerkesztette a szó- és névmagyarázatot és a tanulmányt írta MALLER Sándor, fordította Rakovszky Zsuzsa

Pirnát Antal, Die Ideologie der Siebenbürger Antitrinitarier in den 1570er Jahren, Budapest, 1961.

RafajJ Domokos, Levél, Újszékel, július 1875., KerMagv, 1875, 342-344. 407.

Rezi Elek, Adatok a Manchesteri Unitarian College történetéhez, KerMagv, 1986, 27-32.

Richmond Anna utódai Kolozsvárt, KerMagv, 1885, 322-324.

Simms, P. Marion, The Bible in America: Versions That Have Played Their Part in the Making of the Republic, New York, 1936.

Szabad György, A levéltáros és történetíró Jakab Elek pályaképéhez, Levéltári Közlemények, 44-45. évf., 1973/1-2, 1974/1-2 sz. 549-557.

Szabó Miklós, Az erdélyi unitáriusok külföldi egyetemjárása 1848-ig, KerMagv, 1991, 85-104. 
Szabó Miklós, SzöGI László, Erdélyi peregrinusok. Erdélyi diákok európai egyetemeken 1701-1849, Marosvásárhely, 1998.

Szabó Miklós, Tonk Sándor, Erdélyiek egyetemjárása a korai újkorban 15211700, Szeged, 1992.

SzAniszló József, A budapesti unitárius egyházközség története a jegyzőkönyvek tükrében, Budapesti Unitárius Egyházközség, 2010, 44.

SzentKirÁLyi József, Magyar költemények angol fordításban, Bp., 1943.

SzILAsi László, A selyemgubó és a "bonczoló kés”, Osiris - Pompeji, 2000.

TAGART, Edward A Memoir of the late Edward Tagart, who died 12th October, 1858, [h. n. és é. n.]

TAGART, Lucy, The Hungarian and Transylvanian Unitarians. Some Account of their Origin, Vicissitudes, and Present Condition, Complied from Various Sources, London, 1903.

Tarrant, W. G., Some Chapters in the Story of "The Inquirer", TUHS vol. IV, 1927-1930., 35-44.

TAYLER, John James, Narrative of a Visit to the Unitarian Curches of Transylvania on the Occasion of the Three-Hundredth Anniversary of the First Proclamation of Religious Freedom at Torda in 1568, London, 1869.

The Inquirer a History and other Reflections, é. n. [1992], London.

Andreas ThorwäTcher, Kirchen und Schuletat der Unitarier in Siebenbürgen = Siebenbürgisher Quartalschrift, Fünfter Jahrgang, Hermanstadt, 1797, 1-24. Uö, Von den alten Buchdruckereyen der sozinischen Glaubensverwandten, oder sogenannten Unitarier in Siebenbürgen = Siebenbürgisher Quartalschrift, Fünfter Jahrgang, Hermanstadt, 1794, 264-283.

Twinn, Kenneth, Az első angol unitárius egyházközség megalapitásának 200. évfordulója, KerMagv 1974, 96-100

VARAnnai Aurél, John Bowring és a magyar irodalom, Budapst, 1967.

VÁrfalvi Nagy János, Jakab József életrajza, KerMagv, 1872, 209-236.

Wilbur, Earl Morse, A History of Unitarianism in Transylvania, England, and America, Beacon Press Boston, é. n.

Wilbur, Earl Morse, Our Unitarian Heritage. An Introduction to the History of the Unitarian Movement, Beacon Press, Boston, é. n.

Wykes, L. David, John Paget, M.D., of Transylvania (1808-1892), TUHS vol. 17, July, 1980, 54-72.

WyKes, DAVID L., 'Dissenting academy or Unitarian seminary? Manchester College at York (1803-1840)' TUHS 1988, 102-112.

Zsakó Erzsébet, Hinni és tenni. Az unitárius Nőszövetség története, Kolozsvár, 2003. 


\section{NÉVMUTATÓ}

Abonyi Lajos 105

Aconcio, Jacopo 11

Ács Tivadar 130, 131

Ádám Rázmán (Erasmus) Péter 11

Agh István 84

Ajtai K. Albert 156

Ajtai K. János 159

Ákontz Károly 158

Alder Lipót 155

Alger, William R. 32

Allen, Joseph Henry 32, 142-144, 147,148

Almási Gergely Mihály 85

Ames család 149

Anaxagorasz 203

Andras, Carmen 55

Andrew, John Albion 105, 115

Anghy Anikó 127

Anghy Gyöngyi 127

Annesley, W.F. 160

Antiszthenész 203

Arany János 163

Aranyosrákosi Székely Sándor 46, 53,84

Áriosz 202

Arisztotelész 236

Arminius, Jacob 178

Armstrong, F.C. 164

Armstrong, George 65

Arnoldi, Wilhelm 102

Aspland, Brook Robert 17, 71, 77, 78, 234

Aspland, Robert 15-18, 30, 40, 43, $181,182,224$

Athanasziosz 202

B. Kiss Attila 12,15

Bächer, Charles 122

Bácsi Margit 126

Baker, Derek 102
Balázs Mihály 8, 11, 15, 26

Balog Pál 43, 44

Bancroft, George 47

Bánffy Jánosné 159

Bánhegyi Zsolt 37, 40

Barham, Foster John 58

Barna József 15

Barrows, Isabel C. 159

Barrows, Samuel June 159

Bath Gunszt 68

Báthory család 106

Beard, John Relly 52, 58, 138, 226

Bedő Albert 116

Bedőházi János 162

Béldi Ferenc 44

Bellows, Henry Whitney 32

Belsham, Thomas 17, 34-36, 62, 176, 205, 208, 214, 221

Bélteky János 167

Benczédi Gergely 13, 24, 79, 80, 88-92, 95-99, 102, 120, 149, 234

Benczúr Gyula 151

Benkő József 16

Berde Âron 51, 53, 75, 88, 91

Bethlen Balázs 159

Bethlen Dániel 155

Bethlen Domokos 32, 38

Bethlen Gergelyné 159

Bethlen Sándorné 159

Biandrata, Giorgio 28, 30, 58, 184, 186

Bicknell, Percy Favor 103, 106, 120

Biddle, John 175

Bihari Péter 90

Bikkfalvi Barbara 127

Binetz István 29

Binetz Sándor 29

Bíró Gyöngyi 8

Bixby, James Thompson 150-152

Blumenbach, Johann Friedrich 44

Bock, Samuel Friederich 28, 186 
Boér Lenke 126

Bölöni Farkas Sándor 7, 9, 19, 33, 36, $42,44-47,49,67,95,144,146,148$, 151,224

Bolyai Farkas 163

Bolyai János 162, 163

Boner, Charles 112

Bonet-Maury, Gaston 169

Bonifác, Szent 107

Bonomi, Joseph 126

Borbély István 11, 14, 23, 63, 67, 75, $78,79,82,92,170$

Borbély Lenke 126

Boros György 14, 25, 110, 117, 121, 137-139, 151, 152, 154, 155, 156, $159,162,164,166,170$

Boros Irén 126

Boros Rózsika 126

Borsa Gedeon 11

Bowen, Ednah 153

Bowie, William Copeland 164

Bowring, John 7, 9, 17, 18, 19, 37-41, $43,45,49,50,62,83,84,105,115$, 132

Bracciforti, Ferdinando 143

Brace, Charles Loring 145-147, 151

Brassai Sámuel 46, 107, 124, 132, 142, 154, 156, 158, 159, 162, 167

Bretschneider, Karl Gottlieb 71

Brooke, Lambert 138, 154

Browing, George 129-135, 151

Browning, Robert 114

Budai Parmenius István 11

Buckle tábornok 160

Busă, Daniela 55

Butler, Edward Dundas 132

Buzogány Áron 13, 30, 41, 45, 63, 64, 71-73, 76, 77, 80, 82, 83, 85, 87, 92, 96, 108, 231

Buzogány Mariska 126

Caine, Hall 106, 107, 118

Cappe, Newcome 214

Capper, James Samuel 165

Cardle, Paul 214

Carpenter, Joseph Estlin 129

Carpenter, Lant 36, 214

Carpenter, Mary 129, 130, 135

Cernovodeanu, Paul 10, 11

Chalmers, Andrew 9, 138-142, 147

Channing, William Ellery 47, 79, 95, $96,97,105,125,126,148,149,152$, 169

Channing, William Henry 59

Charlesworth, Samuel 105
Chester, Dyer Frank 162-166

Chickering, Theodore William 164, 165

Chiniah, Abraham 224

Clarke, Samuel 21, 176

Claudius Aelianus 58

Coe, Charles Clement 59

Concha Győző 123, 136, 151, 154, 156, 162

Connel, James MacLuckie 62

Coquerel, Athanase 143

Crane, Walter 166, 167

Cranmer, Thomas 174, 206

Crell, Johann 86

Crell, Krzysztof 25

Crell, Samuel 25

Csetri Elek 24, 27

Csiki Klára 127

Csorba László 8

Czigány Lóránt 37, 55, 104, 132

Dall, Caroline Healey 94

Dall, Charles Henry Appleton 94, 95, $98,105,115,144$

Dán Róbert 51

Dávid Ferenc 14, 25-27, 30, 51, 67, 86, $111,119,136-138,165,170,183$, 184,222

Davidson, Amanda 127

Davidson, Samuel 126

Davis, Valentin David 52

De Gerandó Antónia 125

Deák Ferenc 22, 110

Deák Margit 126

Deáky Albert 153

Deese, Helen R. 94

Demeter Tibor 104

Dersi Gergely István 85

Dersi Máté 15

Derzsi Kanyaró Mihály 27

Derzsi Károly 123, 168, 170

Detzler, Wayne 102

Dickens, Charles 62

Dietriefstein, Giles 127

Diósy Márton 90

Diószeghy Erzsébet 126

Disney, John 176

Disraeli, Benjamin 138

Döbrentei Gábor 39

Dowson, Enfield 164

Duncan liverpooli törvénybíró 153

Duret József 128, 153, 155

Edward III., angol király 158

Edward VI., angol király 174, 206 
Edward, Samuel 164

Egri Lukács 140

Eichhorn, Johann Gottfried 44

Életes Károly 150

Elliot, F.W. 152, 153

Ellis, George E. 32

Ellis, George H. 143

Emlyn, Thomas 177

Enyedi György 28, 51, 138, 152, 186

Eötvös József 106, 107

Epiphaniosz 202

Episcopius, Simon 87

Erasmus, Johann 86

Erdő János 18, 52, 101, 169

Erzsébet I., angol királynő 11, 174

Eszterházy Kálmán 150

Evans, Arthur John 142, 154

Evans, Delta D. 105

Evanson, Edward 176

Fabiny Tibor, ifj. 8, 9, 14, 57, 65, 98, 137

Fabinyi Rudolf 154

Fangh Erzsébet 126

Farkas Gyula 162

Feitinger, magyar emigráns 91

Felméri Lajos 129, 136, 146, 154, 157, 160,162

Ferenc I., császár 185

Ferenc József I., császár 108, 120, 121, 134,167

Ferencz József püspök 13, 14, 18, 63 , $65,71-73,80,82,90,96,104,106$, $107,115,117,119,120,137,146$, $154,160,161,165,231$

Ferencz József 25

Ferenczi, Zoltán 104

Finály Henrik 123, 128, 129, 136, 146, $152,154,156,157$

Firmin, Thomas 175

Fisher, Kuno 235

Fletcher, Margaret 157

Forgách Kálmán 131

Forstner, C. A. 97

Fox, George 165

Fox, Johnson William 15, 17-19, 30, $32-35,37,43,49,83,105,125,181$, $182,189,224$

Fox, Thomas B. 32

Franck, Adam 12, 15, 86

Frank Tibor 10, 98

Fraser, John Foster 164

Fretwell (Traun), Bertha 102, 103

Fretwell, John 97, 101-120, 137, 143, 164,264
Froebelt, Friedrich 102

Fülöp József 46

Fülöp Károly 248

Füzi János 46, 188

Gaal György 12, 55, 122, 132, 149, 170

Gál Ágnes 10

Gál István 10, 166

Gál Julianna 10

Gál Kelemen 14, 29, 55, 75, 113, 120, $122,123,149$

Gálfalvi Sámuel 237

Gálfi Lőrinc 160, 162, 164

Ganett, Ezra Stiles 32, 61

Gaskell, William 138

Gebauer, Georg Christian 24

Gedő József 46

Gedő Sándor 88

Gerald, Fitz 160

Gladstone, William Ewart 138, 139, 143

Glirius, Matthias Vehe 26

Goldsmith, Oliver 142, 162

Goldziher Ignác 162

Gömöri György 11, 12, 15, 74

Gordon, Alexander 9, 112, 125, 136-140, 169

Görgey Etelka 37

Greenwood, Francis W.P. 32

Griesbach, Johann Jakob33, 180, 190

Grisza Ágost 160

Groisz Gusztáv 150

Gubernatis, Angelo 153

Gyalui Farkas 158

Gyergyai Árpád 136

Gyergyai Ferenc 46

Gyergyai László 37, 46

Györffy Miklós 103

Gyurmán Adolf 160

Haas Tivadarné Kovács Margit 67

Hajós János 108, 109

Hale, Edward Everett 32, 47, 108-110, 118, 148

Halsted, George Bruce 162, 163

Hamilton, John T. 85

Hantz Mihály 160

Harsányi Klára 127

Haynes, Hopton 214

Hedge, Frederic Henry 32, 109

Hedworth, Henry 12

Hegedüs István 131, 150

Hegedüs Sándor 131

Heltai Gáspár 28, 183

Henrik VIII., angol király 21, 174, 205 
Herepei János 125

Herford, Brooke 138

Heywood, John Healy 138

Hill, Florence 16,156

Hindy Árpád 158, 160, 162

Hindy Árpádné Gyurmán Etelka 160,164

Hoffmann Gizella 8, 26, 101

Hőgyes Endre 129, 136

Holt, Raymond 67

Horsley, Samuel 35

Horváth Pál 91

Howe, Samuel Gridley 115

Hozman János 125

Hunt, Leigh 15

Hunter, Thomas 43, 57, 59, 65, 234

Huszti János 67

Ierson, Henry 139, 156, 157

Iorga, Nicolae 55

Iszlai József 79

Iszlai László 51

Izabella királynő 186

Jakab Elek 13, 14, 18, 29, 30, 32, 46, $47,67,68,90,101,112,116,137$, 153,169

Jakab I., angol király 174

Jakab József 9, 53

Jancsó Elemér 29

Janke, Otto 103

Jankovich Pál 165

János Zsigmond fejedelem 30, 165, 184,186

Jebb, John 176

Jenei Viktor 123, 136, 155

Jenks, Francis 32

Joan of Kent 21, 174, 206

Jókai Mór 7, 101-107, 110-119, 137, 163

Jósika Miklós 106, 107

József II., császár 185, 187

Justin Martyr 201, 202

K. Papp Miklós 79

Kacsóh Pongrác 162

Kádár Judit 104

Kádár Lázár 237

Káli Nagy Elek 75, 113

Káli Nagy Magda 126

Kálvin János 176, 178

Kanyaró Ferenc 169

Karádi Pál 140

Károly I., angol király 175

Károly II., angol király 175
Károly V., németrómai császár 11

Károlyi Péter 85

Kauffmann Sámuel 155, 156

Kaufmann, Josef 103

Kazinczy Ferenc 40

Kéhler Rezső 91

Kelemen Benő 98

Kelemen Lajos 35, 162

Kelemen Lajos jogász 46

Kemény család 146

Kemény Gábor 116

Kemény Kálmánné 159

Kemény Zsigmond 106, 107

Kénosi Tőzsér János 26-28, 31, 46, 47, 83,99

Kenrick, John 16, 44, 56, 58, 62, 181, 225, 227

Keserü Bálint 12, 20, 125

Killoran, Sue 8

Killyéni Erzsébet 126

Kinghorn, John 206

Kirkconnel, Watson 131

Kiss Dénes 37

Kiss Viola 126

Kittle, Robert W. 105

Klapka György 91

Klaniczay Tibor 11

Koch Antal 136, 142

Kolozsvári Dimjén Pál 12

Koncz Ildikó 127

Koncz János 37

Kopitár Bertalan 39, 40

Körmöczi János 18, 19, 23-25, 27, 29, 32-39, 41, 46, 49, 169, 187, 189

Koronka Antal 88

Kőrösi Csoma Sándor 27

Kós Károly 166

Kossuth Ferenc 68, 69

Kossuth Lajos 7, 9, 57-59, 65-70, 102, $105,115,139,143,148,151,163$

Kovács, magyar emigráns 91

Kovács Árpád 156

Kovács Irén 126

Kovács János 13, 53, 57, 67-69, 96, $101,107,109,110,113,115,119$, 120-124, 127-130, 135, 136, 138-140, 143, 145-152, 154-156, $159,160,163-167,257$

Kovács Kálmán 67

Kovács Sándor 10, 13, 26, 55, 75, 101

Kovácsi Antal 62, 96

Kozma család 12

Kozma Ferenc 155

Kozma János, id. 19, 22, 28

Kozma László 47 
Kriza János 9, 13, 22, 56, 60, 62, 67, $78,81,84,85,88,92,96,97,105$, 107, 109, 114, 143, 169, 228, 231, 232

Kriza Lenka 156

Kropf Lajos 118, 157

Lakó Elemér 18, 37, 39

Lalina, Gaye 90

Lamson, Alvan 32

Lánczy Gyula 155

Lápossy Ferenc 91, 234, 235, 236, 239

Lardner, Nathaniel 178, 214

Lawrence család 154

Lawrence, Henry Alfred 154

Lawrence, James Clark 154

Lawrence, Jane 154

Lawrence, Williams 154

Lázár Ernő 167

Lázár István 12, 13, 25, 27, 29, 186

Lázár Sámuel 22

Legate, Bartholomew 21, 174

Lehmann Róbert 155, 156

Lengyel Dénes 103

Lévai Csaba 145

Liebe, Carl Nicolas lásd Szeremley Miklós

Ligeti Antal 151

Limborch, Philippus von 85,86

Lindsey, Theophilus 12, 13, 21, 25, 26, $105,115,176,208,214$

Linton, Lynn 106, 107

Lipót I., császár 185

Lipót II., császár 185

Liptay Pál 115, 122, 139, 242, 244

Liszt Ferenc 151

Lloyed, John Briggs 164

Lobacsevszkij, Nicolaj Ivanovics 162

Locke, John 20, 21, 175, 177

Long, Arthur 15

Lórant János 90, 102

Lőrinczy Dénes 14, 15

Löw Vilmos 104, 105

Lowe, Charles 94-96

Lowe, Frank H. 164

Lucretius 236

Luther, Martin 102, 183

Lyon, William Henry 160, 161

Mackenzie, Claud 155, 156

Maczelka Csaba 24

Madarász Gyula 151

Madden, Frederic 226

Madison, John V. 34

Maetz Frigyes 156
Magde, Thomas 224

Magyar Ferenc 104

Maller Sándor 43, 44, 51, 55

Mallock, William H. 118

Manning, William 177

Manton, J. 129

Mardon, Benjamin 224

Mária, angol királynő 174

Markó Károly 151

Márkos Albert 26

Marosi Gergely 65, 96

Marshall, Thomas 71, 73, 80, 234

Martineau, David 139

Martineau, Harriet 17

Martineau, James 59, 62, 71, 92, 105, 234, 236

Massmann, Hans Ferdinand 226

Masznyik Endre 169

Máthé Tóth András 8

Mayer, magyar emigráns 91

Mayer, Joannis 19

Mazzini, Giuseppe 115

McLachlan, Herbert 15, 25, 80, 121, 137,138

McLachlan, Herbert John 14

Mednyánszky Sándor 91

Melanchthon, Philipp 183

Meltzl Hugó 132, 135

Meusel, Johann Georg 24

Meyer, Heinrich Christian 102

Mezei János 46

Mezei Sándor 160

Mikó Imre 67, 111, 146

Miles, Henry Adolphus 61, 228

Milton, John 236

Mineka, Francis Edward 15

Molnár B. Lehel 8, 14, 26, 75

Molnos Dávid 18, 37-39, 41, 46, 47, 188

Moore, Thomas 128

Morison, John H. 109

Morison, Robert S. 109, 110, 112, 148

Morvay Ilona 126

Morvay Margit 126

Mosheim, Johann Lorenz von 26, 201

Moskorowski, Hieronim 86

Mózes András 155

Munkácsy Mihály 151

Murádin Jenő 166

N. Kiss István 25

Nagy Ferenc 153, 155

Nagy Lajos 9, 84

Nagy Lázár 29-32, 47, 50 
Nagy Miklós 103

Nagyajtai Kovács István 33-35, 41, $46,49,51,52,84$

Nagyillés János 11

Nagysolymosi Koncz Boldizsár 31, 83

Német István 165

Newcome, William 33

Newman, John Henry 102

Newman, William Francis 102, 115

Newton, Isaac 12, 21, 176

Nightingale, Florence 105

Nisbet, William 53

Norton, Andrews 47

O'Connor, Stephan 145

Oláh Miklós 11

Órigenész 202

Owen, John 23

Paget, Claude 158

Paget, Edomnd Arthur 158

Paget, Ellen 155

Paget, John 9, 10, 13, 15, 50-53, 55-57, 59-65, 70-73, 75-78, 81-83, $94,98,122,124,130,154,155,158$, $159,227,228,231,233$

Paget, Oliver 155

Paget, Oliver Edmond Arthur fia 158

Pákei Lajos 159, 167

Pákei Márta 126

Palaeologus, Jacobus 10, 11, 26, 87

Palfrey, John Gorham 32

Páli Rózsika 126

Pap Mózes 13, 80, 85

Pap Sándor 160

Parker, Theodore 95

Peart, Ann 8

Pecock, Reginald 174

Peirce, James 177, 181, 221

Pennel, John 157

Penn, William 165, 203

Perczel Mór 155

Perry, James 206

Péterfi Dénes 123, 124, 129, 132, 150, $152,155,156,160,162$

Petőfi Sándor 7, 37, 102, 105, 115, 131, 132,163

Petrán József 153

Pirnát Antal 11

Pitagorasz 203

Planck, Gottlieb Jakob 24, 27

Platón 203

Plótinosz 203

Poe, Edgar Allan 152
Poincaré, Henri 162

Porter, Classon Emmet 224

Price, Richard 190

Priestley, Joseph 21, 35, 62, 92, 105, $115,148,152,179-181,190,202$, 208, 214, 225, 226

Przypkowski, Samuel 85

Pucci, Francesco 86

Pucher, Elisa 103

Puffendorf, Samuel 24

Pulszky Ágoston 155

Pulszky Ferenc 91, 122, 155, 254

Pulszky Gábor 91

Pünkösti Márta 126

Putnam, George 32

Quense, Rose de la 157

Rafajj Domokos 113

Raffaj Károly 78

Rákóczi család 106

Rákóczi György I., fejedelem 185

Rakovszky Zsuzsa 51

Ransbourgh Sigismund 242, 244

Rees, Thomas 15, 43, 83, 180, 224

Régeni Mihály Pál 12

Rénan, Ernest 143

Révfy László 256

Reynolds, Grindall 149

Rezi Elek 121

Richmond, Anna 109, 110, 149, 153

Richmond, Caroline 120, 153

Richmond, Knight 153

Richmond, Walter 149

Ritter, Heinrich 235

Roberts, William (Moodelliar Vellazha) 205, 224

Robinson, Crabb Henry 17

Robinson, John 206

Robinson, Robert 178

Roggendorf Arnold 152

Rónay János Jácint 90

Ronge, Bertha 102

Ronge, Johannes 102

Roy, Ramohun 45, 205

Rózsahegyi Aladár 155, 156

Rozsnyai Bálint 37

Rozsnyay Kálmán 166

Ruffy Péter 158

Rumy Károly György 39, 40

Ruston, Alen 15, 16

Ryland, John 67 
Saccheri, Giovanni 162

Sala Sámuel 22, 46

Samarjay Mihály 256

Sámi Magda 126

Samuelson, James 153

Sandius, Christophorus 186

Sándor Gergely 237

Sándor János 113

Sándor Mózes 78, 79, 96

Sárdi Sámuel, id. 46

Sas Péter 162

Schleiermacher, Friedrich 44

Schlichting, Jonas 87

Schlik, Reyer 39

Schurz, Carl 102

Sebes Pál 23

Semler, Johann Salomo 13, 71

Servet, Miguel 30, 206

Shakespeare, William 72, 118, 165, 236

Sharpe, Emily 125

Sharpe, Matilda 125, 126

Sharpe, Samuel 125, 126

Sharpe, Sarah 125

Shippen, Rush R. 108

Sigmond Ákos 153, 156

Sikó István 46

Simén Domokos 14, 19, 23, 32, 52, 63, $67,73,75-82,84,92,96,98,109$

Simms, P. Marion 34

Smith, Leonard 52, 121

Smith, William 43, 181

Sommer, Johann 11, 26, 85

Somogyi, magyar emigráns 91

Southwick, Emma 109, 164

Sozzini, Fausto 25, 26, 30, 86, 87, 206, 222,223

Spalding, Johann Joachim 12, 13

Spányi Béla 151

Sparks, Jared 47

Spears, Robert 68, 105, 126

Stanciu, Ion 11

Stansfeld, James 115

Stearns, George 69

Stearns, Mary 67-69

Stegmann, Joachim 20

Stein Gábor 153

Stein János 123

Steinitz, F. 118

Steinthal, Alfred 9, 51, 64-67, 70-73, $82,115,140,233$

Suki László 187

Sumner, Charles 48

Sumner, George 48, 95
Sylvester György 18, 22, 27, 29-32, 183

Sylvester János 40

Szabad György 68

Szabó József 155

Szabó Júliánna 46

Szabó Károly 136, 146

Szabó Miklós 74

Szabó Sámuel 46

Szádeczky Gyula 157

Szaniszló József 141

Szapolyai János 58

Szász Béla 136, 150, 155

Szász Mózes 187

Szász Róbert 136

Szathmáry Elek 153, 156, 162

Széchy Károly 155

Székely Bertalan 151

Székely Miklós 48, 188

Székely Mózes 36, 45, 49, 50, 56, 80, $82,83,85$

Székely Mózes fejedelem 30

Szekeres László 103, 111, 112

Széky Miklós 123, 128, 155, 156, 162

Szentábrahámi Lombárd Mihály 28, 31, 83, 84, 90, 168, 169, 186

Szentiványi Márkos Dániel 12

Szent-Iványi Sándor 10, 12

Szentkirályi József 131

Szeremley Miklós 91

Szilágyi Ferenc, ifj. 16

Szilasi László 104, 117

Szögi László 74

Szókratész 203

Szolga János 46

Szombathelyi Gusztáv 136

Szőnyi György Endre 8

Tagart, Edward 9, 18, 39, 45, 49, 50, $56,61-65,70,72,83,115,140,167$, 224-226, 233

Tagart, Lucy 63-65, 156, 167

Tagart, William 62

Takács Zoltán 37

Tarrant, W. G. 80

Tayler, Hanna 98

Tayler, John James 9, 59, 60, 71, $82-85,87,88,91,94,98,99,112$, $115,140,169,170,234-236$

Taylor, Arthur 18, 33, 182

Taylor, Richard 33

Telekes Szilvia 126

Teleki Domokosné 146

Teleki grófok 130

Teleki László 155 
Teleki Sándor 111

Tertullianus 201, 202

Teutsch, Georg Daniel 135

Than Mór 151

Thayer, Henry A. 146

Thomson, a Morning Post fómunkatársa 153

Thorwätcher, Andreas 16

Thucydides 46

Tilly, Johann 66

Tompa Mária 126

Tonk Sándor 74

Török Áron 237

Török Aurél 123, 129, 136

Traun, Bertha 102

Traun, Christian Justus Friedrich 102

Trefort Ágoston 116, 121, 147, 150

Turner, William 181

Twinn, Kenneth 12

Ürmösi József 98

Uzoni Fosztó Gábor 79, 80, 91, 96, 234,235

Uzoni Fosztó István 26, 27, 31, 83, 84

Válaszúti György 141

Vámbéry Ármin 139, 155

Van Ness, Thomas 106, 166

Varannai Aurél 37, 40

Várfalvi Kósa János 51

Várfalvi Nagy János 53

Várfalvi Pálfi Zsigmond 12, 15

Varga Béla 138

Varga Dénes 142, 143

Vargyasi Máté Elek 23

Vári Albert 169

Vas Miklósné 156

Veisz Mór 155

Vernes László 67

Vida István Kornél 145

Vidler, William 17

Vilmos III., angol király 175

Völkel, Johann 85, 86

Vörösmarty Mihály 102

Vukovics Sebő 90

Wagner Sándor 151

Wakefield, Gilbert 176

Walker, James 32

Wallace, Robert 49

Wallenstein, Albrecht von 66

Walton Ede 160

Ward, Humphrey 106, 107

Ware, Henry Jr. 32, 47, 48
Ware, William 32

Washington, George 165

Watts, Isaac 178

Watts, Ruth 125

Webb, R. K. 17, 62

Weber Karolina 67

Weber, Peter 55

Węgrovszki, Jakób 26

Weisz József 150

Wellbeloved, Charles 181, 227

Wellin, William 248

Wendeborn, August 24

Wesley, John 152

Wesselényi Farkas 44

Wesselényi Józefa Szacsvai Sándorné 155,159

Whiston, Williams 12, 21, 176, 221

Whittier, John Greenleaf 165

Wilbur, Earl Morse 10, 16, 33

Williams, Roger 152

Wiszowaty, Adrzej 20

Wolzogen, Johannes Ludwig 87

Wood, Samuel 43

Worcester, Noah 32

Wright, John 138

Wright, Richard 36

Wykes, David 15, 44, 49, 55

Xenophón 236

Yäger Gizella 126

Yates, James 43

Zénón 203

Zeyk József 44

Zigán János 25

Zoványi Jenő 16

Zsakó Lenke 126 
REZUMAT

\section{RELAȚIILE UNITARIENE ANGLO-MAGHIARE ÎN SECOLUL AL 19-LEA}

\section{Introducere. Metodologia lucrării}

Prezenta lucrare intitulată Relațiile unitariene anglo-maghiare în secolul al 19-lea, susținută ca lucrare de doctorat la Universitatea din Szeged, Facultatea de Litere, are ca scop prezentarea relațiilor dintre biserica unitariană engleză şi cea maghiară, subliniind rolul celei din urmă în propagarea limbii şi culturii engleze în Transilvania, şi cu precădere în Cluj. Istoria relațiilor dintre comunitățile protestante din Anglia şi Transilvania este bine documentată, excepție făcînd comunitatea unitariană.

Biserica unitariană din Transilvania a luat naştere în timpul Reformei din secolul al 16-lea, reprezentînd aripa radicală a acestei mişcări novatoare. Unitarianismul englez nu are rădăcini atât de timpurii, dar începînd de la formarea primei structuri unitariene engleze (Londra, 1774), şi pînă în prezent, cele două comunități au conlucrat şi colaborat în bună înțelegere. Aceste relații, deşi par să fi avut un caracter confesional, ne deschid perspectiva unui spectru mult mai larg şi variat. Vom păşii în spațiul interior a trei biserici, respectiv cea engleză, americană şi maghiară. În oglindirea corespondenței unitariene anglo-maghiare, a jurnalelor şi impresiilor de călătorie, vom vedea că aceste relații au avut un efect nu numai în dezvoltarea dogmatică şi socială a bisericilor respective, dar şi în propagarea culturii şi limbii engleze, ceea ce a influențat şi sporit cunoştințele despre literatura şi în general cultura engleză, şi cunoştințele despre istoria şi cultura transilvăneană în Anglia şi Statele Unite ale Americii. De ce a fost ignorată prezentarea unitarismului în bibliografiile consacrate relațiilor protestante anglo-maghiare?

Răspunsul la această întrebare nu este atît de simplu precum pare. Ca prim şi poate cel mai important motiv al acestei ignorări se poate invoca numărul relativ mic al acestei comunități. În perioda prezentată unitarienii maghiari numărau aproximativ şaptezeci de mii de suflete, situate în mare parte în Transilvania. Al doilea motiv ar fi dificultatea cercetării. Fără un minim de cunoştințe dogmatice şi de istorie bisericească protestantă, în special unitariană, cercetarea este aproape imposibilă. O a treia problemă constă în vastul material cercetat. Documentarea a fost destul de anevoioasă, din cauza situației bibliografice. Pentru literatura primară am consultat fondurile Arhivei Bisericii Unitariene din Transilvania, ale Bibliotecii Academiei, filiala Cluj, ale Bibliotecii Universitare din Cluj. Un sprijin foarte important mi-a fost oferit de Biblioteca Harris-Manchester College, Oxford şi de 
Biblioteca Universitară John Rylands, Manchester, respectiv British Library, Londra şi Williams Library, Londra.

În cursul lucrării am consultat sute de pagini de manuscrise engleze, maghiare şi latine, misile, jurnale de călătorie, procese-verbale întocmite cu ocazia diferitelor reuniuni bisericeşti, şi, pe lîngă bibliografiile engleze şi maghiare, am răsfoit periodicele unitariene maghiare şi engleze, dar şi periodicele mondene, după cum urmează: Periodice maghiare unitariene - Keresztény Magvető, Unitárius Közlöny, Unitárius Élet - periodice mondene - Ébredés, Magyar Polgár, Kolozsvár, Kelet, Ellenzék, Erdélyi gazda, Hölgyfutár, A Hon, Fővárosi Lapok, Vasárnapi Újság, Pesti Hírlap, Budapesti Szemle - periodice unitariene engleze şi americane - The Monthly Repository, The Christian Reformer, The Inquirer, The Christian Life, The Unitarian Herald, The Christian Register, The Christian Examiner and Theological Review, The Monthly Religious Magazine, The Unitarian Review, The Christian Inquirer, Old and New, Monthly Journal.

Bibliografiile şi sintezele scrise în domeniu sînt menționate în notă şi listate în bibliografie.

Structurarea lucrării este cronologică, considerînd relatarea evenimențială nu numai o metodă practică, dar şi logică. Ceea ce m-a interesat în primul rînd a fost felul în care cadrul instituțional bisericesc s-a folosit în alte scopuri decît cele strict ecleziastice, spre ex. literare sau chiar cel al propagandei politice. Din punct de vedere metodologic lucrarea poate fi catalogată drept pozitivistă. Nu aş avea obiecții la o astfel de încadrare, ştiind că este imposibilă cercetarea relațiilor politice, literare, sociale, ideologice fără prezentarea în detaliu a cadrului instituțional fără de care ar fi de neînțeles rezultatele ecleziastico-politico-sociale ale celor două comunități bisericești. Sînt convins că acestă abordare este doar una din multitudinea de reconstituiri posibile, totuşi consider că se află în raport cu realitatea.

\section{Structura şi conținutul}

Lucrarea este organizată în jurul a trei capitole, primul fiind intitulat Relațiile Bisericii Unitariene Maghiare cu Unitarienii din Anglia şi Statele Unite ale Americii între anii 1821 şi 1848. În acest capitol prezint istoriografia problemei relațiilor anglo-maghiare de la începutul reformei unitariene în secolul al 16-lea, pînă la înființarea Fondului Unitarian în anul 1807 (Unitarian Fund), instituție responsabilă cu redactarea şi publicarea documentului intitulat Brevis Expositio. În anul 1821, confrații unitarienilor Transilvăneni din Insulele Britanice au trimis acest document tipărit pe 16 file către marele centre universitare de pe continent, Berlin, Geneva, Paris. Un exemplar a fost trimis lui György Sylveszter, profesor de dogmatică al Seminarului teologic unitarian din Cluj. Documentul a stârnit un imens val de entuziasm în întreaga comunitate unitariană, fiind tradus de trei preoți cărturari, copiat de mână şi răspândit în mai mult de 120 de exemplare. Vestea existenței altei comunităţi unitariene decît cea maghiară a declanşat o serie de dezbateri în sânul consistoriului Bisericii Unitariene, pe tema scrisorii de răspuns. În timpul călătoriei sale în Europa occidentală, între anii 1794-1797, episcopul János Körmöczi, figură distinctivă a Iluminismului transilvănean, a colectat o serie de date referitoare la unitarienii din Insulele Britanice. Fondul unitarian al Bibliotecii Academiei, filiala Cluj a păstrat manuscrisul şi datele colectate de Körmöczi. Analizînd în detaliu 
acest text am descoperit, că de fapt este vorba despre o traducere a lucrării lui Gottlieb Jakob Plank intitulată Neueste Religions-Geschichte... apărută în anul 1787. Gottlieb la rîndul său a folosit studiul altui coleg, August Wendeborn intitulat Der Zustand des Staats, de Religion... in Grosbritannien referitoare la unitarienii din Anglia. Wendeborn a tradus lucrarea primului preot unitarian Teophil Lindsey, în acest sens Körmöczi putând fi considerat primul interpret al lui Lindsey in limba maghiară. Scrisoarea trimisă de Körmöczi către unitarienii din Anglia, păstrată la British Library, iar mai apoi corespondența între Cluj şi Londra, ne conduc către un alt episod important al relațiilor anglo-maghiare.

Numele poetului şi politicianului John Bowring este binecunoscut în istoria literaturii maghiare, Bowring fiind primul traducător britanic al poeziei maghiare, traducerile sale intitulate Poetry of the Magyars au apărut la Londra în anul 1830. Este însă mai puțin cunoscut cum au ajuns în mâna diplomatului englez poeziile maghiare propuse pentru traducere. În subcapitolul Literatura populară şi triunghiul Molnos-Bowring-Körmöczi am încercat să trasez drumul şi tactica folosită de englez pentru obținerea a cît mai multe informații despre poeții şi literatura maghiară. Prezint în detaliu cum a folosit unitarianul Bowring, secretar al asociației British and Foreign Unitarian Association cadrul instituțional, şi contactele unitariene maghiare în scopul ambițiilor literare personale.

Bowring a cunoscut personal o figură marcantă a unitarienilor transilvăneni, Sándor Farkas Bölöni, primul călător unitarian laic în Marea Britanie şi Statele Unite ale Americii. În lucrarea Călătorie în America de Nord publicată în 1834, Farkas Bölöni vorbeşte despre întâlnirea sa cu unitarienii englezi şi americani. Importanța acestei călătorii a fost îndelung studiată, şi o serie de studii au arătat impactul cărții asupra societății transilvane premergătoare revoluției paşoptiste. Analiştii operei lui Bölöni au omis însă rapoartele scrise de acesta către Consistoriul Bisericii Unitariene, din care reiese că Farkas Bölöni nu a fost nicidecum un simplu călător, ci diplomatul Bisericii Unitariene. Aşa se explică faptul că Bölöni i-a contactat din prima clipă pe cei mai de seamă confrați din Anglia şi Statele Unite. Raportul său a fost publicat de către episcopul Sándor Székely Aranyosrákosi în cartea sa Istoria Bisericii Unitariene apărută în anul 1839. Toate datele referitoare la unitarienii din Marea Britanie, Scoția, Statele Unite, Paris, Gibraltar au fost copiate cuvînt cu cuvînt de fapt din raportul scris de Bölöni la cererea Consistoriului unitarian din Cluj, fară însă a menționa sursa. Datorită călătoriei lui Bölöni şi noilor relații stabilite de acesta cu unitarienii din Statele Unite, în special cu cei din jurul oraşului Boston, corespondența unitariană maghiaro-engleză se intensifică. Clujenii au folosit limba latină ca mijloc de comunicare, dar începînd cu anul 1830 scrisorile s-au scris tot mai des în limba engleză. Această schimbare de situație se datorează vizitei în Anglia a doi preoți maghiari Mózes Székely 1833, şi József Jakab 1848. Engleza folosită nu poate fi caracterizată drept shakespeareană, dar a fost inteligibilă. O deosebit de importantă schimbare în relațiile anglo-maghiare se datorează aristocratului englez, John Paget.

Activitatea şi viața, precum şi raporturile lui Paget cu bisericile unitariene din Transilvania şi Marea Britanie sunt prezentate în al doilea capitol major al lucrării, intitulat Unitarieni englezi în Transilvania, unitarieni maghiari în Anglia între anii 1858 şi 1869. 
John Paget s-a născut în 1808 la Louborough, Leicestershire în Anglia. Şi-a început studiile la Colegiul unitarian din York, iar apoi a urmat cursurile Universității din Edinburgh unde i s-a conferit diploma de medic, dar nu a profesat în acest domeniu. După o scurtă oprire la Paris şi-a continuat studiile în Italia, unde a cunoscut-o pe viitoarea sa soție, Polixéna Wesselényi, fosta soție a baronului László Bánffy (Procesul de divorț era în curs când l-a întâlnit pe englezul Paget). Datorită scrisorilor de recomandare ale baronesei, Paget a cutreierat în lung şi în lat Regatul Ungar şi Transilvania. Impresiile călătoriei aveau să fie publicate în două volume intitulate Hungary and Transylvania; with Remarks on Their Condition, Social, Political, and Economical apărute în anul 1839. S-a scris şi despre impresiile sale de călătorie referitoare la românii din Transilvania, precum şi despre rolul jucat în revoluția din 1848, dar nu s-a analizat strădania lui pentru înființarea unei burse engleze în favoare studenților maghiari, ca potențiali profesori şi intelectuali ai noii Universități din Cluj, şi nici despre conflictele ecleziastice, rezultate de pe urma ideilor sale, referitoare la statutul şi rolul peregrinilor unitarieni trimişi în Anglia.

Un alt demers important al lui Paget a fost inființarea Bibliotecii Engleze, urmată de Clubul Englez din Cluj. Prin aceste gesturi aristocratul englez maghiarizat a contribuit decisiv la promovarea limbii şi culturii engleze în Cluj.

Datorită lui Paget biserica unitariană a primit un important sprijin financiar pentru îmbunătățirea educației în gimnaziile confesionale din Cluj şi Cristuru Secuiesc. Acest aspect, precum şi lobby-ul lui Paget sunt prezentate în subcapitolul intitulat Cererea de sprijin financiar a unitarienilor transilvăneni şi reacția comunității unitariene din Statele Unite ale Americii.

Următoarele două subcapitole prezintă călătoriile a doi englezi în Transilvania în anul 1858, respectiv 1859. Jurnalele de călătorie ale celor doi ne arată condițiile maghiarilor unitarieni de după revoluție, dar descriu şi viața, obiceiurile, portul țăranilor români din Transilvania.

Primul vizitator unitarian englez al Transilvaniei a fost Edward Tagart, secretarul asociației unitariene. Datorită lui Paget şi Tagart o bursă unitariană a fost fondată la Londra.

Vizita celui de-al doilea unitarian englez, Alfred Steinthal are conotații politice, Steinthal fiind agent dublu. Pe de o parte a reprezentat comunitatea unitariană din Anglia, iar pe de altă parte a avut rolul de a strînge informații pentru Lajos Kossuth cu privire la situația morală şi politică din Transilvania. Poliția secretă din Viena 1-a deconspirat pe Steinthal şi după trei săptămîni 1-a declarat persona non grata. Studiind arhivele Bibliotecii John Ryland din Manchester am reuşit să găsesc o serie de dovezi referitoare la metoda folosită de Kossuth pentru a propaga cauza maghiară, folosindu-se de relațiile unitariene şi de instituțiile bisericeşti ale celor două nații. Comunitatea unitariană engleză a avut un rol covîrşitor în omagierea lui Kossuth şi în atragerea simpatiei englezilor față de cauza maghiară.

Următorul subcapitol clarifică importanța călătoriei a doi studenți unitarieni în Anglia. Istoriografia confesională a considerat această vizită ideea spontană a celor doi studenți, József Ferencz şi Áron Buzogány. Însă după o amănunțită cercetare am reuşit să demonstrez că această vizită a fost concepută strategic din Transilvania de către John Paget, avînd ca scop atragerea simpatiei şi înlesnirea relațiilor, după episodul Kossuth. După vizita celor doi studenți în 1859, în curricula Seminariului 
Teologic Unitarian din Cluj a fost introdusă studierea limbii şi literaturii engleze ca disciplină obligatorie. Datorită înțelepciunii lui Paget şi harului celor doi, englezii au votat pentru înființarea bursei maghiare. Capitolele Studenți unitarieni maghiari la universitatea Manchester New College şi respectiv Înființarea bursei Transilvanian Scholarship. Solidificarea relațiilor în oglinda corespondenței din anii 1860 prezintă viața şi dificultățile întîmpinate la Londra de studenții maghiari. În aceste capitole discutăm şi despre receptarea literaturii bisericeşti engleze în Transilvania şi respectiv despre influența teologiei unitariene transilvănene în Anglia, precum şi despre situația delicată a lui John Paget, în legătură cu propunerea sa de înființare a bursei Transilvanian Scholarship.

Ultimul capitol al acestei secțiuni prezintă vizita profesorului, filologului şi istoricului J. J. Tayler în Transilvania şi proiectul acestuia pentru editarea catalogului cărților şi manuscriselor unitariene, respectiv editarea unei istorii unitariene în colaborare cu departamentul de istorie al universității Manchester New College. Ambele proiecte au eşuat.

Partea cea mai importantă şi consistentă a lucrării este capitolul al treilea intitulat Relațiile unitariene anglo-americano-maghiare între anii 1870 şi 1905. În această parte mă ocup în special de întrebările referitoare la literatura şi istoria literaturii maghiare în a doua parte a secolului al 19-lea, îndeosebi traducerile în limba engleză a nuvelelor şi romanelor cunoscutului scriitor maghiar Mór Jókai, şi receptarea acestora în sânul comunității unitariene. Primul traducător al lui Jókai, aproape ignorat în toate bibliografiile de specialitate, a fost John Fretwell, om de afaceri şi francmason unitarian. Datorită acestui zelos misionar al cauzei unitariene de pretutindeni, scriitorul Jókai a decis să scrie un roman unitarian intitulat Egy az Isten. Receptarea acestui roman este prezentată dintr-o altă perspectivă, corectînd clişeele referitoare la geneza, traducerea în limba engleză, şi impactul romanului în Anglia şi Transilvania. Relația lui Jókai cu Fretwell este prezentată sub titlul Vizitele lui Fretwell în Ungaria şi Transilvania.

Răspîndirea limbii engleze în Cluj se datorează în mare parte profesorului János Kovács, primul lector de limbă şi literatură engleză la proaspăt inființata universitate din Cluj, Ferencz József Királyi Tudományegyetem. Kovács a fost la rîndul lui şi fondatorul şi preşedintele Clubului Englez din Cluj. După o scurtă prezentare biografică al lui Kovács am trecut la analizarea şi prezentarea activității acestui Club, a cărei importanță nu poate fi subliniată îndeajuns. În Europa centrală şi de Est acesta a fost singurul Club Englez care a funcționat fără întrerupere timp de un sfert de secol. Membrii clubului au fost sau au devenit figuri emblematice ale culturii transilvănene, mare parte din ei fiind profesori universitari la diferite facultăți ale Universității Ferencz József. Nici bibliografiile engleze, nici anglistica maghiară şi nici cea română nu a studiat istoria şi impactul Clubului în societatea clujeană al sfîrşitului secolului al 19-lea. Prin prisma jurnalelor şi rapoartelor de călătorie ale vizitatorilor acestui Club încerc să redau atmosfera oraşului şi impresiile călătorilor având profesii dintre cele mai diferite. Ultimul capitol al lucrării, Rezultatele relațiilor unitariene anglo-americano-maghiare şi rolul lor în formarea teologiei unitariene maghiare contemporane, pune în balanță influența anglo-americană asupra organizării, dogmaticii şi politicii bisericeşti unitariene maghiare. 


\section{Concluzii finale}

1. Documentul Brevis Expositio trimis de Fondul unitarian a fost cel mai răspîndit şi important document bisericesc al începutului secolului al 19-lea, analiza textului şi copiile existente ne dovedesc că acest document a fost temă de discuții atât în consistoriul bisericesc cît şi la nivelul simplilor enoriaşi. După analizarea amănunțită a textului putem afirma că de fapt, unitarienii englezi au trimis o epistolă în care comunitatea lor este prezentată ca moştenitoarea legitimă a ideilor antitrinitariene, respectiv sociniene, nediferind esențial de dogmatica unitariană transilvană. Această simpificare se regăseşte pe de altă parte şi în scrisoarea adresată englezilor de către consistoriul unitarian din Cluj. Analiza textului ne arată clar cum unitarienii transilvăneni au condensat vasta şi bogata istorie Unitario-Ecclesiastica Historia Transylvanica în citeva pagini misile, căutînd să semene cît mai mult cu putință cu dogmatica unitariană engleză.

2. În lumina epistolelor şi manuscriselor episcopului János Körmöczi este necesară reinterpretarea primelor contacte anglo-maghiare. Istoria bisericească unitariană nu a interpretat corect rolul deosebit jucat de Körmöczi în stabilirea legăturilor anglo-maghiare. Cercetarea manuscriselor episcopului demonstrează că acesta a cunoscut limba engleză, a tradus o serie de lucrări teologice şi predici din această limbă, dar prejudecățile față de acesta au făcut ca manuscrisele sus-menționate să fie catalogate greşit. Scrisorile episcopului, păstrate la British Library, pun într-o nouă lumină rolul acestuia în stabilirea relațiilor anglo-maghiare.

3. Triunghiul Körmöczi-Molnos-John Bowring demonstrează acelaşi lucru, dar şi metodologia politicianului şi poetului Bowring în afişarea ambițiilor literare personale, folosindu-se la maximum de avantajele oferite de comunitatea unitariană.

4. Importanța călătoriei lui Bölöni Farkas Sándor în Statele Unite ale Americii trebuie reinterpretată de data aceasta şi din punct de vedere ecleziastic.

5. Acelaşi lucru trebuie spus şi despre viața şi activitatea fermierului şi aristocratului englez John Paget. Conflictul lui cu biserica unitariană precum şi ideile de înnoire structurală a bisericii şi implicit a Seminariului Unitarian nu au fost luate în considerare pînă acum.

6. Propaganda făcută de Kossuth cu ajutorul comunității unitariene engleze, deşi cunoscută, trebuie revizuită prin prisma articolelor şi scrisorilor apărute în periodicele unitariene engleze şi americane. Comunitatea unitariană din Budapesta a profitat din plin de aceste articole afişându-şi patriotismul şi unitarianismul sub numele lui Kossuth.

7. Relația lui Jókai şi Fretwell pune într-o nouă ipostază geneza romanului Egy az Isten precum şi receptarea acestuia. Compararea originalului cu traducera lui Fretwell, precum şi descoperirea unei alte traduceri în limba engleză a unei nuvele de Jókai îmbogăţeşte cunoştințele noastre despre receptarea în mediul englezesc a marelui romancier.

8. Unul dintre cele mai ample şi interesante capitole ale tezei este cel referitor la Clubul Englez din Cluj. Istoria şi impactul acestui club în răspîndirea limbii şi culturii engleze a fost în întregime necunoscut. În jurnalele lor de călătorie, vizitatorii clubului prezintă oraşul Cluj ca un veritabil centru cultural, unde se poate conversa în limba engleză nu numai despre literatură, dar şi despre delicate probleme politice. 
9. Relațiile unitariene anglo-maghiare au redesenat structura bisericii unitariene transilvănene, ajutînd biserica să promoveze o politică socială şi culturală mult mai amplă, investind în comunităţile orăşeneşti aflate în dezvoltare, precum şi în modernizarea şi restructurarea curriculară a Seminarului unitarian din Cluj. 

ABSTRACT

\section{ENGLISH AND HUNGARIAN UNITARIAN RELATIONS IN THE $19^{\mathrm{TH}}$ CENTURY}

\section{Introduction. Method of investigation}

The theme of this thesis is the history of Anglo-Saxon and Hungarian Unitarian relations in the $19^{\text {th }}$ century. For the last few decades scholarly research of Hungarian-English Unitarian connections has been almost completely neglected. The lack of academic interest could be explained, at least partly, by the insularity of both religious groups. The research material is scattered in the archives and libraries of Oxford, Manchester, and Kolozsvár. The author had the privilege of researching not just the libraries and archives of Kolozsvár (Transylvania), but also the Library of Harris Manchester College, Oxford, and the John Rylands Library, Manchester. The investigational method of the thesis could be labelled as late positivist, and I will agree with such a designation, although my thesis yields new evidence on the impact of Anglo-Saxon Unitarianism on Transylvanian theological thought and ecclesiastical-political life. I am aware that the rich field of English-Hungarian connections embodied in the two small religious denominations must be explored from other perspectives, too. As a Unitarian I might be prejudiced concerning the role this denomination played in $19^{\text {th }}$ century society in England and Transylvania, but I am convinced that the results of my research are relevant to wider issues in the history of Anglo-Hungarian relations.

During the preparation, I have read hundreds of pages of English and Hungarian correspondence, minutes, journals, and articles. As well as many Hungarian periodicals - including Keresztény Magvető (Christian (Seed-)Sower), Unitárius Élet (Unitarian Life), Unitárius Közlöny (Unitarian Bulletin) - I used the most important English and American Unitarian Journals: The Monthly Repository, The Christian Reformer, The Inquirer, The Christian Life, The Unitarian Herald, The Christian Register, The Christian Examiner and Theological Review, The Monthly Religious Magazine, The Unitarian Review, The Christian Inquirer, Old and New, Monthly Journal. I used a linear chronology in order to incorporate the overwhelming abundance of periodicals, miscellanies and minutes, as well as manuscripts in the thesis. This means that the backbone of the book is a historical chronology of the $19^{\text {th }}$ century Transylvanian Unitarian Church which is fleshed out by the series of events proceeding from English-Hungarian connections. 


\section{Structure and content}

The content of the book is composed of three major parts. The first is entitled "The evolution of Hungarian-English-American Unitarian Relations from 1821 to 1848." In this, I present a key document, a printed Latin text, sent to Kolozsvár from the Unitarian Fund on 30 April 1821 under the title Unitariorum in Anglia etc., and investigate how it traced the course of English-Hungarian Unitarian affairs. The detailed analysis of the Latin document and the reply written by the Transylvanian church throws new light on the history of the early relations between the churches, and the role of Bishop John Körmöczi. This enlightened cleric was the facilitator of these newly established connections, and he was the first translator into Hungarian of some parts of Theophilus Lindsey's An Historical View of the State of the Unitarian Doctrine and Worship from the Reformation to our Own Times.

Also in this chapter, I scrutinize John Bowring's translations of Poetry of the Magyars, and investigate how, through his Unitarian acquaintances, he gleaned genuine information about Hungarian poetry and affairs. I point to the importance of Bowring's denominational ties in presenting his very first translations, which appeared in a Unitarian periodical.

The second chapter, under the title "English Unitarians in Transylvania, Hungarian Unitarians in England 1849-1869", describes the consolidation of English-Hungarian relations, through the life and work of John Paget. In this section, I also present the first English visitors to Transylvania and their task as ambassadors of the Unitarian faith.

The third, and longest chapter bears the title "English-American-Hungarian relations from 1870 to 1905". It takes into account the lives of John Fretwell and John Kovács, an alumnus of Manchester New College, as two important figures in the third part of the $19^{\text {th }}$ century. Through an examination of Fretwell's life and career, new light is thrown on the translation of some of Jókai's novels, and their reception in England.

Under the title The English Conversation Club of Kolozsvár, I describe how English language, culture and politics were present in the heart of Transylvania. Through the history of the English Club, I cover the history of English-American-Hungarian Unitarian relations, too. I also describe the endeavours of Kovacs, the former Manchester New College student, and other alumni in spreading English culture and customs in Transylvania.

\section{The outcome of research. Conclusions}

1. The Latin document's view of the opinions, history and institutions of the Unitarians of Great Britain should be considered the most important tract sent to Transylvania in the $19^{\text {th }}$ century. There is no other theological, historical or literary work whose translation was circulated as widely as the above mentioned Brevis Expositio. At least 124 Hungarian copies were made available, and it is probable that the chief goal of the Transylvanian Unitarian elite was the development of a feasible strategy for co-operation with the English Unitarians. The examination of the reply proves that the Transylvanian Unitarian Church officially adopted and canonized the mythical account of the origins and identity of the Church put forward by János Tözsér Kénosi and István Fosztó Uzoni, the authors of the Unitario- 
Ecclesistica Historia Transylvanica. Written in Latin in the last third of the eighteenth century, this work was used by the Unitarians of Transylvania to justify the very existence of their community.

2. The role of John Körmöczi in establishing the new English-Hungarian connections must be re-evaluated. It is due to Körmöczi's diligence that the Hungarian Unitarian elite had some knowledge of English Unitarianism before receiving the Brevis Expositio. Körmöczi's translations of Planck and Wendeborn were in fact the transposition of Lindsey's work. A printed Latin confession of the Transylvanian Unitarians, found in the British Library, throws new light on Körmöczi's efforts to clarify the dogmatic stands of the Transylvanian Unitarian Church. On the last sheet of the printed confession there is a handwritten letter addressed by Körmöczi to the English Unitarians. This could be considered as a first official reply from Transylvania.

3. Sir John Bowring's letter addressed to Körmöczi and the Transylvanian Unitarians proves once more the role of the Unitarian societies in literary matters.

4. Sándor Bölöni Farkas was the first Hungarian Unitarian who travelled in Great Britain and North America. His reputation was widely recognized and acknowledged by his biographers, but they all neglected his role as an accredited diplomat of the Transylvanian Unitarian Church. Re-analyzing his reports as well as the minute records of the BFUA, I am convinced that Bölöni may have been financially supported by his friend and travelling companion, but he was spiritually and intellectually supported by the greater Unitarian community.

5. Similar things could be said about John Paget, one of the chief figures of Anglo-Hungarian relations. In my thesis I focus on his activity as a member of the Hungarian Unitarian Consistory, giving new data with regard to the establishment of the Hungarian Scholarship at Manchester New College.

6. One subdivision of the thesis scrutinizes Louis Kossuth's political activity and the use of his English Unitarian connections for purely political purposes. I point to the Kossuth articles found in the Inquirer as one explanation of the Unitarian propaganda.

7. John Fretwell and Jókai Mór's literary relationship was neglected by the biographers of Jókai. One Jókai novel was written about Transylvanian Unitarians and is entitled God is One. Reading Fretwell's correspondence and articles I propose a new approach to the genesis of Jókai's novel, and its English and American reception. It was Fretwell, who convinced the Hungarian novelist to take on the subject of Unitarians, and he is credited with translating abstracts of Jókai's Unitarian novel into English as early as 1877. The translation and publication of Jókai's novel Slinging-Stones in Edward Hale's periodical, the Old and New, are also examined.

8. The longest chapter of the thesis examines the role of the English Conversation Club of Kolozsvár in spreading English language, culture and customs in $19^{\text {th }}$ century Transylvania. The history of the English Conversation Club was previously entirely unknown; this thesis is the first to reveal the significance of the Club and its visitors to intellectual life in $19^{\text {th }}$ century Transylvania. 
Conclusions:

- As a direct result of Anglo-Hungarian-American relations, the frozen theological thought of Transylvanian Unitarians, which was based on Szentábrahámi's chief work, Summa Theologiae... (1787), started to melt. This stemmed from the availability of the translations of William Ellery Channing's tracts. Step-by-step, the very dogmatic Transylvanian Unitarian theology embraced a more liberal, Christian humanist attitude.

- Inspired by the English and American Unitarian periodicals, Bishop John Kriza founded in 1861 the very first Hungarian theological journal entitled Christian Seed-sower. This journal was, from its first issue, the chief organ of $19^{\text {th }}$ century liberal theology, presenting such topics as the latest results of biblical criticism, the theory of Darwin about evolution, etc.

- Following the pattern of English Unitarian Societies, George Boros founded the Francis David Society for propagation of Unitarianism, in 1885. The Society edited a monthly bulletin, held regular meetings and did much for the improvement of education and morals.

- In the second part of the $19^{\text {th }}$ century, Transylvanian Unitarianism re-discovered its founder, Francis David, and a process of rehabilitation took place, in which English Unitarian historians manifested much interest. The romantic view of Unitarian origins and identity helped English and American Unitarians to discover their forgotten roots.

Due to the financial aid of English and American Unitarians, a successful Hungarian mission was conducted and many congregations were organized outside of Transylvania proper, the most important being the First Unitarian Church of Budapest. 
AN EXTRACT OF THE RULES

\section{OF THE \\ ENGLISH CLUB}

\section{KOLOZSVÁR.}

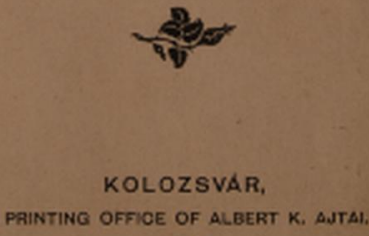

1907.
UNITARIORIOA IN ANGLIA

Vink, HIronua,

ET STATUS PR.XSEXTIB

Bazws s:xnosimo

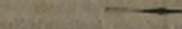

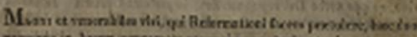

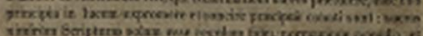

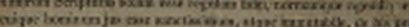

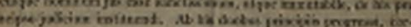

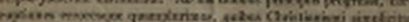

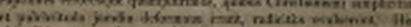

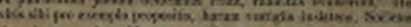

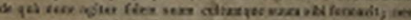

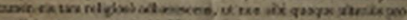

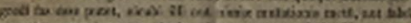

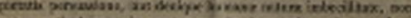

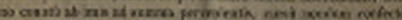



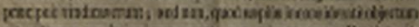

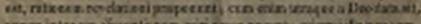

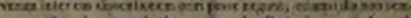

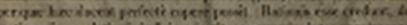

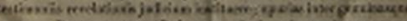

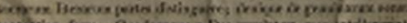

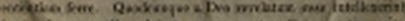

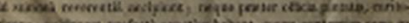

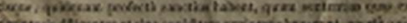

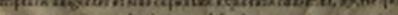

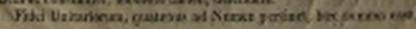

Az angol-magyar protestáns kapsoolatok 19. századi unitánius vonatkozásalt tés az unitátrius egyház intézméngrendszere kủré épulō esemérytörtŕnet mutatja be a szerzõ úgy, hogy közben tekintelyes bibloográfial, intéaménytôrténeti, anchơntológiai, biográfiai, helytörténneti nyersanyagot halmó fel. A szerzó ezek körében Bölönd Farkas Sándor "napnyugati" utazáśnak egyházdiplomáclai mozzantát, Kossuth Lajos angliai média-politzálásanak az unitáríus kaposolatokat érintơ elemeit, llletve Jókai Mór nevezetes regénye, az Egy az Isten

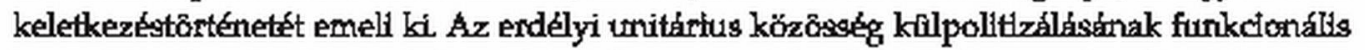
bemutatását szolgálja egy kolozsvári civil szervezet (az English Conversation Club) összetett szerepének érzékeltetése a felekezet társadalmí elhelyezkedésének szerkezetéber, hátteribefolyásónak érvényesittésében.

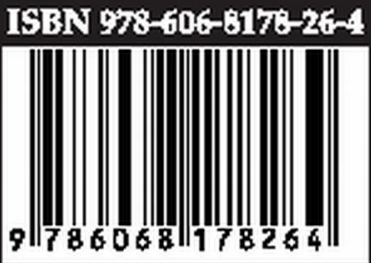

